\title{
ANOMALIAS DENTÁRIAS COMO EXTENSÃO FENOTÍPICA DAS \\ FISSURAS ORAIS: ESTUDOS MOLECULARES DE GENES E REGIÕES CANDIDATAS
}

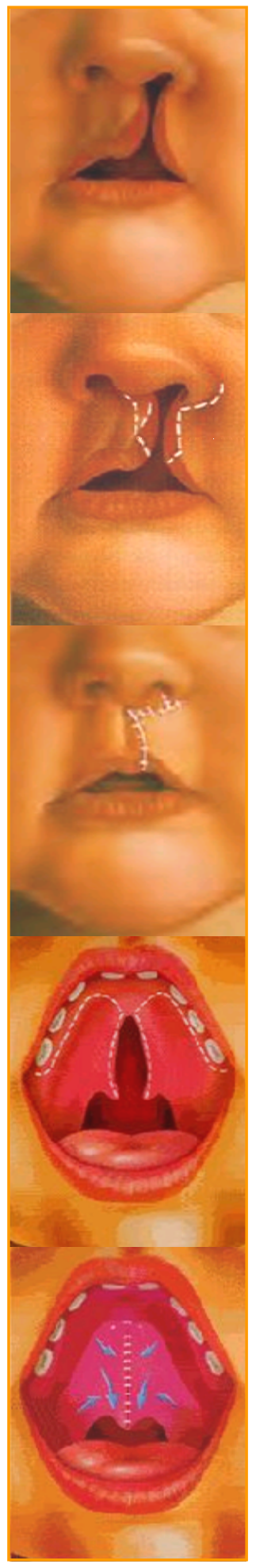

\author{
ARIADNE MACHADO GONÇALVES LETRA
}

Tese apresentada à Faculdade de Odontologia de Bauru, da Universidade de São Paulo, como parte dos requisitos para obtenção do título de Doutor em Odontologia, área de concentração Biologia Oral. 


\title{
ANOMALIAS DENTÁRIAS COMO EXTENSÃO FENOTÍPICA DAS FISSURAS ORAIS: ESTUDOS MOLECULARES DE GENES E REGIÕES CANDIDATAS
}

\author{
ARIADNE MACHADO GONÇALVES LETRA
}

Tese apresentada à Faculdade de Odontologia de Bauru, da Universidade de São Paulo, como parte dos requisitos para obtenção do título de Doutor em Odontologia, área de concentração Biologia Oral.

Orientador: Prof. Dr. José Mauro Granjeiro Orientador no exterior: Prof. Dr. Alexandre Rezende Vieira 


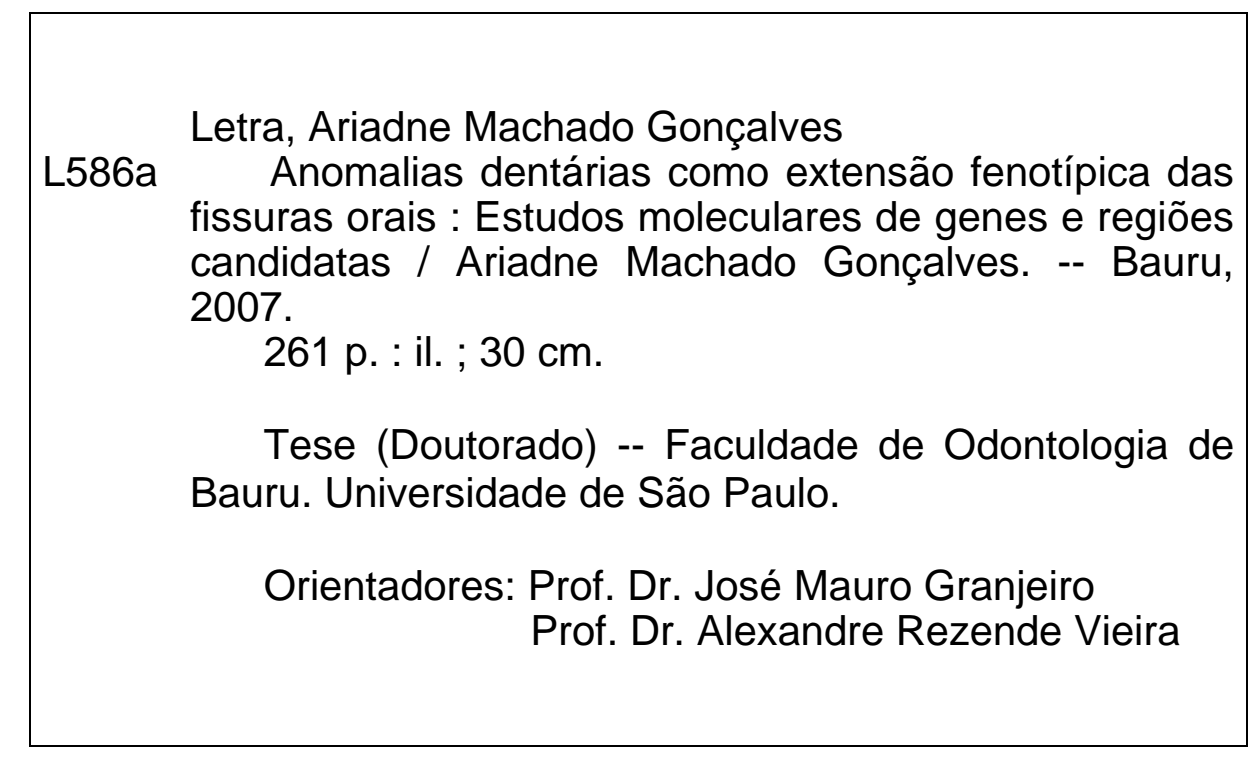

Autorizo, exclusivamente pra fins acadêmicos e científicos, a reprodução total ou parcial desta tese, por processo fotocopiadores oe/ou meios eletrônicos.

Assinatura do autor:

Data:

Comitê de Ética do HRAC/USP

Protocolo n. ${ }^{0}: 265 / 2004$

Data: 25/08/2004 


\section{Dados Curriculares}

\section{Ariadne Machado Gonçalves Letra}

Nascimento

07 de fevereiro de 1974

São Paulo, SP

Filiação

Jose Álvaro Letra e

Carmen Lúcia Machado Gonçalves Letra

$1991-1995$

Graduação em Odontologia

Universidade Federal Fluminense

Niterói, RJ

1996

Atualização em Dentística Restauradora

Associação Brasileira de Odontologia. Seção Niterói

Niterói, RJ

$1998-1999$

Especialização em Endodontia

Odontoclínica Central do Exército - OCEx

Rio de Janeiro, RJ

1999

Extensão em Cirurgia Paraendodôntica

Faculdade de Odontologia de Bauru - FOB/USP

Bauru, SP

$2002-2003$

Pós-Graduação em Endodontia, Nível Mestrado Faculdade de Odontologia da Universidade do Estado do Rio de Janeiro - UERJ. Rio de Janeiro, RJ Agência Financiadora, Centro de Aperfeiçoamento de Pessoal de Nível Superior (CAPES). 
Pós-Graduação em Biologia Oral, Nível Doutorado Faculdade de Odontologia de Bauru - FOB/USP Bauru, SP.

Agência Financiadora, Centro de Aperfeiçoamento de Pessoal de Nível Superior (CAPES).

$2006-2007$

Bolsista do Estágio de Doutorando no Exterior

University of Pittsburgh School of Dental Medicine Department of Oral Biology

Pittsburgh, PA, EUA

Agência Financiadora, Centro de Aperfeiçoamento de Pessoal de Nível Superior (CAPES).

Associações

ABO/RJ. Associação Brasileira de Odontologia, Seção Rio de Janeiro.

APCD/SP. Associação Paulista de Cirurgiões Dentistas.

SBPqO. Sociedade Brasileira de Pesquisa Odontológica.

IADR. International Association of Dental Research. ASHG. American Society of Human Genetics. 
A todos os pacientes e seus familiares, pela generosa participação e contribuição de material biológico para que este estudo pudesse ser realizado...

... DEDICO ESPECIALMENTE ESTE TRABALHO. 


\section{AGRADECIMENTOS ESPECIAIS}

A DEUS, por me manter forte e saudável e por orientar os meus passos todos os dias.

Aos meus pais, Álvaro e Carmen Lúcia, pelos ensinamentos de amor e caráter e pela confiança que sempre tiveram em mim, pelo apoio e incentivo para que eu sempre perseguisse os meus sonhos, por mais que significassem estarmos longe.

À minha querida avó, Maria Donzília, pelo carinho especial e por nos acompanhar para Bauru e cuidar de nós, especialmente o Lucas.

Aos meus queridos Renato e Lucas, por terem tornado o meu sonho seus sonhos, e por oferecerem o seu amor todos os dias de nossas vidas. Lembrando uma música que recentemente se tornou uma das favoritas do Lucas e expressa todo o meu sentimento...

"You're the meaning in my life, you're the inspiration,

You bring feeling to my life, you're the inspiration..."

Aos meus sogros, Renato e Heloísa, pelo carinho e apoio de sempre. 


\section{MEUS SINCEROS AGRADECIMENTOS...}

Ao meu orientador, Professor Dr. José Mauro Granjeiro, por ter se revelado um verdadeiro Mestre, com sua postura sempre otimista orientando $e$ estimulando o exercício do pensamento científico e moral, e por ter se tornado um verdadeiro amigo, com suas palavras sábias e gentis. Pelos incentivos profissionais $e$ pessoais que me possibilitaram estar aqui hoje e por acreditar no meu potencial.

Ao meu orientador no exterior, Professor Dr. Alexandre Vieira, pela carinhosa acolhida em seu laboratório, pelos preciosos ensinamentos, pela confiança e imensa generosidade. Serei sempre grata pelo seu suporte e compreensão, imprescindíveis para a nossa adaptação nos Estados Unidos, pela amizade sincera que surgiu e pelos bons momentos no trabalho e no lazer com as famílias.

À Professora Dra. Ana Paula de Souza Pardo, por ter contribuído significativamente para minha introdução na área de Biologia Molecular, e ter guiado o meu aprendizado nas técnicas laboratoriais de algumas etapas deste projeto. Obrigada pela amizade e pelo carinho de sempre. 
À Faculdade de Odontologia de Bauru, na pessoa do atual Diretor Prof. Dr. Fernando Pegoraro, pelo apoio durante as atividades exercidas durante o curso de Doutorado.

Ao Hospital de Reabilitação e Anomalias Craniofaciais, na pessoa do atual diretor Prof. Dr. José Alberto de Souza Marques, por ter permitido acesso aos pacientes e suas famílias para a realização deste trabalho.

À Universidade do Sagrado Coração, na atual pessoa do Coordenador de Pós-Graduação e Pesquisa, Prof. Dr. Sérgio Catanzaro Guimarães, por ter permitido a utilização das instalações do Laboratório de Pesquisa do Programa de Pós-Graduação em Biologia Oral.

Ao Departamento de Biologia Oral da Faculdade de Odontologia da Universidade de Pittsburgh, na pessoa da atual Chefe de Departamento, Profa. Dra. Mary Louise Marazita, pelo apoio e pela gratificante oportunidade de aprender com um grande nome.

Aos amigos do Departamento de Bioquímica, Professores, Dra. Marilia Rabelo Buzalaf e Dr. Rodrigo Cardoso de Oliveira, Técnicos, Thelma, Ovídio e Flávia Iano, e Alunos, cujos nomes completariam algumas paginas desta tese... pelo apoio, amizade e por terem tornado a Bioquímica a minha segunda casa em Bauru.

Aos queridos amigos da turma de Doutorado em Biologia Oral, Esther, Flavia, Heloisa, Rejane, Tania, Anna Elisa, Silvia, Renato e Claudia, pela amizade e pela convivência maravilhosa nestes anos em Bauru.

Aos colegas do Setor de Saúde Coletiva do HRAC, por terem me recebido de forma tão amigável, pela paciência e ajuda durante os procedimentos com os pacientes. Em especial, à Gisele da Silva Dalben, cujo apoio foi fundamental durante muitos meses de trabalho intenso. 
Ao amigo Rodrigo Augusto da Silva, pela amizade sincera e incansável ajuda durante os procedimentos laboratoriais, principalmente no período que antecedeu a minha viagem ao exterior.

Ao amigo Wilson Aparecido Orcini, pelo inestimável apoio técnico e amizade.

Aos colegas do Vieira Lab, Monica, Jill, Kathleen, e Joe, pelo suporte técnico, pela amizade e pelo excelente ambiente de trabalho, e a Asli, pelo ombro amigo durante a fase final de preparo desta tese.

À Vera Rufino Rosa, pela ajuda imprescindível com as tarefas burocráticas...matrículas, qualificação, defesa de tese...

À equipe da Comissão de Pós-Graduação da FOB/USP, Giane, Margareth, e Letícia, pela simpatia e pela ajuda inestimável durante estes anos.

À Professora Dra. Mari Cleide Sogayar, do Departamento de Bioquímica da USP/SP, pela contribuição de materiais permanentes e reagentes para execução de parte deste projeto.

À Pró Reitoria de Pós-Graduação da USP, pela concessão de auxílio financeiro para participação em eventos científicos.

À CAPES, pela concessão da bolsa de estudos no Brasil e no exterior. 


\section{SUMÁRIO}

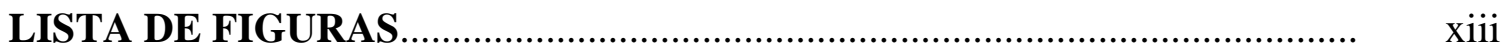

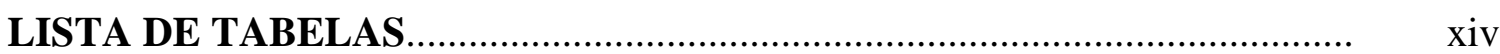

LISTA DE QUADROS............................................................................ x x

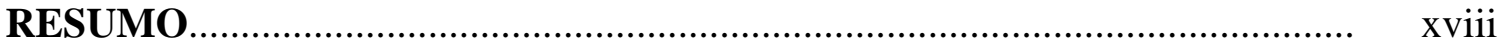

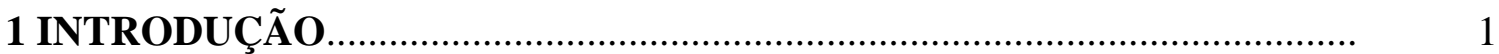

2 REVISÃO DA LITERATURA............................................................. 7

2.1 Desenvolvimento Normal da Face................................................................ 9

2.1.1 Desenvolvimento do Palato Primário......................................................... 9

2.1.2 Desenvolvimento do Palato Secundário..................................................... 10

2.2 As Fissuras Labiais com ou sem Fissuras Palatinas.......................................... 11

2.3 Definição do Fenótipo................................................................................... 12

2.3.1 Fissuras Labiais com ou sem Fissuras Palatinas e Anomalias Dentárias.. 12

2.4 Genes Candidatos e Polimorfismos Genéticos................................................... 14

2.5 Estudos Genéticos das Fissuras Labiais com ou sem Fissuras Palatinas........... 14

2.6 As Metaloproteinases da Matriz Extracelular................................................... 15

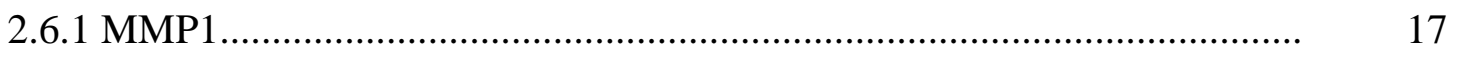

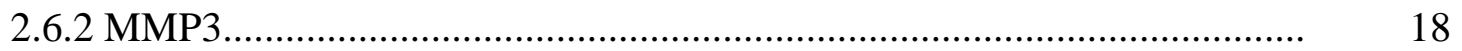

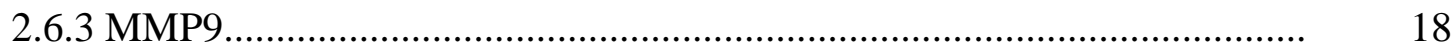

2.7 Fator Transformador de Crescimento Alfa (TGFA),........................................ 19

2.8 Fator Regulador de Interferon-6 (IRF6)......................................................... 20

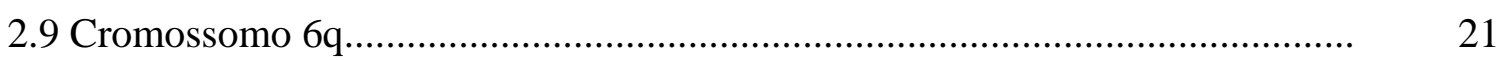

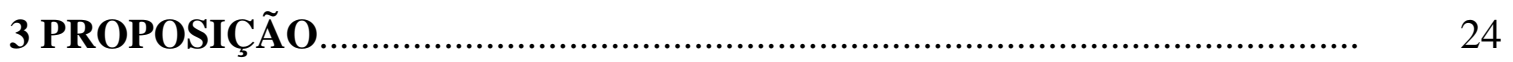

4 MATERIAL E MÉTODOS....................................................................... 27

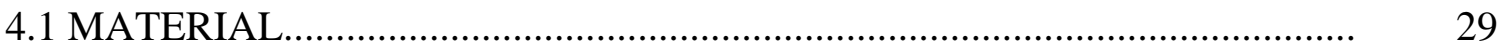

4.1.1 População Estudada............................................................................ 29

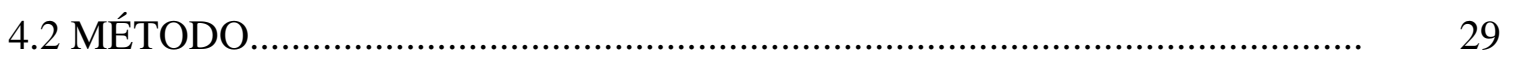

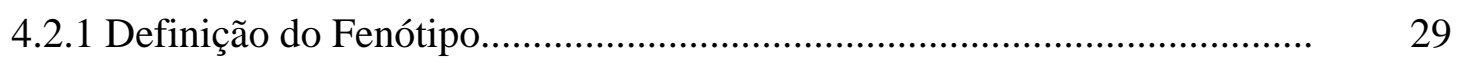

4.2.2 Coleta de Material Biológico................................................................... $\quad 30$

4.2.3 Extração do DNA.................................................................................... $\quad 30$ 
4.2.4 Seleção dos Genes Candidatos e Polimorfismos de um Único Nucleotídeo.... 31

4.2.5 Genotipagem.......................................................................................... 31

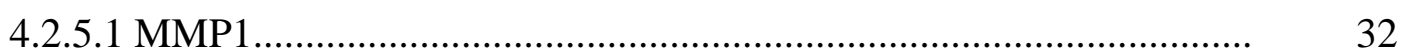

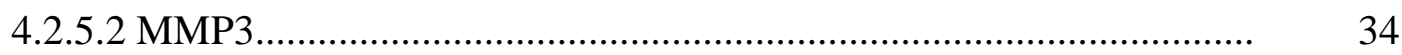

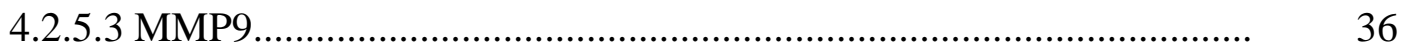

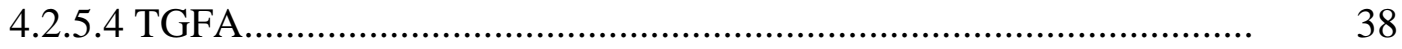

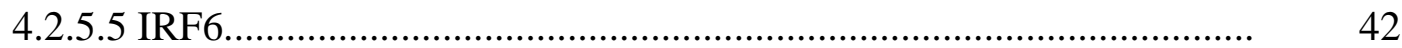

4.2.5.6 Cromossomo 6q............................................................................ 43

4.2.6 Análise dos Dados.............................................................................. 44

4.2.6.1 Definição do Fenótipo................................................................... 44

4.2.6.2 Associação de Polimorfismos Genéticos e Subfenótipos de FL/P.... 45

4.2.6.3 Análise de Desequilíbrio de Ligação entre os Polimorfismos

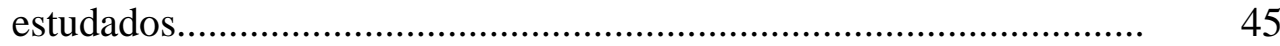

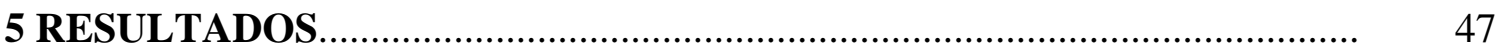

5.1 Definição do Fenótipo...................................................................................... 49

5.1.1 Caracterização da Amostra.................................................................... 49

5.1.2 Tipos de Fissura.................................................................................. 49

5.1.3. Presença de Anomalias Dentárias......................................................... $\quad 50$

5.1.4 Anomalias Dentárias como Subfenótipos Adicionais para FL/P.............. 51

5.2 Novos Subfenótipos Propostos......................................................................... 54

5.3 Estudos Genéticos de Associação com a FL/P................................................. 55

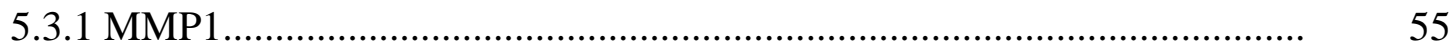

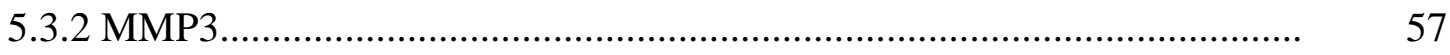

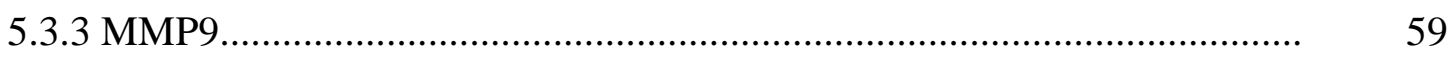

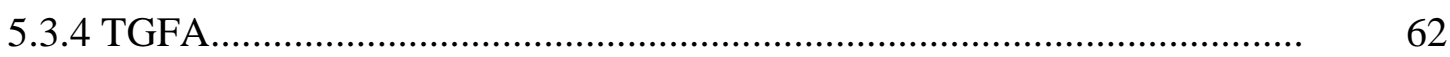

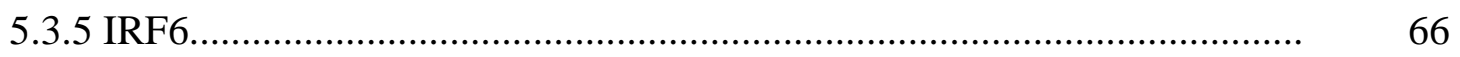

5.3.6 Cromossomo 6q................................................................................. $\quad 70$

5.4 Estudos Genéticos utilizando Anomalias Dentárias como Subfenótipos Adicionais para FL/P.................................................................................... 77

5.5 Análise de Desequilíbrio de Ligação entre os Polimorfismos Testados............ 83

5.6 Sumário dos Resultados................................................................................ 89 
6 DISCUSSÃO

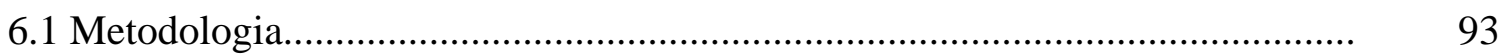

6.1.1 Tipo de Estudo.................................................................................... 93

6.1.2 Seleção dos Genes Candidatos e Polimorfismos Estudados...................... 94

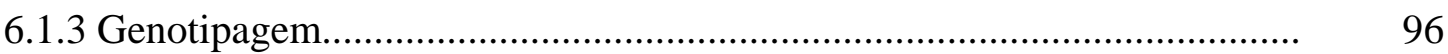

6.1.4 Análise dos Resultados........................................................................ 97

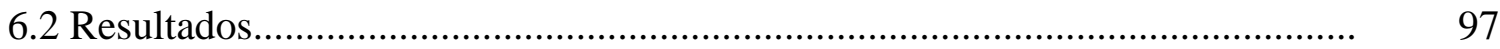

6.2.1 Caracterização da Amostra....................................................................... 97

6.2.2 Definição do Fenótipo.............................................................................. 99

6.3 Estudos Genéticos de Associação com a FL/P.............................................. 101

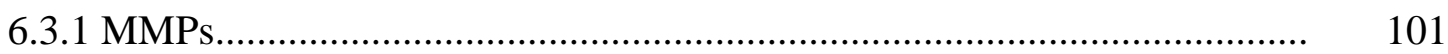

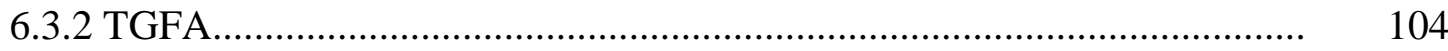

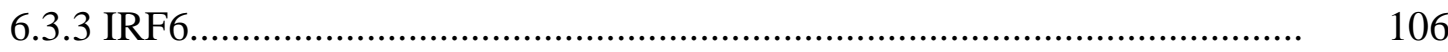

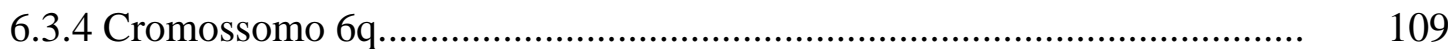

6.4 Estudos Genéticos utilizando Anomalias Dentárias como Subfenótipos Adicionais para FL/P.

6.5 Análise de Desequilíbrio de Ligação entre os Polimorfismos Testados.

7 CONCLUSÕES

REFERÊNCIAS BIBLIOGRÁFICAS..................................................... 231

ABSTRACT

\section{APÊNDICES}




\section{LISTA DE FIGURAS}

Figura 1. $\quad$ Estrutura do gene MMP1 (11q22.2)......................................... 32

Figura 2. Polimorfismo -1607 1G/2G na região promotora do gene MMP1... 34

Figura 3. $\quad$ Estrutura do gene MMP3 (11q22.3)........................................... 34

Figura 4. Polimorfismo -1171 5A/6A na região promotora do gene MMP3.... 36

Figura 5. $\quad$ Estrutura do gene MMP9 (20q13.12)............................................. 36

Figura 6. Polimorfismo $-1562 \mathrm{C} / \mathrm{T}$ na região promotora do gene MMP9.......... 38

Figura 7. Esquema da estrutura do gene TGFA............................................ 38

Figura 8. Resultados obtidos pelo método Taqman no gene TGFA................ 39

Figura 9. Exemplo de indivíduo homozigoto analisado pelo método de PCR cinético

Figura 10. Exemplo de indivíduo heterozigoto analisado pelo método de PCR cinético.

Figura 11. Esquema da estrutura do gene IRF6.

Figura 12. Gráfico de desequilíbrio de ligação ilustrando a região estudada no cromossomo 6q.

Figura 13. Representação gráfica do padrão de desequilíbrio de ligação entre os polimorfismos estudados no gene TGFA em casos e controles (população total)

Figura 14. Representação gráfica do padrão de desequilíbrio de ligação entre os polimorfismos estudados no gene TGFA em casos e controles (caucasianos) e controles japoneses.

Figura 15. Representação gráfica do padrão de desequilíbrio de ligação entre os polimorfismos estudados no gene IRF6 em casos e controles (população total).

Figura 16. Representação gráfica do padrão de desequilíbrio de ligação entre os polimorfismos estudados no gene IRF6 em casos e controles (caucasianos) e controles japoneses

Figura 17. Representação gráfica do padrão de desequilíbrio de ligação entre os polimorfismos estudados no cromossomo $6 \mathrm{q}$ em casos e controles (população total).

Figura 18. Representação gráfica do padrão de desequilíbrio de ligação entre os polimorfismos estudados no cromossomo $6 \mathrm{q}$ em casos e controles (caucasianos) e controles japoneses. 


\section{LISTA DE TABELAS}

Tabela 1. Características observadas para a população estudada.......................

Tabela 2. Diferenças observadas para as freqüências de anomalias dentárias em casos e controles.

Tabela 3. Distribuição das anomalias dentárias nos indivíduos fissurados (divididos de acordo com os subfenótipos apresentados) e controles.

Tabela 4. Número de anomalias dentárias observadas nos indivíduos fissurados, de acordo com o lado da anomalia e lado da fissura.

Tabela 5. Características da população estudada para o gene MMP1

Tabela 6. Distribuição dos alelos e genótipos do polimorfismo -1607 1G/2G no gene MMP1 em casos e controles, na população total e em caucasianos

Tabela 7. Distribuição dos alelos e genótipos do polimorfismo -1607 1G/2G no gene MMP1 em indivíduos com FL/P e FP, na população total e em caucasianos

Tabela 8. Características da população estudada para o gene MMP3.

Tabela 9. Distribuição dos alelos e genótipos do polimorfismo -1171 5A/6A no gene MMP3 em casos e controles, na população total e em caucasianos

Tabela 10. Distribuição dos alelos e genótipos do polimorfismo -1171 5A/6A no gene MMP3 em indivíduos com FL/P e FP, na população total e em caucasianos

Tabela 11. Características da população estudada para o gene MMP9.

Tabela 12. Distribuição dos alelos e genótipos do polimorfismo $-1562 \mathrm{C} / \mathrm{T}$ no gene MMP9 em casos e controles, na população total e em caucasianos.

Tabela 13. Distribuição dos alelos e genótipos do polimorfismo -1562 C/T no gene MMP9 em indivíduos com FL/P e FP, na população total e em caucasianos.

Tabela 14. Análise comparativa das freqüências dos genótipos e dos alelos obtidas para casos e controles (população total) para cada polimorfismo estudado no gene TGFA. 
Tabela 15. Análise comparativa das freqüências dos genótipos obtidos para casos e controles (caucasianos) para cada polimorfismo estudado no gene TGFA

Tabela 16. Análise comparativa das freqüências dos genótipos e alelos obtidos para casos e controles (população total) para cada polimorfismo estudado no gene TGFA

Tabela 17. Análise comparativa das freqüências dos genótipos e alelos obtidos para casos e controles (caucasianos) para cada polimorfismo estudado no gene TGFA

Tabela 18. Análise comparativa das freqüências dos genótipos e dos alelos obtidas para casos e controles (população total) para cada polimorfismo estudado no gene IRF6.

Tabela 19. Análise comparativa das freqüências dos genótipos obtidos para casos e controles (caucasianos) para cada polimorfismo estudado no gene IRF6

Tabela 20. Análise comparativa das freqüências dos genótipos e alelos obtidos para casos e controles (população total) para cada polimorfismo estudado no gene IRF6

Tabela 21. Análise comparativa das freqüências dos genótipos e alelos obtidos para casos e controles (caucasianos) para cada polimorfismo estudado no gene IRF6.

Tabela 22. Análise comparativa das freqüências dos genótipos obtidos em casos e controles para cada polimorfismo estudado no cromossomo $6 q$.

Tabela 23. Diferenças observadas para as freqüências dos genótipos e dos alelos de cada polimorfismo estudado entre casos e controles (caucasianos).

Tabela 24. Análise comparativa das freqüências dos genótipos e alelos obtidos para os subfenótipos de casos e controles (população total) para cada polimorfismo estudado no cromossomo 6q.

Tabela 25. Análise comparativa das freqüências dos genótipos obtidos para os subfenótipos de casos e controles (caucasianos) para cada polimorfismo estudado no cromossomo 6q.

Tabela 26. Análise comparativa das freqüências dos genótipos e alelos obtidos em casos e controles (população total) para cada polimorfismo no gene TGFA, de acordo com os subfenótipos propostos. 
Tabela 27. Análise comparativa das freqüências dos genótipos e alelos obtidos em casos e controles (caucasianos) para cada polimorfismo no gene TGFA, de acordo com os subfenótipos propostos.

Tabela 28. Análise comparativa das freqüências dos genótipos e alelos obtidos em casos e controles (população total) para cada polimorfismo no gene IRF6 de acordo com os subfenótipos propostos.

Tabela 29. Análise comparativa das freqüências dos genótipos e alelos obtidos em casos e controles (caucasianos) para cada polimorfismo no gene IRF6 de acordo com os subfenótipos propostos.

Tabela 30. Análise comparativa das freqüências dos genótipos e alelos obtidos em casos e controles (população total) para cada polimorfismo no cromossomo $6 \mathrm{q}$ de acordo com os subfenótipos propostos..................

Tabela 31. Análise comparativa das freqüências dos genótipos e alelos obtidos em casos e controles (caucasianos) para cada polimorfismo no cromossomo 6q de acordo com os subfenótipos propostos.

Tabela 32. Sumário das associações encontradas de acordo com o polimorfismo estudado. 


\section{LISTA DE QUADROS}

Quadro 1. Condições experimentais para o polimorfismo -1607 1G/2G no gene MMP1.

Quadro 2. Condições experimentais para o polimorfismo -1171 5A/6A no gene MMP3

Quadro 3. Condições experimentais para o polimorfismo -1562C/T no gene MMP9.

Quadro 4. SNPs, posição no cromossomo, região no gene e troca de base dos polimorfismos estudados no gene TGFA.

Quadro 5. Condições experimentais para o polimorfismo C3296T no gene TGFA

Quadro 6. Condições experimentais para o polimorfismo C3827T no gene TGFA.

Quadro 7. SNPs, posição no cromossomo, região no gene e troca de base dos polimorfismos estudados no gene IRF6

Quadro 8. SNPs, posição no cromossomo, região no gene e troca de base dos polimorfismos estudados na região do cromossomo $6 q$.

Quadro 9. Lista de subfenótipos utilizados em estudos genéticos e os subfenótipos adicionais propostos baseados no desenvolvimento dental. 


\section{RESUMO}

A fissura labial com ou sem fissura palatina (FL/P) é uma anomalia craniofacial muito comum em humanos, e pode ocorrer como característica de um quadro sindrômico ou isolada, quando os indivíduos afetados não apresentam qualquer anomalia estrutural associada. A etiologia da FL/P isolada é complexa, com a contribuição de componentes genéticos e ambientais. Diversos genes/loci candidatos a FL/P foram sugeridos nos últimos anos, apesar de discrepâncias entre resultados. Alguns autores consideram a FL/P como parte de um fenótipo mais amplo, e sugerem que características clínicas adicionais, como a presença de anomalias dentárias, poderiam ser utilizadas para uma melhor descrição do fenótipo individual em investigações genéticas da FL/P. Quinhentos indivíduos com FL/P e quinhentos indivíduos sem FL/P e não relacionados entre si foram examinados com relação ao tipo de fissura e anomalias dentárias apresentadas e amostras de saliva foram coletadas de cada indivíduo para estudos moleculares. A freqüência das anomalias dentárias foi significativamente maior nos indivíduos com FL/P e as associações preferenciais observadas para algumas anomalias e determinados subfenótipos de FL/P foram consideradas novos subfenótipos de FL/P e incluídos nas análises moleculares. Um total de 30 polimorfismos distribuídos nos genes MMP1, MMP3, MMP9, TGFA, IRF6 e no cromossomo 6q foram estudados com relação à associação com a FL/P e seus subfenótipos através de restrição enzimática, PCR cinético e método Taqman. As diferenças observadas para as freqüências dos genótipos e alelos de cada polimorfismo estudado em casos e controles foram avaliadas estatisticamente através do teste Qui-quadrado e correção de Bonferroni para múltiplos testes. O padrão de desequilíbrio de ligação entre os polimorfismos estudados também foi avaliado. Os genes MMP3, TGFA, IRF6, e outros e três genes (PRSS35, SNAP91 e CYB5R4) e dois polimorfismos localizados no cromossomo 6q mostraram-se associados a FL/P e seus subfenótipos na população estudada.

Palavras-chave: fissura labial/palatina, subfenótipo, anomalias dentárias, polimorfismos genéticos. 
1 INTRODUÇÃO 


\section{INTRODUÇÃO}

A fissura labial com ou sem fissura palatina (FL/P) é uma das anomalias craniofaciais mais comuns em humanos, cuja incidência varia entre 1/500 a 1/2500 nascimentos (MOSSEY; LITTLE, 2002). Em geral, aproximadamente 70\% das FL/P são consideradas não sindrômicas, ou isoladas, cujos indivíduos afetados não apresentam qualquer outra anomalia estrutural associada, enquanto as 30\% restantes são atribuídas a síndromes ou aberrações cromossômicas e agentes teratogênicos (SCHUTTE; MURRAY, 1999, MURRAY, 2002, MARAZITA; MOONEY, 2004).

A natureza multifatorial complexa da FL/P isolada justifica os inúmeros estudos genéticos demonstrando uma diversidade de genes e fatores ambientais envolvidos na sua etiologia (WYSZYNSKI et al., 1997, LITTLE et al., 2004, JUGESSUR; MURRAY, 2005). Conseqüentemente, diversos genes e loci candidatos foram associados à FL/P isolada em diferentes estudos: fator regulador de interferon-6 (IRF6, 1p36), fator de crescimento transformante alfa (TGFA, 2p13), muscle segment homeobox 1 (MSX1, 4p16), fator de crescimento transformante beta-3 (TGFB3, 14q24), receptor alfa do acido retinóico (RARA, 17q21), B-cell lymphoma 3 (BCL3, 19q13), apesar das discrepâncias entre resultados (VIEIRA; ORIOLLI, 2001, VIEIRA et al., 2003, LIDRAL; MURRAY, 2004, MARAZITA et al., 2004, LIDRAL; MORENO, 2005).

Alguns autores acreditam que parte da dificuldade encontrada nos estudos genéticos da FL/P pode ser atribuída à falta de uma definição mais detalhada do fenótipo. A classificação precisa dos indivíduos afetados torna-se crucial quando se tratando de um traço genético complexo como a FL/P, em que o fenótipo pode ser altamente variável. Inúmeras evidências sugerem que o fenótipo da FL/P pode ser muito mais complexo do que se presume, podendo apresentar diversas combinações de fissura (com relação ao lado afetado e extensão da fissura), ou ainda ser caracterizado por uma variedade de marcadores subclínicos associados. Por exemplo, dados epidemiológicos sugerem que indivíduos com FL/P apresentam uma maior incidência de anomalias dentárias do que indivíduos não-fissurados e ainda, que a severidade das anomalias dentárias parece estar relacionada à severidade da FL/P, sugerindo que a presença de anomalias dentárias em indivíduos com FL/P isolada poderia representar um marcador clínico adicional para a ocorrência de FL/P, implicando uma etiologia genética comum 
entre as duas condições (ADAMS; NISWANDER, 1967, SCHROEDER; GREEN, 1975, LARSON et al., 1998, VAN DEN BOOGARD et al., 2000, EERENS et al., 2001, SLAYTON et al., 2003, VIEIRA, 2003, AIZENBUD et al., 2005, STAHL et al., 2006).

Outra dificuldade relatada pelos autores está relacionada à interpretação dos resultados relatados na literatura, os quais muitas vezes são contraditórios possivelmente devido a viés de estudo, falta de poder estatístico, e diferenças entre populações estudadas, impondo outras dificuldades para o desenvolvimento de novos estudos. Dessa forma, os estudos genéticos recentes visam não só a identificação de novos genes/loci candidatos através de tecnologias avançadas, mas também testar genes/loci sugeridos como potencialmente envolvidos quanto a sua associação com a FL/P isolada (JUGESSUR; MURRAY, 2005, PARK et al., 2006).

Os genes de metaloproteinases da matriz (MMPs) têm sido sugeridos como possíveis candidatos à fissura labial e/ou palatina devido à importante função destas enzimas durante o desenvolvimento craniofacial (IAMAROON et al., 1996). Diversas evidências biológicas (IAMAROON et al., 1996, MORRIS-WIMAN, 1999; 2000, KERRIGAN et al., 2000, BLAVIER et al., 2001, BROWN et al., 2002) sugerem que os genes de diferentes MMPs e suas variações podem estar implicados nas anomalias de desenvolvimento do lábio e palato. Entretanto, até o presente momento, somente um estudo sugeriu uma possível associação entre uma determinada região cromossômica contendo o gene MMP25 e FL/P (BLANTON et al., 2004), revelando uma área relativamente inexplorada nas investigações sobre a etiologia genética da FL/P.

O gene TGFA (Fator de Crescimento Transformante Alfa) foi o primeiro gene associado à FL/P em humanos (ARDINGER et al., 1989). Esse gene foi escolhido juntamente com outros genes relacionados baseado em estudos com modelos animais demonstrando a sua importância na formação do palato (FERGUSON, 1988, DIXON et al., 1991; 1992, IAMAROON et al., 1996). Desde então, diversos estudos com diferentes populações demonstraram associação do TGFA com a FL/P enquanto outros não observaram tal associação. Alguns autores ainda consideram o TGFA como um importante coadjuvante na etiologia da FL/P, pois existem evidências que sugerem que o TGFA interage com fatores ambientais, como o tabagismo materno, ou atua como modificador do fenótipo individual (VIEIRA, 2006). 
Variações no gene IRF6 foram sugeridas como responsáveis pela contribuição genética de 12\% de todos os casos de FL/P (ZUCCHERO et al., 2004), após mutações neste gene terem sido identificadas como causadoras da síndrome de Van der Woude, caracterizada pela presença de FL/P e depressões no lábio inferior dos indivíduos afetados (KONDO et al., 2002). Desde então, estudos subseqüentes em diversas populações diferentes têm replicado estes resultados (BLANTON et al., 2005; GHASSIBÉ et al., 2005; SCAPOLI et al., 2005; SCHRIMTHONG et al., 2005). Estudos biológicos suportam um papel para o IRF6 na etiologia da FL/P, pois a expressão do IRF6 pode ser detectada em camundongos em desenvolvimento, na bainha epitelial dos processos palatinos, além de no germe dentário, folículo capilar, pele, e em diversos tecidos adultos de camundongos (KONDO et al., 2002).

Além dos genes supracitados, a utilização de abordagens estatísticas sofisticadas (VIELAND, 1998) desenvolvidas para avaliar a chance de determinado evento ocorrer em uma dada população, possibilitou a detecção de uma região no cromossomo 6q que apresenta uma probabilidade de $90 \%$ de conter um gene envolvido na etiologia da FL/P (GOVIL et al., 2006). Interessantemente, o gene DDO (Daspartate oxidase), localizado no cromossomo $6 \mathrm{q}$ se mostrou associado à FL/P (MARAZITA et al., 2006).

Em resumo, a complexidade e a diversidade dos mecanismos moleculares envolvidos na embriogênese, com ambos fatores genéticos e ambientais exercendo papéis fundamentais, proporcionam inúmeras oportunidades para investigar a etiologia da FL/P visando uma melhor compreensão do desenvolvimento embriológico humano e suas alterações. Dessa forma, o presente estudo teve como objetivo analisar os fenótipos e subfenótipos encontrados para a FL/P com base no desenvolvimento dental e suas alterações, e verificar a existência de associação entre polimorfismos nos genes MMP1, MMP3, MMP9, TGFA, IRF6, e genes contidos no cromossomo 6q, com a FL/P e seus subfenótipos. 


\section{REVISÃO DE LITERATURA}




\section{REVISÃO DE LITERATURA}

\subsection{Desenvolvimento Normal da Face}

O desenvolvimento normal da face humana compreende uma cascata de eventos complexos e rigidamente controlados durante o desenvolvimento embrionário, regulados através de genes cujos fatores de transcrição podem ser traduzidos em proteínas estruturais, regulatórias ou enzimáticas (SPERBER, 2002a).

Aproximadamente na quarta semana de vida intra-uterina, células originárias da crista neural cranial migram sob a forma de células mesenquimais para os processos embrionários craniofaciais durante o fechamento do tubo neural. Os segmentos da crista neural por sua vez migram para os arcos branquiais em desenvolvimento para se tornarem precursores de cartilagem, osso, músculo e tecido conjuntivo do complexo craniofacial. Uma série de eventos então se iniciam para induzir a formação das cinco proeminências faciais (frontonasal, maxilares e mandibulares bilateralmente) (GARCIA-CASTRO; BROMER-FRASER, 1999, SPERBER, 2002a, COBOURNE, 2004). A diferenciação, crescimento, e eventual fusão destas proeminências darão origem à face humana.

\subsubsection{Desenvolvimento do Palato Primário}

O palato primário consiste na porção da face que separa as cavidades oral e nasal, e compreende parte dos processos nasais mediais e laterais do processo frontonasal e parte dos processos maxilares que contribuem para a separação das cavidades nasal e oral (DIEWERT; LOSANOFF, 2002, JOHNSTON; BRINSKY, 2002; SPERBER, 2002b). A palatogênese do palato primário envolve uma série de eventos celulares e moleculares rigidamente controlados, onde determinadas alterações físicas e biomecânicas associadas ao crescimento craniofacial devem ocorrer especificamente durante a quinta a sétima semana de vida intra-uterina em humanos. $\mathrm{O}$ palato primário inicialmente se forma ao redor das narinas através da rápida proliferação do epitélio lateral e do mesênquima subjacente (CARSTENS, 2002). DIEWERT; LOSANOFF, 1993, demonstraram em embriões de camundongos e humanos, que conforme as proeminências faciais crescem ao redor das narinas para formar a região pré-maxilar, o crescimento do cérebro e dos componentes craniofaciais alteram a 
morfologia facial podendo afetar o período, a localização e a extensão do contato entre as proeminências faciais. Ao mesmo tempo, o cérebro se eleva à medida que o ângulo da base do crânio diminui, a região nasal medial se estreita, e a maxila cresce sagitalmente para encontrar as proeminências nasais medial e lateral. A partir daí, o lábio superior se forma através da fusão das proeminências nasais mediais projetadas a partir da proeminência frontonasal. Esta fusão requer a ocorrência coordenada entre crescimento das proeminências faciais, exata localização, e apoptose e/ou diferenciação do epitélio que forma a ponte nasal transitória entre os processos maxilares e frontonasal. A degradação da ponte nasal subjacente permite o fluxo de células mesenquimais entre os componentes medial e lateral do lábio superior, aproximadamente na sétima semana de vida intra-uterina. $\mathrm{O}$ desenvolvimento anormal deste epitélio pode estar implicado nas fissuras labiais e do palato primário (DIEWERT; LOSANOFF，2002，JOHNSTON; BRONSKY，2002, SPERBER, 2002b).

\subsubsection{Desenvolvimento do Palato Secundário}

O palato secundário compreende as partes do primórdio facial posterior ao palato primário e inclui os dois processos palatinos que se projetam medialmente a partir dos processos maxilares (DIEWERT; LOSANOFF, 2002, JOHNSTON; BRONSKY, 2002, SPERBER, 2002c).

Assim como na palatogênese do palato primário, o fechamento e a fusão do palato secundário requerem a completa interação dos movimentos dos processos palatinos. Durante a oitava semana de vida intra-uterina, os processos palatinos mudam de uma posição vertical a cada lado da língua e se elevam para assumirem uma posição horizontal, para então se encontrarem na linha média através de inúmeros desmossomos formando uma "bainha epitelial", conhecida como bainha epitelial medial, a qual desaparece gradativamente permitindo a confluência do mesênquima de ambos os processos palatinos. O desaparecimento da bainha epitelial medial é um fator essencial para a fusão e eventual ossificação dos processos palatinos, que prossegue da parte posterior do palato secundário em direção a pré-maxila durante a oitava semana de vida intra-uterina (DIEWERT; LOSANOFF，2002, JOHNSTON; BRONSKY，2002, SPERBER, 2002c). Diversas evidências têm sugerido que tanto processos de morte celular programada, migração celular para os epitélios nasal e oral, e transformação 
epitélio-mesenquimal podem estar envolvidos no desaparecimento da bainha epitelial medial (FITCHETT; HAY, 1989, CARETTE; FERGUSON, 1992). Tais processos envolvem a modulação de filamentos intermediários do citoesqueleto (por exemplo, citoqueratina e vimentina), moléculas de adesão celular (caderina-e), e da matriz extracelular (TUDELA et al., 2002).

Distúrbios em qualquer um dos estágios durante a palatogênese: crescimento inadequado dos processos palatinos, elevação atrasada ou falha na elevação dos processos, falhas durante a fusão, falhas levando ao não desaparecimento ou desaparecimento incompleto da bainha epitelial medial, ou ruptura pós-fusão, têm sido sugeridos como possíveis causas de fissuras no palato (FERGUSON, 1988).

\subsection{As Fissuras Labiais com ou sem Fissura Palatina (FL/P)}

As FL/P são defeitos congênitos comuns em humanos, devido a distúrbios no desenvolvimento embrionário normal, e podem ocorrer como característica de uma síndrome, como parte de um fenótipo resultante de aberrações cromossômicas, ou ainda como resultado da exposição materna a determinados teratógenos durante a gestação. Existem aproximadamente 400 síndromes em que a FL/P é considerada parte do fenótipo. Entretanto, a maioria das fissuras é considerada não sindrômica ou isolada, sem qualquer outra anomalia estrutural associada, e somam aproximadamente 70\% dos casos de FL/P (MURRAY, 2002).

Tipicamente, as FL/P são divididas em três grupos principais: fissura labial isolada (FL), fissura labial com ou sem fissura palatina (também denominada fissura lábio-palatina, FLP), e fissura palatina isolada (FP). A incidência relatada para FL/P varia de 1:500 a 1:1000 nascimentos dependendo da população. Para FP, a incidência relatada é menor, de 1:2500 nascimentos aproximadamente. Em geral, os indivíduos de descendência Asiática ou de Índios americanos apresentam maior incidência enquanto indivíduos de descendência Africana apresentam incidências menores, quando comparados a indivíduos caucasianos (NATSUME et al., 1987).

A etiologia da fissura isolada é considerada multifatorial, com componentes genéticos e ambientais. $O$ fato de que os genes atuam de modo determinante no desenvolvimento das estruturas craniofaciais normais é evidente em estudos com gêmeos monozigóticos. Entretanto, tal programação genética individual é 
extremamente sensível a distúrbios pós-concepção, o que pode ser constatado pela longa lista de teratógenos que acarretam FL/P. Fatores ambientais como déficit nutricional, uso de inseticidas, consumo de bebidas alcoólicas e tabagismo durante a gestação, assim como a interação entre estes e os fatores genéticos individualmente têm sido sugeridos como possíveis fatores causais da FL/P (MURRAY, 2002).

\subsection{Definição do Fenótipo}

A busca pela origem genética de qualquer condição através de técnicas de mapeamento genético começa com a definição do fenótipo e a classificação inapropriada ou insuficiente dos indivíduos afetados pode enfraquecer a habilidade de se detectar loci relevantes (HAINES; PERICAK-VANCE, 1998, RICE et al., 2001).

A maioria dos estudos genéticos se refere ao fenótipo das fissuras labiais com ou sem fissuras palatinas como fissura labial isolada (FL), fissura lábio-palatina (FLP), e fissura palatina (FP). FOGH-ANDERSEN, 1942, demonstrou que FP é uma entidade distinta de FL/P do ponto de vista embriológico. Entretanto, diferenças na etiologia ou epidemiologia de tais condições podem permanecer não reveladas devido à alta variabilidade no fenótipo.

Evidências recentes sugerem que o fenótipo da FL/P pode ser muito mais complexo do que se presume, podendo apresentar diversas combinações com relação ao lado afetado e extensão da fissura, ou ainda ser caracterizado por uma variedade de marcadores clínicos associados, os quais poderiam auxiliar na busca da etiologia genética da condição (VIEIRA, 2003). Esforços têm sido dispensados na tentativa de correlacionar características craniofaciais e FL/P utilizando abordagens imagenológicas, tais como ultra-som, radiografias cefalométricas e/ou fotografias (WEINBERG et al., 2006).

\subsubsection{Fissuras Labiais com ou sem Fissuras Palatinas e Anomalias Dentárias}

Os eventos mais críticos durante a formação dos dentes, lábios e palato apresentam períodos de desenvolvimento e localização similares. Muitos dos genes envolvidos no desenvolvimento dos dentes, lábios e palato são os mesmos. O epitélio odontogênico sobre os processos maxilares e mandibulares pode ser detectado no início 
da quinta semana de vida intra-uterina; a FL/P parece ocorrer durante a quarta até a sétima semana (TONGE, 1967). Proliferação e diferenciação celular, bem como apoptose, definem estas estruturas, enquanto que distúrbios nestes processos, por anormalidades ambientais e/ou genéticas, podem predispor a anomalias dentárias e fissuras.

As anomalias dentárias são sinais clínicos comuns em indivíduos com FL/P quando comparados com indivíduos sem fissura em diversas populações (RANTA，1982；1983；1986, RANTA;TULENSALO，1988，WERNER; HARRIS, 1989, HARRIS; HULLINGS, 1990, TSAI et al., 1998, SHAPIRA et al., 1999; 2000, SLAYTON et al., 2003, STAHL et al., 2006). A anomalia mais freqüentemente observada é a agenesia dentária (RANTA, 1983, JIROUTOVA, 1991, LAATIKAINEN; RANTA, 1994, SHAPIRA et al., 1999; 2000, EERENS et al., 2001, SLAYTON et al., 2003). Outras anomalias relatadas incluem atrasos no desenvolvimento da dentição (RANTA, 1982; 1983, NYSTROM; RANTA, 1988; HARRIS; HULLINGS, 1990), presença de dentes supranumerários (NAGAI et al., 1965; HANSEN; MEHDINIA, 2002), assimetria dental acentuada (SOFAER, 1979; NYSTROM; RANTA, 1988; WERNER; HARRIS, 1989), defeitos na formação do esmalte (DIXON, 1968; VICHI; FRANCHI, 1995; MALANCZUK et al., 1999), e microdontia (FOSTER; LAVELLE，1971; PETERKA; MULLEROVA，1983, WERNER; HARRIS, 1989; JAKSIC et al., 2002).

Existem evidências que suportam a idéia de uma possível origem genética comum entre $\mathrm{FL} / \mathrm{P}$ e agenesia dentária isoladas. A mutação mais intrigante relacionando as duas condições foi descrita por VAN DEN BOOGARD et al., 2000, no gene MSX1. A família afetada apresentava uma combinação de agenesia dentária, FL/P e FP. Esta família apresenta a evidência mais convincente de que alguns mecanismos são os mesmos para o desenvolvimento dos dentes, lábios e palato. Além do fato de que indivíduos com FL/P apresentam consideravelmente mais anomalias dentárias do que indivíduos não fissurados, existem evidências de que a severidade das anomalias parece estar relacionada à severidade da FL/P (ADAMS; NISWANDER, 1967, SCHROEDER; GREEN, 1975, RANTA, 1984; 1988, LARSON et al., 1998, VAN DEN BOOGARD et al., 2000, EERENS et al., 2001, DEWINTER et al., 2003, SLAYTON et al., 2003, VIEIRA, 2003, AIZENBUD et al., 2005, STAHL et al., 2006). 
A ocorrência simultânea de FL/P e agenesia dentária sugere que estes dois fenótipos possam estar geneticamente associados. Para se poder testar essa hipótese, uma descrição mais detalhada do fenótipo dental é necessária, com uma completa descrição das anomalias dentárias incluindo dentes ausentes e outros sinais, tais como microdontia e presença de dentes supranumerários. A análise seria realizada testando-se diferentes combinações de manifestações fenotípicas e dados moleculares.

\subsection{Genes Candidatos e Polimorfismos Genéticos}

Genes que potencialmente representam um papel na etiologia de uma alteração em particular são denominados candidatos àquela alteração. A maioria dos genes candidatos à FL/P foram originalmente sugeridos através de observações durante o processo de embriogênese em modelos animais (YOUNG et al., 2000). Outras indicações também surgiram de estudos com aberrações cromossômicas, e estudos de ligação com famílias de indivíduos afetados, apontando determinadas regiões cromossômicas como contendo possíveis genes candidatos (MURRAY, 2002).

Polimorfismos de um único nucleotídeo, também conhecidos como SNPs (single nucleotide polymorphisms), são formas variantes da seqüência de DNA que podem estar presentes nos indivíduos de uma população dentro de um espectro considerado biologicamente normal (KORNMAN et al., 1997). A hipótese de que a forma variante possa estar associada à função alterada de um gene em particular e conseqüentemente possa exercer algum papel na etiologia da FL/P pode ser analisada através da análise das freqüências desses polimorfismos em indivíduos afetados (PRESCOTT et al., 2000).

\subsection{Estudos Genéticos das Fissuras Labiais com ou sem Fissuras Palatinas}

Um componente hereditário para a FL/P foi descrito pela primeira vez por FOGH-ANDERSEN em 1942. Atualmente, é aceito que 2 a 14 genes possam estar envolvidos na etiologia da FL/P (SCHLIEKELMAN; SLATKIN, 2002).

Diversos estudos têm sugerido uma correlação entre a presença de FL/P e variações genéticas em ou próximos a determinados genes, tais como TGFA 
(ARDINGER et al., 1989), RARA (SHAW et al., 1993); TGFB3 (MAESTRI et al., 1997, LIDRAL et al., 1998, ROMITTI et al., 1999, VIEIRA et al., 2003), BCL3 (Bcell lymphoma 3) e PVR (poliovirus receptor) (STEIN et al., 1995, MAESTRI et al., 1997, WYSZYNSKI et al., 1997b, WARRINGTON et al., 2006), MSX1 (muscle segment homeobox 1) (LIDRAL et al., 1998, JEZEWSKI et al., 2003, VIEIRA et al., 2003, SUZUKI et al., 2004), IRF6 (ZUCCHERO et al., 2004, BLANTON et al., 2005, GHASSIBE et al., 2005, SCAPOLI et al., 2005, SCHRIMTHONG et al., 2006), PVRL1 (poliovirus receptor-related 1) (SOZEN et al., 2001, AVILA et al., 2006), FGFs (fibroblast growth receptors) (RILEY et al., 2007), entre outros (VIEIRA et al., 2005). Ainda, uma meta-análise sugeriu um possível envolvimento de genes contidos nos cromossomos 1p, 2q, 6p, 6q, 9q, 14q, 15q, 17q e 19q (MARAZITA et al., 2004). Todavia, a natureza e a função dos genes envolvidos na etiologia da FL/P variam amplamente, sugerindo a alta vulnerabilidade dos processos de desenvolvimento craniofacial, e a complexidade envolvida nos estudos genéticos da FL/P.

\subsection{As Metaloproteinases da Matriz Extracelular}

As metaloproteinases da matriz extracelular (MMPs) constituem uma família de enzimas extracelulares que apresentam domínios estruturais funcionais e mecanismos de ativação similares. As MMPs são endopeptidases cálcio- e zincodependentes, sintetizadas como pró-enzimas secretadas ou de membrana, e cuja ativação requer a remoção de um peptídeo amino-terminal. A maioria destas enzimas não é constitutivamente expressa, e o processo de transcrição só se inicia mediante ativação celular (STERNLICHT; WERB 2001, HANNAS et al., 2007).

Existem 23 MMPs humanas descritas, distribuídas em classes diferentes de acordo com a homologia na seqüência de amino ácidos, presença de domínios peptídicos estruturais específicos, e especificidade do substrato in vivo. As três principais classes de MMPs são: (1) colagenases, ativas contra colágenos fibrilares, (2) gelatinases, altamente ativas contra colágenos desnaturados (gelatina), e (3) estromelisinas, que degradam os componentes não-colágenos da matriz extracelular. Outras classes incluem as MMPs de membrana, matrilisinas, elastase, entre outras (NAGASE, 2006). 
As MMPs são responsáveis pela degradação e remodelação da matriz extracelular e por isso exercem papéis fundamentais durante o desenvolvimento embrionário, não somente removendo moléculas indesejadas, mas também influenciando diversas funções celulares tais como migração e proliferação celular, e modulação de moléculas biologicamente ativas (NAGASE, 2006).

Uma série de mecanismos transcricionais e pós-transcricionais controlam a expressão e a atividade das MMPs individualmente. Acredita-se que para a maioria das MMPs, o principal mecanismo seja a regulação da transcrição, já que as MMPs são expressas somente em períodos de remodelação tecidual ativa (STERNLICHT; WERB 2001). Alguns polimorfismos nos genes de MMPs apresentam efeitos aleloespecíficos sobre as atividades transcricionais das regiões promotoras dos genes, possivelmente contribuindo para diferenças interindividuais na susceptibilidade a doenças complexas, provavelmente através de alterações no equilíbrio entre síntese e degradação de proteínas da matriz extracelular (YE, 2000).

Apesar da formação do palato incluir a síntese e degradação da matriz extracelular do palato, o exato papel das MMPs durante a palatogênese ainda não está bem estabelecido. No entanto, os genes de MMPs podem ser considerados possíveis candidatos devido à importante atuação destas enzimas na remodelação da matriz extracelular durante o desenvolvimento craniofacial (IAMAROON et al., 1996; KERRIGAN et al., 2000). Diversas evidências biológicas sugerem que os genes de diferentes MMPs e suas variações podem estar implicados nas anomalias de desenvolvimento do lábio e palato. A expressão de MMPs, em particular MMPs 2, 3, 7 , 9, e 13, foi observada em padrões temporais e espaciais específicos no desenvolvimento do palato em camundongos (MORRIS-WIMAN et al., 1999; 2000, MANSELL et al., 2000, BLAVIER et al., 2001). Outros estudos ainda demonstraram que a degradação proteolítica da matriz extracelular que precede a fusão do palato só ocorre na presença de MMPs, sugerindo que alterações na expressão destas enzimas poderiam conseqüentemente acarretar em distúrbios nas etapas finais da palatogênese (BLAVIER et al., 2001, BROWN et al., 2002).

O processo de transformação epitélio-mesenquimal no palato requer diversas etapas para que as duas superfícies epiteliais se fundam e as células migrem para os epitélios nasal ou oral. As células apresentam um aumento na expressão de moléculas sinalizadoras, incluindo MMPs, para que a degradação da matriz extracelular ocorra devidamente (KANG; SVOBODA, 2005). Uma redução nos níveis de MMPs 
poderia hipoteticamente acarretar em falhas durante a fusão do palato levando ao aparecimento de fissura palatina.

Entretanto, apesar das evidências implicando as MMPs como moléculas essenciais durante a formação do lábio e do palato, nenhum estudo até hoje investigou o envolvimento das MMPs na etiologia da FL/P. O único relato sugerindo o envolvimento de uma MMP com a FL/P é resultado de um estudo utilizando regiões cromossômicas candidatas a FL/P sugeridas por buscas por todo o genoma, que encontrou um lócus contendo o gene MMP25, como potencialmente envolvido na etiologia da FL/P (BLANTON et al., 2004).

\subsubsection{MMP1}

A MMP-1 pertence à família das colagenases e é a MMP mais abundantemente expressa em humanos. Apresenta atividade proteolítica contra colágenos fibrilares (colágenos tipo I, II e III), componentes mais abundantes do tecido conjuntivo intersticial (DUNLEAVEY et al., 2000). A MMP-1 é expressa durante o desenvolvimento craniofacial, e embora nenhum relato aborde a sua expressão durante a palatogênese especificamente, a MMP-1 tem sido implicada como um gene importante durante o desenvolvimento da dentição (RANDALL; HALL, 2002).

O gene MMP1 está localizado no cromossomo 11q22.3 próximo ao gene MMP3. Ambos estão em desequilíbrio de ligação e portanto existe a chance de estarem atuando em conjunto (HINODA et al., 2002). Polimorfismos no gene MMP1 têm sido associados principalmente a condições inflamatórias e patológicas caracterizadas por destruição de tecidos colágenos (YE, 2000, DE SOUZA et al., 2003, ASTOLFI et al., 2006, LIEVRE et al., 2007). Um dos polimorfismos mais comumente descritos encontra-se na posição -1607 da região promotora do gene MMP1, devido à inserção/deleção de uma guanosina $(\mathrm{G})$ (polimorfismo $1 \mathrm{G} / 2 \mathrm{G}$ ). A presença do alelo $2 \mathrm{G}$ em conjunto com uma adenosina cria um sítio de ligação (5'-GGA-3') para a família de fatores de transcrição Ets, resultando em um aumento de 37 vezes na atividade transcricional da enzima (RUTTER et al., 1998). Entretanto, não existem relatos na literatura sobre polimorfismos neste gene e anomalias de desenvolvimento craniofacial. 


\subsubsection{MMP3}

A MMP-3 pertence à classe das estromelisinas, e o seu gene está situado no cromossomo 11q22.3. A MMP-3 apresenta ampla especificidade de substratos, incluindo colágenos tipo III, IV e V, e componentes não colágenos, como proteoglicanas, fibronectina e laminina. Estudos in vivo demonstraram a imunolocalização destas enzimas subjacente ao epitélio medial, logo após o contato dos processos palatinos na linha média (BROWN et al., 2002). A MMP-3 exerce um papel importante no processo de transformação epitélio-mesenquimal, e a indução de sua expressão resulta na ativação de caderina, perda do fenótipo epitelial e subseqüente conversão de epitélio a mesênquima (LOCHTER et al., 1997). Níveis elevados e constantes de MMP-3 foram observados nos estágios finais da palatogênese, sugerindo que a presença de MMP-3 neste determinado período pode significar o estímulo necessário para o início do processo de transformação epitélio-mesenquimal (MANSELL et al., 2000).

Alterações patológicas na expressão de MMP-3 têm sido associadas a diversas condições sistêmicas, tais como aterosclerose e outras doenças cardiovasculares (YAMADA, 2006), provavelmente devido à ampla variedade de substratos degradada pela enzima. Um polimorfismo funcional no gene MMP3 é resultado de uma variação do comprimento de uma série de adenosinas (A) localizadas na posição -1171 da região promotora, onde podem existir 5 ou 6 adenosinas em seqüência. A presença de 5 adenosinas (alelo 5A) está associada à expressão elevada da MMP-3 in vitro (YE et al., 1995; 1996). Assim como com o gene MMP1, todavia, não existem relatos de polimorfismos no gene MMP3 e anomalias de desenvolvimento craniofacial.

\subsubsection{MMP9}

O gene MMP9 está localizado no cromossomo 20q12.2. Também denominada gelatinase B, a MMP-9 é conhecida por sua habilidade em degradar colágenos tipo IV, V e XI, proteoglicanas e elastina (VU et al., 1998), e em facilitar o processo de migração celular (ZHANG et al., 1999).

Estudos anteriores demonstraram a expressão seletiva e elevada da enzima MMP-9 nos centros de ossificação da maxila em desenvolvimento, logo após a 
reorientação horizontal dos processos palatinos e durante a fusão do palato, e a redução da expressão tão logo a fusão estar completa (MORRIS-WIMAN et al., 2000, BLAVIER et al., 2001), sugerindo uma possível atuação durante os eventos finais da palatogênese. Conseqüentemente, alterações na expressão da MMP-9 devido a variações na estrutura do gene poderiam acarretar falhas durante o processo final de fusão do palato. Um polimorfismo na região promotora do gene MMP9 (-1562 C/T) acarreta em um efeito sobre a transcrição do gene MMP9, onde a troca de uma citosina (C) por uma timina $(\mathrm{T})$ resulta na perda de ligação de uma proteína nuclear nesta região e conseqüentemente resulta em um aumento na atividade transcricional (ZHANG et al. 1999).

\subsection{Fator Transformador de Crescimento Alfa (TGFA)}

O gene TGFA está localizado no cromossomo 2p13 (BRISSENDEN et al., 1985, TRICOLI et al., 1986) e sua expressão ocorre em diversos tecidos desde a embriogênese até a fase adulta (RAPOLEE et al., 1988). Durante o desenvolvimento craniofacial, o gene TGFA é expresso no epitélio medial no momento da fusão dos processos palatinos (DIXON et al., 1991, IAMAROON et al, 1996, MIETTINEN et al., 1999). No tecido de palato cultivado, o gene TGFA promove a síntese de matriz extracelular e migração de células mesenquimais, e subseqüentemente a resistência do palato fusionado (DIXON; FERGUSON, 1992). Apesar do gene TGFA ser expresso durante a palatogênese em camundongos, camundongos que não expressam o gene possuem pele, pelos e olhos anormais mas não possuem fissura palatina (LUETTEKE et al., 1993, MANN et al., 1993). Entretanto, camundongos "knockout” para o gene do receptor do fator de crescimento epidermal (EGFR) apresentam uma alta incidência de fissura de palato, e isto sugere uma explicação para a correlação genética da FL/P com polimorfismos no gene TGFA (MIETTINEN et al., 1999), uma vez que TGFA é um provável ligante do EGFR.

ARDINGER et al., 1989, descreveu pela primeira vez um possível envolvimento do gene TGFA com a etiologia da FL/P. Desde então, alguns estudos confirmaram tal resultado (CHENEVIX-TRENCH et al., 1991; 1992, HOLDER et al., 1992, SASSANI et al., 1993, STOLL et al., 1993, FENG et al., 1994, FIELD et al., 1994, HWANG et al., 1995, JARA et al., 1995a; 1995b, SHAW et al., 1996, 
PRESCOTT et al., 2000, TANABE et al., 2000, BEATY et al., 2002; 2006, MARAZITA et al., 2002, YUAN et al., 2006, MORKŪNIENE் et al., 2007), enquanto outros não observaram correlação alguma (HECHT et al., 1991, VINTINER et al., 1992; BEATY et al., 1997; 2001, LIDRAL et al., 1997, WYSZYNSKI et al., 1997a, SCAPOLI et al., 1998, CHRISTENSEN et al., 1999, ROMITTI et al., 1999,; MARAZITA et al., 2002; PASSOS-BUENO et al., 2004). Outros estudos ainda sugeriram um papel para o TGFA como fator modificador na etiologia da FL/P, interagindo com outros genes e/ou fatores ambientais (FIELD et al., 1994).

Atualmente, mais de 370 polimorfismos foram descritos para o gene TGFA. Entretanto, os relatos atuais corroboram a hipótese de um efeito reduzido do gene TGFA sobre o risco de ocorrência de FL/P em humanos, onde o TGFA modifica a expressão (severidade) da FL/P. Mesmo que pequeno, o papel do TGFA na etiologia da FL/P não deixa de ser significante, e variações neste gene podem representar uma causa rara de FL/P em humanos (VIEIRA, 2006).

\subsection{Fator Regulador de Interferon-6 (IRF6)}

O gene IRF6 (1q32) faz parte de uma família de genes (IRF) que codifica fatores de transcrição e regula a expressão de interferons $-\alpha$ e $-\beta$ após infecções virais. A função exata do IRF6 permanece desconhecida; entretanto, mutações no gene IRF6 foram identificadas em famílias de indivíduos afetados pelas síndromes de Van der Woude (OMIM 119300) e do Pterígio Poplíteo OMIM 119500), ambas caracterizadas pela presença de FL/P (KONDO et al., 2002). Adicionalmente, polimorfismos na estrutura do IRF6 foram relatadas como responsáveis por aproximadamente $12 \%$ de toda a contribuição genética em casos de FL/P isolada (ZUCCHERO et al., 2004), tornando este gene um dos mais significativos até hoje identificados. Em seu estudo cobrindo 36 polimorfismos na região do IRF6, com mais de 8000 indivíduos pertencentes a populações da Ásia, Europa e América do Sul, os autores demonstraram a associação de um destes polimorfismos em todas as populações estudadas e relataram ainda que variações na estrutura do IRF6 podem somar $12 \%$ do risco de ocorrência da FL/P isolada. Ainda, os autores encontraram transmissão preferencial do alelo ancestral da variante V274I em indivíduos com descendência asiática com FL/P isolada, mas não em descendentes europeus. 
Estudos subseqüentes confirmaram a associação de polimorfismos no gene IRF6 e FL/P em diversas populações (SCAPOLI et al., 2005, BLANTON et al., 2005, GHASSIBÉ et al., 2005, SCHRIMTHONG et al., 2005, VIEIRA et al., 2007), o que praticamente confirma o IRF6 como fator etiológico para FL/P. O IRF6 é expresso no epitélio medial dos processos palatinos durante o processo de fusão do palato secundário, nos germens dentários, folículos capilares, e pele de camundongos (KONDO et al., 2002). INGRAHAM et al., 2006, relataram que camundongos que não expressam o gene IRF6 apresentam defeitos no desenvolvimento craniofacial, pele e membros, e são caracterizados também pela presença de fissura palatina, a qual parece ser causada primariamente por defeitos na elevação dos processos palatinos, ou por distúrbios durante o desenvolvimento craniofacial devido à ação constritora da pele ou tecidos orais.

\subsection{Cromossomo 6q}

Estudos sobre a organização do genoma humano (SABETI et al., 2002) têm demonstrado que este contém longos segmentos apresentando alto desequilíbrio de ligação e diversidade de haplótipos limitada, sugerindo que o uso de informações sobre haplótipos é potencialmente útil para os estudos de associação. O termo "desequilíbrio de ligação" significa associação de alelos. Quando dois alelos em loci distintos são transmitidos aos gametas mais freqüentemente do que o esperado, e uma vez que as freqüências dos alelos e a fração de recombinação entre os dois loci são conhecidas, os alelos são considerados em desequilíbrio de ligação um com o outro. Evidências de desequilíbrio de ligação podem ser úteis no mapeamento de genes responsáveis por doenças complexas uma vez que sugerem que os dois loci em desequilíbrio de ligação podem estar localizados próximos uns dos outros.

VIELAND, 1998, descreveu um método para medir a probabilidade de se ter encontrado um resultado de ligação verdadeiro, através da interpretação das evidencias a favor ou contra estes resultados independente da quantidade de evidências disponíveis. GOVIL et al., 2006, utilizaram este método na avaliação de estudos de ligação de FL/P e apontaram uma região de $14 \mathrm{cM}$ no cromossomo $6 \mathrm{q}$ como apresentando aproximadamente $90 \%$ de chance de conter um gene associado a FL/P. Adicionalmente, análises recentes sugeriram resultados intrigantes para regiões nos 
cromossomos 6q e 9q em associação com tipos específicos de fissura, e um gene (DDO) no cromossomo 6q se mostrou associado à FL/P (MARAZITA et al., 2006). 
3 PROPOSIÇÃO 


\section{PROPOSIÇÃO}

Com base nos fatos expostos nas seções anteriores, o objetivo deste estudo foi:

1. Analisar os tipos de FL/P e das anomalias dentárias encontradas na população estudada;

2. Verificar a existência de associação entre polimorfismos nos genes $M M P 1, M M P 3$, MMP9, IRF6 e TGFA, com a FL/P e seus subfenótipos;

3. Verificar a existência de associação entre polimorfismos situados no cromossomo 6q com a FL/P e seus subfenótipos. 
4 - MATERIAL E MÉTODOS 


\section{MATERIAL E MÉTODOS}

\subsection{MATERIAL}

\subsubsection{População estudada}

Quinhentos (500) pacientes portadores de FL/P isolada em tratamento no Setor Odontológico do Hospital de Reabilitação de Anomalias Craniofaciais da Universidade de São Paulo (HRAC/USP) e quinhentos (500) indivíduos sem FL/P e sem história positiva familiar foram utilizados neste estudo. Este estudo foi aprovado pelo Comitê de Ética em Pesquisa do Hospital de Reabilitação e Anomalias Craniofaciais (HRAC/USP) e pela Comissão Nacional de Ética em Pesquisa do Ministério da Saúde do Brasil (CONEP) (Anexo 1). Os indivíduos foram incluídos no estudo após a leitura e assinatura do Termo de Consentimento Livre e Esclarecido (Anexo 2).

\subsection{MÉTODO}

\subsubsection{Definição do fenótipo}

Todos os indivíduos foram analisados clinicamente e/ou através de fichas clínicas e exames radiográficos para os seguintes parâmetros: presença de fissura (FL, FLP ou FP), extensão (completa ou incompleta) e lado da fissura (direito, esquerdo, bilateral, e central), presença de anomalias dentárias (agenesia, microdontia, dente supranumerário, lateroversão ou giroversão, retenção, anomalias de forma e transposição). A presença de múltiplas anomalias dentárias foi registrada na ocasião de um mesmo indivíduo apresentar duas ou mais anomalias distintas. Para cada anomalia, o critério de inclusão foi a presença de pelo menos um dente permanente afetado. As anomalias presentes nas áreas de fissura não foram consideradas por serem conseqüências de alterações de desenvolvimento naquela região. Indivíduos cujo tipo e/ou lado da fissura não puderam ser determinados através de exame clínico ou através 
das fichas clínicas foram considerados como apresentando "tipo/lado de fissura desconhecido".

Adicionalmente, para cada indivíduo, as seguintes informações demográficas foram registradas: história familiar positiva para FL/P, idade, profissão e residência (localização geográfica) dos pais na época da gestação, história de tabagismo materno, uso de substâncias alcoólicas e/ou teratogênicas durante a gestação.

Todos os dados foram registrados em uma ficha individual para cada paciente e então transferidos para uma base de dados.

\subsubsection{Coleta de material biológico}

Amostras de saliva foram coletadas de todos os indivíduos como fonte de DNA genômico seguindo protocolos previamente publicados (TREVILLATO; LINE, 2000). Em resumo, os indivíduos realizaram um bochecho com $5 \mathrm{~mL}$ de solução de dextrose a 5\% durante 1 minuto, após o qual todo o volume do bochecho foi acondicionado em tubos para centrífuga de $15 \mathrm{~mL}$ (Corning Inc., Corning, NY, EUA). Cada tubo contendo saliva foi então centrifugado a $2000 \mathrm{rpm}$ durante 10 minutos para sedimentação do pellet de células. O sobrenadante foi descartado e o pellet transferido para um tubo eppendorf de 1,5mL (Fisher Scientific, Pittsburgh, PA, EUA) contendo $1 \mathrm{~mL}$ de tampão de extração (Tris-HCl 10mM, pH 7.8; EDTA 5mM; SDS 0.5\%) e congelado a $-20^{\circ} \mathrm{C}$ até o momento da extração do DNA.

\subsubsection{Extração do DNA}

Previamente à extração do DNA, as amostras foram descongeladas e incubadas com 100ng/mL Proteinase K (Invitrogen Laboratories, Carlsbad, CA, EUA) em banho-maria a $56^{\circ} \mathrm{C}$ overnight e então submetidas a processos de precipitação utilizando-se solução de acetato de amônio a 10M e purificação com etanol/isopropanol (Anexo 4). A concentração do DNA foi estimada através de medições de OD 260 (MANIATIS, 1989). 


\subsubsection{Seleção dos genes candidatos e polimorfismos genéticos de um único nucleotídeo (SNPs - single nucleotide polimorphisms)}

Para este estudo foram selecionados os SNPs que se classificassem, de preferência, como: 1) potencialmente funcionais por alterarem a seqüência de aminoácidos da proteína final, por ocorrerem próximo à região promotora do gene e potencialmente influenciarem a expressão gênica, ou ainda os que demonstraram alterar a função ou expressão do gene, e 2) SNPs em desequilíbrio de ligação com outros SNPs em regiões de um gene candidato. CARLSON et al., 2004, descreveram uma abordagem para seleção do mínimo de SNPs representando ao máximo a estrutura de desequilíbrio de ligação de determinada região. Os dados do International HapMap Project (THE INTERNATIONAL HAPMAP CONSORTIUM, 2003) foram utilizados para auxiliar na seleção dos SNPs. A distribuição dos haplótipos e a estrutura dos genes foram identificadas para otimizar a cobertura da região a ser estudada e para se selecionar os SNPs mais informativos.

Devido aos dados do HapMap Project serem derivados de populações de não-brasileiros, os genótipos gerados no nosso estudo servirão para uma primeira análise dos haplótipos na nossa população, o que, certamente, poderá beneficiar futuros estudos.

\subsubsection{Genotipagem}

As amostras de DNA genômico foram inicialmente amplificadas através da reação de polimerase em cadeia (PCR - Polymerase Chain Reaction) (SAIKI et al., 1985) utilizada em três tecnologias distintas. As reações de PCR convencional (MMP1, MMP3 e MMP9) foram realizadas em volume total de $25 \mu \mathrm{L}$, contendo 50ng de DNA genômico/reação, $10 \mathrm{mM}$ de tampão de reação (Tris-HCl pH 8.3), $1 \mu \mathrm{M}$ de cada primer, $200 \mathrm{mM}$ dNTPs, $50 \mathrm{mM} \mathrm{KCl}, 1,5 \mathrm{mM} \mathrm{MgCl}_{2}$, e 2,5 unidades de Taq DNA polimerase (Invitrogen Laboratories, Carlsbad, CA, EUA) em um aparelho GeneAmp PCR System 9700 (Perkin Elmer, Norwalk, CT, EUA). As reações de PCR cinético (TGFA C3827T e C3296T) foram realizadas em um seqüenciador automático (ABI PRISM® ${ }^{\circledR}$ 7900HT, Applied Biosystems, Foster City, CA, EUA) em volume total de $3 \mu \mathrm{L}$ contendo 2 ng DNA/reação, 1,8 $\mu \mathrm{L}$ de SYBR ${ }^{\circledR}$ Green PCR Master Mix (Applied Biosystems, Foster 
City, CA, EUA) e 0,1 $\mu \mathrm{L}$ de cada primer (IDT Technologies, Coralville, IA, EUA). As reações de PCR pelo método Taqman (RANADE et al., 2001) (Applied Biosystems, Foster City, CA, EUA) foram realizadas em um seqüenciador automático (ABI PRISM® 7900HT, Applied Biosystems, Foster City, CA, EUA) em volume total de $3 \mu \mathrm{L}$ contendo 2 ng DNA/reação, $1,5 \mu \mathrm{L}$ de Taqman PCR Master Mix (Applied Biosystems, Foster City, CA, EUA) e $0,425 \mu \mathrm{L}$ de água deionizada estéril.

Informações adicionais com relação a genotipagem dos indivíduos para cada polimorfismo estudado seguem em detalhes.

\subsubsection{MMP1 (-1607 1G/2G)}

A região incluindo a posição -1607 no promotor do gene MMP1 (Figura 1) foi amplificada através da técnica de PCR conforme o item 4.2.5. A seqüência dos primers e as condições de PCR utilizadas para MMP1 estão listadas no Quadro 1.

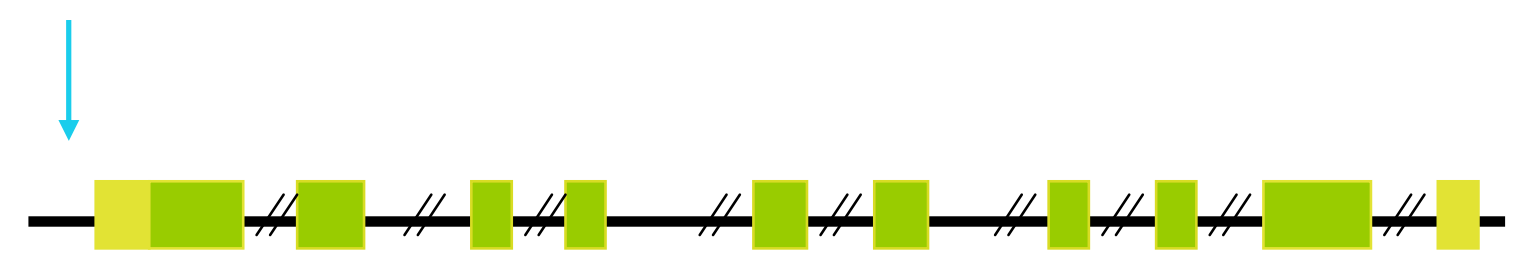

Figura 1. Estrutura do gene MMP1 (11q22.2). Caixas verdes representam regiões codificadoras, barras pretas representam íntrons, caixas amarelas representam regiões nãotraduzidas. A seta azul indica a localização do polimorfismo estudado (-1607 1G/2G). 
Quadro 1. Condições experimentais para o polimorfismo -1607 1G/2G no gene MMP1.

\begin{tabular}{|c|c|}
\hline & MMP1 (-1607 1G/2G) \\
\hline Primer forward & $5^{`}$ TCGTGAGAATGTCTTCCCATT 3 \\
\hline Primer reverse & $5^{`}{\mathrm{TCTTGGATTGATTTGAGATAAGTGAAATC} 3^{`}}^{\prime}$ \\
\hline Condições de PCR & $\begin{array}{c}95^{\circ} \mathrm{C} \text { por } 1 \text { min }(1 \text { ciclo }), 35 \text { ciclos: } 95^{\circ} \mathrm{C} \text { por } 30 \text { segundos, } 54^{\circ} \mathrm{C} \text { por } \\
30 \text { segundos, } 72^{\circ} \mathrm{C} \text { por } 30 \text { segundos, extensão final a } 72^{\circ} \mathrm{C} \text { por } 7 \\
\text { minutos. }\end{array}$ \\
\hline
\end{tabular}

Após a amplificação inicial, os genótipos foram obtidos através de digestão enzimática (RFLP - Restriction-Fragment Length Polymorphism) realizada em volume total de $10 \mu \mathrm{L} /$ reação, contendo $5 \mu \mathrm{L}$ do produto de PCR e $5 \mu \mathrm{L}$ de uma solução contendo $2 \mu \mathrm{L}$ de tampão $\mathrm{NE} 10 \mathrm{X}(50 \mathrm{mM} \mathrm{NaCl}, 10 \mathrm{mM}$ Tris-HCl $\mathrm{pH} 7.8,10 \mathrm{mM}$

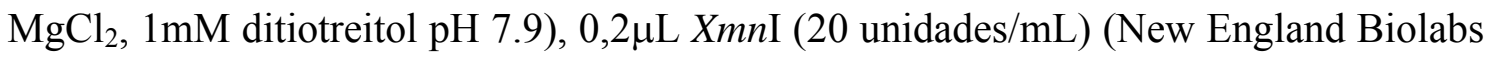
Inc., Beverly, MA, EUA), 0,3 $\mu \mathrm{L}$ de albumina e $2,5 \mu \mathrm{L}$ de água deionizada estéril, sob incubação a $37^{\circ} \mathrm{C}$ overnight. Dois erros foram introduzidos no primer reverse anelado na proximidade do polimorfismo (DUNLEAVEY et al., 2000) criando uma seqüência de reconhecimento (5'-GAANNNNTTC-3') para a enzima de restrição XmnI quando a amostra contém o alelo $1 \mathrm{G}$ (mas não o $2 \mathrm{G}$ ) no local do polimorfismo. Assim, a enzima digere o alelo $1 \mathrm{G}$, criando dois fragmentos de 89 pb e 29 pb. O conteúdo digerido foi adicionado a $1 \mu \mathrm{L}$ de tampão de corrida (Invitrogen Laboratories, Carlsbad, CA, EUA) e analisado em gel de eletroforese não-denaturante a 10\% (Anexo 6), corado pela técnica de impregnação pela prata (SANGUINETTI et al., 1994) (Anexo 7). Um padrão de peso molecular de 1000 pb (Invitrogen Laboratories, Carlsbad, CA, EUA) foi utilizado como referência em todos os géis para identificação apropriada dos produtos (Figura 2). 


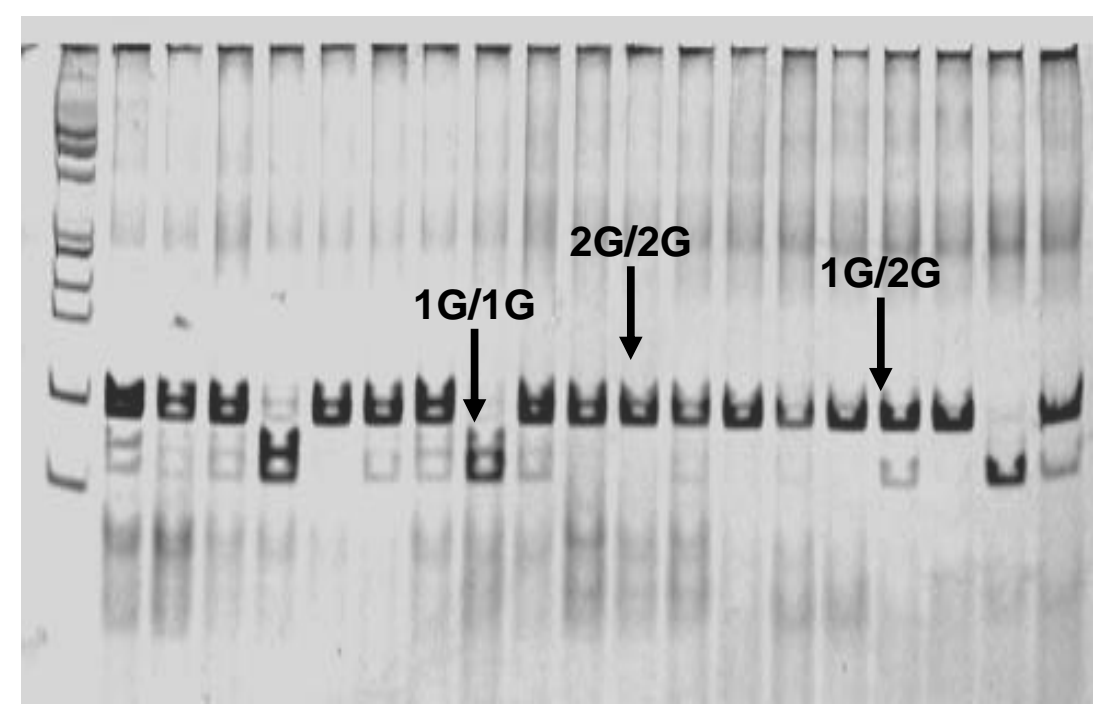

Figura 2. Polimorfismo -1607 1G/2G na região promotora do gene MMP1.

\subsubsection{MMP3 (-1171 5A/6A)}

A região incluindo a posição -1171 no promotor do gene MMP3 (Figura 3) foi amplificada através da técnica de PCR conforme o item 4.2.5, utilizando dois primers forward alelo-específicos e um único primer reverse. Dois primers forward alelo-específicos e um único primer reverse foram utilizados. Um dos primers forward amplifica um fragmento de $95 \mathrm{pb}$ relativo ao alelo $5 \mathrm{~A}$ e o outro amplifica um fragmento de $92 \mathrm{pb}$ relativo ao alelo 6A (Figura 4). A seqüência dos primers e as condições de PCR utilizadas para MMP3 estão listadas no Quadro 2.

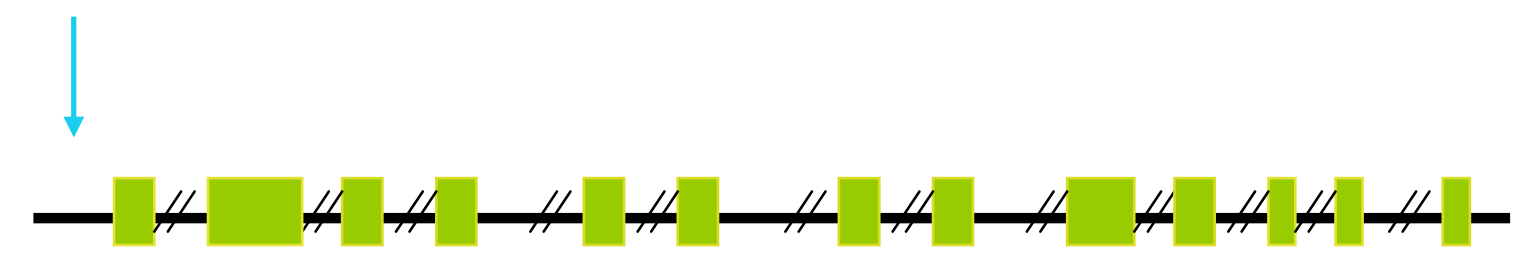

Figura 3. Estrutura do gene MMP3 (11q22.3). Caixas verdes representam regiões codificadoras, barras pretas representam íntrons. A seta azul indica a localização do polimorfismo estudado (-1171 5A/6A). 
Quadro 2. Condições experimentais para o polimorfismo -1171 5A/6A no gene MMP3.

\begin{tabular}{|c|c|}
\hline & MMP3 (-1171 5A/6A) \\
\hline $\begin{array}{l}\text { Primer forward } \\
\text { (alelo 5A) }\end{array}$ & 5' GACAAGACATGGTTTTTC $3{ }^{`}$ \\
\hline $\begin{array}{l}\text { Primer forward } \\
\text { (alelo 6A) }\end{array}$ & 5’AAGACATGGTTTTTT 3’ \\
\hline Primer reverse & 5'AGACATGGGTCACGG $3{ }^{\prime}$ \\
\hline Condições de PCR & $\begin{array}{c}95^{\circ} \mathrm{C} \text { por } 3 \text { minutos ( } 1 \text { ciclo), } 35 \text { ciclos: } 95^{\circ} \mathrm{C} \text { por } 1 \text { minuto, } 41^{\circ} \mathrm{C} \\
\text { (alelo } 6 \mathrm{~A} \text { ) por } 1 \text { minuto ou } 44^{\circ} \mathrm{C} \text { (alelo } 5 \mathrm{~A} \text { ) por } 1 \text { minuto, } 72^{\circ} \mathrm{C} \text { por } 1 \\
\text { minuto, extensão final a } 72^{\circ} \mathrm{C} \text { por } 7 \text { minutos. }\end{array}$ \\
\hline
\end{tabular}

Os produtos amplificados em cada reação foram adicionados a $1 \mu \mathrm{L}$ de tampão de corrida (Invitrogen Laboratories, Carlsbad, CA, EUA) e analisados em gel de eletroforese não-denaturante a $10 \%$, corado pela técnica de impregnação pela prata (SANGUINETTI et al., 1994). Para um mesmo paciente, os produtos amplificados foram aplicados no gel, com a primeira fileira destinada à reação contendo o primer específico para o alelo 5A e a segunda contendo a reação para o alelo 6A. Assim, indivíduos apresentando genótipo 5A/5A apresentavam uma banda para o alelo $5 \mathrm{~A}$ somente e nenhuma banda na fileira seguinte, contendo a reação para o alelo 6A. Indivíduos com genótipo 6A/6A apresentam banda somente na fileira contendo a reação para o alelo 6A. Indivíduos heterozigotos apresentam ambas as bandas. Um padrão de peso molecular de 1000 pb (Invitrogen Laboratories, Carlsbad, CA, EUA) foi utilizado como referência em todos os géis para identificação apropriada dos produtos (Figura 4). 


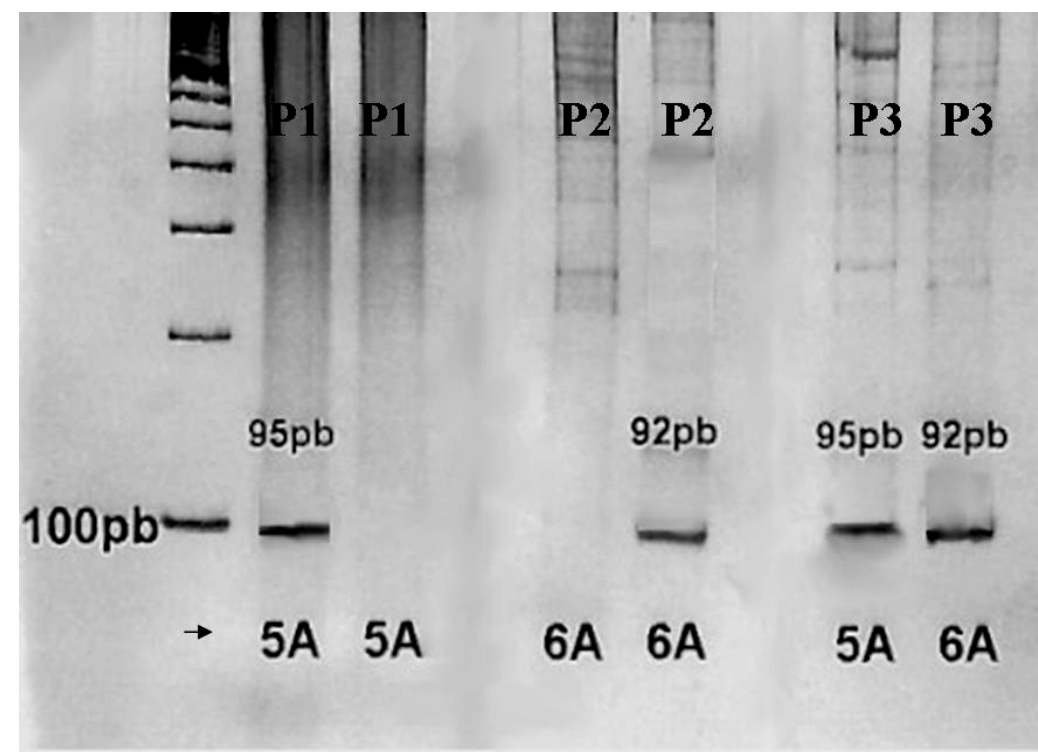

Figura 4. Polimorfismo -1171 5A/6A na região promotora do gene MMP3.

\subsubsection{MMP9 (-1562 C/T)}

A região incluindo a posição -1562 no promotor do gene MMP9 (Figura 5) foi amplificada através da técnica de PCR conforme o item 4.2.5. Os indivíduos foram genotipados através da técnica de RFLP-PCR (Restriction Fragment Length Polymorphism). A seqüência dos primers e as condições de PCR utilizadas para MMP9 estão listadas no Quadro 3.

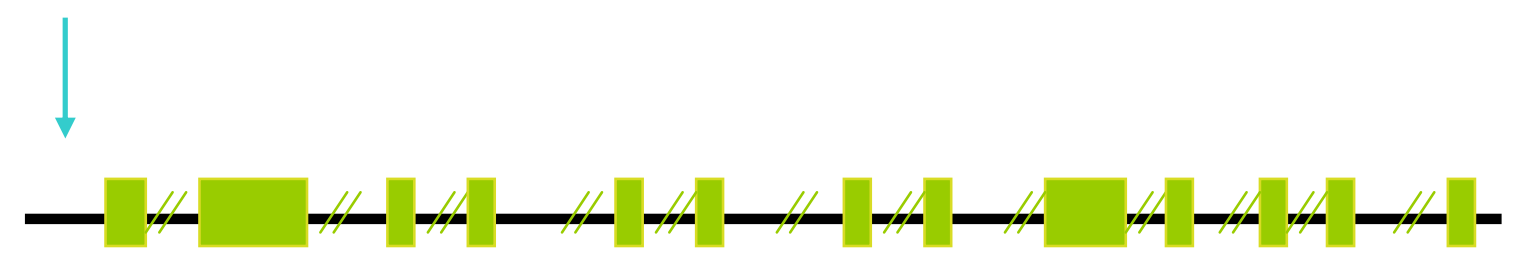

Figura 5. Estrutura do gene MMP9 (20q13.12). Caixas verdes representam regiões codificadoras, barras pretas representam íntrons. A seta azul indica a localização do polimorfismo estudado (-1562 C/T). 
Após a amplificação inicial, os genótipos foram obtidos através de digestão enzimática (RFLP - Restriction-Fragment Length Polymorphism) realizada em volume total de $10 \mu \mathrm{L} /$ reação, contendo $2 \mu \mathrm{L}$ do produto de PCR e $8 \mu \mathrm{L}$ de uma solução

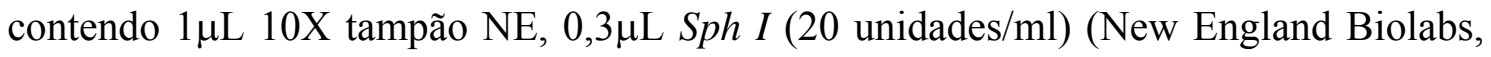
MA) e $6,7 \mu \mathrm{L}$ de água deionizada estéril a $37^{\circ} \mathrm{C}$ overnight. A enzima de restrição SphI reconhece e cliva a seqüência 5'-GCATGC-3'. Como o alelo C não possui sítio de ligação para a SphI, ele não é digerido e pode ser identificado pela visualização de um fragmento de 435 pb. Já o alelo T é clivado pela enzima, criando dois fragmentos, de $247 \mathrm{pb}$ e 188 pb. O conteúdo digerido foi adicionado a $1 \mu \mathrm{L}$ de tampão de corrida (Invitrogen Laboratories, Carlsbad, CA, EUA) e analisado em gel de eletroforese nãodenaturante a 10\%, corado pela técnica de impregnação pela prata (SANGUINETTI et al., 1994). Um padrão de peso molecular de 1000 pb (Invitrogen Laboratories, Carlsbad, CA, EUA) foi utilizado como referência em todos os géis para identificação apropriada dos produtos (Figura 6).

Quadro 3. Condições experimentais para o polimorfismo -1562C/T no gene MMP9.

\begin{tabular}{|c|c|}
\hline & MMP9 (-1562 C/T) \\
\hline Primer forward & 5'GCCTGGCACATAGTAGGCCC 3' \\
\hline Primer reverse & $5^{\prime} \mathrm{CTTCCTAGCCAGCCGGCATC} \mathrm{3'}$ \\
\hline Condições de PCR & $\begin{array}{c}95^{\circ} \mathrm{C} \text { por } 3 \text { minutos }\left(1 \text { ciclo), } 35 \text { ciclos: } 95^{\circ} \mathrm{C} \text { por } 1 \text { minuto, } 65^{\circ} \mathrm{C} \text { por }\right. \\
45 \text { segundos, } 72^{\circ} \mathrm{C} \text { por } 45 \text { segundos, extensão final a } 72^{\circ} \mathrm{C} \text { por } 7 \\
\text { minutos. }\end{array}$ \\
\hline
\end{tabular}




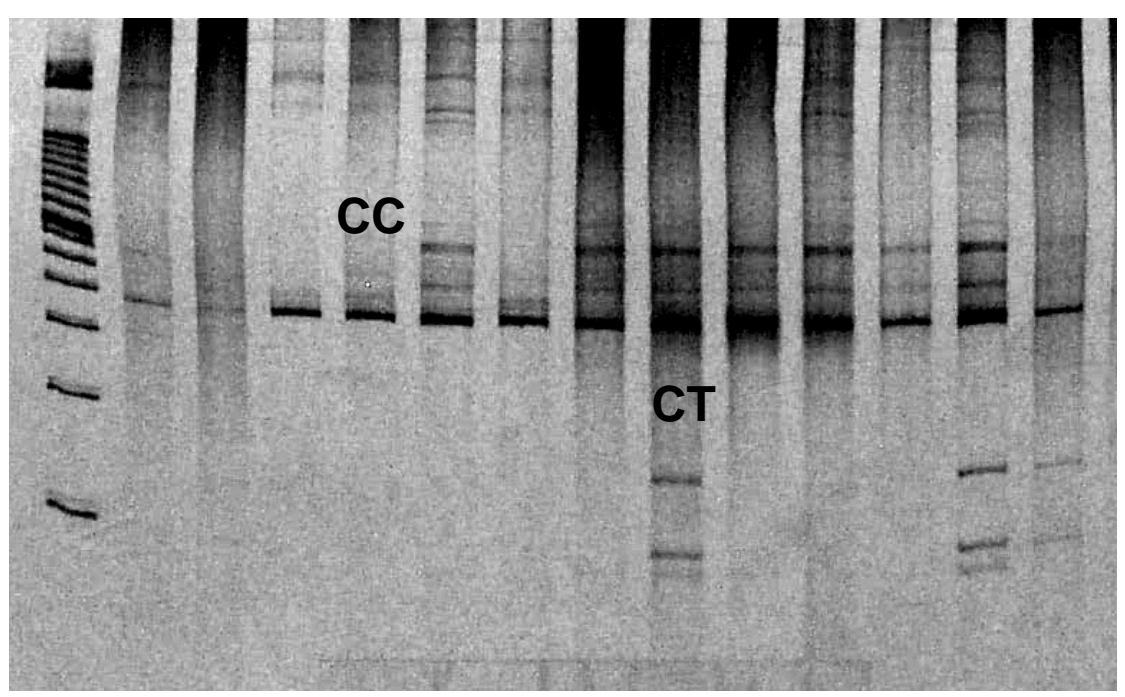

Figura 6. Polimorfismo $-1562 \mathrm{C} / \mathrm{T}$ na região promotora do gene MMP9.

\subsubsection{TGFA (Transforming Growth Factor Alpha)}

Seis polimorfismos no gene TGFA foram estudados (Quadro 4) (Figura 7). Os polimorfismos foram selecionados a partir de resultados de estudos prévios (SHI et al., 2004, VIEIRA et al., 2004, CALLAHAN et al., 2007), e os genótipos obtidos pelo método Taqman (Applied Biosystems, Foster City, CA, EUA) (Quadro 4) (Figura 8) e através de PCR cinético (Figuras 9 e 10), previamente descritos no item 4.2.5. A seqüência dos primers e as condições de PCR cinético utilizadas estão listadas nos Quadros 5-7.

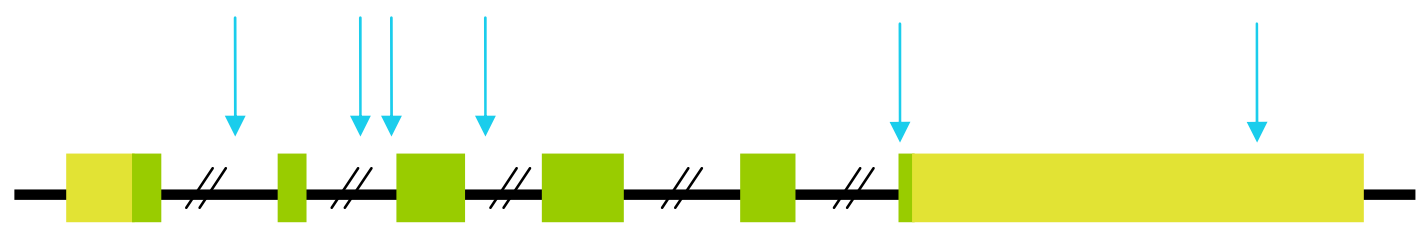

Figura 7. Esquema da estrutura do gene TGFA. Caixas verdes representam regiões codificadoras, barras pretas representam íntrons, caixas amarelas representam regiões nãotraduzidas. As setas azuis indicam a localização dos polimorfismos estudados (da esquerda para a direita): rs377122, rs2902345, rs1523305, rs930655, C3296T (rs2166975) e C3827T (rs1058213). 
Quadro 4. SNPs, posição no cromossomo, região no gene e troca de base dos polimorfismos estudados no gene TGFA.

\begin{tabular}{lcllc}
\hline \multicolumn{1}{c}{ SNP } & Posição* $^{*}$ & Gene & Região & Troca de base \\
\hline rs1058213 & $70,589,118$ & TGFA & 3'UTR & CT \\
rs2166975 & $70,589,649$ & TGFA & Exon 6 & CT \\
rs930655 & $70,596,106$ & TGFA & Intron & AG \\
rs1523305 & $70,610,511$ & TGFA & Intron & CT \\
rs2902345 & $70,628,254$ & TGFA & Intron & CT \\
rs377122 & $70,678,680$ & TGFA & Intron & CT \\
\hline
\end{tabular}

* de acordo com o website http://genome.ucsc.edu, dados de 2004.

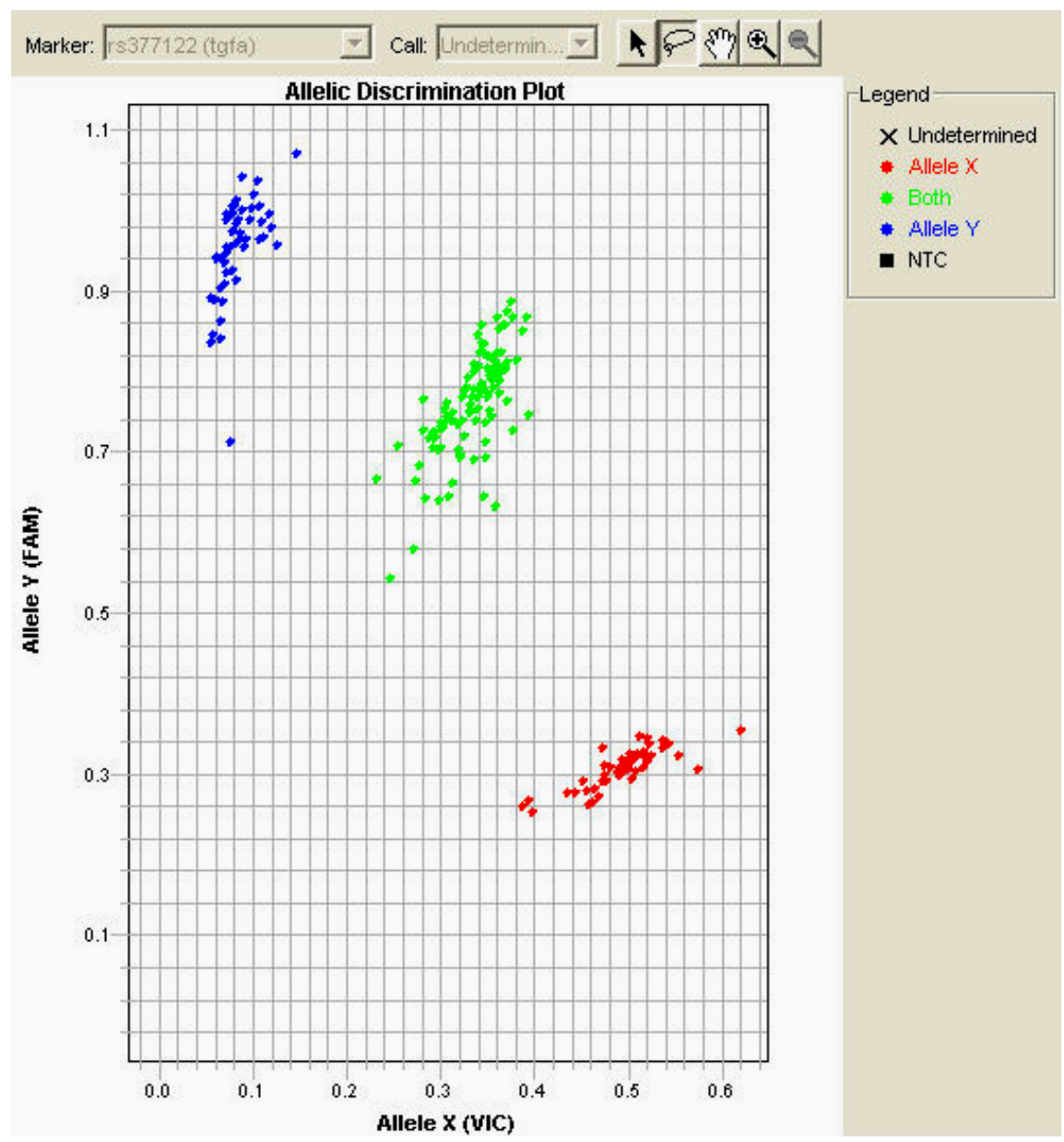

Figura 8. Resultados obtidos pelo método Taqman (ABI PRISM ${ }^{\circledR}$ 7900HT, Applied Biosystems, Foster City, CA, EUA) para o marcador rs377122 no gene TGFA. Indivíduos homozigotos para cada alelo são representados pelas cores vermelha e azul, e indivíduos heterozigotos são representados pela cor verde. 
Quadro 5. Condições experimentais para o polimorfismo C3296T no gene TGFA.

\begin{tabular}{|c|c|}
\hline & TGFA C3296T \\
\hline Primer forward & 5'CTTATTTTCCCAACGTGGCC 3' \\
\hline $\begin{array}{l}\text { Primer } \mathrm{C} \text { reverse } \\
\text { (alelo comum) }\end{array}$ & 5'CTCCTCTGGGCTCTTCTG 3' \\
\hline $\begin{array}{l}\text { Primer T reverse } \\
\quad \text { (alelo raro) }\end{array}$ & 5'ТCСТCСТCTGGGCTCTTCTA 3' \\
\hline Condições de PCR & $\begin{array}{c}95^{\circ} \mathrm{C} \text { por } 10 \mathrm{~min}(1 \mathrm{ciclo}) \\
95^{\circ} \mathrm{C} \text { por } 15 \mathrm{seg}, 56^{\circ} \mathrm{C} \text { por } 40 \mathrm{seg}(55 \text { ciclos })\end{array}$ \\
\hline
\end{tabular}

Quadro 6. Condições experimentais para o polimorfismo C3827T no gene TGFA.

\begin{tabular}{|c|c|}
\hline TGFA C3827T \\
\hline $\begin{array}{c}\text { Primer C forward } \\
\text { (alelo comum) }\end{array}$ & $5^{\prime}$ 'AGAAGGTGTATCCTCTAACCACGAGAAC 3' \\
\hline $\begin{array}{c}\text { Primer T forward } \\
\text { (alelo raro) }\end{array}$ & $5^{\prime}$ GAGAAGCTGTATCCTCTAACCACGAGAAT 3' \\
\hline Primer reverse & $5^{\prime}$ GGATGGTCTTCAATGTCATG 3' \\
\hline Condições de PCR & $95^{\circ} \mathrm{C}$ por 15 seg, $56^{\circ} \mathrm{C}$ por 40 seg $(55$ ciclos $)$ \\
\hline
\end{tabular}




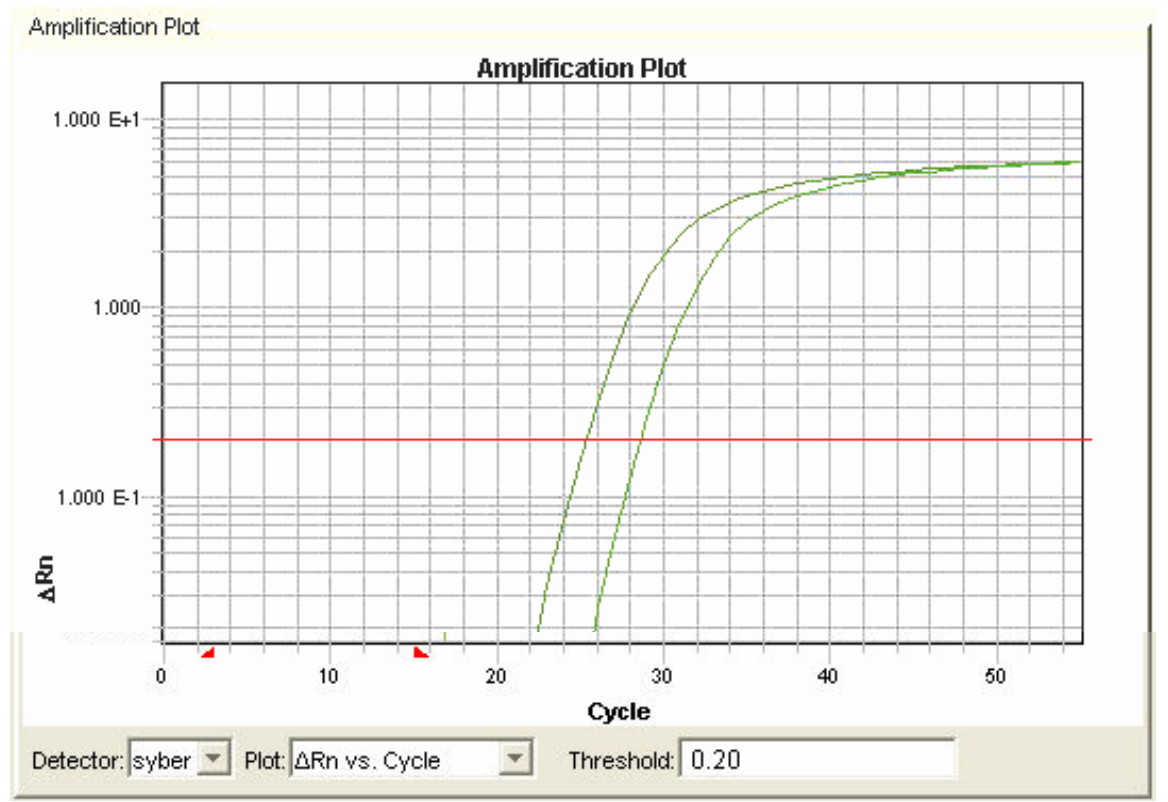

Figura 9. Exemplo de indivíduo homozigoto analisado pelo método de PCR cinético (ABI PRISM® ${ }^{\circledR} 7900 H T$, Applied Biosystems, Foster City, CA, EUA).

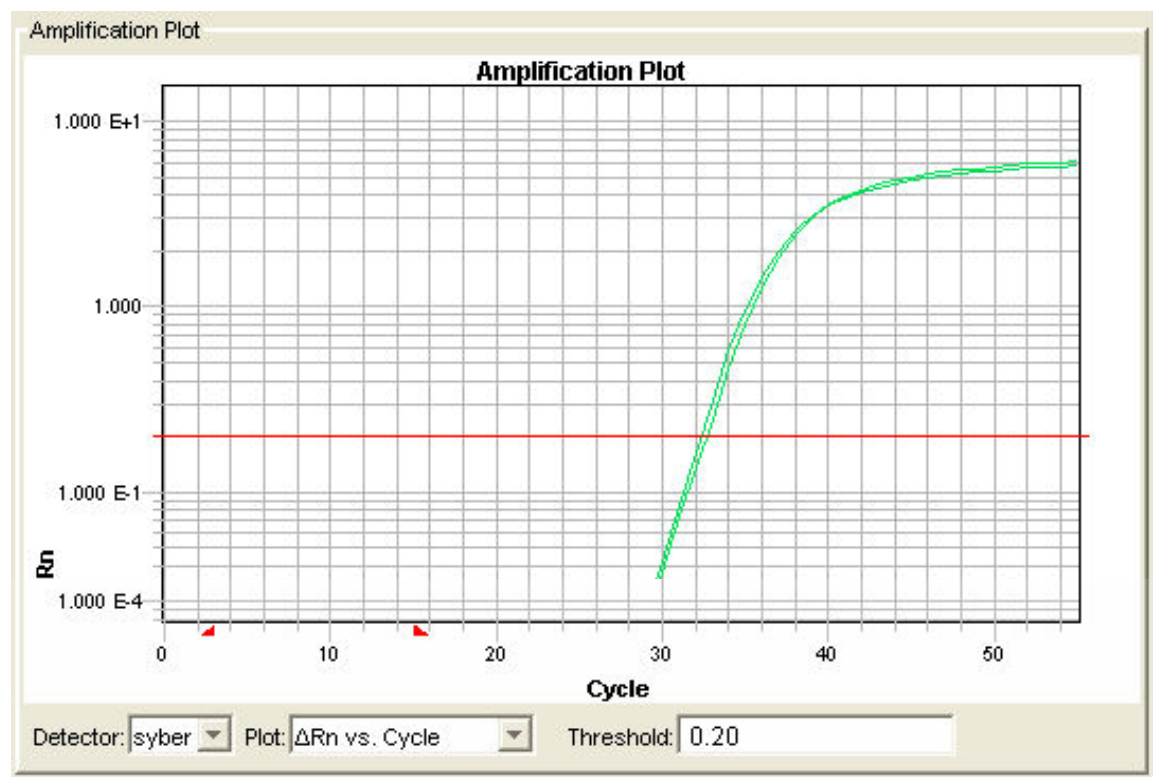

Figura 10. Exemplo de indivíduo heterozigoto analisado pelo método de PCR cinético (ABI PRISM ${ }^{\circledR} 7900$ HT, Applied Biosystems, Foster City, CA, EUA). 


\subsubsection{IRF6}

Seis polimorfismos previamente descritos no gene IRF6 foram estudados (Quadro 8). Os indivíduos foram genotipados utilizando-se o método Taqman (Applied Biosystems, Foster City, CA, EUA) conforme descrito no item 4.2.5. A escolha dos polimorfismos foi baseada em resultados de estudos anteriores (ZUCCHERO et al., 2004; VIEIRA et al., 2007) (Figura 11).

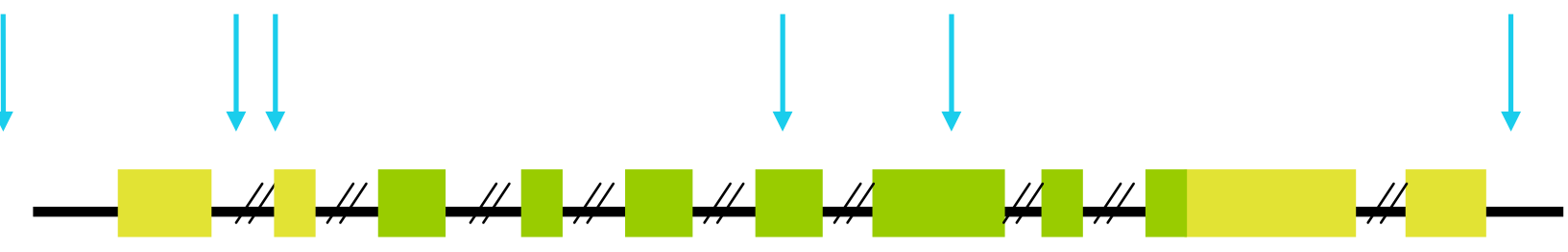

Figura 11. Esquema da estrutura do gene IRF6. Caixas verdes representam regiões codificadoras, barras pretas representam íntrons, caixas amarelas representam regiões nãotraduzidas. As setas azuis indicam a localização dos polimorfismos estudados (da esquerda para a direita): rs658860, rs2073487, rs861019, rs2013162, rs2235371 (V274I), e rs4844880.

Quadro 7. SNPs, posição no cromossomo, região no gene e troca de base dos polimorfismos estudados no gene IRF6.

\begin{tabular}{lcccc}
\hline \multicolumn{1}{c}{ SNP } & Posição* & Gene & Região & Troca de base \\
\hline rs4844880 & $207,937,289$ & HSD11B1** & intron & AT \\
rs2235371 & $208,030,453$ & IRF6 & exon & CT \\
rs2013162 & $208,035,057$ & IRF6 & exon & AC \\
rs861019 & $208,041,759$ & IRF6 & exon & AG \\
rs2073487 & $208,043,019$ & IRF6 & intron & CT \\
rs658860 & $208,056,922$ & --- & --- & CT \\
\hline
\end{tabular}

* de acordo com o website http://genome.ucsc.edu, dados de 2004.

** HSD11B1, hydroxysteroid (11-beta) dehydrogenase 1 


\subsubsection{Cromossomo $6 q$}

Tomando como base a região de $14 \mathrm{cM}$ apontada como apresentando $90 \%$ de chance de conter um gene associado a FL/P isolada (GOVIL et al., 2006), quinze polimorfismos foram selecionados a partir de dados do International HapMap Project (THE INTERNATIONAL HAPMAP CONSORTIUM, 2003) e visualizados através do software Haploview, levando em consideração a distribuição dos haplótipos e a estrutura dos genes visando uma ótima cobertura da região a ser estudada e poder selecionar os SNPs mais informativos (Figura 12) (Quadro 9).

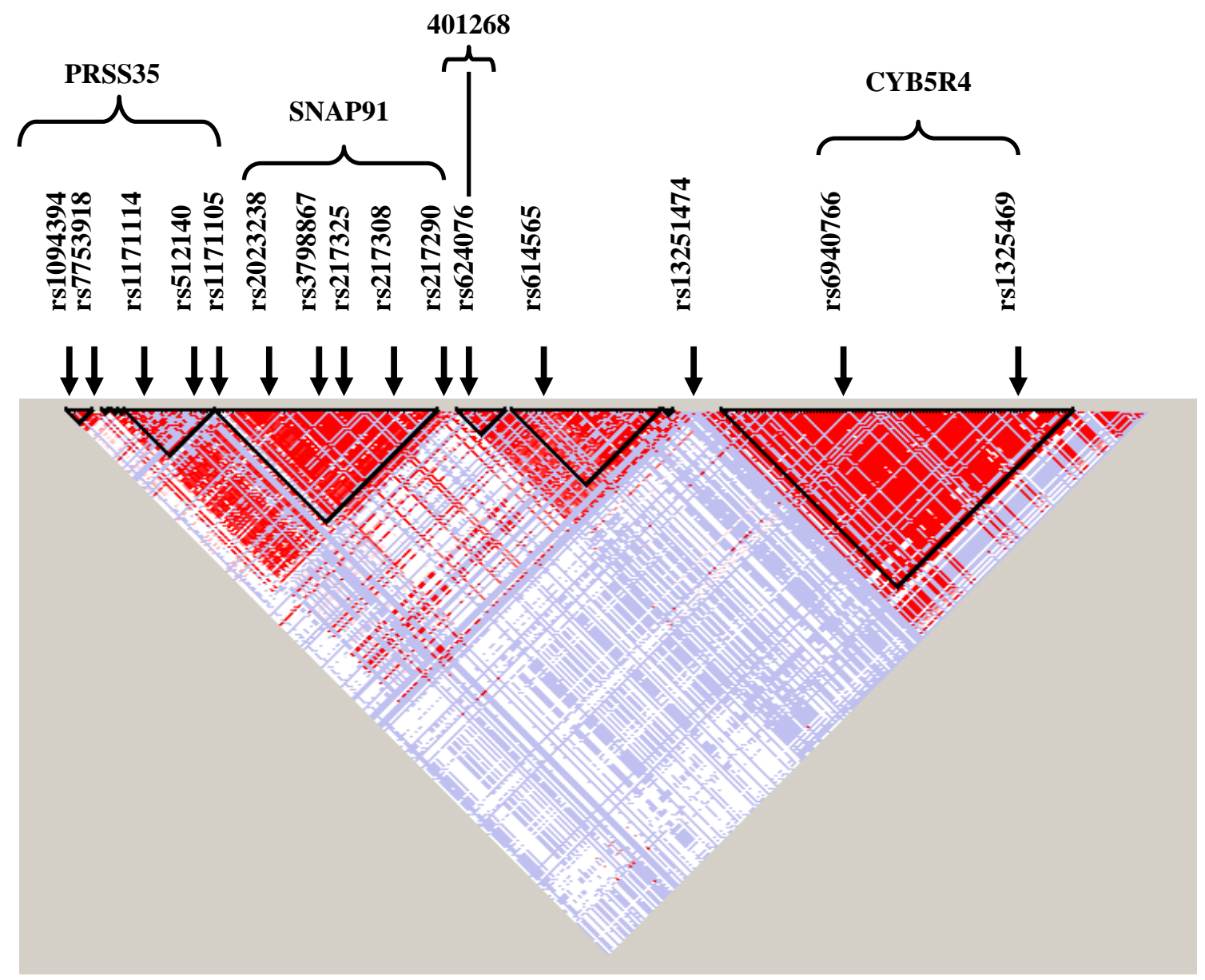

Figura 12. Gráfico de desequilíbrio de ligação ilustrando a região estudada no cromossomo 6q. Os polimorfismos estudados estão situados na posição específica do segmento do cromossomo que ocupam (setas pretas), e estão distribuídos por 4 genes localizados na região estudada (chaves). A relação entre dois polimorfismos e' representada pela intersecção entre dois quadrados e pode apresentar cores (ou intensidade de cor) variadas baseada no valor obtido para a relação. Vermelho indica $D^{\prime}=1$ e $L O D \geq 2$. Azul indica $D^{\prime}=1$ e $L O D<2$. Tons de vermelho/rosa indicam $\mathrm{D}^{\prime}<1$ e $\mathrm{LOD} \geq 2$. Branco indica $\mathrm{D}^{\prime}<1$ e $\mathrm{LOD}<2$. 
Quadro 8. SNPs, posição no cromossomo, região no gene e troca de base dos polimorfismos estudados no cromossomo 6q.

\begin{tabular}{lcccc}
\hline \multicolumn{1}{c}{ SNP } & Posição & Gene & Região & Troca de base \\
\hline rs10943944 & $84,268,655$ & PRSS35§ & intron & CT \\
rs7753918 & $84,273,887$ & PRSS35 & intron & AG \\
rs1171114 & $84,284,365$ & PRSS35 & intron & CT \\
rs512140 & $84,287,372$ & PRSS35 & intron & AG \\
rs1171105 & $84,297,584$ & PRSS35 & 5' UTR & TC \\
rs2023238 & $84,339,480$ & SNAP91† & intron & AG \\
rs3798867 & $84,388,560$ & SNAP91 & intron & CG \\
rs217325 & $84,407,373$ & SNAP91 & exon & CG \\
rs217290 & $84,455,284$ & SNAP91 & intron & CT \\
rs217308 & $84,426,588$ & SNAP91 & intron & CT \\
rs624076 & $84,476,512$ & 401268 & exon & AG \\
rs614565 & $84,498,645$ & --- & --- & CT \\
rs1325474 & $84,596,144$ & ---- & ---- & AG \\
rs6940766 & $84,672,046$ & CYB5R4ł & intron & AG \\
rs1325469 & $84,705,856$ & CYB5R4 & limite intron/exon & AG \\
\hline
\end{tabular}

* de acordo com o website http://genome.ucsc.edu, dados de 2004.

§PRSS35, serine-protease 35.

$\uparrow$ SNAP91, synaptosomal associated protein

$\$$ CYB5R4, cytochrome b5 reductase-4

\subsubsection{Análise dos Dados}

\subsubsection{Definição do Fenótipo}

Diferenças nas freqüências observadas para cada tipo de anomalia dentária nos casos e controles foram acessadas através do teste Qui-quadrado, com nível de significância de $95 \%(\mathrm{p} \leq 0.05)$. O risco estimado (odds ratio) também foi calculado, com intervalo de confiança de 95\%. Além disso, as diferenças entre as freqüências de anomalias observadas para cada subfenótipo de FL/P e controles foram acessadas através dos testes Qui-quadrado e correção de Bonferroni. Nesse caso, foram considerados o número de testes $(23)$ e o número de variáveis $(8)(0,05 / 176$ análises, $p \leq$ 0.0002 indica diferença estatística significante). 


\subsubsection{Associação de polimorfismos genéticos e subfenótipos de FL/P}

As freqüências dos genótipos e alelos obtidos para cada SNP foram testadas com relação ao equilíbrio de Hardy-Weinberg através da equação: $\left(p^{2}+2 p q+q^{2}=1\right)$, onde $p$ e q representam a freqüência observada para cada alelo.

Para os estudos com os genes MMP1, MMP3 e MMP9, devido ao menor número de amostras disponíveis no período em que estes estudos foram realizados, as diferenças observadas para a freqüência dos genótipos e alelos de cada SNP entre casos e controles foi analisada estatisticamente através do teste Qui-quadrado com nível de significância de $95 \%(\mathrm{p} \leq 0.05)$. O risco estimado (odds ratio) também foi calculado, com intervalo de confiança de $95 \%$.

Para os demais estudos (TGFA, IRF6, cromossomo 6q), as diferenças nas freqüências dos genótipos e alelos de cada SNP entre cada subfenótipo de FL/P e controles (com e sem anomalias dentárias) foram analisadas estatisticamente através do teste Qui-quadrado com Correção de Bonferroni. Nesse caso, foram considerados o número de testes (27) e o número de variáveis (35) (0,05/945análises, $\mathrm{p} \leq 0.00005$ indica diferença estatística significante).

\subsubsection{Análise de desequilíbrio de ligação dos polimorfismos estudados}

O padrão de desequilíbrio de ligação entre os polimorfismos testados foi calculado utilizando-se o programa GOLD (Graphical Overview of Linkage Disequilibrium) (ABECASIS; COOKSON, 2000). 
5 RESULTADOS 


\section{RESULTADOS}

\subsection{Definição do Fenótipo}

\subsubsection{Caracterização da amostra}

As características demográficas observadas para a população estudada encontram-se na Tabela 1.

Tabela 1. Características observadas para a população estudada.

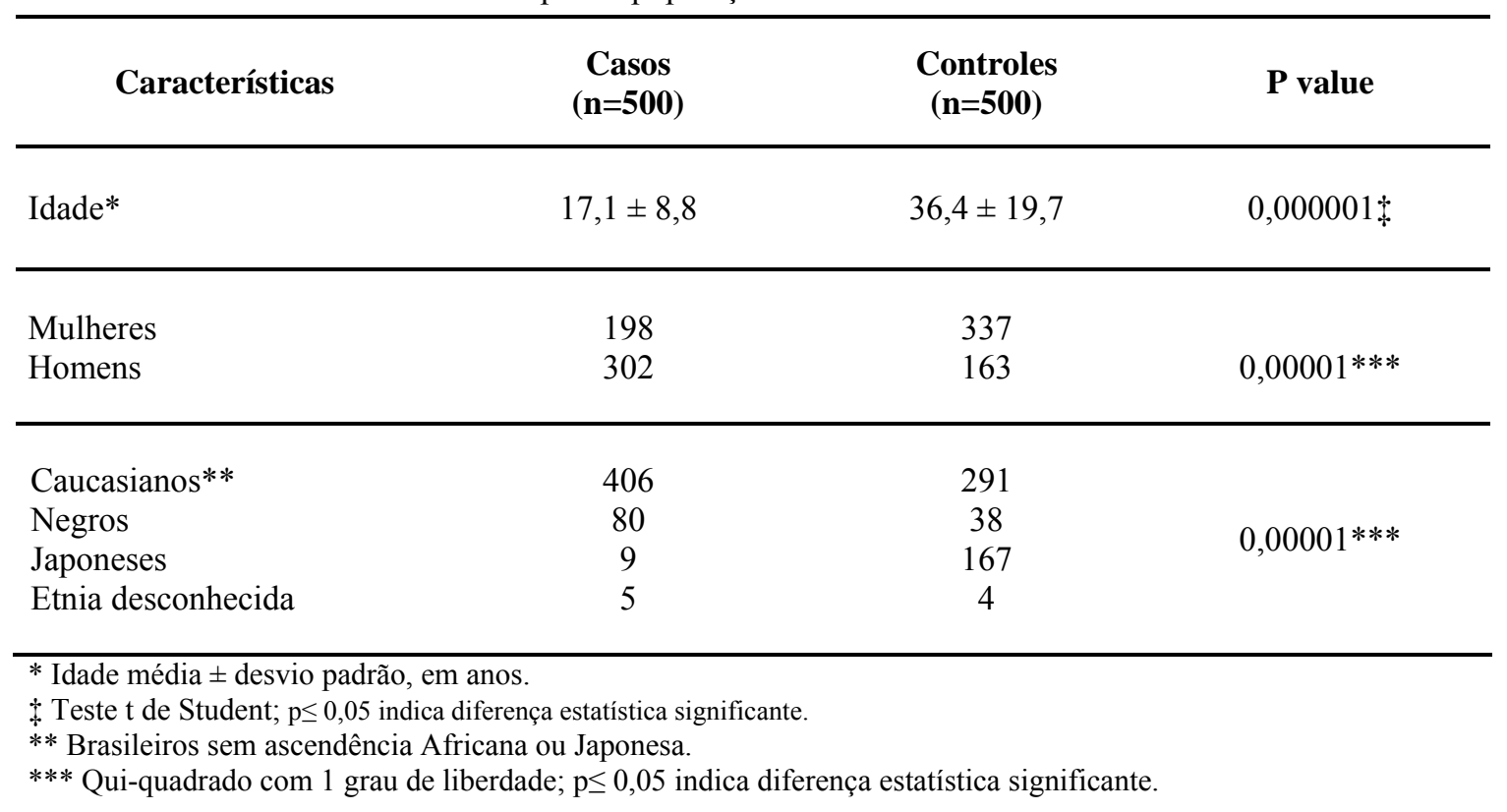

\subsubsection{Tipos de Fissura}

Dos 500 indivíduos com FL/P, 400 apresentavam fissura labial e palatina (168 com fissura labial esquerda, 76 com fissura labial direita, e 54 com fissura bilateral), 6 indivíduos apresentavam fissura labial somente ( 2 no lado direito e 4 no lado esquerdo), 66 indivíduos apresentavam fissura palatina, e 28 apresentavam fissuras cujo tipo ou lado não puderam ser determinados. Devido ao fato de somente 6 indivíduos apresentarem FL, estes foram incluídos no grupo FL/P para posterior análise. 


\subsubsection{Presença de Anomalias Dentárias}

Os indivíduos fissurados apresentaram um número consideravelmente maior de anomalias dentárias fora da área de fissura quando comparados aos indivíduos controles $(\mathrm{p}=0,00001)$. As freqüências observadas para cada tipo de anomalia entre casos e controles estão listadas na Tabela 2. A presença de agenesia dentária, microdontia, dentes supranumerários, anomalias de forma, transposição, e ainda de múltiplas anomalias foi consistentemente mais freqüente nos indivíduos fissurados. A retenção de dentes permanentes também mostrou uma tendência a ser mais freqüente nestes indivíduos (Tabela 2).

A agenesia dentária foi à anomalia mais freqüente em ambos os grupos. Excluindo-se os terceiros molares que apresentaram a maior freqüência de agenesia em ambos indivíduos fissurados $(179 / 352 ; p=0,00001)$ e controles $(34 / 62 ; p=0,00001)$, os pré-molares foram os dentes mais comumente ausentes em indivíduos fissurados $(108 / 352 ; p=0,002)$ sem diferenças significativas com relação ao tipo de fissura apresentada, enquanto indivíduos controles apresentaram maior incidência de agenesia dos incisivos laterais superiores $(13 / 62 ; \mathrm{p}=0,0491)$.

Tabela 2. Diferenças observadas para as freqüências de anomalias dentárias em casos e controles.

\begin{tabular}{lcccc}
\hline \multicolumn{1}{c}{ Tipo de Anomalia } & $\begin{array}{c}\text { Casos } \\
(\mathrm{n}=500)\end{array}$ & $\begin{array}{c}\text { Controles } \\
(\mathrm{n}=500)\end{array}$ & $\mathbf{P}^{*}$ & $\begin{array}{c}\text { Odds ratio } \\
(\mathbf{9 5 \%} \text { IC)** }\end{array}$ \\
\hline Agenesia & 131 & 36 & $\mathbf{0 , 0 0 0 0 1}$ & $4,5757(3,08-6,78)$ \\
Microdontia & 9 & 1 & $\mathbf{0 , 0 0 6}$ & $9,14(1,15-72,47)$ \\
Supranumerário & 22 & 1 & $\mathbf{0 , 0 0 0 0 1}$ & $22,96(3,08-171,05)$ \\
Giroversão/Lateroversão & 47 & 2 & $\mathbf{0 , 0 0 0 0 1}$ & $25,83(6,23-106,96)$ \\
Retenção & 6 & 1 & 0,06 & $6,06(0,72-50,52)$ \\
Anomalia de forma & 2 & 0 & 0,08 & -- \\
Transposição & 7 & 0 & $\mathbf{0 , 0 0 1}$ & -- \\
Múltiplas anomalias & 23 & 1 & $\mathbf{0 , 0 0 0 0 1}$ & $24,06(3,23-178,87)$ \\
Total & 247 & 42 & $\mathbf{0 , 0 0 0 0 1}$ & $10,64(7,41-15,28)$ \\
\hline
\end{tabular}

* Qui-quadrado com 1 grau de liberdade; $\mathrm{p} \leq 0,05$ indica diferença estatística significante.

** IC, intervalo de confiança. 


\subsubsection{Anomalias Dentárias como Subfenótipos Adicionais para FL/P}

Os indivíduos fissurados apresentaram 18 subfenótipos diferentes de fissura, baseados nas observações sobre lado e extensão da fissura, e estão listados na Tabela 3 juntamente com a freqüência das anomalias dentárias observadas nos indivíduos compondo cada subfenótipo e nos indivíduos controles. As diferenças entre as freqüências das anomalias dentárias apresentadas por indivíduos compondo cada subfenótipo de FL/P e controles encontram-se no Anexo 6.

A Tabela 4 mostra a distribuição das quatro anomalias dentárias mais freqüentes (agenesia, microdontia, presença de dente supranumerário e giroversão/lateroversão), de acordo com o lado da fissura em indivíduos com FL/P. Foi possível observar que as anomalias são mais freqüentes no lado oposto da fissura: agenesia do lado esquerdo em indivíduos com fissura unilateral direita, agenesia do lado direito em indivíduos com fissura unilateral esquerda, e presença de dentes supranumerários do lado direito em indivíduos com fissura unilateral esquerda. A presença de microdontia do lado direito também mostrou uma tendência a ser mais freqüente em indivíduos com fissura unilateral esquerda (Tabela 4).

A agenesia do incisivo lateral superior esquerdo mostrou-se associada à fissura unilateral direita $(12 / 78 ; p=0,007)$ e, ao contrário, a agenesia do incisivo lateral superior direito mostrou-se associada à fissura unilateral esquerda $(15 / 172 ; p=0,00001)$.

Alterações na orientação normal dos dentes, como giroversão e lateroversão, foram características comuns nos indivíduos fissurados e mostraram-se associados a diversos subfenótipos de FL/P (Tabela 3). Os caninos inferiores foram os dentes mais afetados $(39 / 47 ; \mathrm{p}=0,00001)$ e freqüentemente associados a FL/P bilateral (Tabela 3).

A retenção de dentes permanentes mostrou associação preferencial com FP completa; a transposição dentária mostrou associação com FL/P bilateral completa e FL/P unilateral incompleta esquerda (Tabela 3).

A presença de múltiplas anomalias foi mais freqüente em indivíduos apresentando FL/P unilateral esquerda completa e incompleta. Dos 23 casos apresentando múltiplas anomalias, 20 apresentaram agenesia dentária junto a outras anomalias. As combinações mais freqüentes foram agenesia e giroversão/lateroversão (11/20) e agenesia e dentes supranumerários (8/20). A combinação de agenesia e 
microdontia foi observada em um indivíduo apenas, com FL/P unilateral direita completa.

Tabela 3. Distribuição das anomalias dentárias nos indivíduos fissurados (divididos de acordo com os subfenótipos apresentados) e controles.

\begin{tabular}{|c|c|c|c|c|c|c|c|c|c|c|}
\hline Subfenótipos & 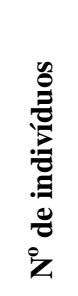 & 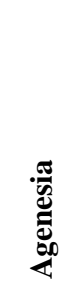 & 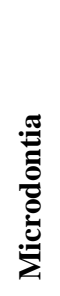 & & 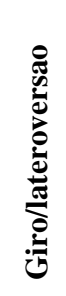 & 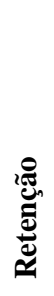 & 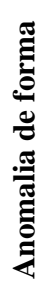 & 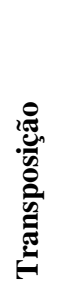 & 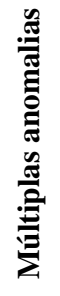 & 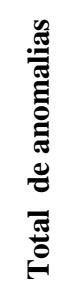 \\
\hline \multicolumn{11}{|l|}{ Fissura Palatina } \\
\hline Completa & 21 & 4 & 0 & 0 & 0 & 2 & 0 & 0 & 2 & 8 \\
\hline Incompleta + submucosa & 45 & 10 & 0 & 1 & 4 & 0 & 1 & 0 & 0 & 16 \\
\hline Total & 66 & 14 & 0 & 1 & 4 & 2 & 1 & 0 & 2 & 24 \\
\hline \multicolumn{11}{|l|}{ Fissura Labio-Palatina } \\
\hline Completa & 300 & 90 & 7 & 16 & 30 & 3 & 0 & 5 & 17 & 168 \\
\hline Incompleta & 104 & 23 & 1 & 4 & 12 & 1 & 0 & 2 & 3 & 46 \\
\hline Unilateral & 250 & 71 & 6 & 16 & 27 & 3 & 0 & 3 & 16 & 142 \\
\hline Completa & 175 & 57 & 5 & 14 & 19 & 2 & 0 & 1 & 13 & 111 \\
\hline Incompleta & 75 & 14 & 1 & 2 & 8 & 1 & 0 & 2 & 3 & 31 \\
\hline Direita & 78 & 28 & 2 & 3 & 9 & 1 & 0 & 0 & 2 & 45 \\
\hline Completa & 54 & 23 & 2 & 3 & 6 & 0 & 0 & 0 & 2 & 36 \\
\hline Incompleta & 16 & 3 & 0 & 0 & 3 & 0 & 0 & 0 & 0 & 6 \\
\hline Incompleta + FP & 8 & 1 & 0 & 0 & 1 & 0 & 0 & 0 & 0 & 2 \\
\hline Esquerda & 172 & 43 & 4 & 13 & 18 & 2 & 0 & 3 & 14 & 97 \\
\hline Completa & 121 & 34 & 3 & 11 & 13 & 2 & 0 & 1 & 11 & 75 \\
\hline Incompleta & 46 & 9 & 1 & 2 & 5 & 0 & 0 & 2 & 3 & 22 \\
\hline Incompleta + FP & 5 & 0 & 0 & 0 & 0 & 0 & 0 & 0 & 0 & 0 \\
\hline Bilateral & 154 & 42 & 2 & 4 & 15 & 1 & 0 & 4 & 4 & 72 \\
\hline Completa & 125 & 33 & 2 & 2 & 11 & 1 & 0 & 4 & 4 & 57 \\
\hline Incompleta & 8 & 1 & 0 & 1 & 1 & 0 & 0 & 0 & 0 & 3 \\
\hline Incompleta + FP & 17 & 7 & 0 & 1 & 3 & 0 & 0 & 0 & 0 & 11 \\
\hline Incompleta mista & 4 & 1 & 0 & 0 & 0 & 0 & 0 & 0 & 0 & 1 \\
\hline $\begin{array}{l}\text { FL direita + FLP } \\
\text { Esquerda }\end{array}$ & 3 & 1 & 0 & 0 & 0 & 0 & 0 & 0 & 0 & 1 \\
\hline $\begin{array}{l}\text { FL esquerda }+F P \\
\text { bilateral }\end{array}$ & 1 & 0 & 0 & 0 & 0 & 0 & 0 & 0 & 0 & 0 \\
\hline Fissura mediana & 2 & 0 & 0 & 0 & 0 & 0 & 0 & 0 & 0 & 0 \\
\hline Total & 406 & 113 & 8 & 20 & 42 & 4 & 0 & 7 & 20 & 214 \\
\hline $\begin{array}{l}\text { Fissura com tipo/lado } \\
\text { desconhecido }\end{array}$ & 28 & 4 & 1 & 1 & 1 & 0 & 1 & 0 & 1 & 9 \\
\hline Total Fissurados & 500 & 131 & 9 & 22 & 47 & 6 & 2 & 7 & 23 & 247 \\
\hline Controles & 500 & 36 & 1 & 1 & 2 & 1 & 0 & 0 & 1 & 42 \\
\hline
\end{tabular}


Tabela 4. Número de anomalias dentárias observadas em indivíduos fissurados, de acordo com o lado da anomalia e lado da fissura.

\begin{tabular}{|c|c|c|c|c|c|c|}
\hline \multirow[t]{2}{*}{ Anomalia } & \multirow{2}{*}{$\begin{array}{l}\text { Lado da } \\
\text { anomalia }\end{array}$} & \multicolumn{4}{|c|}{ Lado da fissura } & \multirow[t]{2}{*}{$\mathbf{P}^{*}$} \\
\hline & & $\begin{array}{c}\text { Direito } \\
(n=78)\end{array}$ & $\begin{array}{c}\text { Esquerdo } \\
(\mathbf{n}=172)\end{array}$ & $\begin{array}{c}\text { Bilateral } \\
(n=154)\end{array}$ & $\begin{array}{c}\text { Central } \\
(n=66)\end{array}$ & \\
\hline \multirow[t]{4}{*}{ Agenesia } & Direito & 5 & 16 & 2 & 2 & 0,01 \\
\hline & Esquerdo & 8 & 6 & 5 & 0 & $\mathbf{0 , 0 1}$ \\
\hline & Bilateral & 13 & 18 & 34 & 12 & 0,04 \\
\hline & Desconhecido & 2 & 3 & 1 & 0 & 0,31 \\
\hline \multirow[t]{4}{*}{ Microdontia } & Direito & 0 & 3 & 0 & 0 & 0,06 \\
\hline & Esquerdo & 2 & 1 & 1 & 0 & 0,29 \\
\hline & Bilateral & 0 & 0 & 1 & 0 & 0,43 \\
\hline & Desconhecido & 0 & 0 & 0 & 0 & --- \\
\hline \multirow[t]{4}{*}{ Supranumerário } & Direito & 0 & 4 & 0 & 0 & 0,02 \\
\hline & Esquerdo & 2 & 3 & 0 & 1 & 0,15 \\
\hline & Bilateral & 0 & 0 & 0 & 0 & --- \\
\hline & Desconhecido & 1 & 6 & 4 & 0 & 0,20 \\
\hline Giroversão/ & Direito & 3 & 11 & 6 & 1 & 0,38 \\
\hline \multirow[t]{3}{*}{ Lateroversão } & Esquerdo & 4 & 3 & 2 & 2 & 0,28 \\
\hline & Bilateral & 2 & 2 & 6 & 0 & 0,10 \\
\hline & Desconhecido & 0 & 2 & 1 & 1 & 0,58 \\
\hline
\end{tabular}

$\overline{* \text { Qui-quadrado com } 3} \overline{\text { graus de liberdade; } \mathrm{p}} \overline{\leq 0,05 \text { indica diferença estatística significante (em negrito). }}$ 


\subsection{Novos Subfenótipos Propostos}

Os resultados expostos na Tabela 3 demonstram a associação preferencial de determinados subfenótipos de FL/P com certos tipos de anomalias dentárias, e a partir destes, 12 novos subfenótipos de FL/P foram propostos com base nas anomalias apresentadas, (Quadro 1) e incluídos nas análises moleculares.

Quadro 9. Lista de subfenótipos utilizados em estudos genéticos e os subfenótipos adicionais propostos baseados no desenvolvimento dental.

\begin{tabular}{|c|c|}
\hline $\begin{array}{l}\text { Subfenótipos utilizados em estudos } \\
\text { genéticos recentes }\end{array}$ & Subfenótipos propostos baseados no desenvolvimento dental \\
\hline $\begin{array}{l}\text { - Todas as fissuras } \\
\text { - Fissura Labial e/ou Palatina (FL/P) } \\
\text { (todos lábios) } \\
\text { - Fissura Labial somente (FL) } \\
\text { - Fissura Labial e Palatina (FLP) } \\
\text { (lábio e palato) } \\
\text { - Fissura Labial e/ou Palatina (FL/P) } \\
\text { (todos palatos) } \\
\text { - Fissura Palatina somente (FP) }\end{array}$ & $\begin{array}{l}\text { - Fissura Labial e/ou Palatina (FL/P) } \\
\text { - unilateral direita com/sem agenesia fora da região de fissura } \\
\text { - unilateral esquerda } \\
\text { - com/sem agenesia fora da região de fissura } \\
\text { - com/sem microdontia ou supranumerário no lado oposto } \\
\text { da fissura } \\
\text { - com/sem múltiplas anomalias } \\
\text { - bilateral } \\
\text { - com/sem agenesia fora da região de fissura } \\
\text { - com/sem dente supranumerário no lado oposto da fissura } \\
\text { - com/sem múltiplas anomalias } \\
\text { - bilateral frustro (FL/P unilateral com agenesia do } \\
\text { incisivo lateral superior oposto) } \\
\text { - com/sem múltiplas anomalias } \\
\text { - Fissura Palatina somente (FP) } \\
\text { - com/sem agenesia fora da região de fissura } \\
\text { - completa } \\
\text { - com/sem retenção de dentes permanentes } \\
\text { - com/sem múltiplas anomalias } \\
\text { - incompleta com/sem giroversão/lateroversão }\end{array}$ \\
\hline
\end{tabular}

* VIEIRA et al. 2003; VIEIRA et al. 2005; AVILA et al. 2006; WARRINGTON et al. 2006. 


\subsection{Estudos genéticos de associação com a FL/P}

Diferentes análises comparativas foram realizadas neste estudo. Os estudos de associação de polimorfismos nos genes MMP1, MMP3, e MMP9, e FL/P foram analisados comparando-se as freqüências obtidas para casos e controles somente, devido ao menor número de indivíduos compondo a amostra no período em que os experimentos foram realizados. As características da amostra referentes a cada estudo estão listadas nas respectivas tabelas.

Para os demais polimorfismos (TGFA, IRF6 e cromossomo 6q), foram realizadas análises comparativas entre casos e controles, e entre subfenótipos de casos e controles, com e sem anomalias dentárias, utilizando-se a amostra total. O número de indivíduos compondo cada grupo da amostra encontra-se detalhado nas respectivas tabelas. As freqüências obtidas para genótipos e alelos referentes a cada polimorfismo estudado encontram-se no Apêndice 7.

A distribuição dos alelos para todos os polimorfismos estudados em casos e controles estava em equilíbrio de Hardy-Weinberg.

\subsubsection{MMP1 (-1607 1G/2G)}

As características da população estudada para o gene MMP1 estão listadas na Tabela 5 .

Não houve diferença estatística significativa comparando-se as freqüências dos genótipos e dos alelos entre casos e controles e entre subfenótipos de casos e controles, utilizando todos os indivíduos ou somente indivíduos caucasianos para as análises (Tabelas 6 e 7). 
Tabela 5. Características da população estudada para o gene MMP1.

Características

\begin{tabular}{|c|c|c|c|}
\hline & $\begin{array}{c}\text { FL/P } \\
(n=170)\end{array}$ & $\begin{array}{c}\text { Controles } \\
(n=225)\end{array}$ & $\mathbf{P} * * *$ \\
\hline Idade* & $17,1 \pm 9,1$ & $38,1 \pm 13$ & $0,000001 \$$ \\
\hline Homens & 89 & 86 & 0,005 \\
\hline Mulheres & 81 & 139 & \\
\hline Caucasianos** & 131 & 193 & \\
\hline Japoneses & 32 & 60 & 0,1919 \\
\hline Negros & 3 & 2 & \\
\hline Etnia desconhecida & 4 & 0 & \\
\hline
\end{tabular}

Tabela 6. Distribuição dos alelos e genótipos do polimorfismo -1607 1G/2G no gene MMP1 em casos e controles, na população total e em caucasianos.

\begin{tabular}{|c|c|c|c|c|c|c|c|c|}
\hline & \multicolumn{5}{|c|}{ Todos os indivíduos } & \multicolumn{2}{|c|}{ Caucasianos } & \multirow[b]{2}{*}{$\begin{array}{c}\text { OR } \\
(\mathrm{IC})^{* *}\end{array}$} \\
\hline & $\begin{array}{c}\text { FL/P } \\
(n=170)\end{array}$ & $\begin{array}{c}\text { Controle } \\
(n=255)\end{array}$ & $\mathbf{P} *$ & $\begin{array}{c}\mathbf{O R} \\
(\mathrm{IC})^{* *}\end{array}$ & $\begin{array}{c}\text { FL/P } \\
(n=131)\end{array}$ & $\begin{array}{c}\text { Controle } \\
(n=193)\end{array}$ & $\mathbf{P}^{*}$ & \\
\hline \multicolumn{9}{|l|}{ Alelo } \\
\hline $\begin{array}{l}1 \mathrm{G} \\
2 \mathrm{G}\end{array}$ & $\begin{array}{l}133 \\
207\end{array}$ & $\begin{array}{l}196 \\
254\end{array}$ & 0,21 & $\begin{array}{c}1,2 \\
(0,9-1,6)\end{array}$ & $\begin{array}{l}106 \\
156\end{array}$ & $\begin{array}{l}171 \\
215\end{array}$ & 0,33 & $\begin{array}{c}0,85 \\
(0,62-1,2)\end{array}$ \\
\hline \multicolumn{9}{|c|}{ Genótipo } \\
\hline $\begin{array}{l}1 \mathrm{G} / 1 \mathrm{G} \\
1 \mathrm{G} / 2 \mathrm{G} \\
2 \mathrm{G} / 2 \mathrm{G}\end{array}$ & $\begin{array}{l}29 \\
75 \\
66\end{array}$ & $\begin{array}{c}46 \\
104 \\
75\end{array}$ & 0,47 & $\begin{array}{c}0,92 \\
(0,6-1,4)\end{array}$ & $\begin{array}{l}28 \\
50 \\
53\end{array}$ & $\begin{array}{l}42 \\
87 \\
64\end{array}$ & 0,36 & $\begin{array}{c}0,88 \\
(0,6-1,3)\end{array}$ \\
\hline
\end{tabular}

\footnotetext{
* Qui-quadrado com 1 e 2 graus de liberdade (para alelo e genótipo, respectivamente); $\mathrm{p} \leq 0,05$ indica diferença estatística significante.

** OR, odds ratio; IC, intervalo de confiança, 95\%.
} 
Tabela 7. Distribuição dos alelos e genótipos do polimorfismo -1607 1G/2G no gene MMP1 em indivíduos com FL/P e FP, na população total e em caucasianos.

\begin{tabular}{|c|c|c|c|c|}
\hline & \multicolumn{2}{|c|}{$\begin{array}{c}\text { Todos os indivíduos } \\
(\mathrm{n}=\mathbf{1 7 0})\end{array}$} & \multicolumn{2}{|c|}{$\begin{array}{c}\text { Caucasianos somente } \\
(\mathrm{n}=131)\end{array}$} \\
\hline & $\begin{array}{r}\text { FL/P } \\
(n=139)\end{array}$ & $\begin{array}{c}\text { FP } \\
(n=24)\end{array}$ & $\begin{array}{c}\text { FL/P } \\
(\mathbf{n}=110)\end{array}$ & $\begin{array}{c}\text { FP } \\
(n=19)\end{array}$ \\
\hline \multicolumn{5}{|l|}{ Alelo } \\
\hline $\begin{array}{l}1 \mathrm{G} \\
2 \mathrm{G}\end{array}$ & $\begin{array}{l}107 \\
171\end{array}$ & $\begin{array}{l}21 \\
27\end{array}$ & $\begin{array}{c}79 \\
133\end{array}$ & $\begin{array}{l}18 \\
20\end{array}$ \\
\hline $\mathbf{P}^{* *}$ & 0,18 & 0,98 & 0,09 & 0,72 \\
\hline \multicolumn{5}{|l|}{ Genótipo } \\
\hline $\begin{array}{l}1 \mathrm{G} / 1 \mathrm{G} \\
1 \mathrm{G} / 2 \mathrm{G} \\
2 \mathrm{G} / 2 \mathrm{G}\end{array}$ & $\begin{array}{l}25 \\
57 \\
57\end{array}$ & $\begin{array}{c}4 \\
13 \\
7\end{array}$ & $\begin{array}{l}21 \\
37 \\
48\end{array}$ & $\begin{array}{c}4 \\
10 \\
5\end{array}$ \\
\hline $\mathbf{P}^{* *}$ & 0,33 & 0,75 & 0,10 & 0,79 \\
\hline
\end{tabular}

*Tipo/lado desconhecido, para todos os indivíduos, $\mathrm{n}=7$; caucasianos somente, $\mathrm{n}=4$.

** Comparados com indivíduos controles. Qui-quadrado com 1 e 2 graus de liberdade (para alelo e genótipo, respectivamente); $\mathrm{p} \leq 0,05$ indica diferença estatística.

\subsubsection{MMP3}

As características da população estudada para o gene MMP3 estão listadas na Tabela 8 .

Diferenças estatísticas significativas foram observadas comparando-se as freqüências dos genótipos e dos alelos entre casos e controles e entre subfenótipos de casos e controles, utilizando todos os indivíduos ou somente indivíduos caucasianos para as análises (Tabelas 9 e 10). 
Tabela 8. Características da população estudada para o gene MMP3.

Características

\begin{tabular}{lccc} 
Características & \multicolumn{3}{c}{ MMP3 } \\
\cline { 2 - 4 } & $\begin{array}{c}\text { FL/P } \\
(\mathbf{n}=\mathbf{7 8})\end{array}$ & $\begin{array}{c}\text { Controles } \\
(\mathbf{n}=\mathbf{2 5 5 )}\end{array}$ & $\mathbf{P}$ \\
\hline Idade* $^{17,7 \pm 10,2}$ & $36,2 \pm 13$ & $0,000001 \%$ \\
\hline Homens & 40 & 96 & $0,03 * * *$ \\
Mulheres & 38 & 159 & $0,6694^{* * *}$ \\
\hline Caucasianos** & 64 & 219 & \\
Japoneses & 11 & 29 & \\
Negros & 2 & 4 & 3 \\
Etnia desconhecida & 1 & & \\
\hline
\end{tabular}

* Idade média \pm desvio padrão, em anos.

† Teste t de Student; $p \leq 0,05$ indica diferença estatística significante.

** Brasileiros sem ascendência Africana ou Japonesa.

*** Qui-quadrado com 1 grau de liberdade; $p \leq 0,05$ indica diferença estatística significante.

Tabela 9. Distribuição dos alelos e genótipos do polimorfismo -1171 5A/6A no gene MMP3 em casos e controles na população total e em caucasianos.

\begin{tabular}{|c|c|c|c|c|c|c|c|c|}
\hline & \multicolumn{4}{|c|}{ Todos os indivíduos } & \multicolumn{4}{|c|}{ Caucasianos } \\
\hline & $\begin{array}{c}\text { FL/P } \\
(n=78)\end{array}$ & $\begin{array}{c}\text { Controle } \\
(n=255)\end{array}$ & $\mathbf{P} *$ & $\begin{array}{c}\text { OR } \\
(\mathrm{IC})^{* *}\end{array}$ & $\begin{array}{c}\text { FL/P } \\
(n=64)\end{array}$ & $\begin{array}{c}\text { Controle } \\
(n=219)\end{array}$ & $\mathbf{P} *$ & $\begin{array}{c}\mathbf{O R} \\
(\mathrm{IC})^{* *}\end{array}$ \\
\hline Alelo & & & & & & & & \\
\hline $\begin{array}{l}5 \mathrm{~A} \\
6 \mathrm{~A}\end{array}$ & $\begin{array}{c}110 \\
46\end{array}$ & $\begin{array}{l}251 \\
259\end{array}$ & 0,00001 & $\begin{array}{c}2,5 \\
(1,7-3,6)\end{array}$ & $\begin{array}{l}92 \\
36\end{array}$ & $\begin{array}{l}225 \\
213\end{array}$ & 0,00001 & $\begin{array}{c}2,4 \\
(1,6-3,7)\end{array}$ \\
\hline Genótip & & & & & & & & \\
\hline $\begin{array}{l}5 \mathrm{~A} / 5 \mathrm{~A} \\
5 \mathrm{~A} / 6 \mathrm{~A} \\
6 \mathrm{~A} / 6 \mathrm{~A}\end{array}$ & $\begin{array}{c}35 \\
40 \\
3\end{array}$ & $\begin{array}{c}65 \\
121 \\
69\end{array}$ & 0,00001 & $\begin{array}{c}2,37 \\
(1,4-4)\end{array}$ & $\begin{array}{c}31 \\
30 \\
3\end{array}$ & $\begin{array}{c}60 \\
105 \\
54\end{array}$ & 0,0002 & $\begin{array}{c}2,5 \\
(1,4-4,4)\end{array}$ \\
\hline
\end{tabular}

* Qui-quadrado com 1 e 2 graus de liberdade (para alelo e genótipo, respectivamente); $\mathrm{p} \leq 0,05$ indica diferença estatística significante. 
Tabela 10. Distribuição dos alelos e genótipos do polimorfismo -1171 5A/6A no gene MMP3 em indivíduos com FL/P e FP, na população total e em caucasianos.

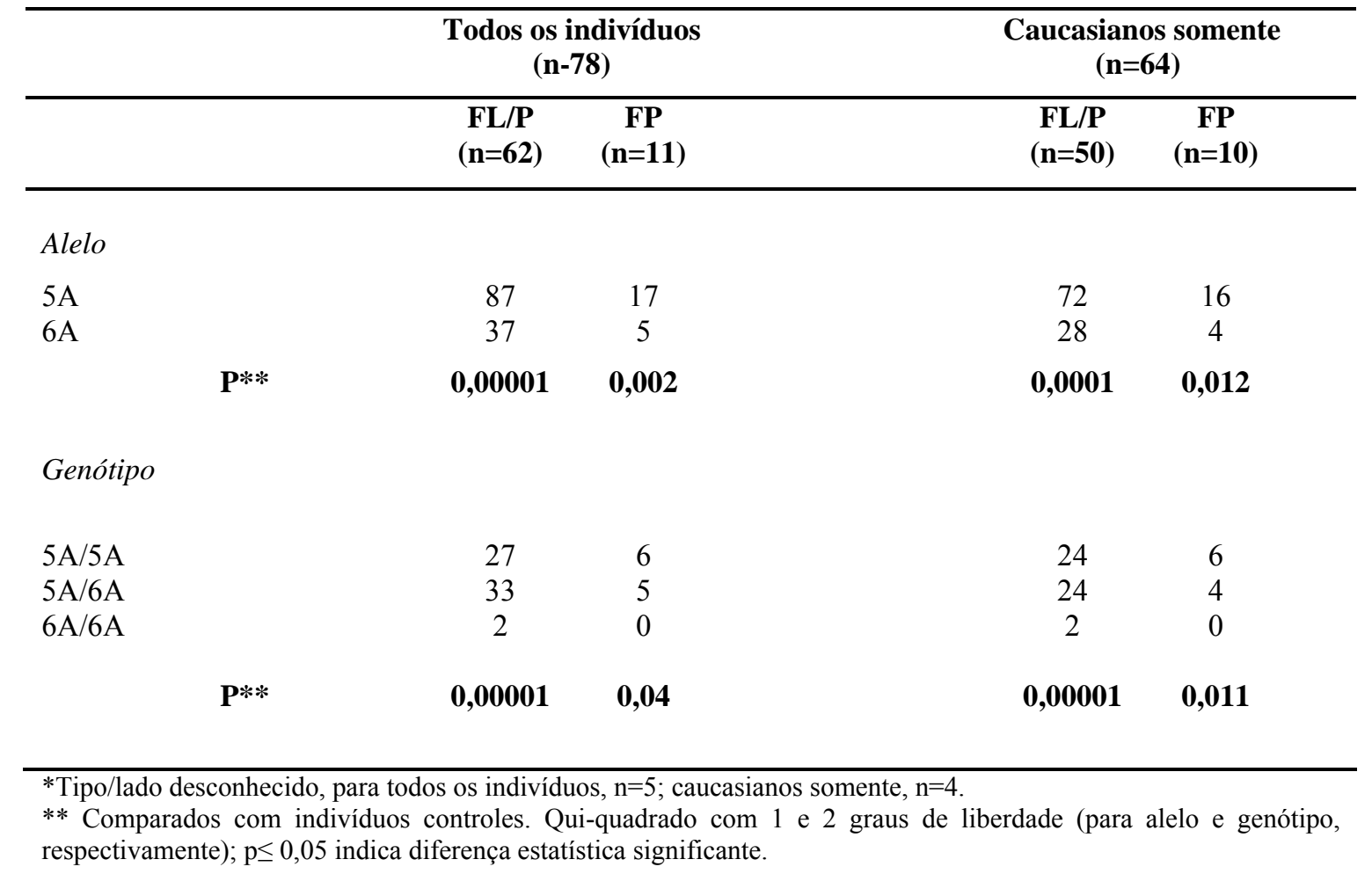

\subsubsection{MMP-9}

As características da população estudada para o gene MMP9 estão listadas na Tabela 11.

Não houve diferença estatística significativa comparando-se as freqüências dos genótipos e dos alelos entre casos e controles e entre subfenótipos de casos e controles, utilizando todos os indivíduos ou somente indivíduos caucasianos para as análises (Tabelas 12 e 13). 
Tabela 11. Características da população estudada para o gene MMP9.

Características

MMP9

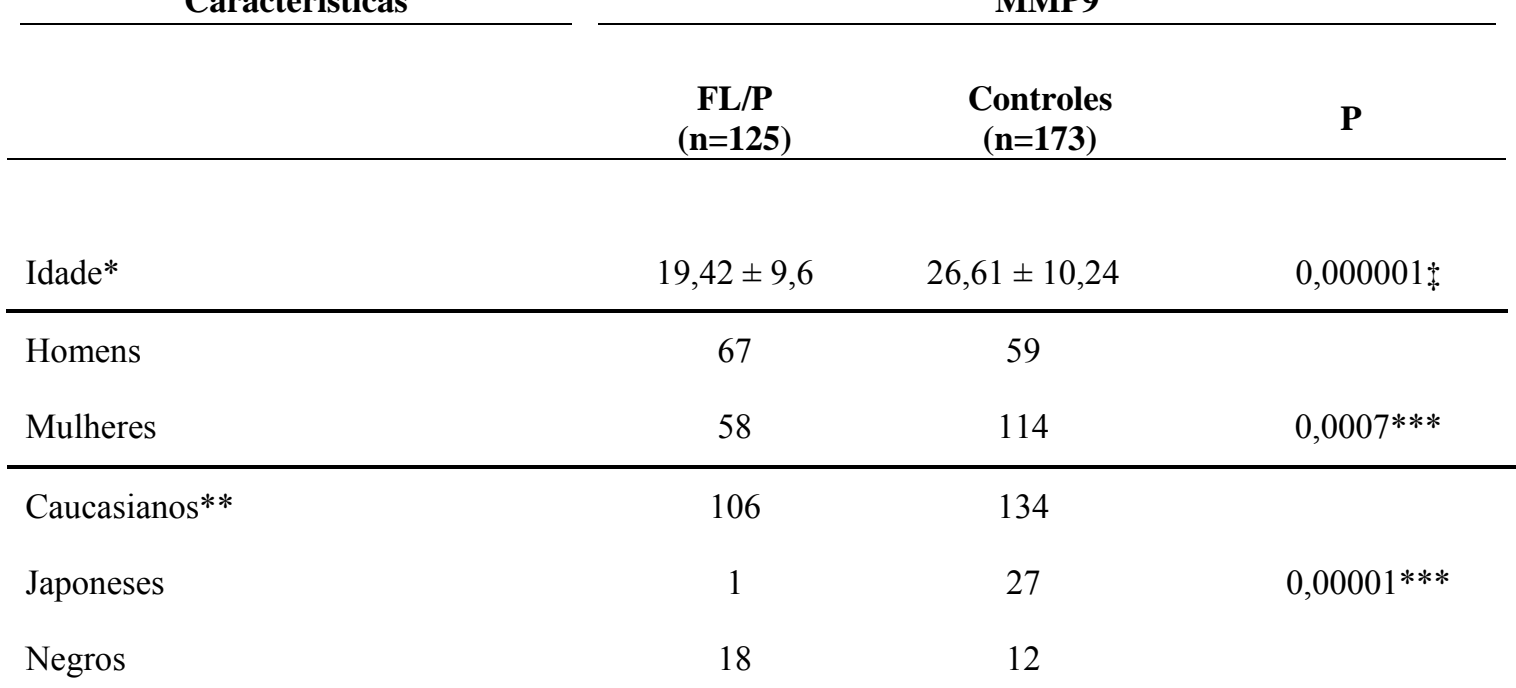

* Idade média \pm desvio padrão, em anos.

$\ddagger$ Teste $T$ de Student; $p \leq 0,05$ indica diferença estatística significante.

** Brasileiros sem ascendência Africana ou Japonesa.

*** Qui-quadrado com 1 grau de liberdade; $p \leq 0,05$ indica diferença estatística significante

Tabela 12. Distribuição dos alelos e genótipos do polimorfismo -1562 C/T no gene MMP9 em casos e controles, na população total e em caucasianos.

Todos os indivíduos

Caucasianos**

\begin{tabular}{|c|c|c|c|c|c|c|c|c|}
\hline & $\begin{array}{c}\text { FL/P } \\
(n=125)\end{array}$ & $\begin{array}{l}\text { Controle } \\
(n=173)\end{array}$ & $\mathbf{P}^{*}$ & $\begin{array}{c}\mathrm{OR} \\
(\mathrm{IC})^{* * *}\end{array}$ & $\begin{array}{c}\text { FL/P } \\
(n=90)\end{array}$ & $\begin{array}{c}\text { Controle } \\
(n=132)\end{array}$ & $\mathbf{P}^{*}$ & $\begin{array}{c}\text { OR } \\
(\mathrm{IC}) * * *\end{array}$ \\
\hline \multicolumn{9}{|c|}{ Alelo } \\
\hline $\mathrm{C}$ & 226 & 305 & \multirow[t]{2}{*}{0,38} & 1.3 & 181 & 237 & \multirow[t]{2}{*}{0,79} & 1.2 \\
\hline $\mathrm{T}$ & 24 & 41 & & $(0,7-2.3)$ & 19 & 27 & & $(0,7-2.2)$ \\
\hline \multicolumn{9}{|c|}{ Genótipo } \\
\hline $\mathrm{CC}$ & 101 & 132 & \multirow[t]{3}{*}{0,35} & \multirow{3}{*}{$\begin{array}{c}1.3 \\
(0,7-2.1)\end{array}$} & 81 & 105 & \multirow[t]{3}{*}{0,78} & \multirow{3}{*}{$\begin{array}{c}1.1 \\
(0,6-2.1)\end{array}$} \\
\hline $\mathrm{CT}$ & 24 & 41 & & & 19 & 27 & & \\
\hline TT & 0 & 0 & & & 0 & 0 & & \\
\hline
\end{tabular}

* Qui-quadrado com 1 e 2 graus de liberdade (para alelo e genótipo, respectivamente); $\mathrm{p} \leq 0,05$ indica diferença estatística significante.

** Brasileiros sem ascendência Africana ou Japonesa.

*** OR, odds ratio; IC, intervalo de confianca (95\%). 
Tabela 13. Distribuição dos alelos e genótipos do polimorfismo -1562 C/T no gene MMP9 em indivíduos com FL/P e FP, na população total e em caucasianos.

\begin{tabular}{|c|c|c|c|c|c|}
\hline & & \multicolumn{2}{|c|}{$\begin{array}{c}\text { Todos os indivíduos } \\
(\mathrm{n}=125)^{*}\end{array}$} & \multicolumn{2}{|c|}{$\begin{array}{c}\text { Caucasianos** } \\
\qquad(\mathrm{n}=94)^{*}\end{array}$} \\
\hline & & $\begin{array}{c}\text { FL/P } \\
(n=103)\end{array}$ & $\begin{array}{c}\text { FP } \\
(n=22)\end{array}$ & $\begin{array}{c}\text { FL/P } \\
(n=83)\end{array}$ & $\begin{array}{c}\text { FP } \\
(n=14)\end{array}$ \\
\hline \multicolumn{6}{|c|}{ Alelo } \\
\hline $\mathrm{C}$ & & 186 & 40 & 149 & 24 \\
\hline $\mathrm{T}$ & & 36 & 4 & 17 & 2 \\
\hline & $\mathbf{P} * * *$ & 0,14 & 0,59 & 0,99 & 0,68 \\
\hline \multicolumn{6}{|c|}{ Genótipo } \\
\hline $\mathrm{CC}$ & & 84 & 18 & 66 & 11 \\
\hline $\mathrm{CT}$ & & 18 & 4 & 17 & 2 \\
\hline TT & & 0 & 0 & 0 & 0 \\
\hline & $\mathbf{P}^{* * *}$ & 0,24 & 0,56 & 0,99 & 0,66 \\
\hline
\end{tabular}

*Tipo/lado desconhecido, para caucasianos, $\mathrm{n}=4$.

** Brasileiros sem ascendência Africana ou Japonesa.

*** Comparados com indivíduos controles. Qui-quadrado com 1 e 2 graus de liberdade (para alelo e genótipo, respectivamente); $\mathrm{p} \leq 0,05$ indica diferença estatística significante. 


\subsubsection{TGFA}

A distribuição dos genótipos e alelos para os polimorfismos estudados no gene TGFA em casos e controles utilizando a população total e caucasianos somente encontra-se nas Tabelas 14 e 15.

A análise comparativa entre casos e controles, utilizando a população total, mostrou diferenças significativas para as freqüências dos genótipos no marcador rs930655 (Tabela 14). Entretanto, a análise utilizando somente os indivíduos caucasianos da amostra não revelou diferenças entre os grupos (Tabela 15).

Tabela 14. Análise comparativa das freqüências dos genótipos e dos alelos obtidas para casos e controles (população total) para cada polimorfismo estudado no gene TGFA.

\begin{tabular}{|c|c|c|c|c|c|c|c|c|}
\hline \multirow{2}{*}{ Marcadores } & \multirow{2}{*}{$\mathbf{n}$} & \multicolumn{3}{|c|}{ Genótipos } & \multirow{2}{*}{ P* } & \multicolumn{2}{|c|}{ Alelos } & \multirow{2}{*}{$\mathbf{P}^{*}$} \\
\hline & & AA & AB & BB & & A & B & \\
\hline $\begin{array}{r}\text { rs1058213 } \\
\text { casos } \\
\text { controles }\end{array}$ & $\begin{array}{l}465 \\
467\end{array}$ & $\begin{array}{l}441 \\
427\end{array}$ & $\begin{array}{c}3 \\
11\end{array}$ & $\begin{array}{l}21 \\
29\end{array}$ & 0,04 & $\begin{array}{l}885 \\
865\end{array}$ & $\begin{array}{l}45 \\
69\end{array}$ & 0,02 \\
\hline $\begin{array}{r}\text { rs2166975 } \\
\text { casos } \\
\text { controles }\end{array}$ & $\begin{array}{l}464 \\
475\end{array}$ & $\begin{array}{l}330 \\
365\end{array}$ & $\begin{array}{l}98 \\
84\end{array}$ & $\begin{array}{l}36 \\
26\end{array}$ & 0,11 & $\begin{array}{l}758 \\
814\end{array}$ & $\begin{array}{l}170 \\
136\end{array}$ & 0,01 \\
\hline $\begin{array}{r}\text { rs930655 } \\
\text { casos } \\
\text { controles }\end{array}$ & $\begin{array}{l}474 \\
480\end{array}$ & $\begin{array}{l}91 \\
85\end{array}$ & $\begin{array}{l}212 \\
237\end{array}$ & $\begin{array}{l}271 \\
158\end{array}$ & 0,00001 & $\begin{array}{l}394 \\
407\end{array}$ & $\begin{array}{l}754 \\
553\end{array}$ & 0,0001 \\
\hline $\begin{array}{r}\text { rs1523305 } \\
\text { casos } \\
\text { controles }\end{array}$ & $\begin{array}{l}463 \\
474\end{array}$ & $\begin{array}{l}104 \\
107\end{array}$ & $\begin{array}{l}231 \\
235\end{array}$ & $\begin{array}{l}128 \\
132\end{array}$ & 0,99 & $\begin{array}{l}439 \\
449\end{array}$ & $\begin{array}{l}487 \\
499\end{array}$ & 0,98 \\
\hline $\begin{array}{r}\text { rs2902345 } \\
\text { casos } \\
\text { controles }\end{array}$ & $\begin{array}{l}457 \\
476\end{array}$ & $\begin{array}{l}144 \\
159\end{array}$ & $\begin{array}{l}225 \\
225\end{array}$ & $\begin{array}{l}88 \\
92\end{array}$ & 0,80 & $\begin{array}{l}513 \\
543\end{array}$ & $\begin{array}{l}401 \\
409\end{array}$ & 0,69 \\
\hline $\begin{array}{r}\text { rs377122 } \\
\text { casos } \\
\text { controles }\end{array}$ & $\begin{array}{l}470 \\
478\end{array}$ & $\begin{array}{c}89 \\
105\end{array}$ & $\begin{array}{l}239 \\
255\end{array}$ & $\begin{array}{l}142 \\
118\end{array}$ & 0,14 & $\begin{array}{l}417 \\
465\end{array}$ & $\begin{array}{l}523 \\
491\end{array}$ & 0,06 \\
\hline
\end{tabular}

* $\mathrm{p} \leq 0,0005$ indica diferença estatística significante (em negrito, realçado em cinza); $\mathrm{p} \leq 0,05$ indica tendência à significância (em itálico). 
Tabela 15. Análise comparativa das freqüências dos genótipos obtidos para casos e controles (caucasianos) para cada polimorfismo estudado no gene TGFA.

\begin{tabular}{|c|c|c|c|c|c|c|c|c|}
\hline \multirow[t]{2}{*}{ Marcadores } & \multirow[t]{2}{*}{$\mathbf{n}$} & \multicolumn{3}{|c|}{$\begin{array}{c}\text { Genótipos } \\
\text { (Caucasianos)** }^{*}\end{array}$} & \multirow[t]{2}{*}{$\mathbf{P} *$} & \multicolumn{2}{|c|}{$\begin{array}{c}\text { Alelos } \\
\text { (Caucasianos)** }\end{array}$} & \multirow[t]{2}{*}{$\mathbf{P}^{*}$} \\
\hline & & AA & AB & BB & & $\mathbf{A}$ & B & \\
\hline $\begin{array}{r}\text { rs1058213 casos } \\
\text { controles }\end{array}$ & $\begin{array}{l}379 \\
276\end{array}$ & $\begin{array}{l}358 \\
259\end{array}$ & $\begin{array}{l}3 \\
1\end{array}$ & $\begin{array}{l}18 \\
16\end{array}$ & 0,66 & $\begin{array}{l}719 \\
519\end{array}$ & $\begin{array}{l}39 \\
33\end{array}$ & 0,51 \\
\hline $\begin{array}{r}\text { rs2166975 } \\
\text { casos } \\
\text { controles }\end{array}$ & $\begin{array}{l}373 \\
282\end{array}$ & $\begin{array}{l}266 \\
215\end{array}$ & $\begin{array}{l}76 \\
51\end{array}$ & $\begin{array}{l}31 \\
16\end{array}$ & 0,28 & $\begin{array}{l}608 \\
481\end{array}$ & $\begin{array}{c}138 \\
83\end{array}$ & 0,07 \\
\hline $\begin{array}{r}\text { rs930655 } \\
\text { casos } \\
\text { controles }\end{array}$ & $\begin{array}{l}386 \\
285\end{array}$ & $\begin{array}{l}79 \\
54\end{array}$ & $\begin{array}{l}181 \\
140\end{array}$ & $\begin{array}{c}126 \\
91\end{array}$ & 0,82 & $\begin{array}{l}339 \\
248\end{array}$ & $\begin{array}{l}433 \\
322\end{array}$ & 0,88 \\
\hline $\begin{array}{r}\text { rs1523305 } \\
\text { casos } \\
\text { controles }\end{array}$ & $\begin{array}{l}375 \\
282\end{array}$ & $\begin{array}{l}80 \\
64\end{array}$ & $\begin{array}{l}194 \\
148\end{array}$ & $\begin{array}{c}101 \\
70\end{array}$ & 0,81 & $\begin{array}{l}354 \\
276\end{array}$ & $\begin{array}{l}396 \\
288\end{array}$ & 0,53 \\
\hline $\begin{array}{r}\text { rs2902345 casos } \\
\text { controles }\end{array}$ & $\begin{array}{l}358 \\
282\end{array}$ & $\begin{array}{c}120 \\
84\end{array}$ & $\begin{array}{l}170 \\
144\end{array}$ & $\begin{array}{l}68 \\
54\end{array}$ & 0,64 & $\begin{array}{l}410 \\
306\end{array}$ & $\begin{array}{l}306 \\
252\end{array}$ & 0,39 \\
\hline $\begin{array}{r}\text { rs377122 } \\
\text { casos } \\
\text { controles }\end{array}$ & $\begin{array}{l}382 \\
284\end{array}$ & $\begin{array}{l}75 \\
62\end{array}$ & $\begin{array}{l}195 \\
160\end{array}$ & $\begin{array}{c}112 \\
62\end{array}$ & 0,09 & $\begin{array}{l}345 \\
284\end{array}$ & $\begin{array}{l}419 \\
284\end{array}$ & 0,08 \\
\hline
\end{tabular}

$* \mathrm{p} \leq 0,0005$ indica diferença estatística significante.

** Brasileiros sem ascendência Africana ou Japonesa.

As Tabelas 16 (todos os indivíduos) e 17 (caucasianos) demonstram as diferenças entre as freqüências dos genótipos e alelos obtidos nos indivíduos de cada subfenótipo de FL/P e controles para cada polimorfismo estudado no gene TGFA, e estão representados pelo valor de $\mathrm{P}$ obtido para os genótipos seguido do valor obtido para os alelos $\left(\mathrm{P}_{\text {genótipo }} / \mathrm{P}_{\text {alelo }}\right)$. Diferenças significantes foram observadas para a freqüência dos genótipos entre os grupos, utilizando a amostra total, para o marcador rs930655 (Tabela 16). Analisando somente os indivíduos caucasianos da amostra, diferenças significativas foram observadas para a freqüência dos alelos do marcador rs1058213 (C3827T) nos grupos FP incompleta + submucosa e FP total, quando comparados com controles. Diferenças significativas também foram observadas entre as freqüências dos genótipos obtidos para o marcador rs2902345 entre os grupos FL/P total e controles (Tabela 17). 
Tabela 16. Análise comparativa das freqüências dos genótipos e alelos (genótipos/alelos) obtidos para casos e controles (população total) para cada polimorfismo estudado no gene TGFA.

\begin{tabular}{|c|c|c|c|c|c|c|c|}
\hline Subfenótipo & $\mathbf{n}$ & 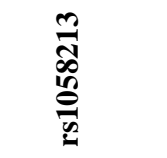 & 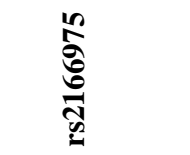 & 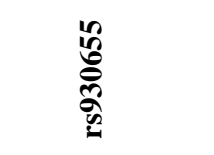 & 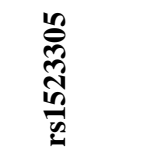 & 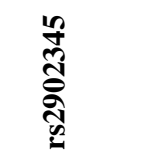 & 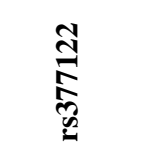 \\
\hline \multicolumn{8}{|l|}{ Fissura Palatina } \\
\hline Completa & 21 & $0,39 / 0,01$ & $0,96 / 0,90$ & $0,62 / 0,34$ & $0,74 / 0,52$ & $0,46 / 0,23$ & $0,74 / 0,65$ \\
\hline $\begin{array}{l}\text { Incompleta }+ \\
\text { submucosa }\end{array}$ & 45 & $0,58 / 0,84$ & $0,48 / 0,24$ & $0,16 / 0,14$ & $0,13 / 0,45$ & $0,05 / 0,86$ & $0,35 / 0,87$ \\
\hline Total FP & 66 & $0,39 / 0,27$ & $0,54 / 0,30$ & $0,54 / 0,49$ & $0,43 / 0,78$ & $0,18 / 0,61$ & $0,30 / 0,71$ \\
\hline \multicolumn{8}{|l|}{$\begin{array}{l}\text { Fissura Labio- } \\
\text { Palatina }\end{array}$} \\
\hline Completa & 300 & $0,26 / 0,08$ & $0,07 / 0,009$ & $0,09 / 0,25$ & $0,88 / 0,75$ & $0,92 / 0,68$ & $0,11 / 0,11$ \\
\hline Incompleta & 104 & $0,30 / 0,56$ & $0,94 / 0,70$ & $0,13 / 0,13$ & $0,61 / 0,35$ & $0,97 / 0,81$ & $0,02 / 0,006$ \\
\hline Unilateral & 250 & $0,46 / 0,19$ & $0,09 / 0,01$ & $0,01 / 0,53$ & $0,52 / 0,48$ & $0,75 / 0,97$ & $0,01 / 0,005$ \\
\hline Completa & 175 & $0,81 / 0,44$ & $0,01 / 0,0009$ & $0,02 / 0,12$ & $0,56 / 0,74$ & $0,56 / 0,94$ & $0,04 / 0,05$ \\
\hline Incompleta & 75 & $0,31 / 0,16$ & $0,86 / 0,55$ & $0,09 / 0,25$ & $0,65 / 0,36$ & $0,97 / 0,85$ & $0,01 / 0,008$ \\
\hline Direita & 78 & $0,05 / 0,008$ & $0,83 / 0,49$ & $0,05 / 0,17$ & $0,31 / 0,12$ & $0,61 / 0,96$ & $0,23 / 0,12$ \\
\hline Completa & 54 & $0,01 / 0,0001$ & $0,76 / 0,46$ & $0,33 / 0,23$ & $0,17 / 0,06$ & $0,81 / 0,84$ & $0,25 / 0,21$ \\
\hline Incompleta & 16 & $0,70 / 0,90$ & $0,64 / 0,38$ & $0,08 \dagger$ & $0,95 / 0,94$ & $0,46 / 0,29$ & $0,34 / 0,19$ \\
\hline Incompleta + FP & 8 & $0,54 / 0,15$ & $0,57 / 0,35$ & $0,03 / 0,26$ & $0,51 / 0,84$ & $0,46 / 0,28$ & $0,97 / 0,91$ \\
\hline Esquerda & 172 & $0,94 / 0,98$ & $0,05 / 0,009$ & $0,11 / 0,87$ & $0,47 / 0,93$ & $0,28 / 0,99$ & $0,02 / 0,009$ \\
\hline Completa & 121 & $0,88 / 0,45$ & $0,003 / 0,0001$ & $0,03 / 0,24$ & $0,45 / 0,43$ & $0,21 / 0,82$ & $0,10 / 0,11$ \\
\hline Incompleta & 46 & $0,30 \dagger$ & $0,90 / 0,64$ & $0,47 / 0,22$ & $0,48 / 0,49$ & $0,97 / 0,80$ & $0,03 / 0,01$ \\
\hline Incompleta + FP & 5 & $0,79 / 0,38$ & $0,26 / 0,07$ & $0,42 / 0,26$ & $0,34 / 0,15$ & $0,38 / 0,65$ & $0,45 / 0,24$ \\
\hline Bilateral & 154 & $0,04 / 0,18$ & $0,25 / 0,28$ & $0,90 / 0,67$ & $0,74 / 0,50$ & $0,86 / 0,90$ & $0,47 / 0,40$ \\
\hline Completa & 125 & $0,04 \dagger$ & $0,25 / 0,65$ & $0,90 / 0,91$ & $0,55 / 0,35$ & $0,69 / 0,82$ & $0,84 / 0,65$ \\
\hline Incompleta & 8 & $0,64 / 0,42$ & $0,56 / 0,22$ & $0,17 / 0,16$ & $0,37 / 0,20$ & $0,60 / 0,34$ & $0,05 / 0,06$ \\
\hline Incompleta + FP & 17 & $0,71 / 0,98$ & $0,23 / 0,48$ & $0,02 / 0,008$ & $0,38 / 0,16$ & $0,68 / 0,45$ & $0,65 / 0,61$ \\
\hline Incompleta mista & 4 & $0,29 / 0,05$ & $0,05 / 0,22$ & $0,51 / 0,78$ & $0,99 / 0,88$ & $0,92 / 0,68$ & $0,38 / 0,18$ \\
\hline Fissura Mediana & 2 & $\begin{array}{l}--- \\
---\end{array}$ & $\begin{array}{l}--- \\
---\end{array}$ & $\begin{array}{ll}--- \\
---\end{array}$ & ---- & $\begin{array}{ll}--- \\
---\end{array}$ & $\begin{array}{ll}--- \\
---\end{array}$ \\
\hline Total FL/P & 406 & $0,14 / 0,07$ & $0,06 / 0,007$ & $0,09 / 0,75$ & $0,88 \dagger$ & $0,92 / 0,70$ & $0,03 / 0,01$ \\
\hline $\begin{array}{l}\text { Tipo/lado } \\
\text { desconhecido }\end{array}$ & 28 & ---- & ---- & ---- & ---- & ---- & ---- \\
\hline $\begin{array}{l}\text { Total } \\
\text { Fissurados }\end{array}$ & 500 & $0,05 / 0,02$ & $0,11 / 0,01$ & $0,00001 / 0,0001$ & $0,99 / 0,98$ & $0,80 / 0,69$ & $0,14 / 0,06$ \\
\hline $\begin{array}{l}\text { Controles } \\
\text { (sem fissura) }\end{array}$ & 500 & ---- & ---- & ---- & ---- & ---- & ---- \\
\hline
\end{tabular}


Tabela 17. Análise comparativa das freqüências dos genótipos e alelos obtidos (genótipos/alelos) para casos e controles (caucasianos) para cada polimorfismo estudado no gene TGFA.

\begin{tabular}{|c|c|c|c|c|c|c|c|}
\hline Subfenótipo & $\mathbf{n}$ & 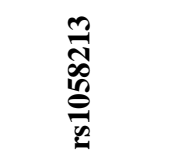 & 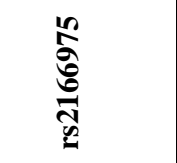 & 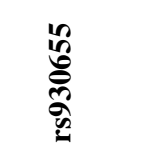 & 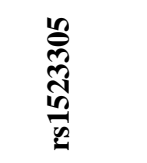 & 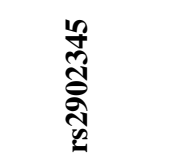 & 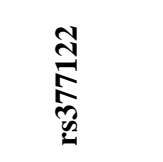 \\
\hline \multicolumn{8}{|l|}{ Fissura Palatina } \\
\hline Completa & 15 & $0,39 / 0,05$ & $0,68 / 0,42$ & $0,74 / 0,48$ & $0,90 \dagger$ & $0,77 / 0,56$ & $0,68 / 0,72$ \\
\hline $\begin{array}{l}\text { Incompleta + } \\
\text { submucosa }\end{array}$ & 38 & $0,77 / \mathbf{0 , 0 0 0 0 1}$ & $0,57 / 0,25$ & $0,10 / 0,18$ & $0,11 / 0,17$ & $0,11 \dagger$ & $0,17 / 0,51$ \\
\hline Total FP & 53 & $0,84 / \mathbf{0 , 0 0 0 0 1}$ & $0,44 / 0,18$ & $0,37 / 0,45$ & $0,32 / 0,28$ & $0,31 / 0,43$ & $0,17 / 0,72$ \\
\hline \multicolumn{8}{|l|}{$\begin{array}{l}\text { Fissura Labio- } \\
\text { Palatina }\end{array}$} \\
\hline Completa & 237 & $0,39 / 0,51$ & $0,10 / 0,01$ & $0,41 / 0,68$ & $0,64 / 0,43$ & $0,60 / 0,44$ & $0,04 / 0,12$ \\
\hline Incompleta & 86 & $0,76 / 0,95$ & $0,78 / 0,47$ & $0,30 / 0,13$ & $0,77 / 0,60$ & $0,96 / 0,95$ & $0,007 / 0,004$ \\
\hline Unilateral & 200 & $0,37 / 0,95$ & $0,21 / 0,06$ & $0,16 / 0,85$ & $0,59 / 0,99$ & $0,52 / 0,55$ & $0,005 / 0,006$ \\
\hline Completa & 136 & $0,19 / 0,81$ & $0,01 / 0,001$ & $0,10 / 0,33$ & $0,48 / 0,82$ & $0,37 / 0,54$ & $0,01 / 0,08$ \\
\hline Incompleta & 64 & $0,78 / 0,62$ & $0,31 / 0,09$ & $0,35 / 0,24$ & $0,90 / 0,70$ & $0,97 / 0,80$ & $0,007 / 0,003$ \\
\hline Direita & 60 & $0,37 / 0,06$ & $0,92 / 0,64$ & $0,15 / 0,46$ & $0,75 / 0,47$ & $0,62 / 0,41$ & $0,23 / 0,18$ \\
\hline Completa & 43 & $0,08 / 0,001$ & $0,50 / 0,19$ & $0,40 / 0,36$ & $0,54 / 0,32$ & $0,73 / 0,46$ & $0,46 / 0,42$ \\
\hline Incompleta & 11 & $0,83 / 0,46$ & $0,56 / 0,55$ & $0,42 / 0,45$ & $0,63 / 0,43$ & $0,20 / 0,08$ & $0,34 / 0,18$ \\
\hline Incompleta + FP & 6 & $0,73 / 0,26$ & $0,19 / 0,05$ & $0,12 / 0,30$ & $0,37 / 0,48$ & $0,26 / 0,12$ & $0,79 / 0,56$ \\
\hline Esquerda & 140 & $0,19 / 0,37$ & $0,13 / \mathbf{0 , 0 4}$ & $0,39 / 0,83$ & $0,35 / 0,67$ & $0,30 / 0,79$ & $0,006 / 0,007$ \\
\hline Completa & 93 & $0,05 / 0,11$ & $0,008 / 0,001$ & $0,17 / 0,51$ & $0,31 / 0,35$ & $0,18 / 0,75$ & $\mathbf{0 , 0 1 / 0 , 0 9}$ \\
\hline Incompleta & 44 & $0,81 / 0,59$ & $0,64 / 0,32$ & $0,52 / 0,25$ & $0,54 / 0,69$ & $0,98 / 0,91$ & $0,03 / 0,01$ \\
\hline Incompleta + FP & 3 & $0,83 / 0,39$ & $0,44 / 0,16$ & $0,48 / 0,25$ & $0,60 / 0,38$ & $0,77 / 0,79$ & $0,16 / 0,10$ \\
\hline Bilateral & 123 & $0,59 / 0,36$ & $0,40 / 0,34$ & $0,69 / 0,41$ & $0,67 / 0,40$ & $0,90 / 0,67$ & $0,18 / 0,38$ \\
\hline Completa & 101 & $0,44 / 0,13$ & $0,46 / 0,64$ & $0,89 / 0,64$ & $0,44 / 0,26$ & $0,76 / 0,53$ & $0,54 / 0,53$ \\
\hline Incompleta & 6 & $0,53 / 0,12$ & $0,29 / 0,07$ & $0,42 / 0,20$ & $0,37 / 0,28$ & $0,55 / 0,43$ & $0,03 / 0,08$ \\
\hline Incompleta + FP & 13 & $0,50 / 0,10$ & $0,13 / 0,55$ & $0,02 / 0,008$ & $0,37 / 0,17$ & $0,65 / 0,36$ & $0,32 / 0,44$ \\
\hline Incompleta mista & 3 & $0,13 / 0,005$ & $0,0004 / 0,01$ & $0,68 / 0,61$ & $0,80 / 0,95$ & $0,77 / 0,79$ & $0,16 / 0,10$ \\
\hline Fissura Mediana & 1 & -ב-- & $-\overline{---}$ & ---- & $\begin{array}{c}--- \\
-1\end{array}$ & ---- & $\begin{array}{c}--- \\
-1\end{array}$ \\
\hline Total FL/P & 324 & $0,68 / 0,86$ & $0,34 / 0,09$ & $0,45 / 0,81$ & $0,71 / 0,63$ & $0,00001 / 0,02$ & $0,007 / 0,01$ \\
\hline $\begin{array}{l}\text { Tipo/lado } \\
\text { desconhecido }\end{array}$ & 16 & ---- & ---. & ---- & ---- & --- & ---- \\
\hline Total Fissurados & 393 & $0,66 / 0,51$ & $0,28 / 0,07$ & $0,82 / 0,88$ & $0,80 / 0,53$ & $0,64 / 0,48$ & $0,09 / 0,07$ \\
\hline $\begin{array}{l}\text { Controles } \\
\text { (sem fissura) }\end{array}$ & 285 & ---- & ---- & -.-- & -.-- & ---- & ---- \\
\hline
\end{tabular}

* $\mathrm{p} \leq 0,0005$ indica diferença estatística significante (em negrito, realçado em cinza); $\mathrm{p} \leq 0,05$ indica tendência à significância (em itálico).

† para ambos genótipo e alelo.

** Brasileiros sem ascendência Africana ou Japonesa. 


\subsubsection{IRF6}

A distribuição dos genótipos e alelos para os polimorfismos estudados no gene IRF6 em casos e controles utilizando a população total e caucasianos somente encontra-se nas Tabelas 18 e 19.

A análise comparativa inicial entre casos e controles utilizando a população total revelou diferenças significativas para as freqüências dos genótipos e alelos obtidos para o marcador rs2235371 (V274I) (Tabela 18). Entretanto, a análise utilizando somente os indivíduos caucasianos da amostra não revelou diferenças entre os grupos (Tabela 19).

Tabela 18. Análise comparativa das freqüências dos genótipos e dos alelos obtidas para casos e controles (população total) para cada polimorfismo estudado no gene IRF6.

\begin{tabular}{|c|c|c|c|c|c|c|c|c|}
\hline \multirow{2}{*}{ Marcadores } & \multirow{2}{*}{$\mathbf{n}$} & \multicolumn{3}{|c|}{ Genótipos } & \multirow{2}{*}{$\mathbf{P}^{*}$} & \multicolumn{2}{|c|}{ Alelos } & \multirow{2}{*}{$\mathbf{P}^{*}$} \\
\hline & & AA & AB & BB & & $\mathbf{A}$ & B & \\
\hline rs4844880 & & & & & \multirow{3}{*}{0,002} & & & \multirow{3}{*}{0,001} \\
\hline casos & 492 & 33 & 183 & 276 & & 249 & 735 & \\
\hline controles & 480 & 62 & 183 & 235 & & 307 & 653 & \\
\hline \multicolumn{9}{|l|}{ rs2235371 } \\
\hline casos & 463 & 413 & 43 & 7 & \multirow{2}{*}{0,00001} & 869 & 57 & \multirow{2}{*}{0,00001} \\
\hline controles & 475 & 344 & 114 & 17 & & 802 & 148 & \\
\hline \multicolumn{9}{|l|}{ rs2013162 } \\
\hline casos & 465 & 59 & 211 & 195 & \multirow{2}{*}{0,002} & 329 & 601 & \multirow{2}{*}{0,0003} \\
\hline controles & 476 & 95 & 223 & 158 & & 413 & 539 & \\
\hline \multicolumn{9}{|l|}{ rs861019 } \\
\hline casos & 490 & 161 & 224 & 105 & \multirow{2}{*}{0,49} & 546 & 434 & \multirow{2}{*}{0,28} \\
\hline controles & 478 & 166 & 224 & 88 & & 556 & 400 & \\
\hline \multicolumn{9}{|l|}{ rs2073487 } \\
\hline casos & 464 & 58 & 209 & 197 & \multirow{2}{*}{0,001} & 325 & 603 & \multirow{2}{*}{0,003} \\
\hline controles & 477 & 95 & 224 & 158 & & 414 & 540 & \\
\hline \multicolumn{9}{|l|}{ rs658860 } \\
\hline casos & 470 & 17 & 130 & 323 & \multirow{2}{*}{0,33} & 164 & 776 & \multirow{2}{*}{0,13} \\
\hline controles & 476 & 12 & 118 & 346 & & 142 & 810 & \\
\hline
\end{tabular}

* $\mathrm{p} \leq 0,0005$ indica diferença estatística significante (em negrito, realçado em cinza); $\mathrm{p} \leq 0,05$ indica tendência à significância (em itálico). 
Tabela 19. Análise comparativa das freqüências dos genótipos obtidos para casos e controles (caucasianos) para cada polimorfismo estudado no gene IRF6.

\begin{tabular}{|c|c|c|c|c|c|c|c|c|}
\hline \multirow[t]{2}{*}{ Marcadores } & \multirow[t]{2}{*}{$\mathbf{n}$} & \multicolumn{3}{|c|}{$\begin{array}{c}\text { Genótipos } \\
\text { (Caucasianos) }\end{array}$} & \multirow[t]{2}{*}{$\mathbf{P}^{*}$} & \multicolumn{2}{|c|}{$\begin{array}{c}\text { Alelos } \\
\text { (Caucasianos) }\end{array}$} & \multirow[t]{2}{*}{$\mathbf{P}^{*}$} \\
\hline & & AA & $\mathbf{A B}$ & BB & & A & B & \\
\hline \multicolumn{9}{|l|}{ rs4844880 } \\
\hline casos & 393 & 20 & 146 & 227 & 0.69 & 186 & 600 & 0.99 \\
\hline controles & 285 & 18 & 99 & 168 & 0,09 & 135 & 435 & \\
\hline \multicolumn{9}{|l|}{ rs2235371 } \\
\hline casos & 377 & 340 & 32 & 5 & & 712 & 42 & \\
\hline controles & 281 & 245 & 34 & 2 & 0,24 & 524 & 38 & 0,31 \\
\hline \multicolumn{9}{|l|}{ rs2013162 } \\
\hline casos & 377 & 44 & 173 & 160 & 0.31 & 261 & 493 & 0.17 \\
\hline controles & 282 & 44 & 128 & 110 & 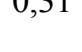 & 216 & 348 & 0,11 \\
\hline \multicolumn{9}{|l|}{ rs861019 } \\
\hline casos & 383 & 106 & 188 & 89 & 0.77 & 400 & 366 & 0,46 \\
\hline controles & 283 & 84 & 139 & 60 & & 307 & 259 & \\
\hline \multicolumn{9}{|l|}{ rs2073487 } \\
\hline casos & 391 & 43 & 186 & 162 & 0.17 & 272 & 510 & 0,14 \\
\hline controles & 282 & 45 & 128 & 109 & & 218 & 346 & \\
\hline \multicolumn{9}{|l|}{ rs658860 } \\
\hline casos & 383 & 10 & 115 & 258 & 0,51 & 135 & 631 & 0,26 \\
\hline controles & 281 & 6 & 74 & 201 & & 86 & 476 & \\
\hline
\end{tabular}

* $\mathrm{p} \leq 0,0005$ indica diferença estatística significante (em negrito, realçado em cinza); $\mathrm{p} \leq 0,05$ indica tendência à significância (em itálico).

** Brasileiros sem ascendência Africana ou Japonesa.

As Tabelas 20 e 21 demonstram as diferenças entre as freqüências dos genótipos e alelos obtidos nos indivíduos de cada subfenótipo de FL/P e controles para cada polimorfismo estudado no gene IRF6, e estão representados pelo valor de P obtido para os genótipos seguido do valor obtido para os alelos $\left(\mathrm{P}_{\text {genótipo }} / \mathrm{P}_{\text {alelo }}\right)$.

Analisando a população total, foram observadas diferenças significantes entre as freqüências de ambos genótipos e alelos para determinados subfenótipos de FL/P e controles para os marcadores rs4844880 (FL/P incompleta), rs2235371 (V274I) (FL/P completa, FL/P incompleta, FL/P unilateral, FL/P esquerda, e FL/P total), rs2013162 (FL/P total) e rs2073487 (FL/P total) (Tabela 20). Diferenças significativas ainda foram observadas para as freqüências dos alelos somente entre FL/P unilateral completa e incompleta, e FL/P bilateral e controles para o marcador rs2235371 (V274I) (Tabela 20). Entretanto, a análise utilizando somente os indivíduos caucasianos da amostra não revelou diferenças entre os grupos (Tabela 21). 
Tabela 20, Análise comparativa das freqüências dos genótipos e alelos (genótipos/alelos) obtidos para casos e controles (população total) para cada polimorfismo estudado no gene IRF6.

\begin{tabular}{|c|c|c|c|c|c|c|c|}
\hline Subfenótipo & $\mathbf{n}$ & 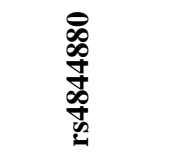 & 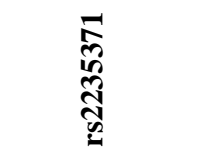 & 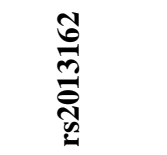 & 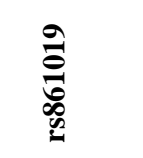 & 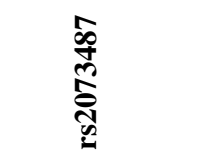 & 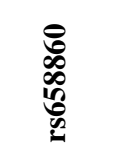 \\
\hline \multicolumn{8}{|l|}{ Fissura Palatina } \\
\hline Completa & 21 & $0,25 / 0,35$ & $0,34 / 0,33$ & $0,46 / 0,60$ & $0,37 / 0,24$ & $0,46 / 0,60$ & $0,51 / 0,67$ \\
\hline Incompleta + submucosa & 45 & $0,47 / 0,41$ & $0,08 / 0,10$ & $0,93 / 0,83$ & $0,86 / 0,70$ & $0,96 / 0,80$ & $0,70 / 0,46$ \\
\hline Total FP & 66 & $0,54 / 0,24$ & $0,03 / 0,06$ & $0,93 / 0,92$ & $0,49 / 0,34$ & $0,88 / 0,93$ & $0,61 / 0,71$ \\
\hline \multicolumn{8}{|l|}{ Fissura Labio-Palatina } \\
\hline Completa & 300 & $0,04 / 0,09$ & $0,00001 \dagger$ & $\begin{array}{l}0,002 / \\
0,0006\end{array}$ & $0,07 / 0,01$ & $0,001 / 0,0002$ & $0,15 / 0,04$ \\
\hline Incompleta & 104 & $\begin{array}{c}\mathbf{0 , 0 0 0 0 5 /} \\
\mathbf{0 , 0 0 0 0 1}\end{array}$ & $0,00001 \dagger$ & $\begin{array}{l}0,001 / \\
0,0002\end{array}$ & $0,18 / 0,14$ & $0,001 / 0,0001$ & $0,60 / 0,32$ \\
\hline Unilateral & 250 & $0,01 / 0,01$ & $0,00001 \dagger$ & $\begin{array}{c}0,0005 / \\
0,0001\end{array}$ & $0,03 / 0,02$ & $0,0004 / 0,0001$ & $0,42 / 0,35$ \\
\hline Completa & 175 & $0,16 / 0,17$ & $0,0001 / 0,00001$ & $0,005 / 0,002$ & $0,09 / 0,03$ & $0,005 / 0,001$ & $0,48 / 0,30$ \\
\hline Incompleta & 75 & $0,008 / 0,0009$ & $0,0003 / 0,00001$ & $0,03 / 0,005$ & $0,13 / 0,16$ & $0,02 / 0,005$ & $0,66 / 0,79$ \\
\hline Direita & 78 & $0,21 / 0,07$ & $0,001 / 0,0004$ & $0,02 / 0,004$ & $0,25 / 0,15$ & $0,02 / 0,004$ & $0,37 / 0,24$ \\
\hline Completa & 54 & $0,34 / 0,25$ & $0,02 / 0,008$ & $0,04 / 0,01$ & $0,14 / 0,11$ & $0,05 / 0,01$ & $0,68 / 0,39$ \\
\hline Incompleta & 16 & $0,29 / 0,11$ & $0,19 / 0,06$ & $0,84 / 0,71$ & $0,72 / 0,89$ & $0,84 / 0,71$ & $0,67 / 0,38$ \\
\hline Incompleta + FP & 8 & $0,72 / 0,55$ & $0,22 / 0,08$ & $0,15 / 0,04$ & $0,31 / 0,51$ & $0,15 / 0,04$ & $0,07 / 0,78$ \\
\hline Esquerda & 172 & $0,04 / 0,01$ & $0,00001 \dagger$ & $0,006 / 0,003$ & $0,07 / 0,03$ & $0,005 / 0,002$ & $0,04 / 0,06$ \\
\hline Completa & 121 & $0,35 / 0,32$ & $0,003 / 0,0008$ & $0,05 / 0,03$ & $0,28 / 0,10$ & $0,04 / 0,02$ & $0,12 / 0,07$ \\
\hline Incompleta & 46 & $0,01 / 0,001$ & $0,004 / 0,0008$ & $0,01 / 0,003$ & $0,08 / 0,28$ & $0,01 / 0,002$ & $0,09 / 0,27$ \\
\hline Incompleta + FP & 5 & $0,68 / 0,41$ & $0,88 / 0,62$ & $0,52 / 0,29$ & $0,20 / 0,07$ & $0,52 / 0,29$ & $0,90 / 0,66$ \\
\hline Bilateral & 154 & $0,07 / 0,13$ & $0,0002 / 0,00001$ & $0,009 / 0,001$ & $0,10 \dagger$ & $0,005 / 0,0009$ & $0,03 / 0,01$ \\
\hline Completa & 125 & $0,14 / 0,21$ & $0,002 / 0,0002$ & $0,08 / 0,02$ & $0,09 / 0,12$ & $0,05 / 0,01$ & $0,06 / \mathbf{0 , 0 2}$ \\
\hline Incompleta & 8 & $0,29 / 0,25$ & $0,22 / 0,08$ & $0,59 / 0,33$ & $0,31 / 0,51$ & $0,59 / 0,33$ & $0,90 / 0,78$ \\
\hline Incompleta + FP & 17 & $0,27 / 0,40$ & $0,50 / 0,22$ & $0,07 / 0,02$ & $0,92 / 0,78$ & $0,07 / 0,02$ & $0,02 / 0,01$ \\
\hline Incompleta mista & 4 & $0,72 / 0,67$ & $0,47 / 0,09$ & $0,19 / 0,07$ & $0,34 / 0,23$ & $0,19 / 0,07$ & $0,95 / 0,84$ \\
\hline Fissura Mediana & 2 & $\begin{array}{ll}--- \\
--\end{array}$ & $\begin{array}{ll}--- \\
--\end{array}$ & $\begin{array}{ll}--- \\
--\end{array}$ & $\begin{array}{ll}--- \\
--\end{array}$ & --- & --- \\
\hline Total FL/P & 406 & $0,002 / 0,001$ & $0,00001 \dagger$ & $0,00001 \dagger$ & $0,30 / 0,12$ & $0,00001 \dagger$ & $0,15 / 0,04$ \\
\hline Tipo/lado desconhecido & 28 & $\begin{array}{ll}--- \\
---\end{array}$ & $\begin{array}{ll}--- \\
-\cdots\end{array}$ & $\begin{array}{ll}--- \\
--\end{array}$ & $\begin{array}{ll}--- \\
-\cdots\end{array}$ & $\begin{array}{ll}--- \\
--\end{array}$ & $\begin{array}{ll}--- \\
--\end{array}$ \\
\hline Total Fissurados & 500 & $0,002 / 0,001$ & $0,00001 \dagger$ & $\begin{array}{l}0,002 / \\
0,0003\end{array}$ & $0,49 / 0,27$ & $0,001 / 0,0001$ & $0,33 / 0,13$ \\
\hline Controles (sem fissura) & 500 & $\begin{array}{ll}--- \\
---\end{array}$ & $\begin{array}{ll}--- \\
-\cdots+\end{array}$ & --- & $\begin{array}{ll}--- \\
---\end{array}$ & $\begin{array}{ll}--- \\
---\end{array}$ & $\begin{array}{ll}--- \\
---\end{array}$ \\
\hline
\end{tabular}

$* \mathrm{p} \leq 0,0005$ indica diferença estatística significante (em negrito, realçado em cinza); $\mathrm{p} \leq 0,05$ indica tendência à significância (em itálico).

$\dagger$ para ambos genótipo e alelo. 
Tabela 21. Análise comparativa das freqüências dos genótipos e alelos (genótipos/alelos) obtidos para casos e controles (caucasianos) para cada polimorfismo estudado no gene IRF6.

\begin{tabular}{|c|c|c|c|c|c|c|c|}
\hline Subfenótipo & n & 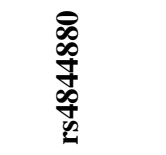 & 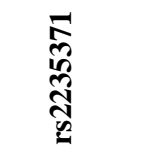 & 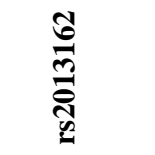 & $\begin{array}{l}0 \\
0 \\
0 \\
0 \\
0 \\
0 \\
0 \\
0\end{array}$ & 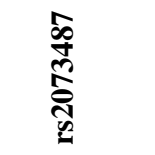 & 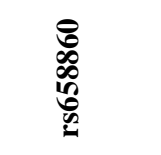 \\
\hline \multicolumn{8}{|l|}{ Fissura Palatina } \\
\hline Completa & 15 & $0,22 / 0,19$ & $0,07 / 0,49$ & $0,18 / 0,10$ & $0,35 / 0,32$ & $0,20 / 0,10$ & $0,48 / 0,84$ \\
\hline Incompleta + submucosa & 38 & $0,31 \dagger$ & $0,05 / 0,20$ & $0,43 / 0,19$ & $0,12 / 0,05$ & $0,49 / 0,22$ & $0,98 / 0,91$ \\
\hline Total FP & 53 & $0,91 / 0,85$ & $0,02 / 0,17$ & $0,17 / 0,05$ & $0,06 / \mathbf{0 , 0 3}$ & $0,20 / 0,07$ & $0,75 / 0,84$ \\
\hline \multicolumn{8}{|l|}{ Fissura Labio-Palatina } \\
\hline Completa & 237 & $0,39 / 0,44$ & $0,65 / 0,46$ & $0,13 / 0,08$ & $0,49 / 0,24$ & $0,06 / 0,04$ & $0,50 / 0,30$ \\
\hline Incompleta & 86 & $0,09 / \mathbf{0 , 0 2}$ & $0,14 / 0,003$ & $0,02 / 0,005$ & $0,42 / 0,40$ & $0,03 \dagger$ & $0,25 / 0,09$ \\
\hline Unilateral & 200 & $0,58 / 0,32$ & $0,22 / 0,18$ & $0,03 / 0,04$ & $0,26 / 0,22$ & $0,01 / 0,06$ & $0,46 / 0,43$ \\
\hline Completa & 136 & $0,51 / 0,59$ & $0,49 / 0,66$ & $0,06 / 0,15$ & $0,51 / 0,34$ & $0,05 / 0,10$ & $0,66 / 0,64$ \\
\hline Incompleta & 64 & $0,03 / 0,008$ & $0,38 / 0,15$ & $0,19 / 0,06$ & $0,29 / 0,30$ & $0,10 / 0,23$ & $0,48 / 0,37$ \\
\hline Direita & 60 & $0,13 / 0,04$ & $0,39 / 0,50$ & $0,36 / 0,28$ & $0,43 / 0,39$ & $0,04 / 0,62$ & $0,26 / 0,30$ \\
\hline Completa & 43 & $0,16 / 0,74$ & $0,37 / 0,74$ & $0,29 / 0,41$ & $0,28 / 0,34$ & $0,27 / 0,38$ & $0,36 / 0,23$ \\
\hline Incompleta & 11 & $0,004 / 0,002$ & $0,94 / 0,75$ & $0,63 / 0,76$ & $0,94 / 0,97$ & $0,04 / 0,45$ & $0,88 / 0,83$ \\
\hline Incompleta + FP & 6 & $0,45 / 0,91$ & $0,64 / 0,19$ & $0,56 / 0,34$ & $0,69 / 0,77$ & $0,55 / 0,33$ & $0,03 / 0,89$ \\
\hline Esquerda & 140 & $0,93 \dagger$ & $0,62 / 0,37$ & $0,06 / 0,05$ & $0,44 / 0,38$ & $0,05 / 0,03$ & $0,01 / 0,17$ \\
\hline Completa & 93 & $0,67 / 0,37$ & $0,80 / 0,73$ & $0,16 / 0,19$ & $0,82 / 0,53$ & $0,14 / 0,13$ & $0,07 / 0,30$ \\
\hline Incompleta & 44 & $0,38 / 0,16$ & $0,33 / 0,12$ & $0,13 / 0,05$ & $0,10 / 0,74$ & $0,11 / 0,03$ & $0,12 / 0,24$ \\
\hline Incompleta + FP & 3 & $0,50 / 0,58$ & $0,53 / 0,33$ & $0,70 / 0,55$ & $0,14 / 0,06$ & $0,71 / 0,57$ & $0,94 / \mathbf{0 , 0 0 2}$ \\
\hline Bilateral & 123 & $0,59 / 0,55$ & $0,39 / 0,18$ & $0,15 / 0,04$ & $0,35 / 0,44$ & $0,06 / 0,01$ & $0,17 / 0,06$ \\
\hline Completa & 101 & $0,57 / 0,46$ & $0,64 / 0,44$ & $0,40 / 0,19$ & $0,25 / 0,36$ & $0,28 / 0,10$ & $0,43 / 0,19$ \\
\hline Incompleta & 6 & $0,45 / 0,91$ & $0,64 / 0,19$ & $0,32 / 0,12$ & $0,17 / 0,38$ & $0,31 / 0,12$ & $0,88 / 0,89$ \\
\hline Incompleta + FP & 13 & $0,29 / 0,70$ & $0,45 / 0,08$ & $0,17 / 0,05$ & $0,61 / 0,38$ & $0,16 / 0,05$ & $0,003 / 0,008$ \\
\hline Incompleta mista & 3 & $0,89 / 0,68$ & $0,80 / 0,36$ & $0,56 / 0,27$ & $0,21 / 0,83$ & $0,55 / 0,27$ & $0,94 / 0,92$ \\
\hline Fissura Mediana & 1 & $\begin{array}{ll}--- \\
\end{array}$ & --- & $\begin{array}{ll}--- \\
\end{array}$ & $\begin{array}{ll}--- \\
\end{array}$ & $\begin{array}{ll}--- \\
\end{array}$ & ---- \\
\hline Total FL/P & 377 & $0,73 / 0,70$ & $0,32 / 0,15$ & $0,02 / 0,01$ & $0,45 / 0,21$ & $0,008 / 0,01$ & $0,24 / 0,09$ \\
\hline Tipo/lado desconhecido & 16 & $\begin{array}{l}--- \\
--\end{array}$ & $\begin{array}{ll}--- \\
--\end{array}$ & $\begin{array}{ll}--- \\
---\end{array}$ & $\begin{array}{ll}--- \\
\end{array}$ & $\begin{array}{ll}--- \\
--1\end{array}$ & $\begin{array}{ll}--- \\
---\end{array}$ \\
\hline Total Fissurados & 393 & $0,69 / 0,57$ & $0,24 / 0,37$ & $0,31 / 0,16$ & $0,77 / 0,46$ & $0,17 / 0,14$ & $0,51 / 0,26$ \\
\hline Controles (sem fissura) & 285 & $\begin{array}{ll}--- \\
--\end{array}$ & $\begin{array}{ll}--- \\
--\end{array}$ & $\begin{array}{ll}--- \\
--\end{array}$ & $\begin{array}{ll}--- \\
-\end{array}$ & $\begin{array}{ll}--- \\
-\end{array}$ & $\begin{array}{ll}--- \\
--\end{array}$ \\
\hline
\end{tabular}

${ }^{*} \mathrm{p} \leq 0,0005$ indica diferença estatística significante (em negrito, realçado em cinza); $\mathrm{p} \leq 0,05$ indica tendência à significância (em itálico).

† para ambos genótipo e alelo.

** Brasileiros sem ascendência Africana ou Japonesa. 


\subsubsection{Cromossomo 6q}

A distribuição dos genótipos e alelos para os polimorfismos estudados no cromossomo $6 \mathrm{q}$ em casos e controles utilizando a população total e caucasianos somente encontra-se nas Tabelas 22 e 23.

A análise comparativa inicial, entre casos e controles, utilizando a população total, mostrou diferenças significativas para as freqüências dos genótipos e alelos em quatro marcadores, rs7753918, rs 1171114, rs217325 e rs6940766 (Tabela 22). Considerando somente os indivíduos caucasianos da amostra, foram observadas diferenças somente para o marcador rs7753918 (Tabela 23).

As Tabelas 24 (todos os indivíduos) e 25 (caucasianos) demonstram as diferenças entre as freqüências dos genótipos e alelos obtidos nos indivíduos de cada subfenótipo de FL/P e controles para cada polimorfismo estudado no cromossomo $6 \mathrm{q}$, e estão representados pela diferença observada para os genótipos seguido da diferença observada para os alelos $\left(\mathrm{P}_{\text {genótipo }} / \mathrm{P}_{\text {alelo }}\right)$.

Analisando a população total, foram observadas diferenças significantes nas freqüências dos genótipos para determinados subfenótipos de FL/P e controles para o marcador rs7753918 (FL/P total, FL/P completa, FL/P unilateral, FL/P unilateral completa, FL/P esquerda, FL/P bilateral, e FL/P bilateral completa); nas freqüências dos alelos para os marcadores rs217325 (FL/P unilateral), rs1325474 (FL/P esquerda incompleta + FP), e rs6940766 (FL/P bilateral completa); e nas freqüências de ambos genótipos e alelos para os marcadores rs1171114 (FL/P total, FL/P completa, FL/P bilateral e F1/P bilateral completa), rs217325 (FL/P total e FL/P completa) e rs6940766 (FL/P total, FL/P completa e FL/P bilateral) (Tabela 24).

Quando analisando somente os indivíduos caucasianos da amostra, as diferenças para o marcador rs1325474 permaneceram significantes para os mesmos subfenótipos; as diferenças para o marcador rs7753918 também permaneceram significantes, exceto para FL/P unilateral, FL/P unilateral completa e FL/P esquerda. Diferenças significantes também foram observadas para a freqüência dos alelos do marcador rs614565 entre os grupos FP incompleta e controle (Tabela 25). 
Tabela 22. Análise comparativa das freqüências dos genótipos obtidos em casos e controles (população total) para cada polimorfismo estudado no cromossomo 6q.

\begin{tabular}{|c|c|c|c|c|c|c|c|c|}
\hline \multirow{2}{*}{ Marcadores } & \multirow{2}{*}{$\mathbf{n}$} & \multicolumn{3}{|c|}{ Genótipos } & \multirow{2}{*}{$\mathbf{P}^{*}$} & \multicolumn{2}{|c|}{ Alelos } & \multirow{2}{*}{$\mathbf{P}^{*}$} \\
\hline & & AA & $\mathbf{A B}$ & BB & & A & B & \\
\hline $\begin{array}{rr}\text { rs10943944 } & \begin{array}{r}\text { casos } \\
\text { controles }\end{array}\end{array}$ & $\begin{array}{l}479 \\
478\end{array}$ & $\begin{array}{l}293 \\
320\end{array}$ & $\begin{array}{l}151 \\
142\end{array}$ & $\begin{array}{l}35 \\
16\end{array}$ & 0,01 & $\begin{array}{l}737 \\
782\end{array}$ & $\begin{array}{l}221 \\
174\end{array}$ & 0,001 \\
\hline $\begin{array}{rr}\text { rs7753918 } & \begin{array}{r}\text { casos } \\
\text { controles }\end{array}\end{array}$ & $\begin{array}{l}479 \\
480\end{array}$ & $\begin{array}{l}13 \\
43\end{array}$ & $\begin{array}{c}131 \\
82\end{array}$ & $\begin{array}{l}335 \\
355\end{array}$ & 0,00001 & $\begin{array}{l}157 \\
168\end{array}$ & $\begin{array}{l}801 \\
792\end{array}$ & 0,52 \\
\hline $\begin{array}{r}\text { rs1171114 } \\
\begin{array}{r}\text { casos } \\
\text { controles }\end{array}\end{array}$ & $\begin{array}{l}474 \\
479\end{array}$ & $\begin{array}{l}158 \\
213\end{array}$ & $\begin{array}{l}230 \\
220\end{array}$ & $\begin{array}{l}86 \\
46\end{array}$ & 0,00001 & $\begin{array}{l}546 \\
646\end{array}$ & $\begin{array}{l}402 \\
312\end{array}$ & 0,00001 \\
\hline $\begin{array}{r}\text { rs512140 } \\
\text { casos } \\
\text { controles }\end{array}$ & $\begin{array}{l}478 \\
479\end{array}$ & $\begin{array}{l}37 \\
40\end{array}$ & $\begin{array}{l}202 \\
167\end{array}$ & $\begin{array}{l}239 \\
272\end{array}$ & 0,06 & $\begin{array}{l}276 \\
247\end{array}$ & $\begin{array}{l}680 \\
711\end{array}$ & 0,13 \\
\hline $\begin{array}{r}\text { rs1171105 } \\
\text { casos } \\
\text { controles }\end{array}$ & $\begin{array}{l}477 \\
479\end{array}$ & $\begin{array}{l}206 \\
196\end{array}$ & $\begin{array}{l}203 \\
221\end{array}$ & $\begin{array}{l}68 \\
62\end{array}$ & 0,53 & $\begin{array}{l}615 \\
613\end{array}$ & $\begin{array}{l}339 \\
345\end{array}$ & 0,83 \\
\hline $\begin{array}{rr}\text { rs2023238 } & \begin{array}{r}\text { casos } \\
\text { controles }\end{array} \\
& \end{array}$ & $\begin{array}{l}464 \\
480\end{array}$ & $\begin{array}{l}65 \\
64\end{array}$ & $\begin{array}{l}195 \\
177\end{array}$ & $\begin{array}{l}203 \\
239\end{array}$ & 0,17 & $\begin{array}{l}325 \\
305\end{array}$ & $\begin{array}{l}601 \\
655\end{array}$ & 0,12 \\
\hline $\begin{array}{rr}\text { rs3798867 } & \text { casos } \\
\text { controles }\end{array}$ & $\begin{array}{l}461 \\
476\end{array}$ & $\begin{array}{l}183 \\
163\end{array}$ & $\begin{array}{l}220 \\
242\end{array}$ & $\begin{array}{l}57 \\
71\end{array}$ & 0,17 & $\begin{array}{l}586 \\
568\end{array}$ & $\begin{array}{l}336 \\
384\end{array}$ & 0,08 \\
\hline $\begin{array}{r}\text { casos } \\
\text { controles }\end{array}$ & $\begin{array}{l}481 \\
480\end{array}$ & $\begin{array}{l}51 \\
29\end{array}$ & $\begin{array}{l}190 \\
140\end{array}$ & $\begin{array}{l}240 \\
311\end{array}$ & 0,00001 & $\begin{array}{l}292 \\
198\end{array}$ & $\begin{array}{l}670 \\
762\end{array}$ & 0,00001 \\
\hline $\begin{array}{r}\text { casos } \\
\text { controles }\end{array}$ & $\begin{array}{l}464 \\
478\end{array}$ & $\begin{array}{l}56 \\
66\end{array}$ & $\begin{array}{l}230 \\
247\end{array}$ & $\begin{array}{l}170 \\
165\end{array}$ & 0,61 & $\begin{array}{l}342 \\
379\end{array}$ & $\begin{array}{l}570 \\
577\end{array}$ & 0,34 \\
\hline $\begin{array}{r}\text { casos } \\
\text { controles }\end{array}$ & $\begin{array}{l}471 \\
478\end{array}$ & $\begin{array}{l}181 \\
169\end{array}$ & $\begin{array}{l}234 \\
238\end{array}$ & $\begin{array}{l}56 \\
71\end{array}$ & 0,33 & $\begin{array}{l}596 \\
576\end{array}$ & $\begin{array}{l}346 \\
380\end{array}$ & 0,17 \\
\hline $\begin{array}{r}\text { casos } \\
\text { controles }\end{array}$ & $\begin{array}{l}440 \\
474\end{array}$ & $\begin{array}{l}31 \\
46\end{array}$ & $\begin{array}{l}181 \\
179\end{array}$ & $\begin{array}{l}228 \\
249\end{array}$ & 0,27 & $\begin{array}{l}243 \\
271\end{array}$ & $\begin{array}{l}637 \\
677\end{array}$ & 0,64 \\
\hline $\begin{array}{r}\text { casos } \\
\text { controles }\end{array}$ & $\begin{array}{l}457 \\
475\end{array}$ & $\begin{array}{l}29 \\
39\end{array}$ & $\begin{array}{l}170 \\
176\end{array}$ & $\begin{array}{l}258 \\
260\end{array}$ & 0,53 & $\begin{array}{l}228 \\
254\end{array}$ & $\begin{array}{l}686 \\
696\end{array}$ & 0,37 \\
\hline $\begin{array}{r}\text { rs1325474 } \begin{array}{r}\text { casos } \\
\text { controles }\end{array} \\
\end{array}$ & $\begin{array}{l}441 \\
464\end{array}$ & $\begin{array}{l}24 \\
21\end{array}$ & $\begin{array}{l}140 \\
126\end{array}$ & $\begin{array}{l}277 \\
317\end{array}$ & 0,22 & $\begin{array}{l}188 \\
168\end{array}$ & $\begin{array}{l}694 \\
760\end{array}$ & 0,08 \\
\hline $\begin{array}{r}\text { casos } \\
\text { controles }\end{array}$ & $\begin{array}{l}481 \\
480\end{array}$ & $\begin{array}{l}22 \\
57\end{array}$ & $\begin{array}{l}150 \\
176\end{array}$ & $\begin{array}{l}309 \\
245\end{array}$ & 0,00001 & $\begin{array}{l}194 \\
290\end{array}$ & $\begin{array}{l}768 \\
666\end{array}$ & 0,00001 \\
\hline $\begin{array}{r}\text { rs1325469 } \begin{array}{r}\text { casos } \\
\text { controles }\end{array} \\
\end{array}$ & $\begin{array}{l}467 \\
479\end{array}$ & $\begin{array}{l}290 \\
323\end{array}$ & $\begin{array}{l}152 \\
134\end{array}$ & $\begin{array}{l}25 \\
22\end{array}$ & 0,22 & $\begin{array}{l}732 \\
780\end{array}$ & $\begin{array}{l}202 \\
178\end{array}$ & 0,09 \\
\hline
\end{tabular}

${ }^{*} \mathrm{p} \leq 0,0005$ indica diferença significante (negrito, em cinza); $\mathrm{p} \leq 0,05$ indica tendência à significância (em itálico). 
Tabela 23. Diferenças observadas para as freqüências dos genótipos e dos alelos em casos e controles (caucasianos) para cada polimorfismo estudado no cromossomo $6 \mathrm{q}$.

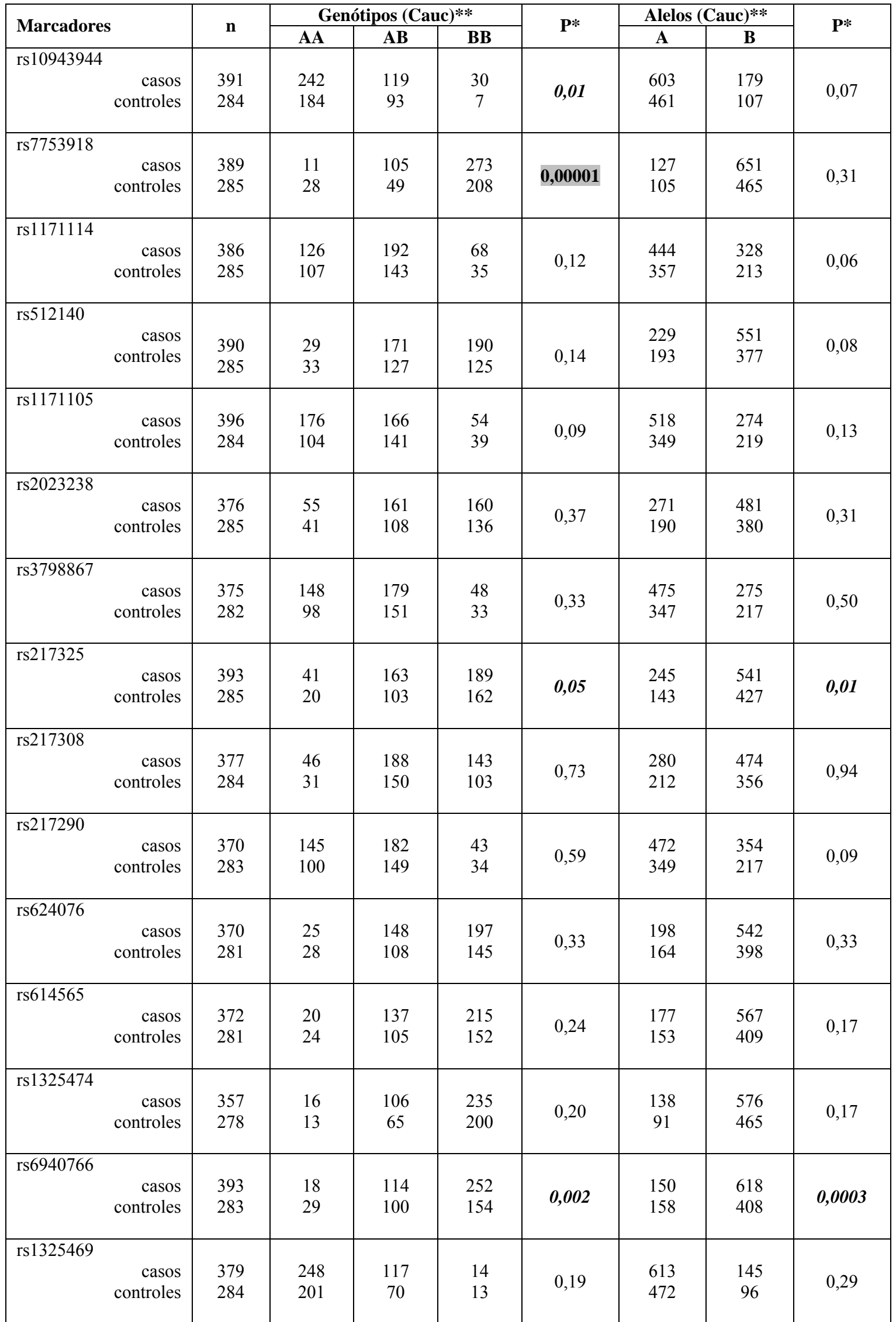

${ }^{*} \mathrm{p} \leq 0,0005$ indica diferença estatística significante (em negrito, realçado em cinza); $\mathrm{p} \leq 0,05$ indica tendência à significância (em itálico). ** Brasileiros sem ascendência Africana ou Japonesa. 
Tabela 24. Análise comparativa das freqüências dos genótipos e alelos (genótipos/alelos) obtidos para os subfenótipos de casos e controles (população total) para cada polimorfismos estudado no cromossomo 6q.

\begin{tabular}{|c|c|c|c|c|c|c|c|c|c|}
\hline Subfenótipo & $\mathbf{n}$ & 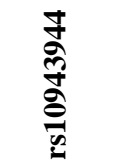 & 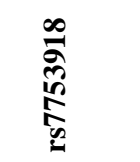 & 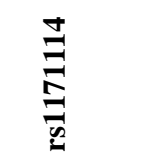 & 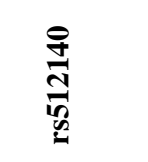 & 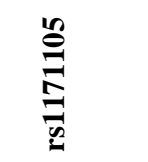 & 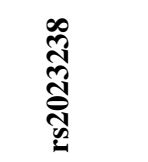 & $\begin{array}{l}\hat{0} \\
\infty \\
: \\
\stackrel{0}{0} \\
\hat{\omega}\end{array}$ & 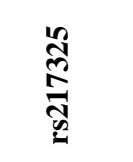 \\
\hline \multicolumn{10}{|l|}{ Fissura Palatina } \\
\hline Completa & 21 & $0,44 / 0,35$ & $0,28 / 0,41$ & $0,92 / 0,83$ & $0,81 / 0,91$ & $0,61 / 0,64$ & $0,74 / 0,92$ & $0,80 / 0,55$ & $0,13 / 0,15$ \\
\hline $\begin{array}{l}\text { Incompleta + } \\
\text { submucosa }\end{array}$ & 45 & $\begin{array}{c}0,006 / \\
0,05\end{array}$ & $0,60 / 0,26$ & $0,19 / 0,27$ & $0,75 / 0,52$ & $0,75 / 0,47$ & $0,36 / 0,50$ & $0,94 / 0,75$ & $0,18 / 0,17$ \\
\hline Total FP & 66 & $0,07 / 0,25$ & $0,83 / 0,62$ & $0,30 / 0,31$ & $0,71 / 0,64$ & $0,57 / 0,40$ & $0,30 / 0,55$ & $0,84 / 0,57$ & $0,14 / 0,06$ \\
\hline \multicolumn{10}{|l|}{$\begin{array}{l}\text { Fissura Labio- } \\
\text { Palatina } \\
\end{array}$} \\
\hline Completa & 300 & $\begin{array}{l}0,007 / \\
0,005\end{array}$ & $\begin{array}{c}\mathbf{0 , 0 0 0 0 1 / 1} \\
0,80\end{array}$ & $0,00001 \dagger$ & $0,27 / 0,21$ & $0,57 / 0,63$ & $0,72 / 0,44$ & 0,09/0,05 & $0,00001 \dagger$ \\
\hline Incompleta & 104 & $0,16 / 0,06$ & $0,02 / 0,73$ & $0,03 / 0,02$ & $0,05 / 0,25$ & $0,58 / 0,42$ & $0,16 / 0,06$ & $0,11 / 0,13$ & $\begin{array}{l}0,005 / \\
0,0006\end{array}$ \\
\hline Unilateral & 250 & $\begin{array}{c}0,0003 / \\
0,04\end{array}$ & $\begin{array}{c}\mathbf{0 , 0 0 0 0 1 / /} \\
0,42\end{array}$ & $\begin{array}{c}0,007 / 1 \\
0,002\end{array}$ & $0,09 / 0,24$ & $0,92 / 0,86$ & $0,25 / 0,08$ & $0,16 / 0,07$ & $\begin{array}{l}0,0003 / \\
0,00001\end{array}$ \\
\hline Completa & 175 & $0,02 / 0,01$ & $\begin{array}{c}\mathbf{0 , 0 0 0 0 1 / /} \\
0,79\end{array}$ & $0,01 \uparrow$ & $0,48 / 0,33$ & $0,77 / 0,88$ & $0,71 / 0,38$ & $0,28 / 0,21$ & $\begin{array}{l}0,001 / \\
0,0003\end{array}$ \\
\hline Incompleta & 75 & $0,69 / 0,31$ & $0,03 / 0,22$ & $0,03 / 0,01$ & $0,03 / 0,39$ & $0,76 / 0,58$ & $0,10 / \mathbf{0 , 0 3}$ & $0,22 / 0,09$ & $0,05 / 0,01$ \\
\hline Direita & 78 & $0,15 / 0,26$ & $0,01 / 0,51$ & $0,09 / 0,07$ & $0,20 / 0,62$ & $0,63 \dagger$ & $0,41 / 0,15$ & $0,14 / \mathbf{0 , 0 5}$ & $0,09 / \mathbf{0 , 0 2}$ \\
\hline Completa & 54 & $0,27 / 0,28$ & $0,06 / 0,64$ & $0,19 / 0,21$ & $0,49 / 0,42$ & $0,56 / 0,30$ & $0,42 / 0,18$ & $0,55 / 0,29$ & $0,11 / 0,10$ \\
\hline Incompleta & 16 & $0,77 / 0,93$ & $0,45 / 0,23$ & $0,47 / 0,45$ & $0,90 / 0,91$ & $0,62 / 0,84$ & $0,43 / 0,18$ & $0,06 / \mathbf{0 , 0 2}$ & $0,07 / 0,02$ \\
\hline Incompleta + FP & 8 & $0,37 / 0,48$ & $0,04 / 0,43$ & $0,27 / 0,14$ & $0,69 / 0,52$ & $0,32 / 0,36$ & $0,36 / 0,40$ & $0,88 / 0,72$ & $0,49 / 0,85$ \\
\hline Esquerda & 172 & $0,09 / 0,04$ & $\begin{array}{c}\mathbf{0 , 0 0 0 0 1 / /} \\
0,54\end{array}$ & $\begin{array}{c}0,005 / \\
0,004\end{array}$ & $0,13 / 0,23$ & $0,71 / 0,93$ & $0,40 / 0,19$ & $0,40 / 0,28$ & $\begin{array}{l}0,0006 / \\
0,0002\end{array}$ \\
\hline Completa & 121 & $0,04 / 0,02$ & $\begin{array}{c}\mathbf{0 , 0 0 0 3 /} \\
0,97\end{array}$ & $\begin{array}{c}0,004 / \\
0,02\end{array}$ & $0,73 / \mathbf{0 , 0 1}$ & $0,39 / 0,40$ & $0,88 / 0,81$ & $0,27 / 0,37$ & $\begin{array}{l}0,002 / \\
0,0003\end{array}$ \\
\hline Incompleta & 46 & $0,92 / 0,74$ & $0,23 / 0,31$ & $0,02 / 0,01$ & $\begin{array}{c}\mathbf{0 , 0 0 5 /} \\
0,10\end{array}$ & $0,27 / 0,11$ & $\begin{array}{l}0,04 / \\
0,008\end{array}$ & $0,55 / 0,34$ & $0,01 / 0,01$ \\
\hline Incompleta + FP & 5 & $0,76 / 0,88$ & $0,78 / 0,53$ & $0,67 / 0,39$ & $0,54 / 0,25$ & $0,56 / 0,36$ & $0,48 / 0,42$ & $0,79 / 0,53$ & $0,10 / 0,03$ \\
\hline Bilateral & 154 & $\begin{array}{l}0,01 / \\
0,003\end{array}$ & $\begin{array}{c}\mathbf{0 , 0 0 0 0 1 /} \\
0,84\end{array}$ & $0,00001 \dagger$ & $0,32 / 0,21$ & $0,27 / 0,75$ & $0,77 / 0,75$ & $0,22 / 0,09$ & $\begin{array}{l}0,0003 / \\
0,00001 \\
\end{array}$ \\
\hline Completa & 125 & $0,08 / 0,04$ & $\begin{array}{c}\mathbf{0 , 0 0 0 0 1 /} \\
0,0008\end{array}$ & $0,00001 \dagger$ & $0,40 / 0,32$ & $0,55 / 0,51$ & $0,85 / 0,77$ & $0,16 / 0,07$ & $\begin{array}{l}0,004 / \\
0,0004\end{array}$ \\
\hline Incompleta & 8 & $0,11 / 0,18$ & $0,25 / 0,89$ & $0,88 / 0,91$ & $0,55 / 0,28$ & $0,62 / 0,52$ & $0,30 \dagger$ & $0,48 / 0,46$ & $\begin{array}{l}0,02 / \\
0,004\end{array}$ \\
\hline Incompleta + FP & 17 & $\begin{array}{l}0,002 / \\
0,0005\end{array}$ & $0,26 / 0,12$ & $0,47 / 0,33$ & $0,79 / 0,60$ & $0,01 / 0,65$ & $0,99 / 0,96$ & $0,71 / 0,62$ & $\mathbf{0 , 0 1 / 0 , 0 6}$ \\
\hline Incompleta mista & 4 & $0,84 / 0,67$ & $0,49 / 0,19$ & $0,50 / 0,91$ & $0,73 / 0,95$ & $0,63 / 0,93$ & $0,42 / 0,24$ & $0,35 / 0,20$ & $0,61 / 0,76$ \\
\hline Fissura Mediana & 2 & --- & ---- & --- & ---- & ---- & ---- & ---- & ---- \\
\hline Total FL/P & 406 & $\begin{array}{c}0,0008 / \\
0,04\end{array}$ & $\begin{array}{c}\mathbf{0 , 0 0 0 0 1 / /} \\
0,62\end{array}$ & $0,00001 \dagger$ & $0,07 / 0,13$ & $0,58 / 0,96$ & $0,32 / 0,15$ & $0,06 / 0,02$ & $\mathbf{0 , 0 0 0 0 1 \dagger}$ \\
\hline $\begin{array}{l}\text { Tipo/lado } \\
\text { desconhecido }\end{array}$ & 28 & ---- & --- & --- & --- & --- & --- & --- & --- \\
\hline Total Fissurados & 500 & $0,01 / 0,08$ & $\begin{array}{c}\mathbf{0 , 0 0 0 0 1 /} \\
0,51\end{array}$ & $0,00001 \dagger$ & $0,06 / 0,12$ & $0,52 / 0,81$ & $0,17 / 0,13$ & $0,17 / 0,08$ & $0,00001 \dagger$ \\
\hline $\begin{array}{l}\text { Controles } \\
\text { (sem fissura) }\end{array}$ & 500 & ---- & --- & --- & ---- & ---- & --- & --- & --- \\
\hline
\end{tabular}




\begin{tabular}{|c|c|c|c|c|c|c|c|c|}
\hline Subfenótipo & $\mathbf{n}$ & 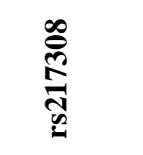 & 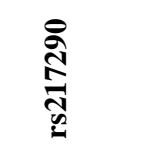 & 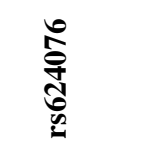 & 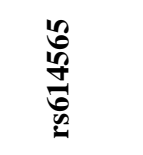 & 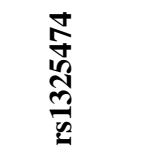 & 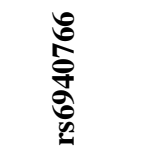 & 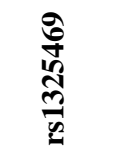 \\
\hline \multicolumn{9}{|l|}{ Fissura Palatina } \\
\hline Completa & 21 & $0,72 / 0,49$ & $0,78 / 0,50$ & $0,73 / 0,59$ & $0,80 \dagger$ & $0,37 / 0,06$ & $0,03 / 0,005$ & $0,36 / 0,33$ \\
\hline $\begin{array}{l}\text { Incompleta }+ \\
\text { submucosa }\end{array}$ & 45 & $0,78 / 0,51$ & $0,56 / 0,96$ & $0,13 / 0,04$ & $0,03 / 0,01$ & $0,72 / 0,25$ & $0,30 / 0,34$ & $0,76 / 0,49$ \\
\hline Total FP & 66 & $0,64 / 0,37$ & $0,69 \dagger$ & $0,18 / 0,05$ & $0,16 / 0,05$ & $0,95 / 0,80$ & $0,07 / 0,02$ & $0,99 / 0,96$ \\
\hline \multicolumn{9}{|l|}{$\begin{array}{l}\text { Fissura Labio- } \\
\text { Palatina }\end{array}$} \\
\hline Completa & 300 & $0,19 / 0,10$ & $0,44 / 0,21$ & $0,25 / 0,38$ & $0,38 / 0,09$ & $0,37 / 0,41$ & $0,00001 \dagger$ & $0,39 / 0,17$ \\
\hline Incompleta & 104 & $0,30 / 0,24$ & $0,09 / 0,08$ & $0,03 / 0,27$ & $0,05 / 0,56$ & $0,12 / 0,20$ & $0,20 / 0,06$ & $0,37 / 0,21$ \\
\hline Unilateral & 250 & $0,35 / 0,17$ & $0,33 / 0,14$ & $0,25 / 0,81$ & $0,10 / 0,25$ & $0,10 / 0,38$ & $0,04 / 0,005$ & $0,10 / 0,07$ \\
\hline Completa & 175 & $0,50 / 0,36$ & $0,76 / 0,50$ & $0,86 / 0,20$ & $0,55 / 0,31$ & $0,19 / 0,52$ & $0,003 \dagger$ & $0,08 / \mathbf{0 , 0 3}$ \\
\hline Incompleta & 75 & $0,36 / 0,19$ & $0,15 / 0,06$ & $0,01 / 0,29$ & $0,02 / 0,48$ & $0,34 / 0,43$ & $0,69 / 0,36$ & $0,46 / 0,87$ \\
\hline Direita & 78 & $0,08 / 0,03$ & $0,15 / 0,06$ & $0,67 / 0,51$ & $0,69 / 0,42$ & $0,43 / 0,49$ & $0,10 / 0,02$ & $0,33 / 0,09$ \\
\hline Completa & 54 & $0,32 / 0,15$ & $0,59 / 0,38$ & $0,54 / 0,29$ & $0,59 / 0,41$ & $0,59 / 0,42$ & $0,09 / 0,02$ & $0,26 / 0,09$ \\
\hline Incompleta & 16 & $0,07 / 0,02$ & $0,08 / 0,02$ & $0,41 / 0,52$ & $0,45 / 0,67$ & $0,78 / 0,54$ & $0,99 / 0,91$ & $0,26 / 0,51$ \\
\hline Incompleta + FP & 8 & $0,98 / 0,86$ & $0,68 / 0,49$ & $0,30 / 0,81$ & $0,47 / 0,87$ & $0,50 / 0,43$ & $0,34 / 0,12$ & $0,60 / 0,98$ \\
\hline Esquerda & 172 & $0,83 / 0,72$ & $0,76 / 0,50$ & $0,23 / 0,35$ & $0,08 / 0,34$ & $0,16 / 0,49$ & $0,21 / \mathbf{0 , 0 3}$ & $0,12 / 0,18$ \\
\hline Completa & 121 & $0,59 / 0,83$ & $0,75 / 0,79$ & $0,70 / 0,81$ & $0,45 / 0,46$ & $0,24 / 0,77$ & $0,10 / 0,02$ & $0,22 / 0,10$ \\
\hline Incompleta & 46 & $0,67 / 0,54$ & $0,51 / 0,35$ & $0,09 / 0,24$ & $0,11 / 0,41$ & $0,48 / 0,37$ & $0,97 / 0,84$ & $0,08 / 0,85$ \\
\hline Incompleta + FP & 5 & $0,77 / 0,50$ & $0,89 / 0,98$ & $0,52 / 0,92$ & $0,52 / 0,81$ & $\begin{array}{l}0,0001 / \\
0,00001\end{array}$ & $0,41 / 0,16$ & $0,24 / 0,35$ \\
\hline Bilateral & 154 & $0,26 / 0,11$ & $0,24 / 0,17$ & $0,02 / 0,05$ & $0,36 / 0,15$ & $0,48 / 0,30$ & $0,00001 \dagger$ & $0,81 / 0,52$ \\
\hline Completa & 125 & $0,19 / 0,09$ & $0,38 / 0,17$ & $0,01 / 0,04$ & $0,25 / 0,10$ & $0,82 / 0,53$ & $\begin{array}{l}0,0001 / \\
0,00001\end{array}$ & $0,97 / 0,82$ \\
\hline Incompleta & 8 & $0,30 / 0,49$ & $0,48 / 0,49$ & $0,14 / 0,04$ & $0,17 / 0,06$ & $0,27 / 0,25$ & $0,56 / 0,31$ & $0,29 / 0,51$ \\
\hline Incompleta + FP & 17 & $0,76 / 0,67$ & $0,21 / 0,47$ & $0,62 / 0,33$ & $0,34 / 0,14$ & $0,17 / 0,009$ & $0,17 / 0,07$ & $0,01 / 0,02$ \\
\hline Incompleta mista & 4 & $0,17 / 0,18$ & $0,33 / 0,19$ & $0,75 / 0,82$ & $0,76 / 0,91$ & $0,52 / 0,42$ & $0,58 / 0,27$ & $0,54 / 0,64$ \\
\hline Fissura Mediana & 2 & ---- & ---- & ---- & ---- & ---- & ---- & ---- \\
\hline Total FL/P & 406 & $0,17 / 0,07$ & $0,17 / 0,08$ & $0,03 / 0,22$ & $0,25 / 0,10$ & $0,15 / 0,24$ & $0,00001 \dagger$ & $0,23 / 0,11$ \\
\hline $\begin{array}{l}\text { Tipo/lado } \\
\text { desconhecido }\end{array}$ & 28 & ---- & ---- & ---- & ---- & ---- & ---- & --- \\
\hline Total Fissurados & 500 & $0,61 / 0,21$ & $0,33 / 0,17$ & $0,27 / 0,64$ & $0,53 / 0,37$ & $0,22 / 0,30$ & $0,00001 \dagger$ & $0,22 / 0,10$ \\
\hline $\begin{array}{l}\text { Controles } \\
\text { (sem fissura) }\end{array}$ & 500 & ---- & ---- & ---- & ---- & ---- & ---- & ---- \\
\hline
\end{tabular}

${ }^{*} \mathrm{p} \leq 0,0005$ indica diferença estatística significante (em negrito, realçado em cinza); $\mathrm{p} \leq 0,05$ indica tendência à significância (em itálico).

$\dagger$ para ambos genótipo e alelo. 
Tabela 25. Análise comparativa das freqüências dos genótipos obtidos para os subfenótipos de casos e controles (caucasianos) para cada polimorfismos estudado no cromossomo 6q.

\begin{tabular}{|c|c|c|c|c|c|c|c|c|c|}
\hline Subfenótipo & $\mathbf{n}$ & 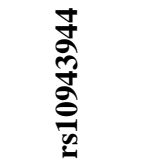 & 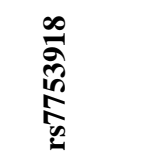 & 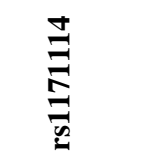 & 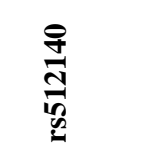 & 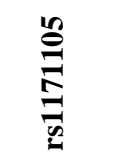 & 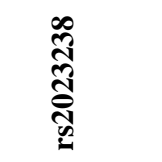 & 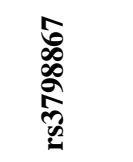 & 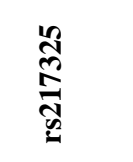 \\
\hline \multicolumn{10}{|l|}{ Fissura Palatina } \\
\hline Completa & 15 & $0,21 / 0,09$ & $0,37 / 0,10$ & $0,69 / 0,93$ & $0,84 / 0,66$ & $0,96 / 0,83$ & $0,46 / 0,92$ & $0,81 / 0,59$ & $0,16 / 0,15$ \\
\hline $\begin{array}{l}\text { Incompleta + } \\
\text { submucosa }\end{array}$ & 38 & $\begin{array}{c}\mathbf{0 , 0 0 0 3 /} \\
0,12\end{array}$ & $0,70 / 0,78$ & $0,77 / 0,76$ & $0,69 / 0,39$ & $0,53 / 0,30$ & $0,62 / 0,50$ & $0,93 / 0,73$ & $0,73 / 0,63$ \\
\hline Total FP & 53 & $0,002 / 0,64$ & $0,75 / 0,55$ & $0,96 / 0,83$ & $0,62 / 0,35$ & $0,57 / 0,34$ & $0,36 / 0,55$ & $0,83 / 0,58$ & $0,55 / 0,27$ \\
\hline \multicolumn{10}{|l|}{$\begin{array}{l}\text { Fissura Labio- } \\
\text { Palatina } \\
\end{array}$} \\
\hline Completa & 237 & $0,01 / 0,03$ & $\begin{array}{c}\mathbf{0 , 0 0 0 0 1 / /} \\
0,70\end{array}$ & $0,13 / 0,07$ & $0,14 / 0,04$ & $0,14 \dagger$ & $0,84 / 0,44$ & $0,18 / 0,03$ & $0,10 / 0,03$ \\
\hline Incompleta & 86 & $0,13 / 0,17$ & $0,07 / 0,44$ & $0,11 / \mathbf{0 , 0 4}$ & $0,38 / 0,78$ & $0,25 / 0,53$ & $0,18 / 0,06$ & $0,50 / 0,27$ & $0,09 / \mathbf{0 , 0 3}$ \\
\hline Unilateral & 200 & $0,03 \uparrow$ & $\begin{array}{c}\mathbf{0 , 0 0 0 2 /} \\
0,29\end{array}$ & $0,26 / 0,13$ & $0,22 / 0,14$ & $0,26 / 0,25$ & $0,46 / 0,08$ & $0,23 / 0,33$ & $0,12 / 0,06$ \\
\hline Completa & 136 & $0,02 / 0,11$ & $\begin{array}{c}\mathbf{0 , 0 0 0 3 /} \\
0,78\end{array}$ & $0,45 / 0,67$ & $0,23 / 0,08$ & $0,31 / 0,20$ & $0,92 / 0,38$ & $0,30 / 0,70$ & $0,20 / 0,14$ \\
\hline Incompleta & 64 & $0,21 / 0,05$ & $0,09 / 0,07$ & $0,02 / 0,01$ & $0,14 / 0,77$ & $0,60 / 0,26$ & $0,11 / \mathbf{0 , 0 3}$ & $0,30 / 0,16$ & $0,28 / 0,10$ \\
\hline Direita & 60 & $0,008 / 0,61$ & $0,08 / 0,18$ & $0,24 / 0,11$ & $0,67 / 0,37$ & $0,36 / 0,27$ & $0,47 / 0,15$ & $0,19 / 0,11$ & $0,64 / 0,35$ \\
\hline Completa & 43 & $0,04 / 0,64$ & $0,14 / 0,45$ & $0,77 / 0,69$ & $0,49 / 0,27$ & $0,55 / 0,26$ & $0,43 / 0,18$ & $0,74 / 0,62$ & $0,69 / 0,92$ \\
\hline Incompleta & 11 & $0,28 / 0,93$ & $0,37 / 0,09$ & $022 / 0,10$ & $0,61 / 0,56$ & $0,06 / 0,02$ & $0,32 / 0,18$ & $0,06 / 0,03$ & $0,04 / 0,03$ \\
\hline Incompleta + FP & 6 & $0,09 / 0,59$ & $0,47 / 0,87$ & $0,09 / \mathbf{0 , 0 3}$ & $0,67 / 0,52$ & $0,55 / 0,71$ & $0,49 / 0,40$ & $0,43 / 0,23$ & $0,47 / 0,99$ \\
\hline Esquerda & 140 & $0,09 / 0,08$ & $\begin{array}{c}\mathbf{0 , 0 0 0 7 /} \\
0,58\end{array}$ & $0,36 / 0,31$ & $0,23 / 0,18$ & $0,46 / 0,33$ & $0,33 / 0,19$ & $0,41 / 0,76$ & $0,09 / 0,06$ \\
\hline Completa & 93 & $0,03 / 0,02$ & $\begin{array}{c}\mathbf{0 , 0 0 0 6 /} \\
0,90\end{array}$ & $0,16 / 0,76$ & $0,32 / 0,13$ & $0,24 / 0,12$ & $0,48 / 0,81$ & $0,29 / 0,86$ & $0,14 / 0,07$ \\
\hline Incompleta & 44 & $0,69 / 0,91$ & $0,20 / 0,31$ & $0,10 / 0,06$ & $0,13 / 0,96$ & $0,65 / 0,45$ & $0,11 / \mathbf{0 , 0 0 8}$ & $0,87 / 0,62$ & $0,19 / 0,18$ \\
\hline Incompleta + FP & 3 & $0,96 / 0,89$ & $0,57 / 0,11$ & $0,54 / 0,29$ & $0,15 / \mathbf{0 , 0 2}$ & $0,52 / 0,27$ & $0,71 / 0,42$ & $0,49 / 0,56$ & $0,32 / 0,06$ \\
\hline Bilateral & 123 & $0,02 \dagger$ & $\begin{array}{c}\mathbf{0 , 0 0 0 0 1 /} \\
0,81\end{array}$ & $0,05 / 0,02$ & $0,44 / 0,20$ & $0,09 / 0,32$ & $0,84 / 0,75$ & $0,56 / 0,52$ & $0,07 / 0,03$ \\
\hline Completa & 101 & $0,10 / 0,11$ & $\begin{array}{c}\mathbf{0 , 0 0 0 0 1 /} \\
0,72\end{array}$ & $0,02 / 0,008$ & $0,34 / 0,16$ & $0,24 / 0,22$ & $0,83 / 0,77$ & $0,22 / 0,42$ & $0,15 / 0,05$ \\
\hline Incompleta & 6 & $0,21 / 0,20$ & $0,10 / 0,56$ & $0,71 / 0,77$ & $0,85 / 0,57$ & $0,97 / 0,82$ & $0,77 / 0,30$ & $0,63 / 0,71$ & $\begin{array}{l}0,02 / \\
0,009\end{array}$ \\
\hline Incompleta + FP & 13 & $0,001 \dagger$ & $0,09 / 0,04$ & $0,47 / 0,61$ & $0,71 / 0,95$ & $0,04 / 0,75$ & $0,94 / 0,96$ & $0,96 / 0,84$ & $0,05 / 0,51$ \\
\hline Incompleta mista & 3 & $0,44 / 0,11$ & $0,57 / 0,11$ & $0,54 / 0,29$ & $0,67 / 0,37$ & $0,21 / 0,79$ & $0,71 / 0,24$ & $0,31 / 0,15$ & $0,87 / 0,63$ \\
\hline Fissura Mediana & 1 & ---- & ---- & ---- & ---- & ---- & ---- & ---- & ---- \\
\hline Total FL/P & 324 & $0,01 / 0,02$ & $\begin{array}{c}\mathbf{0 , 0 0 0 0 1 /} \\
0,46\end{array}$ & $0,06 / 0,02$ & $0,17 / 0,09$ & $0,10 / 0,16$ & $0,55 / 0,15$ & $0,23 / 0,32$ & $0,05 / 0,01$ \\
\hline $\begin{array}{l}\text { Tipo/lado } \\
\text { desconhecido }\end{array}$ & 16 & ---- & ---- & ---- & ---- & ---- & --- & --- & --- \\
\hline Total Fissurados & 393 & $0,01 / 0,07$ & $\begin{array}{c}\mathbf{0 , 0 0 0 0 1 /} \\
0,31\end{array}$ & $0,12 / \mathbf{0 , 0 5}$ & $0,14 / 0,07$ & $0,09 / 0,14$ & $0,37 / 0,12$ & $0,33 / 0,50$ & $0,05 / 0,01$ \\
\hline $\begin{array}{l}\text { Controles } \\
\text { (sem fissura) }\end{array}$ & 285 & --- & --- & --- & --- & --- & --- & --- & --- \\
\hline
\end{tabular}




\begin{tabular}{|c|c|c|c|c|c|c|c|c|}
\hline Subfenótipo & $\mathbf{n}$ & 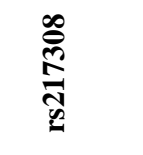 & 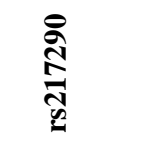 & 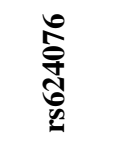 & 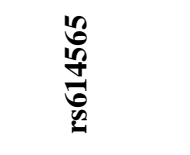 & 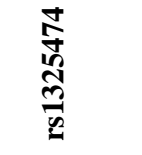 & 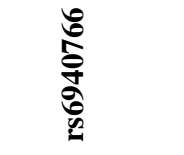 & 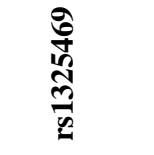 \\
\hline \multicolumn{9}{|l|}{ Fissura Palatina } \\
\hline Completa & 15 & $0,74 / 0,50$ & $0,78 / 0,58$ & $0,79 / 0,49$ & $0,63 / 0,38$ & $0,20 / 0,08$ & $0,04 / 0,01$ & $0,37 / 0,13$ \\
\hline $\begin{array}{l}\text { Incompleta }+ \\
\text { submucosa }\end{array}$ & 38 & $0,70 / 0,44$ & $0,61 / 0,69$ & $0,26 / 0,17$ & $0,09 / \mathbf{0 , 0 0 0 0 1}$ & $0,90 / 0,96$ & $0,52 / 0,76$ & $0,97 / 0,88$ \\
\hline Total FP & 53 & $0,56 / 0,33$ & $0,88 / 0,99$ & $0,57 / 0,44$ & $0,42 / 0,38$ & $0,61 / 0,37$ & $0,28 / 0,12$ & $0,82 / 0,53$ \\
\hline \multicolumn{9}{|l|}{$\begin{array}{l}\text { Fissura Labio- } \\
\text { Palatina }\end{array}$} \\
\hline Completa & 237 & $0,46 / 0,76$ & $0,58 / 0,76$ & $0,48 / 0,27$ & $0,16 / 0,05$ & $0,08 \dagger$ & $0,003 / 0,001$ & $0,22 / 0,25$ \\
\hline Incompleta & 86 & $0,77 / 0,52$ & $0,39 / 0,23$ & $0,09 / 0,23$ & $0,14 / 0,47$ & $0,53 / 0,29$ & $0,48 / 0,19$ & $0,18 / 0,43$ \\
\hline Unilateral & 200 & $0,64 / 0,69$ & $0,46 / 0,44$ & $0,09 / 0,38$ & $0,10 / 0,13$ & $0,09 / 0,04$ & $0,10 / 0,02$ & $0,03 / 0,08$ \\
\hline Completa & 136 & $0,59 / 0,94$ & $0,53 / 0,89$ & $0,53 / 0,69$ & $0,37 / 0,16$ & $0,07 / 0,06$ & $0,04 / 0,01$ & $0,05 \dagger$ \\
\hline Incompleta & 64 & $0,59 / 0,34$ & $0,33 / 0,16$ & $0,03 / 0,23$ & $0,04 / 0,38$ & $0,53 / 0,22$ & $0,88 / 0,62$ & $0,21 / 0,65$ \\
\hline Direita & 60 & $0,23 / 0,11$ & $0,29 / 0,15$ & $0,40 / 0,81$ & $0,35 / 0,17$ & $0,50 / 0,44$ & $0,17 / 0,04$ & $0,68 / 0,37$ \\
\hline Completa & 43 & $0,77 / 0,51$ & $0,86 / 0,68$ & $0,84 / 0,83$ & $0,29 / 0,11$ & $0,56 / 0,25$ & $0,14 / \mathbf{0 , 0 4}$ & $0,53 / 0,23$ \\
\hline Incompleta & 11 & $0,08 / 0,04$ & $0,06 / \mathbf{0 , 0 3}$ & $0,30 / 0,93$ & $0,28 / 0,78$ & $0,49 / 0,87$ & $0,66 / 0,68$ & $0,71 \dagger$ \\
\hline Incompleta + FP & 6 & $0,61 / 0,38$ & $0,58 / 0,34$ & $0,66 / 0,75$ & $0,79 / 0,61$ & $0,26 / 0,09$ & $0,26 / 0,13$ & $0,75 / 0,43$ \\
\hline Esquerda & 140 & $0,62 / 0,66$ & $0,63 / 0,89$ & $0,15 / 0,33$ & $0,19 / 0,27$ & $0,02 \dagger$ & $0,62 / 0,31$ & $0,007 / 0,09$ \\
\hline Completa & 93 & $0,45 / 0,60$ & $0,43 / 0,91$ & $0,58 / 0,71$ & $0,64 / 0,46$ & $0,04 / 0,09$ & $0,56 / 0,25$ & $0,03 / 0,07$ \\
\hline Incompleta & 44 & $0,95 / 0,94$ & $0,81 / 0,57$ & $0,11 / 0,14$ & $0,13 / 0,26$ & $0,17 / 0,32$ & $0,90 / 0,92$ & $0,10 / 0,69$ \\
\hline Incompleta + FP & 3 & $0,45 / 0,52$ & $0,51 / 0,55$ & $0,57 / 0,82$ & $0,55 / 0,73$ & $0,00001 \dagger$ & $0,15 / \mathbf{0 , 0 4}$ & $0,24 / 0,28$ \\
\hline Bilateral & 123 & $0,74 / 0,65$ & $0,93 / 0,73$ & $0,28 / 0,11$ & $0,25 / 0,12$ & $0,43 / 0,47$ & $0,002 / 0,0005$ & $0,81 / 0,97$ \\
\hline Completa & 101 & $0,53 / 0,52$ & $0,84 / 0,71$ & $0,35 / 0,14$ & $0,18 / 0,07$ & $0,48 / 0,37$ & $0,008 / 0,001$ & $0,82 / 0,68$ \\
\hline Incompleta & 6 & $0,64 / 0,77$ & $0,62 / 0,72$ & $0,29 / 0,11$ & $0,34 / 0,14$ & $0,66 / 0,97$ & $0,45 / 0,82$ & $0,34 / 0,46$ \\
\hline Incompleta + FP & 13 & $0,98 / 0,92$ & $0,39 / 0,62$ & $0,68 / 0,38$ & $0,38 / 0,15$ & $0,54 / 0,97$ & $0,12 / 0,06$ & $0,75 / 0,47$ \\
\hline Incompleta mista & 3 & $0,28 / 0,13$ & $0,32 / 0,15$ & $0,79 / 0,50$ & $0,83 / 0,56$ & $0,81 / 0,98$ & $0,54 / 0,33$ & $0,88 / 0,98$ \\
\hline Fissura Mediana & 1 & ---- & --- & ---- & ---- & ---- & ---- & ---- \\
\hline Total FL/P & 2 & $0,60 / 0,62$ & $0,65 / 0,48$ & $0,18 / 0,16$ & $0,13 / 0,05$ & $0,09 / 0,07$ & $0,005 / 0,001$ & $0,12 / 0,23$ \\
\hline $\begin{array}{l}\text { Tipo/lado } \\
\text { desconhecido }\end{array}$ & 16 & ---- & ---- & ---- & ---- & ---- & ---- & ---- \\
\hline Total Fissurados & 324 & $0,73 / 0,94$ & $0,59 / 0,43$ & $0,33 \dagger$ & $0,25 / 0,15$ & $0,20 / 0,17$ & $0,002 / 0,0008$ & $0,19 / 0,29$ \\
\hline $\begin{array}{l}\text { Controles (sem } \\
\text { fissura) }\end{array}$ & 285 & ---- & ---- & ---- & ---- & ---- & ---- & ---- \\
\hline
\end{tabular}

fissura)

$* \mathrm{p} \leq 0,0005$ indica diferença estatística significante (em negrito, realçado em cinza); $\mathrm{p} \leq 0,05$ indica tendência à significância

(em itálico).

$\dagger$ para ambos genótipo e alelo.

** Brasileiros sem ascendência Africana ou Japonesa. 


\subsection{Estudos genéticos utilizando anomalias dentárias como subfenótipos adicionais para FL/P}

As tabelas 26-31 mostram a análise comparativa das freqüências dos genótipos e alelos obtidos para casos e controles em cada polimorfismo estudado, de acordo com os novos subfenótipos propostos no Quadro 1. As freqüências obtidas para genótipos e alelos referentes a cada polimorfismo estudado encontram-se no Anexo 8.

Diferenças significativas foram encontradas entre as freqüências dos genótipos e alelos obtidos para casos e controles (caucasianos) para o marcador rs2235371 (VAL274I) no gene IRF6, sugerindo a associação da presença de FP completa com retenção de dentes permanentes (Tabela 29).

Tabela 26. Análise comparativa das freqüências dos genótipos e alelos (genótipos/alelos) obtidos em casos e controles (população total) para cada polimorfismo no gene TGFA, de acordo com os subfenótipos propostos.

\begin{tabular}{|c|c|c|c|c|c|c|c|}
\hline Subfenótipos adicionais & $\mathbf{n}$ & 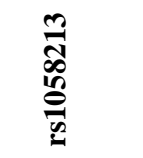 & 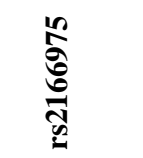 & 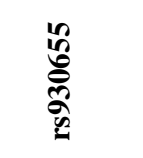 & 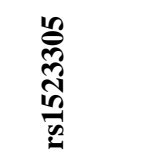 & 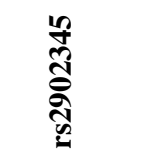 & 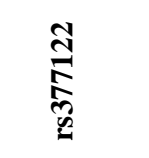 \\
\hline FP total com agenesia & 14 & $0,66 / 0,80$ & $0,21 / 0,22$ & $0,42 / 0,29$ & $0,42 / 0,35$ & $0,56 / 0,37$ & $0,32 / 0,21$ \\
\hline $\begin{array}{l}\text { FP completa com retenção de dentes } \\
\text { permanentes }\end{array}$ & 2 & ---/--- & $---/---$ & $---/---$ & ---/--- & $---/---$ & $---/---$ \\
\hline FP completa com múltiplas anomalias & 2 & ---/--- & ---/--- & ---/--- & ---/--- & ---/--- & ---/--- \\
\hline FP incompleta com giroversão/lateroversão & 4 & ---/--- & $0,76 / 0,87$ & $0,41 / 0,32$ & $0,46 / 0,49$ & $0,49 / 0,63$ & $0,98 / 0,94$ \\
\hline FL/P direita com agenesia & 27 & $---/---$ & $0,93 / 0,69$ & $0,91 / 0,96$ & $0,63 / 0,55$ & $0,30 / 0,33$ & $0,71 / 0,51$ \\
\hline FL/P esquerda com agenesia & 40 & $0,66 / 0,49$ & $0,06 / 0,05$ & $0,40 / 0,24$ & $0,30 / 0,55$ & $0,12 / 0,11$ & $0,53 / 0,37$ \\
\hline FL/P esquerda com supranumerário & 12 & $0,73 / 0,88$ & $0,32 / 0,15$ & $0,41 / 0,19$ & $0,43 / 0,30$ & $0,30 / 0,29$ & $0,37 / 0,89$ \\
\hline FL/P esquerda com múltiplas anomalias & 17 & $0,66 / 0,71$ & $0,99 / 0,95$ & $0,04 / 0,11$ & $0,15 / 0,33$ & $0,08 / 0,13$ & $0,24 / 0,39$ \\
\hline FL/P bilateral com agenesia & 39 & $0,38 / 0,48$ & $0,44 / 0,30$ & $0,68 / 0,99$ & $0,83 / 0,70$ & $0,16 / 0,07$ & $0,87 / 0,61$ \\
\hline FL/P bilateral com supranumerário & 2 & ---/--- & $0,46 / 0,54$ & $0,64 / 0,48$ & ---/--- & ---/--- & ---/--- \\
\hline FL/P bilateral com múltiplas anomalias & 8 & ---/--- & $0,64 / 0,44$ & $0,91 / 0,69$ & $0,37 / 0,19$ & $0,22 / 0,14$ & $0,02 / 0,03$ \\
\hline FL/P bilateral frustro* & 31 & $0,82 / 0,65$ & $0,91 / 0,82$ & $0,52 / 0,96$ & $0,25 / 0,55$ & $0,002 / 0,14$ & $0,003 / 0,05$ \\
\hline $\begin{array}{l}\text { FL/P bilateral frustro* com múltiplas } \\
\text { anomalias }\end{array}$ & 1 & ---/--- & $---/--$ & $---/--$ & $---/--$ & $---/--$ & ---/--- \\
\hline
\end{tabular}

* FL/P unilateral com agenesia ou microdontia do incisivo lateral superior do lado oposto da fissura.

** $\mathrm{p} \leq 0,0005$ indica diferença estatística significante (em negrito, realçado em cinza); $\mathrm{p} \leq 0,05$ indica tendência à significância (em itálico).

$\dagger$ para ambos genótipo e alelo. 
Tabela 27. Análise comparativa das freqüências dos genótipos e alelos (genótipos/alelos) obtidos em casos e controles (caucasianos $\$$ ) para cada polimorfismo no gene TGFA, de acordo com os subfenótipos propostos.

\begin{tabular}{|c|c|c|c|c|c|c|c|}
\hline Subfenótipos adicionais & $\mathbf{n}$ & 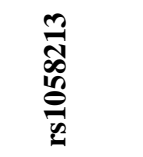 & 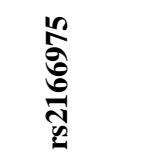 & 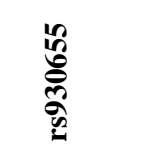 & 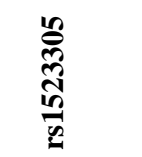 & $\begin{array}{l}\text { 怘 } \\
\text { ஸิ } \\
\text { స్ } \\
\text { }\end{array}$ & 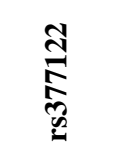 \\
\hline FP total com agenesia & 12 & $0,90 / 0,67$ & $0,06 / 0,04$ & $0,15 / 0,07$ & $0,04 / 0,08$ & $0,06 / 0,09$ & $0,41 / 0,21$ \\
\hline $\begin{array}{l}\text { FP completa com retenção de dentes } \\
\text { permanentes }\end{array}$ & 2 & ---/--- & ---/--- & $---/ 0,006$ & $---/ 0,01$ & $---/ 0,008$ & $---/ 0,01$ \\
\hline FP completa com múltiplas anomalias & $\mathbf{0}$ & ---/--- & ---/--- & $0,61 / 0,72$ & $0,43 / 0,40$ & $0,50 / 0,56$ & $0,32 / 0,60$ \\
\hline FP incompleta com giroversão/lateroversão & 4 & ---/--- & $0,74 / 0,91$ & $0,38 / 0,28$ & $0,44 / 0,41$ & $0,50 / 0,57$ & $0,96 / 0,98$ \\
\hline FL/P direita com agenesia & 24 & $0,24 / 0,02$ & $0,94 / 0,69$ & $0,78 / 0,57$ & $0,97 / 0,83$ & $0,32 / 0,16$ & $0,95 / 0,60$ \\
\hline FL/P esquerda com agenesia & 36 & $0,01 / 0,48$ & $0,06 / 0,03$ & $0,38 / 0,20$ & $0,51 / 0,72$ & $0,21 / 0,16$ & $0,38 / 0,29$ \\
\hline FL/P esquerda com supranumerário & 9 & $\begin{array}{ll}---/--- \\
\end{array}$ & $0,10 / 0,02$ & $0,67 / 0,37$ & $0,58 / 0,60$ & $0,35 / 0,55$ & $0,37 / 0,94$ \\
\hline FL/P esquerda com múltiplas anomalias & 14 & $\begin{array}{ll}--/--- \\
\end{array}$ & $0,94 / 0,92$ & $0,02 / 0,03$ & $0,07 / 0,15$ & $0,02 / 0,04$ & $0,16 / 0,29$ \\
\hline FL/P bilateral com agenesia & 34 & $0,88 / 0,97$ & $0,29 / 0,17$ & $0,73 / 0,96$ & $0,81 / 0,88$ & $0,09 / 0,03$ & $0,71 / 0,50$ \\
\hline FL/P bilateral com supranumerário & 2 & $---/---$ & $0,42 / 0,51$ & $0,61 / 0,45$ & $0,01 \dagger$ & $---/ 0,02$ & $---/ 0,01$ \\
\hline FL/P bilateral com múltiplas anomalias & 6 & ---/--- & $0,73 / 0,73$ & $0,98 / 0,88$ & $0,81 / 0,55$ & $0,57 / 0,42$ & $0,02 / 0,08$ \\
\hline FL/P bilateral frustro* & 26 & $0,02 / 0,31$ & $0,93 / 0,96$ & $0,62 / 0,94$ & $0,20 / 0,60$ & $0,87 / 0,97$ & $0,33 / 0,26$ \\
\hline $\begin{array}{l}\text { FL/P bilateral frustro * com múltiplas } \\
\text { anomalias }\end{array}$ & 1 & ---/--- & ---/--- & $---/ 0,05$ & $---/--$ & $---/ 0,06$ & $---/ 0,98$ \\
\hline
\end{tabular}

* FL/P unilateral com agenesia ou microdontia do incisivo lateral superior do lado oposto da fissura.

** $\mathrm{p} \leq 0,0005$ indica diferença estatística significante (em negrito, realçado em cinza); $\mathrm{p} \leq 0,05$ indica tendência à significância (em itálico).

$\dagger$ para ambos genótipo e alelo. $\$$ Brasileiros sem ascendência Africana ou Japonesa.

Tabela 28. Análise comparativa das freqüências dos genótipos e alelos (genótipos/alelos) obtidos em casos e para cada polimorfismo no gene IRF6 (população total) de acordo com os subfenótipos propostos.

\begin{tabular}{|c|c|c|c|c|c|c|c|}
\hline Subfenótipos adicionais & $\mathbf{n}$ & 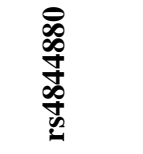 & 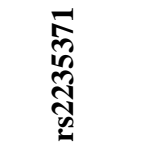 & 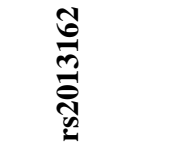 & 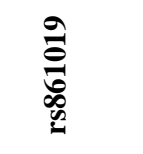 & 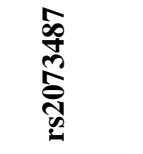 & 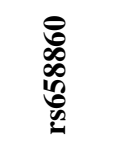 \\
\hline FP total com agenesia & 14 & $0,16 / 0,24$ & $0,63 / 0,56$ & $0,73 / 0,42$ & $0,58 / 0,66$ & $0,89 / 0,62$ & $0,03 / 0,13$ \\
\hline $\begin{array}{l}\text { FP completa com retenção de dentes } \\
\text { permanentes }\end{array}$ & 2 & $0,74 / 0,77$ & ---/--- & $0,009 / 0,006$ & ---/--- & ---/--- & ---/--- \\
\hline FP completa com múltiplas anomalias & 2 & ---/--- & $---/---$ & $---/---$ & $---/---$ & $---/---$ & $---/---$ \\
\hline FP incompleta com giroversão/lateroversão & 4 & $0,23 / 0,72$ & $0,02 / 0,007$ & $0,37 / 0,29$ & $0,69 / 0,81$ & $0,48 / 0,61$ & $0,90 / 0,84$ \\
\hline FL/P direita com agenesia & 27 & $0,03 / 0,14$ & $0,14 / 0,11$ & $0,33 / 0,13$ & $0,39 / 0,40$ & $0,33 / 0,13$ & $0,49 / 0,46$ \\
\hline FL/P esquerda com agenesia & 40 & $0,48 / 0,20$ & $0,01 / 0,004$ & $0,30 / 0,13$ & $0,15 / 0,04$ & $0,30 / 0,13$ & $0,29 / 0,17$ \\
\hline FL/P esquerda com supranumerário & 12 & $0,67 / 0,87$ & $0,34 / 0,68$ & $0,02 / 0,01$ & $0,02 / 0,96$ & $0,02 / 0,01$ & $0,24 / 0,10$ \\
\hline FL/P esquerda com múltiplas anomalias & 17 & $0,61 / 0,30$ & ---/--- & $0,06 / 0,02$ & $0,33 / 0,19$ & $0,06 / 0,02$ & $0,38 / 0,16$ \\
\hline FL/P bilateral com agenesia & 39 & $0,29 / 0,78$ & $0,06 / 0,03$ & $0,23 / 0,15$ & $0,97 / 0,88$ & $0,16 / 0,11$ & $0,99 / 0,90$ \\
\hline FL/P bilateral com supranumerário & 2 & $0,74 / 0,77$ & $---/---$ & $0,19 / 0,79$ & $---/---$ & ---/--- & $0,68 / 0,57$ \\
\hline FL/P bilateral com múltiplas anomalias & 8 & $0,31 / 0,55$ & $\begin{array}{ll}---/-- \\
\end{array}$ & $0,87 / 0,60$ & $0,05 / 0,06$ & $0,28 / 0,14$ & $0,57 / 0,33$ \\
\hline FL/P bilateral frustro* & 31 & $0,23 / 0,07$ & $0,12 / 0,09$ & $0,65 / 0,92$ & $0,87 / 0,76$ & $0,66 / 0,92$ & $0,51 / 0,71$ \\
\hline $\begin{array}{l}\text { FL/P bilateral frustro * com múltiplas } \\
\text { anomalias }\end{array}$ & 1 & ---/--- & ---/--- & ---/--- & ---/--- & ---/--- & ---/--- \\
\hline
\end{tabular}

* FL/P unilateral com agenesia ou microdontia do incisivo lateral superior do lado oposto da fissura. $* * \mathrm{p} \leq 0,0005$ indica diferença estatística significante (em negrito, realçado em cinza); $\mathrm{p} \leq 0,05$ indica tendência à signifícância (em itálico). 
Tabela 29. Análise comparativa das freqüências dos genótipos e alelos (genótipos/alelos) obtidos em casos e controles (caucasianos para cada polimorfismo no gene IRF6 de acordo com os subfenótipos propostos.

\begin{tabular}{|c|c|c|c|c|c|c|c|}
\hline Subfenótipos adicionais & $\mathbf{n}$ & 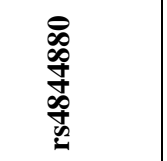 & 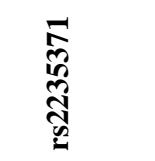 & 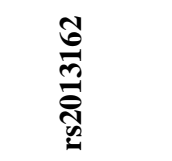 & $\begin{array}{l}\stackrel{9}{0} \\
0 \\
0 \\
0 \\
0 \\
0 \\
0\end{array}$ & 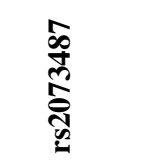 & 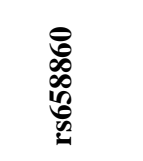 \\
\hline FP total com agenesia & 12 & $0,47 / 0,87$ & $0,16 / 0,12$ & $0,93 / 0,75$ & $0,24 / 0,90$ & $0,76 / 0,53$ & $0,001 / 0,01$ \\
\hline $\begin{array}{l}\text { FP completa com retenção de dentes } \\
\text { permanentes }\end{array}$ & 2 & $0,79 / 0,88$ & $0,00001 \dagger$ & $0,002 / 0,003$ & $---/---$ & ---/--- & ---/--- \\
\hline FP completa com múltiplas anomalias & $\mathbf{0}$ & $\begin{array}{ll}---/-- \\
\end{array}$ & $\begin{array}{ll}---/-- \\
\end{array}$ & $\begin{array}{ll}--/--- \\
\end{array}$ & $\begin{array}{ll}---/-- \\
\end{array}$ & $\begin{array}{ll}---/-- \\
\end{array}$ & $\begin{array}{ll}---/-- \\
\end{array}$ \\
\hline FP incompleta com giroversão/lateroversão & 4 & $0,18 / 0,28$ & $0,39 / 0,24$ & $0,49 / 0,42$ & $0,58 / 0,63$ & $0,54 / 0,77$ & $0,92 / 0,84$ \\
\hline FL/P direita com agenesia & 24 & $0,27 / 0,58$ & $0,20 / 0,81$ & $0,94 / 0,83$ & $0,67 / 0,69$ & $0,93 / 0,79$ & $0,30 / 0,41$ \\
\hline FL/P esquerda com agenesia & 36 & $0,75 / 0,78$ & $0,56 / 0,32$ & $0,54 / 0,36$ & $0,10 / 0,25$ & $0,50 / 0,33$ & $0,19 / 0,39$ \\
\hline FL/P esquerda com supranumerário & 9 & $0,53 / 0,25$ & $0,91 \dagger$ & $0,04 / 0,03$ & $0,04 / 0,86$ & $0,43 / 0,75$ & $0,69 / 0,67$ \\
\hline FL/P esquerda com múltiplas anomalias & 14 & $0,93 / 0,94$ & $0,22 / 0,07$ & $0,14 / 0,06$ & $0,46 / 0,24$ & $0,13 / 0,06$ & $0,59 / 0,67$ \\
\hline FL/P bilateral com agenesia & 34 & $0,57 / 0,28$ & $0,78 / 0,74$ & $0,57 / 0,34$ & $0,29 / 0,35$ & $0,44 / 0,23$ & $0,80 / 0,52$ \\
\hline FL/P bilateral com supranumerário & 2 & $0,79 / 0,88$ & ---/--- & $0,19 / 0,64$ & ---/--- & $0,19 / 0,65$ & $0,73 / 0,57$ \\
\hline FL/P bilateral com múltiplas anomalias & 6 & $0,51 / 0,80$ & $0,51 / 0,24$ & $0,97 / 0,83$ & $0,12 / 0,15$ & $0,97 / 0,85$ & $0,76 / 0,52$ \\
\hline FL/P bilateral frustro* & 26 & $0,54 / 0,33$ & $0,03 / 0,75$ & $0,46 / 0,53$ & $0,86 / 0,70$ & $0,47 / 0,57$ & $0,62 / 0,54$ \\
\hline $\begin{array}{l}\text { FL/P bilateral frustro * com múltiplas } \\
\text { anomalias }\end{array}$ & 1 & ---/--- & ---/--- & ---/--- & ---/--- & $0,32 / 0,15$ & $---/---$ \\
\hline \multicolumn{8}{|c|}{$\begin{array}{l}\text { * FL/P unilateral com agenesia ou microdontia do incisivo lateral superior do lado oposto da fissura. } \\
\text { ** } \mathrm{p} \leq 0,0005 \text { indica diferença estatística significante (em negrito, realçado em cinza); } \mathrm{p} \leq 0,05 \text { indica tendência à significância (em itálico). } \\
\dagger \text { para ambos genótipo e alelo. } \\
\text { † Brasileiros sem ascendência Africana ou Japonesa. } \\
\text { Tabela 30, Análise comparativa das freqüências dos genótipos e alelos (genótipos/alelos) obtidos em casos e controles } \\
\text { (população total) para cada polimorfismo no cromossomo } 6 \mathrm{q} \text { de acordo com os subfenótipos propostos. }\end{array}$} \\
\hline Subfenótipos adicionais & $\mathbf{n}$ & 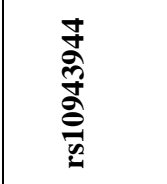 & 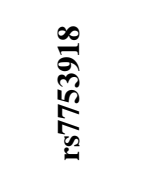 & $\begin{array}{l}\underset{\Xi}{\Xi} \\
\underset{D}{\Xi}\end{array}$ & 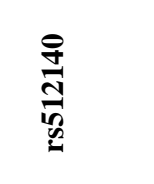 & 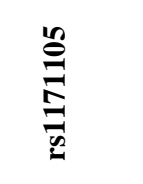 & 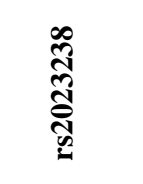 \\
\hline FP total com agenesia & 14 & $0,07 / 0,04$ & $0,89 / 0,91$ & $0,90 \dagger$ & $0,29 / 0,62$ & $0,71 / 0,41$ & $0,70 / 0,95$ \\
\hline $\begin{array}{l}\text { FP completa com retenção de dentes } \\
\text { permanentes }\end{array}$ & 2 & ---/--- & ---/--- & $---/ 0,46$ & $0,78 / 0,97$ & ---/--- & $---/ 0,43$ \\
\hline FP completa com múltiplas anomalias & 2 & ---/--- & ---/--- & ---/--- & ---/--- & $0,70 / 0,41$ & ---/--- \\
\hline FP incompleta com giroversão/lateroversão & 4 & $0,06 / 0,15$ & $0,65 / 0,71$ & $0,62 / 0,97$ & $0,20 / 0,45$ & $0,10 / 0,12$ & $---/ 0,34$ \\
\hline FL/P direita com agenesia & 27 & $0,12 / 0,22$ & $0,35 / 0,93$ & $0,47 / 0,98$ & $0,99 / 0,93$ & $0,23 / 0,34$ & $0,64 / 0,61$ \\
\hline FL/P esquerda com agenesia & 40 & $0,23 / 0,10$ & $0,12 / 0,85$ & $0,83 / 0,77$ & $0,20 / 0,10$ & $0,58 / 0,35$ & $0,05 / 0,01$ \\
\hline FL/P esquerda com supranumerário & 12 & $0,55 / 0,37$ & $0,14 / 0,90$ & $0,21 / 0,36$ & $0,11 / 0,07$ & $0,42 / 0,56$ & $0,66 / 0,35$ \\
\hline FL/P esquerda com múltiplas anomalias & 17 & $0,52 / 0,94$ & $0,20 / 0,18$ & $0,14 / 0,08$ & $0,08 / \mathbf{0 , 0 4}$ & $0,39 / 0,19$ & $0,25 / 0,12$ \\
\hline FL/P bilateral com agenesia & 39 & $0,05 / 0,03$ & $0,60 / 0,62$ & $0,15 / 0,07$ & $0,61 / 0,87$ & $0,40 / 0,39$ & $0,91 / 0,90$ \\
\hline FL/P bilateral com supranumerário & 2 & $0,78 / 0,71$ & $0,41 / 0,69$ & $0,81 / 0,73$ & $---/ 0,26$ & $---/ 0,55$ & $---/ 0,42$ \\
\hline FL/P bilateral com múltiplas anomalias & 8 & $0,25 / 0,87$ & $0,42 / 0,23$ & $0,11 / 0,89$ & $0,88 / 0,62$ & $0,97 / 0,90$ & $0,73 / 0,62$ \\
\hline FL/P bilateral frustro* & 31 & $0,17 / 0,05$ & $0,54 / 0,66$ & $0,02 / 0,16$ & $0,30 / 0,11$ & $0,86 / 0,90$ & $0,59 / 0,27$ \\
\hline $\begin{array}{l}\text { FL/P bilateral frustro* com múltiplas } \\
\text { anomalias }\end{array}$ & 1 & ---/--- & ---/--- & ---/--- & ---/--- & ---/--- & ---/--- \\
\hline
\end{tabular}




\begin{tabular}{|c|c|c|c|c|c|c|c|}
\hline Subfenótipos adicionais & $\mathbf{n}$ & 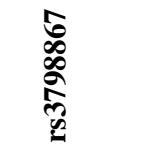 & 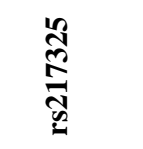 & 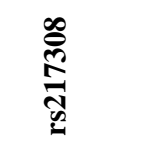 & 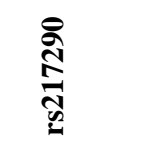 & 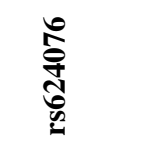 & 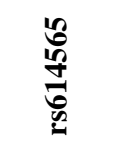 \\
\hline FP total com agenesia & 14 & $0,12 / 0,31$ & $0,82 / 0,54$ & $0,15 / 0,34$ & $0,10 / 0,40$ & $0,19 / 0,86$ & $0,31 / 0,71$ \\
\hline $\begin{array}{l}\text { FP completa com retenção de dentes } \\
\text { permanentes }\end{array}$ & 2 & $---/ 0,69$ & $---/ 0,15$ & $---/ 0,67$ & $---/ 0,67$ & $0,79 / 0,87$ & $0,80 / 0,93$ \\
\hline FP completa com múltiplas anomalias & 2 & ---/--- & $0,30 / 0,24$ & ---/--- & ---/--- & ---/--- & ---/--- \\
\hline FP incompleta com giroversão/lateroversão & 4 & $0,59 / 0,73$ & $0,15 / 0,04$ & $0,61 / 0,75$ & $0,49 / 0,39$ & $0,69 / 0,51$ & $\begin{array}{ll}---/-- \\
\end{array}$ \\
\hline FL/P direita com agenesia & 27 & $0,63 / 0,96$ & $0,82 / 0,99$ & $0,34 / 0,43$ & $0,72 / 0,78$ & $0,69 / 0,93$ & $0,75 / 0,60$ \\
\hline FL/P esquerda com agenesia & 40 & $0,92 / 0,70$ & $0,03 / 0,02$ & $0,95 / 0,78$ & $0,89 / 0,65$ & $0,70 / 0,52$ & $0,40 / 0,70$ \\
\hline FL/P esquerda com supranumerário & 12 & $0,45 / 0,63$ & $0,57 / 0,31$ & $0,38 / 0,58$ & $0,85 / 0,82$ & $0,46 / 0,20$ & $0,33 / 0,13$ \\
\hline FL/P esquerda com múltiplas anomalias & 17 & $0,42 / 0,20$ & $0,05 / 0,42$ & $0,46 / 0,23$ & $0,46 / 0,22$ & $0,56 / 0,65$ & $0,86 / 0,73$ \\
\hline FL/P bilateral com agenesia & 39 & $0,80 \dagger$ & $0,05 / 0,03$ & $0,94 / 0,85$ & $0,84 / 0,89$ & $0,77 / 0,63$ & $0,82 / 0,52$ \\
\hline FL/P bilateral com supranumerário & 2 & $0,69 / 0,53$ & $----/ 0,15$ & $0,70 / 0,54$ & $---/ 0,67$ & $0,08 / 0,34$ & ---/--- \\
\hline FL/P bilateral com múltiplas anomalias & 8 & $0,23 / 0,21$ & $0,76 / 0,68$ & $0,24 / 0,23$ & $0,69 / 0,49$ & $0,75 / 0,74$ & $0,32 / 0,19$ \\
\hline FL/P bilateral frustro* & 31 & $0,35 / 0,81$ & $0,82 / 0,99$ & $0,16 / 0,95$ & $0,38 / 0,74$ & $0,20 / 0,24$ & $0,09 / 0,10$ \\
\hline $\begin{array}{l}\text { FL/P bilateral frustro* com múltiplas } \\
\text { anomalias }\end{array}$ & 1 & ---/--- & ---/--- & ---/--- & ---/--- & ---/--- & ---/--- \\
\hline
\end{tabular}

\begin{tabular}{|c|c|c|c|c|}
\hline Subfenótipos adicionais & $\mathbf{n}$ & 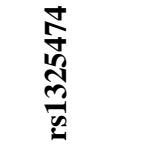 & 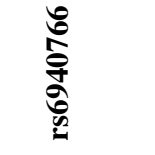 & 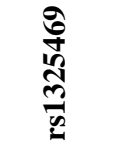 \\
\hline FP total com agenesia & 14 & $0,34 / 0,18$ & $0,10 / 0,07$ & $0,32 / 0,17$ \\
\hline $\begin{array}{l}\text { FP completa com retenção de dentes } \\
\text { permanentes }\end{array}$ & 2 & ---/--- & ---/--- & ---/--- \\
\hline FP completa com múltiplas anomalias & 2 & $---/---$ & $---/---$ & ---/--- \\
\hline FP incompleta com giroversão/lateroversão & 4 & ---/--- & $0,21 / 0,65$ & ---/--- \\
\hline FL/P direita com agenesia & 27 & $0,93 / 0,77$ & $0,78 / 0,53$ & $0,60 / 0,35$ \\
\hline FL/P esquerda com agenesia & 40 & $0,22 / 0,42$ & $0,72 / 0,48$ & $0,18 / 0,76$ \\
\hline FL/P esquerda com supranumerário & 12 & $0,08 / 0,02$ & $0,22 / 0,32$ & $0,09 / 0,03$ \\
\hline FL/P esquerda com múltiplas anomalias & 17 & $0,38 / 0,94$ & $0,73 / 0,64$ & $0,25 / 0,77$ \\
\hline FL/P bilateral com agenesia & 39 & $0,63 / 0,35$ & $0,009 / 0,04$ & $0,14 / 0,11$ \\
\hline FL/P bilateral com supranumerário & 2 & $---/ 0,09$ & $---/---$ & $---/ 0,10$ \\
\hline FL/P bilateral com múltiplas anomalias & 8 & $0,62 / 0,87$ & $0,07 / \mathbf{0 , 0 3}$ & $0,60 / 0,98$ \\
\hline FL/P bilateral frustro* & 31 & $0,20 / 0,13$ & $0,68 / 0,35$ & $0,34 / 0,40$ \\
\hline $\begin{array}{l}\text { FL/P bilateral frustro* com múltiplas } \\
\text { anomalias }\end{array}$ & 1 & ---/--- & $---/---$ & ---/--- \\
\hline
\end{tabular}

* FL/P unilateral com agenesia ou microdontia do incisivo lateral superior do lado oposto da fissura. $* * p \leq 0,0005$ indica diferença estatística significante (em negrito, realçado em cinza); $p \leq 0,05$ indica tendência à significância (em itálico).

$\uparrow$ para ambos genótipo e alelo. 
Tabela 31. Análise comparativa das freqüências dos genótipos e alelos (genótipos/alelos) obtidos em casos e controles (caucasianos $\$$ ) para cada polimorfismo no cromossomo 6q de acordo com os subfenótipos propostos.

\begin{tabular}{|c|c|c|c|c|c|c|c|}
\hline Subfenótipos adicionais & $\mathbf{n}$ & 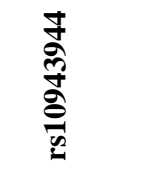 & 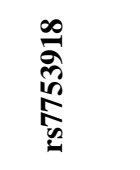 & 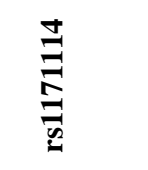 & 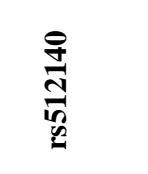 & $\stackrel{\stackrel{ }{\circ}}{\stackrel{ }{ }}$ & 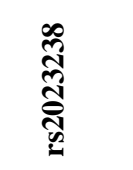 \\
\hline FP total com agenesia & 12 & $0,03 / 0,20$ & $0,66 / 0,53$ & $0,22 / 0,30$ & $0,16 / 0,15$ & $0,58 / 0,32$ & $0,85 / 0,78$ \\
\hline $\begin{array}{l}\text { FP completa com retenção de dentes } \\
\text { permanentes }\end{array}$ & 2 & 0,40/--- & ------- & ------ & $0,76 / 0,66$ & ------- & ------ \\
\hline FP completa com múltiplas anomalias & $\mathbf{0}$ & $\begin{array}{ll}------ \\
\end{array}$ & $0,44 / 0,14$ & $\begin{array}{ll}--/--- \\
\end{array}$ & $\begin{array}{ll}--/--- \\
\end{array}$ & $0,80 / 0,53$ & $0,44 / 0,97$ \\
\hline FP incompleta com giroversão/lateroversão & 4 & $0,04 / 0,01$ & $0,67 / 0,70$ & $0,61 / 0,86$ & $0,37 / 0,90$ & $0,16 / 0,18$ & $\begin{array}{ll}----- \\
\end{array}$ \\
\hline FL/P direita com agenesia & 24 & $0,03 / 0,48$ & $0,74 / 0,38$ & $0,47 / 0,72$ & $0,40 / 0,22$ & $0,12 / 0,28$ & $0,42 / 0,68$ \\
\hline FL/P esquerda com agenesia & 36 & $0,17 / 0,12$ & $0,26 / 0,88$ & $0,83 / 0,58$ & $0,78 \dagger$ & $0,81 / 0,68$ & $0,06 / 0,02$ \\
\hline FL/P esquerda com supranumerário & 9 & $0,29 / 0,33$ & $0,27 / 0,90$ & $0,22 \dagger$ & $0,59 / 0,74$ & $0,57 / 0,98$ & $0,77 / 0,66$ \\
\hline FL/P esquerda com múltiplas anomalias & 14 & $0,68 / 0,91$ & $0,25 / 0,14$ & $0,54 / 0,30$ & $0,55 / 0,68$ & $0,71 / 0,45$ & $0,29 / 0,26$ \\
\hline FL/P bilateral com agenesia & 34 & $0,09 / \mathbf{0 , 0 5}$ & $0,52 / 0,72$ & $0,68 / 0,48$ & $0,45 / 0,21$ & $0,10 / 0,22$ & $0,97 / 0,94$ \\
\hline FL/P bilateral com supranumerário & 2 & $0,83 / 0,74$ & $0,46 / 0,70$ & $0,75 \dagger$ & ------ & ------- & ------- \\
\hline FL/P bilateral com múltiplas anomalias & 6 & $0,57 / 0,34$ & $0,57 / 0,39$ & $0,75 / 0,62$ & $0,82 / 0,87$ & $0,98 / 0,65$ & $0,75 / 0,50$ \\
\hline FL/P bilateral frustro* & 22 & $0,22 / 0,17$ & $0,67 / 0,30$ & $0,14 / 0,33$ & $0,89 / 0,90$ & $0,21 / 0,11$ & $0,73 / 0,40$ \\
\hline $\begin{array}{l}\text { FL/P bilateral frustro* com múltiplas } \\
\text { anomalias }\end{array}$ & 1 & $---/--$ & $---/---$ & $---/---$ & $---/--$ & $---/--$ & $---/---$ \\
\hline
\end{tabular}

\begin{tabular}{|c|c|c|c|c|c|c|c|}
\hline Subfenótipos adicionais & $\mathbf{n}$ & 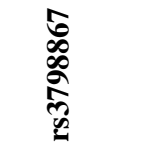 & 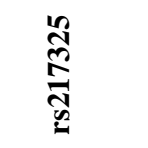 & 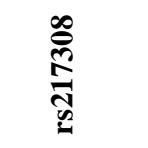 & 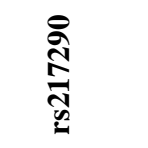 & 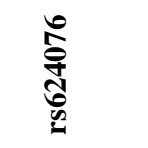 & 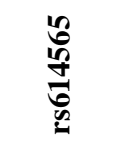 \\
\hline FP total com agenesia & 12 & $0,26 / 0,54$ & $0,98 / 0,99$ & $0,31 / 0,59$ & $0,19 / 0,63$ & $0,29 / 0,93$ & $0,42 / 0,75$ \\
\hline $\begin{array}{l}\text { FP completa com retenção de dentes } \\
\text { permanentes }\end{array}$ & 2 & $---/--$ & $---/---$ & $---/---$ & ------ & $0,81 / 0,88$ & $0,82 / 0,95$ \\
\hline FP completa com múltiplas anomalias & $\mathbf{0}$ & $0,67 / 0,81$ & $0,47 / 0,46$ & $0,69 / 0,85$ & ------- & ------- & (------- \\
\hline FP incompleta com giroversão/lateroversão & 4 & $0,66 / 0,81$ & $0,47 / 0,12$ & $0,69 / 0,85$ & ------ & $0,71 / 0,51$ & ------- \\
\hline FL/P direita com agenesia & 24 & $0,54 / 0,90$ & $0,79 / 0,51$ & $0,58 / 0,72$ & $0,67 / 0,71$ & $0,76 / 0,51$ & $0,83 / 0,55$ \\
\hline FL/P esquerda com agenesia & 36 & $0,87 / 0,78$ & $0,70 / 0,13$ & $0,95 / 0,89$ & $0,94 / 0,90$ & $0,73 / 0,43$ & $0,63 / 0,60$ \\
\hline FL/P esquerda com supranumerário & 9 & $0,10 / 0,14$ & $0,77 / 0,48$ & $0,05 / 0,11$ & $0,66 / 0,57$ & $0,23 / 0,41$ & $0,16 / 0,31$ \\
\hline FL/P esquerda com múltiplas anomalias & 14 & $0,79 / 0,53$ & $0,11 / 0,76$ & $0,85 / 0,60$ & $0,80 / 0,54$ & $0,06 / 0,30$ & $0,37 / 0,86$ \\
\hline FL/P bilateral com agenesia & 34 & $0,68 / 0,90$ & $0,12 \dagger$ & $0,87 / 0,84$ & $0,81 / 0,66$ & $0,71 / 0,44$ & $0,42 / 0,32$ \\
\hline FL/P bilateral com supranumerário & 2 & $0,74 / 0,58$ & $\begin{array}{ll}------ \\
\end{array}$ & $0,76 / 0,61$ & $\begin{array}{l}---/--- \\
\end{array}$ & $0,09 / 0,33$ & $\begin{array}{ll}--/--- \\
--\end{array}$ \\
\hline FL/P bilateral com múltiplas anomalias & 6 & $0,18 / 0,13$ & $0,75 / 0,57$ & $0,20 / 0,14$ & $0,41 / 0,62$ & $0,04 / 0,37$ & $---/---$ \\
\hline FL/P bilateral frustro* & 22 & $0,17 / 0,55$ & $0,88 / 0,72$ & $0,11 / 0,48$ & $0,24 / 0,54$ & $0,39 / 0,54$ & $0,03 / 0,10$ \\
\hline $\begin{array}{l}\text { FL/P bilateral frustro* com múltiplas } \\
\text { anomalias }\end{array}$ & 1 & ------- & ------- & $---/--$ & ------- & $---/--$ & $---/--$ \\
\hline
\end{tabular}




\begin{tabular}{|c|c|c|c|c|}
\hline Subfenótipos adicionais & $\mathbf{n}$ & 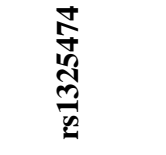 & 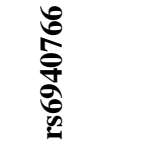 & 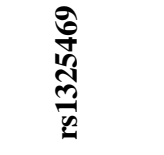 \\
\hline FP total com agenesia & 12 & $0,33 / 0,16$ & $0,31 / 0,28$ & $0,32 / 0,15$ \\
\hline $\begin{array}{l}\text { FP completa com retenção de dentes } \\
\text { permanentes }\end{array}$ & 2 & ---/--- & ---/--- & ---/--- \\
\hline FP completa com múltiplas anomalias & $\mathbf{0}$ & ---/--- & $0,60 / 0,90$ & ---/--- \\
\hline FP incompleta com giroversão/lateroversão & 4 & ---/--- & $0,20 / 0,50$ & ---/--- \\
\hline FL/P direita com agenesia & 24 & $0,89 / 0,69$ & $0,97 / 0,83$ & $0,89 / 0,73$ \\
\hline FL/P esquerda com agenesia & 36 & $0,37 / 0,83$ & $0,89 / 0,79$ & $0,24 / 0,72$ \\
\hline FL/P esquerda com supranumerário & 9 & $0,007 / 0,001$ & $0,39 / 0,66$ & $0,009 / 0,002$ \\
\hline FL/P esquerda com múltiplas anomalias & 14 & $0,43 / 0,67$ & $0,83 / 0,84$ & $0,25 / 0,40$ \\
\hline FL/P bilateral com agenesia & 34 & $0,97 / 0,95$ & $0,05 / 0,19$ & $0,43 / 0,52$ \\
\hline FL/P bilateral com supranumerário & 2 & ---/--- & ---/--- & ---/--- \\
\hline FL/P bilateral com múltiplas anomalias & 6 & $0,30 / 0,33$ & $0,28 / 0,14$ & $0,14 / 0,18$ \\
\hline FL/P bilateral frustro* & 22 & $0,53 / 0,70$ & $0,95 / 0,84$ & $0,55 / 0,53$ \\
\hline $\begin{array}{l}\text { FL/P bilateral frustro* com múltiplas } \\
\text { anomalias }\end{array}$ & 1 & $---/---$ & $---/---$ & $---/---$ \\
\hline
\end{tabular}

* FL/P unilateral com agenesia ou microdontia do incisivo lateral superior do lado oposto da fissura. ** $p \leq 0,0005$ indica diferença estatística significante (em negrito, realçado em cinza); $p \leq 0,05$ indica tendência à significância (em itálico).

$\uparrow$ para ambos genótipo e alelo.

† Brasileiros sem ascendência Africana ou Japonesa. 


\subsection{Análise de desequilíbrio de ligação entre os polimorfismos testados}

As Figuras 13 a 18 representam o padrão de desequilíbrio de ligação entre os polimorfismos estudados em casos e controles. Os eixos horizontais e verticais dos gráficos representam os polimorfismos estudados de acordo com as suas distâncias físicas, e a relação entre cada par de polimorfismos é representada por cores que podem variar de vermelho e azul escuro, de acordo com o grau de desequilíbrio de ligação (vermelho= alto desequilíbrio; azul escuro=baixo desequilíbrio). Para motivos de comparação, as análises foram realizadas utilizando a amostra total e somente os indivíduos caucasianos da amostra, pois havia uma forte suspeita de que os resultados estariam sob influência de uma possível estratificação populacional. Os resultados para o grupo controle contendo somente os indivíduos descendentes de Japoneses foram incluídos para comparação com os controles caucasianos. Os valores individuais das relações ilustradas nos gráficos abaixo se encontram no Anexo 9.

De um modo geral, para os estudos com TGFA e cromossomo 6, tanto na população total como em caucasianos somente, foi possível notar um maior número de polimorfismos em desequilíbrio de ligação nos indivíduos fissurados do que em controles.
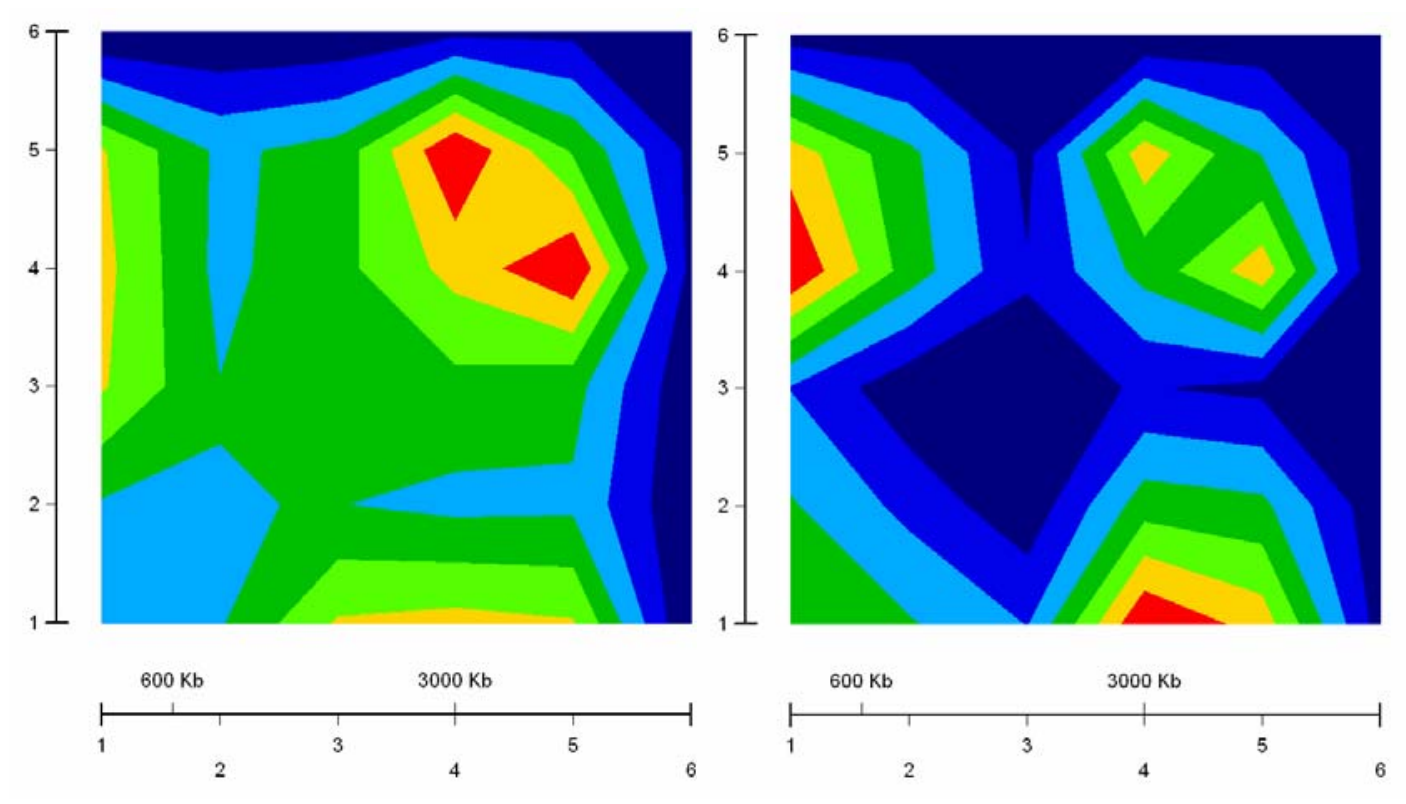

Figura 13. Representação gráfica do padrão de desequilíbrio de ligação entre os polimorfismos estudados no gene TGFA em casos (esquerda) e controles (direita) na população total. Os eixos horizontais e verticais estão representados em escala $(\mathrm{Kb})$ de acordo com a distância entre os polimorfismos. Para cada par de polimorfismos, a análise estatística segue uma escala de cores de acordo com o grau de desequilíbrio de ligação, de vermelho $(1,00)$ a azul escuro $(0,10)$. 

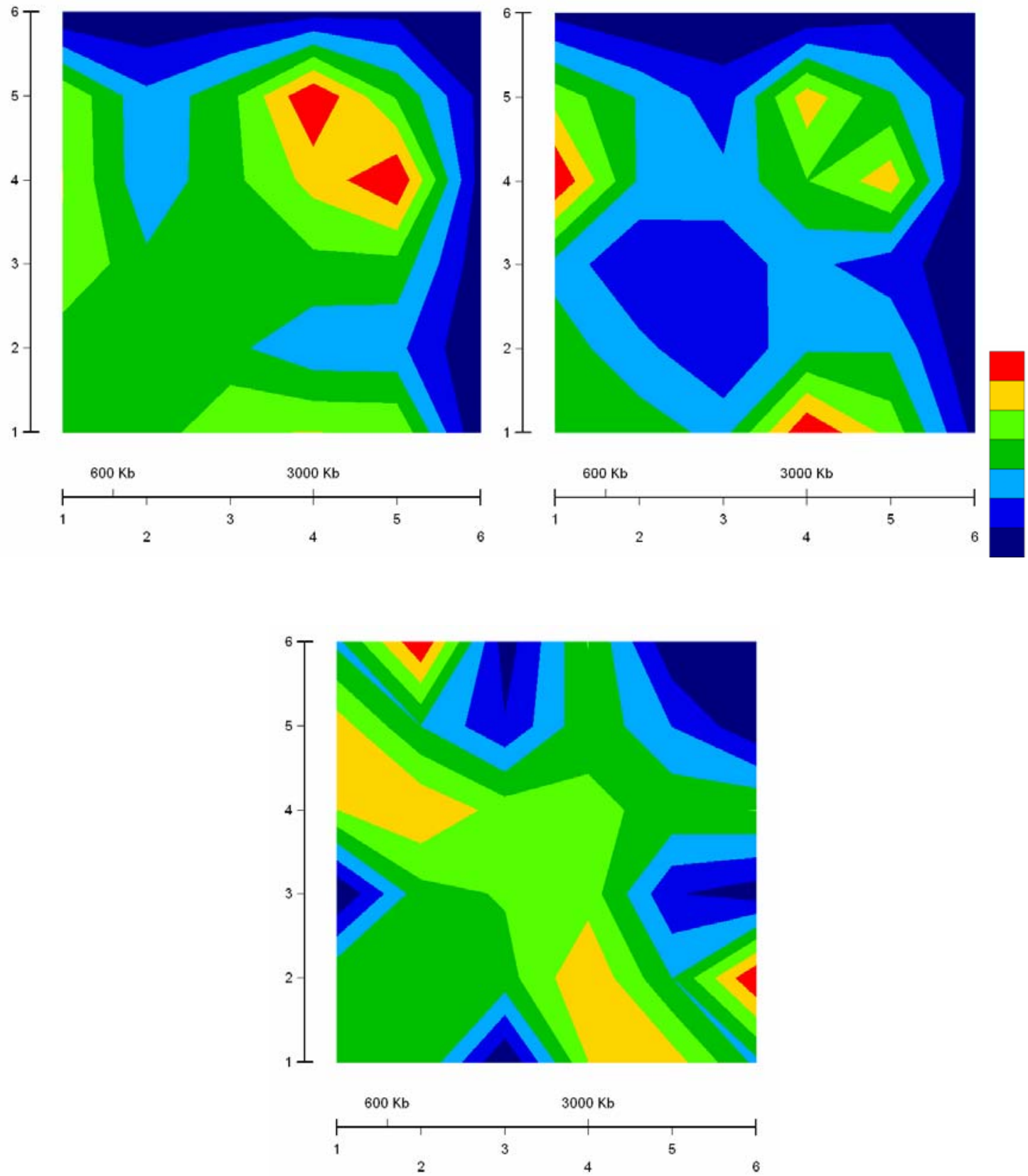

Figura 14. Representação gráfica do padrão de desequilíbrio de ligação entre os polimorfismos estudados no gene TGFA em casos (esquerda) e controles (direita) caucasianos e controles japoneses (abaixo). Os eixos horizontais e verticais estão representados em escala $(\mathrm{Kb})$ de acordo com a distância entre os polimorfismos. Para cada par de polimorfismos, a análise estatística segue uma escala de cores de acordo com o grau de desequilíbrio de ligação, de vermelho $(1,00)$ a azul escuro $(0,10)$. 
A única exceção foi o gene IRF6, o qual apresentou um maior número de polimorfismos em desequilíbrio de ligação nos controles, na população total e em caucasianos.
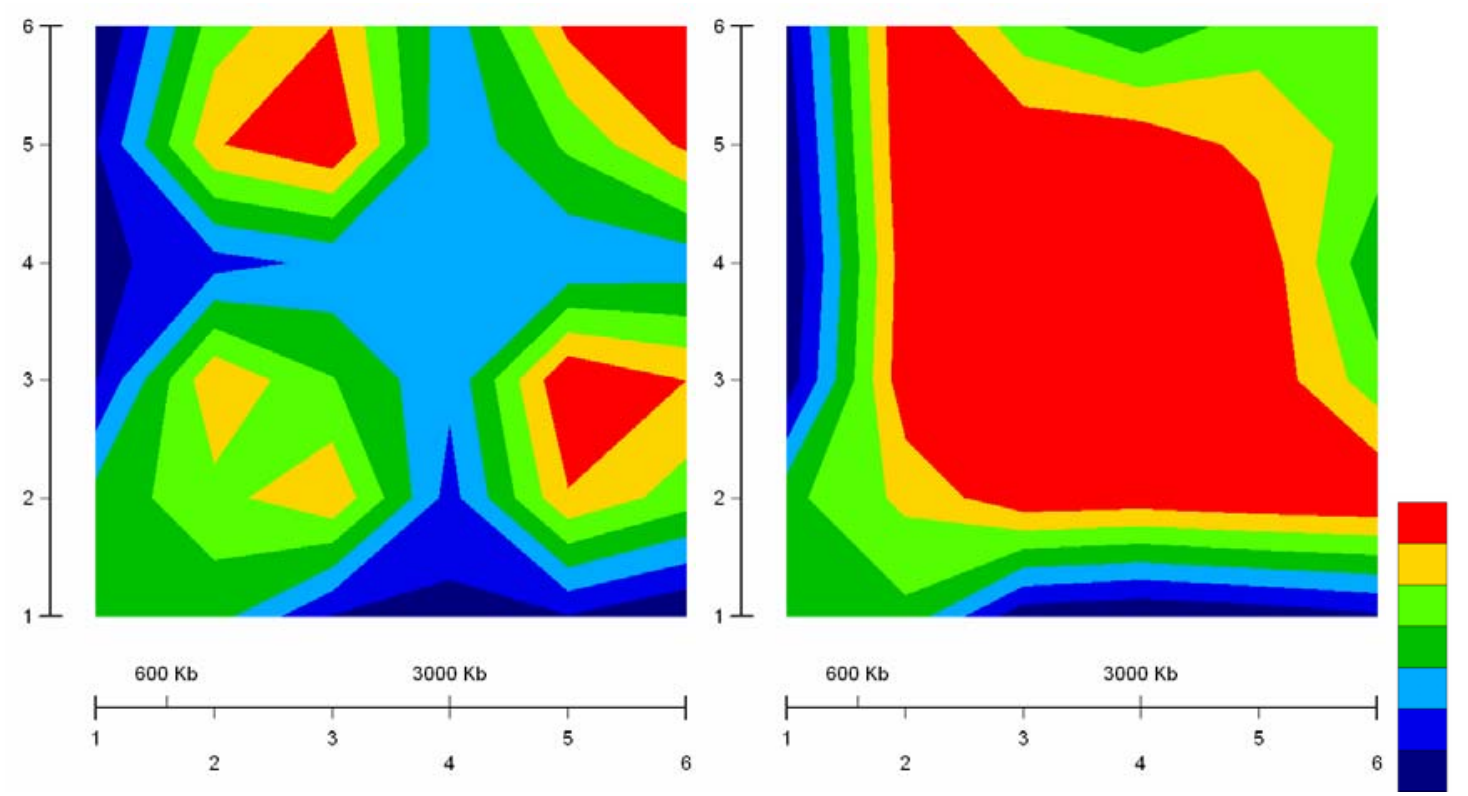

Figura 15. Representação gráfica do padrão de desequilíbrio de ligação entre os polimorfismos estudados no gene IRF6 em casos (esquerda) e controles (direita) na população total. Os eixos horizontais e verticais estão representados em escala $(\mathrm{Kb})$ de acordo com a distância entre os polimorfismos. Para cada par de polimorfismos, a análise estatística segue uma escala de cores de acordo com o grau de desequilíbrio de ligação, de vermelho $(1,00)$ a azul escuro $(0,10)$. 

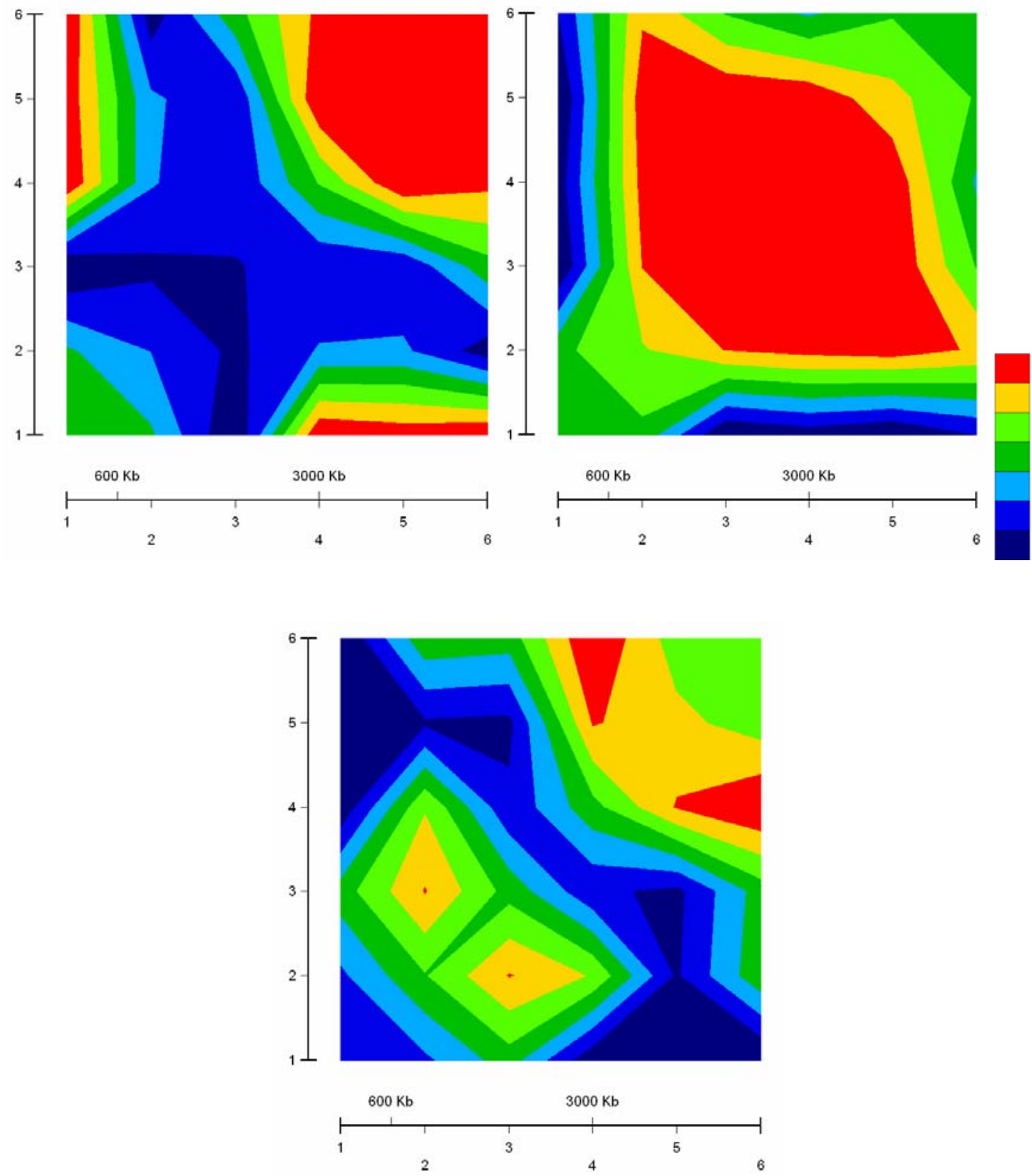

Figura 16. Representação gráfica do padrão de desequilíbrio de ligação entre os polimorfismos estudados no gene IRF6 em casos (esquerda) e controles (direita) caucasianos, e controles japoneses (abaixo). Os eixos horizontais e verticais estão representados em escala $(\mathrm{Kb})$ de acordo com a distância entre os polimorfismos. Para cada par de polimorfismos, a análise estatística segue uma escala de cores de acordo com o grau de desequilíbrio de ligação, de vermelho $(1,00)$ a azul escuro $(0,10)$. 

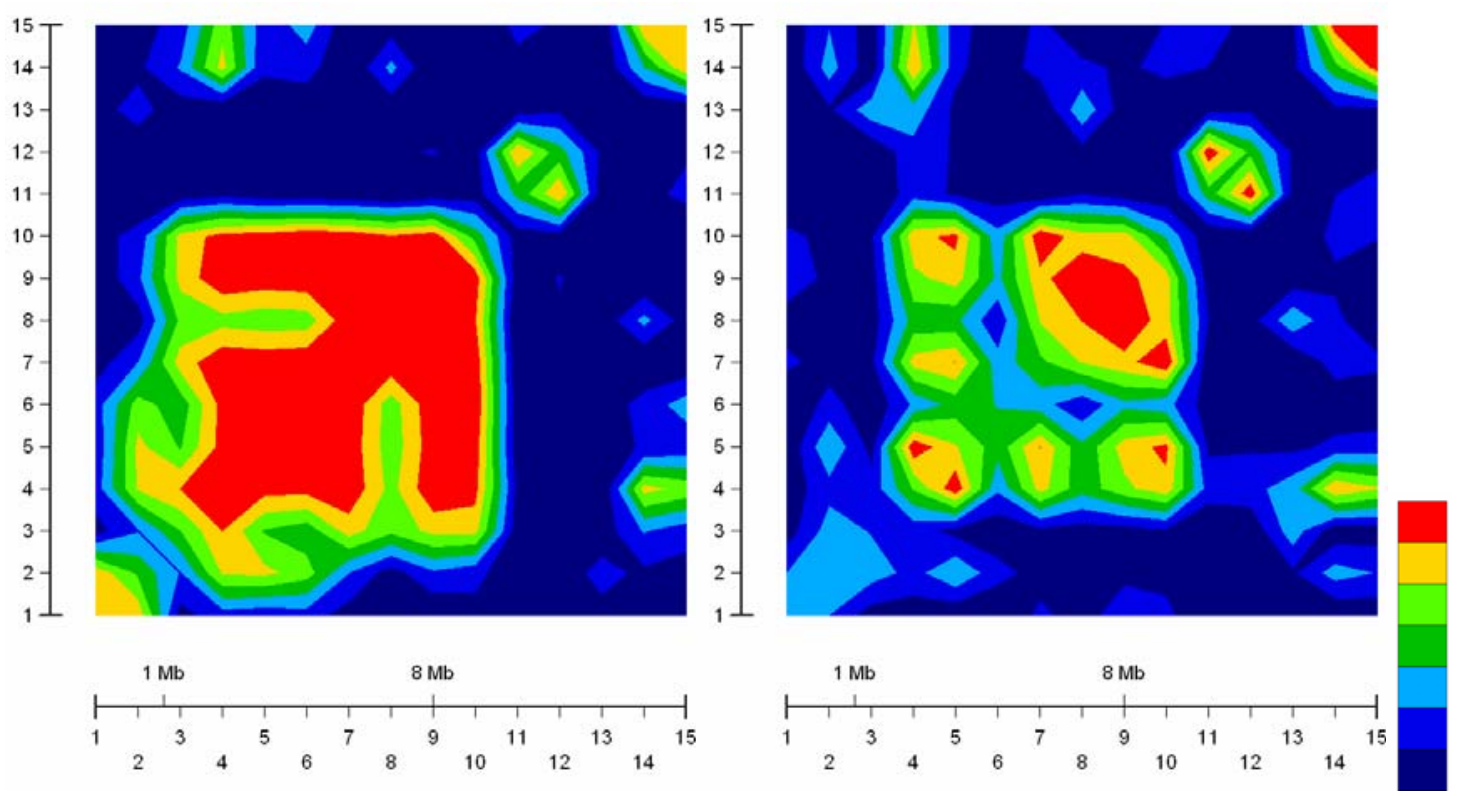

Figura 17. Representação gráfica do padrão de desequilíbrio de ligação entre os polimorfismos estudados no cromossomo $6 \mathrm{q}$ em casos (esquerda) e controles (direita) na população total. Os eixos horizontais e verticais estão representados em escala $(\mathrm{kb})$ de acordo com a distância entre os polimorfismos. Para cada par de polimorfismos, a análise estatística segue uma escala de cores de acordo com o grau de desequilíbrio de ligação, de vermelho $(1,00)$ a azul escuro $(0,10)$. 

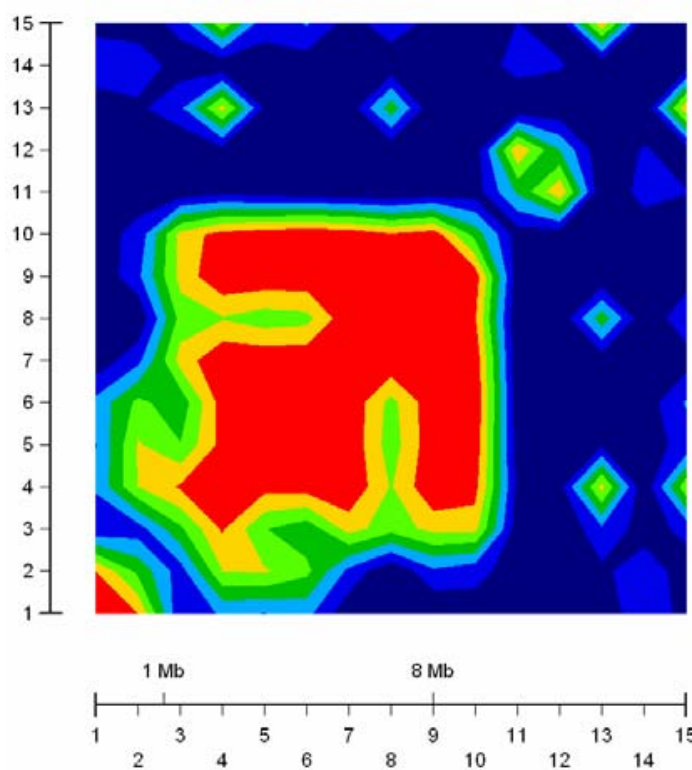
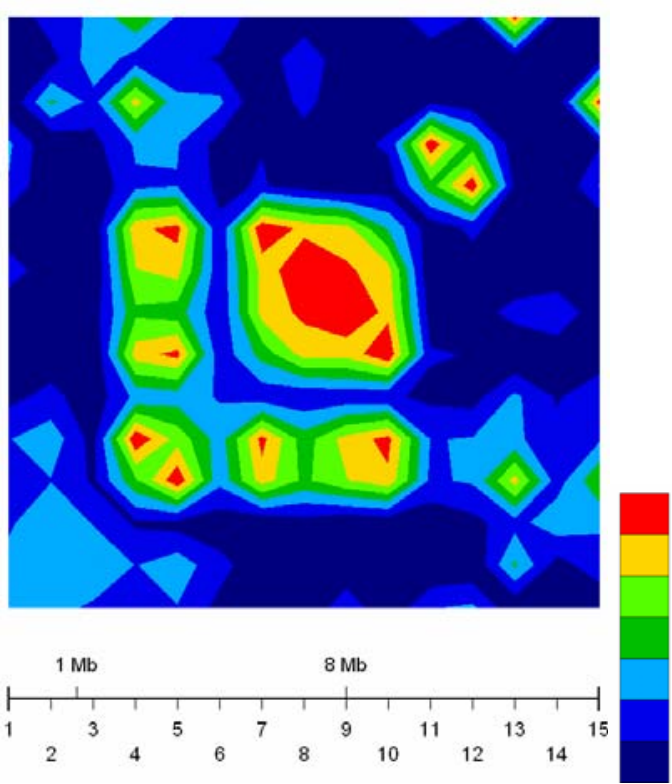

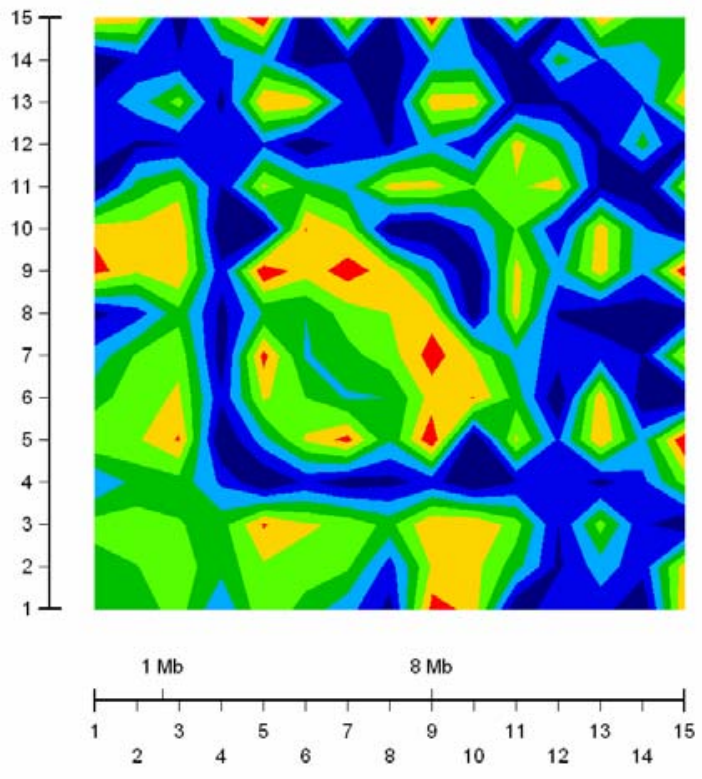

Figura 18. Representação gráfica do padrão de desequilíbrio de ligação entre os polimorfismos estudados no cromossomo 6q em casos (esquerda) e controles (direita) caucasianos, e controles japoneses (abaixo). Os eixos horizontais e verticais estão representados em escala $(\mathrm{Kb})$ de acordo com a distância entre os polimorfismos. Para cada par de polimorfismos, a análise estatística segue uma escala de cores de acordo com o grau de desequilíbrio de ligação, de vermelho $(1,00)$ a azul escuro $(0,10)$. 


\subsection{Sumário dos resultados}

A Tabela 32 apresenta um resumo dos resultados obtidos, de acordo com o polimorfismo estudado e o subfenótipo de FL/P ao qual se mostraram associados. Dos 30 polimorfismos estudados, 11 mostraram-se associados à pelo menos 1 subfenótipo de FL/P.

Tabela 32. Sumário das associações encontradas de acordo com o polimorfismo (SNP) estudado.

\begin{tabular}{|c|c|c|c|c|c|c|}
\hline \multirow[t]{2}{*}{ Subfenótipo } & \multirow[t]{2}{*}{ Gene } & \multirow[t]{2}{*}{ SNP } & \multicolumn{2}{|c|}{$\begin{array}{l}\text { Amostra } \\
\text { completa }\end{array}$} & \multicolumn{2}{|c|}{$\begin{array}{l}\text { Caucasianos } \\
\text { somente }\end{array}$} \\
\hline & & & $\mathbf{P}_{\text {genótipo }}$ & $\mathbf{P}_{\text {alelo }}$ & $\mathbf{P}_{\text {genótipo }}$ & $\mathbf{P}_{\text {alelo }}$ \\
\hline \multicolumn{7}{|l|}{ Fissura Palatina } \\
\hline Completa & --- & --- & --- & --- & --- & --- \\
\hline \multirow[t]{2}{*}{ Incompleta + submucosa } & TGFA & rs 1058213 & --- & --- & --- & 0,00001 \\
\hline & --- & rs614565 & --- & --- & --- & 0,00001 \\
\hline \multirow{2}{*}{$\begin{array}{l}\text { FP total } \\
(\text { completa }+ \text { incompleta })\end{array}$} & TGFA & rs 1058213 & --- & --- & --- & 0,00001 \\
\hline & MMP3 & $-11715 \mathrm{~A} / 6 \mathrm{~A}$ & 0,04 & 0,002 & 0,01 & 0,01 \\
\hline \multicolumn{7}{|l|}{ Fissura Lábio-Palatina } \\
\hline \multirow[t]{5}{*}{ Completa } & IRF6 & rs2235371 & 0,00001 & 0,00001 & --- & -- \\
\hline & PRSS35 & rs7753918 & 0,00001 & -- & 0,00001 & --- \\
\hline & PRSS35 & rs1171114 & 0,00001 & 0,00001 & -- & --- \\
\hline & SNAP91 & rs217325 & 0,00001 & 0,00001 & --- & --- \\
\hline & CYB5R4 & rs6940766 & 0,00001 & 0,00001 & --- & --- \\
\hline \multirow[t]{2}{*}{ Incompleta } & IRF6 & rs 2235371 & 0,00001 & 0,00001 & --- & --- \\
\hline & IRF6 & rs 4844880 & 0,00005 & 0,00001 & --- & --- \\
\hline \multirow[t]{7}{*}{$\begin{array}{l}\text { FL/P total } \\
\text { (completa }+ \text { incompleta })\end{array}$} & IRF6 & rs 2235371 & 0,00001 & 0,00001 & --- & --- \\
\hline & IRF6 & rs2013162 & 0,00001 & 0,00001 & --- & --- \\
\hline & IRF6 & rs2073487 & 0,00001 & 0,00001 & --- & --- \\
\hline & PRSS35 & rs7753918 & 0,00001 & -- & 0,00001 & --- \\
\hline & PRSS35 & rs1171114 & 0,00001 & 0,00001 & --- & --- \\
\hline & SNAP91 & rs217325 & 0,00001 & 0,00001 & --- & --- \\
\hline & CYB5R4 & rs6940766 & 0,00001 & 0,00001 & --- & --- \\
\hline \multirow{3}{*}{ Unilateral } & IRF6 & rs2235371 & 0,00001 & 0,00001 & --- & -- \\
\hline & PRSS35 & rs7753918 & 0,00001 & -- & --- & --- \\
\hline & SNAP91 & rs217325 & --- & 0,00001 & --- & --- \\
\hline \multirow[t]{2}{*}{ Completa } & IRF6 & rs2235371 & --- & 0,00001 & --- & --- \\
\hline & PRSS35 & rs7753918 & 0,00001 & -- & --- & --- \\
\hline Incompleta & IRF6 & rs 2235371 & -- & 0,00001 & --- & --- \\
\hline Direita & --- & --- & --- & --- & --- & --- \\
\hline Completa & --- & --- & --- & --- & --- & -- \\
\hline Incompleta & --- & --- & --- & --- & --- & --- \\
\hline Incompleta $+\mathrm{FP}$ & --- & --- & --- & --- & --- & -- \\
\hline
\end{tabular}




\begin{tabular}{|c|c|c|c|c|c|c|}
\hline \multirow[t]{2}{*}{ Esquerda } & IRF6 & rs2235371 & 0,00001 & 0,00001 & --- & --- \\
\hline & PRSS35 & rs7753918 & 0,00001 & --- & --- & --- \\
\hline Completa & --- & --- & --- & --- & --- & --- \\
\hline Incompleta & --- & --- & --- & --- & --- & --- \\
\hline Incompleta + FP & --- & rs1325474 & --- & --- & --- & 0,00001 \\
\hline \multirow[t]{5}{*}{ Bilateral } & IRF6 & rs2235371 & --- & 0,00001 & --- & --- \\
\hline & PRSS35 & rs7753918 & 0,00001 & --- & 0,00001 & --- \\
\hline & PRSS35 & rs1171114 & 0,00001 & 0,00001 & --- & --- \\
\hline & SNAP91 & rs217325 & --- & 0,00001 & --- & --- \\
\hline & CYB5R4 & rs6940766 & 0,00001 & 0,00001 & --- & --- \\
\hline \multirow[t]{2}{*}{ Completa } & CYB5R4 & rs6940766 & --- & 0,00001 & --- & --- \\
\hline & PRSS35 & rs7753918 & 0,00001 & --- & 0,00001 & --- \\
\hline Incompleta & --- & --- & --- & --- & --- & --- \\
\hline Incompleta + FP & --- & --- & --- & --- & --- & --- \\
\hline Incompleta mista & --- & --- & --- & --- & --- & --- \\
\hline \multirow[t]{8}{*}{$\begin{array}{l}\text { Total Fissurados } \\
\text { (FL/P +FP) }\end{array}$} & TGFA & rs930655 & 0,00001 & --- & --- & --- \\
\hline & TGFA & rs2902345 & --- & --- & 0,00001 & --- \\
\hline & IRF6 & rs2235371 & 0,00001 & 0,00001 & & \\
\hline & PRSS35 & rs7753918 & 0,00001 & --- & 0,00001 & --- \\
\hline & PRSS35 & rs1171114 & 0,00001 & 0,00001 & --- & --- \\
\hline & SNAP91 & rs217325 & 0,00001 & 0,00001 & --- & --- \\
\hline & CYB5R4 & rs6940766 & --- & 0,00001 & --- & --- \\
\hline & MMP3 & $-11715 \mathrm{~A} / 6 \mathrm{~A}$ & 0,00001 & 0,00001 & 0,0002 & 0,00001 \\
\hline FP total com agenesia & --- & --- & --- & --- & --- & --- \\
\hline $\begin{array}{l}\text { FP completa com } \\
\text { retenção de dentes } \\
\text { permanentes }\end{array}$ & IRF6 & rs2235371 & --- & --- & 0,00001 & 0,00001 \\
\hline $\begin{array}{l}\text { FP completa com } \\
\text { múltiplas anomalias }\end{array}$ & --- & --- & --- & --- & --- & --- \\
\hline $\begin{array}{l}\text { FP incompleta com } \\
\text { giroversão/lateroversão }\end{array}$ & --- & --- & --- & --- & --- & --- \\
\hline FL/P direita com agenesia & --- & --- & --- & --- & --- & --- \\
\hline $\begin{array}{l}\text { FL/P esquerda com } \\
\text { agenesia }\end{array}$ & --- & --- & --- & --- & --- & --- \\
\hline $\begin{array}{l}\mathrm{FL} / \mathrm{P} \text { esquerda com } \\
\text { supranumerário }\end{array}$ & --- & --- & --- & --- & --- & --- \\
\hline $\begin{array}{l}\text { FL/P esquerda com } \\
\text { múltiplas anomalias }\end{array}$ & --- & --- & --- & --- & --- & --- \\
\hline $\begin{array}{l}\text { FL/P bilateral com } \\
\text { agenesia }\end{array}$ & --- & --- & --- & --- & --- & --- \\
\hline $\begin{array}{l}\text { FL/P bilateral com } \\
\text { supranumerário }\end{array}$ & --- & --- & --- & --- & --- & --- \\
\hline $\begin{array}{l}\text { FL/P bilateral com } \\
\text { múltiplas anomalias }\end{array}$ & --- & --- & --- & --- & --- & --- \\
\hline FL/P bilateral frustro & --- & --- & --- & --- & --- & --- \\
\hline $\begin{array}{l}\text { FL/P bilateral frustro com } \\
\text { múltiplas anomalias }\end{array}$ & --- & --- & --- & --- & --- & --- \\
\hline
\end{tabular}


6 DISCUSSÃO 


\section{DISCUSSÃO}

\subsection{Metodologia}

\subsubsection{Tipo de Estudo}

Os estudos de associação são uma importante ferramenta para a identificação de variantes genéticas que predispõem a doenças complexas (LI et al., 2006), e podem ser realizados testando famílias de indivíduos afetados ou testando indivíduos não relacionados entre si, compondo um desenho caso-controle, tal qual o utilizado neste estudo. O objetivo é verificar se um determinado alelo do gene candidato está associado à doença e permitir a identificação de genes que possam estar contribuindo para o fenótipo. Uma importante vantagem dos estudos de associação é a possibilidade de identificação de genes refratários a estudos de ligação devido à heterogeneidade genética e/ou penetrância reduzida (FARRAL; HOLDER, 1992).

Os estudos caso-controle são os mais freqüentemente utilizados por permitirem o recrutamento de um número maior de indivíduos afetados isoladamente, sem a necessidade de incluir seus familiares (afetados ou não) na amostra (RISCH, 2000). Outra vantagem é a redução de aproximadamente um terço no custo do estudo, em comparação a um desenho utilizando tríades de famílias de indivíduos afetados. Uma desvantagem é que os resultados podem ser influenciados pela estratificação da população por serem baseados na diferenciação da freqüência dos alelos entre casos e controles e portanto, sujeitos às questões de heterogeneidade populacional (WANG et al., 2005).

A população brasileira pode ser considerada uma das mais heterogêneas do mundo, devido à ocorrência de cruzamentos étnicos entre pessoas de diferentes origens, tais como colonizadores europeus, escravos africanos e índios americanos (ALVES-SILVA et al., 2000) e torna a seleção de um grupo controle adequado extremamente difícil. Entretanto, a utilização de uma amostra robusta minimiza a probabilidade de ocorrência de erros do tipo I por aumentar o poder estatístico do estudo (IOANNIDIS, 2003).

Uma iniciativa primordial durante o planejamento de qualquer estudo cientifico é determinar o número de amostras que devem ser utilizadas para que o efeito esperado seja detectado. Em estudos genéticos, este procedimento é fundamental, 
levando em conta os altos custos envolvidos na genotipagem dos indivíduos, e ainda porque os resultados podem ser interpretados erroneamente caso o tamanho da amostra utilizada não seja suficiente para se detectar alguma associação (PURCELL et al., 2003). A amostra utilizada neste estudo pode ser considerada robusta, sendo composta por 1000 indivíduos, 500 casos portadores de FL/P isolada, e 500 indivíduos controles não relacionados, sem FL/P e sem história familiar positiva de FL/P. Cálculos de poder estatístico sugerem que este tamanho amostral apresenta $80 \%(\alpha=0.05)$ de chance de detecção de associação de um polimorfismo em um gene candidato que esteja em desequilíbrio de ligação $\left(D^{\prime}=0,8\right)$ com o fator causal em questão (PURCELL et al., 2003).

\subsubsection{Seleção dos genes candidatos e polimorfismos estudados}

Os genes candidatos a FL/P têm sido sugeridos através de resultados de estudos biológicos em modelos animais demonstrando a sua importância durante o desenvolvimento embrionário, resultados de estudos de ligação e de desequilíbrio de ligação, resultados de buscas por todo o genoma, aberrações cromossômicas e formas sindrômicas de FL/P (MURRAY, 2002). A nossa abordagem com relação à seleção dos genes estudados seguiu os modelos acima; os genes da MMP1, MMP3 e MMP9 foram escolhidos baseados em resultados de estudos biológicos em modelos animais demonstrando a sua importância durante o desenvolvimento craniofacial (IAMAROON et al., 1996) e na formação do palato (MORRIS-WIMAN et al., 1999; 2000; KERRIGAN et al., 2000; BLAVIER et al., 2001; BROWN et al., 2002). Além disso, até a presente data, não existem relatos de estudos com estes genes na ocorrência de FL/P, conferindo ineditismo ao presente estudo.

Além da tentativa de detectar novos genes/loci potencialmente envolvidos na etiologia da $\mathrm{FL} / \mathrm{P}$, a replicação de estudos anteriores é uma prática comum na genética humana, para verificar se as associações sugeridas se repetem em outras populações. Nesse contexto, os genes TGFA e IRF6, por já terem sido associados com a FL/P em outros estudos (TGFA: ARDINGER et al., 1989, CHENEVIXTRENCH et al., 1991; 1992, HOLDER et al., 1992, SASSANI et al., 1993, STOLL et al., 1993, FENG et al., 1994, FIELD et al., 1994, HWANG et al., 1995, JARA et al., 1995a, 1995b, SHAW et al., 1996, PRESCOTT et al., 2000, TANABE et al., 2000, BEATY et al., 2002; 2006, MARAZITA et al., 2002, YUAN et al., 2006, 
MORKŪNIENE் et al., 2007; IRF6: ZUCCHERO et al., 2004, SCAPOLI et al., 2005, BLANTON et al., 2005, GHASSIBÉ et al., 2005, SCHRIMTHONG et al., 2005), foram escolhidos no intuito de verificarmos a existência de associação na nossa população. Finalmente, a escolha do cromossomo 6q como região candidata foi baseada no ineditismo do assunto, em uma região identificada por métodos estatísticos sofisticados como apresentando uma probabilidade elevada de apresentar um gene associado a FL/P.

A seleção de polimorfismos a serem testados também pode ser realizada a partir de resultados de estudos anteriores, através de observações sobre os efeitos biológicos dos polimorfismos, ou através de informações sobre desequilíbrio de ligação dos marcadores. Para este estudo, os polimorfismos nos genes MMP1, MMP3 e MMP9 foram selecionados por se classificarem como funcionais, ocorrendo no promotor dos genes e potencialmente influenciarem a expressão gênica, enquanto os polimorfismos nos genes TGFA e IRF6 foram escolhidos a partir de estudos anteriores (TGFA: CALLAHAN et al., 2007, MORKŪNIENĖ et al., 2007; IRF6: ZUCCHERO et al., 2004, VIEIRA et al., 2007). Com relação ao cromossomo 6q, devido à ausência de estudos prévios, os polimorfismos testados foram selecionados utilizando-se o Projeto Internacional HapMap (THE INTERNATIONAL HAPMAP CONSORTIUM, 2003), com o objetivo de visualizar a região específica no cromossomo $6 \mathrm{q}$ e selecionar os SNPs mais informativos, a partir das observações sobre desequilíbrio de ligação entre os SNPs, nos blocos de haplótipos e na estrutura dos genes da região. CARLSON et al., 2004, desenvolveu uma abordagem para auxiliar a seleção de um menor numero de SNPs que representem ao máximo a estrutura de desequilíbrio de ligação de uma determinada região. Basicamente, esta abordagem considera os SNPs em desequilíbrio de ligação (LD) existentes para uma determinada região cromossômica e a seleção é realizada de modo que, dos diversos SNPs que possam existir em um mesmo bloco de LD, apenas alguns precisam ser testados, pois todos fornecem praticamente a mesma informação. Dessa forma, os 15 polimorfismos testados foram escolhidos a partir dos 6 blocos de desequilíbrio de ligação existentes na determinada região de $14 \mathrm{cM}$ no cromossomo 6q, ilustrada na Figura 12 do Material e Métodos. 


\subsubsection{Genotipagem}

O presente estudo utilizou quatro técnicas diferentes para genotipagem dos indivíduos: RFLP (Restriction-Fragment Length Polymorphism) utilizando enzimas de restrição específicas, PCR convencional e cinético com primers alelo-específicos, e método Taqman. Todas as técnicas têm sido amplamente utilizadas em investigações de polimorfismos genéticos e são altamente sensíveis e específicas.

A técnica RFLP (Restriction-Fragment Length Polymorphism), utilizada para os estudos com os genes MMP1 e MMP9, é uma técnica altamente específica, onde as enzimas de restrição atuam como "tesouras de DNA", clivando a seqüência de DNA específica de reconhecimento em fragmentos de comprimentos pré-determinados que podem ser visualizados em gel de eletroforese, e correspondem aos alelos específicos do polimorfismo. Esta técnica tem sido amplamente utilizada em estudos de associação de polimorfismos em genes de MMPs com diversas doenças (DE SOUZA et al., 2003; 2005, PERES; LINE, 2005, ASTOLFI et al., 2006, PRZYBYLOWSKA et al., 2006) e também nos estudos de associação de outros genes com FL/P, especialmente TGFA (ARDINGER et al., 1989, SHIANG et al., 1993, JARA et al., 1995, SHAW et al., 1996) e outros (LU et al., 2005).

As técnicas de PCR alelo-específicas, independente de serem utilizadas em PCR convencional ou cinético em tempo real, são de fácil realização e interpretação, e também têm sido utilizadas em estudos prévios de associação com a FL/P (SHI et al., 2004, ZUCCHERO et al., 2004, VIEIRA et al., 2005b). Uma desvantagem do PCR cinético é a necessidade de utilização de um seqüenciador automático (ABI PRISM ${ }^{\circledR}$ 7900HT, Applied Biosystems, Foster City, CA, EUA) de custo elevado.

O método Taqman (Applied Biosystems, Foster City, CA, EUA) proposto por RANADE et al., 2001, consiste na utilização de sondas fluorescentes alelo-específicas, que combinam as etapas de amplificação e detecção dos alelos em uma única etapa e elimina a necessidade de procedimentos adicionais para determinação dos genótipos. Para cada reação, a fluorescência é medida após a reação de PCR e os genótipos inferidos a partir destes valores. Sendo assim, o método Taqman elimina qualquer viés por erro de interpretação, pois os genótipos são gerados automaticamente, sem interferências da análise humana. Entretanto, é uma técnica cara, devido à necessidade de utilização de um seqüenciador automático (ABI PRISM ${ }^{\circledR}$ 7900HT, Applied Biosystems, Foster City, CA, EUA), e do alto custo das sondas fluorescentes. 
Todavia, devido à simplicidade da técnica, alta especificidade e confiabilidade dos resultados, o método Taqman se tornou uma importante ferramenta para os estudos de associação de diversos genes com a FL/P (BLANTON et al. 2004; 2005, ZUCCHERO et al., 2004, GHASSIBE et al., 2005, SCAPOLI et al., 2005, SRICHOMTHONG et al., 2005, VIEIRA et al., 2005a, AVILA et al., 2006, BEATY et al., 2006, NEISWANGER et al., 2006, WARRINGTON et al., 2006, MORKŪNIENE் et al., 2007, RILEY et al. 2007).

\subsubsection{Análise dos resultados}

Um dos maiores problemas nos estudos genéticos de traços complexos é saber se um resultado é estatisticamente significante (LANDER; SCHORK, 1994). Os resultados do presente estudo foram analisados estatisticamente através do teste Quiquadrado com Correção de Bonferroni considerando o número de variáveis e análises realizadas, e o valor indicando significância foi estabelecido em $p \leq 0,00005$. Por ser um método extremamente conservador e, especialmente em se tratando do elevado número de testes como no presente estudo, a Correção de Bonferroni, apesar de corrigir para erros do tipo I (falso-positivos), pode aumentar a probabilidade de erro tipo II (falso-negativos) e evitar que resultados legitimamente significantes sejam detectados. Dessa forma, podemos garantir que as associações encontradas neste estudo apresentam legítima significância e, além disso, outras associações significantes ainda podem ter permanecido não detectadas devido aos valores extremamente rígidos impostos pela Correção de Bonferroni.

\subsection{Resultados}

\subsubsection{Caracterização da amostra}

A amostra utilizada no presente estudo pode ser considerada uma amostra de conveniência, composta por 500 indivíduos portadores de FL/P isolada e 500 indivíduos não relacionados, sem FL/P e sem história familiar positiva de FL/P. Casos e controles não foram pareados e foram observadas diferenças significativas com relação à idade, gênero e etnia entre os grupos de estudo. A diferença na idade não é relevante devido à natureza congênita da FL/P. Com relação ao gênero, a proporção 
entre homens e mulheres nos grupos de estudo foi praticamente inversa, com o grupo de fissurados apresentando mais homens e o grupo de controles apresentando mais mulheres. Uma maior proporção de homens no grupo de fissurados era um resultado esperado uma vez que os homens são mais afetados pela FL/P do que as mulheres, e a proporção observada para homens e mulheres com relação aos tipos de FL/P apresentados coincidem com os dados relatados na literatura. No grupo controle, a maior proporção de mulheres provavelmente se deve ao fato de que o número de mulheres que procura atendimento odontológico nas clínicas da faculdade é notavelmente maior do que o número de homens. Idealmente, em estudos genéticos, o gênero dos indivíduos compondo a amostra também deve ser observado, no caso de que os genes estudados apresentem alguma predileção característica de acordo com o gênero (por exemplo, em estudos com genes no cromossomo $\mathrm{X}$ ou em situações epigenéticas ainda não conhecidas). Se este fosse o caso de algum dos genes estudados no presente estudo, não seria possível detectar estas diferenças.

A diferença na etnia entre os grupos é devida ao número significantemente maior de indivíduos com ascendência Japonesa no grupo controle do que no grupo de fissurados. Uma possível razão para esta diferença é que grande parte dos indivíduos do grupo controle residia em Bauru ou em cidades vizinhas. A região Sudeste do Brasil, especialmente o estado de São Paulo, é caracterizada por uma alta incidência de descendentes Japoneses, e isto parece ter se refletido na composição da amostra do grupo controle. Os indivíduos fissurados entretanto, eram residentes de diversos estados do país, que compareciam para tratamento odontológico no Hospital de Reabilitação de Anomalias Craniofaciais (HRAC) de acordo com a necessidade específica de cada indivíduo, e eram na sua quase totalidade caucasianos.

O método de seleção do grupo controle pode levar a um viés de interpretação devido a fatores como mistura populacional, heterogeneidade genética e estratificação populacional, uma vez que a freqüência aumentada de um alelo em uma determinada população ou grupo étnico tenderá a mostrar associação falso-positiva com o defeito (LANDER; SCHORK, 1994). Desse modo, para evitar qualquer interpretação errônea dos resultados, além das análises utilizando a população total, com todos os 500 indivíduos em cada grupo, foram realizadas análises utilizando somente os indivíduos caucasianos da amostra. Vale ressaltar que, devido aos cruzamentos étnicos na população brasileira, foram considerados caucasianos os indivíduos não descendentes de Japoneses ou Africanos. A estratificação da população é provavelmente 
responsável pelos resultados observados com relação aos polimorfismos genéticos e as associações vistas nas análises com a amostra completa, a qual inclui descendentes de japoneses.

\subsubsection{Definição do Fenótipo}

A ocorrência simultânea de fissuras orais e agenesia dental (RANTA, 1982；1983； 1986, RANTA;TULENSALO， 1988，WERNER; HARRIS， 1989, HARRIS; HULLINGS，1990, JIROUTOVA，1991， LAATIKAINEN; RANTA, 1994, TSAI et al., 1998, SHAPIRA et al., 1999; 2000, EERENS et al., 2001, SLAYTON et al., 2003, STAHL et al., 2006) tem levado à hipótese de que estes dois fenótipos possam estar mais do que associados (VIEIRA, 2003). Em algumas situações, poderia haver uma variação fenotípica do mesmo componente genético. Apesar dos inúmeros relatos sobre a alta incidência de anomalias dentárias em indivíduos fissurados, até a presente data, nenhum estudo considerou a inclusão das anomalias dentárias como subfenótipos clínicos da FL/P.

O presente estudo é pioneiro em subclassificar os tipos de fissura encontrados para uma numerosa população de indivíduos com $\mathrm{FL} / \mathrm{P}$, e o primeiro relato mostrando a ocorrência preferencial de algumas anomalias dentárias com alguns tipos de FL/P, possibilitando a identificação de subfenótipos adicionais para serem incluídos nas investigações genéticas. A hipótese de expansão do fenótipo pode facilitar a identificação de indivíduos saudáveis que apresentem um risco de carregar genes potencialmente candidatos a FL/P, e assim aumentar o poder dos estudos visando o descobrimento da etiologia genética da condição (WEINBERG et al., 2006). Além disso, nós acreditamos que a utilização de definições clínicas mais sofisticadas pode significar uma importante ferramenta na identificação de genes associados a FL/P.

Corroborando os resultados de estudos anteriores (SHPRINTZEN et al., 1985, RANTA, 1986, SHAPIRA et al., 1999, EERENS et al., 2001), a presença de anomalias dentárias, em especial a agenesia de dentes permanentes foi significativamente mais freqüente no grupo $\mathrm{FL} / \mathrm{P}$, sugerindo uma etiologia comum entre as duas condições (VIEIRA, 2003). A presença de microdontia, dentes supranumerários, retenção e transposição dentária também foi mais freqüente em indivíduos com FL/P neste e em outros estudos (NAGAI et al., 1965, FOSTER; LAVELLE，1971，SHPRINTZEN et al.，1985，WERNER; HARRIS，1989, 
HANSEN; MEHDINIA, 2002, JAKSIC et al., 2002). Adicionalmente, um maior número de anomalias dentárias é observado à medida que a severidade da FL/P aumenta (ADAMS; NISWANDER, 1967, VAN DEN BOOGARD et al., 2000, EERENS et al., 2001, SLAYTON et al., 2003, AIZENBUD et al., 2005). Isto também foi notado neste estudo, pois a maioria dos casos afetados por múltiplas anomalias dentárias apresentava fissura labial e palatina. Entretanto, a partir destas observações, seria esperado que indivíduos com FL/P bilateral apresentassem a maior incidência de múltiplas anomalias, e o observado foi que os indivíduos com FL/P unilateral esquerda foram os mais afetados, sugerindo que não existe uma relação direta entre número de anomalias presentes e severidade da FL/P. Não existem outros estudos para compararmos aos nossos resultados.

A agenesia dentária é considerada a anomalia de desenvolvimento mais comum em humanos apresentando uma incidência de $1,6 \%$ a 9,6\% na população em geral (VASTARDIS, 2000), e nossos resultados para o grupo controle $(7,2 \%)$ seguem essa proporção. Nos indivíduos físsurados, a agenesia dentária foi observada em 26,2\% dos indivíduos, corroborando relatos anteriores (EERENS et al., 2001), embora a incidência relatada na literatura varia amplamente, podendo chegar a 67\% (SHAPIRA et al., 2000) e 77\% (AIZENBUD et al., 2005). Estes dois últimos estudos porém, consideraram a presença de agenesia dentária na região de fissura. No presente estudo, foram considerados somente os casos de anomalias fora da região de fissura, uma vez que qualquer anomalia na área da fissura é provavelmente decorrente de alterações do desenvolvimento normal na região.

Com relação aos dentes mais afetados pela agenesia dentária, excluindose os terceiros molares, que são os dentes mais comumente ausentes com uma incidência de 20\% na população (LAVELLE et al., 1970), as opiniões variam com relação ao segundo dente mais afetado. Alguns autores (MULLER et al., 1970, MALIK, 1972) acreditam que os incisivos laterais superiores são os dentes mais afetados, enquanto outros (GRAHNEN, 1956, HUNDSTADBRATEN, 1973, VIEIRA et al., 2004) relatam que os segundos pré-molares inferiores são os dentes mais ausentes. Nossos resultados corroboram a primeira hipótese para os indivíduos controles, e a segunda hipótese para os indivíduos fissurados.

Foi interessante observar as associações entre alguns tipos de anomalia dentária e subfenótipos de FL/P. Por exemplo, notamos que a presença de múltiplas anomalias foi significativamente mais freqüente nos casos com fissuras completas, tanto 
FP e FL/P. Dos casos de FL/P, os casos de FL/P unilateral esquerda apresentaram mais múltiplas anomalias. Além disso, uma outra observação intrigante foi a presença consideravelmente mais freqüente de agenesia, microdontia e dentes supranumerários (especialmente do incisivo lateral superior) no lado oposto de fissuras unilaterais.

Em resumo, nossos resultados demonstraram que a prevalência de anomalias dentárias como sinais de distúrbios do desenvolvimento dentário em indivíduos fissurados foi significativamente maior do que em indivíduos controles, e nos indica que as anomalias dentárias podem ser consideradas um fenótipo adicional para a FL/P e merecem ser incluídas nas análises genéticas. Além disso, a presença de anomalias dentárias no lado oposto da FL/P unilateral com alterações de desenvolvimento do incisivo lateral superior nos leva a acreditar que estas FL/P unilaterais podem ser consideradas FL/P bilaterais "frustradas", e deveriam ser examinadas com cautela com relação à etiologia dos diferentes subfenótipos de FL/P.

\subsection{Estudos genéticos de associação com a FL/P}

\subsubsection{MMPs}

Estudos mostrando a importante atuação das MMPs na remodelação da matriz extracelular durante o desenvolvimento craniofacial e durante a formação e fusão do palato suportam a idéia de que estes genes possam ser considerados candidatos a FL/P (IAMAROON et al., 1996b, KERRIGAN et al., 2000, BLAVIER et al., 2001). A maioria dos estudos porém, aborda a formação do palato secundário somente (KERRIGAN et al., 2000, BLAVIER et al., 2001, BROWN et al., 2002). A presença das MMPs 2, 3, 7, 9 e 13 foi demonstrada durante fases específicas da palatogênese em camundongos (MORRIS-WIMAN et al., 1999; 2000), e alguns autores sugerem que alterações no padrão de expressão das enzimas - possivelmente devido a alterações na estrutura dos genes - possam acarretar distúrbios no desenvolvimento normal do palato secundário (IAMAROON et al., 1996b, BLAVIER et al., 2001, BROWN et al., 2002). Com relação ao palato primário, IAMAROON et al., 1996a, demonstraram a expressão de MMP2 durante o desenvolvimento embrionário do complexo craniofacial de camundongos, com a expressão de MMP2 sendo intensamente localizada nas regiões em crescimento do palato primário concomitantemente com a localização de 
fibronectina, indicando que aberrações na expressão ou função desta enzima poderiam apresentar alguma relação com as anomalias craniofaciais.

A palatogênese é um mecanismo complexo e requer dois eventos principais: elevação e fusão dos processos palatinos. Existem algumas controvérsias com relação ao mecanismo de elevação dos processos palatinos, o qual poderia ocorrer devido a uma força intrínseca produzida pela pressão da hidratação da matriz extracelular rica em glicosaminoglicanas e acido hialurônico, ou devido à proliferação, migração e/ou contração das células mesenquimais dos processos palatinos (MOXHAM, 2003). Com relação à fusão do palato, eventos de morte celular programada (MARTINEZ-ALVAREZ et al., 2000), transdiferenciação epitéliomesenquimal (FITCHETT; HAY, 1989) e migração das células do epitélio medial para outras regiões no epitélio oral ou nasal (CARETTE; FERGUSON, 1992), são necessários para que o mesênquima do palato se torne confluente e a fusão se complete. Acredita-se porém, que o desaparecimento do epitélio medial se dá principalmente através de transdiferenciação celular (KANG; SVOBODA, 2005). Tem sido demonstrado que explantes de tecidos do palato se fundem in vitro após a membrana basal ser estimulada e que as células do epitélio medial se diferenciam em células mesenquimais (FITCHETT; HAY, 1989, SHULER et al., 1992, KAARTINEN et al., 1997). Adicionalmente, a persistência de células do epitélio medial entre os processos palatinos corresponde à fissura palatina in vivo (KAARTINEN et al., 1997, TAYA et al., 1999). Confirmando a atuação das MMPs durante a palatogênese, possivelmente através do seu papel durante o desaparecimento do epitélio medial, BLAVIER et al., 2001, mostraram que a utilização de um inibidor sintético da atividade das MMPs previne a fusão do palato em camundongos. Surpreendentemente, apesar das evidências biológicas implicando genes de MMPs como apresentando algum envolvimento na etiologia da FL/P isolada, este é o primeiro estudo incluindo genes de MMPs como candidatos a FL/P. Até então, o único estudo genético mencionando um possível envolvimento dos genes de MMPs na etiologia da FL/P foi conduzido utilizando regiões candidatas sugeridas por estudos de varredura por todo o genoma, onde um locus contendo o gene MMP25 se mostrou associado a FL/P (BLANTON et al., 2004).

Nossos resultados revelaram uma forte associação entre o gene MMP3 e a FL/P. O gene MMP3 está localizado no cromossomo 11q22.3, próximo ao locus do gene PVRL1, o qual foi sugerido como um fator de risco associado a FL/P (SOZEN et al., 2001; AVILA et al., 2006). Níveis elevados e constantes de MMP3 foram 
observados nos estágios finais da palatogênese, sugerindo que a presença da MMP3 neste determinado período poderia significar o estímulo necessário para o início do processo de transdiferenciação epitélio-mesenquimal no palato (MANSELL et al., 2000). Além disso, estudos in vivo e in vitro demonstraram a expressão de MMP3 na região subjacente ao epitélio medial após o contato dos processos palatinos na linha média (BROWN et al., 2002), o que pode estar correlacionado à degradação da fibronectina presente no local. Uma outra observação importante surgiu do estudo de LOCHTER et al., 1997, demonstrando que as MMPs podem induzir diretamente o processo de transdiferenciação epitélio-mesenquimal em células epiteliais da glândula mamária durante a progressão tumoral. A indução da MMP3 resultou na remoção das porções extracelulares de caderina-e, acarretando no desaparecimento desta proteína das junções aderentes e subseqüente ausência de diferenciação fenotípica. Interessantemente, mutações no gene da caderina-e (CDH1) foram associadas a FL/P em indivíduos com câncer de estômago (FREBOURG et al., 2006).

Os genes MMP1 e MMP9 não se mostraram associados a FL/P neste estudo. A enzima MMP1 é a colagenase mais abundante no organismo humano e seus principais substratos são os colágenos fibrilares (DUNLEAVEY et al., 2000). O exato papel do colágeno nos processos palatinos ainda permanece desconhecido, todavia, PRATT; KING, 1972, demonstraram que a fissura palatina pode resultar da administração de substâncias que exercem efeitos específicos na formação da ligação cruzada do colágeno. Dessa forma, alterações na taxa de degradação do colágeno devido à expressão alterada de MMP1 poderiam estar relacionadas a FL/P. HASSEL; ORKIN, 1976, descreveram a existência de tufos colágenos de orientação definida próximos à membrana basal dos processos palatinos e relataram que a taxa de síntese de colágeno é mais elevada nos momentos que antecedem a elevação dos processos. De fato tem sido sugerido que estas fibras colágenas direcionam a força de elevação (BULLIET; ZIMMERMAN, 1985) e/ou contribuem para que os processos palatinos atinjam o volume necessário para sua reorientação (BEN-KHAIAL; SHAM, 1994). As fibras colágenas podem ser facilmente identificadas imunohistoquimicamente como volumosos tufos de colágenos localizados no centro de cada processo palatino (FERGUSON, 1988). Com relação a MMP9, pertencente à família das gelatinases e reconhecida pela sua habilidade em degradar colágenos desnaturados e em facilitar a migração celular (ZHANG et al., 1999), não foi observada associação com a FL/P no presente estudo. Todavia, a expressão de MMP9 nos sítios de ossificação durante a 
fusão do palato em camundongos (BLAVIER et al., 2001) sugere algum envolvimento nas etapas finais da palatogênese.

\subsubsection{TGFA}

Foi sugerido que o cromossomo 2 pode apresentar um ou mais genes contribuindo para a ocorrência da FL/P (MARAZITA et al., 2004). O gene TGFA está localizado no cromossomo 2p13 (BRISSENDEN et al., 1985, TRICOLI et al., 1986), e sua expressão foi detectada em diversos tecidos normais durante o período de desenvolvimento embrionário até a fase adulta em camundongos (RAPOLEE et al., 1988). O TGFA é produzido por uma variedade de células, primariamente de origem ectodérmica, e pode interagir com o receptor do fator de crescimento epidermal (EGF) e induzir respostas durante o contato celular (WILCOX; DERYNCK, 1988). Durante o desenvolvimento craniofacial, o gene TGFA é expresso no epitélio medial no momento da fusão dos processos palatinos (DIXON et al., 1991, IAMAROON et al., 1996a, MIETTINEN et al., 1999).

O TGFA foi o primeiro gene associado a FL/P isolada em um estudo caso-controle (ARDINGER et al., 1989) e em estudos subseqüentes (CHENEVIXTRENCH et al., 1991; 1992, HOLDER et al., 1992, SASSANI et al., 1993, STOLL et al., 1993, FENG et al., 1994, FIELD et al., 1994, HWANG et al. 1995, JARA et al., 1995a; 1995b, SHAW et al., 1996, PRESCOTT et al., 2000, TANABE et al., 2000, BEATY et al., 2002; 2006, MARAZITA et al., 2002, YUAN et al., 2006, MORKŪNIENÉ et al., 2007). Estes resultados foram replicados também em estudos com famílias de indivíduos afetados (MAESTRI et al., 1997, BEATY et al., 2001, JUGESSUR et al., 2003, SUAZO et al., 2005) e em duas meta-análises (MITCHELL, 1997, IOANNIDIS et al., 2001). Todavia alguns estudos não detectaram qualquer correlação entre variações no gene TGFA e FL/P (HECHT et al., 1991, VINTINER et al., 1992, BEATY et al., 1997; 2001, LIDRAL et al., 1997, WYSZYNSKI et al., 1997a, SCAPOLI et al., 1998, CHRISTENSEN et al., 1999, ROMITTI et al., 1999, MARAZITA et al., 2002, PASSOS-BUENO et al., 2004). Os primeiros estudos sugeriram um efeito genético maior do que os estudos seguintes, e fatores como viés de interpretação e diversidade populacional podem explicar esta tendência dos primeiros estudos em superestimar a predisposição atribuída aos polimorfismos no TGFA. 
Os resultados do presente estudo revelaram a associação do TGFA com ambas FP e FLP. Dos seis polimorfismos testados, foi possível observar a associação do marcador rs1058213 (C3827T) com FP incompleta e FP total (completa + incompleta) e do marcador rs2902345 com FL/P no subgrupo de indivíduos caucasianos, e do marcador rs930655 com FL/P na amostra completa. Ao desconsiderarmos os valores extremamente rígidos impostos pela correção de Bonferroni, cinco dos seis polimorfismos estudados mostraram tendências à associação com diversos subfenótipos de FL/P na análise da população total, e quatro na análise dos caucasianos, apresentando variações de acordo com o subfenótipo. É provável que estas variações se devam ao efeito da estratificação da população e reforçam a importância de se identificar qualquer mistura populacional nos estudos genéticos em geral. Entretanto, a análise de desequilíbrio entre os marcadores no TGFA revelou que o padrão de desequilíbrio se manteve o mesmo para a amostra completa e para os indivíduos caucasianos, e além disso, que os polimorfismos associados não estavam em desequilíbrio de ligação, indicando que não houve sobreposição do efeito dos polimorfismos associados.

Apesar de não termos observado nenhuma associação para o marcador rs2166975 (C3296T), este se mostrou associado à FP em uma população da Lituânia (MORKŪNIENÉ et al., 2007). SHIANG et al., 1993, e FIELD et al., 1994, também encontraram evidências de associação entre TGFA e FP em caucasianos e em uma população da Índia respectivamente. Ambos os polimorfismos C3827T e C3296T foram originalmente descritos por MACHIDA et al., 1999, e correspondem a substituição de uma citosina (C) por uma timina (T) nos nucleotídeos 3827 e 3296 do gene TGFA, respectivamente. Na posição 3296, o polimorfismo está localizado a 1 par de bases do códon terminal e acarreta uma mutação silenciosa (valina-valina). O polimorfismo C3827T está localizado na posição 3' UTR (UTR - untranslated region) do gene e não foi encontrado em nenhum indivíduo do grupo controle (MACHIDA et al., 1999). Apesar do efeito biológico destas variações ainda não estar elucidado, estas UTRs, regiões altamente conservadas, podem exercer um papel importante na estabilidade da mensagem sinalizada pelo gene TGFA (SIOMI; DREYFUSS, 1997). A literatura atual apresenta inúmeras discrepâncias entre as freqüências dos alelos obtidos para os polimorfismos C3296T e C3827T. Algumas populações (Melanésia e Papua) apresentam o alelo T como o mais comum para ambos os loci. Entretanto, o alelo C é o mais comum em ambos os loci nas demais populações que já foram estudadas, 
incluindo a população utilizada neste estudo. Diversas populações ainda apresentam os alelos para ambos os loci em desequilíbrio de ligação (VIEIRA, 2006).

Com relação aos novos subfenótipos de FL/P baseados na presença de anomalias dentárias, as associações observadas para polimorfismos no TGFA não atingiram níveis significantes. Contudo, alguns resultados interessantes foram observados, com tendências a associação com subfenótipos de FL/P com agenesia dentária (incluindo FL/P bilateral "frustrada"), supranumerário e múltiplas anomalias, assim como FP com agenesia e com retenção de dentes permanentes.

A comparação de resultados entre estudos genéticos com TGFA tem se tornado difícil devido a variações no desenho de estudo e nos polimorfismos estudados, e na porcentagem de indivíduos com história familiar positiva; isto sugere ainda que muitas das variações observadas para as freqüências dos alelos podem ser atribuídas ao acaso, devido ao número de amostras utilizadas nos estudos ser geralmente pequeno. Entretanto, apesar dos efeitos das variações genéticas estudadas, principalmente dos marcadores C3296T e C3827T, serem até então desconhecidas, as associações positivas de estudos anteriores e as observadas no presente estudo continuam a defender um papel para o TGFA na etiologia da FL/P.

\subsubsection{IRF6}

O gene IRF6 (1q32) foi identificado como fator etiológico da FL/P (ZUCCHERO et al., 2004) após ter sido atribuído como responsável pela síndrome de Van der Woude (KONDO et al., 2002), condição autossômica dominante e uma das formas sindrômicas mais comuns de FL/P, caracterizada pela presença de FL/P, depressões no lábio inferior e hipodontia (LACOMBE et al., 1995). Variações no gene IRF6 foram consideradas responsáveis por $12 \%$ da contribuição genética para o risco de ocorrência da FL/P, e triplicam o risco de recorrência em famílias que já apresentam uma criança afetada (ZUCCHERO et al., 2004).

Dos 36 polimorfismos testados por ZUCCHERO et al., 2004, o polimorfismo V274I (rs2235371) revelou-se um dos mais significativos (senão o mais significativo) por ter demonstrado transmissão preferencial do alelo $\mathrm{V}$ em indivíduos de populações Asiáticas e Sul-Americanas, mas não em populações Européias. Este polimorfismo corresponde à substituição de uma isoleucina por um resíduo de valina no códon 274 em um domínio de ligação protéica denominado SMIR (smad-interferon 
regulatory factor binding domain) (EROSHKIN; MUSHEGIAN, 1999), e é comum na população em geral (3\% em populações Européias e 22\% em populações Asiáticas) (KONDO et al., 2002). O alelo I, o qual é considerado o "alelo protetor", mostrou-se raro ou ate mesmo ausente em indivíduos de origem Africana e Européia (ZUCCHERO et al., 2004). Foi relatado que o alelo I é especifico em humanos, o que sugere que ele foi selecionado para a evolução humana (CHAKRAVARTI, 2004). Recentemente, SCHRIMTHONG et al., 2005, confirmaram a transmissão preferencial do alelo V em seu estudo em uma população Tailandesa. Além do V274I, a análise de outros polimorfismos mostrou um padrão de desequilíbrio de ligação entre o gene IRF6 e FL/P numa faixa se estendendo desde 40kbp na porção 5' do IRF6 até $135 \mathrm{kbp}$ na porção 3', e esta observação também incluiu as populações Americanas e Dinamarquesas estudadas (ZUCCHERO et al., 2004).

O IRF6 também foi associado à FL/P em outros estudos. SCAPOLI et al., 2005, e BLANTON et al., 2005, testaram quatro dos 36 polimorfismos estudados por ZUCCHERO et al., 2004, com exceção do V274I, e relataram resultados similares, incluindo a transmissão alterada dos alelos comuns nos indivíduos afetados, contribuindo para o fenótipo de FL/P observado nas populações da Itália e dos EUA, respectivamente. O motivo para não ter investigado o V274I foi que devido à ausência do alelo I nas suas populações, seria pouco provável que este polimorfismo pudesse estar diretamente implicado na etiologia da FL/P. GHASSIBÉ et al., 2005, também testaram dois polimorfismos associados previamente com FL/P nos estudos de BLANTON et al., 2005, e SCAPOLI et al., 2005, e confirmaram tais resultados.

Nós investigamos a associação de seis polimorfismos previamente estudados no gene IRF6 (ZUCCHERO et al., 2004) incluindo alguns testados por outros autores (BLANTON et al., 2005, GHASSIBÉ et al., 2005, SCAPOLI et al., 2005). Nossos resultados revelaram associações interessantes com relação ao polimorfismo V274I na população total, o qual se mostrou significantemente associado a diversos subfenótipos de FL/P: FL/P total (FL/P + FP), FL/P completa e incompleta, FL/P unilateral completa e incompleta, FL/P unilateral esquerda e FL/P bilateral. Outros três polimorfismos (rs2013162, rs2073487 e rs4844880) também mostraram associação com a FL/P, e FL/P incompleta no caso do rs4844880, quando analisando a amostra total. Um destes polimorfismos (rs2013162), localizado na posição 5'UTR do gene, foi o único que também se mostrou associado a FL/P em populações de origem caucasiana (BLANTON et al., 2005, GHASSIBÉ et al., 2005, SCAPOLI et al., 2005). 
Interessantemente, quando analisamos somente os indivíduos caucasianos da nossa amostra, os quais na sua maioria são descendentes de Europeus, atribuídos ao cruzamento étnico após a posse do Brasil por colonizadores Portugueses, a associação previamente encontrada para este polimorfismo na população total não atingiu níveis considerados significantes. Entretanto, se levarmos em conta os valores considerados significantes sem a correção de Bonferroni, cada um dos seis polimorfismos estudados no IRF6 mostraram associações com no mínimo dois subfenótipos de FL/P, com algumas das associações sendo as mesmas para a população total e caucasiana, e algumas associações sendo somente reveladas nos indivíduos caucasianos.

A freqüência dos polimorfismos no IRF6 parece ser mais susceptível a mistura populacional. Assim como ZUCCHERO et al., 2004, nós também observamos uma transmissão alterada dos alelos do V274I. Devido ao nosso grupo controle conter mais indivíduos de origem asiática do que o grupo teste, foi possível verificar a diferença na freqüência dos alelos entre os dois grupos, com o alelo I sendo significativamente mais freqüente no grupo controle composto por todos os 500 indivíduos. A análise dos indivíduos caucasianos da amostra não revelou associação alguma para este polimorfismo, o que sugere fortemente o efeito da estratificação populacional nesse resultado. Além disso, a diferença no padrão de desequilíbrio de ligação entre os marcadores observada quando comparando o grupo de fissurados na amostra total e no subgrupo de indivíduos caucasianos demonstra a influência da estratificação populacional nos resultados do IRF6.

A utilização de anomalias dentárias como subfenótipos adicionais de FL/P revelou uma forte associação entre o polimorfismo V274I e FP com retenção de dentes permanentes em indivíduos caucasianos. VIEIRA et al., 2007, verificaram a associação deste polimorfismo em indivíduos com agenesia dentária em uma população brasileira, e a estimativa calculada para a contribuição deste polimorfismo para a agenesia dentária nesta população foi de $16.4 \%$.

Considerando os resultados do presente estudo, o fato de que todos os estudos até a presente data têm reportado a presença de associação entre o IRF6 e a FL/P isolada nos indica que este é um gene importante com relação à etiologia de tal condição. 


\subsubsection{Cromossomo 6q}

O cromossomo 6 tem sido alvo de inúmeras investigações com relação à etiologia da FL/P. Estudos anteriores relataram a associação de FL/P e aberrações cromossômicas envolvendo o cromossomo 6p (KORMANN-BORTOLOTTO et al., 1990, DONNAI et al., 1992) e o primeiro resultado positivo de estudos de ligação envolvendo a FL/P foi no locus 6p24-p25 (F13A) (EIBERG et al., 1987). Entretanto, outros estudos independentes não observaram evidências de associação entre estes loci e FL/P (HECHT et al., 1993, VINTINER et al., 1993, BLANTON et al., 1996).

Uma meta-análise dos resultados de treze estudos de varredura pelo genoma humano indicou quinze regiões cromossômicas que podem conter genes potencialmente envolvidos na etiologia da FL/P (MARAZITA et al., 2004). Uma região específica no cromossomo $6 \mathrm{q}$ apresentou valores significantes, despertando a hipótese de que esta região, até então inexplorada nos estudos genéticos da FL/P, poderia de fato apresentar algum gene envolvido. Análises estatísticas aplicadas sobre os valores obtidos em estudos de ligação da FL/P com esta região cromossômica revelaram que a probabilidade de haver um gene associado à $\mathrm{FL} / \mathrm{P}$ pode chegar a $90 \%$ (GOVIL et al., 2006). Adicionalmente, outras investigações mostraram a associação do gene DDO (D-aspartate oxidase), localizado também no cromossomo 6q, com a FL/P (MARAZITA et al., 2006).

Nossos resultados utilizando a população total demonstraram que, dos quatro genes encontrados na região investigada, três (PRSS35, SNAP91 e CYB5R4) mostraram associação com diversos subfenótipos de FL/P. Além disso, um outro polimorfismo (rs1325474) também mostrou associação com a FL/P. Nenhum gene mostrou associação com fissura palatina somente. Foi possível observar também um determinado padrão com relação aos subfenótipos de FL/P associados, além de FL/P total, FL/P completa, FL/P unilateral, FL/P esquerda, e FL/P bilateral mostraram associação com os genes PRSS35, SNAP91 e CYB5R4. A análise com os indivíduos caucasianos da amostra demonstrou que as associações encontradas para o gene PRSS35 e para o polimorfismo rs1325474 com a FL/P se mantiveram significantes e, adicionalmente um outro polimorfismo (rs614565) mostrou-se associado à FP. Considerando os resultados apresentando tendência à significância $(p \leq 0,05)$, todos os 15 polimorfismos no cromossomo $6 \mathrm{q}$ mostraram-se associados a subfenótipos de FL/P na análise com a amostra completa, e um polimorfismo (rs624076) deixou de mostrar 
associação na análise dos indivíduos caucasianos. Todavia, estas diferenças entre os resultados das análises com a amostra completa versus a amostra de caucasianos são possivelmente devidas à estratificação da população. Apesar destas diferenças nas análises, o padrão de desequilíbrio de ligação dos marcadores na amostra completa e nos indivíduos caucasianos se manteve praticamente idêntico e não parece ter sido afetado pela estratificação populacional.

Nenhum dos marcadores no gene PRSS35 ou os marcadores rs1325474 e rs614565, que se mostraram associados a FL/P, mostraram desequilíbrio de ligação entre si, o que sugere que cada um deles ou algum outro marcador que esteja em desequilíbrio de ligação com cada um deles possa estar contribuindo independentemente para a associação com a FL/P.

O gene PRSS35 (serino-protease 35, 6q14.2) codifica uma protease pertencente à família das serino-proteases, cuja seqüência de amino ácidos é altamente conservada entre espécies relacionadas, como por exemplo, roedores e primatas. As serino-proteases (assim como as metaloproteinases da matriz) exercem funções de remodelação da matriz extracelular, modulam as atividades de fatores de crescimento e citocinas através da regulação da sua biodisponibilidade, e controlam os níveis de expressão de algumas proteínas. Dessa forma, as proteases são fundamentais para os processos de proliferação, diferenciação, migração e adesão celular, necessários para o desenvolvimento normal e homeostasia de diversos tecidos. Não existem informações sobre a expressão do PRSS35 durante o desenvolvimento craniofacial, mas a associação encontrada entre este gene e a FL/P pode sugerir que variações neste gene possam acarretar alterações que levem a ocorrência de FL/P.

As informações obtidas sobre os outros genes associados à FL/P neste estudo, porém, parecem pouco relevantes para tentar explicar o seu envolvimento com a etiologia da FL/P. A expressão do gene SNAP91 (synaptosomal-associated protein, 6q14.2) foi detectada no cérebro, testículos, coração e ovários (ISHIKAWA et al., 1998) e a função da proteína codificada é facilitar a formação de vesículas sinápticas nos tecidos cerebrais. A redução desta proteína foi associada a doenças caracterizadas por disfunções no sistema nervoso central como a doença de Alzheimer (YAO et al. 2003). Apesar da inexistência de relatos sobre a sua expressão durante o desenvolvimento da face, alguns relatos correlacionaram a FL/P com outras malformações, incluindo malformações do sistema nervoso central (GOLDSBERRY et al., 2006) atribuídas a deformidades de redução do componente cerebral 
(CALZOLARI et al., 2007). Com relação ao gene CYB5R4 (cytochrome b5 reductase 4, 6q14.2-14.3), este codifica para a enzima NADPH-reductase (ZHU et al., 1999), responsável pela redução dos níveis de stress oxidativo celular (XIE et al., 2003), o que poderia estar associado aos eventos pré-apoptose ou que antecedem o desaparecimento das células do epitélio medial previamente a fusão do palato.

\subsection{Estudos genéticos utilizando anomalias dentárias como subfenótipos adicionais para FL/P}

Os eventos mais críticos durante a formação dos dentes, lábios e palato ocorrem quase que concomitantemente. Proliferação e diferenciação celular, bem como apoptose, definem estas estruturas, enquanto que distúrbios nestes processos, por anormalidades ambientais e/ou genéticas, podem predispor a anomalias dentárias e FL/P. A ocorrência simultânea de FL/P e agenesia dentária sugere que estes dois fenótipos possam estar geneticamente associados. O objetivo de utilizar observações sobre o desenvolvimento dentário para subclassificar subfenótipos de FL/P visava identificar grupos que pudessem apresentar contribuições genéticas específicas e auxiliar na identificação de genes envolvidos na etiologia de ambas as condições.

A mutação mais intrigante relacionando a presença de fissuras e agenesia dentária foi previamente descrita por VAN DEN BOOGARD et al., 2000, no gene MSX1. A família afetada apresentava uma combinação de agenesia dentária, fissura labial e palatina e fissura palatina somente. Este relato apresenta a evidência mais convincente de que alguns mecanismos são os mesmos para o desenvolvimento dos dentes, lábios e palato.

A associação mais significante desta análise foi a de um polimorfismo no gene IRF6 (rs2235371, VAL274I) e FP completa com retenção de dentes permanentes em indivíduos caucasianos. Entretanto, diversos polimorfismos apresentaram tendências à associação (consideradas sem a correção de Bonferroni) com os novos subfenótipos, em ambas as análises da população total e de caucasianos somente. Por exemplo, os subfenótipos incluindo agenesia dentária mostraram associação com os 6 polimorfismos no gene TGFA, 4 polimorfismos no gene IRF6 e 4 no cromossomo 6q; a presença de FL/P bilateral "frustrada" (FL/P unilateral com agenesia ou microdontia do incisivo lateral no lado oposto da fissura) mostrou associação com 3 polimorfismos no gene TGFA e 2 no cromossomo 6q, embora nenhuma associação foi encontrada para este 
subfenótipo e o gene IRF6. O gene IRF6 foi recentemente associado à agenesia dentária (VIEIRA et al., 2007) onde ficou demonstrado que o alelo comum do polimorfismo V274I foi sempre transmitido aos indivíduos apresentando agenesia dentária, e a contribuição estimada deste polimorfismo à condição foi de 16,4\%. Os autores relataram ainda ter observado uma associação preferencial do alelo comum do V274I em famílias caracterizadas pela agenesia de pré-molares.

Para os subfenótipos apresentando dentes supranumerários, também foram observadas tendências à associação com 4 polimorfismos no gene TGFA, 3 no gene IRF6 e 3 no cromossomo 6q. Para os subfenótipos com múltiplas anomalias dentárias, tendências à associação foram observadas para 3 polimorfismos em TGFA e IRF6, e 4 no cromossomo 6q. A presença de FP completa com retenção de dentes permanentes também mostrou tendência à associação com os genes TGFA e outro polimorfismo no IRF6, e finalmente, a presença de FP incompleta com giroversão/lateroversão mostrou alguma associação com polimorfismos no gene IRF6 e no cromossomo $6 \mathrm{q}$.

Apesar da ausência de estudos similares para comparação, nossos resultados não são suficientes para sugerir que os mesmos genes associados a FL/P possam ser responsáveis pela ocorrência de anomalias dentárias. Entretanto, a associação de alguns destes polimorfismos com subfenótipos específicos de FL/P sugere que as anomalias dentárias podem representar uma extensão fenotípica da FL/P e merecem ser incluídas na descrição do fenótipo dos indivíduos com FL/P compondo a amostra de estudos genéticos.

\subsection{Análise de desequilíbrio de ligação entre os polimorfismos testados}

O padrão de desequilíbrio de ligação entre os polimorfismos estudados foi similar para os polimorfismos no gene TGFA e cromossomo 6q. Entretanto, para o gene IRF6, o inverso foi observado, com o grupo controle apresentando uma maior incidência de desequilíbrio de ligação entre os polimorfismos estudados. Isto confirma o fato de que populações distintas apresentam freqüências diferentes dos alelos de um determinado polimorfismo e justifica a nossa iniciativa em interpretar os dados moleculares deste estudo considerando a amostra completa e o subgrupo de indivíduos caucasianos. Com relação ao gene IRF6 especificamente, estudos prévios relataram uma diferença significativa entre as freqüências observadas para determinados alelos, como, 
por exemplo, no polimorfismo V274I, em indivíduos caucasianos e asiáticos (ZUCCHERO et al., 2004), e isto também pode ser observado nos nossos resultados, subseqüentemente demonstrando a importância de se considerar a composição genética em estudos com populações diferentes.

Com relação à população brasileira, estudos relacionados às suas origens genéticas sugerem um padrão de acasalamento preferencial envolvendo homens imigrantes e mulheres nativas (ALVES-SILVA et al., 2000). Adicionalmente, VIEIRA et al., 2002, relataram diferenças significativas nas freqüências dos haplótipos ancestrais em indivíduos com FL/P e controles, onde os casos apresentaram uma maior freqüência de um alelo específico para populações nativas Americanas e uma menor freqüência de alelos específicos para populações Africanas. Estes resultados estão de acordo com os dados epidemiológicos existentes, indicando que indivíduos de origens indígenas e Asiáticas apresentam uma maior incidência de FL/P, indivíduos de origem caucasiana apresentam incidência intermediária e indivíduos de origem africana apresentam baixa incidência (VANDERAS, 1987). Mediante estas informações, é possível interpretarmos os nossos resultados e compará-los aos resultados de outros estudos, da mesma forma que acreditamos que o nosso estudo possa servir como base de comparação para outros estudos genéticos envolvendo indivíduos brasileiros ou de outras populações. 
7 CONCLUSÕES 


\section{CONCLUSÕES}

Baseado nos objetivos propostos e nos resultados obtidos no presente estudo, foi possível concluir que:

1. As fissuras labiais com ou sem fissuras palatinas apresentam uma ampla variedade de subfenótipos de acordo com lado e extensão da fissura e de acordo com as anomalias dentárias apresentadas.

2. Os genes MMP3, TGFA e IRF6 mostraram-se associados a FL/P e seus subfenótipos na população estudada.

3. Polimorfismos em genes localizados no cromossomo 6q (PRSS35, SNAP91 e CYB5R4) mostraram-se associados a FL/P e seus subfenótipos na população estudada. 


\section{PERSPECTIVAS FUTURAS}




\section{PERSPECTIVAS FUTURAS}

Os resultados do presente estudo reforçam a natureza complexa da FL/P e o papel de genes importantes como TGFA e IRF6 na sua etiologia, e ainda, demonstram pela primeira vez a associação de genes até então nunca testados com relação a FL/P.

As perspectivas futuras do nosso estudo incluem:

1. Verificar se a associação encontrada para o gene MMP3 permanece significante utilizando uma amostra maior e incluir outros genes de MMPs nas análises genéticas.

2. Testar outros polimorfismos em genes do cromossomo 6q.

3. Testar genes associados em outras populações que não tenham sido estudados na população brasileira.

4. Realizar ensaios funcionais para verificar se as variantes genéticas associadas realmente exercem alguma função biológica que possam acarretar FL/P. 
ANEXOS 


\section{ANEXO 1 - Parecer do Comitê de Ética}

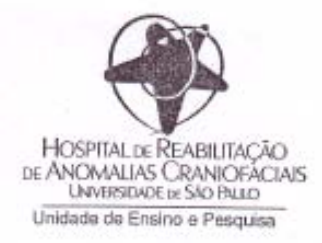

Ofício $n^{\circ} 265 / 2004-U E P-C E P$

Bauru, 14 de outubro de 2004.

Prezado(a) Senhor(a)

O projeto de pesquisa encaminhado a este Comitê de Ética em Pesquisa em Seres Humanos, denominado "Investigaçāo de polimorfismos em genes de metaloproteinases 2 e 9 (MMP-2 e MMP-9) na ocorrência de fissura labial e/ou palatina em indivíduos não sindrômicos", de autoria de ARIADNE MACHADO GONÇALVES LETRA desenvolvido sob sua orientação, foi enviado ao relator para avaliação.

Na reunião de $\mathbf{2 5}$ de agosto de 2004 o parecer do relator, aprovando o projeto, foi aceito pelo Comitê, considerando que nāo existem infraçōes éticas pendentes para início da pesquisa. Solicitamos a V.S a gentileza de comunicar o parecer à pesquisadora.

A pesquisadora fica responsável pela entrega na Unidade de Ensino e Pesquisa dos relatórios semestrais.

Informamos que após o recebimento do trabalho concluído, este Comitê enviará o parecer final para publicaçđo.

Atenciosamente

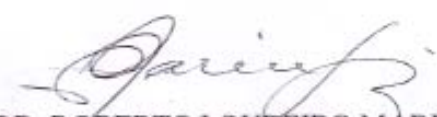

PROF. DR. RØBERTO LOUREIRO MARINGONI

Coordenador do Comitê de Ética em Pesquisa do HRAC-USP

Ilmo(a) $\operatorname{Sr}(\mathrm{a})$

Prof. Dr. José Mauro Granjeiro

Departamento de Ciências Biológicas - FOB/USP 


\section{ANEXO 2 - Carta de Informação ao Sujeito da Pesquisa e Termo de Consentimento Livre e Esclarecido}

O objetivo do presente estudo: "Investigação de polimorfismo em genes de metaloproteinases (mmps) -2 e -9 na ocorrência de fissura labial/palatina em individuos não sindrômicos" de autoria de Ariadne Machado Gonçalves Letra, será investigar possíveis variações genéticas (polimorfismos) em alguns genes do organismo que possam ter envolvimento na formação da fissura labial/palatina em indivíduos não sindrômicos. Espera-se, no caso da associação entre possíveis polimorfismos encontrados ao desenvolvimento da fissura labial/palatina, poder prever procedimentos de diagnóstico avançados.

Não haverão desconfortos, riscos ou custos para os participantes da pesquisa. Os procedimentos para coleta das amostras de material genético (DNA) dos participantes constarão de:

- bochecho com solução de água + dextrose (água com açúcar) a 3\% durante 1 minuto; e coleta do bochecho em um vidro previamente esterilizado.

- coleta de amostras de sangue colhido por técnicos do hospital.

Os participantes receberão respostas a qualquer pergunta ou esclarecimento de qualquer dúvida acerca dos procedimentos, riscos, benefícios e outros assuntos relacionados com a pesquisa. Os participantes serão sempre atualizados, com informações obtidas durante o estudo, mesmo que possam afetar a vontade do indivíduo em continuar participando. A participação é voluntária, podendo o participante a qualquer momento retirar este consentimento livre e esclarecido e deixar de participar desta pesquisa, ciente de que todas as informações prestadas tornaram-se confidenciais e guardadas por forca de sigilo profissional (Art. $9^{\circ}$ do Código de Ética Odontológica). O tratamento no HRAC não será comprometido pela decisão de desistência de participação na pesquisa. Em casos de danos ao indivíduo diretamente causados pela pesquisa, com nexo causal comprovado, o participante terá direito a tratamento médico e indenização por parte da Instituição.

Caso queira apresentar reclamações em relação a sua participação na pesquisa, o participante poderá entrar em contato com o Comitê de Ética em Pesquisa em Seres Humanos, do HRAC/USP, pelo endereço Rua Silvio Marchione, 3-20, na Unidade de Ensino e Pesquisa ou pelo telefone (14) 3235-8421.

Os indivíduos (ou seus responsáveis) que, após a leitura desta carta, concordarem em participar do estudo, deverão assinar o termo de consentimento, e preencher uma ficha com os dados pessoais e história médica e familiar. 


\title{
TERMO DE CONSENTIMENTO LIVRE E ESCLARECIDO
}

\begin{abstract}
$\mathrm{Eu}$, portador de $\mathrm{RG} \mathrm{n}^{\mathrm{o}}$ residente à Rua (Av.) $\mathrm{N}^{\mathrm{O}}$ , na cidade de Estado , (responsável pelo (a) menor * matriculado no HRAC com o $\mathrm{N}^{\circ}$ , concordo em participar na (autorizo sua participação na) pesquisa de título: "INVESTIGAÇÃO DE POLIMORFISMOS EM GENES DE METALOPROTEINASES 2 E 9 EM PACIENTES NÃO SINDRÔMICOS PORTADORES DE FISSURA LABIAL/PALATINA”, realizada por Ariadne Machado Gonçalves Letra, CRORJ 22102-7, sob orientação do Prof. Dr. José Mauro Granjeiro, RG Nº 10593401.
\end{abstract}

Bauru,

* em caso de menor de idade

Nome do responsável:

Nome do pesquisador responsável: Prof. Dr. José Mauro Granjeiro

Endereço institucional: Al. Dr. Octávio Pinheiro Brizolla, 9-75 - Departamento de Bioquímica, FOB/USP.

Cidade: Bauru

Estado: SP

CEP: 18012-901

Telefone: 14 3235-8246 


\section{ANEXO 3 - Protocolo para Extração de DNA}

- Descongelar amostras de saliva

- Adicionar 100ng/mL de Proteinase K e incubar em banho-maria a $56^{\circ}$ overnight

- Colocar $500 \mu \mathrm{L}$ de solução de acetato de amônio a $10 \%$

- Agitar manualmente durante 5 minutos

- Centrifugar por 15 minutos em velocidade alta (aproximadamente $15000 \mathrm{rpm}$ )

- Dividir o sobrenadante em dois tubos eppendorfs

- Adicionar $540 \mu \mathrm{L}$ de álcool isopropílico gelado

- Agitar vigorosamente

- Verificar formação de "nuvem de DNA"

- Deixar descansar na geladeira por 2 horas

- Centrifugar durante 20 minutos

- Descartar sobrenadante com cuidado para não deslocar o pellet de células

- Adicionar $1 \mathrm{~mL}$ de álcool $70^{\circ}$ gelado

- Centrifugar por 5 minutos

- Descartar sobrenadante

- Deixar o tubo aberto para evaporar o excesso de álcool ( \pm 4 a 5 horas)

- Ressuspender o pellet de células em $50 \mu \mathrm{L}$ de água deionizada autoclavada

- Congelar amostra de DNA 
ANEXO 4 - Protocolo para confecção de gel de poliacrilamida não-denaturante a $10 \%$ para analise por eletroforese

$6 \mathrm{~mL}$ de solução de acrilamida a $30 \%$

$3.6 \mathrm{~mL}$ de TBE $5 \mathrm{X}$

$7 \mathrm{~mL}$ de água deionizada autoclavada

$117 \mu \mathrm{L}$ de APS

$9 \mu \mathrm{L}$ de TEMED 
ANEXO 5 - Protocolo de impregnação pela prata (SANGUINETTI et al. 1994)

- Apos a eletroforese, remover o gel com cuidado e colocá-lo em recipiente contendo solução fixadora (10\% etanol, $0.5 \%$ acido acético)

- Agitar em mesa agitadora durante 10 minutos

- Descartar solução fixadora

- Adicionar solução de prata (10\% etanol, $0.5 \%$ acido acético, $0.5 \%$ nitrato de prata, $89.5 \%$ água deionizada autoclavada)

- Agitar durante 40 minutos

- Descartar solução e lavar com água para remover excesso de prata

- Adicionar solução reveladora (3\% NaOH em água, 0.5\% formaldeído)

- Agitar durante alguns minutos ate visualização das bandas

- Descartar solução

- Adicionar solução de contração (50\% metanol, 10\% acido acético, 40\% água deionizada autoclavada) 


\section{ANEXO 6. Anomalias Dentárias como Subfenótipos Adicionais para FL/P (Seção}

\subsection{3)}

Diferenças entre as freqüências das anomalias dentárias apresentadas por indivíduos compondo cada subfenótipo de FL/P e controles ( $\mathrm{p} \leq 0.0002$ indica diferença estatística significante).

\section{FP completa $x$ Controles}

Anomalia dentária
Agenesia
Microdontia
Supranumerário
Giroversão/lateroversão
Retenção
Anomalia de forma
Transposição
Múltiplas anomalias
Total

\section{FP incompleta $x$ Controle}

\begin{tabular}{|c|c|}
\hline $\begin{array}{c}\text { FP } \\
\text { ompleta } \\
(\mathrm{n}=21)\end{array}$ & $\begin{array}{c}\text { Controle } \\
(\mathrm{n}=500)\end{array}$ \\
\hline
\end{tabular}

\section{Anomalia dentária}

0.0457

Agenesia

0.8374

0.8374

Microdontia

Supranumerário

0.7715

0.00001

Giroversão/lateroversão

$\underset{\substack{\text { incompleta } \\(n=45)}}{\begin{array}{c}\text { Controle } \\ (n=500)\end{array}}$

$\mathbf{P}$ $(n=45)$

----
----
0.00001
0.00001

$\begin{array}{ccc}10 & 36 & 0.0005 \\ 0 & 1 & 0.7639 \\ 1 & 1 & 0.0316 \\ 4 & 2 & \mathbf{0 . 0 0 0 0 1} \\ 0 & 1 & 0.7639 \\ 1 & 0 & 0.0008 \\ 0 & 0 & --- \\ 0 & 1 & 0.7639 \\ 16 & 42 & \mathbf{0 . 0 0 0 0 1}\end{array}$

\section{FP total (completa + incompleta) x Controle}

Anomalia dentária $\underset{(\mathrm{n}=66)}{\mathbf{F P}} \begin{gathered}\text { Controle } \\ (\mathrm{n}=500)\end{gathered}$

$\mathbf{P}$

Agenesia

Microdontia

Supranumerário

Giroversão/lateroversão

Retenção

Anomalia de forma

Transposição

Múltiplas anomalias

Total

$\begin{array}{ccc}14 & 36 & 0.0001 \\ 0 & 1 & 0.7161 \\ 1 & 1 & 0.0905 \\ 4 & 2 & \mathbf{0 . 0 0 0 0 1} \\ 2 & 1 & 0.0029 \\ 1 & 0 & 0.0058 \\ 0 & 0 & --- \\ 2 & 1 & 0.0029 \\ 24 & 42 & \mathbf{0 . 0 0 0 0 1}\end{array}$

\section{FL/P incompleta (unilateral + bilateral) $x$ Controle}

$$
\underset{(\mathrm{n}=104)}{\mathbf{\text { Inc}} / \mathbf{P}} \quad \begin{gathered}
\text { Controle } \\
(\mathrm{n}=500)
\end{gathered} \quad \mathbf{P}
$$

Agenesia

Microdontia

Supranumerário

Giro/lateroversão

Retenção

Anomalia de forma

Transposição

Múltiplas anomalias

Total

$\begin{array}{ccc}23 & 36 & 0.00001 \\ 1 & 1 & 0.2187 \\ 4 & 1 & 0.0001 \\ 12 & 2 & 0.00001 \\ 1 & 1 & 0.2187 \\ 0 & 0 & ---- \\ 2 & 0 & 0.0018 \\ 3 & 1 & 0.0021 \\ 44 & 42 & 0.0000001\end{array}$

\section{FL/P completa (unil + bilat) $x$ Controle}

Anomalia dentária

Agenesia

Microdontia

Supranumerário

Giroversão/lateroversão

Retenção

Anomalia de forma

Transposição

Múltiplas anomalias

Total

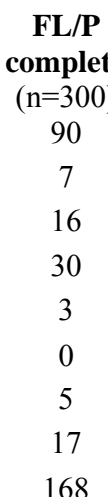

Controle $(\mathrm{n}=500)$

$$
36
$$$$
1-0.0033
$$$$
1 \quad 0.00001
$$$$
2 \quad 0.00001
$$

$$
1 \quad 0.1204
$$$$
\begin{aligned}
& 0 \\
& 0
\end{aligned}
$$

42 0.00001

\section{FL/P unilateral x Controle}

Anomalia dentária

Agenesia

Microdontia

Supranumerário

Giroversão/lateroversão

Retenção

Anomalia de forma

Transposição

Múltiplas anomalias

Total

$\underset{(\mathrm{n}=250)}{\mathbf{\text { Uni}}} \mathbf{( \mathrm { P } = 5 0 0 )}$

$\mathbf{P}$

$\begin{array}{ccc}71 & 36 & 0.00001 \\ 6 & 1 & 0.0031 \\ 16 & 1 & 0.00001 \\ 27 & 2 & 0.00001 \\ 3 & 1 & 0.0763 \\ 0 & 0 & ---- \\ 3 & 0 & 0.0141 \\ 16 & 1 & 0.00001 \\ 139 & 42 & 0.00001\end{array}$




\section{FL/P completa unilateral $x$ Controle}

\begin{tabular}{|c|c|}
\hline Anomalia dentária & $\begin{array}{c}\text { FL/P } \\
\text { comp } \\
\text { uni } \\
(n=175)\end{array}$ \\
\hline
\end{tabular}

Agenesia

Microdontia

Supranumerário

$\begin{array}{cc}57 & 36 \\ 5 & 1 \\ 14 & 1 \\ 19 & 2 \\ 2 & 1 \\ 0 & 0 \\ 1 & 0 \\ 13 & 1 \\ 111 & 42\end{array}$

Giroversão/lateroversão

Retenção

Anomalia de forma

Transposição

Múltiplas anomalias

Total

$\begin{array}{cl}0.00001 & \text { Agenesia } \\ 0.0012 & \text { Microdontia } \\ 0.00001 & \text { Supranumerário } \\ 0.00001 & \text { Giroversão/lateroversão } \\ 0.1065 & \text { Retenção } \\ ---- & \text { Anomalia de forma } \\ 0.0907 & \text { Transposição } \\ 0.00001 & \text { Múltiplas anomalias } \\ 0.00001 & \text { Total }\end{array}$

8. FL/P incompleta unilateral $x$ Controle

\section{FL/P unilateral direita $x$ Controle}

Anomalia dentária $\quad \begin{array}{cc}\underset{\mathbf{d i r}}{(\mathrm{n}=78)} & \begin{array}{c}\text { Controle } \\ (\mathrm{n}=500)\end{array}\end{array}$

Agenesia

Microdontia

Supranumerário

Giroversão/lateroversão

Retenção

Anomalia de forma

Transposição

Múltiplas anomalias

Total

$\begin{array}{cc}28 & 36 \\ 2 & 1 \\ 3 & 1 \\ 9 & 2 \\ 1 & 1 \\ 0 & 0 \\ 0 & 0 \\ 2 & 1 \\ 45 & 42\end{array}$

10. FL/P unilateral direita completa $x$ Controle

$\begin{array}{cl}0.00001 & \text { Agenesia } \\ 0.0068 & \text { Microdontia } \\ 0.0003 & \text { Supranumerário } \\ 0.00001 & \text { Giroversão/lateroversão } \\ 0.1301 & \text { Retenção } \\ ---- & \text { Anomalia de forma } \\ ---- & \text { Transposição } \\ 0.0068 & \text { Múltiplas anomalias } \\ 0.00001 & \text { Total }\end{array}$

\section{P Anomalia dentária}

0.00001 Total

$$
\underset{(n=54)}{\operatorname{dir} \text { comp }} \quad \begin{gathered}
\text { Controle } \\
(\mathrm{n}=500)
\end{gathered}
$$

$\begin{array}{ccc}23 & 36 & 0.00001 \\ 2 & 1 & 0.0008 \\ 3 & 1 & 0.00001 \\ 6 & 2 & 0.00001 \\ 0 & 1 & 0.7422 \\ 0 & 0 & --- \\ 0 & 0 & --- \\ 2 & 1 & 0.0008 \\ 36 & 42 & 0.00001\end{array}$

\section{FL/P unilateral direita incompleta $x$ Controle}

\section{Anomalia dentária}

$$
\begin{aligned}
& \text { FL/P Controle } \\
& \text { inc } \\
& (\mathrm{n}=16)
\end{aligned}
$$

Agenesia
Microdontia
Supranumerário
Giroversão/lateroversão
Retenção
Anomalia de forma
Transposição
Múltiplas anomalias
Total

$\begin{array}{cccl}3 & 36 & 0.0853 & \text { Agenesia } \\ 0 & 1 & 0.8578 & \text { Microdontia } \\ 0 & 1 & 0.8578 & \text { Supranumerário } \\ 3 & 2 & 0.00001 & \text { Giroversão/lateroversão } \\ 0 & 1 & 0.8578 & \text { Retenção } \\ 0 & 0 & ---- & \text { Anomalia de forma } \\ 0 & 0 & ---- & \text { Transposição } \\ 0 & 1 & 0.8578 & \text { Múltiplas anomalias } \\ 6 & 42 & 0.00001 & \text { Total }\end{array}$

\section{FL/P unil direita incomp + FP $\times$ Controle}

$\begin{array}{lccc}\text { Anomalia dentária } & \begin{array}{c}\text { FL/P } \\ \text { unil dir } \\ \text { inc }+ \\ \text { FP } \\ (\mathrm{n}=8)\end{array} & \begin{array}{c}\text { Control } \\ \mathbf{e} \\ (\mathrm{n}=500)\end{array} & \text { P } \\ \text { Agenesia } & 2 & 36 & 0.0576 \\ \text { Microdontia } & 0 & 1 & 0.8992 \\ \text { Supranumerário } & 0 & 1 & 0.8992 \\ \text { Giroversão/lateroversão } & 0 & 2 & 0.8577 \\ \text { Retenção } & 1 & 1 & 0.8578 \\ \text { Anomalia de forma } & 0 & 0 & --- \\ \text { Transposição } & 0 & 0 & --- \\ \text { Múltiplas anomalias } & 0 & 1 & 0.8992 \\ \text { Total } & 3 & 42 & 0.0040\end{array}$

0.0010 
13. FL/P unilateral esquerda $x$ Controle

Anomalia dentária

$\begin{array}{cc}\begin{array}{c}\text { FL/P } \\ \text { unilateral } \\ \text { esquerda } \\ (\mathrm{n}=172)\end{array} & \begin{array}{c}\text { Controle } \\ (\mathrm{n}=500)\end{array} \\ \end{array}$

Agenesia

Microdontia

Supranumerário

Giroversão/lateroversão

Retenção

Anomalia de forma

Transposição

Múltiplas anomalias

Total

$\begin{array}{cccl}43 & 36 & 0.00001 & \text { Agenesia } \\ 4 & 1 & 0.0051 & \text { Microdontia } \\ 13 & 1 & 0.00001 & \text { Supranumerário } \\ 18 & 2 & 0.00001 & \text { Giroversão/lateroversão } \\ 2 & 1 & 0.1023 & \text { Retenção } \\ 0 & 0 & ---- & \text { Anomalia de forma } \\ 3 & 0 & 0.0030 & \text { Transposição } \\ 14 & 1 & 0.00001 & \text { Múltiplas anomalias } \\ 97 & 42 & 0.00001 & \text { Total }\end{array}$

\section{FL/P unilateral esquerda completa $x$ Controle}

\section{Anomalia dentária}

$\begin{array}{ccc}\begin{array}{c}\text { FL/P } \\ \text { unilateral } \\ \text { esquerda } \\ \text { completa } \\ (\mathrm{n}=121) \\ 34\end{array} & \begin{array}{c}\text { Controle } \\ (\mathrm{n}=500)\end{array} & \mathbf{P} \\ 3 & 36 & 0.00001 \\ 11 & 1 & 0.0051 \\ 13 & 1 & 0.00001 \\ 2 & 2 & 0.00001 \\ 0 & 1 & 0.0386 \\ 1 & 0 & ---- \\ 11 & 0 & 0.0419 \\ 75 & 1 & 0.00001 \\ & 42 & 0.00001\end{array}$

15. FL/P unilateral esquerda incompleta $x$ Controle

Anomalia dentária

$\begin{array}{cc}\mathbf{F L} / \mathbf{P} & \begin{array}{c}\text { Controles } \\ \text { uni } \\ \text { esq inc } \\ (\mathrm{n}=500)\end{array} \\ \end{array}$

Agenesia

Microdontia

Supranumerário

Giroversão/lateroversão

Retenção

Anomalia de forma

Transposição

Múltiplas anomalias

Total

9
1
2
5
0
0
2
3
22

\section{FL/P bilateral $x$ Controle}

Anomalia dentária

36
1
1
2
1
0
0
1
42

$\begin{array}{cl}0.0035 & \text { Agenesia } \\ 0.0339 & \text { Microdontia } \\ 0.0002 & \text { Supranumerário } \\ 0.00001 & \text { Giroversão/lateroversão } \\ 0.7614 & \text { Retenção } \\ ---- & \text { Anomalia de forma } \\ 0.00001 & \text { Transposição } \\ 0.00001 & \text { Múltiplas anomalias } \\ 0.00001 & \text { Total }\end{array}$

$\begin{array}{lccclccc}\text { Anomalia dentária } & \begin{array}{c}\text { FL/P } \\ \text { bilateral } \\ (\mathrm{n}=154)\end{array} & \begin{array}{c}\text { Controle } \\ (\mathrm{n}=500)\end{array} & \mathbf{P} & \text { Anomalia dentária } & \begin{array}{c}\text { FL/P bil } \\ \mathbf{c o m p} \\ (\mathrm{n}=125)\end{array} & \begin{array}{c}\text { Controle } \\ (\mathrm{n}=500)\end{array} & \begin{array}{c}\mathbf{P} \\ \text { Agenesia }\end{array} \\ 42 & 36 & 0.00001 & \text { Agenesia } & 33 & 36 & 0.00001 \\ \text { Microdontia } & 2 & 1 & 0.0724 & \text { Microdontia } & 2 & 1 & 0.0460 \\ \text { Supranumerário } & 4 & 1 & 0.0028 & \text { Supranumerário } & 2 & 1 & 0.0460 \\ \text { Giroversão/lateroversão } & 15 & 2 & 0.00001 & \text { Giroversão/lateroversão } & 11 & 2 & 0.00001 \\ \text { Retenção } & 1 & 1 & 0.3772 & \text { Retenção } & 1 & 1 & 0.2976 \\ \text { Anomalia de forma } & 0 & 0 & --- & \text { Anomalia de forma } & 0 & 0 & ---- \\ \text { Transposição } & 4 & 0 & 0.0003 & \text { Transposição } & 4 & 0 & 0.00001 \\ \text { Múltiplas anomalias } & 4 & 1 & 0.0028 & \text { Múltiplas anomalias } & 4 & 1 & 0.0008 \\ \text { Total } & 72 & 42 & 0.00001 & \text { Total } & 57 & 42 & 0.0000001\end{array}$

$\begin{array}{lccclccc}\text { Anomalia dentária } & \begin{array}{c}\text { FL/P } \\ \text { bilateral } \\ (\mathrm{n}=154)\end{array} & \begin{array}{c}\text { Controle } \\ (\mathrm{n}=500)\end{array} & \mathbf{P} & \text { Anomalia dentária } & \begin{array}{c}\text { FL/P bil } \\ \mathbf{c o m p} \\ (\mathrm{n}=125)\end{array} & \begin{array}{c}\text { Controle } \\ (\mathrm{n}=500)\end{array} & \begin{array}{c}\mathbf{P} \\ \text { Agenesia }\end{array} \\ 42 & 36 & 0.00001 & \text { Agenesia } & 33 & 36 & 0.00001 \\ \text { Microdontia } & 2 & 1 & 0.0724 & \text { Microdontia } & 2 & 1 & 0.0460 \\ \text { Supranumerário } & 4 & 1 & 0.0028 & \text { Supranumerário } & 2 & 1 & 0.0460 \\ \text { Giroversão/lateroversão } & 15 & 2 & 0.00001 & \text { Giroversão/lateroversão } & 11 & 2 & 0.00001 \\ \text { Retenção } & 1 & 1 & 0.3772 & \text { Retenção } & 1 & 1 & 0.2976 \\ \text { Anomalia de forma } & 0 & 0 & ---- & \text { Anomalia de forma } & 0 & 0 & --- \\ \text { Transposição } & 4 & 0 & 0.0003 & \text { Transposição } & 4 & 0 & 0.00001 \\ \text { Múltiplas anomalias } & 4 & 1 & 0.0028 & \text { Múltiplas anomalias } & 4 & 1 & 0.0008 \\ \text { Total } & 72 & 42 & 0.00001 & \text { Total } & 57 & 42 & 0.0000001\end{array}$

\section{FL/P unil esq incom + FP $x$ Controle}

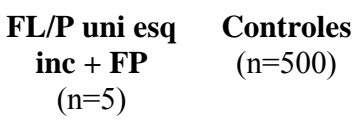

$\mathbf{P}$

0.5335

0.9202

0.9202

0.8873

0.9202

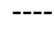

0.9202

0.4985

\section{FL/P bilateral completa $x$ Controle}


19. FL/P bilateral incompleta $x$ Controle

$\begin{array}{ccc}\text { Anomalia dentária } & \begin{array}{c}\text { FL/P bil } \\ \text { inc } \\ (n=8)\end{array} & \begin{array}{c}\text { Controle } \\ (n=500)\end{array} \\ & & \end{array}$

Agenesia
Microdontia
Supranumerário
Giroversão/lateroversão
Retenção
Anomalia de forma
Transposição
Múltiplas anomalias
Total

\section{FL/P bilateral incompleta mista $x$ Controle}

\section{Anomalia dentária}

Anomalia dentária

Agenesia

Microdontia

Supranumerário

Giroversão/lateroversão

Retenção

Anomalia de forma

Transposição

Múltiplas anomalias

Total

FL/P bil
inc mista
$(\mathrm{n}=4)$$\quad \begin{gathered}\text { Controle } \\ (\mathrm{n}=500)\end{gathered}$

$\begin{array}{cccl}1 & 36 & 0.1739 & \text { Agenesia } \\ 0 & 1 & 0.9286 & \text { Microdontia } \\ 0 & 1 & 0.9286 & \text { Supranumerário } \\ 0 & 2 & 0.8991 & \text { Giroversão/lateroversão } \\ 0 & 1 & 0.9286 & \text { Retenção } \\ 0 & 0 & --- & \text { Anomalia de forma } \\ 0 & 0 & --- & \text { Transposição } \\ 0 & 1 & 0.8991 & \text { Múltiplas anomalias } \\ 1 & 42 & 0.2365 & \text { Total }\end{array}$

\section{P Anomalia dentária}

Anomalia dentária

\section{FL/P bilateral incompleta + FP $x$ Controle}

\section{P Anomalia dentária}

0.5671

0.8992

0.00001

0.00001

0.8992

$--$

$---$

0.8992

0.0040
Agenesia

Microdontia

Supranumerário

Giroversão/lateroversão

Retenção

Anomalia de forma

Transposição

Múltiplas anomalias

Total

$\begin{array}{ccc}\begin{array}{c}\text { FL/P } \\ \text { bil inc } \\ +\mathbf{F P} \\ (\mathrm{n}=17)\end{array} & \begin{array}{c}\text { Controle } \\ (\mathrm{n}=500)\end{array} & \mathbf{P} \\ 7 & & \\ 0 & 36 & 0.00001 \\ 1 & 1 & 0.8535 \\ 3 & 1 & 0.0002 \\ 0 & 2 & 0.00001 \\ 0 & 1 & 0.8535 \\ 0 & 0 & --- \\ 0 & 0 & --- \\ 11 & 1 & 0.8535 \\ & 42 & 0.00001\end{array}$

22. FL/P total $x$ Controle

\section{FL/}

total $(\mathrm{n}=500)$

$(\mathrm{n}=406)$

$\begin{array}{ccc}113 & 36 & 0.00001 \\ 8 & 1 & 0.0075 \\ 20 & 1 & 0.00001 \\ 42 & 2 & 0.00001 \\ 4 & 1 & 0.1126 \\ 0 & 0 & --- \\ 7 & 0 & 0.0032 \\ 20 & 1 & 0.00001 \\ 217 & 42 & 0.00001\end{array}$




\section{ANEXO 7. Estudos genéticos de associação com a FL/P (Seção 5.3)}

Freqüências obtidas para genótipos e alelos referentes a cada polimorfismo estudado:

1. TGFA - amostra completa

2. TGFA - caucasianos

3. IRF6 - amostra completa

4. IRF6 - caucasianos

5. Cromossomo $6 \mathrm{q}$ - amostra completa

6. Cromossomo $6 q-$ caucasianos 
rs1058213 (C3827T)

Subfenótipo

N

Fissura Palatina

Completa

Incompleta

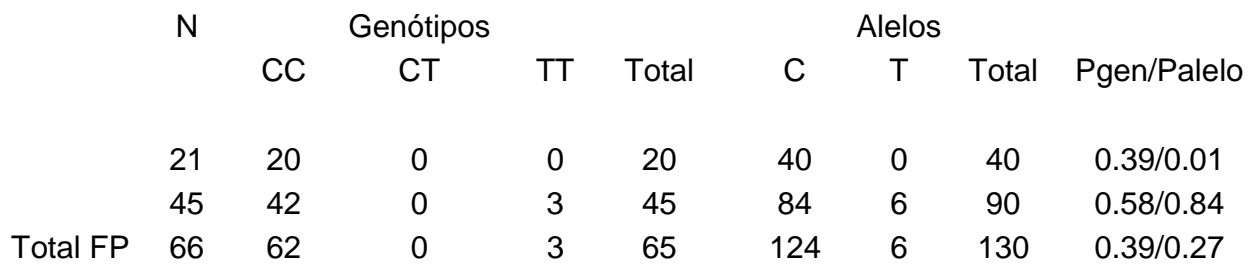

Fissura Labial e/ou Palatina

\begin{tabular}{|c|c|c|c|c|c|c|c|c|c|}
\hline Completa & 300 & 259 & 3 & 12 & 274 & 521 & 27 & 548 & $0.26 / 0.08$ \\
\hline Incompleta & 104 & 93 & 0 & 6 & 99 & 186 & 12 & 198 & $0.30 / 0.56$ \\
\hline Unilateral & 250 & 218 & 3 & 11 & 232 & 439 & 25 & 464 & $0.46 / 0.19$ \\
\hline Completa & 175 & 148 & 3 & 8 & 159 & 299 & 19 & 318 & $0.81 / 0.44$ \\
\hline Incompleta & 75 & 70 & 0 & 3 & 73 & 140 & 6 & 146 & $0.31 / 0.16$ \\
\hline Unilateral Direita & 78 & 71 & 0 & 1 & 72 & 142 & 2 & 144 & $0.05 / 0.008$ \\
\hline Completa & 54 & 50 & 0 & 0 & 50 & 100 & 0 & 100 & $0.01 / 0.0001$ \\
\hline Incompleta & 16 & 14 & 0 & 1 & 15 & 28 & 2 & 30 & $0.70 / 0.90$ \\
\hline Incompleta + FP & 8 & 7 & 0 & 0 & 7 & 14 & 0 & 14 & $0.54 / 0.15$ \\
\hline Unilateral Esquerda & 172 & 147 & 3 & 10 & 160 & 297 & 23 & 320 & $0.94 / 0.98$ \\
\hline Completa & 121 & 98 & 3 & 8 & 109 & 199 & 19 & 218 & $0.88 / 0.45$ \\
\hline Incompleta & 46 & 44 & 0 & 2 & 46 & 88 & 4 & 92 & $0.30 / 0.30$ \\
\hline Incompleta + FP & 5 & 5 & 0 & 0 & 5 & 10 & 0 & 10 & $0.79 / 0.38$ \\
\hline Bilateral & 154 & 134 & 0 & 7 & 141 & 268 & 14 & 282 & $0.04 / 0.18$ \\
\hline Completa & 125 & 111 & 0 & 4 & 115 & 222 & 8 & 230 & $0.04 / 0.04$ \\
\hline Incompleta & 8 & 7 & 0 & 1 & 8 & 14 & 2 & 16 & $0.64 / 0.42$ \\
\hline Incompleta + FP & 17 & 13 & 0 & 1 & 14 & 26 & 2 & 28 & $0.71 / 0.98$ \\
\hline Incompleta Mista & 4 & 3 & 0 & 1 & 4 & 6 & 2 & 8 & $0.29 / 0.05$ \\
\hline FL direita + FL/P esquerda & 3 & 3 & 0 & 0 & 3 & 6 & 0 & 6 & ---- \\
\hline FL esquerda + FP bilateral & 1 & 0 & 0 & 1 & 1 & 0 & 2 & 2 & ---- \\
\hline Fissura Mediana & 2 & 1 & 0 & 0 & 1 & 2 & 0 & 2 & ---- \\
\hline Total FL/P & 406 & 353 & 3 & 18 & 374 & 709 & 39 & 748 & $0.14 / 0.07$ \\
\hline Tipo/lado desconhecido & 28 & 26 & 0 & 0 & 26 & 52 & 0 & 52 & ---- \\
\hline Total fissurados & 500 & 441 & 3 & 21 & 465 & 885 & 45 & 930 & $0.05 / 0.02$ \\
\hline Sem fissura (Controles) & 500 & 427 & 11 & 29 & 467 & 865 & 69 & 934 & ---- \\
\hline
\end{tabular}


rs2166975 (C3296T)

Subfenótipo

N

Fissura Palatina

Completa

Incompleta

\begin{tabular}{cccccccccc} 
& N & \multicolumn{3}{c}{ Genótipos } & \multicolumn{9}{c}{ Alelos } \\
& & CC & CT & TT & Total & C & T & Total & Pgen/Palelo \\
& & & & & & & & & \\
Total FP & 15 & 4 & 1 & 20 & 34 & 6 & 40 & $0.96 / 0.90$ \\
& 45 & 31 & 11 & 3 & 45 & 73 & 17 & 90 & $0.48 / 0.24$ \\
& 66 & 46 & 15 & 4 & 65 & 107 & 23 & 130 & $0.54 / 0.30$
\end{tabular}

Fissura Labial e/ou Palatina

\begin{tabular}{|c|c|c|c|c|c|c|c|c|c|}
\hline Completa & 300 & 188 & 59 & 23 & 270 & 435 & 105 & 540 & $0.07 / 0.009$ \\
\hline Incompleta & 104 & 76 & 19 & 6 & 101 & 171 & 31 & 202 & $0.94 / 0.70$ \\
\hline Unilateral & 250 & 163 & 44 & 22 & 229 & 370 & 88 & 458 & 0.09/0.01 \\
\hline Completa & 175 & 106 & 32 & 19 & 157 & 244 & 70 & 314 & $0.01 / 0.0009$ \\
\hline Incompleta & 75 & 57 & 12 & 3 & 72 & 126 & 18 & 144 & $0.86 / 0.55$ \\
\hline Unilateral Direita & 78 & 54 & 14 & 5 & 73 & 122 & 24 & 146 & $0.83 / 0.49$ \\
\hline Completa & 54 & 37 & 9 & 4 & 50 & 83 & 17 & 100 & $0.76 / 0.46$ \\
\hline Incompleta & 16 & 10 & 4 & 1 & 15 & 24 & 6 & 30 & $0.64 / 0.38$ \\
\hline Incompleta + FP & 8 & 7 & 1 & 0 & 8 & 15 & 1 & 16 & $0.57 / 0.35$ \\
\hline Unilateral Esquerda & 172 & 109 & 30 & 17 & 156 & 248 & 64 & 312 & $0.05 / 0.009$ \\
\hline Completa & 121 & 69 & 23 & 15 & 107 & 161 & 53 & 214 & $0.003 / 0.0001$ \\
\hline Incompleta & 46 & 35 & 7 & 2 & 44 & 77 & 11 & 88 & $0.90 / 0.64$ \\
\hline Incompleta + FP & 5 & 5 & 0 & 0 & 5 & 10 & 0 & 10 & $0.26 / 0.07$ \\
\hline Bilateral & 154 & 101 & 34 & 7 & 142 & 236 & 48 & 284 & $0.25 / 0.28$ \\
\hline Completa & 125 & 82 & 27 & 4 & 113 & 191 & 35 & 226 & $0.25 / 0.65$ \\
\hline Incompleta & 8 & 5 & 2 & 1 & 8 & 12 & 4 & 16 & $0.56 / 0.22$ \\
\hline Incompleta + FP & 17 & 10 & 1 & 2 & 13 & 21 & 5 & 26 & $0.23 / 0.48$ \\
\hline Incompleta Mista & 4 & 4 & 4 & 0 & 8 & 12 & 4 & 16 & $0.05 / 0.22$ \\
\hline FL direita + FL/P esquerda & 3 & 0 & 3 & 0 & 3 & 3 & 3 & 6 & ---- \\
\hline FL esquerda + FP bilateral & 1 & 4 & 1 & 0 & 5 & 9 & 1 & 10 & ---- \\
\hline Fissura Mediana & 2 & 1 & 0 & 0 & 1 & 2 & 0 & 2 & ---- \\
\hline Total FL/P & 406 & 265 & 78 & 33 & 376 & 608 & 144 & 752 & $0.06 / 0.007$ \\
\hline Tipo/lado desconhecido & 28 & 19 & 5 & 3 & 27 & 43 & 11 & 54 & ---- \\
\hline Total fissurados & 500 & 330 & 98 & 36 & 464 & 758 & 170 & 928 & $0.11 / 0.01$ \\
\hline Sem fissura (Controles) & 500 & 365 & 84 & 26 & 475 & 814 & 136 & 950 & ---- \\
\hline
\end{tabular}


rs377122

Subfenótipo

$N$

Genótipos

Alelos

Fissura Palatina

Completa
Incompleta

\begin{tabular}{|c|c|c|c|c|c|c|c|c|c|}
\hline \multirow{2}{*}{\multicolumn{2}{|c|}{$\mathrm{N}$}} & \multicolumn{3}{|c|}{ Genótipos } & \multicolumn{3}{|c|}{ Alelos } & \multirow[b]{2}{*}{ Total } & \multirow[b]{2}{*}{ Pgen/Palelo } \\
\hline & & $\mathrm{CC}$ & CT & TT & Total & C & $\mathrm{T}$ & & \\
\hline & 21 & 3 & 12 & 5 & 20 & 18 & 22 & 40 & $0.74 / 0.65$ \\
\hline & 45 & 7 & 29 & 9 & 45 & 43 & 47 & 90 & $0.35 / 0.87$ \\
\hline Total FP & 66 & 10 & 41 & 14 & 65 & 61 & 69 & 130 & $0.30 / 0.71$ \\
\hline
\end{tabular}

Fissura Labial e/ou Palatina

\begin{tabular}{|c|c|c|c|c|c|c|c|c|c|}
\hline Completa & 300 & 57 & 133 & 88 & 278 & 247 & 309 & 556 & $0.11 / 0.11$ \\
\hline Incompleta & 104 & 12 & 53 & 36 & 101 & 77 & 125 & 202 & $0.02 / 0.006$ \\
\hline Unilateral & 250 & 38 & 115 & 81 & 234 & 191 & 277 & 468 & $0.01 / 0.005$ \\
\hline Completa & 175 & 32 & 73 & 56 & 161 & 137 & 185 & 322 & $0.04 / 0.05$ \\
\hline Incompleta & 75 & 6 & 42 & 25 & 73 & 54 & 92 & 146 & $0.01 / 0.008$ \\
\hline Unilateral Direita & 78 & 13 & 36 & 25 & 74 & 62 & 86 & 148 & $0.23 / 0.12$ \\
\hline Completa & 54 & 10 & 23 & 18 & 51 & 43 & 59 & 102 & $0.25 / 0.21$ \\
\hline Incompleta & 16 & 1 & 9 & 5 & 15 & 11 & 19 & 30 & $0.34 / 0.19$ \\
\hline Incompleta + FP & 8 & 2 & 4 & 2 & 8 & 8 & 8 & 16 & $0.97 / 0.91$ \\
\hline Unilateral Esquerda & 172 & 25 & 79 & 56 & 160 & 129 & 191 & 320 & $0.02 / 0.009$ \\
\hline Completa & 121 & 22 & 50 & 38 & 110 & 94 & 126 & 220 & $0.10 / 0.11$ \\
\hline Incompleta & 46 & 3 & 26 & 16 & 45 & 32 & 58 & 90 & $0.03 / 0.01$ \\
\hline Incompleta + FP & 5 & 0 & 3 & 2 & 5 & 3 & 7 & 10 & $0.45 / 0.24$ \\
\hline Bilateral & 154 & 31 & 71 & 43 & 145 & 133 & 157 & 290 & $0.47 / 0.40$ \\
\hline Completa & 125 & 25 & 60 & 32 & 117 & 110 & 124 & 234 & $0.84 / 0.65$ \\
\hline Incompleta & 8 & 1 & 2 & 5 & 8 & 4 & 12 & 16 & $0.05 / 0.06$ \\
\hline Incompleta + FP & 17 & 5 & 7 & 4 & 16 & 17 & 15 & 32 & $0.65 / 0.61$ \\
\hline Incompleta Mista & 4 & 0 & 2 & 2 & 4 & 2 & 6 & 8 & $0.38 / 0.18$ \\
\hline FL direita + FL/P esquerda & 3 & 0 & 1 & 2 & 3 & 1 & 5 & 6 & ---- \\
\hline FL esquerda + FP bilateral & 1 & 0 & 1 & 0 & 1 & 1 & 1 & 2 & ---- \\
\hline Fissura Mediana & 2 & 0 & 0 & 1 & 1 & 0 & 2 & 2 & ---- \\
\hline Total FL/P & 406 & 69 & 186 & 124 & 379 & 324 & 434 & 758 & $0.03 / 0.01$ \\
\hline Tipo/lado desconhecido & 28 & 10 & 12 & 3 & 25 & 32 & 18 & 50 & ---- \\
\hline Total fissurados & 500 & 89 & 239 & 142 & 470 & 417 & 523 & 940 & $0.14 / 0.06$ \\
\hline Sem fissura (Controles) & 500 & 105 & 255 & 118 & 478 & 465 & 491 & 956 & ---- \\
\hline
\end{tabular}


rs2902345

Subfenótipo

Fissura Palatina

Completa

Incompleta

\begin{tabular}{cccccccccc} 
& N & \multicolumn{9}{c}{$\begin{array}{c}\text { Genótipos } \\
\end{array}$} & & CC & CT & TT & Total & C & T & Total & Pgen/Palelo \\
& & & & & & & & & \\
Total FP & 61 & 5 & 9 & 6 & 20 & 19 & 21 & 40 & $0.46 / 0.23$ \\
& 45 & 11 & 29 & 4 & 44 & 51 & 37 & 88 & $0.05 / 0.86$ \\
& 66 & 16 & 38 & 10 & 64 & 70 & 58 & 128 & $0.18 / 0.61$
\end{tabular}

Fissura Labial e/ou Palatina

\begin{tabular}{|c|c|c|c|c|c|c|c|c|c|}
\hline Completa & 300 & 87 & 126 & 55 & 268 & 300 & 236 & 536 & $0.92 / 0.68$ \\
\hline Incompleta & 104 & 32 & 46 & 20 & 98 & 110 & 86 & 196 & $0.97 / 0.81$ \\
\hline Unilateral & 250 & 80 & 102 & 48 & 230 & 262 & 198 & 460 & $0.75 / 0.97$ \\
\hline Completa & 175 & 57 & 67 & 34 & 158 & 181 & 135 & 316 & $0.56 / 0.94$ \\
\hline Incompleta & 75 & 23 & 35 & 14 & 72 & 81 & 63 & 144 & $0.97 / 0.85$ \\
\hline Unilateral Direita & 78 & 22 & 39 & 12 & 73 & 83 & 63 & 146 & $0.61 / 0.96$ \\
\hline Completa & 54 & 15 & 26 & 9 & 50 & 56 & 44 & 100 & $0.81 / 0.84$ \\
\hline Incompleta & 16 & 6 & 8 & 1 & 15 & 20 & 10 & 30 & $0.46 / 0.29$ \\
\hline Incompleta + FP & 8 & 1 & 5 & 2 & 8 & 7 & 9 & 16 & $0.46 / 0.28$ \\
\hline Unilateral Esquerda & 172 & 58 & 63 & 36 & 157 & 179 & 135 & 314 & $0.28 / 0.99$ \\
\hline Completa & 121 & 42 & 41 & 25 & 108 & 125 & 91 & 216 & $0.21 / 0.82$ \\
\hline Incompleta & 46 & 14 & 21 & 9 & 44 & 49 & 39 & 88 & $0.97 / 0.80$ \\
\hline Incompleta + FP & 5 & 2 & 1 & 2 & 5 & 5 & 5 & 10 & $0.38 / 0.65$ \\
\hline Bilateral & 154 & 46 & 70 & 25 & 141 & 162 & 120 & 282 & $0.86 / 0.90$ \\
\hline Completa & 125 & 37 & 59 & 19 & 115 & 133 & 97 & 230 & $0.69 / 0.82$ \\
\hline Incompleta & 8 & 4 & 3 & 1 & 8 & 11 & 5 & 16 & $0.60 / 0.34$ \\
\hline Incompleta + FP & 17 & 4 & 6 & 4 & 14 & 14 & 14 & 28 & $0.68 / 0.45$ \\
\hline Incompleta Mista & 4 & 1 & 2 & 1 & 4 & 4 & 4 & 8 & $0.92 / 0.68$ \\
\hline FL direita + FL/P esquerda & 3 & 1 & 1 & 1 & 3 & 3 & 3 & 6 & ---- \\
\hline FL esquerda + FP bilateral & 1 & 0 & 1 & 0 & 1 & 1 & 1 & 2 & ---- \\
\hline Fissura Mediana & 2 & 1 & 0 & 0 & 1 & 2 & 0 & 2 & ---- \\
\hline Total FL/P & 406 & 120 & 172 & 75 & 367 & 412 & 322 & 734 & $0.92 / 0.70$ \\
\hline Tipo/lado desconhecido & 28 & 8 & 15 & 3 & 26 & 31 & 21 & 52 & ---- \\
\hline Total fissurados & 500 & 144 & 225 & 88 & 457 & 513 & 401 & 914 & $0.80 / 0.69$ \\
\hline Sem fissura (Controles) & 500 & 159 & 225 & 92 & 476 & 543 & 409 & 952 & ---- \\
\hline
\end{tabular}


rs1523305

Subfenótipo

N

Fissura Palatina

Completa

Incompleta

\begin{tabular}{cccccccccc} 
& N & \multicolumn{9}{c}{$\begin{array}{c}\text { Genótipos } \\
\end{array}$} & & CC & CT & TT & Total & C & T & Total & Pgen/Palelo \\
& & & & & & & & & \\
Total FP & 61 & 6 & 9 & 5 & 20 & 21 & 19 & 40 & $0.74 / 0.52$ \\
& 45 & 5 & 28 & 11 & 44 & 38 & 50 & 88 & $0.13 / 0.45$ \\
& 66 & 11 & 37 & 16 & 64 & 59 & 69 & 128 & $0.43 / 0.78$
\end{tabular}

Fissura Labial e/ou Palatina

\begin{tabular}{|c|c|c|c|c|c|c|c|c|c|}
\hline Completa & 300 & 62 & 132 & 81 & 275 & 256 & 294 & 550 & $0.88 / 0.75$ \\
\hline Incompleta & 104 & 26 & 46 & 24 & 96 & 98 & 94 & 192 & $0.61 / 0.35$ \\
\hline Unilateral & 250 & 60 & 105 & 63 & 228 & 225 & 231 & 456 & $0.52 / 0.48$ \\
\hline Completa & 175 & 41 & 71 & 46 & 158 & 153 & 163 & 316 & $0.56 / 0.74$ \\
\hline Incompleta & 75 & 19 & 34 & 17 & 70 & 72 & 68 & 140 & $0.65 / 0.36$ \\
\hline Unilateral Direita & 78 & 21 & 37 & 15 & 73 & 79 & 67 & 146 & $0.31 / 0.12$ \\
\hline Completa & 54 & 17 & 24 & 10 & 51 & 58 & 44 & 102 & $0.17 / 0.06$ \\
\hline Incompleta & 16 & 3 & 8 & 4 & 15 & 14 & 16 & 30 & $0.95 / 0.94$ \\
\hline Incompleta + FP & 8 & 1 & 5 & 1 & 7 & 7 & 7 & 14 & $0.51 / 0.84$ \\
\hline Unilateral Esquerda & 172 & 39 & 68 & 48 & 155 & 146 & 164 & 310 & $0.47 / 0.93$ \\
\hline Completa & 121 & 24 & 47 & 36 & 107 & 95 & 119 & 214 & $0.45 / 0.43$ \\
\hline Incompleta & 46 & 13 & 18 & 12 & 43 & 44 & 42 & 86 & $0.48 / 0.49$ \\
\hline Incompleta + FP & 5 & 2 & 3 & 0 & 5 & 7 & 3 & 10 & $0.34 / 0.15$ \\
\hline Bilateral & 154 & 28 & 73 & 42 & 143 & 129 & 157 & 286 & $0.74 / 0.50$ \\
\hline Completa & 125 & 21 & 61 & 35 & 117 & 103 & 131 & 234 & $0.55 / 0.35$ \\
\hline Incompleta & 8 & 1 & 3 & 4 & 8 & 5 & 11 & 16 & $0.37 / 0.20$ \\
\hline Incompleta + FP & 17 & 5 & 7 & 2 & 14 & 17 & 11 & 28 & $0.38 / 0.16$ \\
\hline Incompleta Mista & 4 & 1 & 2 & 1 & 4 & 4 & 4 & 8 & $0.99 / 0.88$ \\
\hline FL direita + FL/P esquerda & 3 & 1 & 1 & 1 & 3 & 3 & 3 & 6 & ---- \\
\hline FL esquerda + FP bilateral & 1 & 0 & 1 & 0 & 1 & 1 & 1 & 2 & ---- \\
\hline Fissura Mediana & 2 & 0 & 0 & 1 & 1 & 0 & 2 & 2 & ---- \\
\hline Total FL/P & 406 & 88 & 178 & 105 & 371 & 354 & 388 & 742 & $0.88 / 0.88$ \\
\hline Tipo/lado desconhecido & 28 & 5 & 16 & 6 & 27 & 26 & 28 & 54 & ---- \\
\hline Total fissurados & 500 & 104 & 231 & 128 & 463 & 439 & 487 & 926 & $0.99 / 0.98$ \\
\hline Sem fissura (Controles) & 500 & 107 & 235 & 132 & 474 & 449 & 499 & 948 & ---- \\
\hline
\end{tabular}


rs930655

Subfenótipo

Fissura Palatina

Completa

Incompleta

\begin{tabular}{|c|c|c|c|c|c|c|c|c|c|}
\hline \multirow{2}{*}{\multicolumn{2}{|c|}{$\mathrm{N}$}} & \multicolumn{3}{|c|}{ Genótipos } & \multicolumn{5}{|c|}{ Alelos } \\
\hline & & AA & $A G$ & GG & Total & A & G & Total & Pgen/Palelo \\
\hline & 21 & 5 & 10 & 5 & 20 & 20 & 20 & 40 & $0.62 / 0.34$ \\
\hline & 45 & 3 & 25 & 17 & 45 & 31 & 59 & 90 & $0.16 / 0.14$ \\
\hline Total FP & 66 & 8 & 35 & 22 & 65 & 51 & 79 & 130 & $0.54 / 0.49$ \\
\hline
\end{tabular}

Fissura Labial e/ou Palatina

\begin{tabular}{|c|c|c|c|c|c|c|c|c|c|}
\hline Completa & 300 & 52 & 116 & 111 & 279 & 220 & 338 & 558 & $0.09 / 0.25$ \\
\hline Incompleta & 104 & 27 & 45 & 31 & 103 & 99 & 107 & 206 & $0.13 / 0.13$ \\
\hline Unilateral & 250 & 51 & 90 & 95 & 236 & 192 & 280 & 472 & $0.01 / 0.53$ \\
\hline Completa & 175 & 30 & 60 & 70 & 160 & 120 & 200 & 320 & $0.02 / 0.12$ \\
\hline Incompleta & 75 & 21 & 30 & 25 & 76 & 72 & 80 & 152 & $0.09 / 0.25$ \\
\hline Unilateral Direita & 78 & 14 & 26 & 34 & 74 & 54 & 94 & 148 & $0.05 / 0.17$ \\
\hline Completa & 54 & 8 & 21 & 22 & 51 & 37 & 65 & 102 & $0.33 / 0.23$ \\
\hline Incompleta & 16 & 2 & 4 & 9 & 15 & 8 & 22 & 30 & $0.08 / 0.08$ \\
\hline Incompleta + FP & 8 & 4 & 1 & 3 & 8 & 9 & 7 & 16 & $0.03 / 0.26$ \\
\hline Unilateral Esquerda & 172 & 35 & 64 & 61 & 160 & 134 & 186 & 320 & $0.11 / 0.87$ \\
\hline Completa & 121 & 22 & 39 & 48 & 109 & 83 & 135 & 218 & $0.03 / 0.24$ \\
\hline Incompleta & 46 & 11 & 23 & 12 & 46 & 45 & 47 & 92 & $0.47 / 0.22$ \\
\hline Incompleta + FP & 5 & 2 & 2 & 1 & 5 & 6 & 4 & 10 & $0.42 / 0.26$ \\
\hline Bilateral & 154 & 28 & 71 & 46 & 145 & 127 & 163 & 290 & $0.90 / 0.67$ \\
\hline Completa & 125 & 22 & 56 & 41 & 119 & 100 & 138 & 238 & $0.90 / 0.91$ \\
\hline Incompleta & 8 & 0 & 4 & 4 & 8 & 4 & 12 & 16 & $0.17 / 0.16$ \\
\hline Incompleta + FP & 17 & 6 & 8 & 1 & 15 & 20 & 10 & 30 & $0.02 / 0.008$ \\
\hline Incompleta Mista & 4 & 0 & 3 & 1 & 4 & 3 & 5 & 8 & $0.51 / 0.78$ \\
\hline FL direita + FL/P esquerda & 3 & 0 & 2 & 1 & 3 & 2 & 4 & 6 & ---- \\
\hline FL esquerda + FP bilateral & 1 & 0 & 1 & 0 & 1 & 1 & 1 & 2 & --- \\
\hline Fissura Mediana & 2 & 0 & 0 & 1 & 1 & 0 & 2 & 2 & ---- \\
\hline Total FL/P & 406 & 79 & 161 & 143 & 383 & 319 & 447 & 766 & $0.09 / 0.75$ \\
\hline Tipo/lado desconhecido & 28 & 4 & 16 & 6 & 26 & 24 & 28 & 52 & ---- \\
\hline Total fissurados & 500 & 91 & 212 & 271 & 574 & 394 & 754 & 1148 & $0.00001 / 0.0001$ \\
\hline Sem fissura (Controles) & 500 & 85 & 237 & 158 & 480 & 407 & 553 & 960 & ---- \\
\hline
\end{tabular}


rs1058213 (C3827T) caucasianos

\begin{tabular}{|c|c|c|c|c|c|c|c|c|c|c|}
\hline & & $\mathrm{N}$ & & nótip & & & Alelo & & & \\
\hline Subfenótipo & & & $\mathrm{CC}$ & CT & TT & Total & C & $\mathrm{T}$ & Total & Pgen/Palelo \\
\hline Fissura Palat & & & & & & & & & & \\
\hline Completa & & 15 & 15 & 0 & 0 & 15 & 30 & 0 & 30 & $0.39 / 0.05$ \\
\hline Incompleta & & 38 & 0 & 0 & 3 & 3 & 0 & 6 & 6 & $0.77 / 0.00001$ \\
\hline & Total FP & 53 & 0 & 0 & 3 & 3 & 0 & 6 & 6 & $0.84 / 0.00001$ \\
\hline
\end{tabular}

Fissura Labial e/ou Palatina

\begin{tabular}{|c|c|c|c|c|c|c|c|c|c|}
\hline Completa & 237 & 215 & 3 & 10 & 228 & 433 & 23 & 456 & $0.39 / 0.51$ \\
\hline \multirow[t]{2}{*}{ Incompleta } & 86 & 77 & 0 & 5 & 82 & 154 & 10 & 164 & $0.76 / 0.95$ \\
\hline & & & & & 0 & 0 & 0 & 0 & \\
\hline Unilateral & 200 & 182 & 3 & 10 & 195 & 367 & 23 & 390 & $0.37 / 0.95$ \\
\hline Completa & 136 & 123 & 3 & 7 & 133 & 249 & 17 & 266 & $0.19 / 0.81$ \\
\hline Incompleta & 64 & 59 & 0 & 3 & 62 & 118 & 6 & 124 & $0.78 / 0.62$ \\
\hline Unilateral Direita & 60 & 56 & 0 & 1 & 57 & 112 & 2 & 114 & $0.37 / 0.06$ \\
\hline Completa & 43 & 42 & 0 & 0 & 42 & 84 & 0 & 84 & $0.08 / 0.001$ \\
\hline Incompleta & 11 & 9 & 0 & 1 & 10 & 18 & 2 & 20 & $0.83 / 0.46$ \\
\hline Incompleta + FP & 6 & 5 & 0 & 0 & 5 & 10 & 0 & 10 & $0.73 / 0.26$ \\
\hline Unilateral Esquerda & 140 & 126 & 3 & 9 & 138 & 255 & 21 & 276 & $0.19 / 0.37$ \\
\hline Completa & 93 & 81 & 3 & 7 & 91 & 165 & 17 & 182 & $0.05 / 0.11$ \\
\hline Incompleta & 44 & 42 & 0 & 2 & 44 & 84 & 4 & 88 & $0.81 / 0.59$ \\
\hline Incompleta + FP & 3 & 3 & 0 & 0 & 3 & 6 & 0 & 6 & $0.83 / 0.39$ \\
\hline Bilateral & 123 & 110 & 0 & 5 & 115 & 220 & 10 & 230 & $0.59 / 0.36$ \\
\hline Completa & 101 & 92 & 0 & 3 & 95 & 184 & 6 & 190 & $0.44 / 0.13$ \\
\hline Incompleta & 6 & 5 & 0 & 1 & 6 & 10 & 2 & 12 & $0.53 / 0.12$ \\
\hline Incompleta + FP & 13 & 11 & 0 & 0 & 11 & 22 & 0 & 22 & $0.50 / 0.10$ \\
\hline Incompleta Mista & 3 & 2 & 0 & 1 & 3 & 4 & 2 & 6 & $0.13 / 0.005$ \\
\hline FL direita + FL/P esquerda & 2 & 2 & 0 & 0 & 2 & 4 & 0 & 4 & ---- \\
\hline FL esquerda + FP bilateral & 1 & 0 & 0 & 1 & 1 & 0 & 2 & 2 & ---- \\
\hline Fissura Mediana & 1 & 1 & 0 & 0 & 1 & 2 & 0 & 2 & ---- \\
\hline Total FL/P & 324 & 293 & 3 & 18 & 314 & 589 & 39 & 628 & $0.68 / 0.86$ \\
\hline Tipo/lado desconhecido & 16 & 15 & 0 & 0 & 15 & 30 & 0 & 30 & ---- \\
\hline Total fissurados & 393 & 358 & 3 & 18 & 379 & 719 & 39 & 758 & $0.66 / 0.51$ \\
\hline Sem fissura (Controles) & 285 & 259 & 1 & 16 & 276 & 519 & 33 & 552 & ---- \\
\hline
\end{tabular}


rs2166975 (C3296T) caucasianos

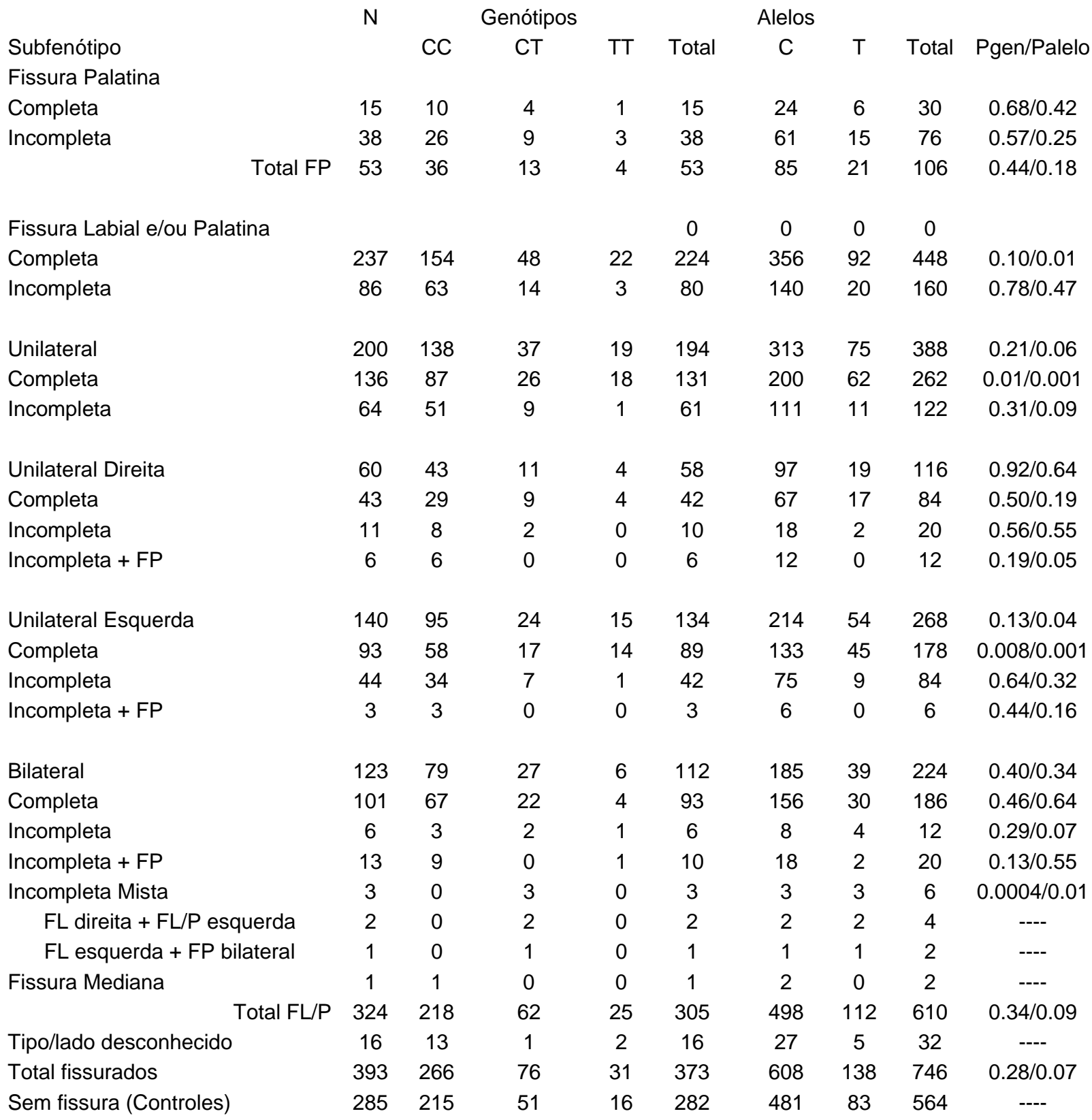


rs377122 caucasianos

Subfenótipo

Fissura Palatina

Completa
Incompleta

\begin{tabular}{cccccccccc} 
& N & \multicolumn{9}{c}{$\begin{array}{c}\text { Genótipos } \\
\end{array}$} & CC & CT & TT & Total & C & T & Total & Pgen/Palelo \\
& & & & & & & & & \\
Total FP & 53 & 2 & 10 & 3 & 15 & 14 & 16 & 30 & $0.68 / 0.72$ \\
& 38 & 7 & 27 & 4 & 38 & 41 & 35 & 76 & $0.17 / 0.51$ \\
& & 9 & 37 & 7 & 53 & 55 & 51 & 106 & $0.17 / 0.72$
\end{tabular}

Fissura Labial e/ou Palatina

\begin{tabular}{|c|c|c|c|c|c|c|c|c|c|}
\hline Completa & 237 & 50 & 108 & 72 & 230 & 208 & 252 & 460 & $0.04 / 0.12$ \\
\hline Incompleta & 86 & 11 & 41 & 32 & 84 & 63 & 105 & 168 & $0.007 / 0.004$ \\
\hline Unilateral & 200 & 34 & 93 & 69 & 196 & 161 & 231 & 392 & $0.005 / 0.006$ \\
\hline Completa & 136 & 29 & 59 & 46 & 134 & 117 & 151 & 268 & $0.01 / 0.08$ \\
\hline Incompleta & 64 & 5 & 34 & 23 & 62 & 44 & 80 & 124 & $0.007 / 0.003$ \\
\hline Unilateral Direita & 60 & 11 & 29 & 19 & 59 & 51 & 67 & 118 & $0.23 / 0.18$ \\
\hline Completa & 43 & 9 & 21 & 13 & 43 & 39 & 47 & 86 & $0.46 / 0.42$ \\
\hline Incompleta & 11 & 1 & 5 & 4 & 10 & 7 & 13 & 20 & $0.34 / 0.18$ \\
\hline Incompleta + FP & 6 & 1 & 3 & 2 & 6 & 5 & 7 & 12 & $0.79 / 0.56$ \\
\hline Unilateral Esquerda & 140 & 23 & 64 & 50 & 137 & 110 & 164 & 274 & $0.006 / 0.007$ \\
\hline Completa & 93 & 20 & 38 & 33 & 91 & 78 & 104 & 182 & $0.01 / 0.09$ \\
\hline Incompleta & 44 & 3 & 25 & 15 & 43 & 31 & 55 & 86 & $0.03 / 0.01$ \\
\hline Incompleta + FP & 3 & 0 & 1 & 2 & 3 & 1 & 5 & 6 & $0.16 / 0.10$ \\
\hline Bilateral & 123 & 27 & 56 & 35 & 118 & 110 & 126 & 236 & $0.18 / 0.38$ \\
\hline Completa & 101 & 21 & 49 & 26 & 96 & 91 & 101 & 192 & $0.54 / 0.53$ \\
\hline Incompleta & 6 & 1 & 1 & 4 & 6 & 3 & 9 & 12 & $0.03 / 0.08$ \\
\hline Incompleta + FP & 13 & 5 & 5 & 3 & 13 & 15 & 11 & 26 & $0.32 / 0.44$ \\
\hline Incompleta Mista & 3 & 0 & 1 & 2 & 3 & 1 & 5 & 6 & $0.16 / 0.10$ \\
\hline FL direita + FL/P esquerda & 2 & 0 & 0 & 2 & 2 & 0 & 4 & 4 & ---- \\
\hline FL esquerda + FP bilateral & 1 & 0 & 1 & 0 & 1 & 1 & 1 & 2 & ---- \\
\hline Fissura Mediana & 1 & 0 & 0 & 1 & 1 & 0 & 2 & 2 & ---- \\
\hline Total FL/P & 324 & 61 & 149 & 105 & 315 & 271 & 359 & 630 & $0.007 / 0.01$ \\
\hline Tipo/lado desconhecido & 16 & 5 & 9 & 0 & 14 & 19 & 9 & 28 & ---- \\
\hline Total fissurados & 393 & 75 & 195 & 112 & 382 & 345 & 419 & 764 & $0.09 / 0.07$ \\
\hline Sem fissura (Controles) & 285 & 62 & 160 & 62 & 284 & 284 & 284 & 568 & ---- \\
\hline
\end{tabular}


rs2902345 caucasianos

\begin{tabular}{|c|c|c|c|c|c|c|c|c|c|}
\hline \multirow[b]{2}{*}{ Subfenótipo } & \multirow[t]{2}{*}{$\mathrm{N}$} & \multicolumn{3}{|c|}{ Genótipos } & \multicolumn{3}{|c|}{ Alelos } & \multirow[b]{2}{*}{ Total } & \multirow[b]{2}{*}{ Pgen/Palelo } \\
\hline & & $\mathrm{CC}$ & CT & TT & Total & $\mathrm{C}$ & $\mathrm{T}$ & & \\
\hline \multicolumn{10}{|l|}{ Fissura Palatina } \\
\hline Completa & 15 & 4 & 7 & 4 & 15 & 15 & 15 & 30 & $0.77 / 0.56$ \\
\hline Incompleta & 38 & 10 & 6 & 3 & 19 & 26 & 12 & 38 & $0.11 / 0.11$ \\
\hline Total FP & 53 & 14 & 13 & 7 & 34 & 41 & 27 & 68 & $0.31 / 0.43$ \\
\hline \multicolumn{10}{|l|}{ Fissura Labial e/ou Palatina } \\
\hline Completa & 237 & 77 & 108 & 42 & 227 & 262 & 192 & 454 & $0.60 / 0.44$ \\
\hline Incompleta & 86 & 25 & 40 & 16 & 81 & 90 & 72 & 162 & $0.96 / 0.95$ \\
\hline Unilateral & 200 & 66 & 89 & 38 & 193 & 221 & 165 & 386 & $0.52 / 0.55$ \\
\hline Completa & 136 & 47 & 58 & 27 & 132 & 152 & 112 & 264 & $0.37 / 0.54$ \\
\hline Incompleta & 64 & 19 & 31 & 11 & 61 & 69 & 53 & 122 & $0.97 / 0.80$ \\
\hline Unilateral Direita & 60 & 19 & 31 & 8 & 58 & 69 & 47 & 116 & $0.62 / 0.41$ \\
\hline Completa & 43 & 14 & 22 & 6 & 42 & 50 & 34 & 84 & $0.73 / 0.46$ \\
\hline Incompleta & 11 & 5 & 5 & 0 & 10 & 15 & 5 & 20 & $0.20 / 0.08$ \\
\hline Incompleta + FP & 6 & 0 & 4 & 2 & 6 & 4 & 8 & 12 & $0.26 / 0.12$ \\
\hline Unilateral Esquerda & 140 & 47 & 58 & 30 & 135 & 152 & 118 & 270 & $0.30 / 0.79$ \\
\hline Completa & 93 & 33 & 36 & 21 & 90 & 102 & 78 & 180 & $0.18 / 0.75$ \\
\hline Incompleta & 44 & 13 & 21 & 8 & 42 & 47 & 37 & 84 & $0.98 / 0.91$ \\
\hline Incompleta + FP & 3 & 1 & 1 & 1 & 3 & 3 & 3 & 6 & $0.77 / 0.79$ \\
\hline Bilateral & 123 & 36 & 59 & 20 & 115 & 131 & 99 & 230 & $0.90 / 0.67$ \\
\hline Completa & 101 & 30 & 50 & 15 & 95 & 110 & 80 & 190 & $0.76 / 0.53$ \\
\hline Incompleta & 6 & 3 & 2 & 1 & 6 & 8 & 4 & 12 & $0.55 / 0.43$ \\
\hline Incompleta + FP & 13 & 2 & 6 & 3 & 11 & 10 & 12 & 22 & $0.65 / 0.36$ \\
\hline Incompleta Mista & 3 & 1 & 1 & 1 & 3 & 3 & 3 & 6 & $0.77 / 0.79$ \\
\hline FL direita + FL/P esquerda & 2 & 1 & 0 & 1 & 2 & 2 & 2 & 4 & ---- \\
\hline FL esquerda + FP bilateral & 1 & 0 & 1 & 0 & 1 & 1 & 1 & 2 & ---- \\
\hline Fissura Mediana & 1 & 1 & 0 & 0 & 1 & 2 & 0 & 2 & ---- \\
\hline Total FL/P & 324 & 103 & 14 & 58 & 175 & 220 & 130 & 350 & $0.00001 / 0.02$ \\
\hline Tipo/lado desconhecido & 16 & 3 & 9 & 3 & 15 & 15 & 15 & 30 & ---- \\
\hline Total fissurados & 393 & 120 & 170 & 68 & 358 & 410 & 306 & 716 & $0.64 / 0.48$ \\
\hline Sem fissura (Controles) & 285 & 84 & 144 & 54 & 282 & 312 & 252 & 564 & ---- \\
\hline
\end{tabular}


rs1523305 caucasianos

Subfenótipo

Fissura Palatina

Completa
Incompleta

\begin{tabular}{cccccccccc} 
& N & \multicolumn{9}{c}{ Genótipos } & \multicolumn{7}{c}{ Alelos } \\
& & CC & CT & TT & Total & C & T & Total & Pgen/Palelo \\
& & & & & & & & & \\
Total FP & 53 & 4 & 7 & 4 & 15 & 15 & 15 & 30 & $0.90 / 0.90$ \\
& 38 & 3 & 24 & 10 & 37 & 30 & 44 & 74 & $0.11 / 0.17$ \\
& & 7 & 31 & 14 & 52 & 45 & 59 & 104 & $0.32 / 0.28$
\end{tabular}

Fissura Labial e/ou Palatina

\begin{tabular}{|c|c|c|c|c|c|c|c|c|c|}
\hline Completa & 237 & 49 & 114 & 65 & 228 & 212 & 244 & 456 & $0.64 / 0.43$ \\
\hline Incompleta & 86 & 21 & 39 & 19 & 79 & 81 & 77 & 158 & $0.77 / 0.60$ \\
\hline Unilateral & 200 & 48 & 91 & 52 & 191 & 187 & 195 & 382 & $0.59 / 0.99$ \\
\hline Completa & 136 & 33 & 61 & 38 & 132 & 127 & 137 & 264 & $0.48 / 0.82$ \\
\hline Incompleta & 64 & 15 & 30 & 14 & 59 & 60 & 58 & 118 & $0.90 / 0.70$ \\
\hline Unilateral Direita & 60 & 15 & 31 & 12 & 58 & 61 & 55 & 116 & $0.75 / 0.47$ \\
\hline Completa & 43 & 13 & 21 & 9 & 43 & 47 & 39 & 86 & $0.54 / 0.32$ \\
\hline Incompleta & 11 & 1 & 6 & 3 & 10 & 8 & 12 & 20 & $0.63 / 0.43$ \\
\hline Incompleta + FP & 6 & 1 & 4 & 0 & 5 & 6 & 4 & 10 & $0.37 / 0.48$ \\
\hline Unilateral Esquerda & 140 & 33 & 60 & 40 & 133 & 126 & 140 & 266 & $0.35 / 0.67$ \\
\hline Completa & 93 & 20 & 40 & 29 & 89 & 80 & 98 & 178 & $0.31 / 0.35$ \\
\hline Incompleta & 44 & 12 & 18 & 11 & 41 & 42 & 40 & 82 & $0.54 / 0.69$ \\
\hline Incompleta + FP & 3 & 1 & 2 & 0 & 3 & 4 & 2 & 6 & $0.60 / 0.38$ \\
\hline Bilateral & 123 & 22 & 62 & 32 & 116 & 106 & 126 & 232 & $0.67 / 0.40$ \\
\hline Completa & 101 & 16 & 53 & 27 & 96 & 85 & 107 & 192 & $0.44 / 0.26$ \\
\hline Incompleta & 6 & 1 & 2 & 3 & 6 & 4 & 8 & 12 & $0.37 / 0.28$ \\
\hline Incompleta + FP & 13 & 4 & 6 & 1 & 11 & 14 & 8 & 22 & $0.37 / 0.17$ \\
\hline Incompleta Mista & 3 & 1 & 1 & 1 & 3 & 3 & 3 & 6 & $0.80 / 0.95$ \\
\hline FL direita + FL/P esquerda & 2 & 1 & 0 & 1 & 2 & 2 & 2 & 4 & ---- \\
\hline FL esquerda + FP bilateral & 1 & 0 & 1 & 0 & 1 & 1 & 1 & 2 & ---- \\
\hline Fissura Mediana & 1 & 0 & 0 & 1 & 1 & 0 & 2 & 2 & ---- \\
\hline Total FL/P & 324 & 70 & 153 & 85 & 308 & 293 & 323 & 616 & $0.71 / 0.63$ \\
\hline Tipo/lado desconhecido & 16 & 3 & 10 & 2 & 15 & 16 & 14 & 30 & ---- \\
\hline Total fissurados & 393 & 80 & 194 & 101 & 375 & 354 & 396 & 750 & $0.80 / 0.53$ \\
\hline Sem fissura (Controles) & 285 & 64 & 148 & 70 & 282 & 276 & 288 & 564 & ---- \\
\hline
\end{tabular}


rs930655 caucasianos

Subfenótipo

$\mathrm{N}$

Fissura Palatina

Completa

Incompleta

\begin{tabular}{cccccccccc} 
& N & \multicolumn{9}{c}{ Genótipos } & \multicolumn{7}{c}{ Alelos } \\
& & AA & AG & GG & Total & A & G & Total & Pgen/Palelo \\
& & & & & & & & & \\
Total FP & 53 & 7 & 4 & 15 & 15 & 15 & 30 & $0.74 / 0.48$ \\
& 38 & 2 & 23 & 13 & 38 & 27 & 49 & 76 & $0.10 / 0.18$ \\
& 53 & 30 & 17 & 53 & 42 & 64 & 106 & $0.37 / 0.45$
\end{tabular}

Fissura Labial e/ou Palatina

\begin{tabular}{|c|c|c|c|c|c|c|c|c|c|}
\hline Completa & 237 & 48 & 101 & 84 & 233 & 197 & 269 & 466 & $0.41 / 0.68$ \\
\hline Incompleta & 86 & 22 & 40 & 22 & 84 & 84 & 84 & 168 & $0.30 / 0.13$ \\
\hline Unilateral & 200 & 45 & 80 & 73 & 198 & 170 & 226 & 396 & $0.16 / 0.85$ \\
\hline Completa & 136 & 28 & 52 & 55 & 135 & 108 & 162 & 270 & $0.10 / 0.33$ \\
\hline Incompleta & 64 & 17 & 28 & 18 & 63 & 62 & 64 & 126 & $0.35 / 0.24$ \\
\hline Unilateral Direita & 60 & 13 & 21 & 25 & 59 & 47 & 71 & 118 & $0.15 / 0.46$ \\
\hline Completa & 43 & 8 & 17 & 18 & 43 & 33 & 53 & 86 & $0.40 / 0.36$ \\
\hline Incompleta & 11 & 2 & 3 & 5 & 10 & 7 & 13 & 20 & $0.42 / 0.45$ \\
\hline Incompleta + FP & 6 & 3 & 1 & 2 & 6 & 7 & 5 & 12 & $0.12 / 0.30$ \\
\hline Unilateral Esquerda & 140 & 32 & 59 & 48 & 139 & 123 & 155 & 278 & $0.39 / 0.83$ \\
\hline Completa & 93 & 20 & 35 & 37 & 92 & 75 & 109 & 184 & $0.17 / 0.51$ \\
\hline Incompleta & 44 & 11 & 22 & 11 & 44 & 44 & 44 & 88 & $0.52 / 0.25$ \\
\hline Incompleta + FP & 3 & 1 & 2 & 0 & 3 & 4 & 2 & 6 & $0.48 / 0.25$ \\
\hline Bilateral & 123 & 25 & 61 & 33 & 119 & 111 & 127 & 238 & $0.69 / 0.41$ \\
\hline Completa & 101 & 20 & 49 & 29 & 98 & 89 & 107 & 196 & $0.89 / 0.64$ \\
\hline Incompleta & 6 & 0 & 3 & 3 & 6 & 3 & 9 & 12 & $0.42 / 0.20$ \\
\hline Incompleta + FP & 13 & 5 & 7 & 0 & 12 & 17 & 7 & 24 & $0.02 / 0.008$ \\
\hline Incompleta Mista & 3 & 0 & 2 & 1 & 3 & 2 & 4 & 6 & $0.68 / 0.61$ \\
\hline FL direita + FL/P esquerda & 2 & 0 & 1 & 1 & 2 & 1 & 3 & 4 & ---- \\
\hline FL esquerda + FP bilateral & 1 & 0 & 1 & 0 & 1 & 1 & 1 & 2 & ---- \\
\hline Fissura Mediana & 1 & 0 & 0 & 1 & 1 & 0 & 2 & 2 & ---- \\
\hline Total FL/P & 324 & 70 & 141 & 107 & 318 & 281 & 355 & 636 & $0.45 / 0.81$ \\
\hline Tipo/lado desconhecido & 16 & 3 & 10 & 2 & 15 & 16 & 14 & 30 & ---- \\
\hline Total fissurados & 393 & 79 & 181 & 126 & 386 & 339 & 433 & 772 & $0.82 / 0.88$ \\
\hline Sem fissura (Controles) & 285 & 54 & 140 & 91 & 285 & 248 & 322 & 570 & ---- \\
\hline
\end{tabular}


rS2235371 (VAL274I)

Subfenótipo

Fissura Palatina

Completa

Incompleta

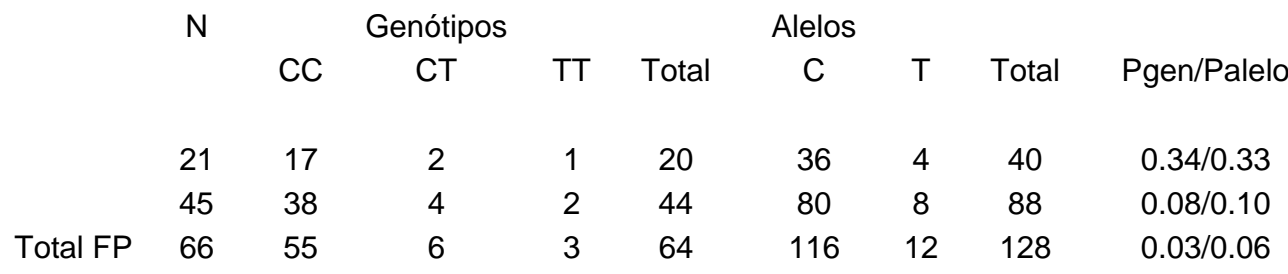

Fissura Labial e/ou Palatina

\begin{tabular}{|c|c|c|c|c|c|c|c|c|c|}
\hline \\
\hline Completa & 300 & 245 & 28 & 3 & 276 & 518 & 34 & 552 & $0.00001 †$ \\
\hline Incompleta & 104 & 91 & 6 & 0 & 97 & 188 & 6 & 194 & $0.00001 \dagger$ \\
\hline Unilateral & 250 & 209 & 19 & 3 & 231 & 437 & 25 & 462 & $0.00001 \dagger$ \\
\hline Completa & 175 & 142 & 15 & 3 & 160 & 299 & 21 & 320 & $0.0001 / 0.00001$ \\
\hline Incompleta & 75 & 67 & 4 & 0 & 71 & 138 & 4 & 142 & $0.0003 / 0.00001$ \\
\hline Unilateral Direita & 78 & 68 & 5 & 1 & 74 & 141 & 7 & 148 & $0.001 / 0.0004$ \\
\hline Completa & 54 & 46 & 4 & 1 & 51 & 96 & 6 & 102 & $0.02 / 00.008$ \\
\hline Incompleta & 16 & 14 & 1 & 0 & 15 & 29 & 1 & 30 & $0.19 / 0.06$ \\
\hline Incompleta + FP & 8 & 8 & 0 & 0 & 8 & 16 & 0 & 16 & $0.22 / 0.08$ \\
\hline Unilateral Esquerda & 172 & 141 & 14 & 2 & 157 & 296 & 18 & 314 & $0.00001 \dagger$ \\
\hline Completa & 121 & 96 & 11 & 2 & 109 & 203 & 15 & 218 & $0.003 / 0.0008$ \\
\hline Incompleta & 46 & 41 & 2 & 0 & 43 & 84 & 2 & 86 & $0.004 / 0.0008$ \\
\hline Incompleta + FP & 5 & 4 & 1 & 0 & 5 & 9 & 1 & 10 & $0.88 / 0.62$ \\
\hline Bilateral & 154 & 127 & 15 & 1 & 143 & 269 & 17 & 286 & $0.0002 / 0.00001$ \\
\hline Completa & 125 & 103 & 13 & 1 & 117 & 219 & 15 & 234 & $0.002 / 0.0002$ \\
\hline Incompleta & 8 & 8 & 0 & 0 & 8 & 16 & 0 & 16 & $0.22 / 0.08$ \\
\hline Incompleta + FP & 17 & 12 & 2 & 0 & 14 & 26 & 2 & 28 & $0.50 / 0.22$ \\
\hline Incompleta Mista & 4 & 4 & 0 & 0 & 4 & 8 & 0 & 8 & $0.47 / 0.09$ \\
\hline FL direita + FL/P esquerda & 3 & 3 & 0 & 0 & 3 & 6 & 0 & 6 & ---- \\
\hline FL esquerda + FP bilateral & 1 & 1 & 0 & 0 & 1 & 2 & 0 & 2 & ---- \\
\hline Fissura Mediana & 2 & 1 & 0 & 0 & 1 & 2 & 0 & 2 & --- \\
\hline Total FL/P & 406 & 336 & 34 & 3 & 373 & 706 & 40 & 746 & $0.00001 \dagger$ \\
\hline Tipo/lado desconhecido & 28 & 21 & 3 & 1 & 25 & 45 & 5 & 50 & ---- \\
\hline Total fissurados & 500 & 413 & 43 & 7 & 463 & 869 & 57 & 926 & $0.00001 \dagger$ \\
\hline Sem fissura (Controles) & 500 & 344 & 114 & 17 & 475 & 802 & 148 & 950 & ---- \\
\hline
\end{tabular}


rs2013162

\begin{tabular}{|c|c|c|c|c|c|c|c|c|c|}
\hline \multirow[b]{2}{*}{ Subfenótipo } & \multirow[t]{2}{*}{$\mathrm{N}$} & \multicolumn{3}{|c|}{ Genótipos } & \multicolumn{3}{|c|}{ Alelos } & \multirow[b]{2}{*}{ Total } & \multirow[b]{2}{*}{ Pgen/Palelo } \\
\hline & & $\mathrm{CC}$ & CT & TT & Total & $\mathrm{C}$ & $\mathrm{T}$ & & \\
\hline \multicolumn{10}{|l|}{ Fissura Palatina } \\
\hline Completa & 21 & 6 & 7 & 7 & 20 & 19 & 21 & 40 & $0.46 / 0.60$ \\
\hline Incompleta & 45 & 8 & 22 & 15 & 45 & 38 & 52 & 90 & $0.93 / 0.83$ \\
\hline Total FP & 66 & 14 & 29 & 22 & 65 & 57 & 73 & 130 & $0.93 / 0.92$ \\
\hline \multicolumn{10}{|l|}{ Fissura Labial e/ou Palatina } \\
\hline Completa & 300 & 31 & 128 & 117 & 276 & 190 & 362 & 552 & $0.002 / 0.0006$ \\
\hline Incompleta & 104 & 8 & 41 & 49 & 98 & 57 & 139 & 196 & $0.001 / 0.002$ \\
\hline Unilateral & 250 & 22 & 110 & 101 & 233 & 154 & 312 & 466 & $0.0005 / 0.0001$ \\
\hline Completa & 175 & 15 & 79 & 67 & 161 & 109 & 213 & 322 & $0.005 / 0.002$ \\
\hline Incompleta & 75 & 7 & 31 & 34 & 72 & 45 & 99 & 144 & $0.03 / 0.005$ \\
\hline Unilateral Direita & 78 & 7 & 32 & 35 & 74 & 46 & 102 & 148 & $0.02 / 0.004$ \\
\hline Completa & 54 & 4 & 23 & 24 & 51 & 31 & 71 & 102 & $0.04 / 0.01$ \\
\hline Incompleta & 16 & 3 & 6 & 6 & 15 & 12 & 18 & 30 & $0.84 / 0.71$ \\
\hline Incompleta + FP & 8 & 0 & 3 & 5 & 8 & 3 & 13 & 16 & $0.15 / 0.04$ \\
\hline Unilateral Esquerda & 172 & 15 & 78 & 66 & 159 & 108 & 210 & 318 & $0.006 / 0.003$ \\
\hline Completa & 121 & 11 & 56 & 43 & 110 & 78 & 142 & 220 & $0.05 / 0.03$ \\
\hline Incompleta & 46 & 2 & 20 & 22 & 44 & 24 & 64 & 88 & $0.01 / 0.003$ \\
\hline Incompleta + FP & 5 & 2 & 2 & 1 & 5 & 6 & 4 & 10 & $0.52 / 0.29$ \\
\hline Bilateral & 154 & 17 & 59 & 65 & 141 & 93 & 189 & 282 & $0.009 / 0.001$ \\
\hline Completa & 125 & 16 & 49 & 50 & 115 & 81 & 149 & 230 & $0.08 / 0.02$ \\
\hline Incompleta & 8 & 1 & 3 & 4 & 8 & 5 & 11 & 16 & $0.59 / 0.33$ \\
\hline Incompleta + FP & 17 & 0 & 6 & 8 & 14 & 6 & 22 & 28 & $0.07 / 0.02$ \\
\hline Incompleta Mista & 4 & 0 & 1 & 3 & 4 & 1 & 7 & 8 & $0.19 / 0.07$ \\
\hline FL direita + FL/P esquerda & 3 & 0 & 0 & 3 & 3 & 0 & 6 & 6 & ---- \\
\hline FL esquerda + FP bilateral & 1 & 0 & 1 & 0 & 1 & 1 & 1 & 2 & ---- \\
\hline Fissura Mediana & 2 & 0 & 0 & 1 & 1 & 0 & 2 & 2 & ---- \\
\hline Total FL/P & 406 & 39 & 169 & 166 & 374 & 247 & 501 & 748 & $0.00001 \dagger$ \\
\hline Tipo/lado desconhecido & 28 & 6 & 13 & 6 & 25 & 25 & 25 & 50 & ---- \\
\hline Total fissurados & 500 & 59 & 211 & 195 & 465 & 329 & 601 & 930 & $0.002 / 0.003$ \\
\hline Sem fissura (Controles) & 500 & 95 & 223 & 158 & 476 & 413 & 539 & 952 & ---- \\
\hline
\end{tabular}


rs2073487

Subfenótipo

$\mathrm{N}$

Fissura Palatina

Completa

Incompleta

\begin{tabular}{cccccccccc} 
& N & \multicolumn{9}{c}{ Genótipos } & \multicolumn{7}{c}{ Alelos } \\
& & CC & CT & TT & Total & C & T & Total & Pgen/Palelo \\
& & & & & & & & & \\
Total FP & 61 & 6 & 7 & 7 & 20 & 19 & 21 & 40 & $0.46 / 0.60$ \\
& 45 & 8 & 21 & 15 & 44 & 37 & 51 & 88 & $0.96 / 0.80$ \\
& 66 & 14 & 28 & 22 & 64 & 56 & 72 & 128 & $0.88 / 0.93$
\end{tabular}

Fissura Labial e/ou Palatina

\begin{tabular}{|c|c|c|c|c|c|c|c|c|c|}
\hline Completa & 300 & 30 & 128 & 119 & 277 & 188 & 366 & 554 & $0.001 / 0.0002$ \\
\hline Incompleta & 104 & 8 & 40 & 49 & 97 & 56 & 138 & 194 & $0.001 / 0.0001$ \\
\hline Unilateral & 250 & 22 & 108 & 102 & 232 & 152 & 312 & 464 & $0.0004 / 0.0001$ \\
\hline Completa & 175 & 15 & 78 & 68 & 161 & 108 & 214 & 322 & $0.005 / 0.001$ \\
\hline Incompleta & 75 & 7 & 30 & 34 & 71 & 44 & 98 & 142 & $0.02 / 0.005$ \\
\hline Unilateral Direita & 78 & 7 & 32 & 35 & 74 & 46 & 102 & 148 & $0.02 / 0.004$ \\
\hline Completa & 54 & 4 & 23 & 24 & 51 & 31 & 71 & 102 & $0.05 / 0.01$ \\
\hline Incompleta & 16 & 3 & 6 & 6 & 15 & 12 & 18 & 30 & $0.84 / 0.71$ \\
\hline Incompleta + FP & 8 & 0 & 3 & 5 & 8 & 3 & 13 & 16 & $0.15 / 0.04$ \\
\hline Unilateral Esquerda & 172 & 15 & 76 & 67 & 158 & 106 & 210 & 316 & $0.005 / 0.002$ \\
\hline Completa & 121 & 11 & 55 & 44 & 110 & 77 & 143 & 220 & $0.04 / 0.02$ \\
\hline Incompleta & 46 & 2 & 19 & 22 & 43 & 23 & 63 & 86 & $0.01 / 0.002$ \\
\hline Incompleta + FP & 5 & 2 & 2 & 1 & 5 & 6 & 4 & 10 & $0.52 / 0.29$ \\
\hline Bilateral & 154 & 16 & 60 & 66 & 142 & 92 & 192 & 284 & $0.005 / 0.0009$ \\
\hline Completa & 125 & 15 & 50 & 51 & 116 & 80 & 152 & 232 & $0.05 / 0.01$ \\
\hline Incompleta & 8 & 1 & 3 & 4 & 8 & 5 & 11 & 16 & $0.59 / 0.33$ \\
\hline Incompleta + FP & 17 & 0 & 6 & 8 & 14 & 6 & 22 & 28 & $0.07 / 0.02$ \\
\hline Incompleta Mista & 4 & 0 & 1 & 3 & 4 & 1 & 7 & 8 & $0.19 / 0.07$ \\
\hline FL direita + FL/P esquerda & 3 & 0 & 0 & 3 & 3 & 0 & 6 & 6 & ---- \\
\hline FL esquerda + FP bilateral & 1 & 0 & 1 & 0 & 1 & 1 & 1 & 2 & ---- \\
\hline Fissura Mediana & 2 & 0 & 0 & 1 & 1 & 0 & 2 & 2 & ---- \\
\hline Total FL/P & 406 & 38 & 168 & 168 & 374 & 244 & 504 & 748 & $0.00001 \dagger$ \\
\hline Tipo/lado desconhecido & 28 & 6 & 13 & 6 & 25 & 25 & 25 & 50 & ---- \\
\hline Total fissurados & 500 & 58 & 209 & 197 & 464 & 325 & 603 & 928 & $0.001 / 0.0001$ \\
\hline Sem fissura (Controles) & 500 & 95 & 224 & 158 & 477 & 414 & 540 & 954 & ---- \\
\hline
\end{tabular}


rs4844880

Subfenótipo

Fissura Palatina

Completa

Incompleta

\begin{tabular}{cccccccccc} 
& N & \multicolumn{9}{c}{$\begin{array}{c}\text { Genótipos } \\
\end{array}$} & & AA & AT & TT & Total & A & T & Total & Pgen/Palelo \\
& & & & & & & & & \\
Total FP & 61 & 3 & 4 & 13 & 20 & 10 & 30 & 40 & $0.25 / 0.35$ \\
& 45 & 3 & 19 & 23 & 45 & 25 & 65 & 90 & $0.47 / 0.41$ \\
& 66 & 6 & 23 & 36 & 65 & 35 & 95 & 130 & $0.54 / 0.24$
\end{tabular}

Fissura Labial e/ou Palatina

Completa

Incompleta

Unilateral
Completa
Incompleta
Unilateral Direita
Completa
Incompleta
Incompleta + FP

\begin{tabular}{|c|c|c|c|c|c|c|c|c|c|}
\hline Unilateral Esquerda & 172 & 10 & 61 & 92 & 163 & 81 & 245 & 326 & $0.04 / 0.01$ \\
\hline Completa & 121 & 9 & 46 & 57 & 112 & 64 & 160 & 224 & $0.35 / 0.32$ \\
\hline Incompleta & 46 & 1 & 13 & 32 & 46 & 15 & 77 & 92 & $0.01 / 0.001$ \\
\hline Incompleta + FP & 5 & 0 & 2 & 3 & 5 & 2 & 8 & 10 & $0.68 / 0.41$ \\
\hline Bilateral & 154 & 9 & 63 & 76 & 148 & 81 & 215 & 296 & $0.07 / 0.13$ \\
\hline Completa & 125 & 8 & 52 & 62 & 122 & 68 & 176 & 244 & $0.14 / 0.21$ \\
\hline Incompleta & 8 & 1 & 1 & 6 & 8 & 3 & 13 & 16 & $0.29 / 0.25$ \\
\hline Incompleta + FP & 17 & 0 & 8 & 8 & 16 & 8 & 24 & 32 & $0.27 / 0.40$ \\
\hline Incompleta Mista & 4 & 0 & 2 & 2 & 4 & 2 & 6 & 8 & $0.72 / 0.67$ \\
\hline FL direita + FL/P esquerda & 3 & 0 & 2 & 1 & 3 & 2 & 4 & 6 & ---- \\
\hline FL esquerda + FP bilateral & 1 & 0 & 0 & 1 & 1 & 0 & 2 & 2 & ---- \\
\hline Fissura Mediana & 2 & 0 & 0 & 1 & 1 & 0 & 2 & 2 & ---- \\
\hline Total FL/P & 406 & 24 & 153 & 224 & 401 & 201 & 601 & 802 & $0.002 / 0.001$ \\
\hline Tipo/lado desconhecido & 28 & 3 & 7 & 16 & 26 & 13 & 39 & 52 & ---- \\
\hline Total fissurados & 500 & 33 & 183 & 276 & 492 & 249 & 735 & 984 & $0.002 / 0.001$ \\
\hline Sem fissura (Controles) & 500 & 62 & 183 & 235 & 480 & 307 & 653 & 960 & ---- \\
\hline
\end{tabular}

$\begin{array}{ccccccccc}300 & 20 & 119 & 146 & 285 & 159 & 411 & 570 & 0.04 / 0.09 \\ 104 & 4 & 34 & 77 & 115 & 42 & 188 & 230 & 0.00005 / 0.00001\end{array}$

$\begin{array}{ccccccccc}250 & 15 & 100 & 135 & 250 & 130 & 370 & 500 & 0.01 / 0.01 \\ 175 & 12 & 67 & 84 & 163 & 91 & 235 & 326 & 0.16 / 0.17 \\ 75 & 3 & 23 & 51 & 77 & 29 & 125 & 154 & 0.008 / 0.0009\end{array}$

$\begin{array}{lllllllll}78 & 5 & 27 & 43 & 75 & 37 & 113 & 150 & 0.21 / 0.07\end{array}$

$\begin{array}{lllllllll}54 & 3 & 21 & 27 & 51 & 27 & 75 & 102 & 0.34 / 0.25\end{array}$

$\begin{array}{lllllllll}16 & 1 & 4 & 11 & 16 & 6 & 26 & 32 & 0.29 / 0.11\end{array}$

$\begin{array}{lllllllll}8 & 1 & 2 & 5 & 8 & 4 & 12 & 16 & 0.72 / 0.55\end{array}$

$172010 \quad 6100.020 .01$


rs658860

Subfenótipo

Fissura Palatina

Completa

Incompleta

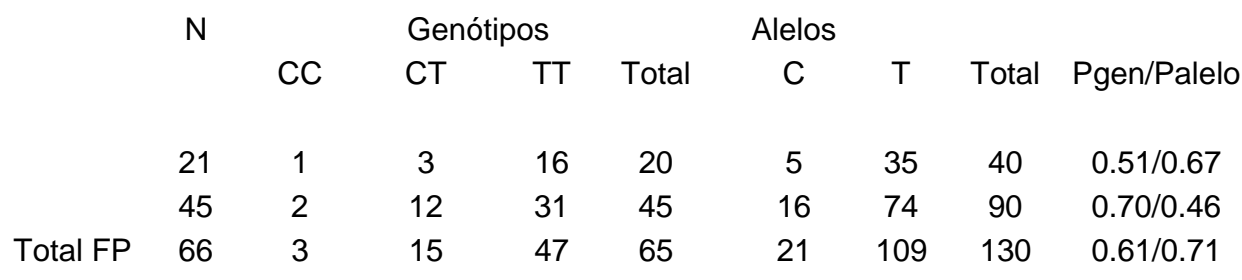

Fissura Labial e/ou Palatina

\begin{tabular}{|c|c|c|c|c|c|c|c|c|c|}
\hline Completa & 300 & 11 & 83 & 185 & 279 & 105 & 453 & 558 & $0.15 / 0.04$ \\
\hline Incompleta & 104 & 3 & 29 & 67 & 99 & 35 & 163 & 198 & $0.60 / 0.32$ \\
\hline Unilateral & 250 & 5 & 69 & 161 & 235 & 79 & 391 & 470 & $0.42 / 0.35$ \\
\hline Completa & 175 & 4 & 48 & 110 & 162 & 56 & 268 & 324 & $0.48 / 0.30$ \\
\hline Incompleta & 75 & 1 & 21 & 51 & 73 & 23 & 123 & 146 & $0.66 / 0.79$ \\
\hline Unilateral Direita & 78 & 2 & 13 & 60 & 75 & 17 & 133 & 150 & $0.37 / 0.24$ \\
\hline Completa & 54 & 1 & 10 & 40 & 51 & 12 & 90 & 102 & $0.68 / 0.39$ \\
\hline Incompleta & 16 & 0 & 3 & 13 & 16 & 3 & 29 & 32 & $0.67 / 0.38$ \\
\hline Incompleta + FP & 8 & 1 & 0 & 7 & 8 & 2 & 14 & 16 & $0.07 / 0.78$ \\
\hline Unilateral Esquerda & 172 & 3 & 56 & 101 & 160 & 62 & 258 & 320 & $0.04 / 0.06$ \\
\hline Completa & 121 & 3 & 38 & 70 & 111 & 44 & 178 & 222 & $0.12 / 0.07$ \\
\hline Incompleta & 46 & 0 & 17 & 27 & 44 & 17 & 71 & 88 & $0.09 / 0.27$ \\
\hline Incompleta + FP & 5 & 0 & 1 & 4 & 5 & 1 & 9 & 10 & $0.90 / 0.66$ \\
\hline Bilateral & 154 & 9 & 43 & 91 & 143 & 61 & 225 & 286 & $0.03 / 0.01$ \\
\hline Completa & 125 & 7 & 35 & 75 & 117 & 49 & 185 & 234 & $0.06 / 0.02$ \\
\hline Incompleta & 8 & 0 & 2 & 6 & 8 & 2 & 14 & 16 & $0.90 / 0.78$ \\
\hline Incompleta + FP & 17 & 2 & 5 & 7 & 14 & 9 & 19 & 28 & $0.02 / 0.01$ \\
\hline Incompleta Mista & 4 & 0 & 1 & 3 & 4 & 1 & 7 & 8 & $0.95 / 0.84$ \\
\hline FL direita + FL/P esquerda & 3 & 0 & 1 & 2 & 3 & 1 & 5 & 6 & ---- \\
\hline FL esquerda + FP bilateral & 1 & 0 & 0 & 1 & 1 & 0 & 2 & 2 & ---- \\
\hline Fissura Mediana & 2 & 0 & 0 & 1 & 1 & 0 & 2 & 2 & --- \\
\hline Total FL/P & 406 & 14 & 112 & 253 & 379 & 140 & 618 & 758 & $0.15 / 0.04$ \\
\hline Tipo/lado desconhecido & 28 & 0 & 3 & 23 & 26 & 3 & 49 & 52 & -.-- \\
\hline Total fissurados & 500 & 17 & 130 & 323 & 470 & 164 & 776 & 940 & $0.33 / 0.13$ \\
\hline Sem fissura (Controles) & 500 & 12 & 118 & 346 & 476 & 142 & 810 & 952 & --- \\
\hline
\end{tabular}


rs861019

Subfenótipo

Fissura Palatina

Completa

Incompleta

\begin{tabular}{|c|c|c|c|c|c|c|c|c|c|}
\hline \multicolumn{2}{|r|}{$\mathrm{N}$} & \multicolumn{3}{|c|}{ Genótipos } & \multicolumn{3}{|c|}{ Alelos } & \multirow[b]{2}{*}{ Total } & \multirow[b]{2}{*}{ Pgen/Palelo } \\
\hline & & AA & AG & GG & Total & A & G & & \\
\hline & 21 & 10 & 7 & 3 & 20 & 27 & 13 & 40 & $0.37 / 0.24$ \\
\hline & 45 & 17 & 19 & 8 & 44 & 53 & 35 & 88 & $0.86 / 0.70$ \\
\hline tal FP & 66 & 27 & 26 & 11 & 64 & 80 & 48 & 128 & $0.49 / 0.34$ \\
\hline
\end{tabular}

Fissura Labial e/ou Palatina

$\begin{array}{lccccccccc}\text { Completa } & 300 & 80 & 132 & 69 & 281 & 292 & 270 & 562 & 0.07 / 0.01 \\ \text { Incompleta } & 104 & 25 & 54 & 20 & 99 & 104 & 94 & 198 & 0.18 / 0.14 \\ & & & & & & & & & \\ \text { Unilateral } & & & & & & & & & \\ \text { Completa } & 250 & 59 & 127 & 51 & 237 & 245 & 229 & 474 & 0.03 / 0.02 \\ \text { Incompleta } & 175 & 42 & 85 & 37 & 164 & 169 & 159 & 328 & 0.09 / 0.03 \\ & 75 & 17 & 42 & 14 & 73 & 76 & 70 & 146 & 0.13 / 0.16 \\ \text { Unilateral Direita } & & & & & & & & & \\ \text { Completa } & 78 & 19 & 41 & 16 & 76 & 79 & 73 & 152 & 0.25 / 0.15 \\ \text { Incompleta } & 54 & 11 & 30 & 11 & 52 & 52 & 52 & 104 & 0.14 / 0.11 \\ \text { Incompleta + FP } & 16 & 5 & 9 & 2 & 16 & 19 & 13 & 32 & 0.72 / 0.89 \\ & 8 & 3 & 2 & 3 & 8 & 8 & 8 & 16 & 0.31 / 0.51 \\ \text { Unilateral Esquerda } & & & & & & & & & \\ \text { Completa } & 172 & 40 & 86 & 35 & 161 & 166 & 156 & 322 & 0.07 / 0.03 \\ \text { Incompleta } & 121 & 31 & 55 & 26 & 112 & 117 & 107 & 224 & 0.28 / 0.10 \\ \text { Incompleta + FP } & 46 & 9 & 28 & 7 & 44 & 46 & 42 & 88 & 0.08 / 0.28 \\ & 5 & 0 & 3 & 2 & 5 & 3 & 7 & 10 & 0.20 / 0.07 \\ \text { Bilateral } & & & & & & & & & \\ \text { Completa } & 154 & 46 & 59 & 38 & 143 & 151 & 135 & 286 & 0.10 / 0.10 \\ \text { Incompleta } & 125 & 38 & 47 & 32 & 117 & 123 & 111 & 234 & 0.09 / 0.12 \\ \text { Incompleta + FP } & 8 & 3 & 2 & 3 & 8 & 8 & 8 & 16 & 0.31 / 0.51 \\ \text { Incompleta Mista } & 17 & 5 & 7 & 2 & 14 & 17 & 11 & 28 & 0.92 / 0.78 \\ \quad \text { FL direita + FL/P esquerda } & 4 & 0 & 3 & 1 & 4 & 3 & 5 & 8 & 0.34 / 0.23 \\ \quad \text { FL esquerda + FP bilateral } & 1 & 0 & 2 & 1 & 3 & 2 & 4 & 6 & ---- \\ \text { Fissura Mediana } & 2 & 0 & 1 & 0 & 1 & 1 & 1 & 2 & ---- \\ & 506 & 125 & 187 & 89 & 401 & 437 & 365 & 802 & 0.30 / 0.12 \\ \text { Tipo/lado desconhecido } & 28 & 9 & 11 & 5 & 25 & 29 & 21 & 50 & ---- \\ \text { Total fissurados } & 500 & 161 & 224 & 105 & 490 & 546 & 434 & 980 & 0.49 / 0.27 \\ \text { Sem fissura (Controles) } & 500 & 166 & 224 & 88 & 478 & 556 & 400 & 956 & ----\end{array}$


rs2235371 (VAL274I) Caucasianos

Subfenótipo
Fissura Palatina
Completa
Incompleta

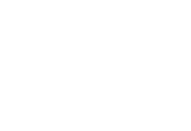

N

$\begin{array}{ccc} & 15 & 1 \\ & 38 & 3 \\ \text { Total FP } & 53 & 4\end{array}$

Fissura Labial e/ou Palatina

\begin{tabular}{|c|c|c|c|c|c|c|c|c|c|}
\hline \\
\hline Completa & 237 & 206 & 22 & 2 & 230 & 434 & 26 & 460 & $0.65 / 0.46$ \\
\hline Incompleta & 86 & 76 & 1 & 0 & 77 & 153 & 1 & 154 & $0.14 / 0.003$ \\
\hline Unilateral & 200 & 176 & 14 & 2 & 192 & 366 & 18 & 384 & $0.22 / 0.18$ \\
\hline Completa & 136 & 120 & 12 & 2 & 134 & 252 & 16 & 268 & $0.49 / 0.66$ \\
\hline Incompleta & 64 & 56 & 4 & 0 & 60 & 116 & 4 & 120 & $0.38 / 0.15$ \\
\hline Unilateral Direita & 60 & 54 & 4 & 1 & 59 & 112 & 6 & 118 & $0.39 / 0.50$ \\
\hline Completa & 43 & 39 & 3 & 1 & 43 & 81 & 5 & 86 & $0.37 / 0.74$ \\
\hline Incompleta & 11 & 9 & 1 & 0 & 10 & 19 & 1 & 20 & $0.94 / 0.75$ \\
\hline Incompleta + FP & 6 & 6 & 0 & 0 & 6 & 12 & 0 & 12 & $0.64 / 0.19$ \\
\hline Unilateral Esquerda & 140 & 122 & 12 & 1 & 135 & 256 & 14 & 270 & $0.62 / 0.37$ \\
\hline Completa & 93 & 81 & 9 & 1 & 91 & 171 & 11 & 182 & $0.80 / 0.73$ \\
\hline Incompleta & 44 & 39 & 2 & 0 & 41 & 80 & 2 & 82 & $0.33 / 0.12$ \\
\hline Incompleta + FP & 3 & 2 & 1 & 0 & 3 & 5 & 1 & 6 & $0.53 / 0.33$ \\
\hline Bilateral & 123 & 106 & 10 & 0 & 116 & 222 & 10 & 232 & $0.39 / 0.18$ \\
\hline Completa & 101 & 86 & 10 & 0 & 96 & 182 & 10 & 192 & $0.64 / 0.44$ \\
\hline Incompleta & 6 & 6 & 0 & 0 & 6 & 12 & 0 & 12 & $0.64 / 0.19$ \\
\hline Incompleta + FP & 13 & 11 & 0 & 0 & 11 & 22 & 0 & 22 & $0.45 / 0.08$ \\
\hline Incompleta Mista & 3 & 3 & 0 & 0 & 3 & 6 & 0 & 6 & $0.80 / 0.36$ \\
\hline FL direita + FL/P esquerda & 2 & 2 & 0 & 0 & 2 & 4 & 0 & 4 & ---- \\
\hline FL esquerda + FP bilateral & 1 & 1 & 0 & 0 & 1 & 2 & 0 & 2 & ---- \\
\hline Fissura Mediana & 1 & 1 & 0 & 0 & 1 & 2 & 0 & 2 & ---- \\
\hline Total FL/P & 324 & 283 & 26 & 2 & 311 & 592 & 30 & 622 & $0.32 / 0.15$ \\
\hline Tipo/lado desconhecido & & 13 & 1 & 0 & 14 & 27 & 1 & 28 & ---- \\
\hline Total fissurados & 377 & 340 & 32 & 5 & 377 & 712 & 42 & 754 & $0.24 / 0.37$ \\
\hline Sem fissura (Controles) & 285 & 245 & 34 & 2 & 281 & 524 & 38 & 562 & ---- \\
\hline
\end{tabular}


rs2013162 Caucasianos

\begin{tabular}{|c|c|c|c|c|c|c|c|c|c|}
\hline \multirow[b]{2}{*}{ Subfenótipo } & \multirow[t]{2}{*}{$\mathrm{N}$} & \multicolumn{3}{|c|}{ Genótipos } & \multicolumn{3}{|c|}{ Alelos } & \multirow[b]{2}{*}{ Total } & \multirow[b]{2}{*}{ Pgen/Palelc } \\
\hline & & $\mathrm{CC}$ & CT & TT & Total & C & $\mathrm{T}$ & & \\
\hline \multicolumn{10}{|l|}{ Fissura Palatina } \\
\hline Completa & 15 & 5 & 6 & 4 & 15 & 16 & 14 & 30 & $0.18 / 0.10$ \\
\hline Incompleta & 38 & 8 & 19 & 11 & 38 & 35 & 41 & 76 & $0.43 / 0.19$ \\
\hline Total FP & 53 & 13 & 25 & 15 & 53 & 51 & 55 & 106 & $0.17 / 0.05$ \\
\hline \multicolumn{10}{|l|}{ Fissura Labial e/ou Palatina } \\
\hline Completa & 237 & 22 & 107 & 99 & 228 & 151 & 305 & 456 & $0.13 / 0.08$ \\
\hline Incompleta & 86 & 5 & 33 & 43 & 81 & 43 & 119 & 162 & $0.02 / 0.005$ \\
\hline Unilateral & 200 & 15 & 95 & 85 & 195 & 125 & 265 & 390 & $0.03 / 0.04$ \\
\hline Completa & 136 & 10 & 69 & 55 & 134 & 89 & 179 & 268 & $0.06 / 0.15$ \\
\hline Incompleta & 64 & 5 & 26 & 30 & 61 & 36 & 86 & 122 & $0.19 / 0.06$ \\
\hline Unilateral Direita & 60 & 5 & 29 & 25 & 59 & 39 & 79 & 118 & $0.36 / 0.28$ \\
\hline Completa & 43 & 3 & 23 & 17 & 43 & 29 & 57 & 86 & $0.29 / 0.41$ \\
\hline Incompleta & 11 & 2 & 3 & 5 & 10 & 7 & 13 & 20 & $0.63 / 0.76$ \\
\hline Incompleta + FP & 6 & 0 & 3 & 3 & 6 & 3 & 9 & 12 & $0.56 / 0.34$ \\
\hline Unilateral Esquerda & 140 & 10 & 66 & 60 & 136 & 86 & 186 & 272 & $0.06 / 0.05$ \\
\hline Completa & 93 & 7 & 46 & 38 & 91 & 60 & 122 & 182 & $0.16 / 0.19$ \\
\hline Incompleta & 44 & 2 & 19 & 21 & 42 & 23 & 61 & 84 & $0.13 / 0.05$ \\
\hline Incompleta + FP & 3 & 1 & 1 & 1 & 3 & 3 & 3 & 6 & $0.70 / 0.55$ \\
\hline Bilateral & 123 & 12 & 45 & 55 & 112 & 69 & 155 & 224 & $0.15 / 0.04$ \\
\hline Completa & 101 & 12 & 38 & 44 & 94 & 62 & 126 & 188 & $0.40 / 0.19$ \\
\hline Incompleta & 6 & 0 & 2 & 4 & 6 & 2 & 10 & 12 & $0.32 / 0.12$ \\
\hline Incompleta + FP & 13 & 0 & 4 & 7 & 11 & 4 & 18 & 22 & $0.17 / 0.05$ \\
\hline Incompleta Mista & 3 & 0 & 1 & 2 & 3 & 1 & 5 & 6 & $0.56 / 0.27$ \\
\hline FL direita + FL/P esquerda & 2 & 0 & 0 & 2 & 2 & 0 & 4 & 4 & ---- \\
\hline FL esquerda + FP bilateral & 1 & 0 & 1 & 0 & 1 & 1 & 1 & 2 & ---- \\
\hline Fissura Mediana & 1 & 0 & 0 & 1 & 1 & 0 & 2 & 2 & ---- \\
\hline Total FL/P & 324 & 27 & 140 & 143 & 310 & 194 & 426 & 620 & $0.02 / 0.01$ \\
\hline Tipo/lado desconhecido & 16 & 4 & 8 & 2 & 14 & 16 & 12 & 28 & ---- \\
\hline Total fissurados & 377 & 44 & 173 & 160 & 377 & 261 & 493 & 754 & $0.31 / 0.16$ \\
\hline Sem fissura (Controles) & 285 & 44 & 128 & 110 & 282 & 216 & 348 & 564 & ---- \\
\hline
\end{tabular}


rs2073487 Caucasianos

\begin{tabular}{|c|c|c|c|c|c|c|c|c|c|}
\hline & $\mathrm{N}$ & & enótip & & & Alelos & & & \\
\hline Subfenótipo & & $\mathrm{CC}$ & CT & TT & Total & C & $\mathrm{T}$ & Total & Pgen/Palelo \\
\hline Fissura Palatina & & & & & & & & & \\
\hline Completa & 15 & 5 & 6 & 4 & 15 & 16 & 14 & 30 & $0.20 / 0.10$ \\
\hline Incompleta & 38 & 8 & 18 & 11 & 37 & 34 & 40 & 74 & $0.49 / 0.22$ \\
\hline Total FP & 53 & 13 & 24 & 15 & 52 & 50 & 54 & 104 & $0.20 / 0.07$ \\
\hline Fissura Labial e/ou Palatina & & & & & & & & & \\
\hline Completa & 237 & 21 & 107 & 101 & 229 & 149 & 309 & 458 & $0.06 / 0.04$ \\
\hline Incompleta & 86 & 5 & 47 & 43 & 95 & 57 & 133 & 190 & $0.03 / 0.03$ \\
\hline Unilateral & 200 & 15 & 108 & 86 & 209 & 138 & 280 & 418 & $0.01 / 0.06$ \\
\hline Completa & 136 & 10 & 68 & 56 & 134 & 88 & 180 & 268 & $0.05 / 0.10$ \\
\hline Incompleta & 64 & 5 & 40 & 30 & 75 & 50 & 100 & 150 & $0.10 / 0.23$ \\
\hline Unilateral Direita & 60 & 5 & 44 & 25 & 74 & 54 & 94 & 148 & $0.04 / 0.62$ \\
\hline Completa & 43 & 3 & 23 & 17 & 43 & 29 & 57 & 86 & $0.27 / 0.38$ \\
\hline Incompleta & 11 & 2 & 18 & 5 & 25 & 22 & 28 & 50 & $0.04 / 0.45$ \\
\hline Incompleta + FP & 6 & 0 & 3 & 3 & 6 & 3 & 9 & 12 & $0.55 / 0.33$ \\
\hline Unilateral Esquerda & 140 & 10 & 64 & 61 & 135 & 84 & 186 & 270 & $0.05 / 0.03$ \\
\hline Completa & 93 & 7 & 45 & 39 & 91 & 59 & 123 & 182 & $0.14 / 0.13$ \\
\hline Incompleta & 44 & 2 & 18 & 21 & 41 & 22 & 60 & 82 & $0.11 / 0.03$ \\
\hline Incompleta + FP & 3 & 1 & 1 & 1 & 3 & 3 & 3 & 6 & $0.71 / 0.57$ \\
\hline Bilateral & 123 & 11 & 46 & 58 & 115 & 68 & 162 & 230 & $0.06 / 0.01$ \\
\hline Completa & 101 & 11 & 39 & 45 & 95 & 61 & 129 & 190 & $0.28 / 0.10$ \\
\hline Incompleta & 6 & 0 & 2 & 4 & 6 & 2 & 10 & 12 & $0.31 / 0.12$ \\
\hline Incompleta + FP & 13 & 0 & 4 & 7 & 11 & 4 & 18 & 22 & $0.16 / 0.05$ \\
\hline Incompleta Mista & 3 & 0 & 1 & 2 & 3 & 1 & 5 & 6 & $0.55 / 0.27$ \\
\hline FL direita + FL/P esquerda & 2 & 0 & 0 & 0 & 0 & 0 & 0 & 0 & ---- \\
\hline FL esquerda + FP bilateral & 1 & 0 & 1 & 0 & 1 & 1 & 1 & 2 & ---- \\
\hline Fissura Mediana & 1 & 0 & 0 & 1 & 1 & 0 & 2 & 2 & ---- \\
\hline Total FL/P & 324 & 26 & 154 & 145 & 325 & 206 & 444 & 650 & $0.008 / 0.01$ \\
\hline Tipo/lado desconhecido & 16 & 4 & 8 & 2 & 14 & 16 & 12 & 28 & ---- \\
\hline Total fissurados & 377 & 43 & 186 & 162 & 391 & 272 & 510 & 782 & $0.17 / 0.14$ \\
\hline Sem fissura (Controles) & 285 & 45 & 128 & 109 & 282 & 218 & 346 & 564 & ---- \\
\hline
\end{tabular}


rs4844880 Caucasianos

Subfenótipo

N

Fissura Palatina

Completa

Incompleta

\begin{tabular}{cccccccccc} 
& N & \multicolumn{9}{c}{ Genótipos } & \multicolumn{7}{c}{ Alelos } \\
& & AA & AT & TT & Total & A & T & Total & Pgen/Palelo \\
& & & & & & & & & \\
Total FP & 15 & 2 & 12 & 15 & 4 & 26 & 30 & $0.22 / 0.19$ \\
& 38 & 2 & 18 & 18 & 38 & 22 & 54 & 76 & $0.31 / 0.31$ \\
& 53 & 3 & 20 & 30 & 53 & 26 & 80 & 106 & $0.91 / 0.85$
\end{tabular}

Fissura Labial e/ou Palatina

\begin{tabular}{|c|c|c|c|c|c|c|c|c|c|}
\hline Completa & 237 & 13 & 96 & 128 & 237 & 122 & 352 & 474 & $0.39 / 0.44$ \\
\hline Incompleta & 86 & 4 & 28 & 77 & 109 & 36 & 182 & 218 & $0.09 / 0.02$ \\
\hline Unilateral & 200 & 10 & 74 & 139 & 223 & 94 & 352 & 446 & $0.58 / 0.32$ \\
\hline Completa & 136 & 7 & 55 & 74 & 136 & 69 & 203 & 272 & $0.51 / 0.59$ \\
\hline Incompleta & 64 & 3 & 19 & 65 & 87 & 25 & 149 & 174 & $0.03 / 0.008$ \\
\hline Unilateral Direita & 60 & 2 & 23 & 58 & 83 & 27 & 139 & 166 & $0.13 / 0.04$ \\
\hline Completa & 43 & 0 & 19 & 24 & 43 & 19 & 67 & 86 & $0.16 / 0.74$ \\
\hline Incompleta & 11 & 1 & 3 & 30 & 34 & 5 & 63 & 68 & $0.004 / 0.002$ \\
\hline Incompleta + FP & 6 & 1 & 1 & 4 & 6 & 3 & 9 & 12 & $0.45 / 0.91$ \\
\hline Unilateral Esquerda & 140 & 8 & 51 & 81 & 140 & 67 & 213 & 280 & $0.93 / 0.93$ \\
\hline Completa & 93 & 7 & 36 & 50 & 93 & 50 & 136 & 186 & $0.67 / 0.37$ \\
\hline Incompleta & 44 & 1 & 13 & 30 & 44 & 15 & 73 & 88 & $0.38 / 0.16$ \\
\hline Incompleta + FP & 3 & 0 & 2 & 1 & 3 & 2 & 4 & 6 & $0.50 / 0.58$ \\
\hline Bilateral & 123 & 7 & 50 & 68 & 125 & 64 & 186 & 250 & $0.59 / 0.55$ \\
\hline Completa & 101 & 6 & 41 & 54 & 101 & 53 & 149 & 202 & $0.57 / 0.46$ \\
\hline Incompleta & 6 & 1 & 1 & 4 & 6 & 3 & 9 & 12 & $0.45 / 0.91$ \\
\hline Incompleta + FP & 13 & 0 & 7 & 6 & 13 & 7 & 19 & 26 & $0.29 / 0.70$ \\
\hline Incompleta Mista & 3 & 0 & 1 & 2 & 3 & 1 & 5 & 6 & $0.89 / 0.68$ \\
\hline FL direita + FL/P esquerda & 2 & 0 & 1 & 1 & 2 & 1 & 3 & 4 & ---- \\
\hline FL esquerda + FP bilateral & 1 & 0 & 0 & 1 & 1 & 0 & 2 & 2 & --- \\
\hline Fissura Mediana & 1 & 0 & 0 & 1 & 1 & 0 & 2 & 2 & ---- \\
\hline Total FL/P & 324 & 17 & 124 & 206 & 347 & 158 & 536 & 694 & $0.73 / 0.70$ \\
\hline Tipo/lado desconhecido & 16 & 0 & 2 & 13 & 15 & 2 & 28 & 30 & ---- \\
\hline Total fissurados & 377 & 20 & 146 & 249 & 415 & 186 & 644 & 830 & $0.69 / 0.57$ \\
\hline Sem fissura (Controles) & 285 & 18 & 99 & 168 & 285 & 135 & 435 & 570 & ---- \\
\hline
\end{tabular}


rs658860 Caucasianos

Subfenótipo

N

Genótipos

Fissura Palatina

Completa

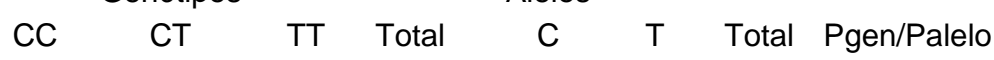

Incompleta

$\begin{array}{cccccccccc} & 15 & 1 & 3 & 11 & 15 & 5 & 25 & 30 & 0.48 / 0.84 \\ & 38 & 1 & 10 & 27 & 38 & 12 & 64 & 76 & 0.98 / 0.91 \\ \text { Total FP } & 53 & 2 & 13 & 38 & 53 & 17 & 89 & 106 & 0.75 / 0.84\end{array}$

Fissura Labial e/ou Palatina

$\begin{array}{lccccccccc}\text { Completa } & 237 & 5 & 72 & 155 & 232 & 82 & 382 & 464 & 0.50 / 0.30 \\ \text { Incompleta } & 86 & 3 & 28 & 51 & 82 & 34 & 130 & 164 & 0.25 / 0.09 \\ & & & & & & & & & \\ \text { Unilateral } & 200 & 3 & 62 & 133 & 198 & 68 & 328 & 396 & 0.46 / 0.43 \\ \text { Completa } & 136 & 2 & 41 & 93 & 136 & 45 & 227 & 272 & 0.66 / 0.64 \\ \text { Incompleta } & 64 & 1 & 21 & 40 & 62 & 23 & 101 & 124 & 0.48 / 0.37 \\ & & & & & & & & & \\ \text { Unilateral Direita } & 60 & 2 & 10 & 48 & 60 & 14 & 106 & 120 & 0.26 / 0.30 \\ \text { Completa } & 43 & 1 & 7 & 35 & 43 & 9 & 77 & 86 & 0.36 / 0.23 \\ \text { Incompleta } & 11 & 0 & 3 & 8 & 11 & 3 & 19 & 22 & 0.88 / 0.83 \\ \text { Incompleta + FP } & 6 & 1 & 0 & 5 & 6 & 2 & 10 & 12 & 0.03 / 0.89 \\ & & & & & & & & & \\ \text { Unilateral Esquerda } & 140 & 0 & 52 & 85 & 137 & 52 & 222 & 274 & 0.01 / 0.17 \\ \text { Completa } & 93 & 0 & 34 & 58 & 92 & 34 & 150 & 184 & 0.07 / 0.30 \\ \text { Incompleta } & 44 & 0 & 17 & 25 & 42 & 17 & 67 & 84 & 0.12 / 0.24 \\ \text { Incompleta + FP } & 3 & 2 & 1 & 2 & 5 & 5 & 5 & 10 & 0.94 / 0.002 \\ & & & & & & & & & \\ \text { Bilateral } & 123 & 5 & 38 & 73 & 116 & 48 & 184 & 232 & 0.17 / 0.06 \\ \text { Completa } & 101 & 3 & 31 & 62 & 96 & 37 & 155 & 192 & 0.43 / 0.19 \\ \text { Incompleta } & 6 & 0 & 2 & 4 & 6 & 2 & 10 & 12 & 0.88 / 0.89 \\ \text { Incompleta + FP } & 13 & 2 & 4 & 5 & 11 & 8 & 14 & 22 & 0.003 / 0.008 \\ \text { Incompleta Mista } & 3 & 0 & 1 & 2 & 3 & 1 & 5 & 6 & 0.94 / 0.92 \\ \quad \text { FL direita + FL/P esquerda } & 2 & 0 & 1 & 1 & 2 & 1 & 3 & 4 & ---- \\ \quad \text { FL esquerda + FP bilateral } & 1 & 0 & 0 & 1 & 1 & 0 & 2 & 2 & ---- \\ \text { Fissura Mediana } & 1 & 0 & 0 & 1 & 1 & 0 & 2 & 2 & ---- \\ & 324 & 10 & 100 & 207 & 317 & 120 & 514 & 634 & 0.24 / 0.09 \\ \text { Tipo/lado desconhecido } & & 0 & 2 & 13 & 15 & 2 & 28 & 30 & ---- \\ \text { Total fissurados } & 377 & 10 & 115 & 258 & 383 & 135 & 631 & 766 & 0.51 / 0.26 \\ \text { Sem fissura (Controles) } & 285 & 6 & 74 & 201 & 281 & 86 & 476 & 562 & ---- \\ & & & & & & & & & \end{array}$


rs861019 Caucasianos

Subfenótipo

Fissura Palatina

Completa

Incompleta

\begin{tabular}{cccccccccc} 
& N & \multicolumn{3}{c}{ Genótipos } & \multicolumn{7}{c}{ Alelos } \\
& & AA & AG & GG & Total & A & G & Total & Pgen/Palelo \\
& & & & & & & & & \\
Total FP & 75 & 5 & 3 & 15 & 19 & 11 & 30 & $0.35 / 0.32$ \\
& 53 & 17 & 15 & 5 & 37 & 49 & 25 & 74 & $0.12 / 0.05$ \\
& 53 & 24 & 20 & 8 & 52 & 68 & 36 & 104 & $0.06 / 0.03$
\end{tabular}

Fissura Labial e/ou Palatina

$\begin{array}{lccccccccc}\text { Completa } & 237 & 62 & 112 & 59 & 233 & 236 & 230 & 466 & 0.49 / 0.24 \\ \text { Incompleta } & 86 & 19 & 47 & 18 & 84 & 85 & 83 & 168 & 0.42 / 0.40 \\ & & & & & & & & & \\ \text { Unilateral } & 200 & 46 & 109 & 45 & 200 & 201 & 199 & 400 & 0.26 / 0.22 \\ \text { Completa } & 136 & 33 & 72 & 31 & 136 & 138 & 134 & 272 & 0.51 / 0.34 \\ \text { Incompleta } & 64 & 13 & 37 & 14 & 64 & 63 & 65 & 128 & 0.29 / 0.30 \\ & & & & & & & & & \\ \text { Unilateral Direita } & 60 & 13 & 34 & 13 & 60 & 60 & 60 & 120 & 0.43 / 0.39 \\ \text { Completa } & 43 & 8 & 26 & 9 & 43 & 42 & 44 & 86 & 0.28 / 0.34 \\ \text { Incompleta } & 11 & 3 & 6 & 2 & 11 & 12 & 10 & 22 & 0.94 / 0.97 \\ \text { Incompleta + FP } & 6 & 2 & 2 & 2 & 6 & 6 & 6 & 12 & 0.69 / 0.77 \\ & & & & & & & & & \\ \text { Unilateral Esquerda } & 140 & 33 & 75 & 30 & 138 & 141 & 135 & 276 & 0.44 / 0.38 \\ \text { Completa } & 93 & 25 & 46 & 22 & 93 & 96 & 90 & 186 & 0.82 / 0.53 \\ \text { Incompleta } & 44 & 8 & 28 & 6 & 42 & 44 & 40 & 84 & 0.10 / 0.74 \\ \text { Incompleta + FP } & 3 & 0 & 1 & 2 & 3 & 1 & 5 & 6 & 0.14 / 0.06 \\ & & & & & & & & & \\ \text { Bilateral } & 123 & 35 & 50 & 32 & 117 & 120 & 114 & 234 & 0.35 / 0.44 \\ \text { Completa } & 101 & 29 & 40 & 28 & 97 & 98 & 96 & 194 & 0.25 / 0.36 \\ \text { Incompleta } & 6 & 2 & 1 & 3 & 6 & 5 & 7 & 12 & 0.17 / 0.38 \\ \text { Incompleta + FP } & 13 & 4 & 6 & 1 & 11 & 14 & 8 & 22 & 0.61 / 0.38 \\ \text { Incompleta Mista } & 3 & 0 & 3 & 0 & 3 & 3 & 3 & 6 & 0.21 / 0.83 \\ \quad \text { FL direita + FL/P esquerda } & 2 & 0 & 2 & 0 & 2 & 2 & 2 & 4 & ---- \\ \quad \text { FL esquerda + FP bilateral } & 1 & 0 & 1 & 0 & 1 & 1 & 1 & 2 & ---- \\ \text { Fissura Mediana } & 1 & 0 & 1 & 0 & 1 & 1 & 1 & 2 & --- \\ & 324 & 81 & 160 & 77 & 318 & 322 & 314 & 636 & 0.45 / 0.21 \\ \text { Tipo/lado desconhecido } & & 2 & 8 & 4 & 14 & 12 & 16 & 28 & ---- \\ \text { Total fissurados } & 377 & 106 & 188 & 89 & 383 & 400 & 366 & 766 & 0.77 / 0.46 \\ \text { Sem fissura (Controles) } & 285 & 84 & 139 & 60 & 283 & 307 & 259 & 566 & ---- \\ & & & & & & & & & \end{array}$


rs10943944

Subfenótipo

Fissura Palatina

Completa

Incompleta

Total FP

$\mathrm{N}$

Genótipos

$\begin{array}{ccccccccc} & & \text { CT } & \text { TT } & \text { Total } & \text { C } & \text { T } & \text { Total } & \text { Pgen/Palelo } \\ 21 & 15 & 5 & 0 & 20 & 35 & 5 & 40 & 0.44 / 0.35 \\ 45 & 27 & 12 & 6 & 45 & 66 & 24 & 90 & 0.006 / 0.05 \\ 66 & 42 & 17 & 6 & 65 & 101 & 29 & 130 & 0.07 / 0.25\end{array}$

Fissura Labial e/ou Palatina

\begin{tabular}{|c|c|c|c|c|c|c|c|c|c|}
\hline Completa & 300 & 169 & 93 & 22 & 284 & 431 & 137 & 568 & $0.007 / 0.005$ \\
\hline Incompleta & 104 & 59 & 37 & 6 & 102 & 135 & 43 & 178 & $0.16 / 0.06$ \\
\hline Unilateral & 250 & 146 & 75 & 17 & 238 & 347 & 103 & 450 & $0.0003 / 0.04$ \\
\hline Completa & 175 & 97 & 53 & 13 & 163 & 247 & 79 & 326 & $0.02 / 0.01$ \\
\hline Incompleta & 75 & 49 & 22 & 4 & 75 & 100 & 24 & 124 & $0.69 / 0.31$ \\
\hline Unilateral Direita & 78 & 48 & 21 & 6 & 75 & 117 & 33 & 150 & $0.15 / 0.26$ \\
\hline Completa & 54 & 32 & 15 & 4 & 51 & 79 & 23 & 102 & $0.27 / 0.28$ \\
\hline Incompleta & 16 & 11 & 4 & 1 & 16 & 26 & 6 & 32 & $0.77 / 0.93$ \\
\hline Incompleta + FP & 8 & 5 & 2 & 1 & 8 & 12 & 4 & 16 & $0.37 / 0.48$ \\
\hline Unilateral Esquerda & 172 & 98 & 54 & 11 & 163 & 250 & 76 & 326 & $0.09 / 0.04$ \\
\hline Completa & 121 & 65 & 38 & 9 & 112 & 168 & 56 & 224 & $0.04 / 0.02$ \\
\hline Incompleta & 46 & 30 & 14 & 2 & 46 & 74 & 18 & 92 & $0.92 / 0.74$ \\
\hline Incompleta + FP & 5 & 3 & 2 & 0 & 5 & 8 & 2 & 10 & $0.76 / 0.88$ \\
\hline Bilateral & 154 & 82 & 55 & 11 & 148 & 219 & 77 & 296 & $0.01 / 0.003$ \\
\hline Completa & 125 & 72 & 40 & 9 & 121 & 184 & 58 & 242 & $0.08 / 0.04$ \\
\hline Incompleta & 8 & 3 & 5 & 0 & 8 & 11 & 5 & 16 & $0.11 / 0.18$ \\
\hline Incompleta + FP & 17 & 4 & 9 & 2 & 15 & 17 & 13 & 30 & $0.002 / 0.0005$ \\
\hline Incompleta Mista & 4 & 3 & 1 & 0 & 4 & 7 & 1 & 8 & $0.84 / 0.67$ \\
\hline FL direita + FL/P esquerda & 3 & 2 & 1 & 0 & 3 & 5 & 1 & 6 & ---- \\
\hline FL esquerda + FP bilateral & 1 & 1 & 0 & 0 & 1 & 2 & 0 & 2 & ---- \\
\hline Fissura Mediana & 2 & 1 & 0 & 0 & 1 & 2 & 0 & 2 & ---- \\
\hline Total FL/P & 406 & 229 & 130 & 28 & 387 & 349 & 103 & 452 & $0.0008 / 0.04$ \\
\hline Tipo/lado desconhecido & 28 & 22 & 4 & 1 & 27 & 48 & 6 & 54 & ---- \\
\hline Total fissurados & 500 & 293 & 151 & 35 & 479 & 498 & 138 & 636 & $0.01 / 0.08$ \\
\hline Sem fissura (Controles) & 500 & 320 & 142 & 16 & 478 & 782 & 174 & 956 & ---- \\
\hline
\end{tabular}


rs1171105

Subfenótipo

Fissura Palatina

Completa

Incompleta

Total FP

\begin{tabular}{ccccccccc} 
N & \multicolumn{3}{c}{ Genótipos } & \multicolumn{5}{c}{ Alelos } \\
& CC & CT & TT & Total & C & T & Total & Pgen/Palelo \\
21 & 10 & 7 & 3 & 20 & 27 & 13 & 40 & $0.61 / 0.64$ \\
45 & 21 & 19 & 5 & 45 & 61 & 29 & 90 & $0.75 / 0.47$ \\
66 & 31 & 26 & 8 & 65 & 88 & 42 & 130 & $0.57 / 0.40$
\end{tabular}

Fissura Labial e/ou Palatina

\begin{tabular}{|c|c|c|c|c|c|c|c|c|c|}
\hline \\
\hline Completa & 300 & 125 & 119 & 39 & 283 & 369 & 197 & 566 & $0.57 / 0.63$ \\
\hline Incompleta & 104 & 40 & 47 & 17 & 104 & 127 & 81 & 208 & $0.58 / 0.42$ \\
\hline Unilateral & 250 & 98 & 109 & 33 & 240 & 305 & 175 & 480 & $0.92 / 0.86$ \\
\hline Completa & 175 & 70 & 70 & 23 & 163 & 210 & 116 & 326 & $0.77 / 0.88$ \\
\hline Incompleta & 75 & 28 & 39 & 10 & 77 & 95 & 59 & 154 & $0.76 / 0.58$ \\
\hline Unilateral Direita & 78 & 27 & 39 & 9 & 75 & 93 & 57 & 150 & $0.63 / 0.63$ \\
\hline Completa & 54 & 17 & 26 & 8 & 51 & 60 & 42 & 102 & $0.56 / 0.30$ \\
\hline Incompleta & 16 & 6 & 9 & 1 & 16 & 21 & 11 & 32 & $0.62 / 0.84$ \\
\hline Incompleta + FP & 8 & 4 & 4 & 0 & 8 & 12 & 4 & 16 & $0.32 / 0.36$ \\
\hline Unilateral Esquerda & 172 & 71 & 70 & 24 & 165 & 212 & 118 & 330 & $0.71 / 0.93$ \\
\hline Completa & 121 & 53 & 44 & 15 & 112 & 150 & 74 & 224 & $0.39 / 0.40$ \\
\hline Incompleta & 46 & 14 & 22 & 9 & 45 & 50 & 40 & 90 & $0.27 / 0.11$ \\
\hline Incompleta + FP & 5 & 4 & 4 & 0 & 8 & 12 & 4 & 16 & $0.56 / 0.36$ \\
\hline Bilateral & 154 & 67 & 57 & 23 & 147 & 191 & 103 & 294 & $0.27 / 0.75$ \\
\hline Completa & 125 & 55 & 49 & 16 & 120 & 159 & 81 & 240 & $0.55 / 0.51$ \\
\hline Incompleta & 8 & 2 & 5 & 1 & 8 & 9 & 7 & 16 & $0.62 / 0.52$ \\
\hline Incompleta + FP & 17 & 8 & 2 & 5 & 15 & 18 & 12 & 30 & $0.01 / 0.65$ \\
\hline Incompleta Mista & 4 & 2 & 1 & 1 & 4 & 5 & 3 & 8 & $0.63 / 0.93$ \\
\hline FL direita + FL/P esquerda & 3 & 2 & 1 & 0 & 3 & 5 & 1 & 6 & ---- \\
\hline FL esquerda + FP bilateral & 1 & 0 & 0 & 1 & 1 & 0 & 2 & 2 & ---- \\
\hline Fissura Mediana & 2 & 0 & 1 & 0 & 1 & 1 & 1 & 2 & ---- \\
\hline Total FL/P & 406 & 165 & 166 & 56 & 387 & 496 & 278 & 774 & $0.58 / 0.96$ \\
\hline Tipo/lado desconhecido & 28 & 11 & 12 & 4 & 27 & 34 & 20 & 54 & ---- \\
\hline Total fissurados & 500 & 207 & 204 & 68 & 479 & 618 & 340 & 958 & $0.52 / 0.81$ \\
\hline Sem fissura (Controles) & 500 & 196 & 221 & 62 & 479 & 613 & 345 & 958 & ---- \\
\hline
\end{tabular}


rs1171114

Subfenótipo

N

Fissura Palatina

Completa

Incompleta

Total FP

Fissura Labial e/ou Palatina

\begin{tabular}{|c|c|c|c|c|c|c|c|c|c|}
\hline Completa & 300 & 89 & 137 & 53 & 279 & 315 & 243 & 558 & $0.00001^{*}$ \\
\hline Incompleta & 104 & 35 & 53 & 16 & 104 & 123 & 85 & 208 & $0.03 / 0.02$ \\
\hline Unilateral & 250 & 81 & 111 & 39 & 231 & 273 & 189 & 462 & $0.007 / 0.002$ \\
\hline Completa & 175 & 60 & 71 & 28 & 159 & 191 & 127 & 318 & $0.01 / 0.01$ \\
\hline Incompleta & 75 & 21 & 40 & 11 & 72 & 82 & 62 & 144 & $0.03 / 0.01$ \\
\hline Unilateral Direita & 78 & 23 & 39 & 9 & 71 & 85 & 57 & 142 & $0.09 / 0.07$ \\
\hline Completa & 54 & 16 & 28 & 5 & 49 & 60 & 38 & 98 & $0.19 / 0.21$ \\
\hline Incompleta & 16 & 5 & 7 & 2 & 14 & 17 & 11 & 28 & $0.47 / 0.45$ \\
\hline Incompleta + FP & 8 & 2 & 4 & 2 & 8 & 8 & 8 & 16 & $0.27 / 0.14$ \\
\hline Unilateral Esquerda & 172 & 58 & 72 & 30 & 160 & 188 & 132 & 320 & $0.005 / 0.004$ \\
\hline Completa & 121 & 44 & 43 & 23 & 110 & 131 & 89 & 220 & $0.004 / 0.02$ \\
\hline Incompleta & 46 & 11 & 27 & 7 & 45 & 49 & 41 & 90 & $0.02 / 0.01$ \\
\hline Incompleta + FP & 5 & 3 & 2 & 0 & 5 & 8 & 2 & 10 & $0.67 / 0.39$ \\
\hline Bilateral & 154 & 43 & 79 & 30 & 152 & 165 & 139 & 304 & $0.00001^{*}$ \\
\hline Completa & 125 & 29 & 66 & 25 & 120 & 124 & 116 & 240 & $0.00001^{*}$ \\
\hline Incompleta & 8 & 4 & 3 & 1 & 8 & 11 & 5 & 16 & $0.88 / 0.91$ \\
\hline Incompleta + FP & 17 & 6 & 7 & 3 & 16 & 19 & 13 & 32 & $0.47 / 0.33$ \\
\hline Incompleta Mista & 4 & 4 & 3 & 1 & 8 & 11 & 5 & 16 & $0.50 / 0.91$ \\
\hline FL direita + FL/P esquerda & 3 & 2 & 0 & 0 & 2 & 4 & 0 & 4 & ---- \\
\hline FL esquerda + FP bilateral & 1 & 0 & 0 & 0 & 0 & 0 & 0 & 0 & ---- \\
\hline Fissura Mediana & 2 & 0 & 1 & 0 & 1 & 1 & 1 & 2 & ---- \\
\hline Total FL/P & 406 & 124 & 191 & 69 & 384 & 439 & 329 & 768 & $0.00001^{*}$ \\
\hline Tipo/lado desconhecido & 28 & 8 & 14 & 4 & 26 & 30 & 22 & 52 & ---- \\
\hline Total fissurados & 500 & 157 & 233 & 82 & 472 & 547 & 397 & 944 & $0.00001^{*}$ \\
\hline Sem fissura (Controles) & 500 & 213 & 220 & 46 & 479 & 646 & 312 & 958 & ---- \\
\hline
\end{tabular}

Alelos

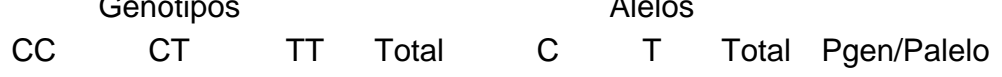

$\begin{array}{lllllllll}21 & 8 & 9 & 2 & 19 & 25 & 13 & 38 & 0.92 / 0.83\end{array}$

$\begin{array}{lllllllll}45 & 17 & 19 & 7 & 43 & 53 & 33 & 86 & 0.19 / 0.27\end{array}$

$\begin{array}{lllllllll}66 & 25 & 28 & 9 & 62 & 78 & 46 & 124 & 0.30 / 0.31\end{array}$ 
rs1325469

$\mathrm{N}$

Subfenótipo

Fissura Palatina

Completa

Incompleta

N
Genótipos AA AG GG Total

$5 \quad 0 \quad 20$

20
44

69

64

Total FP 66

$$
13
$$

18

$$
300
$$

\section{Completa}

Incompleta

Unilateral

Completa

Incompleta

Unilateral Direita

Completa

Incompleta

Incompleta + FP

Unilateral Esquerda

Completa

Incompleta

Incompleta + FP

\section{Bilateral}

Completa

Incompleta

Incompleta + FP

Incompleta Mista

FL direita + FL/P esquerda

FL esquerda + FP bilateral

Fissura Mediana

Tipo/lado desconhecido

Total fissurados

\begin{tabular}{|c|c|c|c|c|c|c|c|c|}
\hline 300 & 173 & 89 & 15 & 277 & 435 & 119 & 554 & $0.39 / 0.17$ \\
\hline 104 & 52 & 29 & 5 & 86 & 133 & 39 & 172 & $0.37 / 0.21$ \\
\hline 250 & 132 & 76 & 12 & 220 & 340 & 100 & 440 & $0.10 / 0.07$ \\
\hline 175 & 93 & 57 & 10 & 160 & 243 & 77 & 320 & $0.08 / 0.03$ \\
\hline 75 & 39 & 19 & 2 & 60 & 97 & 23 & 120 & $0.46 / 0.87$ \\
\hline 78 & 44 & 24 & 6 & 74 & 112 & 36 & 148 & $0.33 / 0.09$ \\
\hline 54 & 29 & 18 & 4 & 51 & 76 & 26 & 102 & $0.26 / 0.09$ \\
\hline 16 & 10 & 3 & 2 & 15 & 23 & 7 & 30 & $0.26 / 0.51$ \\
\hline 8 & 5 & 3 & 0 & 8 & 13 & 3 & 16 & $0.60 / 0.98$ \\
\hline 172 & 95 & 58 & 6 & 159 & 248 & 70 & 318 & $0.12 / 0.18$ \\
\hline 121 & 64 & 39 & 6 & 109 & 167 & 51 & 218 & $0.22 / 0.10$ \\
\hline 46 & 29 & 16 & 0 & 45 & 74 & 16 & 90 & $0.08 / 0.85$ \\
\hline 5 & 2 & 3 & 0 & 5 & 7 & 3 & 10 & $0.24 / 0.35$ \\
\hline 154 & 93 & 42 & 8 & 143 & 228 & 58 & 286 & $0.81 / 0.52$ \\
\hline 125 & 80 & 32 & 5 & 117 & 192 & 42 & 234 & $0.97 / 0.82$ \\
\hline 8 & 4 & 4 & 0 & 8 & 12 & 4 & 16 & $0.29 / 0.51$ \\
\hline 17 & 7 & 4 & 3 & 14 & 18 & 10 & 28 & $0.01 / 0.02$ \\
\hline 4 & 2 & 2 & 0 & 4 & 6 & 2 & 8 & $0.54 / 0.64$ \\
\hline 3 & 1 & 2 & 0 & 3 & 4 & 2 & 6 & ---- \\
\hline 1 & 1 & 0 & 0 & 1 & 2 & 0 & 2 & ---- \\
\hline 2 & 1 & 0 & 0 & 1 & 2 & 0 & 2 & ---- \\
\hline 406 & 226 & 118 & 20 & 364 & 570 & 158 & 728 & $0.23 / 0.11$ \\
\hline 28 & 14 & 10 & 2 & 26 & 38 & 14 & 52 & ---- \\
\hline 500 & 283 & 146 & 25 & 454 & 712 & 196 & 908 & $0.22 / 0.10$ \\
\hline 500 & 323 & 134 & 22 & 479 & 780 & 178 & 958 & ---- \\
\hline
\end{tabular}

Sem fissura (Controles)
Alelos

G Total Pgen/Palelo

540

$0.36 / 0.33$

$0.76 / 0.49$

$0.99 / 0.96$ 
rs1325474

Subfenótipo

Fissura Palatina

Completa

Incompleta
N

$\begin{array}{cccccccccc} & 21 & 0 & 4 & 14 & 18 & 0 & 32 & 32 & 0.37 / 0.06 \\ & 45 & 3 & 11 & 27 & 41 & 6 & 65 & 71 & 0.72 / 0.25 \\ \text { Total FP } & 66 & 3 & 15 & 41 & 59 & 6 & 97 & 103 & 0.95 / 0.80\end{array}$

Fissura Labial e/ou Palatina

\begin{tabular}{|c|c|c|c|c|c|c|c|c|c|}
\hline Completa & 300 & 14 & 82 & 165 & 261 & 28 & 412 & 440 & $0.37 / 0.41$ \\
\hline Incompleta & 104 & 6 & 34 & 54 & 94 & 12 & 142 & 154 & $0.12 / 0.20$ \\
\hline Unilateral & 250 & 12 & 77 & 134 & 223 & 24 & 345 & 369 & $0.10 / 0.38$ \\
\hline Completa & 175 & 8 & 53 & 93 & 154 & 16 & 239 & 255 & $0.19 / 0.52$ \\
\hline Incompleta & 75 & 4 & 24 & 41 & 69 & 8 & 106 & 114 & $0.34 / 0.43$ \\
\hline Unilateral Direita & 78 & 4 & 24 & 43 & 71 & 8 & 110 & 118 & $0.43 / 0.49$ \\
\hline Completa & 54 & 3 & 16 & 30 & 49 & 6 & 76 & 82 & $0.59 / 0.42$ \\
\hline Incompleta & 16 & 1 & 5 & 9 & 15 & 2 & 23 & 25 & $0.78 / 0.54$ \\
\hline Incompleta + FP & 8 & 0 & 3 & 4 & 7 & 0 & 11 & 11 & $0.50 / 0.43$ \\
\hline Unilateral Esquerda & 172 & 8 & 53 & 91 & 152 & 16 & 235 & 251 & $0.16 / 0.49$ \\
\hline Completa & 121 & 5 & 37 & 63 & 105 & 10 & 163 & 173 & $0.24 / 0.77$ \\
\hline Incompleta & 46 & 1 & 15 & 27 & 43 & 2 & 69 & 71 & $0.48 / 0.37$ \\
\hline Incompleta + FP & 5 & 2 & 1 & 1 & 4 & 4 & 3 & 7 & $0.0001 / 0.00001$ \\
\hline Bilateral & 154 & 8 & 42 & 85 & 135 & 16 & 212 & 228 & $0.48 / 0.30$ \\
\hline Completa & 125 & 6 & 32 & 72 & 110 & 12 & 176 & 188 & $0.82 / 0.53$ \\
\hline Incompleta & 8 & 0 & 4 & 4 & 8 & 0 & 12 & 12 & $0.27 / 0.25$ \\
\hline Incompleta + FP & 17 & 2 & 4 & 7 & 13 & 4 & 18 & 22 & $0.17 / 0.009$ \\
\hline Incompleta Mista & 4 & 0 & 2 & 2 & 4 & 0 & 6 & 6 & $0.52 / 0.42$ \\
\hline FL direita + FL/P esquerda & 3 & 0 & 2 & 1 & 3 & 0 & 4 & 4 & ---- \\
\hline FL esquerda + FP bilateral & 1 & 0 & 0 & 1 & 1 & 0 & 2 & 2 & ---- \\
\hline Fissura Mediana & 2 & 0 & 2 & 1 & 3 & 0 & 4 & 4 & ---- \\
\hline Total FL/P & 406 & 20 & 116 & 220 & 356 & 40 & 556 & 596 & $0.15 / 0.24$ \\
\hline Tipo/lado desconhecido & 28 & 1 & 8 & 16 & 25 & 2 & 40 & 42 & ---- \\
\hline Total fissurados & 500 & 24 & 140 & 277 & 441 & 48 & 694 & 742 & $0.22 / 0.30$ \\
\hline Sem fissuras (Controles) & 500 & 21 & 126 & 317 & 464 & 42 & 760 & 802 & ---- \\
\hline
\end{tabular}


rs2023238

Subfenótipo

$\mathrm{N}$

Genótipos

Fissura Palatina

Completa

Incompleta

Total FP

$\begin{array}{ccccccccc} & \text { AA } & \text { AG } & \text { GG } & \text { Total } & \text { A } & \text { G } & \text { Total } & \text { Pgen/Palelo } \\ & & & & & & & & \\ 21 & 2 & 9 & 9 & 20 & 13 & 27 & 40 & 0.74 / 0.92 \\ 45 & 5 & 21 & 18 & 44 & 31 & 57 & 88 & 0.36 / 0.50 \\ 66 & 7 & 30 & 27 & 64 & 44 & 84 & 128 & 0.30 / 0.55\end{array}$

Fissura Labial e/ou Palatina

\begin{tabular}{|c|c|c|c|c|c|c|c|c|c|}
\hline Completa & 300 & 39 & 108 & 129 & 276 & 186 & 366 & 552 & $0.72 / 0.44$ \\
\hline Incompleta & 104 & 16 & 43 & 38 & 97 & 75 & 119 & 194 & $0.16 / 0.06$ \\
\hline Unilateral & 250 & 37 & 94 & 100 & 231 & 168 & 294 & 462 & $0.25 / 0.08$ \\
\hline Completa & 175 & 24 & 62 & 74 & 160 & 110 & 210 & 320 & $0.71 / 0.38$ \\
\hline Incompleta & 75 & 13 & 32 & 26 & $\begin{array}{c}71 \\
0\end{array}$ & 58 & 84 & 142 & $0.10 / 0.03$ \\
\hline Unilateral Direita & 78 & 13 & 29 & 31 & 73 & 55 & 91 & 146 & $0.41 / 0.15$ \\
\hline Completa & 54 & 10 & 19 & 22 & 51 & 39 & 63 & 102 & $0.42 / 0.18$ \\
\hline Incompleta & 16 & 3 & 7 & 5 & 15 & 13 & 17 & 30 & $0.43 / 0.18$ \\
\hline Incompleta + FP & 8 & 0 & 3 & 4 & 7 & 3 & 11 & 14 & $0.36 / 0.40$ \\
\hline Unilateral Esquerda & 172 & 24 & 65 & 69 & 158 & 113 & 203 & 316 & $0.40 / 0.19$ \\
\hline Completa & 121 & 14 & 43 & 52 & 109 & 71 & 147 & 218 & $0.88 / 0.81$ \\
\hline Incompleta & 46 & 10 & 20 & 14 & 44 & 40 & 48 & 88 & $0.04 / 0.008$ \\
\hline Incompleta + FP & 5 & 0 & 2 & 3 & 5 & 2 & 8 & 10 & $0.48 / 0.42$ \\
\hline Bilateral & 154 & 18 & 57 & 67 & 142 & 93 & 191 & 284 & $0.77 / 0.75$ \\
\hline Completa & 125 & 15 & 46 & 55 & 116 & 76 & 156 & 232 & $0.85 / 0.77$ \\
\hline Incompleta & 8 & 1 & 5 & 2 & 8 & 7 & 9 & 16 & $0.30 / 0.30$ \\
\hline Incompleta + FP & 17 & 2 & 5 & 7 & 14 & 9 & 19 & 28 & $0.99 / 0.96$ \\
\hline Incompleta Mista & 4 & 0 & 1 & 3 & 4 & 1 & 7 & 8 & $0.42 / 0.24$ \\
\hline FL direita + FL/P esquerda & 3 & 0 & 0 & 3 & 3 & 0 & 6 & 6 & ---- \\
\hline FL esquerda + FP bilateral & 1 & 0 & 1 & 0 & 1 & 1 & 1 & 2 & ---- \\
\hline Fissura Mediana & 2 & 0 & 1 & 0 & 1 & 1 & 1 & 2 & ---- \\
\hline Total FL/P & 406 & 55 & 152 & 167 & 374 & 262 & 486 & 748 & $0.32 / 0.15$ \\
\hline Tipo/lado desconhecido & 28 & 3 & 13 & 10 & 26 & 19 & 33 & 52 & ---- \\
\hline Total fissurados & 500 & 65 & 195 & 204 & 464 & 325 & 603 & 928 & $0.17 / 0.13$ \\
\hline Sem fissuras (Controles) & 500 & 64 & 177 & 239 & 490 & 305 & 655 & 960 & ---- \\
\hline
\end{tabular}


rs217290

Subfenótipo

N

Fissura Palatina

Completa

Incompleta

Total FP

Fissura Labial e/ou Palatina

Completa

Incompleta

Unilateral

Completa

Incompleta

Unilateral Direita

Completa

Incompleta

Incompleta + FP

Unilateral Esquerda

Completa

Incompleta

Incompleta + FP

Bilateral

Completa

Incompleta

Incompleta + FP

Incompleta Mista

FL direita + FL/P esquerda

FL esquerda + FP bilateral

Fissura Mediana

Total FL/P

Tipo/lado desconhecido

Total fissurados

Sem fissura (Controles)

30

25

75

$$
78
$$

$$
\begin{aligned}
& 15 \\
& 125
\end{aligned}
$$

\begin{tabular}{ccccccccc} 
N & \multicolumn{3}{c}{ Genótipos } & \multicolumn{5}{c}{ Alelos } \\
& CC & CT & TT & Total & C & T & Total & Pgen/Palelo \\
21 & 6 & 10 & 4 & 20 & 22 & 18 & 40 & $0.78 / 0.50$ \\
45 & 14 & 26 & 5 & 45 & 54 & 36 & 90 & $0.56 / 0.96$ \\
66 & 20 & 36 & 9 & 65 & 76 & 54 & 130 & $0.69 *$
\end{tabular}

Genótipos

133

35

278

353

$203 \quad 556$

$0.44 / 0.21$

$104 \quad 41$

53

$7 \quad 101$

135

$67 \quad 202$

$0.09 / 0.08$

175

110

$28 \quad 232$

$298 \quad 166 \quad 464$

$\begin{array}{lll}197 & 119 & 316\end{array}$

$0.33 / 0.14$

75

$22 \quad 158$

$\begin{array}{lll}101 & 47 \quad 148\end{array}$

$0.76 / 0.50$

$0.15 / 0.06$

78

35

$6 \quad 74$

101

$47 \quad 148$

$0.15 / 0.06$

$54 \quad 20$

26

$6 \quad 74$

66

$36 \quad 102$

$0.59 / 0.38$

16

84

6

$0 \quad 15$

$24 \quad 6 \quad 30$

$0.08 / 0.02$

3

$$
3
$$

$172 \quad 61 \quad 75$

12141

1

11

516

$0.68 / 0.49$

$46 \quad 18$

49

$$
22
$$

$22 \quad 158$

$197 \quad 119 \quad 316$

$0.76 / 0.50$

5

24

$17 \quad 107$

$\begin{array}{lll}131 & 83 & 214\end{array}$

$0.75 / 0.79$

$0.51 / 0.35$

$0.89 / 0.98$

$154 \quad 57 \quad 76$

$125 \quad 49$

76

(1)

$\begin{array}{cc}4 & 46 \\ 1 & 5\end{array}$

$\begin{array}{lll}60 & 32 & 92\end{array}$

8

17

4

3

1

1
2

$2 \quad 0$

$28 \quad 10$

$500 \quad 181$

$500 \quad 169$

49
3
5
0
0
0
0
151
10
181
169

58
5
10
3
2
1
1
186
11
234
238$$
14 \quad 147
$$$$
\begin{array}{ll}
14 & 147 \\
13 & 12
\end{array}
$$

$\begin{array}{ccc}190 & 104 & 294 \\ 156 & 84 & 240\end{array}$

$0.24 / 0.17$

$0.38 / 0.17$

$0.48 / 0.49$

$0.21 / 0.47$

$0.33 / 0.19$

$\begin{array}{lllll}0 & 15 & 20 & 10 & 30\end{array}$

$\begin{array}{ccccc}1 & 4 & 3 & 5 & 8\end{array}$

$\begin{array}{lllll}1 & 4 & 3 & 5 & 8\end{array}$

$\begin{array}{lllll}1 & 3 & 2 & 4 & 6\end{array}$

$\begin{array}{lllll}0 & 1 & 1 & 1 & 2\end{array}$

$\begin{array}{lllll}0 & 1 & 1 & 1 & 2\end{array}$

$42 \quad 379$

$488 \quad 270 \quad 758$

$0.17 / 0.08$

$\begin{array}{ccccc}5 & 26 & 31 & 21 & 52 \\ 56 & 471 & 596 & 346 & 942\end{array}$

$\begin{array}{lllll}71 & 478 & 576 & 380 & 956\end{array}$

$0.33 / 0.17$ 
rs217308

Subfenótipo

Fissura Palatina

Completa

Incompleta

Total FP

Fissura Labial e/ou Palatina

Completa

Incompleta

Unilateral

Completa

Incompleta

Unilateral Direita

Completa

Incompleta

Incompleta + FP

Unilateral Esquerda

Completa

Incompleta

Incompleta + FP

Bilateral

Completa

Incompleta

Incompleta + FP

Incompleta Mista

FL direita + FL/P esquerda

FL esquerda + FP bilateral

Fissura Mediana

Total FL/P 406

Tipo/lado desconhecido

Total fissurados

Sem fissuras (Controles)
N

$$
\text { AG }
$$

GG Total

$21 \quad 4 \quad 10$

$\begin{array}{lll}45 & 7 & 24\end{array}$

620

1344

44
64

18
38

$$
38
$$

$22-40$

$50 \quad 88$

$72 / 0.49$

66

34

19

56

$72 \quad 128$

$0.78 / 0.51$

$0.64 / 0.37$

$\begin{array}{ccccccccc}300 & 33 & 129 & 113 & 275 & 195 & 355 & 550 & 0.19 / 0.10 \\ 104 & 8 & 53 & 37 & 98 & 69 & 127 & 196 & 0.30 / 0.24 \\ & & & & & & & & \\ 250 & 27 & 112 & 92 & 231 & 166 & 296 & 462 & 0.35 / 0.17 \\ 175 & 21 & 75 & 63 & 159 & 117 & 201 & 318 & 0.50 / 0.36 \\ 75 & 6 & 37 & 29 & 72 & 49 & 95 & 144 & 0.36 / 0.19 \\ & & & & & & & & \\ 78 & 5 & 35 & 34 & 74 & 45 & 103 & 148 & 0.08 / 0.03 \\ 54 & 4 & 25 & 22 & 51 & 33 & 69 & 102 & 0.32 / 0.15 \\ 16 & 0 & 6 & 9 & 15 & 6 & 24 & 30 & 0.07 / 0.02 \\ 8 & 1 & 4 & 3 & 8 & 6 & 10 & 16 & 0.98 / 0.86\end{array}$

$\begin{array}{ccccccccc}172 & 22 & 77 & 58 & 157 & 121 & 193 & 314 & 0.83 / 0.72 \\ 121 & 17 & 50 & 41 & 108 & 84 & 132 & 216 & 0.59 / 0.83 \\ 46 & 4 & 24 & 16 & 44 & 32 & 56 & 88 & 0.67 / 0.54 \\ 5 & 1 & 3 & 1 & 5 & 5 & 5 & 10 & 0.77 / 0.50 \\ & & & & & & & & \\ 154 & 14 & 70 & 58 & 142 & 98 & 186 & 284 & 0.26 / 0.11 \\ 125 & 12 & 54 & 50 & 116 & 78 & 154 & 232 & 0.19 / 0.09 \\ 8 & 0 & 5 & 3 & 8 & 5 & 11 & 16 & 0.30 / 0.49 \\ 17 & 1 & 8 & 5 & 14 & 10 & 18 & 28 & 0.76 / 0.67 \\ 4 & 1 & 3 & 0 & 4 & 5 & 3 & 8 & 0.17 / 0.18 \\ 3 & 1 & 2 & 0 & 3 & 4 & 2 & 6 & ---- \\ 1 & 0 & 1 & 0 & 1 & 1 & 1 & 2 & ---- \\ 2 & 0 & 1 & 0 & 1 & 1 & 1 & 2 & ---- \\ 406 & 41 & 183 & 150 & 374 & 265 & 483 & 748 & 0.17 / 0.07 \\ 28 & 4 & 13 & 9 & 26 & 21 & 31 & 52 & ---- \\ 500 & 56 & 230 & 178 & 464 & 342 & 586 & 928 & 0.61 / 0.21 \\ 500 & 66 & 247 & 165 & 478 & 379 & 577 & 956 & ----\end{array}$


rs217325

Subfenótipo

Fissura Palatina

Completa

Incompleta

Total FP

$\mathrm{N}$

\begin{tabular}{cccccccc}
\multicolumn{3}{c}{ Genótipos } & \multicolumn{5}{c}{ Alelos } \\
CC & CT & TT & Total & C & T & Total & Pgen/Palelo \\
& & & & & & & \\
1 & 10 & 9 & 20 & 12 & 28 & 40 & $0.13 / 0.15$ \\
4 & 16 & 25 & 45 & 24 & 66 & 90 & $0.18 / 0.17$ \\
5 & 26 & 34 & 65 & 36 & 94 & 130 & $0.14 / 0.06$
\end{tabular}

Fissura Labial e/ou Palatina

\begin{tabular}{|c|c|c|c|c|c|c|c|c|c|}
\hline Completa & 300 & 30 & 115 & 140 & 285 & 175 & 395 & 570 & $0.00001^{*}$ \\
\hline Incompleta & 104 & 13 & 39 & 51 & 103 & 65 & 141 & 206 & $0.005 / 0.0006$ \\
\hline Unilateral & 250 & 22 & 99 & 117 & 238 & 143 & 333 & 476 & $0.0003 / 0.00001$ \\
\hline Completa & 175 & 15 & 69 & 79 & 163 & 99 & 227 & 326 & $0.001 / 0.0003$ \\
\hline Incompleta & 75 & 7 & 30 & 38 & 75 & 44 & 106 & 150 & $0.05 / 0.01$ \\
\hline Unilateral Direita & 78 & 7 & 29 & 39 & 75 & 43 & 107 & 150 & $0.09 / 0.02$ \\
\hline Completa & 54 & 3 & 22 & 26 & 51 & 28 & 74 & 102 & $0.11 / 0.10$ \\
\hline Incompleta & 16 & 3 & 6 & 7 & 16 & 12 & 20 & 32 & $0.07 / 0.02$ \\
\hline Incompleta + FP & 8 & 1 & 1 & 6 & 8 & 3 & 13 & 16 & $0.49 / 0.85$ \\
\hline Unilateral Esquerda & 172 & 15 & 70 & 78 & 163 & 100 & 226 & 326 & $0.0006 / 0.0002$ \\
\hline Completa & 121 & 12 & 47 & 53 & 112 & 71 & 153 & 224 & $0.002 / 0.0003$ \\
\hline Incompleta & 46 & 3 & 23 & 20 & 46 & 29 & 63 & 92 & $0.01 / 0.01$ \\
\hline Incompleta + FP & 5 & 0 & 0 & 5 & 5 & 0 & 10 & 10 & $0.10 / 0.03$ \\
\hline Bilateral & 154 & 21 & 55 & 74 & 150 & 97 & 203 & 300 & $0.0003 / 0.00001$ \\
\hline Completa & 125 & 15 & 46 & 61 & 122 & 76 & 168 & 244 & $0.004 / 0.0004$ \\
\hline Incompleta & 8 & 2 & 4 & 2 & 8 & 8 & 8 & 16 & $0.02 / 0.004$ \\
\hline Incompleta + FP & 17 & 4 & 3 & 9 & 16 & 11 & 21 & 32 & $0.01 / 0.06$ \\
\hline Incompleta Mista & 4 & 0 & 2 & 2 & 4 & 2 & 6 & 8 & $0.61 / 0.76$ \\
\hline FL direita + FL/P esquerda & 3 & 0 & 1 & 2 & 3 & 1 & 5 & 6 & ---- \\
\hline FL esquerda + FP bilateral & 1 & 0 & 1 & 0 & 1 & 1 & 1 & 2 & ---- \\
\hline Fissura Mediana & 2 & 0 & 1 & 0 & 1 & 1 & 1 & 2 & ---- \\
\hline Total FL/P & 406 & 43 & 155 & 191 & 389 & 241 & 537 & 778 & $0.00001^{*}$ \\
\hline Tipo/lado desconhecido & 28 & 3 & 9 & 15 & 27 & 15 & 39 & 54 & ---- \\
\hline Total fissurados & 500 & 51 & 190 & 240 & 481 & 292 & 670 & 962 & $0.00001^{*}$ \\
\hline Sem fissuras (Controles) & 500 & 29 & 140 & 311 & 480 & 198 & 762 & 960 & ---- \\
\hline
\end{tabular}


rs3798867

Subfenótipo

Fissura Palatina

Completa

Incompleta

Total FP

Fissura Labial e/ou Palatina

\begin{tabular}{|c|c|c|c|c|c|c|c|c|c|}
\hline \multirow[b]{2}{*}{ Subfenótipo } & \multirow[t]{2}{*}{$\mathrm{N}$} & \multicolumn{3}{|c|}{ Genótipos } & \multicolumn{5}{|c|}{ Alelos } \\
\hline & & $\mathrm{CC}$ & $\mathrm{CT}$ & TT & Total & $\mathrm{C}$ & $\mathrm{T}$ & Total & Pgen/Palelo \\
\hline \multicolumn{10}{|l|}{ Fissura Palatina } \\
\hline Completa & 21 & 6 & 10 & 4 & 20 & 22 & 18 & 40 & $0.80 / 0.55$ \\
\hline Incompleta & 45 & 14 & 23 & 7 & 44 & 51 & 37 & 88 & $0.94 / 0.75$ \\
\hline Total FP & 66 & 20 & 33 & 11 & 64 & 73 & 55 & 128 & $0.84 / 0.57$ \\
\hline \multicolumn{10}{|l|}{ Fissura Labial e/ou Palatina } \\
\hline Completa & 300 & 115 & 123 & 35 & 273 & 353 & 193 & 546 & $0.09 / 0.05$ \\
\hline Incompleta & 104 & 38 & 51 & 8 & 97 & 127 & 67 & 194 & $0.11 / 0.13$ \\
\hline Unilateral & 250 & 95 & 106 & 28 & 229 & 296 & 162 & 458 & $0.16 / 0.07$ \\
\hline Completa & 175 & 65 & 71 & 22 & 158 & 201 & 115 & 316 & $0.28 / 0.21$ \\
\hline Incompleta & 75 & 30 & 35 & 6 & 71 & 95 & 47 & 142 & $0.22 / 0.09$ \\
\hline Unilateral Direita & 78 & 32 & 34 & 6 & 72 & 98 & 46 & 144 & $0.14 / 0.05$ \\
\hline Completa & 54 & 20 & 25 & 5 & 50 & 65 & 35 & 100 & $0.55 / 0.29$ \\
\hline Incompleta & 16 & 9 & 6 & 0 & 15 & 24 & 6 & 30 & $0.06 / 0.02$ \\
\hline Incompleta + FP & 8 & 3 & 3 & 1 & 7 & 9 & 5 & 14 & $0.88 / 0.72$ \\
\hline Unilateral Esquerda & 172 & 63 & 72 & 22 & 157 & 198 & 116 & 314 & $0.40 / 0.28$ \\
\hline Completa & 121 & 45 & 46 & 17 & 108 & 136 & 80 & 216 & $0.27 / 0.37$ \\
\hline Incompleta & 46 & 17 & 23 & 4 & 44 & 57 & 31 & 88 & $0.55 / 0.34$ \\
\hline Incompleta + FP & 5 & 1 & 3 & 1 & 5 & 5 & 5 & 10 & $0.79 / 0.53$ \\
\hline Bilateral & 154 & 58 & 68 & 15 & 141 & 184 & 98 & 282 & $0.22 / 0.09$ \\
\hline Completa & 125 & 50 & 52 & 13 & 115 & 152 & 78 & 230 & $0.16 / 0.07$ \\
\hline Incompleta & 8 & 3 & 5 & 0 & 8 & 11 & 5 & 16 & $0.48 / 0.46$ \\
\hline Incompleta + FP & 17 & 5 & 8 & 1 & 14 & 18 & 10 & 28 & $0.71 / 0.62$ \\
\hline Incompleta Mista & 4 & 0 & 3 & 1 & 4 & 3 & 5 & 8 & $0.35 / 0.20$ \\
\hline FL direita + FL/P esquerda & 3 & 0 & 2 & 1 & 3 & 2 & 4 & 6 & ---- \\
\hline FL esquerda + FP bilateral & 1 & 0 & 1 & 0 & 1 & 1 & 1 & 2 & ---- \\
\hline Fissura Mediana & 2 & 0 & 1 & 0 & 1 & 1 & 1 & 2 & ---- \\
\hline Total FL/P & 406 & 153 & 175 & 43 & 371 & 481 & 261 & 742 & $0.06 / 0.02$ \\
\hline Tipo/lado desconhecido & 28 & 10 & 12 & 4 & 26 & 32 & 20 & 52 & ---- \\
\hline Total fissurados & 500 & 183 & 220 & 58 & 461 & 586 & 336 & 922 & $0.17 / 0.08$ \\
\hline Sem fissuras (Controles) & 500 & 163 & 242 & 71 & 476 & 568 & 384 & 952 & ---- \\
\hline
\end{tabular}


rs512140

Subfenótipo

Fissura Palatina

Completa

Incompleta

Total FP

N

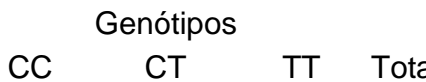

$21 \quad 1$

$45 \quad 4 \quad 18$

$66 \quad 5 \quad 26$

Fissura Labial e/ou Palatina

\begin{tabular}{|c|c|c|c|c|c|c|c|c|c|}
\hline Completa & 300 & 24 & 115 & 145 & 284 & 163 & 405 & 568 & $0.27 / 0.21$ \\
\hline Incompleta & 104 & 6 & 48 & 47 & 101 & 60 & 142 & 202 & $0.05 / 0.25$ \\
\hline Unilateral & 250 & 17 & 102 & 118 & 237 & 136 & 338 & 474 & $0.09 / 0.24$ \\
\hline Completa & 175 & 14 & 65 & 84 & 163 & 93 & 233 & 326 & $0.48 / 0.33$ \\
\hline Incompleta & 75 & 3 & 37 & 34 & 74 & 43 & 105 & 148 & $0.03 / 0.39$ \\
\hline Unilateral Direita & 78 & 5 & 31 & 38 & 74 & 41 & 107 & 148 & $0.2 / 0.620$ \\
\hline Completa & 54 & 4 & 22 & 25 & 51 & 30 & 72 & 102 & $0.49 / 0.42$ \\
\hline Incompleta & 16 & 1 & 6 & 8 & 15 & 8 & 22 & 30 & $0.90 / 0.91$ \\
\hline Incompleta + FP & 8 & 0 & 3 & 5 & 8 & 3 & 13 & 16 & $0.69 / 0.52$ \\
\hline Unilateral Esquerda & 172 & 12 & 71 & 80 & 163 & 95 & 231 & 326 & $0.13 / 0.23$ \\
\hline Completa & 121 & 10 & 43 & 59 & 112 & 63 & 161 & 224 & $0.73 / 0.01$ \\
\hline Incompleta & 46 & 2 & 27 & 17 & 46 & 31 & 61 & 92 & $0.005 / 0.10$ \\
\hline Incompleta + FP & 5 & 0 & 1 & 4 & 5 & 1 & 9 & 10 & $0.54 / 0.25$ \\
\hline Bilateral & 154 & 13 & 61 & 74 & 148 & 87 & 209 & 296 & $0.32 / 0.21$ \\
\hline Completa & 125 & 10 & 50 & 61 & 121 & 70 & 172 & 242 & $0.40 / 0.32$ \\
\hline Incompleta & 8 & 1 & 4 & 3 & 8 & 6 & 10 & 16 & $0.55 / 0.28$ \\
\hline Incompleta + FP & 17 & 2 & 5 & 8 & 15 & 9 & 21 & 30 & $0.79 / 0.60$ \\
\hline Incompleta Mista & 4 & 0 & 2 & 2 & 4 & 2 & 6 & 8 & $0.73 / 0.95$ \\
\hline FL direita + FL/P esquerda & 3 & 0 & 1 & 2 & 3 & 1 & 5 & 6 & ---- \\
\hline FL esquerda + FP bilateral & 1 & 0 & 1 & 0 & 1 & 1 & 1 & 2 & ---- \\
\hline Fissura Mediana & 2 & 0 & 1 & 0 & 1 & 1 & 1 & 2 & ---- \\
\hline Total FL/P & 406 & 30 & 164 & 192 & 386 & 224 & 548 & 772 & $0.07 / 0.13$ \\
\hline Tipo/lado desconhecido & 28 & 2 & 12 & 13 & 27 & 16 & 38 & 54 & ---- \\
\hline Total fissurados & 500 & 37 & 202 & 239 & 478 & 276 & 680 & 956 & $0.06 / 0.12$ \\
\hline Sem fissuras (Controles) & 500 & 40 & 167 & 272 & 479 & 247 & 711 & 958 & ---- \\
\hline
\end{tabular}

Alelos

C T Total Pgen/Palelo

$8 \quad 11$

20

10

$30 \quad 40$

$0.81 / 0.91$

1823

45

6490

$0.75 / 0.52$

$0.71 / 0.64$

$\begin{array}{lll}36 & 94 & 130\end{array}$

4


rs614565

Subfenótipo

Fissura Palatina

Completa

Incompleta

Total FP

\begin{tabular}{ccccccccc} 
N & \multicolumn{3}{c}{ Genótipos } & \multicolumn{5}{c}{ Alelos } \\
& CC & CT & TT & Total & C & T & Total & Pgen/Palelo \\
21 & 2 & 6 & 12 & 20 & 10 & 30 & 40 & $0.80^{\star}$ \\
45 & 6 & 22 & 15 & 43 & 34 & 52 & 86 & $0.03 / 0.01$ \\
66 & 8 & 28 & 27 & 63 & 44 & 82 & 126 & $0.16 / 0.05$
\end{tabular}

Fissura Labial e/ou Palatina

\begin{tabular}{|c|c|c|c|c|c|c|c|c|c|}
\hline Completa & 300 & 16 & 92 & 163 & 271 & 124 & 418 & 542 & $0.38 / 0.09$ \\
\hline Incompleta & 104 & 2 & 44 & 51 & 97 & 48 & 146 & 194 & $0.05 / 0.56$ \\
\hline Unilateral & 250 & 9 & 91 & 128 & 228 & 109 & 347 & 456 & $0.10 / 0.25$ \\
\hline Completa & 175 & 9 & 57 & 91 & 157 & 75 & 239 & 314 & $0.55 / 0.31$ \\
\hline Incompleta & 75 & 0 & 34 & 37 & 71 & 34 & 108 & 142 & $0.02 / 0.48$ \\
\hline Unilateral Direita & 78 & 4 & 26 & 42 & 72 & 34 & 110 & 144 & $0.69 / 0.42$ \\
\hline Completa & 54 & 4 & 15 & 31 & 50 & 23 & 77 & 100 & $0.59 / 0.41$ \\
\hline Incompleta & 16 & 0 & 7 & 8 & 15 & 7 & 23 & 30 & $0.45 / 0.67$ \\
\hline Incompleta + FP & 8 & 0 & 4 & 3 & 7 & 4 & 10 & 14 & $0.47 / 0.87$ \\
\hline Unilateral Esquerda & 172 & 5 & 65 & 86 & 156 & 75 & 237 & 312 & $0.08 / 0.34$ \\
\hline Completa & 121 & 5 & 42 & 60 & 107 & 52 & 162 & 214 & $0.45 / 0.46$ \\
\hline Incompleta & 46 & 0 & 20 & 24 & 44 & 20 & 68 & 88 & $0.11 / 0.41$ \\
\hline Incompleta + FP & 5 & 0 & 3 & 2 & 5 & 3 & 7 & 10 & $0.52 / 0.81$ \\
\hline Bilateral & 154 & 9 & 45 & 86 & 140 & 63 & 217 & 280 & $0.36 / 0.15$ \\
\hline Completa & 125 & 7 & 35 & 72 & 114 & 49 & 179 & 228 & $0.25 / 0.10$ \\
\hline Incompleta & 8 & 0 & 1 & 7 & 8 & 1 & 15 & 16 & $0.17 / 0.06$ \\
\hline Incompleta + FP & 17 & 2 & 7 & 5 & 14 & 11 & 17 & 28 & $0.34 / 0.14$ \\
\hline Incompleta Mista & 4 & 0 & 2 & 2 & 4 & 2 & 6 & 8 & $0.76 / 0.91$ \\
\hline FL direita + FL/P esquerda & 3 & 0 & 1 & 2 & 3 & 1 & 5 & 6 & ---- \\
\hline FL esquerda + FP bilateral & 1 & 0 & 1 & 0 & 1 & 1 & 1 & 2 & ---- \\
\hline Fissura Mediana & 2 & 0 & 0 & 1 & 1 & 0 & 2 & 2 & ---- \\
\hline Total FL/P & 406 & 18 & 136 & 215 & 369 & 172 & 566 & 738 & $0.25 / 0.10$ \\
\hline Tipo/lado desconhecido & 28 & 3 & 6 & 16 & 25 & 12 & 38 & 50 & ---- \\
\hline Total fissurados & 500 & 29 & 170 & 258 & 457 & 228 & 686 & 914 & $0.53 / 0.37$ \\
\hline Sem fissuras (Controles) & 500 & 39 & 176 & 260 & 475 & 254 & 696 & 950 & ---- \\
\hline
\end{tabular}


rs6940766

Subfenótipo

$\mathrm{N}$

Genótipos

Alelos

Fissura Palatina

Completa
Incompleta

\begin{tabular}{cccccccccc} 
& N & \multicolumn{3}{c}{ Genótipos } & \multicolumn{7}{c}{ Alelos } \\
& & AA & AG & GG & Total & A & G & Total & Pgen/Palelo \\
& & & & & & & & & \\
Total FP & 61 & 0 & 4 & 16 & 20 & 4 & 36 & 40 & $0.03 / 0.005$ \\
& 45 & 2 & 19 & 24 & 45 & 23 & 67 & 90 & $0.30 / 0.34$ \\
& 66 & 2 & 23 & 40 & 65 & 27 & 103 & 130 & $0.07 / 0.02$
\end{tabular}

Fissura Labial e/ou Palatina

\begin{tabular}{|c|c|c|c|c|c|c|c|c|c|}
\hline Completa & 300 & 12 & 86 & 187 & 285 & 110 & 460 & 570 & $0.00001^{*}$ \\
\hline Incompleta & 104 & 8 & 33 & 62 & 103 & 49 & 157 & 206 & $0.20 / 0.06$ \\
\hline Unilateral & 250 & 17 & 77 & 144 & 238 & 111 & 365 & 476 & $0.04 / 0.005$ \\
\hline Completa & 175 & 10 & 51 & 102 & 163 & 71 & 255 & 326 & $0.003^{*}$ \\
\hline Incompleta & 75 & 7 & 26 & 42 & 75 & 40 & 110 & 150 & $0.69 / 0.36$ \\
\hline Unilateral Direita & 78 & 4 & 24 & 47 & 75 & 32 & 118 & 150 & $0.10 / 0.02$ \\
\hline Completa & 54 & 2 & 16 & 33 & 51 & 20 & 82 & 102 & 0.09/0.02 \\
\hline Incompleta & 16 & 2 & 6 & 8 & 16 & 10 & 22 & 32 & 0.99/0.91 \\
\hline Incompleta + FP & 8 & 0 & 2 & 6 & 8 & 2 & 14 & 16 & $0.34 / 0.12$ \\
\hline Unilateral Esquerda & 172 & 13 & 53 & 97 & 163 & 79 & 247 & 326 & $0.21 / 0.03$ \\
\hline Completa & 121 & 8 & 35 & 69 & 112 & 51 & 173 & 224 & $0.10 / 0.02$ \\
\hline Incompleta & 46 & 5 & 17 & 24 & 46 & 27 & 65 & 92 & $0.97 / 0.84$ \\
\hline Incompleta + FP & 5 & 0 & 1 & 4 & 5 & 1 & 9 & 10 & $0.41 / 0.16$ \\
\hline Bilateral & 154 & 3 & 42 & 105 & 150 & 48 & 252 & 300 & $0.00001^{*}$ \\
\hline Completa & 125 & 2 & 35 & 85 & 122 & 39 & 205 & 244 & $0.0001 / 0.00001$ \\
\hline Incompleta & 8 & 0 & 3 & 5 & 8 & 3 & 13 & 16 & $0.56 / 0.31$ \\
\hline Incompleta + FP & 17 & 1 & 3 & 12 & 16 & 5 & 27 & 32 & $0.17 / 0.07$ \\
\hline Incompleta Mista & 4 & 0 & 1 & 3 & 4 & 1 & 7 & 8 & $0.58 / 0.27$ \\
\hline FL direita + FL/P esquerda & 3 & 0 & 1 & 2 & 3 & 1 & 5 & 6 & ---- \\
\hline FL esquerda + FP bilateral & 1 & 0 & 0 & 1 & 1 & 0 & 2 & 2 & ---- \\
\hline Fissura Mediana & 2 & 0 & 0 & 1 & 1 & 0 & 2 & 2 & --- \\
\hline Total FL/P & 406 & 20 & 119 & 250 & 389 & 159 & 619 & 778 & $0.00001^{*}$ \\
\hline Tipo/lado desconhecido & 28 & 0 & 8 & 19 & 27 & 8 & 46 & 54 & --- \\
\hline Total fissurados & 500 & 22 & 150 & 309 & 481 & 194 & 768 & 962 & $0.00001^{*}$ \\
\hline Sem fissuras (Controles) & 500 & 57 & 176 & 245 & 478 & 290 & 666 & 956 & ---- \\
\hline
\end{tabular}


rs624076

Subfenótipo

Fissura Palatina

Completa

Incompleta

Total FP

N

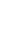

Genótipos

$\begin{array}{ccccccccc} & \text { AA } & \text { AG } & \text { GG } & \text { Total } & \text { A } & \text { G } & \text { Total } & \text { Pgen/Palelo } \\ 21 & 3 & 7 & 10 & 20 & 13 & 27 & 40 & 0.73 / 0.59 \\ 45 & 6 & 20 & 15 & 41 & 32 & 50 & 82 & 0.13 / 0.04 \\ 66 & 9 & 27 & 25 & 61 & 45 & 77 & 122 & 0.18 / 0.05\end{array}$

Fissura Labial e/ou Palatina

\begin{tabular}{|c|c|c|c|c|c|c|c|c|c|}
\hline Completa & 300 & 16 & 104 & 137 & 257 & 136 & 378 & 514 & $0.25 / 0.38$ \\
\hline Incompleta & 104 & 2 & 44 & 51 & 97 & 48 & 146 & 194 & $0.03 / 0.27$ \\
\hline Unilateral & 250 & 15 & 97 & 115 & 227 & 127 & 327 & 454 & $0.25 / 0.81$ \\
\hline Completa & 175 & 5 & 63 & 79 & 147 & 73 & 221 & 294 & $0.86 / 0.20$ \\
\hline Incompleta & 75 & 0 & 34 & 36 & 70 & 34 & 106 & 140 & $0.01 / 0.29$ \\
\hline Unilateral Direita & 78 & 7 & 31 & 34 & 72 & 45 & 99 & 144 & $0.67 / 0.51$ \\
\hline Completa & 54 & 7 & 19 & 23 & 49 & 33 & 65 & 98 & $0.54 / 0.29$ \\
\hline Incompleta & 16 & 0 & 7 & 8 & 15 & 7 & 23 & 30 & $0.41 / 0.52$ \\
\hline Incompleta + FP & 8 & 0 & 5 & 3 & 8 & 5 & 11 & 16 & $0.30 / 0.81$ \\
\hline Unilateral Esquerda & 172 & 8 & 62 & 81 & 151 & 78 & 224 & 302 & $0.23 / 0.35$ \\
\hline Completa & 121 & 8 & 44 & 56 & 108 & 60 & 156 & 216 & $0.70 / 0.81$ \\
\hline Incompleta & 46 & 0 & 19 & 23 & 42 & 19 & 65 & 84 & $0.09 / 0.24$ \\
\hline Incompleta + FP & 5 & 0 & 3 & 2 & 5 & 3 & 7 & 10 & $0.52 / 0.92$ \\
\hline Bilateral & 154 & 3 & 51 & 73 & 127 & 57 & 197 & 254 & $0.02 / 0.05$ \\
\hline Completa & 125 & 1 & 41 & 58 & 100 & 43 & 157 & 200 & $0.01 / 0.04$ \\
\hline Incompleta & 8 & 0 & 1 & 7 & 8 & 1 & 15 & 16 & $0.14 / 0.04$ \\
\hline Incompleta + FP & 17 & 2 & 7 & 6 & 15 & 11 & 19 & 30 & $0.62 / 0.33$ \\
\hline Incompleta Mista & 4 & 0 & 2 & 2 & 4 & 2 & 6 & 8 & $0.75 / 0.82$ \\
\hline FL direita + FL/P esquerda & 3 & 0 & 1 & 2 & 3 & 1 & 5 & 6 & ---- \\
\hline FL esquerda + FP bilateral & 1 & 0 & 1 & 0 & 1 & 1 & 1 & 2 & ---- \\
\hline Fissura Mediana & 2 & 0 & 0 & 1 & 1 & 0 & 2 & 2 & ---- \\
\hline Total FL/P & 406 & 18 & 148 & 189 & 355 & 184 & 526 & 710 & $0.03 / 0.22$ \\
\hline Tipo/lado desconhecido & 28 & 4 & 6 & 14 & 24 & 14 & 34 & 48 & ---- \\
\hline Total fissurados & 500 & 31 & 181 & 228 & 440 & 243 & 637 & 880 & $0.27 / 0.64$ \\
\hline Sem fissuras (Controles) & 500 & 46 & 179 & 249 & 474 & 271 & 677 & 948 & ---- \\
\hline
\end{tabular}

Alelos 
rs7753918

Subfenótipo

N

Genótipos

Alelos

Fissura Palatina

Completa

Incompleta

Total FP

$\begin{array}{ccccccccc}21 & 0 & 5 & 15 & 20 & 5 & 35 & 40 & 0.28 / 0.41 \\ 45 & 6 & 8 & 31 & 45 & 20 & 70 & 90 & 0.60 / 0.26 \\ 66 & 6 & 13 & 46 & 65 & 25 & 105 & 130 & 0.83 / 0.62\end{array}$

Fissura Labial e/ou Palatina

\begin{tabular}{|c|c|c|c|c|c|c|c|c|c|}
\hline Completa & 300 & 4 & 89 & 192 & 285 & 97 & 473 & 570 & $0.00001 / 0.80$ \\
\hline Incompleta & 104 & 3 & 26 & 73 & 102 & 32 & 172 & 204 & $0.02 / 0.73$ \\
\hline Unilateral & 250 & 4 & 67 & 166 & 237 & 75 & 399 & 474 & $0.00001 / 0.42$ \\
\hline Completa & 175 & 3 & 49 & 111 & 163 & 55 & 271 & 326 & $0.00001 / 0.79$ \\
\hline Incompleta & 75 & 1 & 18 & 55 & 74 & 20 & 128 & 148 & $0.03 / 0.22$ \\
\hline Unilateral Direita & 78 & 1 & 21 & 53 & 75 & 23 & 127 & 150 & $0.01 / 0.51$ \\
\hline Completa & 54 & 1 & 14 & 36 & 51 & 16 & 86 & 102 & $0.06 / 0.64$ \\
\hline Incompleta & 16 & 0 & 3 & 13 & 16 & 3 & 29 & 32 & $0.45 / 0.23$ \\
\hline Incompleta + FP & 8 & 0 & 4 & 4 & 8 & 4 & 12 & 16 & $0.04 / 0.43$ \\
\hline Unilateral Esquerda & 172 & 3 & 46 & 113 & 162 & 52 & 272 & 324 & $0.00001 / 0.54$ \\
\hline Completa & 121 & 2 & 35 & 75 & 112 & 39 & 185 & 224 & $0.0003 / 0.97$ \\
\hline Incompleta & 46 & 1 & 10 & 34 & 45 & 12 & 78 & 90 & $0.23 / 0.31$ \\
\hline Incompleta + FP & 5 & 0 & 1 & 4 & 5 & 1 & 9 & 10 & $0.78 / 0.53$ \\
\hline Bilateral & 154 & 3 & 48 & 99 & 150 & 54 & 246 & 300 & $0.00001 / 0.84$ \\
\hline Completa & 125 & 1 & 40 & 81 & 122 & 42 & 202 & 244 & $0.00001 / 0.0008$ \\
\hline Incompleta & 8 & 0 & 3 & 5 & 8 & 3 & 13 & 16 & $0.25 / 0.89$ \\
\hline Incompleta + FP & 17 & 2 & 5 & 9 & 16 & 9 & 23 & 32 & $0.26 / 0.12$ \\
\hline Incompleta Mista & 4 & 0 & 0 & 4 & 4 & 0 & 8 & 8 & $0.49 / 0.19$ \\
\hline FL direita + FL/P esquerda & 3 & 0 & 0 & 3 & 3 & 0 & 6 & 6 & ---- \\
\hline FL esquerda + FP bilateral & 1 & 0 & 0 & 1 & 1 & 0 & 2 & 2 & ---- \\
\hline Fissura Mediana & 2 & 0 & 0 & 1 & 1 & 0 & 2 & 2 & ---- \\
\hline Total FL/P & 406 & 7 & 115 & 266 & 388 & 129 & 647 & 776 & $0.00001 / 0.62$ \\
\hline Tipo/lado desconhecido & 28 & 0 & 3 & 23 & 26 & 3 & 49 & 52 & ---- \\
\hline Total fissurados & 500 & 13 & 131 & 335 & 479 & 157 & 801 & 958 & $0.00001 / 0.51$ \\
\hline Sem fissuras (Controles) & 500 & 43 & 82 & 355 & 480 & 168 & 792 & 960 & ---- \\
\hline
\end{tabular}


rs10943944 Caucasianos

Subfenótipo

$\mathrm{N}$

Fissura Palatina

Completa

Incompleta

Total FP

Fissura Labial e/ou Palatina

\begin{tabular}{|c|c|c|c|c|c|c|c|c|c|}
\hline Completa & 237 & 139 & 79 & 18 & 236 & 357 & 115 & 472 & $0.01 / 0.03$ \\
\hline Incompleta & 86 & 51 & 28 & 6 & 85 & 130 & 40 & 170 & $0.13 / 0.17$ \\
\hline Unilateral & 336 & 203 & 107 & 26 & 336 & 513 & 159 & 672 & $0.03^{\star}$ \\
\hline Completa & 200 & 123 & 62 & 15 & 200 & 308 & 92 & 400 & $0.02 / 0.11$ \\
\hline Incompleta & 136 & 80 & 45 & 11 & 136 & 205 & 67 & 272 & $0.21 / 0.05$ \\
\hline Unilateral Direita & 60 & 41 & 13 & 6 & 60 & 95 & 25 & 120 & $0.008 / 0.61$ \\
\hline Completa & 43 & 29 & 10 & 4 & 43 & 68 & 18 & 86 & $0.04 / 0.64$ \\
\hline Incompleta & 11 & 8 & 2 & 1 & 11 & 18 & 4 & 22 & $0.28 / 0.93$ \\
\hline Incompleta + FP & 6 & 4 & 1 & 1 & 6 & 9 & 3 & 12 & $0.09 / 0.59$ \\
\hline Unilateral Esquerda & 140 & 82 & 49 & 9 & 140 & 213 & 67 & 280 & $0.09 / 0.08$ \\
\hline Completa & 93 & 51 & 35 & 7 & 93 & 137 & 49 & 186 & $0.03 / 0.02$ \\
\hline Incompleta & 44 & 29 & 13 & 2 & 44 & 71 & 17 & 88 & $0.69 / 0.91$ \\
\hline Incompleta + FP & 3 & 2 & 1 & 0 & 3 & 5 & 1 & 6 & $0.96 / 0.89$ \\
\hline Bilateral & 123 & 67 & 45 & 9 & 121 & 179 & 63 & 242 & $0.02 / 0.02$ \\
\hline Completa & 101 & 59 & 34 & 7 & 100 & 152 & 48 & 200 & $0.10 / 0.11$ \\
\hline Incompleta & 6 & 2 & 4 & 0 & 6 & 8 & 4 & 12 & $0.21 / 0.20$ \\
\hline Incompleta + FP & 13 & 3 & 7 & 2 & 12 & 13 & 11 & 24 & $0.001^{*}$ \\
\hline Incompleta Mista & 3 & 3 & 0 & 0 & 3 & 6 & 0 & 6 & $0.44 / 0.11$ \\
\hline FL direita + FL/P esquerda & 2 & 2 & 0 & 0 & 2 & 4 & 0 & 4 & ---- \\
\hline FL esquerda + FP bilateral & 1 & 0 & 0 & 0 & 0 & 0 & 0 & 0 & ---- \\
\hline Fissura Mediana & 1 & 1 & 0 & 0 & 1 & 2 & 0 & 2 & ---- \\
\hline Total FL/P & 377 & 191 & 107 & 24 & 322 & 489 & 155 & 644 & $0.01 / 0.02$ \\
\hline Tipo/lado desconhecido & 16 & 14 & 2 & 0 & 16 & 30 & 2 & 32 & ---- \\
\hline Total Fissurados & 393 & 242 & 119 & 30 & 391 & 603 & 179 & 782 & $0.01 / 0.07$ \\
\hline Sem fissura (Controles) & 285 & 184 & 93 & 7 & 284 & 461 & 107 & 568 & ---- \\
\hline
\end{tabular}

Alelos

$\begin{array}{ccccccccc} & \text { CC } & \text { CT } & \text { TT } & \text { Total } & \text { C } & \text { T } & \text { Total } & \text { Pgen/Palelo } \\ 15 & 13 & 2 & 0 & 15 & 28 & 2 & 30 & 0.21 / 0.09 \\ 38 & 24 & 8 & 6 & 38 & 56 & 20 & 76 & 0.0003 / 0.12 \\ 53 & 37 & 10 & 6 & 53 & 84 & 22 & 106 & 0.002 / 0.64\end{array}$


rs1171105 Caucasianos

Subfenótipo

Fissura Palatina

Completa

Incompleta

Total FP

\begin{tabular}{ccccccccc} 
N & \multicolumn{3}{c}{ Genótipos } & \multicolumn{5}{c}{ Alelos } \\
& CC & CT & TT & Total & C & T & Total & Pgen/Palelo \\
15 & 6 & 7 & 2 & 15 & 19 & 11 & 30 & $0.96 / 0.83$ \\
38 & 17 & 16 & 4 & 37 & 50 & 24 & 74 & $0.53 / 0.30$ \\
53 & 23 & 23 & 6 & 52 & 69 & 35 & 104 & $0.57 / 0.34$
\end{tabular}

Fissura Labial e/ou Palatina

\begin{tabular}{|c|c|c|c|c|c|c|c|c|c|}
\hline Completa & 237 & 105 & 98 & 31 & 234 & 308 & 160 & 468 & $0.14 / 0.14$ \\
\hline Incompleta & 86 & 41 & 37 & 15 & 93 & 119 & 67 & 186 & $0.25 / 0.53$ \\
\hline Unilateral & 336 & 91 & 148 & 45 & 284 & 330 & 238 & 568 & $0.26 / 0.25$ \\
\hline Completa & 200 & 60 & 90 & 27 & 177 & 210 & 144 & 354 & $0.31 / 0.20$ \\
\hline Incompleta & 136 & 31 & 58 & 18 & 107 & 120 & 94 & 214 & $0.60 / 0.26$ \\
\hline Unilateral Direita & 60 & 32 & 29 & 9 & 70 & 93 & 47 & 140 & $0.36 / 0.27$ \\
\hline Completa & 43 & 17 & 18 & 8 & 43 & 52 & 34 & 86 & $0.55 / 0.26$ \\
\hline Incompleta & 11 & 13 & 7 & 1 & 21 & 33 & 9 & 42 & $0.06 / 0.02$ \\
\hline Incompleta + FP & 6 & 2 & 4 & 0 & 6 & 8 & 4 & 12 & $0.55 / 0.71$ \\
\hline Unilateral Esquerda & 140 & 59 & 61 & 18 & 138 & 179 & 97 & 276 & $0.46 / 0.33$ \\
\hline Completa & 93 & 43 & 40 & 10 & 93 & 126 & 60 & 186 & $0.24 / 0.12$ \\
\hline Incompleta & 44 & 14 & 20 & 8 & 42 & 48 & 36 & 84 & $0.65 / 0.45$ \\
\hline Incompleta + FP & 3 & 2 & 1 & 0 & 3 & 5 & 1 & 6 & $0.52 / 0.27$ \\
\hline Bilateral & 123 & 55 & 45 & 19 & 119 & 155 & 83 & 238 & $0.09 / 0.32$ \\
\hline Completa & 101 & 45 & 40 & 13 & 98 & 130 & 66 & 196 & $0.24 / 0.22$ \\
\hline Incompleta & 6 & 2 & 3 & 1 & 6 & 7 & 5 & 12 & $0.97 / 0.82$ \\
\hline Incompleta + FP & 13 & 6 & 2 & 4 & 12 & 14 & 10 & 24 & $0.04 / 0.75$ \\
\hline Incompleta Mista & 3 & 2 & 0 & 1 & 3 & 4 & 2 & 6 & $0.21 / 0.79$ \\
\hline FL direita + FL/P esquerda & 2 & 2 & 0 & 0 & 2 & 4 & 0 & 4 & ---- \\
\hline FL esquerda + FP bilateral & 1 & 0 & 0 & 1 & 1 & 0 & 2 & 2 & ---- \\
\hline Fissura Mediana & 1 & 0 & 1 & 0 & 1 & 1 & 1 & 2 & ---- \\
\hline Total FL/P & 377 & 146 & 136 & 46 & 328 & 428 & 228 & 656 & $0.10 / 0.16$ \\
\hline Tipo/lado desconhecido & 16 & 7 & 7 & 2 & 16 & 21 & 11 & 32 & ---- \\
\hline Total Fissurados & 393 & 176 & 168 & 54 & 398 & 520 & 276 & 796 & $0.09 / 0.14$ \\
\hline Sem fissura (Controles) & 285 & 104 & 141 & 39 & 284 & 349 & 219 & 568 & ---- \\
\hline
\end{tabular}


rs1171114 Caucasianos

Subfenótipo

N

Fissura Palatina

Completa

Incompleta

Total FP

Fissura Labial e/ou Palatina

Completa

Incompleta

Unilateral

Completa

Incompleta

Unilateral Direita

Completa

Incompleta

Incompleta + FP

Unilateral Esquerda

Completa

Incompleta

Incompleta + FP

Bilateral

Completa

Incompleta

Incompleta + FP

Incompleta Mista

FL direita + FL/P esquerda

FL esquerda + FP bilateral

Fissura Mediana

Total FL/P

Tipo/lado desconhecido

Total fissurados

Sem fissura (Controles)

\begin{tabular}{ccccccccc} 
N & \multicolumn{3}{c}{ Genótipos } & \multicolumn{5}{c}{ Alelos } \\
& CC & CT & TT & Total & C & T & Total & Pgen/Palelo \\
& & & & & & & & \\
15 & 5 & 9 & 1 & 15 & 19 & 11 & 30 & $0.69 / 0.93$ \\
38 & 14 & 17 & 6 & 37 & 45 & 29 & 74 & $0.77 / 0.76$ \\
53 & 19 & 26 & 7 & 52 & 64 & 40 & 104 & $0.96 / 0.83$
\end{tabular}

$\begin{array}{ccccccccc}237 & 77 & 114 & 43 & 234 & 268 & 200 & 468 & 0.13 / 0.07 \\ 86 & 23 & 46 & 16 & 85 & 92 & 78 & 170 & 0.11 / 0.04 \\ & & & & & & & & \\ 236 & 65 & 99 & 34 & 198 & 229 & 167 & 396 & 0.26 / 0.13 \\ 200 & 52 & 61 & 22 & 135 & 165 & 105 & 270 & 0.45 / 0.67 \\ 136 & 13 & 38 & 12 & 63 & 64 & 62 & 126 & 0.02 / 0.01\end{array}$

$\begin{array}{lllllllll}136 & 13 & 38 & 12 & 63 & 64 & 62 & 126 & 0.02 / 0.01\end{array}$

$\begin{array}{lllllllll}60 & 16 & 34 & 10 & 60 & 66 & 54 & 120 & 0.24 / 0.11\end{array}$

$\begin{array}{lllllllll}43 & 14 & 24 & 5 & 43 & 52 & 34 & 86 & 0.77 / 0.69\end{array}$

$\begin{array}{lllllllll}11 & 2 & 6 & 3 & 11 & 10 & 12 & 22 & 022 / 0.10\end{array}$

$\begin{array}{lllllllll}6 & 0 & 4 & 2 & 6 & 4 & 8 & 12 & 0.09 / 0.03\end{array}$

$\begin{array}{lllllllll}140 & 49 & 65 & 24 & 138 & 163 & 113 & 276 & 0.36 / 0.31\end{array}$

$\begin{array}{lllllllll}93 & 38 & 37 & 17 & 92 & 113 & 71 & 184 & 0.16 / 0.76\end{array}$

$\begin{array}{lllllllll}44 & 9 & 27 & 7 & 43 & 45 & 41 & 86 & 0.10 / 0.06\end{array}$

$\begin{array}{lllllllll}3 & 2 & 1 & 0 & 3 & 5 & 1 & 6 & 0.54 / 0.29\end{array}$

$\begin{array}{lllllllll}123 & 35 & 61 & 25 & 121 & 131 & 111 & 242 & 0.05 / 0.02\end{array}$

$\begin{array}{lllllllll}101 & 25 & 53 & 21 & 99 & 103 & 95 & 198 & 0.02 / 0.008\end{array}$

$\begin{array}{lllllllll}6 & 3 & 2 & 1 & 6 & 8 & 4 & 12 & 0.71 / 0.77\end{array}$

$\begin{array}{lllllllll}13 & 5 & 5 & 3 & 13 & 15 & 11 & 26 & 0.47 / 0.61\end{array}$

$\begin{array}{lllllllll}3 & 2 & 1 & 0 & 3 & 5 & 1 & 6 & 0.54 / 0.29\end{array}$

$\begin{array}{lllllllll}2 & 2 & 0 & 0 & 2 & 4 & 0 & 4 & ---\end{array}$

$\begin{array}{llllllll}0 & 1 & 0 & 1 & 1 & 1 & 2 & -.-\end{array}$

$\begin{array}{lllllllll}1 & 0 & 1 & 0 & 1 & 1 & 1 & 2 & \ldots\end{array}$

$\begin{array}{lllllllll}377 & 100 & 161 & 59 & 320 & 361 & 279 & 640 & 0.06 / 0.02\end{array}$

$\begin{array}{cccccccccc}16 & 7 & 5 & 2 & 14 & 19 & 9 & 28 & --- \\ 393 & 126 & 192 & 68 & 386 & 444 & 328 & 772 & 0.12 / 0.05\end{array}$

$\begin{array}{lllllllll}285 & 107 & 143 & 35 & 285 & 357 & 213 & 570 & ---\end{array}$ 
rs1325469 Caucasianos

Subfenótipo

Fissura Palatina

Completa

Incompleta

Total FP

Fissura Labial e/ou Palatina

Completa

Incompleta

Unilateral

Completa

Incompleta

Unilateral Direita

Completa

Incompleta

Incompleta + FP

Unilateral Esquerda

Completa

Incompleta

Incompleta + FP

Bilateral

Completa

Incompleta

Incompleta + FP

Incompleta Mista

FL direita + FL/P esquerda

FL esquerda + FP bilateral

Fissura Mediana

Total FL/P

Tipo/lado desconhecido

Total fissurados

Controles (sem fissura)
Genótipos

$\begin{array}{cc}N & \text { AA } \\ 15 & 13 \\ 38 & 26 \\ 53 & 39\end{array}$

$$
\text { AG }
$$

GG Total

A

Alelos

G Total Pgen/Palelo

$\begin{array}{ccc}2 & 0 & 15 \\ 9 & 2 & 37 \\ 11 & 2 & 52\end{array}$

28

230

$0.37 / 0.13$

$\begin{array}{lll}61 & 13 & 74\end{array}$

$0.97 / 0.88$

$89 \quad 15 \quad 104$

$0.82 / 0.53$

\begin{tabular}{|c|c|c|c|c|c|c|c|c|}
\hline 237 & 148 & 72 & 9 & 229 & 368 & 90 & 458 & $0.22 / 0.25$ \\
\hline 86 & 52 & 28 & 2 & 82 & 132 & 32 & 164 & $0.18 / 0.43$ \\
\hline 200 & 119 & 69 & 7 & 195 & 307 & 83 & 390 & $0.03 / 0.08$ \\
\hline 136 & 79 & 48 & 6 & 133 & 206 & 60 & 266 & $0.05 / 0.05$ \\
\hline 64 & 40 & 21 & 1 & 62 & 101 & 23 & 124 & $0.21 / 0.65$ \\
\hline 60 & 39 & 16 & 4 & 59 & 94 & 24 & 118 & $0.68 / 0.37$ \\
\hline 43 & 27 & 13 & 3 & 43 & 67 & 19 & 86 & $0.53 / 0.23$ \\
\hline 11 & 7 & 2 & 1 & 10 & 16 & 4 & 20 & $0.71 / 0.71$ \\
\hline 6 & 5 & 1 & 0 & 6 & 11 & 1 & 12 & $0.75 / 0.43$ \\
\hline 140 & 80 & 53 & 3 & 136 & 213 & 59 & 272 & $0.007 / 0.09$ \\
\hline 93 & 52 & 35 & 3 & 90 & 139 & 41 & 180 & $0.03 / 0.07$ \\
\hline 44 & 27 & 16 & 0 & 43 & 70 & 16 & 86 & $0.10 / 0.69$ \\
\hline 3 & 1 & 2 & 0 & 3 & 4 & 2 & 6 & $0.24 / 0.28$ \\
\hline 123 & 81 & 31 & 4 & 116 & 193 & 39 & 232 & $0.81 / 0.97$ \\
\hline 101 & 69 & 24 & 3 & 96 & 162 & 30 & 192 & $0.82 / 0.68$ \\
\hline 6 & 3 & 3 & 0 & 6 & 9 & 3 & 12 & $0.34 / 0.46$ \\
\hline 13 & 7 & 3 & 1 & 11 & 17 & 5 & 22 & $0.75 / 0.47$ \\
\hline 3 & 2 & 1 & 0 & 3 & 5 & 1 & 6 & $0.88 / 0.98$ \\
\hline 2 & 1 & 1 & 0 & 2 & 3 & 1 & 4 & ---- \\
\hline 1 & 1 & 0 & 0 & 1 & 2 & 0 & 2 & ---- \\
\hline 1 & 1 & 0 & 0 & 1 & 2 & 0 & 2 & ---- \\
\hline 377 & 201 & 100 & 11 & 312 & 502 & 122 & 624 & $0.12 / 0.23$ \\
\hline 16 & 8 & 6 & 1 & 15 & 22 & 8 & 30 & ---- \\
\hline 393 & 248 & 117 & 14 & 379 & 613 & 145 & 758 & $0.19 / 0.29$ \\
\hline 285 & 201 & 70 & 13 & 284 & 472 & 96 & 568 & ---- \\
\hline
\end{tabular}


rs1325474 Caucasianos

Subfenótipo

Fissura Palatina

Completa

Incompleta

Total FP

Fissura Labial e/ou Palatina

Completa

Incompleta

Unilateral

Completa

Incompleta

Unilateral Direita

Completa

Incompleta

Incompleta + FP

Unilateral Esquerda

Completa

Incompleta

Incompleta + FP

Bilateral
Completa
Incompleta
Incompleta + FP
Incompleta Mista
FL direita + FL/P esquerda
FL esquerda + FP bilateral

Fissura Mediana
N
Genótipos AA AG GG Total A G Total Pgen/Palelo

$\begin{array}{lllll}15 & 0 & 1 & 12 & 13\end{array}$

$\begin{array}{lllll}38 & 2 & 7 & 25 & 34\end{array}$

$\begin{array}{lllll}53 & 2 & 8 & 37 & 47\end{array}$

$\mathrm{N}$

$$
237
$$$$
\begin{aligned}
& 237 \\
& 86
\end{aligned}
$$$$
200
$$$$
20
$$$$
136
$$

60

43

11

6

140

93

441

3

$$
123
$$

123
6
13
3
2

10

71
22

$$
139220
$$$$
49 \quad 75
$$$$
91
$$$$
91 \quad 349 \quad 440
$$$$
30 \quad 120 \quad 150
$$$$
0.08 *
$$$$
0.53 / 0.29
$$$$
\begin{array}{llll}
10 & 60 & 116 & 186
\end{array}
$$$$
80 \quad 292 \quad 372
$$$$
0.09 / 0.04
$$$$
0.07 / 0.06
$$$$
44 \quad 79 \quad 129
$$$$
56 \quad 202 \quad 258
$$$$
24 \quad 90 \quad 114
$$$$
0.53 / 0.22
$$

16

$37 \quad 57$

21

$131 \quad 152$

13
12

$59 \quad 76$

$27 \quad 42$

$\begin{array}{ccc}21 & 131 & 152 \\ 18 & 66 & 84\end{array}$

$0.50 / 0.44$

$0.56 / 0.25$

$8 \quad 10$

3

$\begin{array}{lll}3 & 17 & 20\end{array}$

$0.49 / 0.87$

$\begin{array}{lll}1 & 4\end{array}$

0

8

$0.26 / 0.09$

$\begin{array}{ccccccc}47 & 77 & 130 & 59 & 201 & 260 & 0.02 / 0.02 \\ 32 & 52 & 87 & 38 & 136 & 174 & 0.04 / 0.09 \\ 15 & 25 & 41 & 17 & 65 & 82 & 0.17 / 0.32 \\ 0 & 0 & 2 & 4 & 0 & 4 & 0.00001 \dagger\end{array}$

$\begin{array}{cc}16 & 0 \\ 393 & 16\end{array}$

$285 \quad 13$


rs2023238 Caucasianos

Subfenótipo

Fissura Palatina

Completa

Incompleta

Total FP

N

Genótipos

Alelos

$\begin{array}{ccccccccc} & \text { AA } & \text { AG } & \text { GG } & \text { Total } & \text { A } & \text { G } & \text { Total } & \text { Pgen/Palelo } \\ 15 & 2 & 9 & 9 & 20 & 13 & 27 & 40 & 0.46 / 0.92 \\ 38 & 5 & 21 & 18 & 44 & 31 & 57 & 88 & 0.62 / 0.50 \\ 53 & 7 & 30 & 27 & 64 & 44 & 84 & 128 & 0.36 / 0.55\end{array}$

Fissura Labial e/ou Palatina

\begin{tabular}{|c|c|c|c|c|c|c|c|c|c|}
\hline Completa & 237 & 39 & 108 & 129 & 276 & 186 & 366 & 552 & $0.84 / 0.44$ \\
\hline Incompleta & 86 & 16 & 43 & 38 & 97 & 75 & 119 & 194 & $0.18 / 0.06$ \\
\hline Unilateral & 200 & 37 & 94 & 100 & 231 & 168 & 294 & 462 & $0.46 / 0.08$ \\
\hline Completa & 136 & 24 & 62 & 74 & 160 & 110 & 210 & 320 & $0.92 / 0.38$ \\
\hline Incompleta & 64 & 13 & 32 & 26 & 71 & 58 & 84 & 142 & $0.11 / 0.03$ \\
\hline Unilateral Direita & 60 & 13 & 29 & 31 & 73 & 55 & 91 & 146 & $0.47 / 0.15$ \\
\hline Completa & 43 & 10 & 19 & 22 & 51 & 39 & 63 & 102 & $0.43 / 0.18$ \\
\hline Incompleta & 11 & 3 & 7 & 5 & 15 & 13 & 17 & 30 & $0.32 / 0.18$ \\
\hline Incompleta + FP & 6 & 0 & 3 & 4 & 7 & 3 & 11 & 14 & $0.49 / 0.40$ \\
\hline Unilateral Esquerda & 140 & 24 & 65 & 69 & 158 & 113 & 203 & 316 & $0.33 / 0.19$ \\
\hline Completa & 93 & 14 & 43 & 52 & 109 & 71 & 147 & 218 & $0.48 / 0.81$ \\
\hline Incompleta & 44 & 10 & 20 & 14 & 44 & 40 & 48 & 88 & $0.11 / 0.008$ \\
\hline Incompleta + FP & 3 & 0 & 2 & 3 & 5 & 2 & 8 & 10 & $0.71 / 0.42$ \\
\hline Bilateral & 123 & 18 & 57 & 67 & 142 & 93 & 191 & 284 & $0.84 / 0.75$ \\
\hline Completa & 101 & 15 & 46 & 55 & 116 & 76 & 156 & 232 & $0.83 / 0.77$ \\
\hline Incompleta & 6 & 1 & 5 & 2 & 8 & 7 & 9 & 16 & $0.77 / 0.30$ \\
\hline Incompleta + FP & 13 & 2 & 5 & 7 & 14 & 9 & 19 & 28 & $0.94 / 0.96$ \\
\hline Incompleta Mista & 3 & 0 & 1 & 3 & 4 & 1 & 7 & 8 & $0.71 / 0.24$ \\
\hline FL direita + FL/P esquerda & 2 & 0 & 0 & 3 & 3 & 0 & 6 & 6 & ---- \\
\hline FL esquerda + FP bilateral & 1 & 0 & 1 & 0 & 1 & 1 & 1 & 2 & ---- \\
\hline Fissura Mediana & 1 & 0 & 1 & 0 & 1 & 1 & 1 & 2 & ---- \\
\hline Total FL/P & 377 & 55 & 152 & 167 & 374 & 262 & 486 & 748 & $0.55 / 0.15$ \\
\hline Tipo/lado desconhecido & 16 & 3 & 13 & 10 & 26 & 19 & 33 & 52 & --- \\
\hline Total fissurados & 393 & 65 & 195 & 203 & 463 & 325 & 601 & 926 & $0.37 / 0.12$ \\
\hline Sem fissura (Controles) & 285 & 64 & 177 & 239 & 480 & 305 & 655 & 960 & --- \\
\hline
\end{tabular}


rs217290 Caucasianos

Subfenótipo

Fissura Palatina

Completa

Incompleta

Total FP

Fissura Labial e/ou Palatina

Completa

Incompleta

Unilateral

Completa

Incompleta

Unilateral Direita

Completa

Incompleta

Incompleta + FP

Unilateral Esquerda

Completa

Incompleta

Incompleta + FP

Bilateral

Completa

Incompleta

Incompleta + FP

Incompleta Mista

FL direita + FL/P esquerda

$\mathrm{FL}$ esquerda + FP bilateral

Fissura Mediana

Tipo/lado desconhecido

Total fissurados

Sem fissura (Controles)
N

$$
\text { AA AG GG Total }
$$

$\begin{array}{ccccc}15 & 4 & 9 & 2 & 15 \\ 38 & 12 & 12 & 4 & 28 \\ 53 & 16 & 21 & 6 & 43\end{array}$

Genótipos
A

Alelos

G Total Pgen/Palelo

$\begin{array}{lll}17 & 13 & 30\end{array}$

$0.78 / 0.58$

$36 \quad 20 \quad 56$

$0.61 / 0.69$

$\begin{array}{lll}53 & 33 \quad 86\end{array}$

$0.88 / 0.99$

$\begin{array}{ccccccccc}237 & 89 & 111 & 31 & 231 & 289 & 173 & 462 & 0.58 / 0.76 \\ 86 & 34 & 44 & 6 & 84 & 112 & 56 & 168 & 0.39 / 0.23 \\ & & & & & & & & \\ 200 & 79 & 92 & 24 & 195 & 250 & 140 & 390 & 0.46 / 0.44 \\ 136 & 51 & 62 & 19 & 132 & 164 & 100 & 264 & 0.53 / 0.89 \\ 64 & 28 & 30 & 5 & 63 & 86 & 40 & 126 & 0.33 / 0.16\end{array}$

$\begin{array}{ccccccccc}60 & 27 & 27 & 5 & 59 & 81 & 37 & 118 & 0.29 / 0.15 \\ 43 & 17 & 21 & 5 & 43 & 55 & 31 & 86 & 0.86 / 0.68 \\ 11 & 7 & 3 & 0 & 10 & 17 & 3 & 20 & 0.06 / 0.03 \\ 6 & 3 & 3 & 0 & 6 & 9 & 3 & 12 & 0.58 / 0.34\end{array}$

$$
\text { (1) }
$$

$\begin{array}{ccccccccc}140 & 52 & 65 & 19 & 136 & 169 & 103 & 272 & 0.63 / 0.89 \\ 93 & 34 & 41 & 14 & 89 & 109 & 69 & 178 & 0.43 / 0.91 \\ 44 & 17 & 23 & 4 & 44 & 57 & 31 & 88 & 0.81 / 0.57 \\ 3 & 1 & 1 & 1 & 3 & 3 & 3 & 6 & 0.51 / 0.55\end{array}$

$\begin{array}{lllllllll}123 & 44 & 63 & 13 & 120 & 151 & 89 & 240 & 0.93 / 0.73\end{array}$

$\begin{array}{lllllllll}101 & 38 & 49 & 12 & 99 & 125 & 73 & 198 & 0.84 / 0.71\end{array}$

$\begin{array}{lllllllll}6 & 2 & 4 & 0 & 6 & 8 & 4 & 12 & 0.62 / 0.72\end{array}$

$\begin{array}{lllllllll}13 & 4 & 8 & 0 & 12 & 16 & 8 & 24 & 0.39 / 0.62\end{array}$

$\begin{array}{lllllllll}3 & 0 & 2 & 1 & 3 & 2 & 4 & 6 & 0.32 / 0.15\end{array}$

$\begin{array}{lllllllll}2 & 0 & 1 & 1 & 2 & 1 & 3 & 4 & ---\end{array}$

$\begin{array}{lllllllll}1 & 0 & 1 & 0 & 1 & 1 & 1 & 2 & ---\end{array}$

$\begin{array}{llllllllll}1 & 0 & 1 & 0 & 1 & 1 & 1 & 2 & ---\end{array}$

$\begin{array}{lllllllll}377 & 123 & 156 & 37 & 316 & 402 & 230 & 632 & 0.65 / 0.48\end{array}$

$\begin{array}{ccccccccc}16 & 6 & 5 & 0 & 11 & 17 & 5 & 22 & --- \\ 393 & 145 & 182 & 43 & 370 & 472 & 268 & 740 & 0.59 / 0.43\end{array}$

$\begin{array}{lllllllll}285 & 100 & 149 & 34 & 283 & 349 & 217 & 566 & ---\end{array}$ 
rs217308 Caucasianos

\begin{tabular}{|c|c|c|c|c|c|c|c|c|c|}
\hline \multirow{2}{*}{ Subfenótipo } & \multirow[t]{2}{*}{$\mathrm{N}$} & \multicolumn{3}{|c|}{ Genótipos } & \multicolumn{5}{|c|}{ Alelos } \\
\hline & & $\mathrm{AA}$ & $A G$ & GG & Total & $A$ & G & Total & Pgen/Palelo \\
\hline \multicolumn{10}{|l|}{ Fissura Palatina } \\
\hline Completa & 15 & 2 & 9 & 4 & 15 & 13 & 17 & 30 & $0.74 / 0.50$ \\
\hline Incompleta & 38 & 5 & 21 & 11 & 37 & 31 & 43 & 74 & $0.70 / 0.44$ \\
\hline Total FP & 53 & 7 & 30 & 15 & 52 & 44 & 60 & 104 & $0.56 / 0.33$ \\
\hline \multicolumn{10}{|l|}{ Fissura Labial e/ou Palatina } \\
\hline Completa & 237 & 29 & 108 & 91 & 228 & 166 & 290 & 456 & $0.46 / 0.76$ \\
\hline Incompleta & 86 & 7 & 42 & 32 & 81 & 56 & 106 & 162 & $0.77 / 0.52$ \\
\hline Unilateral & 200 & 23 & 94 & 77 & 194 & 140 & 248 & 388 & $0.64 / 0.69$ \\
\hline Completa & 136 & 18 & 64 & 51 & 133 & 100 & 166 & 266 & $0.59 / 0.94$ \\
\hline Incompleta & 64 & 5 & 30 & 26 & 61 & 40 & 82 & 122 & $0.59 / 0.34$ \\
\hline Unilateral Direita & 60 & 4 & 27 & 28 & 59 & 35 & 83 & 118 & $0.23 / 0.11$ \\
\hline Completa & 43 & 4 & 21 & 18 & 43 & 29 & 57 & 86 & $0.77 / 0.51$ \\
\hline Incompleta & 11 & 0 & 3 & 7 & 10 & 3 & 17 & 20 & $0.08 / 0.04$ \\
\hline Incompleta + FP & 6 & 0 & 3 & 3 & 6 & 3 & 9 & 12 & $0.61 / 0.38$ \\
\hline Unilateral Esquerda & 140 & 19 & 67 & 49 & 135 & 105 & 165 & 270 & $0.62 / 0.66$ \\
\hline Completa & 93 & 14 & 43 & 33 & 90 & 71 & 109 & 180 & $0.45 / 0.60$ \\
\hline Incompleta & 44 & 4 & 23 & 15 & 42 & 31 & 53 & 84 & $0.95 / 0.94$ \\
\hline Incompleta + FP & 3 & 1 & 1 & 1 & 3 & 3 & 3 & 6 & $0.45 / 0.52$ \\
\hline Bilateral & 123 & 13 & 56 & 46 & 115 & 82 & 148 & 230 & $0.74 / 0.65$ \\
\hline Completa & 101 & 11 & 44 & 40 & 95 & 66 & 124 & 190 & $0.53 / 0.52$ \\
\hline Incompleta & 6 & 0 & 4 & 2 & 6 & 4 & 8 & 12 & $0.64 / 0.77$ \\
\hline Incompleta + FP & 13 & 1 & 6 & 4 & 11 & 8 & 14 & 22 & $0.98 / 0.92$ \\
\hline Incompleta Mista & 3 & 1 & 2 & 0 & 3 & 4 & 2 & 6 & $0.28 / 0.13$ \\
\hline FL direita + FL/P esquerda & 2 & 1 & 1 & 0 & 2 & 3 & 1 & 4 & ---- \\
\hline FL esquerda + FP bilateral & 1 & 0 & 1 & 0 & 1 & 1 & 1 & 2 & ---- \\
\hline Fissura Mediana & 1 & 0 & 1 & 0 & 1 & 1 & 1 & 2 & ---- \\
\hline Total FL/P & 377 & 36 & 151 & 123 & 310 & 223 & 397 & 620 & $0.60 / 0.62$ \\
\hline Tipo/lado desconhecido & 16 & 3 & 7 & 5 & 15 & 13 & 17 & 30 & ---- \\
\hline Total fissurados & 393 & 46 & 188 & 143 & 377 & 280 & 474 & 754 & $0.73 / 0.94$ \\
\hline Sem fissura (Controles) & 285 & 31 & 150 & 103 & 284 & 212 & 356 & 568 & ---- \\
\hline
\end{tabular}


rs217325 Caucasianos

Subfenótipo

Fissura Palatina

Completa

Incompleta

Total FP

\begin{tabular}{|c|c|c|c|c|c|c|c|c|}
\hline \multirow[t]{2}{*}{$\mathrm{N}$} & \multicolumn{3}{|c|}{ Genótipos } & \multicolumn{5}{|c|}{ Alelos } \\
\hline & $\mathrm{CC}$ & CT & TT & Total & C & $\mathrm{T}$ & Total & Pgen/Palelo \\
\hline 15 & 1 & 9 & 5 & 15 & 11 & 19 & 30 & $0.16 / 0.15$ \\
\hline 38 & 4 & 13 & 21 & 38 & 21 & 55 & 76 & $0.73 / 0.63$ \\
\hline 53 & 5 & 22 & 26 & 53 & 32 & 74 & 106 & $0.55 / 0.27$ \\
\hline
\end{tabular}

Fissura Labial e/ou Palatina

\begin{tabular}{|c|c|c|c|c|c|c|c|c|c|}
\hline Completa & 237 & 22 & 102 & 113 & 237 & 146 & 328 & 474 & $0.10 / 0.03$ \\
\hline Incompleta & 86 & 12 & 33 & 41 & 86 & 57 & 115 & 172 & $0.09 / 0.03$ \\
\hline Unilateral & 200 & 17 & 88 & 95 & 200 & 122 & 278 & 400 & $0.12 / 0.06$ \\
\hline Completa & 136 & 10 & 61 & 65 & 136 & 81 & 191 & 272 & $0.20 / 0.14$ \\
\hline Incompleta & 64 & 7 & 27 & 30 & 64 & 41 & 87 & 128 & $0.28 / 0.10$ \\
\hline Unilateral Direita & 60 & 6 & 23 & 31 & 60 & 35 & 85 & 120 & $0.64 / 0.35$ \\
\hline Completa & 43 & 2 & 18 & 23 & 43 & 22 & 64 & 86 & $0.69 / 0.92$ \\
\hline Incompleta & 11 & 3 & 4 & 4 & 11 & 10 & 12 & 22 & $0.04 / 0.03$ \\
\hline Incompleta + FP & 6 & 1 & 1 & 4 & 6 & 3 & 9 & 12 & $0.47 / 0.99$ \\
\hline Unilateral Esquerda & 140 & 11 & 65 & 64 & 140 & 87 & 193 & 280 & $0.09 / 0.06$ \\
\hline Completa & 93 & 8 & 43 & 42 & 93 & 59 & 127 & 186 & $0.14 / 0.07$ \\
\hline Incompleta & 44 & 3 & 22 & 19 & 44 & 28 & 60 & 88 & $0.19 / 0.18$ \\
\hline Incompleta + FP & 3 & 0 & 0 & 3 & 3 & 0 & 6 & 6 & $0.32 / 0.06$ \\
\hline Bilateral & 123 & 17 & 47 & 61 & 125 & 81 & 169 & 250 & $0.07 / 0.03$ \\
\hline Completa & 101 & 12 & 41 & 48 & 101 & 65 & 137 & 202 & $0.15 / 0.05$ \\
\hline Incompleta & 6 & 2 & 3 & 1 & 6 & 7 & 5 & 12 & $0.02 / 0.009$ \\
\hline Incompleta + FP & 13 & 3 & 2 & 8 & 13 & 8 & 18 & 26 & $0.05 / 0.51$ \\
\hline Incompleta Mista & 3 & 0 & 1 & 2 & 3 & 1 & 5 & 6 & $0.87 / 0.63$ \\
\hline FL direita + FL/P esquerda & 2 & 0 & 0 & 2 & 2 & 0 & 4 & 4 & ---- \\
\hline FL esquerda + FP bilateral & 1 & 0 & 1 & 0 & 1 & 1 & 1 & 2 & ---- \\
\hline Fissura Mediana & 1 & 0 & 1 & 0 & 1 & 1 & 1 & 2 & ---- \\
\hline Total FL/P & 377 & 34 & 135 & 154 & 323 & 203 & 443 & 646 & $0.05 / 0.01$ \\
\hline Tipo/lado desconhecido & 16 & 2 & 5 & 9 & 16 & 9 & 23 & 32 & ---- \\
\hline Total fissurados & 393 & 41 & 163 & 189 & 393 & 245 & 541 & 786 & $0.05 / 0.01$ \\
\hline Sem fissura (Controles) & 285 & 20 & 103 & 162 & 285 & 143 & 427 & 570 & ---- \\
\hline
\end{tabular}


rs3798867 Caucasianos

Subfenótipo

Fissura Palatina

Completa

Incompleta

Total FP

\begin{tabular}{|c|c|c|c|c|c|c|c|c|}
\hline \multirow[t]{2}{*}{$\mathrm{N}$} & \multicolumn{3}{|c|}{ Genótipos } & \multicolumn{5}{|c|}{ Alelos } \\
\hline & $\mathrm{CC}$ & CT & TT & Total & C & $\mathrm{T}$ & Total & Pgen/Palelo \\
\hline 15 & 4 & 9 & 2 & 15 & 17 & 13 & 30 & $0.81 / 0.59$ \\
\hline 38 & 12 & 20 & 5 & 37 & 44 & 30 & 74 & $0.93 / 0.73$ \\
\hline 53 & 16 & 29 & 7 & 52 & 61 & 43 & 104 & $0.83 / 0.58$ \\
\hline
\end{tabular}

Fissura Labial e/ou Palatina

\begin{tabular}{|c|c|c|c|c|c|c|c|c|c|}
\hline Completa & 237 & 93 & 103 & 31 & 227 & 289 & 165 & 454 & $0.18 / 0.03$ \\
\hline Incompleta & 86 & 33 & 40 & 7 & 80 & 106 & 54 & 160 & $0.50 / 0.27$ \\
\hline Unilateral & 200 & 80 & 88 & 24 & 192 & 248 & 136 & 384 & $0.23 / 0.33$ \\
\hline Completa & 136 & 53 & 60 & 19 & 132 & 166 & 98 & 264 & $0.30 / 0.70$ \\
\hline Incompleta & 64 & 27 & 28 & 5 & 60 & 82 & 38 & 120 & $0.30 / 0.16$ \\
\hline Unilateral Direita & 60 & 27 & 25 & 5 & 57 & 79 & 35 & 114 & $0.19 / 0.11$ \\
\hline Completa & 43 & 17 & 20 & 5 & 42 & 54 & 30 & 84 & $0.74 / 0.62$ \\
\hline Incompleta & 11 & 7 & 3 & 0 & 10 & 17 & 3 & 20 & $0.06 / 0.03$ \\
\hline Incompleta + FP & 6 & 3 & 2 & 0 & 5 & 8 & 2 & 10 & $0.43 / 0.23$ \\
\hline Unilateral Esquerda & 140 & 53 & 63 & 19 & 135 & 169 & 101 & 270 & $0.41 / 0.76$ \\
\hline Completa & 93 & 36 & 40 & 14 & 90 & 112 & 68 & 180 & $0.29 / 0.86$ \\
\hline Incompleta & 44 & 16 & 22 & 4 & 42 & 54 & 30 & 84 & $0.87 / 0.62$ \\
\hline Incompleta + FP & 3 & 1 & 1 & 1 & 3 & 3 & 3 & 6 & $0.49 / 0.56$ \\
\hline Bilateral & 123 & 46 & 55 & 14 & 115 & 147 & 83 & 230 & $0.56 / 0.52$ \\
\hline Completa & 101 & 40 & 43 & 12 & 95 & 123 & 67 & 190 & $0.22 / 0.42$ \\
\hline Incompleta & 6 & 2 & 4 & 0 & 6 & 8 & 4 & 12 & $0.63 / 0.71$ \\
\hline Incompleta + FP & 13 & 4 & 6 & 1 & 11 & 14 & 8 & 22 & $0.96 / 0.84$ \\
\hline Incompleta Mista & 3 & 0 & 2 & 1 & 3 & 2 & 4 & 6 & $0.31 / 0.15$ \\
\hline FL direita + FL/P esquerda & 2 & 0 & 1 & 1 & 2 & 1 & 3 & 4 & ---- \\
\hline FL esquerda + FP bilateral & 1 & 0 & 1 & 0 & 1 & 1 & 1 & 2 & ---- \\
\hline Fissura Mediana & 1 & 0 & 1 & 0 & 1 & 1 & 1 & 2 & ---- \\
\hline Total FL/P & 377 & 126 & 144 & 38 & 308 & 396 & 220 & 616 & $0.23 / 0.32$ \\
\hline Tipo/lado desconhecido & 16 & 6 & 6 & 3 & 15 & 18 & 12 & 30 & ---- \\
\hline Total fissurados & 393 & 148 & 179 & 48 & 375 & 475 & 275 & 750 & $0.33 / 0.50$ \\
\hline Sem fissura (Controles) & 285 & 98 & 151 & 33 & 282 & 347 & 217 & 564 & ---- \\
\hline
\end{tabular}


rs512140 Caucasianos

Subfenótipo

Fissura Palatina

Completa

Incompleta

Total FP

N

$\begin{array}{ccccccccc} & \text { CC } & \text { CT } & \text { TT } & \text { Total } & \text { C } & \text { T } & \text { Total } & \text { Pgen/Palelo } \\ & & & & & & & & \\ 15 & 1 & 7 & 7 & 15 & 9 & 21 & 30 & 0.84 / 0.66 \\ 38 & 3 & 16 & 19 & 38 & 22 & 54 & 76 & 0.69 / 0.39 \\ 53 & 4 & 23 & 26 & 53 & 31 & 75 & 106 & 0.62 / 0.35\end{array}$

Fissura Labial e/ou Palatina

\begin{tabular}{|c|c|c|c|c|c|c|c|c|c|}
\hline Completa & 237 & 18 & 97 & 121 & 236 & 133 & 339 & 472 & $0.14 / 0.04$ \\
\hline Incompleta & 86 & 6 & 43 & 35 & 84 & 55 & 113 & 168 & $0.38 / 0.78$ \\
\hline Unilateral & 200 & 14 & 89 & 96 & 199 & 117 & 281 & 398 & $0.22 / 0.14$ \\
\hline Completa & 136 & 11 & 54 & 71 & 136 & 76 & 196 & 272 & $0.23 / 0.08$ \\
\hline Incompleta & 64 & 3 & 35 & 25 & 63 & 41 & 85 & 126 & $0.14 / 0.77$ \\
\hline Unilateral Direita & 60 & 5 & 25 & 29 & 59 & 35 & 83 & 118 & $0.67 / 0.37$ \\
\hline Completa & 43 & 4 & 16 & 23 & 43 & 24 & 62 & 86 & $0.49 / 0.27$ \\
\hline Incompleta & 11 & 1 & 6 & 3 & 10 & 8 & 12 & 20 & $0.61 / 0.56$ \\
\hline Incompleta + FP & 6 & 0 & 3 & 3 & 6 & 3 & 9 & 12 & $0.67 / 0.52$ \\
\hline Unilateral Esquerda & 140 & 9 & 64 & 67 & 140 & 82 & 198 & 280 & $0.23 / 0.18$ \\
\hline Completa & 93 & 7 & 38 & 48 & 93 & 52 & 134 & 186 & $0.32 / 0.13$ \\
\hline Incompleta & 44 & 2 & 26 & 16 & 44 & 30 & 58 & 88 & $0.13 / 0.96$ \\
\hline Incompleta + FP & 3 & 0 & 0 & 3 & 3 & 0 & 6 & 6 & $0.15 / 0.02$ \\
\hline Bilateral & 123 & 10 & 51 & 60 & 121 & 71 & 171 & 242 & $0.44 / 0.20$ \\
\hline Completa & 101 & 7 & 43 & 50 & 100 & 57 & 143 & 200 & $0.34 / 0.16$ \\
\hline Incompleta & 6 & 1 & 3 & 2 & 6 & 5 & 7 & 12 & $0.85 / 0.57$ \\
\hline Incompleta + FP & 13 & 2 & 4 & 6 & 12 & 8 & 16 & 24 & $0.71 / 0.95$ \\
\hline Incompleta Mista & 3 & 0 & 1 & 2 & 3 & 1 & 5 & 6 & $0.67 / 0.37$ \\
\hline FL direita + FL/P esquerda & 2 & 0 & 0 & 2 & 2 & 0 & 4 & 4 & ---- \\
\hline FL esquerda + FP bilateral & 1 & 0 & 1 & 0 & 1 & 1 & 1 & 2 & ---- \\
\hline Fissura Mediana & 1 & 0 & 1 & 0 & 1 & 1 & 1 & 2 & ---- \\
\hline Total FL/P & 377 & 24 & 141 & 156 & 321 & 189 & 453 & 642 & $0.17 / 0.09$ \\
\hline Tipo/lado desconhecido & 16 & 1 & 7 & 8 & 16 & 9 & 23 & 32 & ---- \\
\hline Total fissurados & 393 & 29 & 171 & 190 & 390 & 229 & 551 & 780 & $0.14 / 0.07$ \\
\hline Sem fissura (Controles) & 285 & 33 & 127 & 125 & 285 & 193 & 377 & 570 & ---- \\
\hline
\end{tabular}


rs614565 Caucasianos

Subfenótipo

Fissura Palatina

Completa

Incompleta

Total FP

\begin{tabular}{ccccccccc} 
N & \multicolumn{3}{c}{ Genótipos } & \multicolumn{5}{c}{ Alelos } \\
& CC & CT & TT & Total & C & T & Total & Pgen/Palelo \\
& & & & & & & & \\
15 & 1 & 4 & 10 & 15 & 6 & 24 & 30 & $0.63 / 0.38$ \\
38 & 3 & 20 & 113 & 136 & 26 & 246 & 272 & $0.09 / 0.00001$ \\
53 & 4 & 24 & 23 & 51 & 32 & 70 & 102 & $0.42 / 0.38$
\end{tabular}

Fissura Labial e/ou Palatina

\begin{tabular}{|c|c|c|c|c|c|c|c|c|c|}
\hline Completa & 237 & 13 & 73 & 140 & 226 & 99 & 353 & 452 & $0.16 / 0.05$ \\
\hline Incompleta & 86 & 2 & 35 & 43 & 80 & 39 & 121 & 160 & $0.14 / 0.47$ \\
\hline Unilateral & 200 & 7 & 74 & 111 & 192 & 88 & 296 & 384 & $0.10 / 0.13$ \\
\hline Completa & 136 & 7 & 46 & 79 & 132 & 60 & 204 & 264 & $0.37 / 0.16$ \\
\hline Incompleta & 64 & 0 & 28 & 32 & 60 & 28 & 92 & 120 & $0.04 / 0.38$ \\
\hline Unilateral Direita & 60 & 2 & 20 & 35 & 57 & 24 & 90 & 114 & $0.35 / 0.17$ \\
\hline Completa & 43 & 2 & 12 & 28 & 42 & 16 & 68 & 84 & $0.29 / 0.11$ \\
\hline Incompleta & 11 & 0 & 6 & 4 & 10 & 6 & 14 & 20 & $0.28 / 0.78$ \\
\hline Incompleta + FP & 6 & 0 & 2 & 3 & 5 & 2 & 8 & 10 & $0.79 / 0.61$ \\
\hline Unilateral Esquerda & 140 & 5 & 54 & 76 & 135 & 64 & 206 & 270 & $0.19 / 0.27$ \\
\hline Completa & 93 & 5 & 34 & 51 & 90 & 44 & 136 & 180 & $0.64 / 0.46$ \\
\hline Incompleta & 44 & 0 & 18 & 24 & 42 & 18 & 66 & 84 & $0.13 / 0.26$ \\
\hline Incompleta + FP & 3 & 0 & 2 & 1 & 3 & 2 & 4 & 6 & $0.55 / 0.73$ \\
\hline Bilateral & 123 & 8 & 34 & 72 & 114 & 50 & 178 & 228 & $0.25 / 0.12$ \\
\hline Completa & 101 & 6 & 27 & 61 & 94 & 39 & 149 & 188 & $0.18 / 0.07$ \\
\hline Incompleta & 6 & 0 & 1 & 5 & 6 & 1 & 11 & 12 & $0.34 / 0.14$ \\
\hline Incompleta + FP & 13 & 2 & 5 & 4 & 11 & 9 & 13 & 22 & $0.38 / 0.15$ \\
\hline Incompleta Mista & 3 & 0 & 1 & 2 & 3 & 1 & 5 & 6 & $0.83 / 0.56$ \\
\hline FL direita + FL/P esquerda & 2 & 0 & 0 & 2 & 2 & 0 & 4 & 4 & ---- \\
\hline FL esquerda + FP bilateral & 1 & 0 & 0 & 0 & 0 & 0 & 0 & 0 & ---- \\
\hline Fissura Mediana & 1 & 0 & 0 & 1 & 1 & 0 & 2 & 2 & ---- \\
\hline Total FL/P & 377 & 15 & 108 & 184 & 307 & 138 & 476 & 614 & $0.13 / 0.05$ \\
\hline Tipo/lado desconhecido & 16 & 1 & 5 & 8 & 14 & 7 & 21 & 28 & ---- \\
\hline Total fissurados & 393 & 20 & 137 & 215 & 372 & 177 & 567 & 744 & $0.25 / 0.15$ \\
\hline Sem fissura (Controles) & 285 & 24 & 105 & 152 & 281 & 153 & 409 & 562 & ---- \\
\hline
\end{tabular}


rs624076 Caucasianos

Subfenótipo

N Genótipos

Fissura Palatina

Completa
Incompleta
Total FP
AA AG GG Total A G Total Pgen/Palelo

$\begin{array}{llllllll}15 & 1 & 5 & 9 & 15 & 7 & 23 & 30\end{array}$

$0.79 / 0.49$

$\begin{array}{llllllll}38 & 4 & 18 & 13 & 35 & 26 & 44 & 70\end{array}$

$0.26 / 0.17$

53

$23 \quad 22 \quad 50$

$67 \quad 100$

$0.57 / 0.44$

Fissura Labial e/ou Palatina

\begin{tabular}{|c|c|c|c|c|c|c|c|c|c|}
\hline Completa & 237 & 16 & 86 & 124 & 226 & 118 & 334 & 452 & $0.48 / 0.27$ \\
\hline Incompleta & 86 & 2 & 35 & 43 & 80 & 39 & 121 & 160 & $0.09 / 0.23$ \\
\hline Unilateral & 200 & 9 & 83 & 98 & 190 & 101 & 279 & 380 & $0.09 / 0.38$ \\
\hline Completa & 136 & 9 & 55 & 67 & 131 & 73 & 189 & 262 & $0.53 / 0.69$ \\
\hline Incompleta & 64 & 0 & 28 & 31 & 59 & 28 & 90 & 118 & $0.03 / 0.23$ \\
\hline Unilateral Direita & 60 & 3 & 26 & 28 & 57 & 32 & 82 & 114 & $0.40 / 0.81$ \\
\hline Completa & 43 & 3 & 17 & 21 & 41 & 23 & 59 & 82 & $0.84 / 0.83$ \\
\hline Incompleta & 11 & 0 & 6 & 4 & 10 & 6 & 14 & 20 & $0.30 / 0.93$ \\
\hline Incompleta + FP & 6 & 0 & 3 & 3 & 6 & 3 & 9 & 12 & $0.66 / 0.75$ \\
\hline Unilateral Esquerda & 140 & 6 & 57 & 70 & 133 & 69 & 197 & 266 & $0.15 / 0.33$ \\
\hline Completa & 93 & 6 & 38 & 46 & 90 & 50 & 130 & 180 & $0.58 / 0.71$ \\
\hline Incompleta & 44 & 0 & 17 & 23 & 40 & 17 & 63 & 80 & $0.11 / 0.14$ \\
\hline Incompleta + FP & 3 & 0 & 2 & 1 & 3 & 2 & 4 & 6 & $0.57 / 0.82$ \\
\hline Bilateral & 123 & 9 & 38 & 71 & 118 & 56 & 180 & 236 & $0.28 / 0.11$ \\
\hline Completa & 101 & 7 & 31 & 57 & 95 & 45 & 145 & 190 & $0.35 / 0.14$ \\
\hline Incompleta & 6 & 0 & 1 & 5 & 6 & 1 & 11 & 12 & $0.29 / 0.11$ \\
\hline Incompleta + FP & 13 & 2 & 5 & 5 & 12 & 9 & 15 & 24 & $0.68 / 0.38$ \\
\hline Incompleta Mista & 3 & 0 & 1 & 2 & 3 & 1 & 5 & 6 & $0.79 / 0.50$ \\
\hline FL direita + FL/P esquerda & 2 & 0 & 0 & 2 & 2 & 0 & 4 & 4 & ---- \\
\hline FL esquerda + FP bilateral & 1 & 0 & 1 & 0 & 1 & 1 & 1 & 2 & ---- \\
\hline Fissura Mediana & 1 & 0 & 0 & 1 & 1 & 0 & 2 & 2 & ---- \\
\hline Total FL/P & 377 & 18 & 121 & 168 & 307 & 157 & 457 & 614 & $0.18 / 0.16$ \\
\hline Tipo/lado desconhecido & 16 & 2 & 4 & 7 & 13 & 8 & 18 & 26 & ---- \\
\hline Total fissurados & 393 & 25 & 148 & 197 & 370 & 198 & 542 & 740 & $0.33 / 0.33$ \\
\hline Sem fissura (Controles) & 285 & 28 & 108 & 145 & 281 & 164 & 398 & 562 & ---- \\
\hline
\end{tabular}


rs6940766 Caucasianos

Subfenótipo

N

Fissura Palatina

Completa

Incompleta

Total FP

Fissura Labial e/ou Palatina

Completa

Incompleta

Unilateral

Completa

Incompleta

Unilateral Direita

Completa

Incompleta

Incompleta + FP

Unilateral Esquerda

Completa

Incompleta

Incompleta + FP

Bilateral

Completa

Incompleta

Incompleta + FP

Incompleta Mista

FL direita + FL/P esquerda

FL esquerda + FP bilateral

Fissura Mediana

Total FL/P

Tipo/lado desconhecido

Total fissurados

Sem fissura (Controles)

53

$\begin{array}{lllll}38 & 2 & 16 & 20 & 38\end{array}$

\begin{tabular}{|c|c|c|c|c|c|c|c|c|}
\hline 237 & 10 & 63 & 144 & 217 & 83 & 351 & 434 & $0.003 / 0.001$ \\
\hline 86 & 6 & 28 & 53 & 87 & 40 & 134 & 174 & $0.48 / 0.19$ \\
\hline 200 & 14 & 54 & 122 & 190 & 82 & 298 & 380 & $0.10 / 0.02$ \\
\hline 136 & 8 & 33 & 85 & 126 & 49 & 203 & 252 & $0.04 / 0.01$ \\
\hline 64 & 6 & 21 & 37 & 64 & 33 & 95 & 128 & $0.88 / 0.62$ \\
\hline 60 & 3 & 17 & 40 & 60 & 23 & 97 & 120 & $0.17 / 0.04$ \\
\hline 43 & 1 & 13 & 29 & 43 & 15 & 71 & 86 & $0.14 / 0.04$ \\
\hline 11 & 2 & 3 & 6 & 11 & 7 & 15 & 22 & $0.66 / 0.68$ \\
\hline 6 & 0 & 1 & 5 & 6 & 1 & 11 & 12 & $0.26 / 0.13$ \\
\hline 140 & 11 & 47 & 82 & 140 & 69 & 211 & 280 & $0.62 / 0.31$ \\
\hline 93 & 7 & 30 & 56 & 93 & 44 & 142 & 186 & $0.56 / 0.25$ \\
\hline 44 & 4 & 17 & 23 & 44 & 25 & 63 & 88 & $0.90 / 0.92$ \\
\hline 3 & 0 & 0 & 3 & 3 & 0 & 6 & 6 & $0.15 / 0.04$ \\
\hline 123 & 2 & 37 & 85 & 124 & 41 & 207 & 248 & $0.002 / 0.0005$ \\
\hline 101 & 2 & 30 & 69 & 101 & 34 & 168 & 202 & $0.008 / 0.001$ \\
\hline 6 & 0 & 3 & 3 & 6 & 3 & 9 & 12 & $0.45 / 0.82$ \\
\hline 13 & 0 & 3 & 10 & 13 & 3 & 23 & 26 & $0.12 / 0.06$ \\
\hline 3 & 0 & 1 & 3 & 4 & 1 & 7 & 8 & $0.54 / 0.33$ \\
\hline 2 & 0 & 0 & 2 & 2 & 0 & 4 & 4 & ---- \\
\hline 1 & 0 & 1 & 1 & 2 & 1 & 3 & 4 & ---- \\
\hline 1 & 0 & 0 & 1 & 1 & 0 & 2 & 2 & ---- \\
\hline 377 & 16 & 91 & 198 & 305 & 123 & 487 & 610 & $0.005 / 0.001$ \\
\hline 16 & 0 & 5 & 11 & 16 & 5 & 27 & 32 & ---- \\
\hline 393 & 18 & 114 & 242 & 374 & 150 & 598 & 748 & $0.002 / 0.0008$ \\
\hline 285 & 29 & 100 & 154 & 283 & 158 & 408 & 566 & ---- \\
\hline
\end{tabular}

Alelos

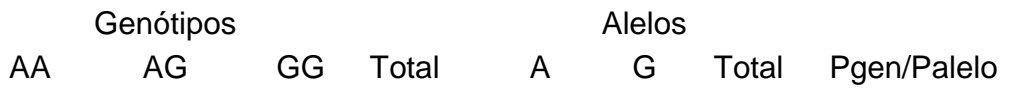

$\begin{array}{lllllllll}15 & 0 & 2 & 13 & 15 & 2 & 28 & 30 & 0.04 / 0.01\end{array}$

$\begin{array}{llll}20 & 56 & 76 & 0.52 / 0.76\end{array}$

$\begin{array}{llll}22 & 84 & 106 & 0.28 / 0.12\end{array}$ 
rs7753918 Caucasianos

Subfenótipo

Fissura Palatina

Completa

Incompleta

Total FP

Fissura Labial e/ou Palatina

Completa

Incompleta

Unilateral

Completa

Incompleta

Unilateral Direita

Completa

Incompleta

Incompleta + FP

Unilateral Esquerda

Completa

Incompleta

Incompleta + FP

Bilateral

Completa

Incompleta

Incompleta + FP

Incompleta Mista

FL direita + FL/P esquerda

FL esquerda + FP bilateral

Fissura Mediana

Total FL/P

Tipo/lado desconhecido

Total fissurados

Sem fissura (Controles)

\begin{tabular}{|c|c|c|c|c|c|c|c|c|}
\hline \multirow[t]{2}{*}{$\mathrm{N}$} & \multicolumn{3}{|c|}{ Genótipos } & \multicolumn{5}{|c|}{ Alelos } \\
\hline & $\mathrm{CC}$ & $\mathrm{CT}$ & $\mathrm{TT}$ & Total & $\mathrm{C}$ & $\mathrm{T}$ & Total & Pgen/Palelo \\
\hline 15 & 0 & 2 & 13 & 15 & 2 & 28 & 30 & $0.37 / 0.10$ \\
\hline 38 & 5 & 5 & 28 & 38 & 15 & 61 & 76 & $0.70 / 0.78$ \\
\hline 53 & 5 & 7 & 41 & 53 & 17 & 89 & 106 & $0.75 / 0.55$ \\
\hline 237 & 3 & 77 & 157 & 237 & 83 & 391 & 474 & $0.00001 / 0.7$ \\
\hline 86 & 3 & 21 & 61 & 85 & 27 & 143 & 170 & $0.07 / 0.44$ \\
\hline 200 & 4 & 55 & 140 & 199 & 63 & 335 & 398 & $0.0002 / 0.29$ \\
\hline 136 & 3 & 42 & 91 & 136 & 48 & 224 & 272 & $0.0003 / 0.78$ \\
\hline 64 & 1 & 13 & 49 & 63 & 15 & 111 & 126 & $0.09 / 0.07$ \\
\hline 60 & 1 & 14 & 45 & 60 & 16 & 104 & 120 & $0.08 / 0.18$ \\
\hline 43 & 1 & 11 & 31 & 43 & 13 & 73 & 86 & $0.14 / 0.45$ \\
\hline 11 & 0 & 1 & 10 & 11 & 1 & 21 & 22 & $0.37 / 0.09$ \\
\hline 6 & 0 & 2 & 4 & 6 & 2 & 10 & 12 & $0.47 / 0.87$ \\
\hline 140 & 3 & 41 & 95 & 139 & 47 & 231 & 278 & $0.0007 / 0.58$ \\
\hline 93 & 2 & 31 & 60 & 93 & 35 & 151 & 186 & $0.0006 / 0.9$ \\
\hline 44 & 1 & 10 & 32 & 43 & 12 & 74 & 86 & $0.20 / 0.31$ \\
\hline 3 & 0 & 0 & 3 & 3 & 0 & 6 & 6 & $0.57 / 0.11$ \\
\hline 123 & 2 & 43 & 78 & 123 & 47 & 199 & 246 & $0.00001 / 0.81$ \\
\hline 101 & 0 & 35 & 66 & 101 & 35 & 167 & 202 & $0.00001 / 0.72$ \\
\hline 6 & 0 & 3 & 3 & 6 & 3 & 9 & 12 & $0.10 / 0.56$ \\
\hline 13 & 2 & 5 & 6 & 13 & 9 & 17 & 26 & $0.09 / 0.04$ \\
\hline 3 & 0 & 0 & 3 & 3 & 0 & 6 & 6 & $0.57 / 0.11$ \\
\hline 2 & 0 & 0 & 2 & 2 & 0 & 4 & 4 & ---- \\
\hline 1 & 0 & 0 & 1 & 1 & 0 & 2 & 2 & ---- \\
\hline 1 & 0 & 0 & 1 & 1 & 0 & 2 & 2 & ---- \\
\hline 377 & 6 & 96 & 219 & 321 & 108 & 534 & 642 & $0.00001 / 0.46$ \\
\hline 16 & 0 & 2 & 13 & 15 & 2 & 28 & 30 & ---- \\
\hline 393 & 11 & 105 & 273 & 389 & 127 & 651 & 778 & $0.00001 / 0.31$ \\
\hline 285 & 28 & 49 & 208 & 285 & 105 & 465 & 570 & ---- \\
\hline
\end{tabular}


ANEXO 8. Estudos genéticos utilizando anomalias dentárias como subfenótipos adicionais para FL/P (Seção 5.4)

Freqüências obtidas para genótipos e alelos referentes a cada polimorfismo estudado:

1. TGFA - amostra completa

2. TGFA - caucasianos

3. IRF6 - amostra completa

4. IRF6 - caucasianos

5. Cromossomo $6 \mathrm{q}-$ amostra completa

6. Cromossomo $6 \mathrm{q}-$ caucasianos 
Fissurados

\begin{tabular}{|c|c|c|c|c|c|c|c|}
\hline & & & & & & & \\
\hline$n$ & CC & CT & TT & Total & C & $\mathbf{T}$ & tota \\
\hline 14 & 1 & 8 & 4 & 13 & 10 & 16 & 26 \\
\hline 2 & 2 & 0 & 0 & 2 & 4 & 0 & 4 \\
\hline 2 & 0 & 0 & 0 & 0 & 0 & 0 & \\
\hline 4 & 0 & 2 & 1 & 3 & 2 & 4 & \\
\hline 27 & 6 & 15 & 5 & 26 & 27 & 25 & 2 \\
\hline 40 & 12 & 14 & 11 & 37 & 38 & 36 & \\
\hline 12 & 2 & 4 & 5 & 11 & 8 & 14 & 22 \\
\hline 17 & 7 & 5 & 5 & 17 & 19 & 15 & 34 \\
\hline 39 & 10 & 17 & 10 & 37 & 37 & 37 & \\
\hline 2 & 0 & 0 & 2 & 2 & 0 & 4 & \\
\hline 8 & 1 & 3 & 4 & 8 & 5 & 11 & 6 \\
\hline 27 & 9 & 9 & 8 & 26 & 27 & 25 & 52 \\
\hline 1 & 1 & 0 & 0 & 1 & 2 & 0 & \\
\hline
\end{tabular}

Controles

FP total com agenesia

FP completa com retencao de dentes permanentes

FP completa com multiplas anomalias

FP incompleta com giroversao/lateroversao

FL/P direita com agenesia

FL/P esquerda com agenesia

FL/P esquerda com microdontia ou

supranumerario

FL/P esquerda com multiplas anomalias

FL/P bilateral com agenesia

FL/P bilateral com supranumerario

FL/P bilateral com multiplas anomalias

FL/P bilateral frustro

FL/P bilateral frustro com multiplas anomalias

\section{rs2902345}

Novos subfenotipos propostos

FP total com agenesia

FP completa com retencao de dentes

permanentes

FP completa com multiplas anomalias

FP incompleta com giroversao/lateroversao

FL/P direita com agenesia

FL/P esquerda com agenesia

FL/P esquerda com microdontia ou

supranumerario

FL/P esquerda com multiplas anomalias

FL/P bilateral com agenesia

FL/P bilateral com supranumerario

FL/P bilateral com multiplas anomalias

FL/P bilateral frustro

FL/P bilateral frustro com multiplas anomalias

\section{Fissurados}

$\begin{array}{cccccccc}\mathbf{n} & \mathbf{C C} & \mathbf{C T} & \mathbf{T T} & \text { Total } & \mathbf{C} & \mathbf{T} & \text { to } \\ \mathbf{1 4} & 5 & 7 & 1 & 13 & 17 & 9 & 26 \\ \mathbf{2} & 0 & 0 & 2 & 2 & 0 & 4 & 4 \\ \mathbf{2} & 0 & 0 & 0 & 0 & 0 & 0 & 0 \\ \mathbf{4} & 1 & 2 & 0 & 3 & 4 & 2 & 6 \\ & & & & & & & \\ \mathbf{2 7} & 9 & 15 & 2 & 26 & 33 & 19 & 5 \\ \mathbf{4 0} & 11 & 15 & 13 & 39 & 37 & 41 & 7 \\ \mathbf{1 2} & 6 & 3 & 2 & 11 & 15 & 7 & 2 \\ \mathbf{1 7} & 5 & 5 & 7 & 17 & 15 & 19 & 3 \\ & & & & & & & \\ \mathbf{3 9} & 9 & 16 & 12 & 37 & 34 & 40 & 74 \\ \mathbf{2} & 2 & 0 & 0 & 2 & 4 & 0 & 4 \\ \mathbf{8} & 5 & 2 & 1 & 8 & 12 & 4 & 16 \\ \mathbf{2 7} & 9 & 11 & 6 & 26 & 29 & 23 & 5 \\ \mathbf{1} & 0 & 0 & 1 & 1 & 0 & 2 & 2\end{array}$

\section{CT TT Total}

C $\mathrm{T}$ total

Pgen/Palelo

$\begin{array}{llll}101 & 220 & 121 & 442 \\ 108 & 236 & 131 & 475 \\ 108 & 236 & 132 & 476 \\ 106 & 236 & 132 & 474 \\ & & & \\ 101 & 220 & 121 & 442 \\ 101 & 220 & 121 & 442 \\ 108 & 235 & 132 & 475 \\ 108 & 236 & 132 & 476 \\ & & & \\ 101 & 220 & 121 & 442 \\ 108 & 235 & 132 & 475 \\ 108 & 236 & 132 & 476 \\ 101 & 220 & 121 & 442 \\ 108 & 236 & 132 & 476\end{array}$

$422 \quad 462 \quad 884$

$0.42 / 0.35$

$\begin{array}{lll}452 & 498 \quad 950\end{array}$

$452 \quad 500 \quad 952$

$448 \quad 500 \quad 948$

$\begin{array}{lll}422 & 462 \quad 884\end{array}$

$422 \quad 462 \quad 884$

$451499 \quad 950$

$452 \quad 500 \quad 952$

$422 \quad 462 \quad 884$

$451499 \quad 950$

$452 \quad 500 \quad 952$

$422 \quad 462 \quad 884$

$452 \quad 500 \quad 952$

\section{Controles}

$\begin{array}{cccccccc}\mathbf{C C} & \mathbf{C T} & \text { TT } & \text { Total } & \mathbf{C} & \mathbf{T} & \text { total } & \text { Pgen/Palelo } \\ 146 & 211 & 87 & 444 & 503 & 385 & 888 & 0.56 / 0.37 \\ 158 & 226 & 93 & 477 & 542 & 412 & 954 & ---/--- \\ 159 & 226 & 93 & 478 & 544 & 412 & 956 & ------ \\ 159 & 225 & 92 & 476 & 543 & 409 & 952 & 0.49 / 0.63 \\ & & & & & & & \\ 146 & 211 & 87 & 444 & 503 & 385 & 888 & 0.30 / 0.33 \\ 146 & 211 & 87 & 444 & 503 & 385 & 888 & 0.12 / 0.11 \\ 159 & 225 & 93 & 477 & 543 & 411 & 954 & 0.30 / 0.29 \\ 159 & 226 & 93 & 478 & 544 & 412 & 956 & 0.08 / 0.13 \\ & & & & & & & \\ 146 & 211 & 87 & 444 & 503 & 385 & 888 & 0.16 / 0.07 \\ 159 & 225 & 93 & 477 & 543 & 411 & 954 & ------ \\ 159 & 226 & 93 & 478 & 544 & 412 & 956 & 0.22 / 0.14 \\ 146 & 211 & 87 & 444 & 503 & 385 & 888 & 0.002 / 0.14 \\ 159 & 226 & 93 & 478 & 544 & 412 & 956 & --1\end{array}$

$---/-$

$---/--$

$0.46 / 0.49$

$0.63 / 0.55$

$0.30 / 0.55$

$0.43 / 0.30$

$0.15 / 0.33$

$0.83 / 0.70$

$37 / 0.19$

$0.25 / 0.55$

---/---

$.002 / 0.14$

---/--- 


\section{Novos subfenotipos propostos}

FP total com agenesia

FP completa com retencao de dentes permanentes

FP completa com multiplas anomalias

FP incompleta com giroversao/lateroversao

FL/P direita com agenesia

FL/P esquerda com agenesia

FL/P esquerda com microdontia ou supranumerario

FL/P esquerda com multiplas anomalias

FL/P bilateral com agenesia

FL/P bilateral com supranumerario

FL/P bilateral com multiplas anomalias

FL/P bilateral frustro

FL/P bilateral frustro com multiplas anomalias

\section{rs930655}

Novos subfenotipos propostos

FP total com agenesia

FP completa com retencao de dentes permanentes

FP completa com multiplas anomalias

FP incompleta com giroversao/lateroversao

FL/P direita com agenesia

FL/P esquerda com agenesia

FL/P esquerda com microdontia ou supranumerario

FL/P esquerda com multiplas anomalias

FL/P bilateral com agenesia

FL/P bilateral com supranumerario

FL/P bilateral com multiplas anomalias

FL/P bilateral frustro

FL/P bilateral frustro com multiplas anomalias
Fissurados

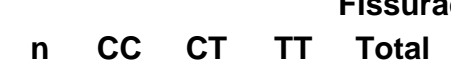

C

total

$\begin{array}{lllll}14 & 4 & 9 & 1 & 14\end{array}$

200012

$\begin{array}{lllll}2 & 0 & 0 & 0 & 0 \\ 4 & 1 & 2 & 1 & 4\end{array}$

$\begin{array}{lllll}27 & 4 & 15 & 7 & 26\end{array}$

$\begin{array}{lllll}40 & 8 & 19 & 13 & 40\end{array}$

$\begin{array}{lllll}12 & 4 & 4 & 4 & 12\end{array}$

$\begin{array}{lllll}17 & 4 & 6 & 7 & 17\end{array}$

$\begin{array}{ccccc}\mathbf{3 9} & 7 & 19 & 10 & 36 \\ \mathbf{2} & 2 & 0 & 0 & 2 \\ \mathbf{8} & 5 & 2 & 1 & 8 \\ \mathbf{2 7} & 4 & 3 & 10 & 17 \\ \mathbf{1} & 0 & 1 & 0 & 1\end{array}$

\section{Fissurados}

\section{n AA AG GG Total}

$\begin{array}{cccccccc}14 & 2 & 5 & 7 & 14 & 9 & 19 & 28 \\ 2 & 2 & 0 & 0 & 2 & 4 & 0 & 4 \\ 2 & 0 & 0 & 0 & 0 & 0 & 0 & 0 \\ 4 & 0 & 2 & 2 & 4 & 2 & 6 & 8\end{array}$

$\begin{array}{llllllll}27 & 4 & 14 & 8 & 26 & 22 & 30 & 52\end{array}$

$\begin{array}{lllll}40 & 10 & 18 & 11 & 39\end{array}$

$\begin{array}{lllll}12 & 1 & 5 & 6 & 12\end{array}$

$\begin{array}{lllll}17 & 7 & 5 & 5 & 17\end{array}$

$\begin{array}{ccccc}\mathbf{3 9} & 5 & 21 & 11 & 37 \\ \mathbf{2} & 0 & 1 & 1 & 2 \\ \mathbf{8} & 1 & 4 & 3 & 8 \\ \mathbf{2 7} & 6 & 10 & 10 & 26 \\ \mathbf{1} & 1 & 0 & 0 & 1\end{array}$

Controles

CC CT TT Total C $\mathrm{T}$ total Pgen/Palelo

$\begin{array}{lll}436 & 456 \quad 892\end{array}$

$\begin{array}{lll}467 & 491 & 958\end{array}$

$\begin{array}{lll}467 & 493 \quad 960\end{array}$

$466 \quad 490 \quad 956$

$\begin{array}{lll}436 & 456 \quad 892\end{array}$

$436 \quad 456 \quad 892$

$\begin{array}{lll}466 & 492 \quad 958\end{array}$

$467 \quad 493 \quad 960$

$\begin{array}{lll}436 & 456 \quad 892\end{array}$

$\begin{array}{lll}466 & 492 \quad 958\end{array}$

$\begin{array}{lll}467 & 493 \quad 960\end{array}$

$436 \quad 456 \quad 892$

$467 \quad 493 \quad 960$

$0.32 / 0.21$

$---/---$

$---/---$

$0.98 / 0.94$

$0.71 / 0.51$

$0.53 / 0.37$

$0.37 / 0.89$

$0.24 / 0.39$

$0.87 / 0.61$

$---/---$

$0.02 / 0.03$

$0.003 / 0.05$

$---/---$

Controles

AA AG GG Total

A G total

Pgen/Palelo

$\begin{array}{lllllll}77 & 222 & 149 & 448 & 376 & 520 & 896\end{array}$

$\begin{array}{llll}85 & 239 & 157 & 481\end{array}$

$\begin{array}{llll}85 & 239 & 158 & 482\end{array}$

$\begin{array}{llll}84 & 239 & 157 & 480\end{array}$

$409 \quad 553 \quad 962$

$409 \quad 555 \quad 964$

$407 \quad 553 \quad 960$

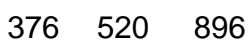

$376 \quad 520 \quad 896$

$408 \quad 554 \quad 962$

$409 \quad 555 \quad 964$

$\begin{array}{lll}376 & 520 \quad 896\end{array}$

$408 \quad 554 \quad 962$

$409 \quad 555 \quad 964$

$376 \quad 520 \quad 896$

$409 \quad 555 \quad 964$
$0.42 / 0.29$

$---/--$

$0.41 / 0.32$

$0.91 / 0.96$

$0.40 / 0.24$

$0.41 / 0.19$

$0.04 / 0.11$

$0.68 / 0.99$

$0.64 / 0.48$

$0.91 / 0.69$

$0.52 / 0.96$ 
Novos subfenotipos propostos

FP total com agenesia

FP completa com retencao de dentes permanentes

FP completa com multiplas anomalias

FP incompleta com giroversao/lateroversao

FL/P direita com agenesia

FL/P esquerda com agenesia

FL/P esquerda com microdontia ou supranumerario

FL/P esquerda com multiplas anomalias

FL/P bilateral com agenesia

FL/P bilateral com supranumerario

FL/P bilateral com multiplas anomalias

FL/P bilateral frustro

FL/P bilateral frustro com multiplas anomalias

\section{rs2166975 (C3296T)}

Novos subfenotipos propostos

FP total com agenesia

FP completa com retencao de dentes permanentes

FP completa com multiplas anomalias

FP incompleta com giroversao/lateroversao

FL/P direita com agenesia

FL/P esquerda com agenesia

FL/P esquerda com microdontia ou supranumerario

FL/P esquerda com multiplas anomalias

FL/P bilateral com agenesia

FL/P bilateral com supranumerario

FL/P bilateral com multiplas anomalias

FL/P bilateral frustro

FL/P bilateral frustro com multiplas anomalias
Fissurados

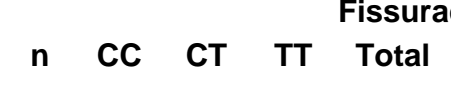

$\begin{array}{lllll}14 & 15 & 0 & 1 & 16\end{array}$

$\begin{array}{lllll}2 & 2 & 0 & 0 & 2 \\ 2 & 0 & 0 & 0 & 0\end{array}$

$$
\begin{array}{lllll}
27 & 25 & 0 & 0 & 25
\end{array}
$$

$\begin{array}{lllll}40 & 37 & 2 & 3 & 42\end{array}$

$\begin{array}{lllll}12 & 11 & 0 & 1 & 12\end{array}$

$\begin{array}{lllll}17 & 16 & 0 & 1 & 17\end{array}$

$\begin{array}{lllll}39 & 36 & 0 & 2 & 38\end{array}$

$\begin{array}{lllll}2 & 2 & 0 & 0 & 2\end{array}$

$\begin{array}{lllll}8 & 8 & 0 & 0 & 8\end{array}$

$\begin{array}{lllll}27 & 24 & 1 & 1 & 26\end{array}$

\section{C}

302

4

0

total

32

4

4

0
8 n CC CT TT Total

$\begin{array}{ccccc}\mathbf{1 4} & 8 & 5 & 1 & 14 \\ \mathbf{2} & 2 & 0 & 0 & 2 \\ \mathbf{2} & 0 & 0 & 0 & 0 \\ \mathbf{4} & 3 & 1 & 0 & 4 \\ & & & & \\ \mathbf{2 7} & 19 & 4 & 1 & 2 \\ \mathbf{4 0} & 28 & 6 & 6 & 4 \\ \mathbf{1 2} & 11 & 1 & 0 & 1 \\ \mathbf{1 7} & 13 & 3 & 1 & 1 \\ & & & & \\ \mathbf{3 9} & 23 & 9 & 2 & 34 \\ \mathbf{2} & 1 & 1 & 0 & 2 \\ \mathbf{8} & 6 & 1 & 0 & 7 \\ \mathbf{2 7} & 20 & 5 & 1 & 26 \\ \mathbf{1} & 1 & 0 & 0 & 1\end{array}$

Controles

$\begin{array}{cccccccc}\text { CC } & \text { CT } & \text { TT } & \text { Total } & \text { C } & \text { T } & \text { total } & \text { Pgen/Palelo } \\ 399 & 11 & 27 & 437 & 809 & 65 & 874 & 0.66 / 0.80 \\ 429 & 11 & 29 & 469 & 869 & 69 & 938 & ---/-- \\ 429 & 11 & 30 & 470 & 869 & 71 & 940 & ---/-- \\ 427 & 11 & 30 & 468 & 865 & 71 & 936 & ---/--- \\ & & & & & & & \\ 399 & 11 & 27 & 437 & 809 & 65 & 874 & ---/-- \\ 399 & 11 & 27 & 437 & 809 & 65 & 874 & 0.66 / 0.49 \\ 428 & 11 & 30 & 469 & 867 & 71 & 938 & 0.73 / 0.88 \\ 429 & 11 & 30 & 470 & 869 & 71 & 940 & 0.66 / 0.71 \\ & & & & & & & \\ 399 & 11 & 27 & 437 & 809 & 65 & 874 & 0.38 / 0.48 \\ 428 & 11 & 30 & 469 & 867 & 71 & 938 & ---/--- \\ 429 & 11 & 30 & 470 & 869 & 71 & 940 & ---/--- \\ 399 & 11 & 27 & 437 & 809 & 65 & 874 & 0.82 / 0.65 \\ 429 & 11 & 30 & 470 & 869 & 71 & 940 & ---/--\end{array}$

Controles

$\begin{array}{cccccccc}\text { CC } & \text { CT } & \text { TT } & \text { Total } & \text { C } & \text { T } & \text { total } & \text { Pgen/Palelo } \\ & & & & & & & \\ 339 & 79 & 25 & 443 & 757 & 129 & 886 & 0.21 / 0.22 \\ 365 & 84 & 26 & 475 & 814 & 136 & 950 & ---/-- \\ 365 & 85 & 26 & 476 & 815 & 137 & 952 & ---/-- \\ 363 & 85 & 26 & 474 & 811 & 137 & 948 & 0.76 / 0.87 \\ & & & & & & & \\ 339 & 79 & 25 & 443 & 757 & 129 & 886 & 0.93 / 0.69 \\ 339 & 79 & 25 & 443 & 757 & 129 & 886 & 0.06 / 0.05 \\ 364 & 85 & 26 & 475 & 813 & 137 & 950 & 0.32 / 0.15 \\ 365 & 85 & 26 & 476 & 815 & 137 & 952 & 0.99 / 0.95 \\ & & & & & & & \\ 339 & 79 & 25 & 443 & 757 & 129 & 886 & 0.44 / 0.30 \\ 364 & 85 & 26 & 475 & 813 & 137 & 950 & 0.46 / 0.54 \\ 365 & 85 & 26 & 476 & 815 & 137 & 952 & 0.64 / 0.44 \\ 339 & 79 & 25 & 443 & 757 & 129 & 886 & 0.91 / 0.82 \\ 365 & 85 & 26 & 476 & 815 & 137 & 952 & ---/--\end{array}$




\section{Novos subfenotipos propostos}

FP total com agenesia

FP completa com retencao de dentes permanentes

FP completa com multiplas anomalias

FP incompleta com giroversao/lateroversao

FL/P direita com agenesia

FL/P esquerda com agenesia

FL/P esquerda com microdontia ou supranumerario

FL/P esquerda com multiplas anomalias

FL/P bilateral com agenesia

FL/P bilateral com supranumerario

FL/P bilateral com multiplas anomalias

FL/P bilateral frustro

FL/P bilateral frustro com multiplas anomalias

\section{rs2902345 caucasianos}

Novos subfenotipos propostos

FP total com agenesia

FP completa com retencao de dentes permanentes

FP completa com multiplas anomalias

FP incompleta com giroversao/lateroversao

FL/P direita com agenesia

FL/P esquerda com agenesia

FL/P esquerda com microdontia ou supranumerario

FL/P esquerda com multiplas anomalias

FL/P bilateral com agenesia

FL/P bilateral com supranumerario

FL/P bilateral com multiplas anomalias

FL/P bilateral frustro

FL/P bilateral frustro com multiplas anomalias
Fissurados

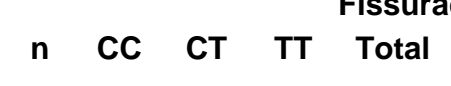

$\begin{array}{lll}\mathbf{2} & 0 & 7 \\ \mathbf{0} & 2 & 0 \\ \mathbf{4} & 0 & 2\end{array}$

\section{$\begin{array}{lllll}24 & 6 & 12 & 5 & 23\end{array}$}

$\begin{array}{lllll}36 & 11 & 15 & 9 & 35\end{array}$

$\begin{array}{lllll}9 & 2 & 3 & 3 & 8\end{array}$

$\begin{array}{lllll}14 & 7 & 4 & 3 & 14\end{array}$

$\begin{array}{ccccc}\mathbf{3 4} & 9 & 15 & 8 & 32 \\ \mathbf{2} & 0 & 0 & 2 & 2 \\ \mathbf{6} & 1 & 3 & 2 & 6 \\ \mathbf{2 2} & 8 & 7 & 6 & 21 \\ \mathbf{1} & 1 & 0 & 0 & 1\end{array}$

\section{Fissurados}

\section{n CC CT TT Total}

$\begin{array}{cccccccc}12 & 5 & 6 & 0 & 11 & 16 & 6 & 22 \\ \mathbf{2} & 0 & 0 & 2 & 2 & 0 & 4 & 4 \\ \mathbf{0} & 1 & 2 & 0 & 3 & 4 & 2 & 6 \\ \mathbf{4} & 1 & 2 & 0 & 3 & 4 & 2 & 6\end{array}$

$\begin{array}{llllllll}24 & 9 & 12 & 2 & 23 & 30 & 16 & 46\end{array}$

$\begin{array}{llllllll}36 & 9 & 14 & 12 & 35 & 32 & 38 & 70\end{array}$

$\begin{array}{lllll}9 & 4 & 2 & 2 & 8\end{array}$

$\begin{array}{lllll}14 & 3 & 4 & 7 & 14\end{array}$

$\begin{array}{cccccccc}\mathbf{3 4} & 6 & 14 & 12 & 32 & 26 & 38 & 64 \\ \mathbf{2} & 2 & 0 & 0 & 2 & 4 & 0 & 4 \\ \mathbf{6} & 3 & 2 & 1 & 6 & 8 & 4 & 12 \\ \mathbf{2 2} & 7 & 9 & 5 & 21 & 23 & 19 & 42 \\ \mathbf{1} & 0 & 0 & 1 & 1 & 0 & 2 & 2\end{array}$

Controles

CC CT TT Total C $\mathrm{T}$ total Pgen/Palelo

$\begin{array}{llll}259 & 253 & 512 & 0.04 / 0.08\end{array}$

$281 \quad 275 \quad 556$

$\begin{array}{lll}281 & 277 \quad 558\end{array}$

$277 \quad 277 \quad 554$

$0.43 / 0.40$

$0.44 / 0.41$

$259 \quad 253 \quad 512$

$\begin{array}{lll}259 & 253 \quad 512\end{array}$

$280 \quad 276 \quad 556$

$0.97 / 0.83$

$0.51 / 0.72$

$0.58 / 0.60$

$\begin{array}{llll}66 & 148 & 64 & 278\end{array}$

$\begin{array}{lll}281 & 277 \quad 558\end{array}$

$0.07 / 0.15$

$\begin{array}{lll}259 & 253 \quad 512\end{array}$

$0.81 / 0.88$

$0.01 / 0.01$

$0.81 / 0.55$

$\begin{array}{lll}281 & 277 \quad 558\end{array}$

$259 \quad 253 \quad 512$

$0.20 / 0.60$

---l---

Controles

CC CT TT Total

\section{C $\mathbf{T}$ total}

Pgen/Palelo

$\begin{array}{llll}77 & 125 & 54 & 256\end{array}$

$\begin{array}{llll}83 & 139 & 56 & 278\end{array}$

$\begin{array}{llll}84 & 139 & 56 & 279\end{array}$

$\begin{array}{lll}279 & 233 & 512\end{array}$

$\begin{array}{lll}305 & 251 & 556\end{array}$

$307 \quad 251 \quad 558$

$306 \quad 248 \quad 554$

0.06/0.09

$---/ 0.008$

$0.50 / 0.56$

$0.50 / 0.57$

$\begin{array}{lllllll}77 & 125 & 54 & 256 & 279 & 233 & 512\end{array}$

$0.32 / 0.16$

$0.21 / 0.16$

$0.35 / 0.55$

$\begin{array}{llll}84 & 138 & 56 & 278\end{array}$

$\begin{array}{lll}279 & 233 \quad 512\end{array}$

$\begin{array}{lll}306 & 250 \quad 556\end{array}$

$307 \quad 251 \quad 558$

$0.02 / 0.04$

$\begin{array}{llll}77 & 125 & 54 & 256\end{array}$

$\begin{array}{lll}279 & 233 & 512\end{array}$

$0.09 / 0.03$

$---/ 0.02$

$\begin{array}{llll}84 & 138 & 56 & 278 \\ 84 & 139 & 56 & 279\end{array}$

$306 \quad 250 \quad 556$

$\begin{array}{lll}307 & 251 \quad 558\end{array}$

$\begin{array}{lll}279 & 233 & 512\end{array}$

$0.57 / 0.42$

$\begin{array}{llll}77 & 125 & 54 & 256\end{array}$

$\begin{array}{lll}307 & 251 \quad 558\end{array}$ 
Novos subfenotipos propostos

FP total com agenesia

FP completa com retencao de dentes permanentes

FP completa com multiplas anomalias

FP incompleta com giroversao/lateroversao

FL/P direita com agenesia

FL/P esquerda com agenesia

FL/P esquerda com microdontia ou supranumerario

FL/P esquerda com multiplas anomalias

FL/P bilateral com agenesia

FL/P bilateral com supranumerario

FL/P bilateral com multiplas anomalias

FL/P bilateral frustro

FL/P bilateral frustro com multiplas anomalias

\section{rs930655 caucasianos}

Novos subfenotipos propostos

FP total com agenesia

FP completa com retencao de dentes permanentes

FP completa com multiplas anomalias

FP incompleta com giroversao/lateroversao

FL/P direita com agenesia

FL/P esquerda com agenesia

FL/P esquerda com microdontia ou supranumerario

FL/P esquerda com multiplas anomalias

FL/P bilateral com agenesia

FL/P bilateral com supranumerario

FL/P bilateral com multiplas anomalias

FL/P bilateral frustro

FL/P bilateral frustro com multiplas anomalias
Fissurados

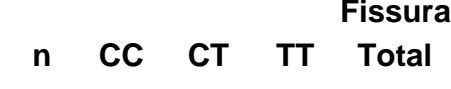

C

$\begin{array}{cccccccc}12 & 4 & 7 & 1 & 12 & 15 & 9 & 24 \\ \mathbf{2} & 0 & 0 & 2 & 2 & 0 & 4 & 4 \\ \mathbf{0} & 2 & 1 & 1 & 4 & 5 & 3 & 8 \\ \mathbf{4} & 1 & 2 & 1 & 4 & 4 & 4 & 8\end{array}$

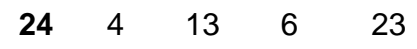

$\begin{array}{lllll}36 & 7 & 17 & 12 & 36\end{array}$

$\begin{array}{lllll}9 & 3 & 3 & 3 & 9\end{array}$

$\begin{array}{lllll}14 & 3 & 5 & 6 & 14\end{array}$

$\begin{array}{cccccccc}\mathbf{3 4} & 6 & 16 & 9 & 31 & 28 & 34 & 62 \\ \mathbf{2} & 2 & 0 & 0 & 2 & 4 & 0 & 4 \\ \mathbf{6} & 4 & 1 & 1 & 6 & 9 & 3 & 12 \\ \mathbf{2 2} & 4 & 10 & 8 & 22 & 18 & 26 & 44 \\ \mathbf{1} & 0 & 1 & 0 & 1 & 1 & 1 & 2\end{array}$

\section{Fissurados}

n AA AG GG Total

$\begin{array}{cccccccc}\mathbf{1 2} & 1 & 4 & 7 & 12 & 6 & 18 & 24 \\ \mathbf{2} & 2 & 0 & 0 & 2 & 4 & 0 & 4 \\ \mathbf{0} & 1 & 1 & 2 & 4 & 3 & 5 & 8 \\ \mathbf{4} & 0 & 2 & 2 & 4 & 2 & 6 & 8 \\ & & & & & & & \\ \mathbf{2 4} & 3 & 12 & 8 & 23 & 18 & 28 & 46 \\ \mathbf{3 6} & 10 & 16 & 9 & 35 & 36 & 34 & 70 \\ \mathbf{9} & 1 & 4 & 4 & 9 & 6 & 12 & 18 \\ \mathbf{1 4} & 7 & 4 & 3 & 14 & 18 & 10 & 28\end{array}$

$\begin{array}{llllllll}34 & 5 & 18 & 9 & 32 & 28 & 36 & 64\end{array}$

$\begin{array}{llllllll}2 & 0 & 1 & 1 & 2 & 1 & 3 & 4\end{array}$

$\begin{array}{llllllll}6 & 1 & 3 & 2 & 6 & 5 & 7 & 12\end{array}$

$\begin{array}{llllllll}22 & 5 & 8 & 8 & 21 & 18 & 24 & 42\end{array}$
Controles

CC CT TT Total C $\mathrm{T}$ total Pgen/Palelo

$256 \quad 260 \quad 516$

$0.41 / 0.21$

$\begin{array}{llll}59 & 160 & 61 & 280\end{array}$

$\begin{array}{lll}278 & 282 & 560\end{array}$

$\begin{array}{lll}278 & 284 & 562\end{array}$

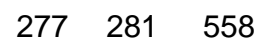

$0.32 / 0.6$

$\begin{array}{llll}59 & 159 & 61 & 279\end{array}$

$256 \quad 260 \quad 516$

$256 \quad 260 \quad 516$

$277 \quad 283 \quad 560$

$\begin{array}{lll}278 & 284 & 562\end{array}$

$0.95 / 0.60$

$0.38 / 0.29$

$0.37 / 0.94$

$0.16 / 0.29$

$\begin{array}{lll}256 & 260 & 516\end{array}$

$0.71 / 0.50$

$---/ 0.01$

$0.02 / 0.08$

$0.33 / 0.26$

$278 \quad 284 \quad 562$

$\begin{array}{lll}256 & 260 \quad 516\end{array}$

$---/ 0.98$

Controles

AA AG GG Total

A G total

Pgen/Palelo

$\begin{array}{llll}49 & 127 & 83 & 259\end{array}$

$\begin{array}{lll}225 & 293 & 518\end{array}$

$\begin{array}{lll}247 & 315 & 562\end{array}$

$\begin{array}{lll}247 & 317 & 564\end{array}$

$245 \quad 315 \quad 560$

0.15/0.07

$---/ 0.006$

$0.61 / 0.72$

$\begin{array}{llll}54 & 139 & 89 & 282\end{array}$

$\begin{array}{llll}53 & 139 & 88 & 280\end{array}$

$\begin{array}{lll}225 & 293 & 518\end{array}$

$0.38 / 0.28$

$\begin{array}{llll}49 & 127 & 83 & 259\end{array}$

$\begin{array}{lll}225 & 293 \quad 518\end{array}$

$0.78 / 0.057$

$0.38 / 0.20$

$\begin{array}{llll}54 & 138 & 89 & 281\end{array}$

$\begin{array}{llll}54 & 139 & 89 & 282\end{array}$

$246 \quad 316 \quad 562$

$247 \quad 317 \quad 564$

$\begin{array}{llll}49 & 127 & 83 & 259\end{array}$

$\begin{array}{lll}225 & 293 \quad 518\end{array}$

$0.67 / 0.37$

$0.02 / 0.03$

$\begin{array}{llll}54 & 138 & 89 & 281\end{array}$

$\begin{array}{llll}54 & 139 & 89 & 282\end{array}$

$246 \quad 316 \quad 562$

$\begin{array}{lll}247 & 317 & 564\end{array}$

$0.73 / 0.96$

$0.61 / 0.45$

$0.98 / 0.88$

$\begin{array}{lll}225 & 293 \quad 518\end{array}$

$0.62 / 0.94$

$---/ 0.05$ 
Fissurados

Novos subfenotipos propostos

FP total com agenesia

FP completa com retencao de dentes permanentes

FP completa com multiplas anomalias

FP incompleta com giroversao/lateroversao

FL/P direita com agenesia

FL/P esquerda com agenesia

FL/P esquerda com microdontia ou supranumerario

FL/P esquerda com multiplas anomalias

FL/P bilateral com agenesia

FL/P bilateral com supranumerario

FL/P bilateral com multiplas anomalias

FL/P bilateral frustro

FL/P bilateral frustro com multiplas anomalias

\section{n CC CT TT Total}

$\begin{array}{lll}12 & 11 & 0\end{array}$

0

4

$\begin{array}{llll}24 & 22 & 0 & 0\end{array}$

$\begin{array}{lll}36 & 32 & 2\end{array}$

$\begin{array}{lll}9 & 9 & 0\end{array}$

$14 \quad 14$

$\begin{array}{lllll}34 & 31 & 0 & 2 & 33\end{array}$

$\begin{array}{lllll}2 & 2 & 0 & 0 & 2\end{array}$

$\begin{array}{lllll}6 & 6 & 0 & 0 & 6\end{array}$

$\begin{array}{lllll}22 & 20 & 1 & 0 & 21\end{array}$

s

C $\mathbf{T}$ total

Controles

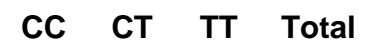

C $\mathbf{T}$ total

Pgen/Palelo

$0.90 / 0.67$

$---/--$

$515 \quad 31 \quad 546$

$\begin{array}{lll}515 & 33 & 548\end{array}$

$\begin{array}{lll}511 & 33 & 544\end{array}$

$---/--$

$---/---$

$0.24 / 0.02$

$0.01 / 0.48$

$---/---$

$---/---$

$0.88 / 0.97$

$---/--$

$---/---$

$0.02 / 0.31$

$$
---/--
$$

\section{rs2166975 (C3296T) caucasianos}

Novos subfenotipos propostos

\section{Fissurados}

\section{n CC CT TT Total}

\section{C}

$\begin{array}{cccccccc}12 & 6 & 5 & 1 & 12 & 17 & 7 & 24 \\ \mathbf{2} & 2 & 0 & 0 & 2 & 4 & 0 & 4 \\ \mathbf{0} & 0 & 0 & 0 & 0 & 0 & 0 & 0 \\ \mathbf{4} & \mathbf{3} & \mathbf{1} & \mathbf{0} & 4 & 7 & 1 & 8\end{array}$

FP total com agenesia

FP completa com retencao de dentes permanentes

FP completa com multiplas anomalias

FP incompleta com giroversao/lateroversao

FL/P direita com agenesia

FL/P esquerda com agenesia

FL/P esquerda com microdontia ou supranumerario

FL/P esquerda com multiplas anomalias

$\begin{array}{ccccc}\mathbf{2 4} & 17 & 3 & 1 & 21 \\ \mathbf{3 6} & 25 & 5 & 6 & 36 \\ \mathbf{9} & 9 & 0 & 0 & \\ 14 & 11 & 2 & 1 & \end{array}$

FL/P bilateral com agenesia

FL/P bilateral com supranumerario

FL/P bilateral com multiplas anomalias

FL/P bilateral frustro

FL/P bilateral frustro com multiplas anomalias

$\begin{array}{llllllll}14 & 11 & 2 & 1 & 14 & 24 & 4 & 28\end{array}$

$\begin{array}{llllllll}34 & 19 & 8 & 2 & 29 & 46 & 12 & 58\end{array}$

$\begin{array}{llllllll}2 & 1 & 1 & 0 & 2 & 3 & 1 & 4\end{array}$

$\begin{array}{llllllll}6 & 4 & 1 & 0 & 5 & 9 & 1 & 10\end{array}$

$\begin{array}{llllllll}22 & 16 & 4 & 1 & 21 & 36 & 6 & 42\end{array}$

\section{Controles}

$\begin{array}{cccccccc}\text { CC } & \text { CT } & \text { TT } & \text { Total } & \text { C } & \text { T } & \text { total } & \text { Pgen/Palelo } \\ 199 & 42 & 15 & 256 & 440 & 72 & 512 & 0.06 / 0.04 \\ 217 & 45 & 15 & 277 & 479 & 75 & 554 & ---/-- \\ 217 & 46 & 15 & 278 & 480 & 76 & 556 & ---/-- \\ 215 & 46 & 15 & 276 & 476 & 76 & 552 & 0.74 / 0.91 \\ & & & & & & & \\ 199 & 42 & 15 & 256 & 440 & 72 & 512 & 0.94 / 0.69 \\ 199 & 42 & 15 & 256 & 440 & 72 & 512 & 0.06 / 0.03 \\ 216 & 46 & 15 & 277 & 478 & 76 & 554 & 0.10 / 0.02 \\ 217 & 46 & 15 & 278 & 480 & 76 & 556 & 0.94 / 0.92 \\ & & & & & & & \\ 199 & 42 & 15 & 256 & 440 & 72 & 512 & 0.29 / 0.17 \\ 216 & 46 & 15 & 277 & 478 & 76 & 554 & 0.42 / 0.51 \\ 217 & 46 & 15 & 278 & 480 & 76 & 556 & 0.73 / 0.73 \\ 199 & 42 & 15 & 256 & 440 & 72 & 512 & 0.93 / 0.96 \\ 217 & 46 & 15 & 278 & 480 & 76 & 556 & ---/--\end{array}$


Novos subfenotipos propostos

FP total com agenesia

FP completa com retencao de dentes permanentes

FP completa com multiplas anomalias

FP incompleta com giroversao/lateroversao

FL/P direita com agenesia

FL/P esquerda com agenesia

FL/P esquerda com microdontia ou supranumerario

FL/P esquerda com multiplas anomalias

FL/P bilateral com agenesia

FL/P bilateral com supranumerario

FL/P bilateral com multiplas anomalias

FL/P bilateral frustro

FL/P bilateral frustro com multiplas anomalias

\section{rs2073487}

Novos subfenotipos propostos

FP total com agenesia

FP completa com retencao de dentes permanentes

FP completa com multiplas anomalias

FP incompleta com giroversao/lateroversao

FL/P direita com agenesia

FL/P esquerda com agenesia

FL/P esquerda com microdontia ou supranumerario

FL/P esquerda com multiplas anomalias

FL/P bilateral com agenesia

FL/P bilateral com supranumerario

FL/P bilateral com multiplas anomalias

FL/P bilateral frustro

FL/P bilateral frustro com multiplas anomalias
Fissurados

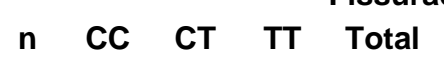

C

\section{total}

142

2

40

$\begin{array}{lllll}27 & 3 & 11 & 12 & 26\end{array}$

$\begin{array}{lllll}40 & 4 & 19 & 16 & 39\end{array}$

$\begin{array}{lllll}12 & 0 & 4 & 7 & 11\end{array}$

$\begin{array}{lllll}17 & 1 & 6 & 10 & 17\end{array}$

$\begin{array}{lllll}39 & 6 & 13 & 17 & 36\end{array}$

$\begin{array}{lllll}2 & 0 & 2 & 0 & 2\end{array}$

82045

$\begin{array}{lllll}27 & 4 & 15 & 8 & 27\end{array}$

$\begin{array}{lllll}1 & 0 & 0 & 1 & 1\end{array}$

\section{Controles}

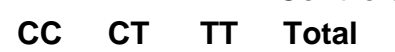

C $\mathbf{T}$ total

Pgen/Palelo

$\begin{array}{llll}384 & 504 & 888 & 0.73 / 0.42\end{array}$

$\begin{array}{llll}415 & 539 & 954 & 0.009 / 0.006\end{array}$

$416 \quad 540 \quad 956$

$415 \quad 537 \quad 952$

$---/---$

$0.37 / 0.29$

$0.33 / 0.13$

$0.30 / 0.13$

$0.02 / 0.01$

$416 \quad 538 \quad 954$

$416 \quad 540 \quad 956$

$0.06 / 0.02$

$\begin{array}{lll}384 & 504 \quad 888\end{array}$

$0.23 / 0.15$

$0.19 / 0.79$

$0.87 / 0.60$

$0.65 / 0.92$

$\begin{array}{lll}384 & 504 \quad 888\end{array}$

$416 \quad 540 \quad 956$

\section{n CC CT TT Total}

$\begin{array}{ccccc}14 & 2 & 6 & 5 & 13 \\ 2 & 2 & 0 & 0 & 2 \\ 2 & 0 & 0 & 0 & 0 \\ 4 & 0 & 2 & 1 & 3\end{array}$

$\begin{array}{lllll}27 & 3 & 11 & 12 & 26\end{array}$

$\begin{array}{ccccc}40 & 4 & 19 & 16 & 39 \\ 12 & 0 & 4 & 7 & 11\end{array}$

$\begin{array}{lllll}17 & 1 & 6 & 10 & 17\end{array}$

$\begin{array}{lllll}39 & 6 & 13 & 18 & 37\end{array}$

$\begin{array}{lllll}2 & 0 & 2 & 0 & 2\end{array}$

$\begin{array}{lllll}8 & 4 & 4 & 2 & 10\end{array}$

$\begin{array}{lllll}27 & 4 & 15 & 8 & 27\end{array}$

4

C $\mathrm{T}$ total

$10 \quad 16 \quad 26$

$\begin{array}{lll}4 & 0 & 4 \\ 0 & 0 & 0\end{array}$

246

$\begin{array}{lll}17 & 35 & 52\end{array}$

$27 \quad 51 \quad 78$

$\begin{array}{lll}4 & 18 & 22 \\ 8 & 26 & 34\end{array}$

$\begin{array}{lll}25 & 49 & 74\end{array}$

$2 \quad 2 \quad 4$

$\begin{array}{lll}12 & 8 & 20\end{array}$

$\begin{array}{lll}23 & 31 & 54\end{array}$

\section{Controles}

CC CT TT Total

C $\mathbf{T}$ total

Pgen/Palelo

$\begin{array}{lllllll}88 & 209 & 148 & 445 & 385 & 505 & 890 \\ 96 & 224 & 158 & 478 & 416 & 540 & 956 \\ 96 & 225 & 158 & 479 & 417 & 541 & 958\end{array}$

$\begin{array}{llll}96 & 224 & 157 & 477\end{array}$

$416 \quad 538 \quad 954$

$\begin{array}{lll}385 & 505 & 890\end{array}$

$385 \quad 505 \quad 890$

$\begin{array}{lll}417 & 539 \quad 956\end{array}$

$417 \quad 541 \quad 958$

$\begin{array}{lll}385 & 505 \quad 890\end{array}$

$\begin{array}{lll}417 & 539 \quad 956\end{array}$

$417 \quad 541 \quad 958$

$385 \quad 505 \quad 890$

$417 \quad 541 \quad 958$
$0.89 / 0.62$

$---/--$

$0.48 / 0.61$

$0.33 / 0.13$

$0.30 / 0.13$

$0.02 / 0.01$

$0.06 / 0.02$

$0.16 / 0.11$

---/---

$0.28 / 0.14$

$0.66 / 0.92$

$---/--$ 
Novos subfenotipos propostos

FP total com agenesia

FP completa com retencao de dentes permanentes

FP completa com multiplas anomalias

FP incompleta com giroversao/lateroversao

FL/P direita com agenesia

FL/P esquerda com agenesia

FL/P esquerda com microdontia ou supranumerario

FL/P esquerda com multiplas anomalias

FL/P bilateral com agenesia

FL/P bilateral com supranumerario

FL/P bilateral com multiplas anomalias

FL/P bilateral frustro

FL/P bilateral frustro com multiplas anomalias

\section{rs4844880}

Novos subfenotipos propostos

FP total com agenesia

FP completa com retencao de dentes permanentes

FP completa com multiplas anomalias

FP incompleta com giroversao/lateroversao

FL/P direita com agenesia

FL/P esquerda com agenesia

FL/P esquerda com microdontia ou supranumerario

FL/P esquerda com multiplas anomalias

FL/P bilateral com agenesia

FL/P bilateral com supranumerario

FL/P bilateral com multiplas anomalias

FL/P bilateral frustro

FL/P bilateral frustro com multiplas anomalias
Fissurados

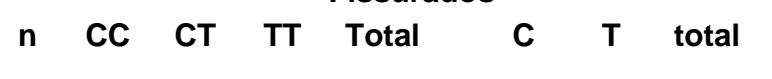

$\begin{array}{lllll}14 & 10 & 3 & 0 & 13\end{array}$

$\begin{array}{lllll}2 & 0 & 1 & 1 & 2 \\ 2 & 0 & 0 & 0 & 0\end{array}$

$\begin{array}{lllll}40 & 36 & 3 & 0 & 39\end{array}$

$\begin{array}{lllll}12 & 10 & 1 & 1 & 12\end{array}$

$\begin{array}{lllll}17 & 17 & 0 & 0 & 17\end{array}$

$\begin{array}{lllll}39 & 33 & 3 & 1 & 37\end{array}$

$\begin{array}{lllll}2 & 2 & 0 & 0 & 2\end{array}$

$\begin{array}{lllll}8 & 8 & 0 & 0 & 8\end{array}$

$\begin{array}{lllll}27 & 24 & 2 & 1 & 27\end{array}$

$\begin{array}{lllll}1 & 1 & 0 & 0 & 1\end{array}$

$\begin{array}{lllll}27 & 23 & 2 & 1 & 26\end{array}$

Controles

CC CT TT Total C $T$ total Pgen/Palelo

$\begin{array}{lllllll}319 & 109 & 15 & 443 & 747 & 139 & 886\end{array}$

$\begin{array}{lllllll}345 & 114 & 17 & 476 & 804 & 148 & 952\end{array}$

$\begin{array}{lllllll}346 & 114 & 17 & 477 & 806 & 148 & 954\end{array}$

$\begin{array}{lllllll}344 & 114 & 17 & 475 & 802 & 148 & 950\end{array}$

$\begin{array}{lllllll}319 & 109 & 15 & 443 & 747 & 139 & 886\end{array}$

$\begin{array}{lllllll}319 & 109 & 15 & 443 & 747 & 139 & 886\end{array}$

$\begin{array}{lllllll}345 & 114 & 17 & 476 & 804 & 148 & 952\end{array}$

$806 \quad 148 \quad 954$

$747 \quad 139 \quad 886$

$804 \quad 148 \quad 952$

$806 \quad 148 \quad 954$

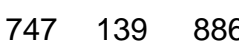

$806 \quad 148 \quad 954$

\section{Controles}

\section{n AA AG GG Total}

$\begin{array}{ccc}\text { A } & \text { G } & \text { tota } \\ & & \\ 6 & 22 & 28 \\ 1 & 3 & 4 \\ 0 & 0 & 0 \\ 3 & 5 & 8 \\ & & \\ 12 & 42 & 54 \\ 20 & 60 & 80 \\ 8 & 16 & 24 \\ 8 & 26 & 34 \\ & & \\ 23 & 53 & 76 \\ 1 & 3 & 4 \\ 4 & 12 & 16 \\ 11 & 43 & 54 \\ 0 & 2 & 2\end{array}$

\section{AA AG GG Total}

$\begin{array}{llll}55 & 175 & 218 & 448\end{array}$

$\begin{array}{llll}62 & 182 & 237 & 481\end{array}$

$\begin{array}{llll}62 & 183 & 237 & 482\end{array}$

$\begin{array}{llll}61 & 183 & 236 & 480\end{array}$

$\begin{array}{llll}55 & 175 & 218 & 448\end{array}$

$\begin{array}{llll}55 & 175 & 218 & 448\end{array}$

$62 \quad 182 \quad 237$

$\begin{array}{llll}62 & 183 & 237 & 482\end{array}$

$\begin{array}{llll}62 & 182 & 237 & 481\end{array}$

$\begin{array}{llll}62 & 183 & 237 & 482\end{array}$

$\begin{array}{llll}55 & 175 & 218 & 448\end{array}$

$\begin{array}{llll}62 & 183 & 237 & 482\end{array}$ $\begin{array}{llll}55 & 175 & 218 & 448\end{array}$
Pgen/Palelo

$0.63 / 0.56$

$---1--$

$0.02 / 0.007$

$0.14 / 0.11$

$0.01 / 0.004$

$0.34 / 0.68$

---/---

$0.06 / 0.03$

$---/--$

$---1--$

$0.12 / 0.09$

---/---
Pgen/Palelo

$\begin{array}{cccc}285 & 611 & 896 & 0.16 / 0.24 \\ 306 & 656 & 962 & 0.74 / 0.77 \\ 307 & 657 & 964 & ------ \\ 305 & 655 & 960 & 0.23 / 0.72 \\ & & & \\ 285 & 611 & 896 & 0.03 / 0.14 \\ 285 & 611 & 896 & 0.48 / 0.20 \\ 306 & 656 & 962 & 0.67 / 0.87 \\ 307 & 657 & 964 & 0.61 / 0.30 \\ & & & \\ 285 & 611 & 896 & 0.29 / 0.78 \\ 306 & 656 & 962 & 0.74 / 0.77 \\ 307 & 657 & 964 & 0.31 / 0.55 \\ 285 & 611 & 896 & 0.23 / 0.07 \\ 307 & 657 & 964 & ---/--\end{array}$

$0.16 / 0.24$

$03 / 0.14$

$0.67 / 0.87$

$0.29 / 0.78$

$0.31 / 0.55$

---/--- 
Novos subfenotipos propostos

FP total com agenesia

FP completa com retencao de dentes permanentes

FP completa com multiplas anomalias

FP incompleta com giroversao/lateroversao

FL/P direita com agenesia

FL/P esquerda com agenesia

FL/P esquerda com microdontia ou supranumerario

FL/P esquerda com multiplas anomalias

FL/P bilateral com agenesia

FL/P bilateral com supranumerario

FL/P bilateral com multiplas anomalias

FL/P bilateral frustro

FL/P bilateral frustro com multiplas anomalias

\section{rs861019}

Novos subfenotipos propostos

FP total com agenesia

FP completa com retencao de dentes permanentes

FP completa com multiplas anomalias

FP incompleta com giroversao/lateroversao

FL/P direita com agenesia

FL/P esquerda com agenesia

FL/P esquerda com microdontia ou supranumerario

FL/P esquerda com multiplas anomalias

FL/P bilateral com agenesia

FL/P bilateral com supranumerario

FL/P bilateral com multiplas anomalias

FL/P bilateral frustro

FL/P bilateral frustro com multiplas anomalias
Fissurados

$\begin{array}{cccccccc}\mathbf{n} & \mathbf{C C} & \mathbf{C T} & \mathbf{T T} & \text { Total } & \mathbf{C} & \mathbf{T} & \text { tota } \\ \mathbf{1 4} & 2 & 3 & 9 & 14 & 7 & 21 & 28 \\ \mathbf{2} & 0 & 0 & 2 & 2 & 0 & 4 & 4 \\ \mathbf{2} & 0 & 0 & 0 & 0 & 0 & 0 & 0 \\ \mathbf{4} & 0 & 1 & 3 & 4 & 1 & 7 & 8\end{array}$

$\begin{array}{lllll}27 & 1 & 4 & 22 & 27\end{array}$

$\begin{array}{lllll}40 & 1 & 14 & 24 & 39\end{array}$

$\begin{array}{lllll}12 & 1 & 4 & 6 & 11\end{array}$

$\begin{array}{lllll}17 & 1 & 6 & 10 & 17\end{array}$

$\begin{array}{lllll}39 & 1 & 9 & 26 & 36\end{array}$

$\begin{array}{lllll}2 & 0 & 1 & 1 & 2\end{array}$

$\begin{array}{lllll}8 & 0 & 1 & 7 & 8\end{array}$

$\begin{array}{lllll}27 & 0 & 7 & 20 & 27\end{array}$

$\begin{array}{lllll}1 & 0 & 0 & 1 & 1\end{array}$

Controles

CC CT TT Total C T total Pgen/Palelo

$\begin{array}{lllllll}11 & 109 & 324 & 444 & 131 & 757 & 888\end{array}$

$\begin{array}{lllllll}12 & 118 & 347 & 477 & 142 & 812 & 954\end{array}$

$\begin{array}{llll}12 & 118 & 348 & 478\end{array}$

$\begin{array}{llll}12 & 118 & 346 & 476\end{array}$

$142 \quad 814 \quad 956$

$142 \quad 810 \quad 952$

$\begin{array}{llll}11 & 109 & 324 & 444\end{array}$

$\begin{array}{lll}131 & 757 \quad 888\end{array}$

$\begin{array}{lll}131 & 757 & 888\end{array}$

$142 \quad 812954$

$142 \quad 814 \quad 956$

$\begin{array}{lll}131 & 757 \quad 888\end{array}$

$142 \quad 812 \quad 954$

$142814 \quad 956$

$\begin{array}{lll}131 & 757 \quad 888\end{array}$

$142 \quad 814 \quad 956$

$0.03 / 0.13$

$---/---$

$---/---$

$0.90 / 0.84$

$0.49 / 0.46$

$0.29 / 0.17$

$0.24 / 0.10$

$0.38 / 0.16$

$0.99 / 0.90$

$0.68 / 0.57$

$0.57 / 0.33$

$0.51 / 0.71$

$---/---$

\section{n CC CT TT Total}

$\begin{array}{ccccc}14 & 5 & 5 & 4 & 14 \\ 2 & 0 & 2 & 0 & 2 \\ 2 & 0 & 0 & 0 & 0 \\ 4 & 2 & 1 & 1 & 4\end{array}$

$\begin{array}{lllll}27 & 6 & 16 & 5 & 27\end{array}$

$\begin{array}{lllll}40 & 9 & 20 & 12 & 41\end{array}$

$\begin{array}{lllll}12 & 2 & 9 & 0 & 11\end{array}$

$\begin{array}{lllll}17 & 3 & 10 & 4 & 17\end{array}$

$\begin{array}{lllll}39 & 12 & 18 & 7 & 37\end{array}$

$\begin{array}{lllll}2 & 2 & 0 & 0 & 2\end{array}$

$\begin{array}{lllll}8 & 6 & 1 & 1 & 8\end{array}$

$\begin{array}{lllll}27 & 8 & 14 & 5 & 27\end{array}$

48

$\begin{array}{ccc}\mathbf{C} & \mathbf{T} & \text { total } \\ & & \\ 15 & 13 & 28 \\ 2 & 2 & 4 \\ 0 & 0 & 0 \\ 5 & 3 & 8 \\ & & \\ 28 & 26 & 54 \\ 38 & 44 & 82 \\ 13 & 9 & 22 \\ 16 & 18 & 34 \\ & & \\ 42 & 32 & 74 \\ 4 & 0 & 4 \\ 13 & 3 & 16 \\ 30 & 24 & 54 \\ 0 & 2 & 2\end{array}$

Controles

$\begin{array}{llllll}\text { CC CT TT Total C } & \mathrm{T} \text { total Pgen/Palelo }\end{array}$

$\begin{array}{lllllll}152 & 210 & 84 & 446 & 514 & 378 & 892\end{array}$

$\begin{array}{lllllll}168 & 223 & 88 & 479 & 559 & 399 & 958\end{array}$

$\begin{array}{lllllll}168 & 224 & 88 & 480 & 560 & 400 & 960\end{array}$

$\begin{array}{llll}168 & 222 & 88 & 478\end{array}$

$\begin{array}{llll}152 & 210 & 84 & 446\end{array}$

$\begin{array}{llll}152 & 210 & 84 & 446\end{array}$

$\begin{array}{llll}168 & 223 & 88 & 479\end{array}$

$\begin{array}{llll}168 & 224 & 88 & 480\end{array}$

$\begin{array}{llll}152 & 210 & 84 & 446\end{array}$

$\begin{array}{llll}168 & 223 & 88 & 479\end{array}$

$\begin{array}{llll}168 & 224 & 88 & 480\end{array}$

$\begin{array}{llll}152 & 210 & 84 & 446\end{array}$

$\begin{array}{llll}168 & 224 & 88 & 480\end{array}$
$0.58 / 0.66$

$---/--$

$---/--$

$0.69 / 0.81$

$0.39 / 0.40$

$0.15 / 0.04$

$0.02 / 0.96$

$0.33 / 0.19$

$0.97 / 0.88$

$---1--$

$0.05 / 0.06$

$\begin{array}{llll}514 & 378 & 892 & 0.87 / 0.76\end{array}$

$560400 \quad 960$ 
Novos subfenotipos propostos

FP total com agenesia

FP completa com retencao de dentes permanentes

FP completa com multiplas anomalias

FP incompleta com giroversao/lateroversao

FL/P direita com agenesia

FL/P esquerda com agenesia

FL/P esquerda com microdontia ou supranumerario

FL/P esquerda com multiplas anomalias

FL/P bilateral com agenesia

FL/P bilateral com supranumerario

FL/P bilateral com multiplas anomalias

FL/P bilateral frustro

FL/P bilateral frustro com multiplas anomalias

\section{rs2073487 caucasianos}

Novos subfenotipos propostos

FP total com agenesia

FP completa com retencao de dentes permanentes

FP completa com multiplas anomalias

FP incompleta com giroversao/lateroversao

FL/P direita com agenesia

FL/P esquerda com agenesia

FL/P esquerda com microdontia ou supranumerario

FL/P esquerda com multiplas anomalias

FL/P bilateral com agenesia

FL/P bilateral com supranumerario

FL/P bilateral com multiplas anomalias

FL/P bilateral frustro

FL/P bilateral frustro com multiplas anomalias
Fissurados

$\begin{array}{cccccccc}\mathbf{n} & \mathbf{C C} & \mathbf{C T} & \mathbf{T T} & \text { Total } & \mathbf{C} & \mathbf{T} & \text { total } \\ \mathbf{1 2} & 2 & 6 & 4 & 12 & 10 & 14 & 24 \\ \mathbf{2} & 2 & 0 & 0 & 2 & 4 & 0 & 4 \\ \mathbf{0} & 0 & 0 & 0 & 0 & 0 & 0 & 0 \\ \mathbf{4} & 0 & 2 & 2 & 4 & 2 & 6 & 8\end{array}$

$\begin{array}{lllll}36 & 3 & 17 & 15 & 35\end{array}$

$\begin{array}{lllll}9 & 0 & 2 & 6 & 8\end{array}$

$\begin{array}{lllll}14 & 1 & 4 & 9 & 14\end{array}$

$\begin{array}{lllll}34 & 4 & 12 & 15 & 31\end{array}$

$\begin{array}{lllll}2 & 0 & 2 & 0 & 2\end{array}$

$\begin{array}{lllll}6 & 1 & 3 & 2 & 6\end{array}$

$\begin{array}{lllll}22 & 3 & 13 & 6 & 22\end{array}$

$\begin{array}{llllllll}1 & 0 & 0 & 1 & 1 & 0 & 2 & 2\end{array}$ $\begin{array}{lllll}24 & 3 & 11 & 9 & 23\end{array}$

\section{Controles}

$\begin{array}{llllll}\text { CC CT TT Total C } & \text { T total Pgen/Palelo }\end{array}$

$\begin{array}{llll}40 & 117 & 99 & 256\end{array}$

$\begin{array}{llll}43 & 129 & 105 & 277\end{array}$

$\begin{array}{cccccccc}\mathbf{n} & \mathbf{C C} & \mathbf{C T} & \mathbf{T T} & \text { Total } & \mathbf{C} & \mathbf{T} & \text { total } \\ \mathbf{1 2} & 2 & 6 & 3 & 11 & 10 & 12 & 22 \\ \mathbf{2} & 2 & 0 & 0 & 2 & 4 & 0 & 4 \\ \mathbf{0} & 0 & 0 & 0 & 0 & 0 & 0 & 0 \\ \mathbf{4} & 0 & 2 & 1 & 3 & 2 & 4 & 6 \\ & & & & & & & \\ \mathbf{2 4} & 3 & 11 & 9 & 23 & 17 & 29 & 46 \\ \mathbf{3 6} & 3 & 17 & 15 & 35 & 23 & 47 & 70 \\ \mathbf{9} & 0 & 1 & 0 & 1 & 1 & 1 & 2 \\ \mathbf{1 4} & 1 & 4 & 9 & 14 & 6 & 22 & 28 \\ & & & & & & & \\ \mathbf{3 4} & 4 & 12 & 16 & 32 & 20 & 44 & 64 \\ \mathbf{2} & 0 & 2 & 0 & 2 & 2 & 2 & 4 \\ \mathbf{6} & 1 & 3 & 2 & 6 & 5 & 7 & 12 \\ \mathbf{2 2} & 3 & 13 & 6 & 22 & 19 & 25 & 44 \\ \mathbf{1} & 0 & 0 & 1 & 1 & 0 & 2 & 2\end{array}$

$\begin{array}{llll}43 & 129 & 106 & 278\end{array}$

$\begin{array}{llll}43 & 130 & 106 & 279\end{array}$

$\begin{array}{lll}197 & 315 & 512\end{array}$

$215 \quad 341 \quad 556$

$216 \quad 342 \quad 558$

$215 \quad 339 \quad 554$

$\begin{array}{lll}197 & 315 & 512\end{array}$

$\begin{array}{lll}197 & 315 & 512\end{array}$

$216 \quad 340 \quad 556$

$216 \quad 342 \quad 558$

$\begin{array}{lll}197 & 315 & 512\end{array}$

$216 \quad 340 \quad 556$

$\begin{array}{lll}216 & 342 \quad 558\end{array}$

$\begin{array}{lll}197 & 315 & 512\end{array}$

$216 \quad 342 \quad 558$

Controles

$0.93 / 0.75$

$0.002 / 0.003$

$---/---$

$0.49 / 0.42$

$0.94 / 0.83$

$0.54 / 0.36$

$0.04 / 0.03$

$0.14 / 0.06$

$0.57 / 0.34$

$0.19 / 0.64$

$0.97 / 0.83$

$0.46 / 0.53$

---/---

\begin{tabular}{|c|c|c|c|c|c|c|c|}
\hline \multirow{2}{*}{ CC } & \multicolumn{5}{|c|}{ Controles } & \multirow[b]{2}{*}{ total } & \multirow[b]{2}{*}{ Pgen/Palel } \\
\hline & CT & TT & Total & C & $\mathbf{T}$ & & \\
\hline 41 & 117 & 98 & 256 & 199 & 313 & 512 & $0.76 / 0.53$ \\
\hline 44 & 129 & 105 & 278 & 217 & 339 & 556 & ---/--- \\
\hline 44 & 130 & 105 & 279 & 218 & 340 & 558 & ---/--- \\
\hline 44 & 129 & 104 & 277 & 217 & 337 & 554 & $0.54 / 0.77$ \\
\hline 41 & 117 & 98 & 256 & 199 & 313 & 512 & $0.93 / 0.79$ \\
\hline 41 & 117 & 98 & 256 & 199 & 313 & 512 & $0.50 / 0.33$ \\
\hline 44 & 130 & 104 & 278 & 218 & 338 & 556 & $0.43 / 0.75$ \\
\hline 44 & 130 & 105 & 279 & 218 & 340 & 558 & $0.13 / 0.06$ \\
\hline 41 & 117 & 98 & 256 & 199 & 313 & 512 & $0.44 / 0.23$ \\
\hline 44 & 130 & 104 & 278 & 218 & 338 & 556 & $0.19 / 0.65$ \\
\hline 44 & 130 & 105 & 279 & 218 & 340 & 558 & $0.97 / 0.85$ \\
\hline 41 & 117 & 98 & 256 & 199 & 313 & 512 & $0.47 / 0.57$ \\
\hline 44 & 130 & 105 & 279 & 218 & 340 & 558 & $0.32 / 0.15$ \\
\hline
\end{tabular}


Fissurados

Novos subfenotipos propostos

FP total com agenesia

FP completa com retencao de dentes permanentes

FP completa com multiplas anomalias

FP incompleta com giroversao/lateroversao

FL/P direita com agenesia

FL/P esquerda com agenesia

FL/P esquerda com microdontia ou supranumerario

FL/P esquerda com multiplas anomalias

FL/P bilateral com agenesia

FL/P bilateral com supranumerario

FL/P bilateral com multiplas anomalias

FL/P bilateral frustro

FL/P bilateral frustro com multiplas anomalias

\section{rs4844880 caucasianos}

Novos subfenotipos propostos

FP total com agenesia

FP completa com retencao de dentes permanentes

FP completa com multiplas anomalias

FP incompleta com giroversao/lateroversao

FL/P direita com agenesia

FL/P esquerda com agenesia

FL/P esquerda com microdontia ou supranumerario

FL/P esquerda com multiplas anomalias

FL/P bilateral com agenesia

FL/P bilateral com supranumerario

FL/P bilateral com multiplas anomalias

FL/P bilateral frustro

FL/P bilateral frustro com multiplas anomalias

\section{n CC CT TT Total}

$\begin{array}{lll}\mathbf{2} & 0 & 1 \\ \mathbf{0} & 0 & 0 \\ \mathbf{4} & 2 & 1\end{array}$

$\begin{array}{lllll}24 & 21 & 1 & 1 & 23\end{array}$

$\begin{array}{lllll}36 & 33 & 2 & 0 & 35\end{array}$

$\begin{array}{lllll}9 & 7 & 1 & 0 & 8\end{array}$

$\begin{array}{lllll}14 & 14 & 0 & 0 & 14\end{array}$

$\begin{array}{lllll}34 & 29 & 3 & 0 & 32\end{array}$

$\begin{array}{lllll}2 & 2 & 0 & 0 & 2\end{array}$

$\begin{array}{lllll}6 & 6 & 0 & 0 & 6\end{array}$

$\begin{array}{lllll}22 & 21 & 0 & 1 & 22\end{array}$ c

$\mathrm{T}$ total

\section{Fissurados}

\section{n AA AG GG Total}

\section{A}

$\begin{array}{cccccccc}12 & 0 & 5 & 7 & 12 & 5 & 19 & 24 \\ 2 & 0 & 1 & 1 & 2 & 1 & 3 & 4 \\ \mathbf{0} & 0 & 0 & 0 & 0 & 0 & 0 & 0 \\ 4 & 0 & 3 & 1 & 4 & 3 & 5 & 8\end{array}$

$\begin{array}{llllllll}24 & 0 & 9 & 15 & 24 & 9 & 39 & 48\end{array}$

$\begin{array}{llllllll}36 & 3 & 11 & 22 & 36 & 17 & 55 & 72\end{array}$

$\begin{array}{lllll}9 & 1 & 4 & 4 & 9\end{array}$

$\begin{array}{lllll}14 & 1 & 4 & 9 & 14\end{array}$

$\begin{array}{cccccccc}\mathbf{3 4} & 3 & 13 & 18 & 34 & 19 & 49 & 68 \\ \mathbf{2} & 0 & 1 & 1 & 2 & 1 & 3 & 4 \\ \mathbf{6} & 0 & 3 & 3 & 6 & 3 & 9 & 12 \\ \mathbf{2 2} & 1 & 5 & 16 & 22 & 7 & 37 & 44 \\ \mathbf{1} & 0 & 0 & 1 & 1 & 0 & 2 & 2\end{array}$

\section{Controles}

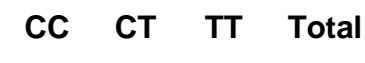

C $\mathbf{T}$ total

Pgen/Palelo

$\begin{array}{lllllll}228 & 25 & 2 & 255 & 481 & 29 & 510\end{array}$

$\begin{array}{lllllll}248 & 27 & 2 & 277 & 523 & 31 & 554\end{array}$

$\begin{array}{lllllll}249 & 27 & 2 & 278 & 525 & 31 & 556\end{array}$

$\begin{array}{lllllll}247 & 27 & 2 & 276 & 521 & 31 & 552\end{array}$

$0.16 / 0.12$

$0.00001 \dagger$

$---/---$

$0.39 / 0.24$

\section{$\begin{array}{llll}228 & 25 & 2 & 255\end{array}$}

$\begin{array}{llll}228 & 25 & 2 & 255\end{array}$

$\begin{array}{llll}248 & 27 & 2 & 277\end{array}$

$\begin{array}{llll}249 & 27 & 2 & 278\end{array}$

$\begin{array}{lll}481 & 29 & 510\end{array}$

$481 \quad 29 \quad 510$

$523 \quad 31 \quad 554$

$525 \quad 31 \quad 556$

$0.20 / 0.81$

$0.56 / 0.32$

$0.91 \dagger$

$0.22 / 0.07$

$0.78 / 0.74$

---/---

$0.51 / 0.24$

$0.03 / 0.75$

$---/--$

\section{Controles}

\section{AA AG GG Total}

A G total

Pgen/Palelo

$\begin{array}{lllllll}14 & 87 & 158 & 259 & 115 & 403 & 518 \\ 16 & 91 & 174 & 281 & 123 & 439 & 562 \\ 16 & 92 & 174 & 282 & 124 & 440 & 564 \\ 15 & 92 & 173 & 280 & 122 & 438 & 560\end{array}$

$0.47 / 0.87$

$0.79 / 0.88$

$---/--$

$0.18 / 0.28$

$0.27 / 0.58$

$0.75 / 0.78$

$0.53 / 0.25$

$0.93 / 0.94$

$0.57 / 0.28$

$0.79 / 0.88$

$0.51 / 0.80$

$0.54 / 0.33$

---/--- 


\section{Novos subfenotipos propostos}

FP total com agenesia

FP completa com retencao de dentes permanentes

FP completa com multiplas anomalias

FP incompleta com giroversao/lateroversao

FL/P direita com agenesia

FL/P esquerda com agenesia

FL/P esquerda com microdontia ou supranumerario

FL/P esquerda com multiplas anomalias

FL/P bilateral com agenesia

FL/P bilateral com supranumerario

FL/P bilateral com multiplas anomalias

FL/P bilateral frustro

FL/P bilateral frustro com multiplas anomalias

\section{rs861019 caucasianos}

Novos subfenotipos propostos

FP total com agenesia

FP completa com retencao de dentes permanentes

FP completa com multiplas anomalias

FP incompleta com giroversao/lateroversao

FL/P direita com agenesia

FL/P esquerda com agenesia

FL/P esquerda com microdontia ou supranumerario

FL/P esquerda com multiplas anomalias

FL/P bilateral com agenesia

FL/P bilateral com supranumerario

FL/P bilateral com multiplas anomalias

FL/P bilateral frustro

FL/P bilateral frustro com multiplas anomalias
Fissurados

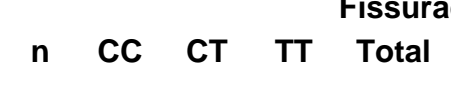

C

$\begin{array}{llllllll}12 & 2 & 3 & 5 & 10 & 7 & 13 & 20\end{array}$

200012

0

4

$\begin{array}{lllll}24 & 1 & 3 & 20 & 24\end{array}$

$\begin{array}{lllll}36 & 0 & 13 & 22 & 35\end{array}$

$\begin{array}{lllll}9 & 0 & 3 & 5 & 8\end{array}$

$\begin{array}{lllll}14 & 0 & 5 & 9 & 14\end{array}$

$\begin{array}{lllll}34 & 1 & 9 & 21 & 31\end{array}$

$\begin{array}{lllll}2 & 0 & 1 & 1 & 2\end{array}$

$\begin{array}{lllll}6 & 0 & 1 & 5 & 6\end{array}$

$\begin{array}{lllll}22 & 0 & 5 & 17 & 22\end{array}$

$\begin{array}{lllll}1 & 0 & 0 & 1 & 1\end{array}$
Controles

$\begin{array}{cccc}\text { CC } & \text { CT } & \text { TT } & \text { Total } \\ & & & \\ 5 & 65 & 185 & 255 \\ 5 & 73 & 199 & 277 \\ 5 & 73 & 200 & 278 \\ 5 & 73 & 198 & 276 \\ & & & \\ 5 & 65 & 185 & 255 \\ 5 & 65 & 185 & 255 \\ 5 & 73 & 199 & 277 \\ 5 & 73 & 200 & 278 \\ & & & \\ 5 & 65 & 185 & 255 \\ 5 & 73 & 199 & 277 \\ 5 & 73 & 200 & 278 \\ 5 & 65 & 185 & 255 \\ 5 & 73 & 200 & 278\end{array}$

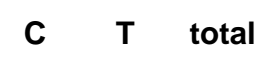

$\begin{array}{lll}75 & 435 \quad 510\end{array}$

$\begin{array}{lll}83 & 471 & 554\end{array}$

$83 \quad 473 \quad 556$

$83 \quad 469 \quad 552$

$\begin{array}{lll}75 & 435 & 510\end{array}$

$\begin{array}{lll}75 & 435 & 510\end{array}$

$\begin{array}{lll}83 & 471 & 554\end{array}$

$83 \quad 473 \quad 556$

$\begin{array}{lll}75 & 435 & 510\end{array}$

$\begin{array}{lll}83 & 471 \quad 554\end{array}$

$83473 \quad 556$

$\begin{array}{lll}83 & 473 & 556 \\ 75 & 435 & 510\end{array}$

$83 \quad 473 \quad 556$
Pgen/Palelo

$0.001 / 0.01$

$---/--$

$0.92 / 0.84$

$0.30 / 0.41$

$0.19 / 0.39$

$0.69 / 0.67$

$0.59 / 0.67$

$0.80 / 0.52$

$0.73 / 0.57$

$0.76 / 0.52$

$0.62 / 0.54$

$---/---$

\section{Controles}

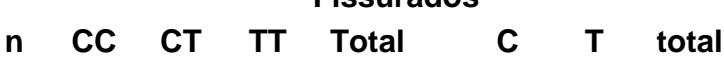

CC CT TT Total

C $\quad \mathrm{T}$ total

Pgen/Palelo

$\begin{array}{cccccccc}\mathbf{1 2} & 5 & 3 & 4 & 12 & 13 & 11 & 24 \\ \mathbf{2} & 2 & 0 & 0 & 2 & 4 & 0 & 4 \\ \mathbf{0} & 0 & 0 & 0 & 0 & 0 & 0 & 0 \\ \mathbf{4} & 2 & 1 & 1 & 4 & 5 & 3 & 8 \\ & & & & & & & \\ \mathbf{2 4} & 5 & 14 & 5 & 24 & 24 & 24 & 48 \\ \mathbf{3 6} & 7 & 18 & 10 & 35 & 32 & 38 & 70 \\ \mathbf{9} & 1 & 7 & 0 & 8 & 9 & 7 & 16 \\ \mathbf{1 4} & 2 & 8 & 4 & 14 & 12 & 16 & 28\end{array}$

$\begin{array}{llll}72 & 128 & 57 & 257\end{array}$

$\begin{array}{lll}272 & 242 \quad 514\end{array}$

$302 \quad 256 \quad 558$

$303 \quad 257 \quad 560$

$301 \quad 255 \quad 556$

$\begin{array}{llll}82 & 137 & 59 & 278\end{array}$

$\begin{array}{lll}272 & 242 \quad 514\end{array}$

$\begin{array}{lll}272 & 242 \quad 514\end{array}$

$302 \quad 256 \quad 558$

$303 \quad 257 \quad 560$

$\begin{array}{lll}272 & 242 \quad 514\end{array}$

$302 \quad 256 \quad 558$

$\begin{array}{lll}303 & 257 \quad 560\end{array}$

$\begin{array}{lll}272 & 242 \quad 514\end{array}$

$\begin{array}{lll}303 & 257 \quad 560\end{array}$
$0.24 / 0.90$

$---/--$

$---/---$

$0.58 / 0.63$

$0.67 / 0.69$

$0.10 / 0.25$

$0.04 / 0.86$

$0.46 / 0.24$

$0.29 / 0.35$

---/---

$0.12 / 0.15$

$0.86 / 0.70$

------- 
Novos subfenotipos propostos

FP total com agenesia

FP completa com retencao de dentes permanentes

FP completa com multiplas anomalias

FP incompleta com giroversao/lateroversao

FL/P direita com agenesia

FL/P esquerda com agenesia

FL/P esquerda com microdontia ou supranumerario

FL/P esquerda com multiplas anomalias

FL/P bilateral com agenesia

FL/P bilateral com supranumerario

FL/P bilateral com multiplas anomalias

FL/P bilateral frustro

FL/P bilateral frustro com multiplas anomalias

\section{rs1171105}

Novos subfenotipos propostos

FP total com agenesia

FP completa com retencao de dentes permanentes

FP completa com multiplas anomalias

FP incompleta com giroversao/lateroversao

FL/P direita com agenesia

FL/P esquerda com agenesia

FL/P esquerda com microdontia ou supranumerario

FL/P esquerda com multiplas anomalias

FL/P bilateral com agenesia

FL/P bilateral com supranumerario

FL/P bilateral com multiplas anomalias

FL/P bilateral frustro

FL/P bilateral frustro com multiplas anomalias
Fissurados

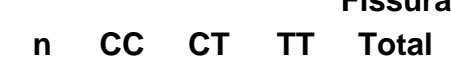

CC CT TT Total

C $\mathrm{T}$ total

$\begin{array}{lll}735 & 157 & 892\end{array}$

$\begin{array}{lll}784 & 174 & 958\end{array}$

$\begin{array}{lll}786 & 174 & 960\end{array}$

$\begin{array}{lll}783 & 173 \quad 956\end{array}$

322142

$\begin{array}{lll}735 & 157 & 892\end{array}$

$\begin{array}{lll}735 & 157 & 892\end{array}$

$\begin{array}{lll}786 & 172 & 958\end{array}$

$\begin{array}{lll}786 & 174 \quad 960\end{array}$

$\begin{array}{llll}322 & 142 & 15 & 479\end{array}$

$\begin{array}{llll}322 & 142 & 16 & 480\end{array}$

$\begin{array}{llll}304 & 127 & 15 & 446\end{array}$

$\begin{array}{llll}322 & 142 & 15 & 479\end{array}$

$\begin{array}{llll}322 & 142 & 16 & 480\end{array}$

$\begin{array}{llll}304 & 127 & 15 & 446\end{array}$

$\begin{array}{llll}322 & 142 & 16 & 480\end{array}$
C $\mathbf{T}$ total

$\begin{array}{llll}321 & 141 & 16 & 478\end{array}$ $\begin{array}{lll}735 & 157 \quad 892\end{array}$

$\begin{array}{lll}786 & 172 & 958\end{array}$

$\begin{array}{lll}786 & 174 & 960\end{array}$

$\begin{array}{lll}735 & 157 & 892\end{array}$

$\begin{array}{lll}786 & 174 \quad 960\end{array}$
Pgen/Palelo

$0.07 / 0.04$

$------$

$---/--$

$0.06 / 0.15$

$0.12 / 0.22$

$0.23 / 0.10$

$0.55 / 0.37$

$0.52 / 0.94$

$0.05 / 0.03$

$0.78 / 0.71$

$0.25 / 0.87$

$0.17 / 0.05$

$---/---$

\section{Controles}

$\begin{array}{ccccc}\mathbf{1 4} & 7 & 6 & 1 & 1 \\ \mathbf{2} & 2 & 0 & 0 & 2 \\ \mathbf{2} & 1 & 2 & 1 & 4 \\ \mathbf{4} & 0 & 3 & 1 & 4 \\ & & & & \\ \mathbf{2 7} & 15 & 8 & 4 & 27 \\ \mathbf{4 0} & 13 & 21 & 6 & 40 \\ \mathbf{1 2} & 5 & 4 & 3 & 12 \\ \mathbf{1 7} & 5 & 8 & 4 & 17 \\ & & & & \\ \mathbf{3 9} & 19 & 13 & 5 & 37 \\ \mathbf{2} & 0 & 2 & 0 & 2 \\ \mathbf{8} & 3 & 4 & 1 & 8 \\ \mathbf{2 7} & 12 & 11 & 4 & 27 \\ \mathbf{1} & 1 & 0 & 0 & 1\end{array}$

\section{CT TT Total}

$\begin{array}{llll}183 & 206 & 58 & 447\end{array}$

$\begin{array}{llll}197 & 220 & 63 & 480\end{array}$

$\begin{array}{llll}197 & 221 & 63 & 481\end{array}$

$\begin{array}{llll}197 & 220 & 63 & 480\end{array}$

$\begin{array}{llll}183 & 206 & 58 & 447\end{array}$

$\begin{array}{llll}183 & 206 & 58 & 447\end{array}$

$\begin{array}{llll}197 & 221 & 62 & 480\end{array}$

$\begin{array}{llll}197 & 221 & 63 & 481\end{array}$

$\begin{array}{llll}197 & 221 & 62 & 480\end{array}$

$\begin{array}{llll}197 & 221 & 63 & 481\end{array}$

$\begin{array}{llll}183 & 206 & 58 & 447\end{array}$

$\begin{array}{llll}197 & 221 & 63 & 481\end{array}$ $\begin{array}{llll}183 & 206 & 58 & 447\end{array}$

\section{C $\mathrm{T}$ total}

$572 \quad 322 \quad 894$

$\begin{array}{lll}614 & 346 \quad 960\end{array}$

$\begin{array}{lll}615 & 347 & 962\end{array}$

$614346 \quad 960$

$\begin{array}{lll}572 & 322 \quad 894\end{array}$

$\begin{array}{lll}572 & 322 & 894\end{array}$

$\begin{array}{lll}615 & 345 \quad 960\end{array}$

$\begin{array}{lll}615 & 347 \quad 962\end{array}$

$\begin{array}{lll}572 & 322 & 894\end{array}$

$\begin{array}{lll}615 & 345 \quad 960\end{array}$

$\begin{array}{lll}615 & 347 & 962\end{array}$

$\begin{array}{lll}572 & 322 & 894\end{array}$

$\begin{array}{lll}615 & 347 \quad 962\end{array}$
Pgen/Palelo

$0.71 / 0.41$

$---/---$

$0.70 / 0.41$

$0.10 / 0.12$

$0.23 / 0.34$

$0.58 / 0.35$

$0.42 / 0.56$

$0.39 / 0.19$

$0.40 / 0.39$

$---/ 0.55$

$0.97 / 0.90$

$0.86 / 0.90$ 
Novos subfenotipos propostos

FP total com agenesia

FP completa com retencao de dentes permanentes

FP completa com multiplas anomalias

FP incompleta com giroversao/lateroversao

FL/P direita com agenesia

FL/P esquerda com agenesia

FL/P esquerda com microdontia ou supranumerario

FL/P esquerda com multiplas anomalias

FL/P bilateral com agenesia

FL/P bilateral com supranumerario

FL/P bilateral com multiplas anomalias

FL/P bilateral frustro

FL/P bilateral frustro com multiplas anomalias

\section{rs1325469}

Novos subfenotipos propostos

FP total com agenesia

FP completa com retencao de dentes permanentes

FP completa com multiplas anomalias

FP incompleta com giroversao/lateroversao

FL/P direita com agenesia

FL/P esquerda com agenesia

FL/P esquerda com microdontia ou supranumerario

FL/P esquerda com multiplas anomalias

FL/P bilateral com agenesia

FL/P bilateral com supranumerario

FL/P bilateral com multiplas anomalias

FL/P bilateral frustro

FL/P bilateral frustro com multiplas anomalias

\section{Fissurados}

n CC CT TT Total C

$\begin{array}{lllllllll}\text { CT } & T & \text { Total } & C & T & \text { total } & \text { CC } & \text { CT } & \text { TT Total }\end{array}$

$\begin{array}{lllll}27 & 13 & 10 & 4 & 27\end{array}$

$\begin{array}{lllll}40 & 17 & 18 & 5 & 40\end{array}$

$\begin{array}{lllll}12 & 5 & 4 & 3 & 12\end{array}$

$\begin{array}{lllll}17 & 5 & 8 & 4 & 17\end{array}$

$\begin{array}{llllllll}39 & 12 & 19 & 7 & 38 & 43 & 33 & 76\end{array}$

$\begin{array}{llllllll}2 & 1 & 1 & 0 & 2 & 3 & 1 & 4\end{array}$

$\begin{array}{llllllll}8 & 5 & 1 & 2 & 8 & 11 & 5 & 16\end{array}$

$\begin{array}{llllllll}27 & 11 & 9 & 7 & 27 & 31 & 23 & 54\end{array}$

\section{Fissurados}

\section{n AA AG GG Total}

$\begin{array}{llllllll}14 & 11 & 2 & 0 & 13 & 24 & 2 & 26\end{array}$

$\begin{array}{llllllll}2 & 2 & 0 & 0 & 2 & 4 & 0 & 4\end{array}$

200000

$\begin{array}{lllll}4 & 3 & 0 & 0 & 3\end{array}$

$\begin{array}{lllll}27 & 16 & 8 & 2 & 26\end{array}$

$\begin{array}{lllll}40 & 26 & 13 & 0 & 39\end{array}$

$\begin{array}{lllll}12 & 4 & 6 & 1 & 11\end{array}$

$\begin{array}{lllll}17 & 10 & 7 & 0 & 17\end{array}$

$\begin{array}{ccccc}39 & 29 & 8 & 0 & 37 \\ \mathbf{2} & 0 & 2 & 0 & 2 \\ \mathbf{8} & 5 & 3 & 0 & 8 \\ \mathbf{2 7} & 19 & 7 & 0 & 26 \\ \mathbf{1} & 1 & 0 & 0 & 1\end{array}$

$\begin{array}{llll}191 & 213 & 43 & 447\end{array}$

$\begin{array}{llll}213 & 220 & 47 & 480\end{array}$

$\begin{array}{llll}213 & 221 & 47 & 481\end{array}$

$\begin{array}{llll}213 & 219 & 47 & 479\end{array}$

$\begin{array}{llll}191 & 213 & 43 & 447\end{array}$

$\begin{array}{llll}191 & 213 & 43 & 447\end{array}$

$\begin{array}{llll}212 & 221 & 47 & 480\end{array}$

$\begin{array}{llll}213 & 221 & 47 & 481\end{array}$

$\begin{array}{llll}212 & 221 & 47 & 480\end{array}$

$\begin{array}{llll}213 & 221 & 47 & 481\end{array}$

$\begin{array}{llll}191 & 213 & 43 & 447\end{array}$

$\begin{array}{llll}213 & 221 & 47 & 481\end{array}$ $\begin{array}{llll}191 & 213 & 43 & 447\end{array}$
C $\mathbf{T}$ total Pgen/Palelo

$595 \quad 299 \quad 894$

$\begin{array}{lll}646 \quad 314 & 960\end{array}$

$\begin{array}{lll}647 & 315 & 962\end{array}$

$\begin{array}{lll}645 & 313 & 958\end{array}$

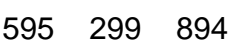

$\begin{array}{lll}595 & 299 & 894\end{array}$

$\begin{array}{lll}645 & 315 & 960\end{array}$

$647 \quad 315 \quad 962$

$\begin{array}{lll}595 & 299 & 894\end{array}$

$645315 \quad 960$

$595 \quad 299 \quad 894$

$647 \quad 315 \quad 962$

$0.90 \dagger$

$---/ 0.46$

$---/--$

$0.62 / 0.97$

$0.47 / 0.98$

$0.83 / 0.77$

$0.21 / 0.36$

$0.14 / 0.08$

$0.15 / 0.07$

$0.81 / 0.73$

$0.11 / 0.89$

$0.02 / 0.16$

---/--- $\begin{array}{lll}647 & 315 & 962\end{array}$

\section{Controles}

$\begin{array}{cccccccc}\text { AA } & \text { AG } & \text { GG } & \text { Total } & \text { A } & \text { G } & \text { total } & \text { Pgen/Palelo } \\ 304 & 125 & 18 & 447 & 733 & 161 & 894 & 0.32 / 0.17 \\ 323 & 135 & 22 & 480 & 781 & 179 & 960 & ---/-- \\ 324 & 135 & 22 & 481 & 783 & 179 & 962 & ---/-- \\ 322 & 135 & 22 & 479 & 779 & 179 & 958 & ---/--\end{array}$

$0.60 / 0.35$

$0.18 / 0.76$

$0.09 / 0.03$

$0.25 / 0.77$

$\begin{array}{lllllll}324 & 135 & 21 & 480 & 783 & 177 & 960\end{array}$

$\begin{array}{lll}783 & 179 & 962\end{array}$

$0.14 / 0.11$

$\begin{array}{llll}304 & 125 & 18 & 447\end{array}$

$\begin{array}{llll}324 & 135 & 21 & 480\end{array}$

$\begin{array}{llll}324 & 135 & 22 & 481\end{array}$

$\begin{array}{llll}304 & 125 & 18 & 447\end{array}$

$\begin{array}{lll}733 & 161 & 894\end{array}$

$\begin{array}{lll}783 & 177 & 960\end{array}$

$---/ 0.10$

$0.60 / 0.98$

$0.34 / 0.40$ 
Novos subfenotipos propostos

FP total com agenesia

FP completa com retencao de dentes permanentes

FP completa com multiplas anomalias

FP incompleta com giroversao/lateroversao

FL/P direita com agenesia

FL/P esquerda com agenesia

FL/P esquerda com microdontia ou supranumerario

FL/P esquerda com multiplas anomalias

FL/P bilateral com agenesia

FL/P bilateral com supranumerario

FL/P bilateral com multiplas anomalias

FL/P bilateral frustro

FL/P bilateral frustro com multiplas anomalias

\section{rs217290}

Novos subfenotipos propostos

FP total com agenesia

FP completa com retencao de dentes permanentes

FP completa com multiplas anomalias

FP incompleta com giroversao/lateroversao

FL/P direita com agenesia

FL/P esquerda com agenesia

FL/P esquerda com microdontia ou supranumerario

FL/P esquerda com multiplas anomalias

FL/P bilateral com agenesia

FL/P bilateral com supranumerario

FL/P bilateral com multiplas anomalias

FL/P bilateral frustro

FL/P bilateral frustro com multiplas anomalias

Fissurados

n AA AG GG Total

A G total

Controles

$\begin{array}{ccccc}14 & 0 & 2 & 11 & 13 \\ 2 & 0 & 0 & 2 & 2 \\ 2 & 0 & 0 & 0 & 0 \\ 4 & 0 & 0 & 3 & 3\end{array}$

2426

A

G total

Pgen/Palelo

$\begin{array}{llll}17 & 119 & 297 & 433\end{array}$

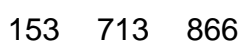

$\begin{array}{lll}169 & 761 \quad 930\end{array}$

$\begin{array}{lll}169 & 763 \quad 932\end{array}$

$169759 \quad 928$

$0.34 / 0.18$

$---/--$

$---/---$

$---/--$

$\begin{array}{ccccc}\mathbf{2 7} & 1 & 8 & 17 & 26 \\ \mathbf{4 0} & 0 & 11 & 28 & 39 \\ \mathbf{1 2} & 1 & 6 & 4 & 11 \\ \mathbf{1 7} & 0 & 6 & 11 & 17 \\ & & & & \\ \mathbf{3 9} & 1 & 7 & 26 & 34 \\ \mathbf{2} & 0 & 2 & 0 & 2 \\ \mathbf{8} & 0 & 3 & 6 & 9 \\ \mathbf{2 7} & 0 & 5 & 21 & 26 \\ \mathbf{1} & 0 & 0 & 1 & 1\end{array}$

$\begin{array}{llll}21 & 127 & 316 & 464\end{array}$

$\begin{array}{lll}153 & 713 \quad 866\end{array}$

$\begin{array}{lll}153 & 713 & 866\end{array}$

$\begin{array}{lll}167 & 763 \quad 930\end{array}$

$\begin{array}{lll}169 & 763 \quad 932\end{array}$

$3 / 0.77$

$0.22 / 0.42$

$0.08 / 0.02$

$0.38 / 0.94$

$0.63 / 0.35$

$---/ 0.09$

$0.62 / 0.87$

$0.20 / 0.13$

$---/--$

Fissurados

n CC CT TT Total

$\begin{array}{ccccc}\mathbf{1 4} & 5 & 9 & 0 & 14 \\ \mathbf{2} & 0 & 2 & 0 & 2 \\ \mathbf{2} & 0 & 0 & 0 & 0 \\ \mathbf{4} & 2 & 2 & 0 & 4 \\ & & & & \\ \mathbf{2 7} & 9 & 11 & 5 & 25 \\ \mathbf{4 0} & 15 & 20 & 5 & 40 \\ \mathbf{1 2} & 5 & 5 & 2 & 12 \\ \mathbf{1 7} & 8 & 8 & 1 & 17 \\ & & & & \\ \mathbf{3 9} & 12 & 21 & 5 & 38 \\ \mathbf{2} & 0 & 2 & 0 & 2 \\ \mathbf{8} & 4 & 3 & 1 & 8 \\ \mathbf{2 7} & 10 & 10 & 6 & 26 \\ \mathbf{1} & 1 & 0 & 0 & 1\end{array}$

\section{Controles}

CC CT TT Total

$\begin{array}{llll}155 & 225 & 66 & 446\end{array}$

$\begin{array}{llll}170 & 238 & 71 & 479\end{array}$

$\begin{array}{llll}170 & 239 & 71 & 480\end{array}$

$\begin{array}{llll}170 & 237 & 71 & 478\end{array}$

$\begin{array}{llll}155 & 225 & 66 & 446\end{array}$

$\begin{array}{llll}155 & 225 & 66 & 446\end{array}$

$\begin{array}{llll}169 & 239 & 71 & 479\end{array}$

$\begin{array}{llll}170 & 239 & 71 & 480\end{array}$

$\begin{array}{llll}155 & 225 & 66 & 446\end{array}$

$\begin{array}{llll}169 & 239 & 71 & 479\end{array}$

$\begin{array}{llll}170 & 239 & 71 & 480\end{array}$

$\begin{array}{llll}155 & 225 & 66 & 446\end{array}$

$\begin{array}{llll}170 & 239 & 71 & 480\end{array}$ $\begin{array}{lll}167 & 763 \quad 930\end{array}$

$\begin{array}{lll}169 & 763 \quad 932\end{array}$

$153713 \quad 866$

$\begin{array}{lll}169 & 763 \quad 932\end{array}$
C T total Pgen/Palelo

$\begin{array}{llll}535 & 357 & 892 & 0.10 / 0.40\end{array}$

$\begin{array}{llll}578 & 380 & 958 & ---/ 0.67\end{array}$

$\begin{array}{llll}579 & 381 & 960 & ---/---\end{array}$

$\begin{array}{llll}577 & 379 & 956 & 0.49 / 0.39\end{array}$

$\begin{array}{llll}535 & 357 & 892 & 0.72 / 0.78\end{array}$

$\begin{array}{llll}535 & 357 & 892 & 0.89 / 0.65\end{array}$

$\begin{array}{llll}577 & 381 & 958 & 0.85 / 0.82\end{array}$

$\begin{array}{llll}579 & 381 & 960 & 0.46 / 0.22\end{array}$

$\begin{array}{llll}535 & 357 & 892 & 0.84 / 0.89\end{array}$

$\begin{array}{lll}577 & 381 & 958\end{array}$

$\begin{array}{lll}579 & 381 \quad 960\end{array}$

$\begin{array}{lll}535 & 357 \quad 892\end{array}$

$579381 \quad 960$

$---/ 0.67$

$0.69 / 0.49$

$0.38 / 0.74$

$---/---$ 


\section{Novos subfenotipos propostos}

FP total com agenesia

FP completa com retencao de dentes permanentes

FP completa com multiplas anomalias

FP incompleta com giroversao/lateroversao

FL/P direita com agenesia

FL/P esquerda com agenesia

FL/P esquerda com microdontia ou supranumerario

FL/P esquerda com multiplas anomalias

FL/P bilateral com agenesia

FL/P bilateral com supranumerario

FL/P bilateral com multiplas anomalias

FL/P bilateral frustro

FL/P bilateral frustro com multiplas anomalias

\section{rs217325}

Novos subfenotipos propostos

FP total com agenesia

FP completa com retencao de dentes permanentes

FP completa com multiplas anomalias

FP incompleta com giroversao/lateroversao

FL/P direita com agenesia

FL/P esquerda com agenesia

FL/P esquerda com microdontia ou supranumerario

FL/P esquerda com multiplas anomalias

FL/P bilateral com agenesia

FL/P bilateral com supranumerario

FL/P bilateral com multiplas anomalias

FL/P bilateral frustro

FL/P bilateral frustro com multiplas anomalias
Fissurados

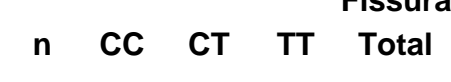

C

total

$\begin{array}{llllllll}14 & 0 & 8 & 5 & 13 & 8 & 18 & 26\end{array}$

200014

2

4

$\begin{array}{cccc}\mathbf{2 7} & 4 & 10 & 12 \\ \mathbf{4 0} & 5 & 20 & 14 \\ \mathbf{1 2} & 3 & 4 & 4 \\ \mathbf{1 7} & 1 & 8 & 8\end{array}$

$\begin{array}{ccccc}\mathbf{3 9} & 5 & 18 & 13 & 36 \\ \mathbf{2} & 0 & 1 & 1 & 2 \\ \mathbf{8} & 1 & 2 & 5 & 8 \\ \mathbf{2 7} & 6 & 9 & 11 & 26 \\ \mathbf{1} & 0 & 0 & 1 & 1\end{array}$

\section{Fissurados}

n CC CG GG Total C G total

$\begin{array}{llllllll}14 & 1 & 5 & 8 & 14 & 7 & 21 & 28\end{array}$

$\begin{array}{lllll}2 & 0 & 2 & 0 & 2\end{array}$

$\begin{array}{lllll}2 & 1 & 1 & 2 & 4\end{array}$

$\begin{array}{lllll}4 & 1 & 2 & 1 & 4\end{array}$

$\begin{array}{ccccc}\mathbf{2 7} & 1 & 9 & 17 & 27 \\ \mathbf{4 0} & 3 & 19 & 18 & 40 \\ \mathbf{1 2} & 1 & 5 & 6 & 12\end{array}$

$\begin{array}{lllll}17 & 0 & 9 & 8 & 17\end{array}$

$\begin{array}{llllllll}39 & 6 & 12 & 21 & 39 & 24 & 54 & 78\end{array}$

$\begin{array}{llllllll}2 & 0 & 2 & 0 & 2 & 2 & 2 & 4\end{array}$

$\begin{array}{llllllll}8 & 1 & 2 & 5 & 8 & 4 & 12 & 16\end{array}$

$\begin{array}{llllllll}27 & 1 & 9 & 17 & 27 & 11 & 43 & 54\end{array}$
Controles

CC CT TT Total

C $\mathrm{T}$ total

Pgen/Palelo

$\begin{array}{llll}61 & 235 & 150 & 446\end{array}$

$\begin{array}{llll}66 & 247 & 166 & 479\end{array}$

$\begin{array}{llll}66 & 248 & 166 & 480\end{array}$

$\begin{array}{lll}357 & 535 \quad 892\end{array}$

$0.15 / 0.34$

$379 \quad 579 \quad 958$

$\begin{array}{lll}380 & 580 & 960\end{array}$

$378 \quad 578 \quad 956$

----/---

$\begin{array}{lll}357 & 535 \quad 892\end{array}$

$\begin{array}{lll}357 & 535 \quad 892\end{array}$

$\begin{array}{lll}380 & 578 \quad 958\end{array}$

$380 \quad 580 \quad 960$

$0.34 / 0.43$

$0.95 / 0.78$

$0.38 / 0.58$

$0.46 / 0.23$

$0.94 / 0.85$

$0.70 / 0.54$

$0.24 / 0.23$

$0.16 / 0.95$

$---/---$

Controles

CC CG GG Total C G total Pgen/Palelo

$\begin{array}{lllllll}26 & 130 & 292 & 448 & 182 & 714 & 896\end{array}$

$30 \quad 140 \quad 311 \quad 481$

$\begin{array}{llll}30 & 141 & 311 & 482\end{array}$

$30 \quad 140 \quad 310 \quad 480$

$200762 \quad 962$

$\begin{array}{lll}201 & 763 & 964\end{array}$

200760960

$---/ 0.15$

$0.30 / 0.24$

$0.15 / 0.04$

$0.82 / 0.99$

$0.03 / 0.02$

$0.57 / 0.31$

$0.05 / 0.42$

$763 \quad 964$

$0.05 / 0.03$

$---/ 0.15$

$0.76 / 0.68$

$0.82 / 0.99$ 
Novos subfenotipos propostos

FP total com agenesia

FP completa com retencao de dentes permanentes

FP completa com multiplas anomalias

FP incompleta com giroversao/lateroversao

FL/P direita com agenesia

FL/P esquerda com agenesia

FL/P esquerda com microdontia ou supranumerario

FL/P esquerda com multiplas anomalias

FL/P bilateral com agenesia

FL/P bilateral com supranumerario

FL/P bilateral com multiplas anomalias

FL/P bilateral frustro

FL/P bilateral frustro com multiplas anomalias

\section{rs3798867}

Novos subfenotipos propostos

FP total com agenesia

FP completa com retencao de dentes permanentes

FP completa com multiplas anomalias

FP incompleta com giroversao/lateroversao

FL/P direita com agenesia

FL/P esquerda com agenesia

FL/P esquerda com microdontia ou supranumerario

FL/P esquerda com multiplas anomalias

FL/P bilateral com agenesia

FL/P bilateral com supranumerario

FL/P bilateral com multiplas anomalias

FL/P bilateral frustro

FL/P bilateral frustro com multiplas anomalias
Fissurados

\section{n CC CG GG Total}

$\begin{array}{lllll}14 & 1 & 6 & 6 & 13\end{array}$

2

4

$\begin{array}{lllll}27 & 5 & 8 & 13 & 26\end{array}$

$\begin{array}{lllll}40 & 8 & 19 & 12 & 39\end{array}$

$\begin{array}{lllll}12 & 2 & 5 & 4 & 11\end{array}$

$\begin{array}{lllll}17 & 3 & 9 & 5 & 17\end{array}$

$\begin{array}{lllll}39 & 4 & 14 & 18 & 36\end{array}$

2002002

$\begin{array}{lllll}8 & 1 & 4 & 3 & 8\end{array}$

$\begin{array}{lllll}27 & 5 & 10 & 11 & 26\end{array}$

$\begin{array}{lllll}1 & 0 & 0 & 1 & 1\end{array}$

$\begin{array}{lllll}2 & 0 & 2 & 0 & 2\end{array}$

\section{Controles}

C G total

CC CG GG Total

C G total

Pgen/Palelo

$280 \quad 616 \quad 896$

$305 \quad 657 \quad 962$

$\begin{array}{lll}306 & 658 & 964\end{array}$

$306 \quad 654 \quad 960$

$280 \quad 616 \quad 896$

$280 \quad 616 \quad 896$

$304 \quad 658 \quad 962$

$306 \quad 658 \quad 964$

$280 \quad 616 \quad 896$

$304 \quad 658 \quad 962$

$306 \quad 658 \quad 964$

$280 \quad 616 \quad 896$

$306 \quad 658 \quad 964$

$0.70 / 0.95$

$---/ 0.43$

$---/---$

$---/ 0.34$

$0.64 / 0.61$

$0.05 / 0.01$

$0.66 / 0.35$

$0.25 / 0.12$

$0.91 / 0.90$

$---/ 0.42$

$0.73 / 0.62$

$0.59 / 0.27$

---/---

\section{Controles}

\section{n CC CG GG Total}

CC CG GG Total

C G total

Pgen/Palelo

$\begin{array}{cccccccc}\mathbf{1 4} & 5 & 8 & 0 & 13 & 18 & 8 & 26 \\ \mathbf{2} & 0 & 2 & 0 & 2 & 2 & 2 & 4 \\ \mathbf{2} & 0 & 0 & 0 & 0 & 0 & 0 & 0 \\ \mathbf{4} & 1 & 2 & 0 & 3 & 4 & 2 & 6 \\ \mathbf{2 7} & 10 & 11 & 5 & 26 & 31 & 21 & 52 \\ \mathbf{4 0} & 14 & 20 & 5 & 39 & 48 & 30 & 78 \\ \mathbf{1 2} & 4 & 4 & 3 & 11 & 12 & 10 & 22 \\ \mathbf{1 7} & 8 & 8 & 1 & 17 & 24 & 10 & 34\end{array}$

$\begin{array}{llll}149 & 229 & 66 & 444\end{array}$

$\begin{array}{llll}164 & 242 & 71 & 477\end{array}$

$\begin{array}{llll}164 & 243 & 71 & 478\end{array}$

$\begin{array}{llll}164 & 241 & 71 & 476\end{array}$

$\begin{array}{llll}149 & 229 & 66 & 444\end{array}$

$\begin{array}{llll}149 & 229 & 66 & 444\end{array}$

$\begin{array}{llll}163 & 243 & 71 & 477\end{array}$

$\begin{array}{llll}164 & 243 & 71 & 478\end{array}$

$\begin{array}{ccccc}\mathbf{3 9} & 14 & 17 & 6 & 37 \\ \mathbf{2} & 1 & 1 & 0 & 2 \\ \mathbf{8} & 5 & 2 & 1 & 8 \\ \mathbf{2 7} & 10 & 10 & 6 & 26 \\ \mathbf{1} & 1 & 0 & 0 & 1\end{array}$

$\begin{array}{llll}149 & 229 & 66 & 444\end{array}$

$\begin{array}{llll}163 & 243 & 71 & 477\end{array}$

$\begin{array}{llll}164 & 243 & 71 & 478\end{array}$

$\begin{array}{llll}149 & 229 & 66 & 444\end{array}$

$\begin{array}{llll}164 & 243 & 71 & 478\end{array}$
$0.12 / 0.31$

$---/ 0.69$

$---/--$

$0.59 / 0.73$

$0.63 / 0.96$

$0.92 / 0.70$

$0.45 / 0.63$

$0.42 / 0.20$

$0.80 \dagger$

$0.69 / 0.53$

$0.23 / 0.21$

$0.35 / 0.81$

---/--- 


\section{Novos subfenotipos propostos}

FP total com agenesia

FP completa com retencao de dentes permanentes

FP completa com multiplas anomalias

FP incompleta com giroversao/lateroversao

FL/P direita com agenesia

FL/P esquerda com agenesia

FL/P esquerda com microdontia ou supranumerario

FL/P esquerda com multiplas anomalias

FL/P bilateral com agenesia

FL/P bilateral com supranumerario

FL/P bilateral com multiplas anomalias

FL/P bilateral frustro

FL/P bilateral frustro com multiplas anomalias

\section{rs614565}

Novos subfenotipos propostos

FP total com agenesia

FP completa com retencao de dentes permanentes

FP completa com multiplas anomalias

FP incompleta com giroversao/lateroversao

FL/P direita com agenesia

FL/P esquerda com agenesia

FL/P esquerda com microdontia ou supranumerario

FL/P esquerda com multiplas anomalias

FL/P bilateral com agenesia

FL/P bilateral com supranumerario

FL/P bilateral com multiplas anomalias

FL/P bilateral frustro

FL/P bilateral frustro com multiplas anomalias
Fissurados

\section{n CC CG GG Total}

$\begin{array}{lllll}14 & 0 & 6 & 8 & 14\end{array}$

$\begin{array}{llllll}2 & 0 & 1 & 1 & 2\end{array}$

\section{$\begin{array}{lllll}27 & 2 & 9 & 15 & 26\end{array}$}

$\begin{array}{lllll}40 & 4 & 19 & 17 & 40\end{array}$

$\begin{array}{lllll}12 & 3 & 4 & 5 & 12\end{array}$

$\begin{array}{lllll}17 & 4 & 6 & 7 & 17\end{array}$

$\begin{array}{ccccc}\mathbf{3 9} & 2 & 16 & 20 & 38 \\ \mathbf{2} & 0 & 2 & 0 & 2 \\ \mathbf{8} & 1 & 3 & 4 & 8 \\ \mathbf{2 7} & 4 & 11 & 12 & 27 \\ \mathbf{1} & 0 & 0 & 1 & 1\end{array}$

\section{Fissurados}

\section{n CC CG GG Total}

$\begin{array}{ccccc}\mathbf{1 4} & 0 & 6 & 7 & 13 \\ \mathbf{2} & 0 & 1 & 1 & 2 \\ \mathbf{2} & 0 & 0 & 0 & 0 \\ \mathbf{4} & 0 & 0 & 3 & 3\end{array}$

$\begin{array}{llccc}\mathbf{2 7} & 1 & 10 & 15 & 26 \\ \mathbf{4 0} & 1 & 17 & 21 & 39 \\ \mathbf{1 2} & 2 & 5 & 4 & 11 \\ \mathbf{1 7} & 2 & 6 & 9 & 17\end{array}$

$\begin{array}{ccccc}\mathbf{3 9} & 2 & 12 & 21 & 35 \\ \mathbf{2} & 0 & 0 & 2 & 2 \\ \mathbf{8} & 0 & 2 & 6 & 8 \\ \mathbf{2 7} & 2 & 15 & 9 & 26 \\ \mathbf{1} & 0 & 0 & 1 & 1\end{array}$

Controles

C G total CC CG GG Total

$\begin{array}{ccc}\text { C } & \text { G } & \text { total } \\ & & \\ 228 & 666 & 894 \\ 247 & 713 & 960 \\ 248 & 714 & 962 \\ 247 & 711 & 958 \\ & & \\ 228 & 666 & 894 \\ 228 & 666 & 894 \\ 246 & 714 & 960 \\ 248 & 714 & 962 \\ & & \\ 228 & 666 & 894 \\ 246 & 714 & 960 \\ 248 & 714 & 962 \\ 228 & 666 & 894 \\ 248 & 714 & 962\end{array}$

Pgen/Palelo

$0.29 / 0.62$

$0.78 / 0.97$

$---/---$

$0.20 / 0.45$

$0.99 / 0.93$

$0.20 / 0.10$

$0.11 / 0.07$

$0.08 / 0.04$

$0.61 / 0.87$

$---/ 0.26$

$0.88 / 0.62$

$0.30 / 0.11$

$---/---$

Controles

CC CG GG Total C G total Pgen/Palelo

$\begin{array}{lllllllc}35 & 163 & 245 & 443 & 233 & 653 & 886 & 0.31 / 0.71 \\ 39 & 177 & 260 & 476 & 255 & 697 & 952 & 0.80 / 0.93 \\ 39 & 178 & 260 & 477 & 256 & 698 & 954 & ---/-- \\ 39 & 178 & 258 & 475 & 256 & 694 & 950 & ---/-- \\ & & & & & & & \\ 35 & 163 & 245 & 443 & 233 & 653 & 886 & 0.75 / 0.60 \\ 35 & 163 & 245 & 443 & 233 & 653 & 886 & 0.40 / 0.70 \\ 38 & 178 & 260 & 476 & 254 & 698 & 952 & 0.33 / 0.13 \\ 39 & 178 & 260 & 477 & 256 & 698 & 954 & 0.86 / 0.73 \\ & & & & & & & \\ 35 & 163 & 245 & 443 & 233 & 653 & 886 & 0.82 / 0.52 \\ 38 & 178 & 260 & 476 & 254 & 698 & 952 & ---/-- \\ 39 & 178 & 260 & 477 & 256 & 698 & 954 & 0.32 / 0.19 \\ 35 & 163 & 245 & 443 & 233 & 653 & 886 & 0.09 / 0.10 \\ 39 & 178 & 260 & 477 & 256 & 698 & 954 & ---/--\end{array}$




\section{Novos subfenotipos propostos}

FP total com agenesia

FP completa com retencao de dentes permanentes

FP completa com multiplas anomalias

FP incompleta com giroversao/lateroversao

FL/P direita com agenesia

FL/P esquerda com agenesia

FL/P esquerda com microdontia ou supranumerario

FL/P esquerda com multiplas anomalias

FL/P bilateral com agenesia

FL/P bilateral com supranumerario

FL/P bilateral com multiplas anomalias

FL/P bilateral frustro

FL/P bilateral frustro com multiplas anomalias

\section{rs6940766}

Novos subfenotipos propostos

FP total com agenesia

FP completa com retencao de dentes permanentes

FP completa com multiplas anomalias

FP incompleta com giroversao/lateroversao

FL/P direita com agenesia

FL/P esquerda com agenesia

FL/P esquerda com microdontia ou supranumerario

FL/P esquerda com multiplas anomalias

FL/P bilateral com agenesia

FL/P bilateral com supranumerario

FL/P bilateral com multiplas anomalias

FL/P bilateral frustro

FL/P bilateral frustro com multiplas anomalias
Fissurados

\section{n CC CG GG Total}

$\begin{array}{lllll}14 & 0 & 7 & 6 & 13\end{array}$

$\begin{array}{llllll}2 & 0 & 1 & 1 & 2\end{array}$

$\begin{array}{lllll}2 & 0 & 0 & 0 & 0 \\ 4 & 0 & 1 & 2 & 3\end{array}$

$\begin{array}{lllll}27 & 2 & 15 & 17 & 34\end{array}$

$\begin{array}{lllll}40 & 2 & 15 & 21 & 38\end{array}$

$\begin{array}{lllll}12 & 2 & 5 & 4 & 11\end{array}$

$\begin{array}{lllll}17 & 2 & 4 & 10 & 16\end{array}$

$\begin{array}{lllll}39 & 2 & 14 & 19 & 35\end{array}$

$\begin{array}{lllll}2 & 1 & 0 & 1 & 2\end{array}$

$\begin{array}{lllll}8 & 1 & 2 & 5 & 8\end{array}$

$\begin{array}{lllll}27 & 2 & 14 & 9 & 25\end{array}$

$\begin{array}{lllll}1 & 0 & 0 & 1 & 1\end{array}$

Controles

C G total CC CG GG Total

$\begin{array}{ccc}\text { C } & \text { G } & \text { total } \\ & & \\ 251 & 633 & 884 \\ 272 & 678 & 950 \\ 273 & 679 & 952 \\ 273 & 675 & 948 \\ & & \\ 251 & 633 & 884 \\ 251 & 633 & 884 \\ 271 & 679 & 950 \\ 273 & 679 & 952 \\ & & \\ 251 & 633 & 884 \\ 271 & 679 & 950 \\ 273 & 679 & 952 \\ 251 & 633 & 884 \\ 273 & 679 & 952\end{array}$

Pgen/Palelo

$0.19 / 0.86$

$0.79 / 0.87$

$---/---$

$0.69 / 0.51$

$0.69 / 0.93$

$0.70 / 0.52$

$0.46 / 0.20$

$0.56 / 0.65$

$0.77 / 0.63$

$0.08 / 0.34$

$0.75 / 0.74$

$0.20 / 0.24$

---/---

\section{Fissurados}

\section{n CC CG GG Total}

$\begin{array}{ccccc}14 & 0 & 4 & 10 & 14 \\ 2 & 0 & 0 & 2 & 2 \\ 2 & 0 & 0 & 0 & 0 \\ 4 & 0 & 3 & 1 & 4\end{array}$

$\begin{array}{lllll}27 & 2 & 10 & 15 & 27\end{array}$

$\begin{array}{ccccc}40 & 3 & 15 & 22 & 40 \\ 12 & 0 & 5 & 7 & 12\end{array}$

$\begin{array}{lllll}17 & 1 & 7 & 9 & 17\end{array}$

$\begin{array}{cccccccc}\mathbf{3 9} & 0 & 15 & 24 & 39 & 15 & 63 & 78 \\ \mathbf{2} & 0 & 0 & 2 & 2 & 0 & 4 & 4 \\ \mathbf{8} & 0 & 1 & 7 & 8 & 1 & 15 & 16 \\ \mathbf{2 7} & 2 & 9 & 16 & 27 & 13 & 41 & 54 \\ \mathbf{1} & 0 & 0 & 1 & 1 & 0 & 2 & 2\end{array}$

\section{Controles}

CC CG GG Total

C G total

Pgen/Palelo

$\begin{array}{lllllll}52 & 163 & 231 & 446 & 267 & 625 & 892\end{array}$

$\begin{array}{llll}57 & 175 & 247 & 479\end{array}$

$\begin{array}{llll}57 & 176 & 247 & 480\end{array}$

$\begin{array}{llll}57 & 175 & 246 & 478\end{array}$

$\begin{array}{llll}52 & 163 & 231 & 446\end{array}$

$\begin{array}{llll}52 & 163 & 231 & 446\end{array}$

$\begin{array}{llll}57 & 175 & 247 & 479\end{array}$

$\begin{array}{llll}57 & 176 & 247 & 480\end{array}$

$\begin{array}{llll}52 & 163 & 231 & 446\end{array}$

$\begin{array}{llll}57 & 175 & 247 & 479\end{array}$

$\begin{array}{llll}57 & 176 & 247 & 480\end{array}$

$\begin{array}{llll}52 & 163 & 231 & 446\end{array}$

$\begin{array}{llll}57 & 176 & 247 & 480\end{array}$ $\begin{array}{lll}267 & 625 & 892 \\ 289 & 669 & 958\end{array}$

$290 \quad 670 \quad 960$

$289667 \quad 956$

$\begin{array}{lll}267 & 625 & 892\end{array}$

$\begin{array}{lll}267 & 625 & 892\end{array}$

$289 \quad 669 \quad 958$

$290 \quad 670 \quad 960$

$\begin{array}{lll}267 & 625 & 892\end{array}$

$\begin{array}{lll}289 & 669 & 958\end{array}$

$\begin{array}{lll}290 & 670 \quad 960\end{array}$

$\begin{array}{lll}267 & 625 & 892\end{array}$

$290 \quad 670 \quad 960$
$0.10 / 0.07$

---/---

$0.21 / 0.65$

$0.78 / 0.53$

$0.72 / 0.48$

$0.22 / 0.32$

$0.73 / 0.64$

$0.009 / 0.04$

$---/---$

$0.07 / 0.03$

$0.68 / 0.35$

---/--- 


\section{Novos subfenotipos propostos}

FP total com agenesia

FP completa com retencao de dentes permanentes

FP completa com multiplas anomalias

FP incompleta com giroversao/lateroversao

FL/P direita com agenesia

FL/P esquerda com agenesia

FL/P esquerda com microdontia ou supranumerario

FL/P esquerda com multiplas anomalias

FL/P bilateral com agenesia

FL/P bilateral com supranumerario

FL/P bilateral com multiplas anomalias

FL/P bilateral frustro

FL/P bilateral frustro com multiplas anomalias
Fissurados

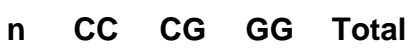

total

CC

CG GG Total

$\begin{array}{llll}43 & 83 & 355 & 481\end{array}$

$\begin{array}{llll}43 & 83 & 356 & 482\end{array}$

$\begin{array}{llll}43 & 82 & 355 & 480\end{array}$

$\begin{array}{lll}169 & 793 \quad 962\end{array}$

$\begin{array}{lll}169 & 795 & 964\end{array}$

$\begin{array}{lll}168 & 792 \quad 960\end{array}$

$\begin{array}{lllll}4 & 0 & 1 & 3 & 4\end{array}$

$\begin{array}{lllll}27 & 1 & 7 & 19 & 27\end{array}$

$\begin{array}{lllll}40 & 1 & 11 & 28 & 40\end{array}$

$\begin{array}{lllll}12 & 0 & 4 & 8 & 12\end{array}$

$\begin{array}{lllll}17 & 0 & 3 & 14 & 17\end{array}$

$\begin{array}{lllll}39 & 3 & 9 & 27 & 39\end{array}$

$\begin{array}{lllll}2 & 0 & 1 & 1 & 2\end{array}$

$\begin{array}{lllll}8 & 0 & 1 & 7 & 8\end{array}$

$\begin{array}{lllll}27 & 1 & 6 & 20 & 27\end{array}$

$\begin{array}{lllll}1 & 0 & 0 & 1 & 1\end{array}$

$\begin{array}{ccc}9 & 45 & 54 \\ 13 & 67 & 80 \\ 4 & 20 & 24 \\ 3 & 31 & 34 \\ & & \\ 15 & 63 & 78 \\ 1 & 3 & 4 \\ 1 & 15 & 16 \\ 8 & 46 & 54 \\ 0 & 2 & 2\end{array}$

$\begin{array}{llll}39 & 75 & 334 & 448\end{array}$

$\begin{array}{llll}39 & 75 & 334 & 448\end{array}$

$\begin{array}{llll}43 & 83 & 355 & 481\end{array}$

$\begin{array}{llll}43 & 83 & 356 & 482\end{array}$

$\begin{array}{lll}153 & 743 \quad 896\end{array}$

$\begin{array}{lll}153 & 743 \quad 896\end{array}$

$\begin{array}{lll}169 & 793 \quad 962\end{array}$

$169795 \quad 964$

$\begin{array}{lll}153 & 743 \quad 896\end{array}$

$\begin{array}{lll}169 & 793 \quad 962\end{array}$

$\begin{array}{lll}169 & 795 & 964\end{array}$

$\begin{array}{lll}153 & 743 \quad 896\end{array}$

$\begin{array}{lll}169 & 795 & 964\end{array}$
Pgen/Palelo

\subsection{9/0.91}

---/---

$---/---$

$0.65 / 0.71$

$0.35 / 0.93$

$0.12 / 0.85$

$0.14 / 0.90$

$0.20 / 0.18$

$0.60 / 0.62$

$0.41 / 0.69$

$0.42 / 0.23$

$0.54 / 0.66$ 
Fissurados

Novos subfenotipos propostos

FP total com agenesia

FP completa com retencao de dentes permanentes

FP completa com multiplas anomalias

FP incompleta com giroversao/lateroversao

FL/P direita com agenesia

FL/P esquerda com agenesia

FL/P esquerda com microdontia ou supranumerario

FL/P esquerda com multiplas anomalias

FL/P bilateral com agenesia

FL/P bilateral com supranumerario

FL/P bilateral com multiplas anomalias

FL/P bilateral frustro

FL/P bilateral frustro com multiplas anomalias

\section{rs1171105 caucasianos}

Novos subfenotipos propostos

FP total com agenesia

FP completa com retencao de dentes permanentes

FP completa com multiplas anomalias

FP incompleta com giroversao/lateroversao

FL/P direita com agenesia

FL/P esquerda com agenesia

FL/P esquerda com microdontia ou supranumerario

FL/P esquerda com multiplas anomalias

FL/P bilateral com agenesia

FL/P bilateral com supranumerario

FL/P bilateral com multiplas anomalias

FL/P bilateral frustro

FL/P bilateral frustro com multiplas anomalias

\section{n CC CT TT Total}

12
2
0

0

4

$\begin{array}{lllll}9 & 5 & 3 & 1 & 9\end{array}$

$\begin{array}{lllll}14 & 6 & 4 & 0 & 10\end{array}$

$\begin{array}{lllll}34 & 17 & 13 & 3 & 33\end{array}$

$\begin{array}{lllll}2 & 1 & 1 & 0 & 2\end{array}$

$\begin{array}{lllll}6 & 5 & 1 & 0 & 6\end{array}$

$\begin{array}{lllll}22 & 12 & 8 & 2 & 22\end{array}$ $\begin{array}{lllll}24 & 16 & 5 & 3 & 24\end{array}$

$\begin{array}{lllll}36 & 20 & 13 & 3 & 36\end{array}$ s

$\mathrm{T}$ total

$17 \quad 7 \quad 24$

0

$\begin{array}{ll}0 & 0 \\ 5 & 3\end{array}$

4

\section{$\begin{array}{lll}37 & 11 & 48\end{array}$}

$\begin{array}{lll}53 & 19 & 72\end{array}$

$13 \quad 5 \quad 18$

$\begin{array}{lll}16 & 4 & 20\end{array}$

$47 \quad 19 \quad 66$

$\begin{array}{lll}3 & 1 & 4\end{array}$

$11 \quad 1 \quad 12$

$\begin{array}{lll}32 & 12 & 44\end{array}$

\section{Fissurados}

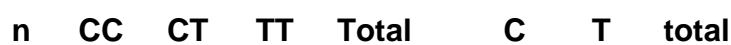

$\begin{array}{llllllll}12 & 6 & 5 & 1 & 12 & 17 & 7 & 24\end{array}$

$\begin{array}{lllll}2 & 2 & 0 & 0 & 2 \\ 0 & 1 & 2 & 1 & 4\end{array}$

$\begin{array}{lllll}0 & 1 & 2 & 1 & 4\end{array}$

$\begin{array}{lllll}4 & 0 & 3 & 1 & 4\end{array}$

$\begin{array}{lllll}24 & 13 & 7 & 4 & 24\end{array}$

$\begin{array}{ccccc}36 & 11 & 20 & 5 & 36 \\ 9 & 4 & 3 & 2 & 9\end{array}$

$\begin{array}{lllll}14 & 4 & 7 & 3 & 14\end{array}$

$\begin{array}{llllllll}34 & 17 & 10 & 5 & 32 & 44 & 20 & 64\end{array}$

$\begin{array}{llllllll}2 & 0 & 2 & 0 & 2 & 2 & 2 & 4\end{array}$

$\begin{array}{llllllll}6 & 2 & 3 & 1 & 6 & 7 & 5 & 12\end{array}$

$\begin{array}{llllllll}22 & 12 & 8 & 2 & 22 & 32 & 12 & 44\end{array}$
Controles

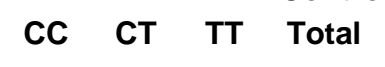

C $\mathrm{T}$ total

Pgen/Palelo

$\begin{array}{llll}168 & 83 & 7 & 258\end{array}$

$\begin{array}{llll}181 & 91 & 8 & 280\end{array}$

$\begin{array}{llll}182 & 91 & 8 & 281\end{array}$

$\begin{array}{llll}181 & 90 & 8 & 279\end{array}$

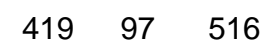

$\begin{array}{lll}453 & 107 & 560\end{array}$

$\begin{array}{lll}455 & 107 \quad 562\end{array}$

$452 \quad 106 \quad 558$

$0.03 / 0.20$

$0.40 /-$

$---/---$

$0.04 / 0.018$

$\begin{array}{llll}168 & 83 & 7 & 258 \\ 168 & 83 & 7 & 258 \\ 182 & 91 & 7 & 280 \\ 182 & 91 & 8 & 281 \\ & & & \\ 168 & 83 & 7 & 258 \\ 182 & 91 & 7 & 280 \\ 182 & 91 & 8 & 281 \\ 168 & 83 & 7 & 258 \\ 182 & 91 & 8 & 281\end{array}$

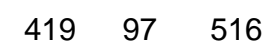

$\begin{array}{lll}419 & 97 \quad 516\end{array}$

$\begin{array}{lll}455 & 105 & 560\end{array}$

$\begin{array}{lll}455 & 107 \quad 562\end{array}$

$0.03 / 0.48$

$0.17 / 0.12$

$0.29 / 0.33$

$0.68 / 0.91$

$\begin{array}{lll}419 & 97 \quad 516\end{array}$

$455 \quad 105 \quad 560$

$0.09 / 0.05$

$0.83 / 0.74$

$\begin{array}{lll}455 & 107 \quad 562\end{array}$

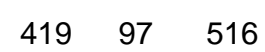

$\begin{array}{lll}455 & 107 \quad 562\end{array}$

$0.57 / 0.34$

$0.22 / 0.17$

---/---

\section{Controles}

$\begin{array}{lllllll}\text { CC CT TT Total } & \text { C } & \text { T total Pgen/Palelo }\end{array}$

$\begin{array}{cllllll}92 & 130 & 36 & 258 & 314 & 202 & 516 \\ 100 & 140 & 40 & 280 & 340 & 220 & 560 \\ 100 & 141 & 40 & 281 & 341 & 221 & 562\end{array}$

$338 \quad 220 \quad 558$

$0.58 / 0.32$

$---/---$

$0.80 / 0.53$

$0.16 / 0.18$

$0.12 / 0.28$

$0.81 / 0.68$

$0.57 / 0.98$

$0.71 / 0.45$

\begin{tabular}{llll}
141 & 39 & 280 \\
\hline & 141 & 40 & 281
\end{tabular}

$314 \quad 202 \quad 516$

$341219 \quad 560$

$341221 \quad 562$

$\begin{array}{llll}92 & 130 & 36 & 258\end{array}$

$\begin{array}{llll}100 & 141 & 39 & 280\end{array}$

$\begin{array}{llll}100 & 141 & 40 & 281\end{array}$

$\begin{array}{lll}314 & 202 \quad 516\end{array}$

$341 \quad 219 \quad 560$

$\begin{array}{lll}341 & 221 & 562\end{array}$

$314 \quad 202 \quad 516$

$341 \quad 221 \quad 562$
$0.10 / 0.22$

$---/---$

$0.98 / 0.65$

$0.21 / 0.11$ $\begin{array}{llll}92 & 130 & 36 & 258\end{array}$

---/--- 
Fissurados

Novos subfenotipos propostos

FP total com agenesia

FP completa com retencao de dentes permanentes

FP completa com multiplas anomalias

FP incompleta com giroversao/lateroversao

FL/P direita com agenesia

FL/P esquerda com agenesia

FL/P esquerda com microdontia ou supranumerario

FL/P esquerda com multiplas anomalias

FL/P bilateral com agenesia

FL/P bilateral com supranumerario

FL/P bilateral com multiplas anomalias

FL/P bilateral frustro

FL/P bilateral frustro com multiplas anomalias

\section{rs1325469 caucasianos}

Novos subfenotipos propostos

FP total com agenesia

FP completa com retencao de dentes permanentes

FP completa com multiplas anomalias

FP incompleta com giroversao/lateroversao

FL/P direita com agenesia

FL/P esquerda com agenesia

FL/P esquerda com microdontia ou supranumerario

FL/P esquerda com multiplas anomalias

FL/P bilateral com agenesia

FL/P bilateral com supranumerario

FL/P bilateral com multiplas anomalias

FL/P bilateral frustro

FL/P bilateral frustro com multiplas anomalias

\section{n $\quad$ CC $\quad$ CT TT Total}

125

0

$\begin{array}{lllll}24 & 11 & 9 & 4 & 24\end{array}$

$\begin{array}{lllll}36 & 15 & 17 & 4 & 36\end{array}$

$\begin{array}{lllll}9 & 4 & 3 & 3 & 10\end{array}$

$\begin{array}{lllll}14 & 4 & 7 & 3 & 14\end{array}$

$\begin{array}{lllll}34 & 11 & 16 & 6 & 33\end{array}$

$\begin{array}{lllll}2 & 1 & 1 & 0 & 2\end{array}$

$\begin{array}{lllll}6 & 1 & 1 & 0 & 2\end{array}$

$\begin{array}{lllll}22 & 8 & 8 & 6 & 22\end{array}$
C

$16 \quad 6 \quad 22$

2

$\begin{array}{ll}0 & 0 \\ 4 & 2\end{array}$

$\begin{array}{lll}47 & 25 & 72\end{array}$

$\begin{array}{lll}15 & 13 & 28\end{array}$

3

31

$\begin{array}{lll}24 & 20 & 44\end{array}$ $\begin{array}{lll}31 & 17 & 48\end{array}$

$\begin{array}{lll}11 & 9 & 20\end{array}$

Controles

CC CT TT Total

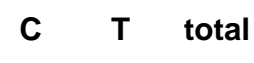

Pgen/Palelo

$\begin{array}{llll}95 & 131 & 33 & 259\end{array}$

$\begin{array}{llll}109 & 137 & 35 & 281\end{array}$

$\begin{array}{llll}109 & 137 & 35 & 281\end{array}$

$\begin{array}{llll}109 & 136 & 35 & 280\end{array}$

$\begin{array}{lll}321 & 197 & 518\end{array}$

$\begin{array}{lll}355 & 207 \quad 562\end{array}$

$\begin{array}{lll}355 & 207 \quad 562\end{array}$

$354 \quad 206 \quad 560$

$\begin{array}{llll}95 & 131 & 33 & 259\end{array}$

$\begin{array}{llll}95 & 131 & 33 & 259\end{array}$

$\begin{array}{llll}108 & 138 & 35 & 281\end{array}$

$\begin{array}{llll}109 & 137 & 35 & 281\end{array}$

$\begin{array}{lll}321 & 197 & 518\end{array}$

$\begin{array}{lll}321 & 197 & 518\end{array}$

$354 \quad 208 \quad 562$

$\begin{array}{lll}355 & 207 \quad 562\end{array}$

$\begin{array}{llll}95 & 131 & 33 & 259\end{array}$

$\begin{array}{lll}321 & 197 \quad 518\end{array}$

$354 \quad 208 \quad 562$

$\begin{array}{lll}355 & 207 \quad 562\end{array}$

$\begin{array}{lll}321 & 197 \quad 518\end{array}$

$355 \quad 207 \quad 562$

$0.22 / 0.30$

---/---

0.61/0.86

$0.47 / 0.72$

$0.83 / 0.58$

$0.22 \dagger$

$0.54 / 0.30$

$0.68 / 0.48$

$0.75 \dagger$

$0.75 / 0.62$

$0.14 / 0.33$

---/---

\section{Fissurados}

n AA AG GG Total

$\begin{array}{llllllll}12 & 10 & 1 & 0 & 11 & 21 & 1 & 22\end{array}$

$\begin{array}{lllll}2 & 0 & 0 & 0 & 0 \\ 0 & 0 & 0 & 0 & 0\end{array}$

$\begin{array}{lllll}0 & 0 & 0 & 0 & 0\end{array}$

4

$\begin{array}{llll}24 & 16 & 6 & 1\end{array}$

$\begin{array}{cccc}36 & 23 & 12 & 0 \\ 9 & 2 & 5 & 1\end{array}$

1486

$\begin{array}{llll}34 & 24 & 8 & 0\end{array}$

$\begin{array}{llll}2 & 0 & 2 & 0\end{array}$

$\begin{array}{llll}6 & 3 & 4 & 0\end{array}$

$22 \quad 16 \quad 5 \quad 0$
Controles

\section{AA AG GG Total}

$\begin{array}{llll}185 & 66 & 7 & 258\end{array}$

$\begin{array}{llll}201 & 71 & 8 & 280\end{array}$

$\begin{array}{llll}201 & 71 & 8 & 280\end{array}$

$\begin{array}{llll}200 & 71 & 8 & 279\end{array}$

$\begin{array}{llll}185 & 66 & 7 & 258\end{array}$

$\begin{array}{llll}185 & 66 & 7 & 258\end{array}$

$\begin{array}{llll}202 & 71 & 7 & 280\end{array}$

$\begin{array}{llll}201 & 71 & 8 & 280\end{array}$

$\begin{array}{llll}185 & 66 & 7 & 258 \\ 201 & 71 & 7 & 279 \\ 201 & 71 & 8 & 280 \\ 185 & 66 & 7 & 258 \\ 185 & 66 & 7 & 258\end{array}$
A

$\begin{array}{lll}436 & 80 & 516 \\ 473 & 87 & 560 \\ 473 & 87 & 560\end{array}$

$471 \quad 87 \quad 558$

$436 \quad 80 \quad 516$

$436 \quad 80 \quad 516$

$\begin{array}{lll}475 & 85 & 560\end{array}$

$473 \quad 87 \quad 560$

$\begin{array}{lll}436 & 80 \quad 516\end{array}$

$\begin{array}{lll}473 \quad 85 & 558\end{array}$

$\begin{array}{lll}473 & 87 & 560\end{array}$

$436 \quad 80 \quad 516$

$436 \quad 80 \quad 516$
Pgen/Palelo

$0.32 / 0.15$

---/---

$---/---$

$---/--$

$0.89 / 0.73$

$0.24 / 0.72$

$0.009 / 0.002$

$0.25 / 0.40$

$0.43 / 0.52$

$---/---$

$0.14 / 0.18$

$0.55 / 0.53$ 
Fissurados

Novos subfenotipos propostos

FP total com agenesia

FP completa com retencao de dentes permanentes

FP completa com multiplas anomalias

FP incompleta com giroversao/lateroversao

FL/P direita com agenesia

FL/P esquerda com agenesia

FL/P esquerda com microdontia ou supranumerario

FL/P esquerda com multiplas anomalias

FL/P bilateral com agenesia

FL/P bilateral com supranumerario

FL/P bilateral com multiplas anomalias

FL/P bilateral frustro

FL/P bilateral frustro com multiplas anomalias

\section{n AA AG GG Total}

$\begin{array}{ccccc}12 & 0 & 1 & 10 & 11 \\ 2 & 0 & 0 & 2 & 2 \\ 0 & 0 & 0 & 0 & 0 \\ 4 & 0 & 0 & 0 & 0\end{array}$

\section{$\begin{array}{lllll}24 & 1 & 6 & 16 & 23\end{array}$}

$\begin{array}{lllll}36 & 0 & 10 & 25 & 35\end{array}$

$\begin{array}{lllll}9 & 1 & 5 & 2 & 8\end{array}$

$\begin{array}{lllll}14 & 0 & 5 & 9 & 14\end{array}$

$\begin{array}{ccccc}\mathbf{3 4} & 1 & 7 & 21 & 29 \\ \mathbf{2} & 0 & 2 & 0 & 2 \\ \mathbf{6} & 0 & 3 & 3 & 6 \\ \mathbf{2 2} & 0 & 4 & 7 & 11 \\ \mathbf{1} & & & & \end{array}$

Novos subfenotipos propostos

FP total com agenesia

FP completa com retencao de dentes permanentes

FP completa com multiplas anomalias

FP incompleta com giroversao/lateroversao

FL/P direita com agenesia

FL/P esquerda com agenesia

FL/P esquerda com microdontia ou supranumerario

FL/P esquerda com multiplas anomalias

FL/P bilateral com agenesia

FL/P bilateral com supranumerario

FL/P bilateral com multiplas anomalias

FL/P bilateral frustro

FL/P bilateral frustro com multiplas anomalias$$
4
$$

\section{Fissurados \\ n CC CT TT Total \\ C $\mathrm{T}$ total}

2

$\begin{array}{llll}0 & 2 & 0 & 2\end{array}$

$\begin{array}{lcclllll}24 & 8 & 10 & 4 & 22 & 26 & 18 & 44 \\ 36 & 13 & 18 & 5 & 36 & 44 & 28 & 72\end{array}$

$\begin{array}{llllllll}36 & 13 & 18 & 5 & 36 & 44 & 28 & 72\end{array}$

$\begin{array}{llllllll}9 & 3 & 4 & 2 & 9 & 10 & 8 & 18\end{array}$

$\begin{array}{llllllll}14 & 6 & 7 & 1 & 14 & 19 & 9 & 28\end{array}$

$\begin{array}{llllllll}34 & 10 & 19 & 4 & 33 & 39 & 27 & 66\end{array}$

$\begin{array}{llllllll}2 & 0 & 2 & 0 & 2 & 2 & 2 & 4\end{array}$

$\begin{array}{llllllll}6 & 3 & 3 & 0 & 6 & 9 & 3 & 12\end{array}$

$\begin{array}{llllllll}22 & 8 & 8 & 5 & 21 & 24 & 18 & 42\end{array}$

\section{Controles}

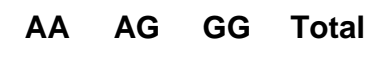

$\begin{array}{cccc}\text { A } & \text { G } & \text { total } & \text { Pgen/Palelo } \\ & & & \\ 77 & 429 & 506 & 0.33 / 0.16 \\ 82 & 466 & 548 & ---/-- \\ 82 & 468 & 550 & ---/-- \\ 82 & 464 & 546 & ---/---\end{array}$

$0.89 / 0.69$

$0.37 / 0.83$

$0.007 / 0.001$

$0.43 / 0.67$

$0.97 / 0.95$

$---/---$

$0.30 / 0.33$

$0.53 / 0.70$

$---/--$

\section{Controles}

\begin{tabular}{|c|c|c|c|c|c|c|}
\hline \multicolumn{5}{|c|}{ Controles } & \multirow[b]{2}{*}{ total } & \multirow[b]{2}{*}{ Pgen/Palelo } \\
\hline CC $\quad$ CT & TT & Total & C & $\begin{array}{ll}T \\
\text { t }\end{array}$ & & \\
\hline 134 & 31 & 257 & 318 & 196 & 514 & $0.19 / 0.63$ \\
\hline 143 & 34 & 279 & 347 & 211 & 558 & ---/--- \\
\hline 102144 & 34 & 280 & 348 & 212 & 560 & ---/--- \\
\hline 142 & 34 & 278 & 346 & 210 & 556 & ---/--- \\
\hline 134 & 31 & 257 & 318 & 196 & 514 & $0.67 / 0.71$ \\
\hline 134 & 31 & 257 & 318 & 196 & 514 & $0.94 / 0.90$ \\
\hline $101 \quad 144$ & 34 & 279 & 346 & 212 & 558 & $0.66 / 0.57$ \\
\hline 144 & 34 & 280 & 348 & 212 & 560 & $0.80 / 0.54$ \\
\hline 134 & 31 & 257 & 318 & 196 & 514 & $0.81 / 0.66$ \\
\hline 144 & 34 & 279 & 346 & 212 & 558 & ---/--- \\
\hline 144 & 34 & 280 & 348 & 212 & 560 & $0.41 / 0.62$ \\
\hline 134 & 31 & 257 & 318 & 196 & 514 & $0.24 / 0.54$ \\
\hline 144 & 34 & 280 & 348 & 212 & 560 & ---|--- \\
\hline
\end{tabular}




\section{Novos subfenotipos propostos}

FP total com agenesia

FP completa com retencao de dentes permanentes

FP completa com multiplas anomalias

FP incompleta com giroversao/lateroversao

FL/P direita com agenesia

FL/P esquerda com agenesia

FL/P esquerda com microdontia ou supranumerario

FL/P esquerda com multiplas anomalias

FL/P bilateral com agenesia

FL/P bilateral com supranumerario

FL/P bilateral com multiplas anomalias

FL/P bilateral frustro

FL/P bilateral frustro com multiplas anomalias

\section{rs217325 caucasianos}

Novos subfenotipos propostos

FP total com agenesia

FP completa com retencao de dentes permanentes

FP completa com multiplas anomalias

FP incompleta com giroversao/lateroversao

FL/P direita com agenesia

FL/P esquerda com agenesia

FL/P esquerda com microdontia ou supranumerario

FL/P esquerda com multiplas anomalias

FL/P bilateral com agenesia

FL/P bilateral com supranumerario

FL/P bilateral com multiplas anomalias

FL/P bilateral frustro

FL/P bilateral frustro com multiplas anomalias
Fissurados

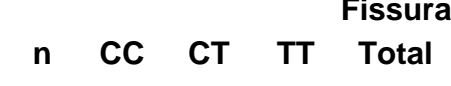

$\begin{array}{ccccc}\mathbf{2} & 0 & 2 & 4 & 11 \\ 0 & 0 & 2 & 1 & 3 \\ 4 & 0 & 2 & 1 & 3\end{array}$
C

$\begin{array}{lllll}24 & 3 & 10 & 10 & 23\end{array}$

$\begin{array}{lllll}36 & 4 & 18 & 12 & 34\end{array}$

$\begin{array}{lllll}9 & 3 & 3 & 2 & 8\end{array}$

$\begin{array}{lllll}14 & 1 & 7 & 6 & 14\end{array}$

$\begin{array}{ccccc}\mathbf{3 4} & 4 & 16 & 11 & 31 \\ \mathbf{2} & 0 & 1 & 1 & 2 \\ \mathbf{6} & 0 & 2 & 4 & 6 \\ \mathbf{2 2} & 5 & 8 & 8 & 21 \\ \mathbf{1} & 0 & 0 & 1 & 1\end{array}$

\section{Fissurados}

\section{n CC CG GG Total \\ C G total}$$
\begin{array}{lllll}
12 & 1 & 4 & 7 & 12
\end{array}
$$

$\begin{array}{lllll}2 & 0 & 2 & 0 & 2\end{array}$

$\begin{array}{lllll}0 & 1 & 1 & 2 & 4\end{array}$

$\begin{array}{lllll}4 & 1 & 2 & 1 & 4\end{array}$

$\begin{array}{ccccc}24 & 1 & 8 & 15 & 24 \\ \mathbf{3 6} & 3 & 18 & 15 & 36 \\ \mathbf{9} & 1 & 4 & 4 & 9 \\ 14 & 0 & 8 & 6 & 14\end{array}$

$\begin{array}{ccc}10 & 38 & 48 \\ 24 & 48 & 72 \\ 6 & 12 & 18 \\ 8 & 20 & 28\end{array}$

$\begin{array}{ccccc}\mathbf{3 4} & 6 & 11 & 17 & 34 \\ \mathbf{2} & 0 & 2 & 0 & 2 \\ \mathbf{6} & 1 & 2 & 3 & 6 \\ \mathbf{2 2} & 1 & 8 & 13 & 22 \\ \mathbf{1} & 0 & 0 & 1 & 1\end{array}$

\section{Controles}

CC CT TT Total

C T total

Pgen/Palelo

$\begin{array}{cccc}26 & 141 & 91 & 258\end{array}$

$\begin{array}{llll}29 & 149 & 102 & 280\end{array}$

$\begin{array}{llll}29 & 150 & 102 & 281\end{array}$

$\begin{array}{llll}29 & 148 & 102 & 279\end{array}$

$\begin{array}{lll}193 & 323 \quad 516\end{array}$

$207 \quad 353 \quad 560$

$208 \quad 354 \quad 562$

$206 \quad 352 \quad 558$

$\begin{array}{lll}193 & 323 \quad 516\end{array}$

$193 \quad 323 \quad 516$

$\begin{array}{lll}208 & 352 \quad 560\end{array}$

$208 \quad 354 \quad 562$

$\begin{array}{lll}193 & 323 & 516\end{array}$

$208 \quad 352 \quad 560$

$208 \quad 354 \quad 562$

$\begin{array}{lll}193 & 323 & 516\end{array}$

$208 \quad 354 \quad 562$

$0.31 / 0.59$

$---/--$

$0.69 / 0.85$

$0.69 / 0.85$

$0.58 / 0.72$

$0.95 / 0.89$

$0.05 / 0.11$

$0.85 / 0.60$

$0.87 / 0.84$

$0.76 / 0.61$

$0.20 / 0.14$

$0.11 / 0.48$

---/---

\section{Controles}

CC CG GG Total

C G total

Pgen/Palelo

$0.98 / 0.99$

---/---

$0.47 / 0.46$

$0.47 / 0.12$

$0.79 / 0.51$

$0.70 / 0.13$

$0.77 / 0.48$

$0.11 / 0.76$

$\begin{array}{lll}146 & 416 \quad 562\end{array}$

$147 \quad 417 \quad 564$

$0.12 \dagger$

$\begin{array}{lll}130 & 388 & 518\end{array}$

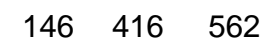

$\begin{array}{lll}147 & 417 & 564\end{array}$

$\begin{array}{lll}130 & 388 & 518\end{array}$

$147 \quad 417 \quad 564$
---/---

$0.75 / 0.57$

$0.88 / 0.72$ 
Fissurados

Novos subfenotipos propostos

FP total com agenesia

FP completa com retencao de dentes permanentes

FP completa com multiplas anomalias

FP incompleta com giroversao/lateroversao

FL/P direita com agenesia

FL/P esquerda com agenesia

FL/P esquerda com microdontia ou supranumerario

FL/P esquerda com multiplas anomalias

FL/P bilateral com agenesia

FL/P bilateral com supranumerario

FL/P bilateral com multiplas anomalias

FL/P bilateral frustro

FL/P bilateral frustro com multiplas anomalias

\section{rs3798867 caucasianos}

Novos subfenotipos propostos

FP total com agenesia

FP completa com retencao de dentes permanentes

FP completa com multiplas anomalias

FP incompleta com giroversao/lateroversao

FL/P direita com agenesia

FL/P esquerda com agenesia

FL/P esquerda com microdontia ou supranumerario

FL/P esquerda com multiplas anomalias

FL/P bilateral com agenesia

FL/P bilateral com supranumerario

FL/P bilateral com multiplas anomalias

FL/P bilateral frustro

FL/P bilateral frustro com multiplas anomalias

\section{n CC CG GG Total}

$\begin{array}{ccccc}12 & 1 & 5 & 6 & 12 \\ \mathbf{2} & 0 & 2 & 0 & 2 \\ \mathbf{0} & 0 & 2 & 1 & 3 \\ \mathbf{4} & 0 & 3 & 0 & 3\end{array}$

$\begin{array}{lllll}24 & 5 & 6 & 12 & 23\end{array}$

$\begin{array}{lllll}36 & 7 & 18 & 10 & 35\end{array}$

$\begin{array}{lllll}9 & 1 & 4 & 3 & 8\end{array}$

$\begin{array}{lllll}14 & 2 & 8 & 4 & 14\end{array}$

$\begin{array}{lllll}34 & 4 & 12 & 15 & 31\end{array}$

$\begin{array}{lllll}2 & 0 & 2 & 0 & 2\end{array}$

$\begin{array}{lllll}6 & 1 & 3 & 2 & 6\end{array}$

$\begin{array}{lllll}22 & 4 & 8 & 9 & 21\end{array}$

$\begin{array}{lllll}1 & 0 & 0 & 1 & 1\end{array}$

\section{Fissurados}

\section{Controles}

CC CG GG Total

C G total

Pgen/Palelo

$\begin{array}{llll}35 & 95 & 129 & 259\end{array}$

$\begin{array}{llll}39 & 105 & 137 & 281\end{array}$

$\begin{array}{llll}39 & 106 & 137 & 282\end{array}$

$\begin{array}{llll}39 & 106 & 135 & 280\end{array}$

$\begin{array}{lll}165 & 353 \quad 518\end{array}$

$\begin{array}{lll}183 & 379 & 562\end{array}$

$\begin{array}{lll}184 & 380 & 564\end{array}$

$184 \quad 376 \quad 560$

$0.85 / 0.78$

$---/---$

$0.44 / 0.97$

---/---

$0.42 / 0.68$

$0.06 / 0.02$

$0.77 / 0.66$

$0.29 / 0.26$

$0.97 / 0.94$

$---/---$

$0.75 / 0.50$

$0.73 / 0.40$

---/---

\section{n CC CG GG Total \\ C G total}

Controles

$\begin{array}{cccccccc}\mathbf{1 2} & 4 & 7 & 0 & 11 & 15 & 7 & 22 \\ \mathbf{2} & 0 & 2 & 0 & 2 & 2 & 2 & 4 \\ \mathbf{0} & 1 & 2 & 0 & 3 & 4 & 2 & 6 \\ \mathbf{4} & 1 & 2 & 0 & 3 & 4 & 2 & 6 \\ & & & & & & & \\ \mathbf{2 4} & 9 & 10 & 4 & 23 & 28 & 18 & 46 \\ \mathbf{3 6} & 12 & 18 & 5 & 35 & 42 & 28 & 70 \\ \mathbf{9} & 2 & 3 & 3 & 8 & 7 & 9 & 16 \\ \mathbf{1 4} & 6 & 7 & 1 & 14 & 19 & 9 & 28\end{array}$

$\begin{array}{llll}89 & 138 & 29 & 256\end{array}$

$\begin{array}{llll}99 & 147 & 32 & 278\end{array}$

$\begin{array}{llll}99 & 148 & 32 & 279\end{array}$

$\begin{array}{llll}99 & 146 & 32 & 277\end{array}$

$\begin{array}{llll}89 & 138 & 29 & 256\end{array}$

$\begin{array}{llll}89 & 138 & 29 & 256\end{array}$

$\begin{array}{llll}98 & 148 & 32 & 278\end{array}$

$\begin{array}{llll}99 & 148 & 32 & 279\end{array}$

$\begin{array}{llllllll}34 & 12 & 15 & 5 & 32 & 39 & 25 & 64\end{array}$

$\begin{array}{llllllll}2 & 1 & 1 & 0 & 2 & 3 & 1 & 4\end{array}$

$\begin{array}{llllllll}6 & 4 & 2 & 0 & 6 & 10 & 2 & 12\end{array}$

$\begin{array}{llllllll}22 & 8 & 8 & 5 & 21 & 24 & 18 & 42\end{array}$

$\begin{array}{cccccccc}1 & 1 & 0 & 0 & 1 & 2 & 0 & 2\end{array}$ $\begin{array}{llll}89 & 138 & 29 & 256\end{array}$

$\begin{array}{llll}98 & 148 & 32 & 278\end{array}$

$\begin{array}{llll}89 & 138 & 29 & 256\end{array}$

$\begin{array}{llll}99 & 148 & 32 & 279\end{array}$ $\begin{array}{llll}99 & 148 & 32 & 279\end{array}$

\section{G total}

$316 \quad 196 \quad 512$

$\begin{array}{lll}345 & 211 \quad 556\end{array}$

$\begin{array}{lll}346 & 212 \quad 558\end{array}$

$344 \quad 210 \quad 554$

$\begin{array}{lll}316 & 196 \quad 512\end{array}$

$316 \quad 196 \quad 512$

$346 \quad 212 \quad 558$

$\begin{array}{lll}316 & 196 \quad 512\end{array}$

$344 \quad 212 \quad 556$

$\begin{array}{lll}346 & 212 & 558\end{array}$

$\begin{array}{lll}316 & 196 \quad 512\end{array}$

$346 \quad 212 \quad 558$ $\begin{array}{lll}344 & 212 \quad 556\end{array}$
Pgen/Palelo

$0.26 / 0.54$

$---/---$

$0.67 / 0.81$

$0.66 / 0.81$

$0.54 / 0.90$

$0.87 / 0.78$

$0.10 / 0.14$

$0.79 / 0.53$

$0.68 / 0.90$

$0.74 / 0.58$

$0.18 / 0.13$

$0.17 / 0.55$ 
Novos subfenotipos propostos

FP total com agenesia

FP completa com retencao de dentes permanentes

FP completa com multiplas anomalias

FP incompleta com giroversao/lateroversao

FL/P direita com agenesia

FL/P esquerda com agenesia

FL/P esquerda com microdontia ou supranumerario

FL/P esquerda com multiplas anomalias

FL/P bilateral com agenesia

FL/P bilateral com supranumerario

FL/P bilateral com multiplas anomalias

FL/P bilateral frustro

FL/P bilateral frustro com multiplas anomalias

\section{rs614565 caucasianos}

Novos subfenotipos propostos

FP total com agenesia

FP completa com retencao de dentes permanentes

FP completa com multiplas anomalias

FP incompleta com giroversao/lateroversao

FL/P direita com agenesia

FL/P esquerda com agenesia

FL/P esquerda com microdontia ou supranumerario

FL/P esquerda com multiplas anomalias

FL/P bilateral com agenesia

FL/P bilateral com supranumerario

FL/P bilateral com multiplas anomalias

FL/P bilateral frustro

FL/P bilateral frustro com multiplas anomalias

Fissurados

n

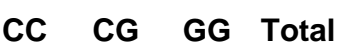

C G total

CC CG GG Total

G total Pgen/Palelo

$\begin{array}{ccccc}14 & 0 & 5 & 7 & 12 \\ 2 & 0 & 1 & 1 & 2 \\ 2 & 0 & 0 & 0 & 0\end{array}$

$\begin{array}{ccc}5 & 19 & 24 \\ 1 & 3 & 4 \\ 0 & 0 & 0\end{array}$

$\begin{array}{llll}31 & 119 & 109 & 259\end{array}$

$\begin{array}{lll}181 & 337 \quad 518\end{array}$

$0.16 / 0.15$

$\begin{array}{llll}35 & 129 & 117 & 281\end{array}$

$\begin{array}{llll}35 & 130 & 117 & 282\end{array}$

$199363 \quad 562$

$200 \quad 364 \quad 564$

$199361 \quad 560$

$0.76 / 0.66$

$---/---$

0.370 .90

$\begin{array}{cccccccc}23 & 2 & 8 & 13 & 23 & 12 & 34 & 46 \\ 34 & 3 & 18 & 15 & 36 & 24 & 48 & 72 \\ 13 & 2 & 3 & 4 & 9 & 7 & 11 & 18 \\ 14 & 3 & 5 & 6 & 14 & 11 & 17 & 28\end{array}$

$\begin{array}{llll}31 & 119 & 109 & 259\end{array}$

$\begin{array}{lll}181 & 337 & 518\end{array}$

$0.40 / 0.22$

$0.78 \dagger$

$\begin{array}{llll}31 & 119 & 109 & 259 \\ 34 & 130 & 117 & 281\end{array}$

$\begin{array}{lll}181 & 337 & 518\end{array}$

$198 \quad 364 \quad 562$

$200 \quad 364 \quad 564$

$0.59 / 0.74$

$0.55 / 0.68$

$\begin{array}{cccccccc}42 & 2 & 14 & 17 & 33 & 18 & 48 & 66 \\ 4 & 0 & 2 & 0 & 2 & 2 & 2 & 4 \\ 4 & 1 & 2 & 3 & 6 & 4 & 8 & 12 \\ 27 & 3 & 9 & 10 & 22 & 15 & 29 & 44 \\ & 0 & 0 & 1 & 1 & 0 & 2 & 2\end{array}$

$\begin{array}{llll}31 & 119 & 109 & 259\end{array}$

$\begin{array}{lll}181 & 337 & 518\end{array}$

$\begin{array}{lll}198 & 364 & 562\end{array}$

$\begin{array}{lll}200 & 364 & 564\end{array}$

$\begin{array}{lll}181 & 337 & 518\end{array}$

$200 \quad 364 \quad 564$

$0.45 / 0.21$

$---/---$

$0.82 / 0.87$

$0.89 / 0.90$

---I---

\section{Fissurados}

\section{n CC CG GG Total}

C G total

\section{Controles}

\section{CG GG Total}

$\begin{array}{ccccc}12 & 0 & 5 & 6 & 11 \\ \mathbf{2} & 0 & 1 & 1 & 2 \\ \mathbf{0} & 0 & 0 & 0 & 0\end{array}$

$\begin{array}{lllll}4 & 0 & 0 & 3 & 3\end{array}$

$\begin{array}{lllll}24 & 1 & 8 & 14 & 23\end{array}$

$\begin{array}{ccccc}24 & 1 & 8 & 14 & 23 \\ 36 & 1 & 14 & 20 & 35\end{array}$

$\begin{array}{lllll}9 & 2 & 2 & 4 & 8\end{array}$

$\begin{array}{lllll}14 & 2 & 3 & 9 & 14\end{array}$

$\begin{array}{lllll}34 & 2 & 7 & 19 & 28\end{array}$

$\begin{array}{lllll}2 & 0 & 0 & 2 & 2\end{array}$

$\begin{array}{lllll}6 & 0 & 0 & 6 & 6\end{array}$

$\begin{array}{lllll}22 & 2 & 2 & 17 & 21\end{array}$

$\begin{array}{lllcc}1 & 0 & 0 & 1 & 1\end{array}$

$\begin{array}{lll}5 & 17 & 22\end{array}$

$\begin{array}{llll}18 & 95 & 142 & 255\end{array}$

$\begin{array}{llll}21 & 104 & 152 & 277\end{array}$

$\begin{array}{llll}21 & 105 & 152 & 278\end{array}$

$\begin{array}{llll}21 & 105 & 150 & 276\end{array}$

$\begin{array}{llll}18 & 95 & 142 & 255\end{array}$

$\begin{array}{llll}18 & 95 & 142 & 255\end{array}$

$\begin{array}{llll}20 & 105 & 152 & 277\end{array}$

$\begin{array}{llll}21 & 105 & 152 & 278\end{array}$

$\begin{array}{llll}18 & 95 & 142 & 255\end{array}$

$\begin{array}{llll}20 & 105 & 152 & 277\end{array}$

$\begin{array}{llll}21 & 105 & 152 & 278\end{array}$

$\begin{array}{llll}18 & 95 & 142 & 255\end{array}$

$\begin{array}{llll}21 & 105 & 152 & 278\end{array}$ $\begin{array}{lll}131 & 379 \quad 510\end{array}$

$\begin{array}{lll}146 & 408 \quad 554\end{array}$

$\begin{array}{lll}147 & 409 \quad 556\end{array}$

$147 \quad 405 \quad 552$

$\begin{array}{lll}131 & 379 & 510\end{array}$

$\begin{array}{lll}131 & 379 \quad 510\end{array}$

$\begin{array}{lll}145 & 409 & 554\end{array}$

$147 \quad 409 \quad 556$

$\begin{array}{lll}131 & 379 & 510\end{array}$

$\begin{array}{lll}145 & 409 \quad 554\end{array}$

$\begin{array}{lll}147 & 409 & 556\end{array}$

$\begin{array}{lll}131 & 379 \quad 510\end{array}$

$147 \quad 409 \quad 556$

\section{Pgen/Palelo}

$0.42 / 0.75$

$0.82 / 0.95$

---/---

---/---

$0.83 / 0.55$

$0.63 / 0.60$

$0.16 / 0.31$

$0.37 / 0.86$

$0.42 / 0.32$

$---/--$

$0.03 / 0.10$

---/--- 
Fissurados

n CC CG GG Total

FP total com agenesia

FP completa com retencao de dentes permanentes

FP completa com multiplas anomalias

FP incompleta com giroversao/lateroversao

FL/P direita com agenesia

FL/P esquerda com agenesia

FL/P esquerda com microdontia ou supranumerario

FL/P esquerda com multiplas anomalias

FL/P bilateral com agenesia

FL/P bilateral com supranumerario

FL/P bilateral com multiplas anomalias

FL/P bilateral frustro

FL/P bilateral frustro com multiplas anomalias

\section{rs6940766 caucasianos}

Novos subfenotipos propostos

FP total com agenesia

FP completa com retencao de dentes permanentes

FP completa com multiplas anomalias

FP incompleta com giroversao/lateroversao

FL/P direita com agenesia

FL/P esquerda com agenesia

FL/P esquerda com microdontia ou supranumerario

FL/P esquerda com multiplas anomalias

FL/P bilateral com agenesia

FL/P bilateral com supranumerario

FL/P bilateral com multiplas anomalias

FL/P bilateral frustro

FL/P bilateral frustro com multiplas anomalias

$\begin{array}{cccccccccccccccc}14 & 0 & 6 & 5 & 11 & 6 & 16 & 22 & 21 & 101 & 133 & 255 & 143 & 367 & 510 & 0.29 / 0.93 \\ 2 & 0 & 1 & 1 & 2 & 1 & 3 & 4 & 24 & 109 & 144 & 277 & 157 & 397 & 554 & 0.81 / 0.88 \\ 2 & 0 & 0 & 0 & 0 & 0 & 0 & 0 & 24 & 110 & 144 & 278 & 158 & 398 & 556 & ---/-- \\ 4 & 0 & 1 & 2 & 3 & 1 & 5 & 6 & 24 & 110 & 142 & 276 & 158 & 394 & 552 & 0.71 / 0.51 \\ & & & & & & & & & & & & & & & \\ 23 & 1 & 10 & 11 & 22 & 12 & 32 & 44 & 21 & 101 & 133 & 255 & 143 & 367 & 510 & 0.76 / 0.51 \\ 34 & 2 & 12 & 20 & 34 & 16 & 52 & 68 & 21 & 101 & 133 & 255 & 143 & 367 & 510 & 0.73 / 0.43 \\ 13 & 2 & 2 & 4 & 8 & 6 & 10 & 16 & 23 & 110 & 144 & 277 & 156 & 398 & 554 & 0.23 / 0.41 \\ 14 & 2 & 1 & 10 & 13 & 5 & 21 & 26 & 24 & 110 & 144 & 278 & 158 & 398 & 556 & 0.06 / 0.30 \\ & & & & & & & & & & & & & & & \\ 42 & 2 & 10 & 18 & 30 & 14 & 46 & 60 & 21 & 101 & 133 & 255 & 143 & 367 & 510 & 0.71 / 0.44 \\ 4 & 1 & 0 & 1 & 2 & 2 & 2 & 4 & 23 & 110 & 144 & 277 & 156 & 398 & 554 & 0.09 / 0.33 \\ 4 & 1 & 0 & 5 & 6 & 2 & 10 & 12 & 24 & 110 & 144 & 278 & 158 & 398 & 556 & 0.04 / 0.37 \\ 27 & 1 & 11 & 8 & 20 & 13 & 27 & 40 & 21 & 101 & 133 & 255 & 143 & 367 & 510 & 0.39 / 0.54 \\ & 0 & 0 & 1 & 1 & 0 & 2 & 2 & 24 & 110 & 144 & 278 & 158 & 398 & 556 & ---/--\end{array}$

\section{Fissurados}

n CC CG

\section{Controles}

$\begin{array}{cccccccc}\mathbf{1 2} & 0 & 4 & 8 & 12 & 4 & 20 & 24 \\ \mathbf{2} & 0 & 0 & 2 & 2 & 0 & 4 & 4 \\ \mathbf{0} & 0 & 2 & 2 & 4 & 2 & 6 & 8 \\ \mathbf{4} & 0 & 3 & 1 & 4 & 3 & 5 & 8 \\ & & & & & & & \\ \mathbf{2 4} & 2 & 8 & 14 & 24 & 12 & 36 & 48 \\ \mathbf{3 6} & 3 & 14 & 19 & 36 & 20 & 52 & 72 \\ \mathbf{9} & 0 & 4 & 5 & 9 & 4 & 14 & 18 \\ \mathbf{1 4} & 1 & 6 & 7 & 14 & 8 & 20 & 28\end{array}$

$\begin{array}{cccccccc}\mathbf{3 4} & 0 & 13 & 21 & 34 & 13 & 55 & 68 \\ \mathbf{2} & 0 & 0 & 2 & 2 & 0 & 4 & 4 \\ \mathbf{6} & 0 & 1 & 5 & 6 & 1 & 11 & 12 \\ \mathbf{2 2} & 2 & 7 & 13 & 22 & 11 & 33 & 44 \\ \mathbf{1} & 0 & 0 & 1 & 1 & 0 & 2 & 2\end{array}$

\section{Controles}

CC CG GG Total

C G total Pgen/Palelo

$\begin{array}{llllllll}23 & 90 & 145 & 258 & 136 & 380 & 516 & 0.31 / 0.28 \\ 26 & 98 & 156 & 280 & 150 & 410 & 560 & ------ \\ 26 & 99 & 156 & 281 & 151 & 411 & 562 & 0.60 / 0.90 \\ 26 & 98 & 155 & 279 & 150 & 408 & 558 & 0.20 / 0.50 \\ & & & & & & & \\ 23 & 90 & 145 & 258 & 136 & 380 & 516 & 0.97 / 0.83 \\ 23 & 90 & 145 & 258 & 136 & 380 & 516 & 0.89 / 0.79 \\ 26 & 98 & 156 & 280 & 150 & 410 & 560 & 0.39 / 0.66 \\ 26 & 99 & 156 & 281 & 151 & 411 & 562 & 0.83 / 0.84 \\ & & & & & & & \\ 23 & 90 & 145 & 258 & 136 & 380 & 516 & 0.05 / 0.19 \\ 26 & 98 & 156 & 280 & 150 & 410 & 560 & ----- \\ 26 & 99 & 156 & 281 & 151 & 411 & 562 & 0.28 / 0.14 \\ 23 & 90 & 145 & 258 & 136 & 380 & 516 & 0.95 / 0.84 \\ 26 & 99 & 156 & 281 & 151 & 411 & 562 & ---/--\end{array}$


Novos subfenotipos propostos

FP total com agenesia

FP completa com retencao de dentes permanentes

FP completa com multiplas anomalias

FP incompleta com giroversao/lateroversao

FL/P direita com agenesia

FL/P esquerda com agenesia

FL/P esquerda com microdontia ou supranumerario

FL/P esquerda com multiplas anomalias

FL/P bilateral com agenesia

FL/P bilateral com supranumerario

FL/P bilateral com multiplas anomalias

FL/P bilateral frustro

FL/P bilateral frustro com multiplas anomalias

\section{Fissurados \\ n CC CG GG Total \\ C G total \\ CC \\ G GG Total \\ C G total Pgen/Palelo}

$\begin{array}{cccccccccccccccc}\mathbf{1 2} & 1 & 1 & 10 & 12 & 3 & 21 & 24 & 21 & 48 & 190 & 259 & 90 & 428 & 518 & 0.66 / 0.53 \\ \mathbf{2} & 0 & 0 & 2 & 2 & 0 & 4 & 4 & 24 & 52 & 205 & 281 & 100 & 462 & 562 & ---/-- \\ \mathbf{0} & 1 & 1 & 2 & 4 & 3 & 5 & 8 & 24 & 52 & 206 & 282 & 100 & 464 & 564 & 0.44 / 0.14 \\ \mathbf{4} & \mathbf{0} & \mathbf{1} & \mathbf{3} & 4 & 1 & 7 & 8 & 24 & 51 & 205 & 280 & 99 & 461 & 560 & 0.67 / 0.70 \\ & & & & & & & & & & & & & & & \\ \mathbf{2 4} & 1 & 4 & 19 & 24 & 6 & 42 & 48 & 21 & 48 & 190 & 259 & 90 & 428 & 518 & 0.74 / 0.38 \\ \mathbf{3 6} & 1 & 10 & 25 & 36 & 12 & 60 & 72 & 21 & 48 & 190 & 259 & 90 & 428 & 518 & 0.26 / 0.88 \\ \mathbf{9} & 0 & 3 & 6 & 9 & 3 & 15 & 18 & 24 & 52 & 205 & 281 & 100 & 462 & 562 & 0.27 / 0.90 \\ \mathbf{1 4} & 0 & 2 & 12 & 14 & 2 & 26 & 28 & 24 & 52 & 206 & 282 & 100 & 464 & 564 & 0.25 / 0.14 \\ & & & & & & & & & & & & & & & \\ \mathbf{3 4} & 2 & 9 & 23 & 34 & 13 & 55 & 68 & 21 & 48 & 190 & 259 & 90 & 428 & 518 & 0.52 / 0.72 \\ \mathbf{2} & 0 & 1 & 1 & 2 & 1 & 3 & 4 & 24 & 52 & 205 & 281 & 100 & 462 & 562 & 0.46 / 0.70 \\ \mathbf{6} & 0 & 1 & 5 & 6 & 1 & 11 & 12 & 24 & 52 & 206 & 282 & 100 & 464 & 564 & 0.57 / 0.39 \\ \mathbf{2 2} & 1 & 3 & 18 & 22 & 5 & 39 & 44 & 21 & 48 & 190 & 259 & 90 & 428 & 518 & 0.67 / 0.30 \\ \mathbf{1} & 0 & 0 & 1 & 1 & 0 & 2 & 2 & 24 & 52 & 206 & 282 & 100 & 464 & 564 & ---/--\end{array}$


ANEXO 9. Análise de desequilíbrio de ligação entre os polimorfismos estudados (Seção 5.5)

\begin{tabular}{|c|c|c|c|c|c|c|c|c|c|}
\hline \multicolumn{10}{|c|}{ TGFA - CASOS AMOSTRA COMPLETA } \\
\hline M2 & al1 & al2 & $\mathrm{N}$ & $d f(\Theta)$ & $d f(1)$ & Chisq & pvalue & delta2 & $D^{\prime}$ \\
\hline 2 & 2 & 2 & 455 & 453 & 452 & 29.93 & $\odot .0 \odot \odot \odot \odot$ & 43 & 0.434 \\
\hline 3 & 2 & 2 & 465 & 463 & 46 & 18.93 & $\odot .000 \odot 1$ & 17 & 0.717 \\
\hline 4 & 2 & 2 & 462 & 46 & 45 & 24 & $\odot$. & & 742 \\
\hline 5 & 2 & 2 & 462 & 46 & & 18. & $\Theta$. & & 0.712 \\
\hline 6 & 2 & 2 & 466 & 46 & 4 & & $\odot$. & & 65 \\
\hline 3 & 2 & 2 & 459 & 7 & & 20 . & & & \\
\hline 4 & 2 & 2 & 453 & & & & & & 13 \\
\hline 5 & 2 & 2 & 455 & & & 18 & 0. & & 20 \\
\hline 6 & 2 & 2 & 460 & & & & 0. & & 0.074 \\
\hline 4 & 2 & 2 & 464 & 4 & 461 & 119 & 0.0 & 23 & 0.536 \\
\hline 5 & 2 & 2 & 464 & 402 & 461 & 124.39 & $\odot .000 \odot \odot$ & 32 & 0.494 \\
\hline 6 & 2 & 2 & 472 & 470 & 469 & 3.80 & 0.05113 & 0.008 & $\odot .092$ \\
\hline 5 & 2 & 2 & 465 & 463 & 462 & 562.15 & $\odot . \odot \odot \odot \odot \odot$ & $\odot .741$ & $\odot .954$ \\
\hline 6 & 2 & 2 & 467 & 465 & 464 & 8.03 & 0.00459 & 0.018 & 0.160 \\
\hline 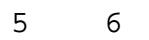 & 2 & $\angle$ & 467 & 465 & 464 & 6.79 & $\odot .0 \odot 917$ & 0.015 & $\odot .160$ \\
\hline
\end{tabular}

TGFA - CONTROLES AMOSTRA COMPLETA

\begin{tabular}{|c|c|c|c|c|c|c|c|c|c|c|}
\hline M1 & M2 & al1 & al2 & $\mathrm{N}$ & $\mathrm{df}(\odot)$ & $\mathrm{df}(1)$ & ChiSq & pvalue & delta2 & $D^{\prime}$ \\
\hline 1 & 2 & 2 & 2 & 466 & 464 & 463 & 46.68 & $\odot .0000 \odot$ & 0.074 & 0.390 \\
\hline 1 & 3 & 2 & 2 & 467 & 465 & 464 & 3.21 & 0.07311 & 0.004 & 0.249 \\
\hline 1 & 4 & 2 & 2 & 463 & 461 & 460 & 60.78 & 0.00000 & 0.055 & 0.875 \\
\hline 1 & 5 & 2 & 2 & 466 & 464 & 463 & 31.54 & $\odot .0 \odot \odot \odot \odot$ & 0.030 & 0.698 \\
\hline 1 & 6 & 2 & 2 & 467 & 465 & 464 & 0.41 & ๑. 52199 & $\odot .0 \odot \odot$ & 0.074 \\
\hline 2 & 3 & 2 & 2 & 473 & 471 & 470 & 0.12 & 0.72519 & 0.000 & 0.040 \\
\hline 2 & 4 & 2 & 2 & 468 & 466 & 465 & 19.27 & ๑ . 00001 & 0.030 & 0.446 \\
\hline 2 & 5 & 2 & 2 & 471 & 469 & 468 & 13.48 & ๑ . 00024 & 0.021 & 0.409 \\
\hline 2 & 6 & 2 & 2 & 472 & 470 & 469 & 0.18 & 0.66824 & $\odot .0 \odot \odot$ & 0.040 \\
\hline 3 & 4 & 2 & 2 & 473 & 471 & 470 & 6.30 & 0.01206 & 0.015 & 0.137 \\
\hline 3 & 5 & 2 & 2 & 475 & 473 & 472 & 4.03 & 0.04473 & $\odot .009$ & ०. .098 \\
\hline 3 & 6 & 2 & 2 & 477 & 475 & 474 & 0.02 & ๑. 90189 & 0.000 & 0.006 \\
\hline 4 & 5 & 2 & 2 & 470 & 468 & 467 & 245.73 & $\odot .00000$ & 0.421 & 0.704 \\
\hline 4 & 6 & 2 & 2 & 472 & 470 & 469 & 0.00 & 0.94663 & $\odot .000$ & 0.003 \\
\hline - & 6 & 2 & 2 & 475 & 473 & 472 & 0.46 & 0.49756 & 0.001 & 0.038 \\
\hline
\end{tabular}

\begin{tabular}{|c|c|c|c|c|c|c|c|c|c|c|}
\hline \multicolumn{11}{|c|}{ TGFA - CASOS CAUCASIANOS } \\
\hline M1 & M2 & al1 & al2 & $\mathrm{N}$ & $d f(\theta)$ & $d f(1)$ & Chisq & pvalue & delta2 & $D^{\prime}$ \\
\hline 1 & 2 & 2 & 2 & 370 & 368 & 367 & 30.65 & $\odot .0000 \odot$ & 0.055 & 0.473 \\
\hline 1 & 3 & 2 & 2 & 379 & 377 & 376 & 16.16 & 0.00006 & 0.019 & 0.689 \\
\hline 1 & 4 & 2 & 2 & 375 & 373 & 372 & 17.57 & 0.00003 & 0.022 & 0.695 \\
\hline 1 & 5 & 2 & 2 & 376 & 374 & 373 & 15.35 & 0.00009 & 0.018 & 0.682 \\
\hline 1 & 6 & 2 & 2 & 379 & 377 & 376 & 0.07 & 0.79429 & 0.000 & 0.047 \\
\hline 2 & 3 & 2 & 2 & 373 & 371 & 370 & 19.98 & ๑. .0०००1 & 0.038 & 0.465 \\
\hline 2 & 4 & 2 & 2 & 367 & 365 & 364 & 10.93 & ๑. .०००95 & 0.024 & 0.341 \\
\hline 2 & 5 & 2 & 2 & 370 & 368 & 367 & 9.87 & ๑. . 00168 & 0.020 & 0.339 \\
\hline 2 & 6 & 2 & 2 & 373 & 371 & 370 & 0.43 & 0.51308 & 0.001 & 0.056 \\
\hline 3 & 4 & 2 & 2 & 377 & 375 & 374 & 104.52 & $\odot .0 \odot \odot \odot \odot$ & 0.243 & 0.528 \\
\hline 3 & 5 & 2 & 2 & 378 & 376 & 375 & 115.55 & $\odot .0 \odot \odot \odot \odot$ & 0.263 & 0.525 \\
\hline 3 & 6 & 2 & 2 & 384 & 382 & 381 & 2.91 & ๑. 08790 & 0.007 & ๑. 088 \\
\hline 4 & 5 & 2 & 2 & 378 & 376 & 375 & 452.55 & $\odot .0000 \odot$ & 0.748 & 0.950 \\
\hline 4 & 6 & 2 & 2 & 379 & 377 & 376 & 3.43 & ๑. 06389 & 0.010 & 0.120 \\
\hline 5 & 6 & 2 & 2 & 380 & 378 & 377 & 4.25 & ๑.03932 & 0.012 & 0.142 \\
\hline
\end{tabular}


TGFA - CONTROLES CAUCASIANOS

\begin{tabular}{|c|c|c|c|c|c|c|c|c|c|c|}
\hline M1 & M2 & al1 & al2 & $\mathrm{N}$ & $d f(\odot)$ & $d f(1)$ & Chisq & pvalue & delta2 & $D^{\prime}$ \\
\hline 1 & 2 & 2 & 2 & 270 & 268 & 267 & 27.62 & $\odot . \odot \odot \odot \odot \odot$ & 0.078 & $\odot .439$ \\
\hline 1 & 3 & 2 & 2 & 271 & 269 & 268 & 2.86 & ๑.०9०91 & $\odot .005$ & 0.330 \\
\hline 1 & 4 & 2 & 2 & 270 & 268 & 267 & 27.86 & $\odot . \odot \odot \odot \odot \odot$ & $\odot .044$ & $\odot .865$ \\
\hline 1 & 5 & 2 & 2 & 270 & 268 & 267 & 9.89 & $\odot .0 \odot 166$ & 0.017 & 0.575 \\
\hline 1 & 6 & 2 & 2 & 271 & 269 & 268 & 0.24 & $\odot .62279$ & $\odot .0 \odot \odot$ & ๑. 087 \\
\hline 2 & 3 & 2 & 2 & 276 & 274 & 273 & 0.73 & $\odot .39241$ & $\odot .0 \odot 2$ & $\odot .128$ \\
\hline 2 & 4 & 2 & 2 & 274 & 272 & 271 & 6.96 & ๑.๑०832 & ๑. 020 & ๑. 351 \\
\hline 2 & 5 & 2 & 2 & 275 & 273 & 272 & 5.94 & $\odot .01480$ & 0.017 & $\odot .361$ \\
\hline 2 & 6 & 2 & 2 & 276 & 274 & 273 & $\odot .0 \odot$ & $\odot .97762$ & $\odot .0 \odot \odot$ & ๑.0०3 \\
\hline 3 & 4 & 2 & 2 & 277 & 275 & 274 & 14.56 & $\odot .00014$ & 0.062 & ๑.284 \\
\hline 3 & 5 & 2 & 2 & 277 & 275 & 274 & 7.17 & $\odot .0 \odot 743$ & 0.028 & 0.172 \\
\hline 3 & 6 & 2 & 2 & 279 & 277 & 276 & 0.37 & $\odot .54190$ & 0.002 & 0.045 \\
\hline 4 & 5 & 2 & 2 & 275 & 273 & 272 & 124.52 & $\odot . \odot \odot \odot \odot \odot$ & 0.394 & ๑.698 \\
\hline 4 & 6 & 2 & 2 & 277 & 275 & 274 & $\odot . \odot \odot$ & $\odot .99668$ & $\odot .0 \odot \odot$ & ๑. 000 \\
\hline 5 & 6 & 2 & 2 & 277 & 275 & 274 & 1.31 & $\odot .25188$ & $\odot .0 \odot 6$ & $\odot .086$ \\
\hline
\end{tabular}

TGFA - CONTROLES JAPONESES

\begin{tabular}{|c|c|c|c|c|c|c|c|c|c|c|}
\hline y1 & M2 & al1 & al2 & $\mathrm{N}$ & $d f(\theta)$ & $d f(1)$ & ChiSq & value & delta2 & $D^{\prime}$ \\
\hline 1 & 2 & 2 & 2 & 154 & 152 & 151 & 10.79 & ๑.00102 & 0.061 & $\odot .567$ \\
\hline 1 & 3 & 2 & 2 & 154 & 152 & 151 & 1.71 & $\odot .19140$ & 0.018 & $\odot .157$ \\
\hline 1 & 4 & 2 & 2 & 152 & 150 & 149 & 12.70 & $\odot .0 \odot \odot 37$ & 0.164 & 0.677 \\
\hline 1 & 5 & 2 & 2 & 152 & 150 & 149 & 12.86 & $\odot .0 \odot \odot 34$ & 0.266 & 0.730 \\
\hline 1 & 6 & 2 & 2 & 154 & 152 & 151 & 9.05 & $\odot .0 \odot 263$ & $\odot .077$ & 0.442 \\
\hline 2 & 3 & 2 & 2 & 154 & 152 & 151 & 9.88 & ๑. 00167 & $\odot .072$ & 0.532 \\
\hline 2 & 4 & 2 & 2 & 152 & 150 & 149 & 11.61 & ๑. .0००66 & 0.041 & $\odot .772$ \\
\hline 2 & 5 & 2 & 2 & 152 & 150 & 149 & 1.08 & ๑.29859 & 0.023 & 0.468 \\
\hline 2 & 6 & 2 & 2 & 154 & 152 & 151 & 16.02 & $\odot .0 \odot \odot \odot 6$ & ๑. 058 & 0.883 \\
\hline 3 & 4 & 2 & 2 & 154 & 152 & 151 & 13.60 & $\odot .0 \odot \odot 23$ & 0.110 & 0.633 \\
\hline 3 & 5 & 2 & 2 & 153 & 151 & 150 & 0.42 & $\odot .51659$ & $\odot .028$ & 0.272 \\
\hline 3 & 6 & 2 & 2 & 155 & 153 & 152 & 1.93 & 0.16450 & 0.013 & 0.205 \\
\hline 4 & 5 & 2 & 2 & 155 & 153 & 152 & 8.27 & $\odot .0 \odot 4 \odot 4$ & 0.193 & 0.548 \\
\hline 4 & 6 & 2 & 2 & 155 & 153 & 152 & 42.08 & $\odot .0 \odot \odot \odot \odot$ & 0.296 & ๑. 577 \\
\hline 5 & 6 & 2 & 2 & 155 & 153 & 152 & 0.29 & $\odot .58892$ & 0.025 & 0.17 \\
\hline
\end{tabular}

\section{IRF6 - CASOS AMOSTRA COMPLETA}

\begin{tabular}{|c|c|c|c|c|c|c|c|c|c|c|}
\hline M1 & M2 & al1 & al2 & $\mathrm{N}$ & $d f(\theta)$ & $d f(1)$ & Chisq & pvalue & delta2 & $D^{\prime}$ \\
\hline 1 & 2 & 2 & 2 & 471 & 469 & 468 & 30.39 & $\odot . ๑ \odot \odot \odot \odot ~$ & $\odot .057$ & 0.538 \\
\hline 1 & 3 & 2 & 2 & 472 & 470 & 469 & 4.87 & $\odot .02734$ & $\odot .0 \odot 9$ & 0.221 \\
\hline 1 & 4 & 2 & 2 & 477 & 475 & 474 & 5.82 & ๑. 01581 & ๑. .011 & 0.190 \\
\hline 1 & 5 & 2 & 2 & 471 & 469 & 468 & 4.77 & ๑. 02895 & $\odot . \odot \odot 9$ & 0.223 \\
\hline 1 & 6 & 2 & 2 & 478 & 476 & 475 & 3.04 & $\odot .08120$ & ๑. 006 & 0.097 \\
\hline 2 & 3 & 2 & 2 & 469 & 467 & 466 & 53.17 & $\odot .0 \odot \odot \odot \odot ~$ & ๑. 091 & 0.858 \\
\hline 2 & 4 & 2 & 2 & 467 & 465 & 464 & 3.42 & $\odot .06445$ & ๑. 005 & 0.309 \\
\hline 2 & 5 & 2 & 2 & 470 & 468 & 467 & 54.41 & $\odot . ๑ \odot \odot \odot \odot ~$ & ๑. 093 & 0.860 \\
\hline 2 & 6 & 2 & 2 & 468 & 466 & 465 & 3.96 & ๑. 04658 & $\odot .0 \odot 7$ & 0.677 \\
\hline 3 & 4 & 2 & 2 & 468 & 466 & 465 & 32.87 & $\odot . ๑ \odot \odot \odot \odot ~$ & $\odot .070$ & 0.385 \\
\hline 3 & 5 & 2 & 2 & 470 & 468 & 467 & 889.09 & $\odot . ๑ \odot \odot \odot \odot ~$ & 0.986 & $1.00 \odot$ \\
\hline 3 & 6 & 2 & 2 & 468 & 466 & 465 & 55.77 & $\odot . ๑ \odot \odot \odot \odot ~$ & $\odot .09 \odot$ & 0.873 \\
\hline 4 & 5 & 2 & 2 & 467 & 465 & 464 & 30.69 & $\odot . ๑ \odot \odot \odot \odot ~$ & ๑. 066 & 0.375 \\
\hline 4 & 6 & 2 & 2 & 473 & 471 & 470 & 14.28 & ๑. $0 \odot \odot 16$ & ๑.०3० & $0.4 \odot 4$ \\
\hline 5 & 6 & 2 & 2 & 468 & 466 & 465 & 59.81 & $\odot . \odot \odot \odot \odot \odot$ & $\odot .095$ & $\odot .903$ \\
\hline
\end{tabular}


IRF6 - CONTROLES AMOSTRA COMPLETA

\begin{tabular}{|c|c|c|c|c|c|c|c|c|c|c|}
\hline \multicolumn{11}{|c|}{ IRF6 - CONTROLES AMOSTRA COMPLETA } \\
\hline M1 & M2 & al1 & al2 & $\mathrm{N}$ & $d f(0)$ & $d f(1)$ & ChiSq & pvalue & delta2 & D' \\
\hline 1 & 2 & 2 & 2 & 474 & 472 & 471 & 72.51 & $\odot .00000$ & 0.126 & 0.562 \\
\hline 1 & 3 & 2 & 2 & 475 & 473 & 472 & 4.22 & $\odot .03993$ & 0.007 & 0.109 \\
\hline 1 & 4 & 2 & 2 & 476 & 474 & 473 & 0.70 & 0.40421 & 0.001 & 0.060 \\
\hline 1 & 5 & 2 & 2 & 476 & 474 & 473 & 4.25 & 0.03920 & $\odot .007$ & 0.110 \\
\hline 1 & 6 & 2 & 2 & 474 & 472 & 471 & 1.36 & ๑.24395 & $\odot .0 \odot 2$ & 0.171 \\
\hline 2 & 3 & 2 & 2 & 473 & 471 & 470 & 159.40 & $\odot .0 \odot \odot \odot \odot$ & 0.226 & 0.968 \\
\hline 2 & 4 & 2 & 2 & 474 & 472 & 471 & 87.51 & $\odot . \odot \odot \odot \odot \odot ~$ & 0.119 & 0.948 \\
\hline 2 & 5 & 2 & 2 & 473 & 471 & 470 & 164.05 & $\odot .0 \odot \odot \odot \odot$ & 0.231 & 0.984 \\
\hline 2 & 6 & 2 & 2 & 470 & 468 & 467 & 19.68 & $\odot .0 \odot \odot \odot 1$ & ๑.032 & 1.000 \\
\hline 3 & 4 & 2 & 2 & 475 & 473 & 472 & 400.96 & $\odot . \odot \odot \odot \odot \odot ~$ & 0.525 & 0.973 \\
\hline 3 & 5 & 2 & 2 & 474 & 472 & 471 & 851.77 & $\odot .0 \odot \odot \odot \odot$ & 0.940 & 0.970 \\
\hline 3 & 6 & 2 & 2 & 471 & 469 & 468 & 34.57 & $\odot . \odot \odot \odot \odot \odot ~$ & $\odot .059$ & 0.655 \\
\hline 4 & 5 & 2 & 2 & 475 & 473 & 472 & 390.19 & $\odot .0 \odot \odot \odot \odot$ & 0.518 & 0.966 \\
\hline 4 & 6 & 2 & 2 & 472 & 470 & 469 & 16.20 & $\odot .0 \odot \odot \odot 6$ & $\odot .030$ & 0.488 \\
\hline 5 & 6 & 2 & 2 & 472 & 470 & 469 & 37.00 & $\odot . \odot \odot \odot \odot \odot ~$ & 0.063 & 0.679 \\
\hline
\end{tabular}

$\begin{array}{cccc}\text { M1 } & \text { M2 } & \text { al1 } & \text { al } \\ 1 & 2 & 2 & 2 \\ 1 & 3 & 2 & 2 \\ 1 & 4 & 2 & 2 \\ 1 & 5 & 2 & 2 \\ 1 & 6 & 2 & 2 \\ 2 & 3 & 2 & 2 \\ 2 & 4 & 2 & 2 \\ 2 & 5 & 2 & 2 \\ 2 & 6 & 2 & 2 \\ 3 & 4 & 2 & 2 \\ 3 & 5 & 2 & 2 \\ 3 & 6 & 2 & 2 \\ 4 & 5 & 2 & 2 \\ 4 & 6 & 2 & 2 \\ 5 & 6 & 2 & 2\end{array}$

\begin{tabular}{ccr}
\multicolumn{3}{c}{ IRF6 - CASOS CA } \\
$\mathrm{N}$ & $\mathrm{df}(\Theta)$ & $\mathrm{df}(1)$ \\
385 & 383 & 382 \\
389 & 387 & 386 \\
379 & 377 & 376 \\
379 & 377 & 376 \\
380 & 378 & 377 \\
389 & 387 & 386 \\
379 & 377 & 376 \\
380 & 378 & 377 \\
380 & 378 & 377 \\
382 & 380 & 379 \\
383 & 381 & 380 \\
383 & 381 & 380 \\
381 & 379 & 378 \\
382 & 380 & 379 \\
381 & 379 & 378
\end{tabular}

CASIANOS

ChiSq pvalue delta2 $D^{\prime}$ $16.36 \quad 0.00005 \quad 0.046 \quad 0.488$ $\begin{array}{lllll}1.19 & 0.27492 & 0.003 & 0.067\end{array}$ $60.44 \quad 0.00000 \quad 0.112 \quad 1.000$ $\begin{array}{lllll}52.58 & 0.00000 & 0.104 & 0.957\end{array}$ $8.22 \quad 0.00415 \quad 0.0121 .000$ $\begin{array}{lllll}3.42 & 0.06436 & 0.008 & 0.173\end{array}$ $20.32 \quad 0.00001 \quad 0.056 \quad 0.346$ $22.41 \quad 0.0000 \odot \quad 0.062 \quad 0.359$ $0.40 \quad 0.52469 \quad 0.001 \quad 0.130$ $\begin{array}{lllll}3.05 & 0.08052 & 0.008 & 0.222\end{array}$ $\begin{array}{lllll}3.08 & 0.07939 & 0.008 & 0.219\end{array}$ $24.23 \quad 0.0000 \odot \quad \odot .06 \odot \quad 0.556$ $705.42 \quad 0.00000 \quad 0.9831 .000$ $43.59 \quad 0.00000 \quad 0.091 \quad 0.902$ $42.45 \quad 0.00000 \quad 0.0890 .900$

\section{IRF6 - CONTROLES CAUCASIANOS}

\begin{tabular}{|c|c|c|c|c|c|c|c|c|c|c|}
\hline M1 & M2 & al1 & al2 & $\mathrm{N}$ & $\mathrm{df}(\odot)$ & $d f(1)$ & Chisq & pvalue & delta2 & $D^{\prime}$ \\
\hline 1 & 2 & 2 & 2 & 276 & 274 & 273 & $16.90^{\circ}$ & $\odot . \odot \odot \odot \odot 4$ & $\odot .064$ & $\odot .548$ \\
\hline 1 & 3 & 2 & 2 & 277 & 275 & 274 & 0.10 & $\odot .75747$ & $\odot . \odot \odot \odot$ & $\odot .041$ \\
\hline 1 & 4 & 2 & 2 & 277 & 275 & 274 & 1.14 & $\odot .28608$ & $\odot .0 \odot 4$ & $\odot .108$ \\
\hline 1 & 5 & 2 & 2 & 277 & 275 & 274 & $\odot .08$ & 0.77064 & $\odot .0 \odot \odot$ & $\odot .038$ \\
\hline 1 & 6 & 2 & 2 & 275 & 273 & 272 & 0.51 & 0.47620 & 0.002 & 0.179 \\
\hline 2 & 3 & 2 & 2 & 276 & 274 & 273 & 26.53 & $\odot .0 \odot \odot \odot \odot$ & $\odot .070$ & 0.858 \\
\hline 2 & 4 & 2 & 2 & 276 & 274 & 273 & 19.53 & $\odot .0 \odot \odot \odot 1$ & 0.041 & $\odot .899$ \\
\hline 2 & 5 & 2 & 2 & 275 & 273 & 272 & 30.98 & $\odot .0 \odot \odot \odot \odot$ & $\odot .080$ & 0.927 \\
\hline 2 & 6 & 2 & 2 & 272 & 270 & 269 & 1.62 & $\odot .20369$ & 0.007 & 0.835 \\
\hline 3 & 4 & 2 & 2 & 277 & 275 & 274 & 237.20 & $\odot . \odot \odot \odot \odot \odot$ & 0.528 & $\odot .988$ \\
\hline 3 & 5 & 2 & 2 & 276 & 274 & 273 & 466.58 & $\odot . \odot \odot \odot \odot \odot$ & 0.925 & $\odot .969$ \\
\hline 3 & 6 & 2 & 2 & 273 & 271 & 270 & 12.84 & $\odot .00034$ & 0.037 & 0.573 \\
\hline 4 & 5 & 2 & 2 & 276 & 274 & 273 & 209.54 & $\odot . ๑ \odot \odot \odot \odot$ & $\odot .497$ & $\odot .952$ \\
\hline 4 & 6 & 2 & 2 & 273 & 271 & 270 & 6.70 & $\odot .0 \odot 963$ & 0.028 & 0.425 \\
\hline 5 & 6 & 2 & 2 & 273 & 271 & 270 & 12.58 & ๑.๑००39 & ๑.๑37 & 0.569 \\
\hline
\end{tabular}

$\begin{array}{ccccccc}\text { M1 } & \text { M2 } & \text { al1 } & \text { al2 } & \text { N } & \text { df }(\odot) & \text { df }(1) \\ 1 & 2 & 2 & 2 & 157 & 155 & 154 \\ 1 & 3 & 2 & 2 & 157 & 155 & 154 \\ 1 & 4 & 2 & 2 & 158 & 156 & 155 \\ 1 & 5 & 2 & 2 & 158 & 156 & 155 \\ 1 & 6 & 2 & 2 & 158 & 156 & 155 \\ 2 & 3 & 2 & 2 & 157 & 155 & 154 \\ 2 & 4 & 2 & 2 & 157 & 155 & 154 \\ 2 & 5 & 2 & 2 & 157 & 155 & 154 \\ 2 & 6 & 2 & 2 & 157 & 155 & 154\end{array}$

$\begin{array}{rccc}\text { ChiSq pvalue delta2 } & D^{\prime} \\ 3.54 & 0.05982 & 0.058 & 0.255 \\ 9.34 & 0.00224 & 0.129 & 0.471 \\ 0.25 & 0.61389 & 0.003 & 0.061 \\ 0.19 & 0.66383 & 0.001 & 0.048 \\ \odot .03 & 0.86837 & 0.00 \odot & 0.028 \\ 20.11 & 0.00001 & 0.325 & 0.792 \\ 15.44 & 0.00 \odot \odot 8 & 0.204 & 0.648 \\ 0.83 & 0.36333 & 0.008 & 0.137 \\ 7.97 & 0.00476 & 0.129 & 0.499\end{array}$




\begin{tabular}{|c|c|c|c|c|c|c|c|c|}
\hline 4 & 2 & 2 & 157 & 155 & 154 & 0.12 & $\odot .72502$ & $\odot .015$ \\
\hline 3 & 2 & 2 & 157 & 155 & 154 & 1.38 & ๑. 23981 & $\odot .012$ \\
\hline 6 & 2 & 2 & 157 & 155 & 154 & 4.08 & 0.04345 & 0.125 \\
\hline 5 & 2 & 2 & 158 & 156 & 155 & 116.78 & $\odot . \odot \odot \odot \odot \odot$ & $\odot .553$ \\
\hline 6 & 2 & 2 & 158 & 156 & 155 & 39.98 & ๑. . 00000 & 0.209 \\
\hline 6 & 2 & 2 & 158 & 156 & 155 & 24.38 & $\odot . \odot \odot \odot \odot \odot$ & $\odot .078$ \\
\hline
\end{tabular}

CROMOSSOMO 6q - CASOS AMOSTRA COMPLETA

\begin{tabular}{|c|c|c|c|c|c|c|c|c|c|c|}
\hline M1 & M2 & al1 & al2 & $\mathrm{N}$ & $d f(\odot)$ & $\mathrm{df}(1)$ & Chisq & pvalue & delta2 & $D^{\prime}$ \\
\hline 1 & 2 & 2 & 2 & 485 & 483 & 482 & 243.17 & $\odot . \odot \odot \odot \odot \odot$ & 0.421 & $\odot .804$ \\
\hline 1 & 3 & 2 & 2 & 480 & 478 & 477 & 1.00 & $\odot .31647$ & $\odot . \odot \odot 2$ & $\odot .092$ \\
\hline 1 & 4 & 2 & 2 & 485 & 483 & 482 & 3.51 & $\odot .06106$ & $\odot .006$ & 0.221 \\
\hline 1 & 5 & 2 & 2 & 480 & 478 & 477 & 3.05 & $\odot . \odot 8 \odot 63$ & $\odot .0 \odot 6$ & $\odot .182$ \\
\hline 1 & 6 & 2 & 2 & 469 & 467 & 466 & 3.75 & 0.05273 & $\odot .007$ & 0.224 \\
\hline 1 & 7 & 2 & 2 & 466 & 464 & 463 & 0.36 & $\odot .54920$ & $\odot . \odot \odot 1$ & $\odot .071$ \\
\hline 1 & 8 & 2 & 2 & 486 & 484 & 483 & 2.39 & 0.12238 & $\odot .0 \odot 4$ & $\odot .078$ \\
\hline 1 & 9 & 2 & 2 & 469 & 467 & 466 & 0.01 & ๑. 91708 & $\odot . \odot \odot \odot$ & 0.011 \\
\hline 1 & 10 & 2 & 2 & 474 & 472 & 471 & $\odot .71$ & $\odot .40 \odot 85$ & $\odot . \odot \odot 2$ & $\odot . \odot 97$ \\
\hline 1 & 11 & 2 & 2 & 460 & 458 & 457 & 2.99 & ๑.๑8399 & $\odot .006$ & $\odot .090$ \\
\hline 1 & 12 & 2 & 2 & 464 & 462 & 461 & 6.83 & $\odot . \odot \odot 899$ & $\odot .014$ & $\odot .129$ \\
\hline 1 & 13 & 2 & 2 & 486 & 484 & 483 & 0.42 & $\odot .51796$ & $\odot .001$ & $\odot .098$ \\
\hline 1 & 14 & 2 & 2 & 449 & 447 & 446 & 6.80 & $\odot . \odot \odot 91 \odot$ & $\odot .015$ & $\odot .124$ \\
\hline 1 & 15 & 2 & 2 & 472 & 470 & 469 & 7.07 & $\odot .00785$ & 0.014 & 0.121 \\
\hline 2 & 3 & 2 & 2 & 481 & 479 & 478 & 4.85 & $\odot .02770$ & 0.011 & $\odot .272$ \\
\hline 2 & 4 & 2 & 2 & 484 & 482 & 481 & 20.88 & $\odot . \odot \odot \odot \odot \odot$ & $\odot .041$ & $\odot .717$ \\
\hline 2 & 5 & 2 & 2 & 480 & 478 & 477 & 37.61 & $\odot .00000$ & 0.061 & 0.743 \\
\hline 2 & 6 & 2 & 2 & 469 & 467 & 466 & 24.09 & $\odot .0 \odot \odot \odot \odot$ & 0.039 & 0.624 \\
\hline 2 & 7 & 2 & 2 & 466 & 464 & 463 & 12.33 & $\odot .00045$ & $\odot .026$ & 0.283 \\
\hline 2 & 8 & 2 & 2 & 487 & 485 & 484 & 0.27 & $\odot .60122$ & $\odot . \odot \odot \odot$ & 0.075 \\
\hline 2 & 9 & 2 & 2 & 470 & 468 & 467 & 10.31 & 0.00133 & ๑. .022 & 0.262 \\
\hline 2 & 10 & 2 & 2 & 475 & 473 & 472 & 4.87 & $\odot .02729$ & 0.011 & $\odot .180$ \\
\hline 2 & 11 & 2 & 2 & 461 & 459 & 458 & 0.44 & $\odot .50680$ & $\odot .001$ & 0.042 \\
\hline 2 & 12 & 2 & 2 & 463 & 461 & 460 & 1.55 & 0.21330 & 0.003 & 0.073 \\
\hline 2 & 13 & 2 & 2 & 487 & 485 & 484 & 1.05 & $\odot .30618$ & $\odot .0 \odot 2$ & $\odot .185$ \\
\hline 2 & 14 & 2 & 2 & 448 & 446 & 445 & 3.90 & 0.04820 & $\odot .009$ & 0.116 \\
\hline 2 & 15 & 2 & 2 & 472 & 470 & 469 & 2.31 & 0.12881 & $\odot . \odot \odot 5$ & $\odot .083$ \\
\hline 3 & 4 & 2 & 2 & 479 & 477 & 476 & 236.08 & $\odot .00000$ & 0.387 & 0.846 \\
\hline 3 & 5 & 2 & 2 & 474 & 472 & 471 & 123.04 & $\odot .00000$ & 0.226 & 0.547 \\
\hline 3 & 6 & 2 & 2 & 470 & 468 & 467 & 88.62 & $\odot .00000$ & 0.169 & 0.478 \\
\hline 3 & 7 & 2 & 2 & 467 & 465 & 464 & 141.16 & $\odot .00000$ & 0.252 & 0.768 \\
\hline 3 & 8 & 2 & 2 & 482 & 480 & 479 & 110.08 & 0.00000 & ๑. 201 & $\odot .592$ \\
\hline 3 & 9 & 2 & 2 & 469 & 467 & 466 & 130.89 & $\odot .00000$ & 0.242 & 0.749 \\
\hline 3 & 10 & 2 & 2 & 472 & 470 & 469 & 128.62 & $\odot .00000$ & 0.241 & 0.748 \\
\hline 3 & 11 & 2 & 2 & 459 & 457 & 456 & 0.99 & ๑. 32049 & 0.002 & 0.063 \\
\hline 3 & 12 & 2 & 2 & 462 & 460 & 459 & 0.02 & ๑.88037 & 0.000 & 0.012 \\
\hline 3 & 13 & 2 & 2 & 482 & 480 & 479 & 0.55 & $\odot .45694$ & $\odot .001$ & 0.073 \\
\hline 3 & 14 & 2 & 2 & 449 & 447 & 446 & 9.06 & 0.00261 & 0.017 & 0.294 \\
\hline 3 & 15 & 2 & 2 & 472 & 470 & 469 & 4.37 & 0.03655 & $\odot .008$ & $\odot .198$ \\
\hline 4 & 5 & 2 & 2 & 479 & 477 & 476 & 413.07 & $\odot .00000$ & 0.590 & 0.902 \\
\hline 4 & 6 & 2 & 2 & 469 & 467 & 466 & 399.75 & $\odot .00000$ & $\odot .587$ & $\odot .904$ \\
\hline 4 & 7 & 2 & 2 & 466 & 464 & 463 & 132.46 & $\odot .00000$ & 0.204 & $\odot .951$ \\
\hline 4 & 8 & 2 & 2 & 485 & 483 & 482 & 242.23 & $\odot .00000$ & 0.403 & 0.656 \\
\hline 4 & 9 & 2 & 2 & 469 & 467 & 466 & 134.52 & $\odot .00000$ & 0.210 & $\odot .952$ \\
\hline 4 & 10 & 2 & 2 & 474 & 472 & 471 & 115.73 & $\odot .00000$ & 0.190 & 0.903 \\
\hline 4 & 11 & 2 & 2 & 460 & 458 & 457 & 4.59 & 0.03218 & $\odot .010$ & $\odot .101$ \\
\hline 4 & 12 & 2 & 2 & 464 & 462 & 461 & 3.12 & 0.07750 & $\odot .0 \odot 7$ & ๑. 091 \\
\hline 4 & 13 & 2 & 2 & 485 & 483 & 482 & 0.02 & ๑. 87883 & $\odot .00 \odot$ & $\odot .008$ \\
\hline 4 & 14 & 2 & 2 & 449 & 447 & 446 & 31.02 & $\odot .00000$ & $\odot .060$ & 0.756 \\
\hline 4 & 15 & 2 & 2 & 472 & 470 & 469 & 25.03 & $\odot .00000$ & $\odot .048$ & 0.662 \\
\hline 5 & 6 & 2 & 2 & 463 & 461 & 460 & 559.43 & $\odot . \odot \odot \odot \odot \odot$ & $\odot .752$ & $\odot .877$ \\
\hline 5 & 7 & 2 & 2 & 461 & 459 & 458 & 195.52 & $\odot .00000$ & $\odot .290$ & 0.943 \\
\hline 5 & 8 & 2 & 2 & 480 & 478 & 477 & 171.32 & $\odot .00000$ & ๑. 292 & 0.614 \\
\hline 5 & 9 & 2 & 2 & 465 & 463 & 462 & 196.43 & $\odot .00000$ & ๑. 291 & $\odot .934$ \\
\hline 5 & 10 & 2 & 2 & 469 & 467 & 466 & 191.29 & $\odot . \odot \odot \odot \odot \odot$ & $\odot .287$ & $\odot .933$ \\
\hline 5 & 11 & 2 & 2 & 458 & 456 & 455 & 1.14 & $\odot .28638$ & $\odot . \odot \odot 2$ & $\odot .055$ \\
\hline 5 & 12 & 2 & 2 & 459 & 457 & 456 & 0.34 & 0.56074 & $\odot .001$ & 0.032 \\
\hline 5 & 13 & 2 & 2 & 480 & 478 & 477 & 1.99 & $\odot .15816$ & $\odot .0 \odot 4$ & $\odot .088$ \\
\hline
\end{tabular}




\begin{tabular}{|c|c|c|c|c|c|c|c|c|c|c|}
\hline 5 & 14 & 2 & 2 & 447 & 445 & 444 & 1.86 & $\odot .17304$ & $\odot .004$ & 0.155 \\
\hline 5 & 15 & 2 & 2 & 467 & 465 & 464 & 2.87 & $\odot .09 \odot 22$ & $\odot . \odot \odot 5$ & 0.187 \\
\hline 6 & 7 & 2 & 2 & 465 & 463 & 462 & 204.89 & $\odot . \odot \odot \odot \odot \odot$ & .300 & 0.966 \\
\hline 6 & 8 & 0 & 2 & 470 & 468 & 467 & 162.28 & $\odot . \odot \odot \odot \odot \odot ~$ & .287 & 0.624 \\
\hline 6 & 9 & 2 & 2 & 467 & 465 & 464 & 196.37 & $\odot . ๑ \odot \odot \odot \odot ~$ & .293 & 0.95 \\
\hline 6 & 10 & 2 & 2 & 465 & 463 & 462 & 204.31 & $\odot . ๑ \odot \odot \odot \odot ~$ & .304 & 0.977 \\
\hline 6 & 11 & 2 & 2 & 452 & 450 & 449 & 0.62 & ๑. 43115 & .001 & $\odot .042$ \\
\hline 6 & 12 & 2 & 2 & 461 & 459 & 458 & 0.55 & ๑. 45872 & .001 & 0.043 \\
\hline 6 & 13 & 2 & 2 & 470 & 468 & 467 & $\odot .56$ & ๑. 45587 & .001 & 0.046 \\
\hline 6 & 14 & 2 & 2 & 448 & 446 & 445 & 3.26 & ๑. .07121 & 0.006 & $\odot .201$ \\
\hline 6 & 15 & 2 & 2 & 467 & 465 & 464 & 10.37 & ๑. 00128 & .018 & 0.346 \\
\hline 7 & 8 & 2 & 2 & 467 & 465 & 464 & 128.34 & $\odot .00000$ & 0.205 & 0.950 \\
\hline 7 & 9 & 2 & 2 & 465 & 463 & 462 & 775.62 & $\odot . ๑ \odot \odot \odot \odot ~$ & 0.936 & 0.972 \\
\hline 7 & 10 & 2 & 2 & 464 & 462 & 461 & 695.83 & ๑.๑९७९९ & .886 & 0.948 \\
\hline 7 & 11 & 2 & 2 & 451 & 449 & 448 & 0.36 & ๑.55017 & 0.001 & 0.034 \\
\hline 7 & 12 & 2 & 2 & 461 & 459 & 458 & 3.35 & ๑.06730 & $\odot .007$ & 0.115 \\
\hline 7 & 13 & 2 & 2 & 467 & 465 & 464 & 0.14 & 0.71076 & $\odot .00 \odot$ & 0.024 \\
\hline 7 & 14 & 2 & 2 & 449 & 447 & 446 & $\odot .01$ & ๑.94294 & 0.000 & $0.0 \odot 4$ \\
\hline 7 & 15 & 2 & 2 & 466 & 464 & 463 & 0.13 & 0.71902 & $\odot .00 \odot$ & 0.038 \\
\hline 8 & 9 & 2 & 2 & 470 & 468 & 467 & 129.58 & $\odot .0 \odot \odot \odot \odot$ & 0.212 & 0.951 \\
\hline 8 & 10 & 2 & 2 & 476 & 474 & 473 & 109.29 & 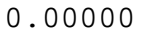 & 0.183 & 0.863 \\
\hline 8 & 11 & 2 & 2 & 461 & 459 & 458 & $\odot .0 \odot$ & ๑.97448 & $\odot .000$ & 0.001 \\
\hline 8 & 12 & 2 & 2 & 464 & 462 & 461 & $\odot .96$ & ๑. 32707 & .002 & 0.126 \\
\hline 8 & 13 & 2 & 2 & 488 & 486 & 485 & $\odot .6 \odot$ & 0.43787 & .001 & 0.044 \\
\hline 8 & 14 & 2 & 2 & 449 & 447 & 446 & 4.94 & ○.02629 & .011 & 0.326 \\
\hline 8 & 15 & 2 & 2 & 473 & 471 & 470 & ๑. 29 & $\odot .59056$ & 0.001 & 0.069 \\
\hline 9 & 10 & 2 & 2 & 467 & 465 & 464 & 652.70 & $\odot .0 \odot \odot \odot \odot$ & 0.856 & 0.929 \\
\hline 9 & 11 & 2 & 2 & 454 & 452 & 451 & $\odot .69$ & ๑. 40539 & $\odot .0 \odot 2$ & 0.049 \\
\hline 9 & 12 & 2 & 2 & 461 & 459 & 458 & 5.54 & ๑. 01861 & 0.012 & 0.149 \\
\hline 9 & 13 & 2 & 2 & 470 & 468 & 467 & 0.21 & $\odot .64494$ & $\odot .00 \odot$ & 0.032 \\
\hline 9 & 14 & 2 & 2 & 448 & 446 & 445 & 0.02 & ๑. 88710 & $\odot .0 \odot \odot$ & 0.009 \\
\hline 9 & 15 & 2 & 2 & 469 & 467 & 466 & 0.43 & $\odot .51298$ & 0.001 & 0.070 \\
\hline & 11 & 2 & 2 & 454 & 452 & 451 & 1.69 & ๑.19329 & $\odot .0 \odot 4$ & $\odot .078$ \\
\hline & 12 & 2 & 2 & 460 & 458 & 457 & 1.91 & $\odot .16731$ & 0.004 & ๑.๑88 \\
\hline & 13 & 2 & 2 & 476 & 474 & 473 & 0.07 & ๑.79104 & 0.000 & 0.030 \\
\hline$\circlearrowright$ & 14 & 2 & 2 & 446 & 444 & 443 & $\odot .0 \odot$ & 0.97421 & $\odot .000$ & $\odot .0 \odot 2$ \\
\hline 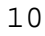 & 15 & 2 & 2 & 469 & 467 & 466 & 0.02 & ๑.87947 & 0.000 & 0.015 \\
\hline 1 & 12 & 2 & 2 & 448 & 446 & 445 & 359.27 & $\odot .0 \odot \odot \odot \odot$ & 0.618 & 0.847 \\
\hline 1 & 13 & 2 & 2 & 461 & 459 & 458 & 0.18 & ๑.66903 & 0.000 & 0.05 \\
\hline L1 & 14 & 2 & 2 & 437 & 435 & 434 & 2.82 & ๑.09282 & 0.006 & $\odot .091$ \\
\hline 11 & 15 & 2 & 2 & 455 & 453 & 452 & 11.37 & ๑.๑००75 & 0.023 & 0.183 \\
\hline$\perp 2$ & 13 & 2 & 2 & 464 & 462 & 461 & 0.62 & 0.43278 & 0.001 & 0.117 \\
\hline$\perp 2$ & 14 & 2 & 2 & 447 & 445 & 444 & 1.01 & ๑.31387 & $0.0 \odot 2$ & $0.04 \mathrm{~S}$ \\
\hline L2 & 15 & 2 & 2 & 461 & 459 & 458 & 5.87 & ๑.01542 & 0.012 & 0.118 \\
\hline 3 & 14 & 2 & 2 & 449 & 447 & 446 & $\odot .02$ & $\odot .90121$ & 0.000 & 0.005 \\
\hline 13 & 15 & 2 & 2 & 473 & 471 & 470 & $\odot .03$ & ๑.85923 & $\odot . \odot \odot \odot$ & $\odot . \odot \odot 7$ \\
\hline & 15 & 2 & 2 & 449 & 447 & 446 & 389.85 & $\odot .0 \odot \odot \odot \odot$ & 0.672 & 0.82 \\
\hline
\end{tabular}

\section{CROMOSSOMO 6q - CONTROLES AMOSTRA COMPLETA}

\begin{tabular}{|c|c|c|c|c|c|c|c|c|c|c|}
\hline M1 & M2 & al1 & al2 & $\mathrm{N}$ & $\mathrm{df}(\odot)$ & $d f(1)$ & Chisq & pvalue & delta2 & $D^{\prime}$ \\
\hline 1 & 2 & 2 & 2 & 476 & 474 & 473 & 45.99 & $\odot .000 \odot \odot$ & $\odot .080$ & 0.288 \\
\hline 1 & 3 & 2 & 2 & 475 & 473 & 472 & $\odot .31$ & $\odot .58051$ & $\odot .001$ & 0.076 \\
\hline 1 & 4 & 2 & 2 & 476 & 474 & 473 & 1.24 & ๑. 26593 & $\odot .002$ & 0.063 \\
\hline 1 & 5 & 2 & 2 & 475 & 473 & 472 & 0.19 & 0.66417 & $\odot . \odot \odot \odot ~$ & 0.032 \\
\hline 1 & 6 & 2 & 2 & 476 & 474 & 473 & $\odot .02$ & $\odot .89530$ & $\odot . \odot \odot \odot$ & $\odot . \odot \odot 7$ \\
\hline 1 & 7 & 2 & 2 & 473 & 471 & 470 & 2.06 & 0.15144 & $\odot .005$ & 0.179 \\
\hline 1 & 8 & 2 & 2 & 476 & 474 & 473 & 0.22 & 0.64146 & $\odot . \odot \odot \odot ~$ & ๑.०81 \\
\hline 1 & 9 & 2 & 2 & 476 & 474 & 473 & 3.31 & ๑. . 06896 & $\odot .008$ & 0.230 \\
\hline 1 & 10 & 2 & 2 & 475 & 473 & 472 & 2.14 & 0.14369 & 0.005 & 0.182 \\
\hline 1 & 11 & 2 & 2 & 472 & 470 & 469 & 0.10 & $\odot .75553$ & $\odot .0 \odot \odot$ & 0.018 \\
\hline 1 & 12 & 2 & 2 & 472 & 470 & 469 & $\odot .02$ & ๑. 88999 & $\odot .0 \odot \odot$ & 0.007 \\
\hline 1 & 13 & 2 & 2 & 474 & 472 & 471 & 1.40 & $\odot .23602$ & $\odot .003$ & 0.071 \\
\hline 1 & 14 & 2 & 2 & 462 & 460 & 459 & $\odot . \odot 4$ & 0.83717 & $\odot .00 \odot$ & 0.009 \\
\hline 1 & 15 & 2 & 2 & 476 & 474 & 473 & $\odot . \odot 8$ & 0.77527 & $\odot .00 \odot$ & 0.053 \\
\hline 2 & 3 & 2 & 2 & 477 & 475 & 474 & 8.44 & $\odot .00367$ & 0.013 & 0.354 \\
\hline 2 & 4 & 2 & 2 & 477 & 475 & 474 & 2.72 & ๑. 09922 & 0.004 & 0.238 \\
\hline 2 & 5 & 2 & 2 & 477 & 475 & 474 & 12.98 & $\odot .00 \odot 31$ & $\odot .020$ & 0.413 \\
\hline
\end{tabular}




\begin{tabular}{|c|c|c|c|c|c|c|c|c|c|}
\hline 6 & 2 & 2 & 478 & 476 & 475 & 3.14 & $\odot .07657$ & 0.004 & 3 \\
\hline 7 & 2 & 2 & 475 & 473 & 472 & 1.45 & 0.22837 & $\odot .0 \odot 2$ & 0.084 \\
\hline 8 & 2 & 2 & 478 & 476 & 475 & $\odot .26$ & $\odot .60829$ & 0.000 & 023 \\
\hline 9 & 2 & 2 & 477 & 475 & 474 & 2.93 & ๑. 08696 & $\odot .0 \odot 4$ & 0.115 \\
\hline 10 & 2 & 2 & 477 & 475 & 474 & 2.30 & $\odot .12908$ & $\bullet .003$ & 0.102 \\
\hline 1 & 2 & 2 & 473 & 471 & 470 & $\odot .03$ & $\odot .86024$ & $\odot . \odot \odot \odot$ & $\odot . \odot \odot 9$ \\
\hline 12 & 2 & 2 & 474 & 472 & 471 & 0.04 & $\odot .84638$ & $\odot . \odot \odot \odot$ & 0.010 \\
\hline 13 & 2 & 2 & 476 & 474 & 473 & 5.66 & 0.01737 & $\odot .0 \odot 8$ & 0.129 \\
\hline 14 & 2 & 2 & 463 & 461 & 460 & 4.92 & 0.02650 & 0.006 & 0.353 \\
\hline 15 & 2 & 2 & 478 & 476 & 475 & 3.13 & ๑.07708 & $0.0 \odot 4$ & $\odot .279$ \\
\hline 4 & 2 & 2 & 476 & 474 & 473 & 14.29 & $\odot .00016$ & 0.028 & 0.199 \\
\hline 5 & 2 & 2 & 476 & 474 & 473 & 4.48 & 0.03438 & 10 & 0.107 \\
\hline 6 & 2 & 2 & 477 & 475 & 474 & 0.92 & 3745 & 02 & 0.041 \\
\hline 7 & 2 & 2 & 474 & 472 & 471 & 1.84 & 459 & 04 & 0.117 \\
\hline 8 & 2 & 2 & 477 & 475 & 474 & 1.55 & 328 & & $\odot .075$ \\
\hline 9 & 2 & 2 & 476 & 474 & 473 & 1.16 & $\odot$. & & 0.09 \\
\hline 10 & 2 & 2 & 476 & 474 & 473 & 2.07 & ๑. 15032 & & 0.123 \\
\hline 11 & 2 & 2 & 472 & 470 & 469 & 0.02 & 0. & & 0.00 \\
\hline 12 & 2 & 2 & 473 & 471 & 470 & 0.49 & 8502 & & $\odot .037$ \\
\hline 13 & 2 & 2 & 475 & 473 & 472 & 15.57 & $\Theta$. & & 0.376 \\
\hline 14 & 2 & 2 & 462 & $46 \odot$ & 459 & 0.11 & $\Theta$. & & 0.04 \\
\hline 15 & 2 & 2 & 477 & 475 & 474 & 0.31 & 7487 & & 0.072 \\
\hline 5 & 2 & 2 & 476 & 474 & 473 & 380.41 & $\Theta$. & & $\odot .950$ \\
\hline 6 & 2 & 2 & 477 & 475 & 474 & 37.79 & $\odot$. & & 0.310 \\
\hline 7 & 2 & 2 & 474 & 472 & 471 & 68.77 & ๑.๑०००९ & 31 & 0.757 \\
\hline 8 & 2 & 2 & 477 & 475 & 474 & 91.56 & $\Theta$. & 70 & 0.480 \\
\hline 9 & 2 & 2 & 477 & 475 & 474 & 45.71 & $\odot \odot \odot \odot$ & & 0.662 \\
\hline 10 & 2 & 2 & 476 & 474 & 473 & 78.88 & $\odot .0000 \odot$ & 0. & 0.795 \\
\hline 11 & 2 & 2 & 473 & 471 & 470 & 23.56 & $\odot .0 \odot \odot \odot \odot$ & 43 & 0.224 \\
\hline 12 & 2 & 2 & 473 & 471 & 470 & 26.60 & $\odot .0000 \odot$ & 50 & 0.233 \\
\hline 13 & 2 & 2 & 475 & 473 & 472 & 13.96 & $\odot .0 \odot \odot 19$ & 20 & $\odot .368$ \\
\hline 14 & 2 & 2 & 463 & 461 & $46 \odot$ & 32.72 & $\odot .0000 \odot$ & 0. & 0.845 \\
\hline 15 & 2 & 2 & 477 & 475 & 474 & 24.36 & $\odot . \odot \odot \odot \odot \odot$ & 41 & ๑. 718 \\
\hline 6 & 2 & 2 & 477 & 475 & 474 & 101.72 & $\odot . \odot \odot \odot \odot \odot$ & 0.196 & 0.485 \\
\hline 7 & 2 & 2 & 475 & 473 & 472 & 158.64 & $\odot .0 \odot \odot \odot \odot$ & 70 & 0.847 \\
\hline 8 & 2 & 2 & 477 & 475 & 474 & 48.84 & 0. & 95 & 0.455 \\
\hline 9 & 2 & 2 & 476 & 474 & 473 & 114.70 & $0.00 \mathrm{C}$ & 18 & 0.772 \\
\hline 10 & 2 & 2 & 477 & 475 & 474 & 173.30 & $\odot . \odot \odot \odot \odot \odot$ & ๑. 284 & $\odot .877$ \\
\hline 11 & 2 & 2 & 473 & 471 & 470 & 5.55 & ๑. . 01843 & 11 & 0.121 \\
\hline 12 & 2 & 2 & 474 & 472 & 471 & 5.51 & 895 & & ๑. 128 \\
\hline 13 & 2 & 2 & 475 & 473 & 472 & 1.84 & 0.17527 & $\odot 3$ & 0.112 \\
\hline 14 & 2 & 2 & 463 & 461 & $46 \odot$ & 1.83 & $6 \odot 8$ & $\odot 4$ & $\odot .179$ \\
\hline 15 & 2 & 2 & 477 & 475 & 474 & 2.82 & $\odot .09334$ & $\odot 6$ & 0.210 \\
\hline 7 & 2 & 2 & 475 & 473 & 472 & 19.85 & $\odot . \odot \odot \odot \odot 1$ & 38 & 0.347 \\
\hline 8 & 2 & 2 & 478 & 476 & 475 & 9.39 & 218 & & 0.175 \\
\hline 9 & 2 & 2 & 477 & 475 & 474 & 23.91 & $\odot . \odot \odot \odot \odot \odot$ & 48 & ๑. 395 \\
\hline 10 & 2 & 2 & 477 & 475 & 474 & 18.20 & $\odot \odot 2$ & 34 & $\odot .335$ \\
\hline 11 & 2 & 2 & 473 & 471 & 470 & 2.84 & 9220 & 05 & 0.074 \\
\hline 12 & 2 & 2 & 474 & 472 & 471 & 2.42 & 95 & $\odot 4$ & $\odot .070$ \\
\hline 13 & 2 & 2 & 476 & 474 & 473 & $\odot .79$ & 30 & 01 & 0.078 \\
\hline 14 & 2 & 2 & 463 & 461 & $46 \odot$ & $\odot .22$ & 0.63722 & $\odot \odot$ & $\odot .060$ \\
\hline 15 & 2 & 2 & 478 & 476 & 475 & 0.11 & 321 & $\odot \odot$ & 0.041 \\
\hline 8 & 2 & 2 & 47 & 473 & 472 & 43.44 & $\odot \odot \odot \odot$ & 88 & 0.713 \\
\hline 9 & 2 & 2 & 474 & 472 & 471 & 392.76 & $\odot \odot$ & 13 & $\odot .792$ \\
\hline 10 & 2 & 2 & 475 & 473 & 472 & 752.08 & $\odot \odot$ & 05 & 0.964 \\
\hline 11 & 2 & 2 & 473 & 471 & 470 & $\odot .26$ & $\odot .61339$ & 01 & $\odot .029$ \\
\hline 12 & 2 & 2 & 474 & 472 & 471 & $\odot .89$ & ๑. 34531 & $\odot 2$ & 0.059 \\
\hline 13 & 2 & 2 & 473 & 471 & 470 & $\odot . \odot 9$ & $\odot .76320$ & $\odot \odot$ & $\odot .015$ \\
\hline 14 & 2 & 2 & 463 & 461 & $46 \odot$ & 2.87 & ๑. .9๑९०३ & $\odot 6$ & $\odot .205$ \\
\hline 15 & 2 & 2 & 475 & 473 & 472 & 2.37 & $\odot .12340$ & $\odot 5$ & $\odot .179$ \\
\hline 9 & 2 & 2 & 477 & 475 & 474 & 99.80 & $\odot . \odot \odot \odot \odot \odot$ & 0.159 & ๑. 976 \\
\hline 10 & 2 & 2 & 477 & 475 & 474 & 50.37 & $\odot . \odot \odot \odot \odot \odot$ & $\odot .097$ & 0.760 \\
\hline 11 & 2 & 2 & 473 & 471 & 470 & 7.61 & ๑. $\odot \odot 581$ & 0.014 & 0.148 \\
\hline 12 & 2 & 2 & 474 & 472 & 471 & 3.49 & ๑.06186 & $\odot .006$ & $\odot .094$ \\
\hline 13 & 2 & 2 & 476 & 474 & 473 & 11.37 & $\odot .00 \odot 74$ & 0.017 & ๑. 396 \\
\hline 14 & 2 & 2 & 463 & 461 & $46 \odot$ & 1.02 & ๑. 31143 & $\odot .0 \odot 2$ & 0.178 \\
\hline 15 & 2 & 2 & 478 & 476 & 475 & 0.05 & $\odot .83009$ & $\odot .0 \odot \odot$ & ๑. 035 \\
\hline 10 & 2 & 2 & 476 & 474 & 473 & 5 & .000 & ๑. 590 & \\
\hline
\end{tabular}




$\begin{array}{ccc}9 & 11 & 2 \\ 9 & 12 & 2 \\ 9 & 13 & 2 \\ 9 & 14 & 2 \\ 9 & 15 & 2 \\ 10 & 11 & 2 \\ 10 & 12 & 2 \\ 10 & 13 & 2 \\ 10 & 14 & 2 \\ 10 & 15 & 2 \\ 11 & 12 & 2 \\ 11 & 13 & 2 \\ 11 & 14 & 2 \\ 11 & 15 & 2 \\ 12 & 13 & 2 \\ 12 & 14 & 2 \\ 12 & 15 & 2 \\ 13 & 14 & 2 \\ 13 & 15 & 2 \\ 14 & 15 & 2\end{array}$

$\begin{array}{cc}473 & 471 \\ 473 & 471 \\ 475 & 473 \\ 463 & 461 \\ 477 & 475 \\ 473 & 471 \\ 474 & 472 \\ 475 & 473 \\ 463 & 461 \\ 477 & 475 \\ 472 & 470 \\ 471 & 469 \\ 462 & 460 \\ 473 & 471 \\ 472 & 470 \\ 462 & 460 \\ 474 & 472 \\ 461 & 459 \\ 476 & 474 \\ 463 & 461\end{array}$

470

470

472

460

474

470

471

472

460

474

469

468

459

470

469

459

471

458

473

460
$1.46 \quad 0.22670$

$1.14 \quad 0.28572$

1.320 .25069

$1.08 \quad 0.29837$

$0.14 \quad 0.70695$

$0.36 \quad 0.55021$

$\odot .18 \quad 0.66931$

$\odot .33 \quad 0.56472$

$2.56 \quad 0.10991$

$1.85 \quad 0.17414$

$597.00 \quad 0.00000$

1.010 .31550

$5.85 \quad 0.01559$

13.520 .00024

$1.36 \quad 0.24294$

$1.34 \quad 0.24682$

$3.23 \quad 0.07247$

$3.64 \quad 0.05647$

3.640 .05645

476.120 .00000
$0.003 \quad 0.071$

$0.002 \quad 0.065$

0.0020 .061

$0.002 \quad 0.122$

$0.000 \quad 0.044$

0.0010 .034

$0.000 \quad 0.026$

$0.001 \quad 0.029$

$0.005 \quad 0.185$

$0.004 \quad 0.155$

$0.813 \quad 0.943$

$0.002 \quad 0.100$

0.0110 .142

$0.026 \quad 0.213$

$0.002 \quad 0.121$

$0.003 \quad 0.065$

$\odot .006 \quad 0.098$

$\odot .007 \quad 0.118$

$0.007 \quad 0.115$

$0.788 \quad 0.910$

CROMOSSOMO 6q - CASOS CAUCASIANOS

\begin{tabular}{|c|c|c|c|c|c|c|c|c|c|c|}
\hline & & & & & & & & & & \\
\hline M1 & M2 & al1 & al2 & $\mathrm{N}$ & $d f(0)$ & $\mathrm{df}(1)$ & Chisq & pvalue & delta2 & $D^{\prime}$ \\
\hline 1 & 2 & 2 & 2 & 396 & 394 & 393 & 227.63 & 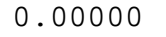 & 0.464 & 0.839 \\
\hline 1 & 3 & 2 & 2 & 391 & 389 & 388 & 2.51 & 0.11304 & $\odot .006$ & 0.165 \\
\hline 1 & 4 & 2 & 2 & 396 & 394 & 393 & 5.51 & ๑. . 01888 & ๑.011 & 0.302 \\
\hline 1 & 5 & 2 & 2 & 392 & $39 \odot$ & 389 & 5.84 & ๑. .01567 & 0.013 & 0.278 \\
\hline 1 & 6 & 2 & 2 & 381 & 379 & 378 & 6.90 & ๑. .०८6९ & ๑. 017 & 0.330 \\
\hline 1 & 7 & 2 & 2 & 379 & 377 & 376 & $\odot . \odot 9$ & 0.76865 & $\odot . \odot \odot \odot$ & 0.037 \\
\hline 1 & 8 & 2 & 2 & 397 & 395 & 394 & 2.42 & 0.11970 & ๑.๑०5 & ๑.๑89 \\
\hline 1 & 9 & 2 & 2 & 381 & 379 & 378 & 0.07 & ๑.79296 & $\odot . \odot \odot \odot$ & 0.019 \\
\hline 1 & 10 & 2 & 2 & 386 & 384 & 383 & 0.43 & 0.51082 & $\odot .001$ & ๑.๑84 \\
\hline 1 & 11 & 2 & 2 & 374 & 372 & 371 & $\odot . \odot \odot$ & ๑.97793 & $\odot . \odot \odot \odot$ & $\odot .001$ \\
\hline 1 & 12 & 2 & 2 & 377 & 375 & 374 & 3.42 & 0.06443 & $\odot . \odot \odot 9$ & 0.100 \\
\hline 1 & 13 & 2 & 2 & 364 & 362 & 361 & 4.13 & ๑. 04223 & ๑.011 & 0.112 \\
\hline 1 & 14 & 2 & 2 & 397 & 395 & 394 & 1.14 & ○. 28523 & $\odot . \odot \odot 2$ & 0.175 \\
\hline 1 & 15 & 2 & 2 & 383 & 381 & 380 & 5.20 & 0.02261 & ๑. .014 & 0.124 \\
\hline 2 & 3 & 2 & 2 & 392 & 390 & 389 & 2.34 & 0.12588 & $\odot .007$ & 0.215 \\
\hline 2 & 4 & 2 & 2 & 395 & 393 & 392 & 15.44 & ๑.๑०९०९ & ๑.041 & 0.704 \\
\hline 2 & 5 & 2 & 2 & 392 & $39 \odot$ & 389 & 27.43 & ๑.๑๑९९९ & $\odot .057$ & 0.717 \\
\hline 2 & 6 & 2 & 2 & 381 & 379 & 378 & 18.75 & ๑. $0 \odot \odot \odot 1$ & ๑. 038 & 0.599 \\
\hline 2 & 7 & 2 & 2 & 379 & 377 & 376 & 7.49 & 0.00619 & ๑ . 019 & 0.244 \\
\hline 2 & 8 & 2 & 2 & 398 & 396 & 395 & 0.01 & 0.90400 & $\odot .00 \odot$ & 0.017 \\
\hline 2 & 9 & 2 & 2 & 382 & 380 & 379 & 7.55 & 0.00601 & $\odot .020$ & 0.250 \\
\hline 2 & 10 & 2 & 2 & 387 & 385 & 384 & 3.92 & 0.04773 & 0.011 & 0.182 \\
\hline 2 & 11 & 2 & 2 & 375 & 373 & 372 & 0.21 & 0.64613 & $\odot .000$ & 0.084 \\
\hline 2 & 12 & 2 & 2 & 376 & 374 & 373 & 0.49 & 0.48308 & 0.001 & 0.043 \\
\hline 2 & 13 & 2 & 2 & 363 & 361 & 360 & 3.16 & ๑. 07552 & ๑. . 010 & 0.111 \\
\hline 2 & 14 & 2 & 2 & 398 & 396 & 395 & 1.34 & ๑. 24776 & $\odot .003$ & 0.226 \\
\hline 2 & 15 & 2 & 2 & 383 & 381 & 380 & 1.73 & ๑. 18879 & 0.004 & $\odot .074$ \\
\hline 3 & 4 & 2 & 2 & 390 & 388 & 387 & 199.45 & $\odot . \odot \odot \odot \odot \odot$ & $\odot .408$ & 0.860 \\
\hline 3 & 5 & 2 & 2 & 386 & 384 & 383 & 104.74 & $\odot .0 \odot \odot \odot \odot$ & 0.242 & 0.569 \\
\hline 3 & 6 & 2 & 2 & 382 & 380 & 379 & 71.62 & $\odot . \odot \odot \odot \odot \odot$ & 0.171 & 0.469 \\
\hline 3 & 7 & 2 & 2 & 380 & 378 & 377 & 110.80 & $\odot .0 \odot \odot \odot \odot$ & 0.246 & 0.759 \\
\hline 3 & 8 & 2 & 2 & 393 & 391 & 390 & 100.75 & $\odot .00 \odot \odot \odot$ & ๑. 228 & 0.621 \\
\hline 3 & 9 & 2 & 2 & 381 & 379 & 378 & 104.48 & $\odot . ๑ \odot \odot \odot \odot$ & 0.241 & 0.747 \\
\hline 3 & 10 & 2 & 2 & 384 & 382 & 381 & 108.06 & $\odot .0 \odot \odot \odot \odot$ & 0.247 & 0.752 \\
\hline 3 & 11 & 2 & 2 & 373 & 371 & 370 & $\odot .75$ & 0.38583 & $\odot .002$ & 0.063 \\
\hline 3 & 12 & 2 & 2 & 375 & 373 & 372 & 0.02 & 0.87944 & $\odot .00 \odot$ & 0.011 \\
\hline 3 & 13 & 2 & 2 & 364 & 362 & 361 & 4.59 & 0.03217 & 0.011 & 0.255 \\
\hline 3 & 14 & 2 & 2 & 393 & 391 & 390 & 0.46 & $\odot .49573$ & $\odot .0 \odot 1$ & $\odot .077$ \\
\hline 3 & 15 & 2 & 2 & 383 & 381 & 380 & 2.42 & 0.11941 & $\odot .006$ & 0.180 \\
\hline 4 & 5 & 2 & 2 & 391 & 389 & 388 & 335.14 & $\odot . ๑ \odot \odot \odot \odot$ & $\odot .597$ & 0.896 \\
\hline 4 & 6 & 2 & 2 & 381 & 379 & 378 & 322.85 & $\odot .0 \odot \odot \odot \odot$ & 0.585 & 0.913 \\
\hline 4 & 7 & 2 & 2 & 379 & 377 & 376 & 110.85 & $\odot . \odot \odot \odot \odot \odot$ & 0.214 & 0.960 \\
\hline 4 & 8 & 2 & 2 & 396 & 394 & 393 & 216.82 & $\odot . ๑ \odot \odot \odot \odot$ & 0.440 & $\odot .690$ \\
\hline 4 & 9 & 2 & 2 & 381 & 379 & 378 & 112.95 & ๑.๑૦૦०९ & 0.221 & 0.961 \\
\hline
\end{tabular}




\begin{tabular}{|c|c|c|c|c|c|c|c|c|c|}
\hline 10 & 2 & 2 & 386 & 384 & 383 & 95.86 & $\odot .0000 \odot$ & 0.199 & 0.904 \\
\hline 11 & 0 & 2 & 374 & 372 & 371 & 3.62 & ๑. . 05699 & 0.010 & 0.106 \\
\hline 12 & 2 & 2 & 377 & 375 & 374 & 2.62 & $\odot .10532$ & $\odot .007$ & ๑. 096 \\
\hline 13 & 2 & 2 & 364 & 362 & 361 & 21.39 & $\odot .0 \odot \odot \odot \odot$ & .055 & 0.758 \\
\hline 14 & & 2 & 396 & 394 & 393 & 0.05 & $\odot .81573$ & ๑.००० & 0.033 \\
\hline 15 & 2 & 2 & 383 & 381 & 380 & 18.19 & $\odot .0 \odot \odot \odot 2$ & 0.043 & 0.673 \\
\hline 6 & 2 & 2 & 376 & 374 & 373 & 467.01 & $\odot . ๑ \odot \odot \odot \odot$ & 0.767 & 0.886 \\
\hline 7 & 2 & 0 & 375 & 373 & 372 & 164.77 & $\odot . \odot \odot \odot \odot \odot ~$ & 0.299 & 0.958 \\
\hline 8 & 2 & 2 & 392 & 390 & 389 & 149.82 & $\odot .0 \odot \odot \odot \odot$ & 317 & 0.628 \\
\hline 9 & 2 & 2 & 378 & 376 & 375 & 165.19 & $\odot . \odot \odot \odot \odot \odot ~$ & 0.301 & 0.946 \\
\hline 10 & 2 & 8 & 382 & 380 & 379 & 163.21 & $\odot .0 \odot \odot \odot \odot$ & ๑. 299 & 0.946 \\
\hline 11 & 2 & 2 & 372 & 370 & 369 & 1.40 & $\odot .23660$ & 0.003 & 0.071 \\
\hline 12 & 2 & 2 & 373 & 371 & 370 & $\odot .23$ & 0.63220 & 001 & 30 \\
\hline 13 & 2 & 2 & 362 & 360 & 359 & 0.95 & ๑. 33092 & 002 & 0.130 \\
\hline 14 & 2 & 2 & 392 & 390 & 389 & 2.47 & 1619 & 06 & 0.112 \\
\hline 15 & 2 & 2 & 379 & 377 & 376 & 1.53 & 631 & 04 & 0.163 \\
\hline 7 & 2 & 2 & 378 & 376 & 375 & 170.11 & $\odot \odot \odot$ & 11 & 0 \\
\hline 8 & 2 & 2 & 382 & 380 & 379 & 142.41 & ๑९० & 11 & 53 \\
\hline 9 & 2 & 2 & 379 & 377 & 376 & 161.82 & & 03 & 46 \\
\hline 10 & 2 & 2 & 377 & 375 & 374 & 172.48 & 00 & 321 & 72 \\
\hline 11 & 2 & 2 & 367 & 365 & 364 & 0.84 & 59 & $\odot 2$ & 0 \\
\hline 12 & 2 & 2 & 374 & 372 & 371 & $\odot .75$ & 604 & $\odot 2$ & 0 \\
\hline 13 & 2 & 0 & 363 & 361 & 360 & 1.10 & 423 & 02 & 32 \\
\hline 14 & 2 & 2 & 382 & 380 & 379 & $\odot .61$ & 568 & 01 & 0 \\
\hline 15 & 2 & 2 & 379 & 377 & 376 & 5.69 & 706 & 12 & 999 \\
\hline 8 & 2 & 2 & 380 & 378 & 377 & 104. & & & 959 \\
\hline 9 & 2 & 2 & 378 & 376 & 375 & 640.51 & & & 977 \\
\hline 10 & 2 & 2 & 377 & 375 & 374 & 574.69 & & & 959 \\
\hline 11 & 2 & 2 & 366 & 364 & 363 & 0.17 & 190 & & 27 \\
\hline 12 & 2 & 2 & 374 & 372 & 371 & & 012 & & 77 \\
\hline 13 & 2 & 0 & 364 & 362 & 361 & $\odot$ & & & 51 \\
\hline 14 & 2 & 2 & 380 & 378 & 377 & & 10 & & 30 \\
\hline 15 & 2 & 0 & 379 & 377 & 376 & & & & 75 \\
\hline 9 & 2 & 2 & 382 & 380 & 379 & 100 & & & 40 \\
\hline 10 & 2 & 0 & 388 & 386 & 385 & & & & 357 \\
\hline 11 & 2 & 2 & 375 & 373 & 372 & & 28 & & 911 \\
\hline 12 & 2 & 2 & 377 & 375 & 374 & & & & 29 \\
\hline 13 & 2 & 2 & 364 & 362 & 361 & & & & 13 \\
\hline 14 & 2 & 2 & 399 & 397 & 396 & & & & 30 \\
\hline 15 & 2 & 2 & 384 & 382 & 381 & & & & 32 \\
\hline 10 & 2 & 2 & 379 & 377 & 376 & 8 & & & 31 \\
\hline 11 & 2 & 2 & 369 & 367 & 366 & & & & 57 \\
\hline 12 & 2 & 2 & 374 & 372 & 371 & & & & 12 \\
\hline 13 & 2 & 2 & 363 & 361 & 360 & & & & 19 \\
\hline 14 & 2 & 2 & & & 379 & & & & 37 \\
\hline 15 & 2 & 2 & 381 & 379 & 378 & & & & $\odot .087$ \\
\hline 11 & 2 & 2 & & & 66 & & & & 0.077 \\
\hline 12 & 2 & 2 & 373 & 371 & 370 & & 23 & $\odot 2$ & 959 \\
\hline 13 & 2 & 2 & 361 & 359 & 358 & & & $\odot \odot$ & 918 \\
\hline 14 & 2 & 2 & 388 & 386 & 385 & & 209 & 01 & 0.059 \\
\hline 15 & 2 & 2 & 381 & 379 & 378 & & 281 & $\odot \odot$ & 0.026 \\
\hline 12 & 2 & 2 & 363 & 361 & 360 & 270.99 & 0.00000 & 00 & 0.825 \\
\hline 13 & 2 & 2 & 353 & 351 & 350 & 0.20 & $\odot .65226$ & 001 & 0.028 \\
\hline 14 & 2 & 2 & 375 & 373 & 372 & & 0.23830 & 0.003 & 0.194 \\
\hline 15 & 2 & 2 & 369 & 367 & 366 & 4.94 & 0.02618 & 0.014 & 0.147 \\
\hline 13 & 2 & 2 & 362 & 360 & 359 & 0.03 & 0.86512 & $\odot .000$ & 0.029 \\
\hline 14 & 2 & 2 & 377 & 375 & 374 & $\odot .82$ & 0.36635 & $\odot .002$ & 0.157 \\
\hline 15 & 2 & 2 & 374 & 372 & 371 & 1.39 & 0.23796 & $\odot .004$ & 0.069 \\
\hline 14 & 2 & 2 & 364 & 362 & 361 & 0.20 & 0.65253 & 0.001 & 0.024 \\
\hline 15 & 2 & 2 & 364 & 362 & 361 & 290.91 & $\odot .00000$ & 0.656 & 0.810 \\
\hline 15 & 2 & 2 & 384 & 382 & 381 & 0.80 & 0.37061 & $\odot .0 \odot 2$ & $\odot . \odot$ \\
\hline
\end{tabular}

CROMOSSOMO 6q - CONTROLES CAUCASIANOS

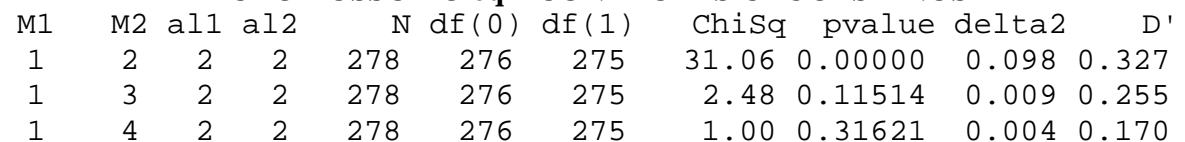




\begin{tabular}{|c|c|c|c|c|c|c|c|c|c|c|}
\hline 1 & 5 & 2 & 2 & 277 & 275 & 274 & 2.19 & $\odot .13907$ & 0.011 & 0.272 \\
\hline 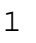 & 6 & 2 & 2 & 278 & 276 & 275 & $\odot .42$ & ๑. 51891 & $\odot .001$ & 0.102 \\
\hline & 7 & 2 & 2 & 276 & 274 & 273 & $\odot . \odot \odot$ & ๑. 98413 & 0.000 & 0.001 \\
\hline & 8 & 2 & 2 & 278 & 276 & 275 & $\odot .02$ & ๑.89726 & $\odot .0 \odot \odot$ & 0.008 \\
\hline & 9 & 2 & 2 & 278 & 276 & 275 & 1.54 & ๑. 21412 & 0.007 & 0.232 \\
\hline & 10 & 2 & 2 & 277 & 275 & 274 & $\odot .01$ & 0.91524 & $\odot .0 \odot \odot$ & 0.017 \\
\hline & 11 & 2 & 2 & 275 & 273 & 272 & 1.51 & $\odot .21960$ & $\odot .007$ & 0.265 \\
\hline & 12 & 2 & 2 & 275 & 273 & 272 & 2.04 & ๑.15311 & 0.008 & 0.304 \\
\hline & 13 & 2 & 2 & 272 & 270 & 269 & 0.14 & 0.71002 & 0.001 & 0.026 \\
\hline & 14 & 2 & 2 & 277 & 275 & 274 & 2.47 & $\odot .11571$ & 0.009 & 0.116 \\
\hline & 15 & 2 & 2 & 278 & 276 & 275 & $\odot .01$ & 0.90790 & $\odot .000$ & 0.008 \\
\hline & 3 & 2 & 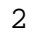 & 279 & 277 & 276 & 8.50 & ๑.0๑355 & 0.021 & 0.417 \\
\hline & 4 & 2 & 2 & 279 & 277 & 276 & 3.06 & ๑. .08०28 & $\odot .0 \odot 9$ & 0.272 \\
\hline & 5 & 2 & 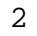 & 278 & 276 & 275 & 5.74 & ๑.01658 & 0.017 & 0.360 \\
\hline & 6 & 2 & 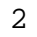 & 279 & 277 & 276 & 1.56 & 0.21126 & $\odot .003$ & 0.183 \\
\hline & 7 & 2 & 2 & 277 & 275 & 274 & 0.12 & $\odot .72553$ & $\odot . \odot \odot \odot$ & 0.050 \\
\hline & 8 & 2 & 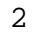 & 279 & 277 & 276 & $\odot .03$ & ๑.87361 & $\odot .00 \odot$ & 0.010 \\
\hline & 9 & 2 & 8 & 279 & 277 & 276 & 0.19 & 0.66284 & 0. & 0.036 \\
\hline & 10 & 2 & 2 & 278 & 276 & 275 & 0.02 & ๑.89127 & $\odot .00 \odot$ & 0.019 \\
\hline & 11 & 2 & 0 & 276 & 274 & 273 & $\odot . \odot \odot$ & 491 & & $\odot .0 \odot 4$ \\
\hline & 12 & 2 & 2 & 276 & 274 & 273 & 0.01 & $0 . \varsigma$ & $\odot$. & 0.018 \\
\hline & 13 & 2 & 2 & 273 & 271 & 270 & 3.72 & 389 & $\odot$. & 0.445 \\
\hline & 14 & 2 & 2 & 278 & 276 & 275 & 1.60 & 0.2 & 0. & 0.081 \\
\hline & 15 & 2 & 2 & 279 & 277 & 276 & 0.97 & 0.3 & 0.002 & 0.234 \\
\hline & 4 & 2 & 2 & 279 & 277 & 276 & 3.79 & 0.0 & 0. & 0.122 \\
\hline & 5 & 2 & 2 & 278 & 276 & 275 & 1.70 & $0.1 \mathrm{~s}$ & & 0.089 \\
\hline & 6 & 2 & 2 & 279 & 277 & 276 & 0.87 & 0. & & 0.058 \\
\hline & 7 & 2 & 2 & 277 & 275 & 274 & 0.01 & $\odot$. & & 0.008 \\
\hline & 8 & 2 & 2 & 279 & 277 & 276 & 0.27 & $\odot$. & & 0.069 \\
\hline & 9 & 2 & 2 & 279 & 277 & 276 & $\odot .0 \odot$ & $\odot$. & & 0.004 \\
\hline & 10 & 2 & 2 & 278 & 276 & 275 & 0.07 & $\Theta$. & & 30 \\
\hline & 11 & 2 & 2 & 276 & 274 & 273 & 0.15 & $\odot$. & & 28 \\
\hline & 12 & 2 & 2 & 276 & 274 & 273 & 1.44 & $\Theta$. & & 0.094 \\
\hline & 13 & 2 & 2 & 273 & 271 & 270 & 1.40 & $\odot$. & & 0.228 \\
\hline & 14 & 2 & 2 & 278 & 276 & 275 & 9.29 & $\odot$. & & 0.370 \\
\hline & 15 & 2 & 2 & 279 & 277 & 276 & 2.71 & & & 0.293 \\
\hline & 5 & 2 & 2 & 278 & 276 & 275 & 335.77 & & & $\odot .947$ \\
\hline & 6 & 2 & 2 & 279 & 277 & 276 & 26 & $\Theta$. & & 0.314 \\
\hline & 7 & 2 & 2 & 277 & 275 & 274 & 58 & & & 0.772 \\
\hline & 8 & 2 & 2 & 279 & 277 & 276 & & & & 524 \\
\hline & 9 & 2 & 2 & 279 & 277 & 276 & & & & 0.683 \\
\hline & 10 & 2 & 2 & 278 & 276 & 275 & & & & 99 \\
\hline & 11 & 2 & 2 & 276 & 274 & 273 & & & & 0.254 \\
\hline & 12 & 2 & 2 & 276 & 274 & 273 & & & & 0.299 \\
\hline & 13 & 2 & 2 & 273 & 271 & 270 & 46 & & & $\odot .754$ \\
\hline & 14 & 2 & 2 & 278 & 276 & 275 & 3.14 & $\odot$. & & 0.215 \\
\hline & 15 & 2 & 2 & 279 & 277 & 276 & 8.42 & & & 0.548 \\
\hline & 6 & 2 & 2 & 278 & 276 & 275 & 24 & & & 0.345 \\
\hline 5 & 7 & 2 & 2 & 277 & 275 & 274 & 92 & & & 0.876 \\
\hline 5 & 8 & 2 & 2 & 278 & 276 & 275 & 37 & & & 0.490 \\
\hline 5 & 9 & 2 & 2 & 278 & 276 & 275 & 57 & & & 0.752 \\
\hline 5 & 10 & 2 & 2 & 278 & 276 & 275 & & & & 0.879 \\
\hline 5 & 11 & 2 & 2 & 276 & 274 & 273 & 97 & 0. & 46 & 0.271 \\
\hline 5 & 12 & 2 & 2 & 276 & 274 & 273 & 12.58 & $\Theta$. & 47 & 0.286 \\
\hline 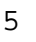 & 13 & 2 & 2 & 273 & 271 & 270 & 2.55 & 0. & 10 & $\odot .310$ \\
\hline 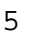 & 14 & 2 & 2 & 277 & 275 & 274 & 2.34 & 0. & & 0.176 \\
\hline 5 & 15 & 2 & 2 & 278 & 276 & 275 & 2.02 & 0.15487 & $\odot 8$ & 0.259 \\
\hline 6 & 7 & 2 & 2 & 277 & 275 & 274 & 3.11 & ๑. 07781 & 11 & 0.187 \\
\hline 6 & 8 & 2 & 2 & 279 & 277 & 276 & 5.81 & ๑. 01596 & 18 & 0.161 \\
\hline 6 & 9 & 2 & 2 & 279 & 277 & 276 & 2.54 & 0.11071 & 0. & 0.177 \\
\hline 6 & 10 & 2 & 2 & 278 & 276 & 275 & 2.41 & 0.12047 & $\odot .0 \odot 8$ & 0.163 \\
\hline 6 & 11 & 2 & 2 & 276 & 274 & 273 & 3.14 & 0.07651 & 0.010 & 0.108 \\
\hline 6 & 12 & 2 & 2 & 276 & 274 & 273 & 1.74 & 0.18696 & 0.005 & $\odot .082$ \\
\hline 6 & 13 & 2 & 2 & 273 & 271 & 270 & 2.95 & ๑.08596 & ๑. . 08 & $\odot .307$ \\
\hline 6 & 14 & 2 & 2 & 278 & 276 & 275 & 0.98 & 0.32277 & 0.003 & 0.127 \\
\hline & 15 & 2 & 2 & 279 & 277 & 276 & 1.62 & ๑. 20358 & 0.005 & $\odot .229$ \\
\hline & 8 & 2 & 2 & 277 & 275 & 274 & 32.02 & $\odot .0000 \odot$ & 0.119 & 0.753 \\
\hline & 9 & 2 & 2 & 277 & & & 4.87 & 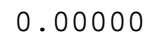 & $\odot .532$ & \\
\hline
\end{tabular}




\begin{tabular}{|c|c|c|c|c|c|c|c|c|c|}
\hline 10 & 2 & 2 & 277 & 275 & 274 & 426.88 & ๑.๑९९๑९ & $\odot .909$ & 95 \\
\hline 11 & 2 & 2 & 276 & 274 & 273 & 1.30 & ๑. 25416 & $\odot .006$ & 151 \\
\hline 12 & 2 & 2 & 276 & 274 & 273 & 93 & 3464 & $\odot 4$ & 134 \\
\hline 13 & 2 & 2 & 273 & 271 & 270 & $\odot . \odot \odot$ & $\odot .95475$ & $\odot \odot$ & $\odot \odot 8$ \\
\hline 14 & 2 & 2 & 276 & 274 & 273 & 22 & 4061 & 01 & 957 \\
\hline 15 & 2 & 2 & 277 & 275 & 274 & $\odot .12$ & 73198 & $\odot \odot$ & 64 \\
\hline 9 & 2 & 2 & 279 & 277 & 276 & 63.67 & ๑०९९ & 87 & 966 \\
\hline 10 & 2 & 2 & 278 & 276 & 275 & 37.08 & $\partial \odot$ & & 2 \\
\hline 11 & 2 & 2 & 276 & 274 & 273 & 1.54 & 0.21 & & 78 \\
\hline 12 & 2 & 2 & 276 & 274 & 273 & 1.09 & 87 & & 62 \\
\hline 13 & 2 & 2 & 273 & 271 & 270 & $\odot .62$ & 26 & & 91 \\
\hline 14 & 2 & 2 & 278 & 276 & 275 & 2.58 & & & \\
\hline 15 & 2 & 2 & 279 & 277 & 276 & $\odot .42$ & & & \\
\hline 10 & 2 & 2 & 278 & 276 & 275 & 179.02 & & & \\
\hline 11 & 2 & 2 & 276 & 274 & 273 & 1 & & & \\
\hline 12 & 2 & 2 & 276 & 274 & 273 & 0.29 & & & \\
\hline 13 & 2 & 2 & 273 & 271 & 270 & 0.05 & 6 & & \\
\hline 14 & 2 & 2 & 278 & 276 & 275 & $\odot .08$ & 39 & & \\
\hline 15 & 2 & 2 & 279 & 277 & 276 & 0.60 & $\Theta$. & & 3 \\
\hline 11 & 2 & 2 & 276 & 274 & 273 & 28 & & & \\
\hline 12 & 2 & 2 & 276 & 274 & 273 & 57 & $\odot$. & & \\
\hline 13 & 2 & 2 & 273 & 271 & 270 & 0.19 & $\odot$. & & \\
\hline 14 & 2 & 2 & 277 & 275 & 274 & 94 & $\odot$. & & \\
\hline 15 & 2 & 2 & 278 & 276 & 275 & $\odot .06$ & $\odot$. & & 27 \\
\hline 12 & 2 & 2 & 275 & 273 & 272 & 321.84 & 0. & 0. & 31 \\
\hline 13 & 2 & 2 & 272 & 270 & 269 & 1.94 & 0.1 & & 0.127 \\
\hline 14 & 2 & 2 & 275 & 273 & 272 & 0.00 & $\odot .95632$ & $\odot$. & $\odot .0 \odot 7$ \\
\hline 15 & 2 & 2 & 276 & 274 & 273 & 10.02 & ๑. . 00155 & 0.036 & 0.28 \\
\hline 13 & 2 & 2 & 272 & 270 & 269 & 0.32 & $\odot .57459$ & 0.001 & 0.05 \\
\hline 14 & 2 & 2 & 275 & 273 & 272 & 0.05 & 0.82634 & 0.000 & $\odot .03$ \\
\hline 15 & 2 & 2 & 276 & 274 & 273 & 2.42 & 0.12001 & $\odot .0 \odot 8$ & 0.12 \\
\hline 14 & 2 & 2 & 272 & 270 & 269 & 0.46 & 0.49547 & 0.002 & $\odot .060$ \\
\hline 15 & 2 & 2 & 273 & 271 & 270 & 228.47 & ๑. . 00000 & 0.732 & $\odot .880$ \\
\hline 15 & 2 & 2 & 278 & 276 & 275 & 1.35 & $\odot .24525$ & 0.005 & 0.1 \\
\hline
\end{tabular}

\section{CROMOSSOMO 6q - CONTROLES JAPONESES}

\begin{tabular}{|c|c|c|c|c|c|c|c|c|c|c|}
\hline M1 & M2 & al1 & al2 & $\mathrm{N}$ & $d f(0)$ & $d f(1)$ & Chisq & pvalue & delta2 & $D^{\prime}$ \\
\hline 1 & 2 & 2 & 2 & 156 & 154 & 153 & 2.76 & $\odot .09686$ & 0.107 & $\odot .498$ \\
\hline 1 & 3 & 2 & 2 & 155 & 153 & 152 & 7.97 & $\odot .0 \odot 474$ & 0.210 & 0.633 \\
\hline 1 & 4 & 2 & 2 & 155 & 153 & 152 & 1.51 & 0.21854 & 0.025 & 0.300 \\
\hline 1 & 5 & 2 & 2 & 156 & 154 & 153 & 15.36 & $\odot .0 \odot \odot \odot 9$ & 0.286 & 0.696 \\
\hline 1 & 6 & 2 & 2 & 156 & 154 & 153 & 2.62 & $\odot .10585$ & 0.121 & 0.519 \\
\hline 1 & 7 & 2 & 2 & 155 & 153 & 152 & 0.97 & 0.32474 & 0.045 & 0.342 \\
\hline 1 & 8 & 2 & 2 & 155 & 153 & 152 & 0.89 & ๑. 34611 & 0.007 & 0.104 \\
\hline 1 & 9 & 2 & 2 & 156 & 154 & 153 & 10.70 & 0.00107 & 0.236 & 0.925 \\
\hline 1 & 10 & 2 & 2 & 156 & 154 & 153 & 20.29 & ๑. . & 0.321 & 0.807 \\
\hline 1 & 11 & 2 & 2 & 155 & 153 & 152 & $\odot .01$ & 0.91131 & $\odot .00 \odot$ & 0.023 \\
\hline 1 & 12 & 2 & 2 & 155 & 153 & 152 & 1.39 & ๑. 23919 & 0.012 & 0.271 \\
\hline 1 & 13 & 2 & 2 & 155 & 153 & 152 & 2.07 & 0.15056 & 0.038 & 0.204 \\
\hline 1 & 14 & 2 & 2 & 148 & 146 & 145 & $\odot . \odot 5$ & ๑.82091 & $\odot . \odot \odot \odot$ & $\odot .026$ \\
\hline 1 & 15 & 2 & 2 & 148 & 146 & 145 & 22.32 & $\odot . \odot \odot \odot \odot \odot$ & $\odot .358$ & $\odot .862$ \\
\hline 2 & 3 & 2 & 2 & 155 & 153 & 152 & 21.28 & $\odot . \odot \odot \odot \odot \odot$ & 0.344 & $\odot .642$ \\
\hline 2 & 4 & 2 & 2 & 155 & 153 & 152 & 8.17 & $\odot .0 \odot 425$ & 0.114 & $\odot .485$ \\
\hline 2 & 5 & 2 & 2 & 156 & 154 & 153 & 38.51 & $\odot . \odot \odot \odot \odot \odot$ & $\odot .463$ & $\odot .698$ \\
\hline 2 & 6 & 2 & 2 & 156 & 154 & 153 & 35.02 & $\odot . ๑ \odot \odot \odot \odot$ & 0.406 & 0.650 \\
\hline 2 & 7 & 2 & 2 & 155 & 153 & 152 & 15.30 & $\odot .0 \odot \odot \odot 9$ & $\odot .243$ & $\odot .599$ \\
\hline 2 & 8 & 2 & 2 & 155 & 153 & 152 & 1.60 & $\odot .20542$ & $\odot .012$ & $\odot .217$ \\
\hline 2 & 9 & 2 & 2 & 156 & 154 & 153 & 29.61 & $\odot . \odot \odot \odot \odot \odot$ & $\odot .349$ & 0.740 \\
\hline 2 & 10 & 2 & 2 & 156 & 154 & 153 & 49.77 & $\odot . \odot \odot \odot \odot \odot$ & $\odot .521$ & $\odot .770$ \\
\hline 2 & 11 & 2 & 2 & 155 & 153 & 152 & 8.63 & $\odot .00330$ & 0.124 & 0.489 \\
\hline 2 & 12 & 2 & 2 & 155 & 153 & 152 & 0.40 & 0.52653 & $\odot .0 \odot 4$ & 0.120 \\
\hline 2 & 13 & 2 & 2 & 155 & 153 & 152 & 1.30 & 0.25347 & 0.067 & 0.360 \\
\hline 2 & 14 & 2 & 2 & 148 & 146 & 145 & 0.62 & $\odot .43200$ & ๑. 013 & $\odot .199$ \\
\hline 2 & 15 & 2 & 2 & 148 & 146 & 145 & 53.92 & $\odot . \odot \odot \odot \odot \odot ~$ & 0.575 & 0.811 \\
\hline 3 & 4 & 2 & 2 & 155 & 153 & 152 & 5.55 & $\odot .01845$ & 0.141 & $\odot .519$ \\
\hline 3 & 5 & 2 & 2 & 155 & 153 & 152 & 64.21 & $\odot .0000 \odot$ & 0.609 & 0.877 \\
\hline 3 & 6 & 2 & 2 & 156 & 154 & 153 & 39.13 & $\odot .0 \odot \odot \odot \odot$ & $\odot .472$ & $\odot .742$ \\
\hline
\end{tabular}




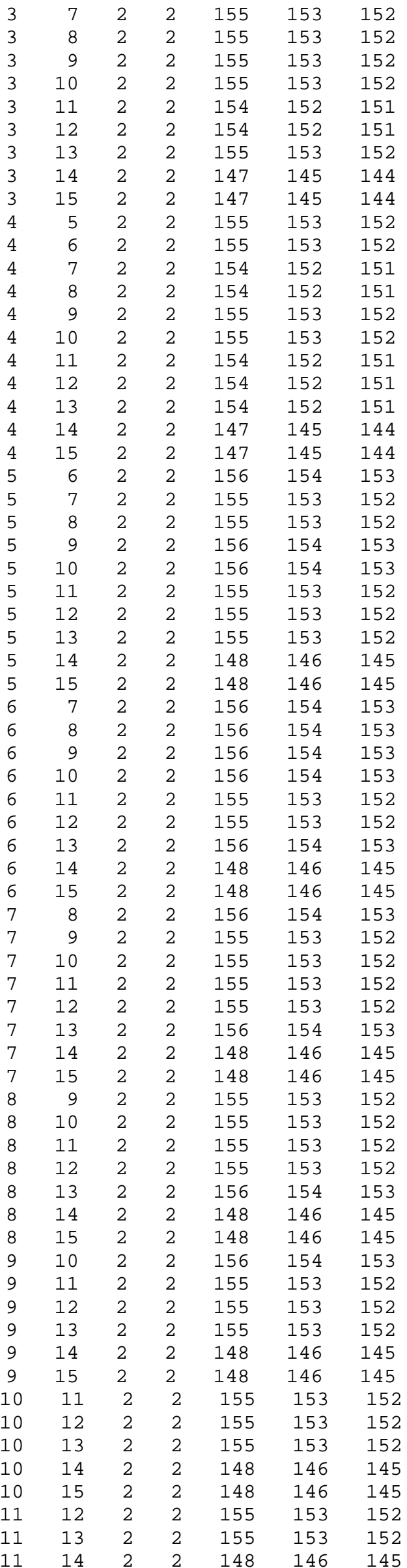

$28.73 \quad 0.00000 \quad 0.375 \quad 0.680$

$\begin{array}{lllll}7.58 & 0.00589 & 0.089 & 0.528\end{array}$

$\begin{array}{lllll}30.49 & 0.00000 & 0.390 & 0.858\end{array}$

$83.10 \quad 0.00000 \quad 0.692 \quad 0.853$

$\begin{array}{lllll}17.58 & 0.00003 & 0.268 & 0.649\end{array}$

$\begin{array}{lllll}0.41 & 0.52161 & 0.007 & 0.143\end{array}$

$5.38 \quad 0.02042 \quad 0.173 \quad 0.641$

$0.43 \quad 0.50966 \quad 0.012 \quad 0.176$

$\odot .0 \odot \quad 0.98937 \quad 0.00 \odot \quad 0.001$

$0.00 \quad 0.98670 \quad 0.000 \quad 0.001$

$\begin{array}{lllll}0.32 & 0.57047 & 0.015 & 0.171\end{array}$

$0.20 \quad 0.65860 \quad 0.003 \quad 0.070$

$0.670 .41294 \quad 0.005 \quad 0.096$

$\begin{array}{lllll}1.68 & 0.19489 & 0.037 & 0.195\end{array}$

$0.001 .00000 \quad 0.000 \quad 0.000$

$\begin{array}{lllll}1.46 & 0.22742 & 0.017 & 0.137\end{array}$

$\begin{array}{lllll}7.44 & 0.00639 & 0.045 & 0.276\end{array}$

$\begin{array}{lllll}0.13 & 0.71728 & 0.002 & 0.088\end{array}$

$\begin{array}{lllll}1.43 & 0.23220 & 0.012 & 0.249\end{array}$

$\begin{array}{llll}7.82 & 0.00516 & 0.221 & 0.635\end{array}$

$41.73 \quad 0.00000 \quad 0.501 \quad 0.741$

$\begin{array}{llll}66.11 & 0.0000 \odot & 0.548 & 0.916\end{array}$

$5.46 \quad 0.01940 \quad 0.049 \quad 0.443$

$105.66 \quad 0.00000 \quad 0.6701 .000$

$0.001 .00000 \quad 0.000 \quad 0.000$

$21.04 \quad 0.00000 \quad 0.282 \quad 0.752$

$1.290 .25609 \quad 0.028 \quad 0.266$

$16.48 \quad 0.00005 \quad 0.279 \quad 0.863$

$1.06 \quad 0.30408 \quad 0.045 \quad 0.388$

$126.00 \quad 0.00000 \quad 0.8161 .000$

$\begin{array}{lllll}4.14 & 0.04178 & 0.147 & 0.411\end{array}$

$\begin{array}{lllll}5.67 & 0.01728 & 0.050 & 0.432\end{array}$

$28.010 .0000 \odot \quad 0.3710 .778$

$87.16 \quad 0.00000 \quad 0.684 \quad 0.865$

$\begin{array}{lllll}7.10 & 0.00769 & 0.144 & 0.517\end{array}$

$\begin{array}{llllll}0.00 & 0.98630 & 0.000 & 0.002\end{array}$

$18.49 \quad 0.00002 \quad 0.276 \quad 0.835$

$0.00 \quad 0.94849 \quad 0.000 \quad 0.010$

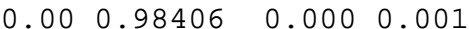

$24.33 \quad 0.00000 \quad 0.163 \quad 0.648$

$\begin{array}{lllll}47.21 & 0.00000 & 0.382 & 0.936\end{array}$

$\begin{array}{lllll}26.87 & 0.0000 \odot & 0.400 & 0.710\end{array}$

$\begin{array}{lllll}8.70 & 0.00318 & 0.108 & 0.376\end{array}$

$\begin{array}{lllll}1.54 & 0.21475 & 0.013 & 0.222\end{array}$

$\begin{array}{lllll}0.54 & 0.46173 & 0.017 & 0.223\end{array}$

$\begin{array}{lllll}0.46 & 0.49867 & 0.009 & 0.140\end{array}$

$\begin{array}{lllll}36.70 & 0.00000 & 0.477 & 0.770\end{array}$

$27.84 \quad 0.00000 \quad 0.104 \quad 0.792$

$0.03 \quad 0.87240 \quad 0.000 \quad 0.035$

$\begin{array}{lllll}54.79 & 0.00000 & 0.301 & 0.779\end{array}$

$0.45 \quad 0.50442 \quad 0.002 \quad 0.132$

$0.32 \quad 0.57426 \quad 0.002 \quad 0.055$

$0.50 \quad 0.48158 \quad 0.003 \quad 0.063$

$0.04 \quad 0.85010 \quad 0.001 \quad 0.051$

$0.001 .0000 \odot \quad 0.00 \odot \quad 0.000$

$\begin{array}{lllll}21.41 & 0.00000 & 0.202 & 0.778\end{array}$

$\begin{array}{lllll}6.75 & 0.00936 & 0.076 & 0.362\end{array}$

$\begin{array}{llllll}5.41 & 0.02004 & 0.165 & 0.813\end{array}$

$\begin{array}{llll}1.63 & 0.20142 & 0.019 & 0.305\end{array}$

$\begin{array}{llll}61.55 & 0.00000 & 0.550 & 1.000\end{array}$

$\begin{array}{llll}6.89 & 0.00865 & 0.203 & 0.587\end{array}$

$\begin{array}{lllll}0.30 & 0.58209 & 0.006 & 0.141\end{array}$

$\begin{array}{llll}16.64 & 0.00005 & 0.293 & 0.813\end{array}$

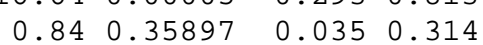

$\begin{array}{lllll}0.00 & 0.99772 & 0.000 & 0.000\end{array}$

$59.34 \quad 0.00000 \quad 0.342 \quad 0.793$

$0.70 \quad 0.40163 \quad 0.009 \quad 0.110$

$0.00 \quad 0.99529 \quad 0.000 \quad 0.000$ 


\begin{tabular}{|c|c|c|c|c|c|c|c|c|c|c|}
\hline 11 & 15 & 2 & 2 & 148 & 146 & 145 & 13.33 & $\odot .0 \odot \odot 26$ & 0.283 & 0.687 \\
\hline 12 & 13 & 2 & 2 & 155 & 153 & 152 & 1.80 & 0.17999 & $\odot .011$ & 0.122 \\
\hline 12 & 14 & 2 & 2 & 148 & 146 & 145 & 4.10 & $\odot .0429 \odot$ & $\odot .029$ & $\odot .497$ \\
\hline 12 & 15 & 2 & 2 & 148 & 146 & 145 & $\odot .06$ & ๑.81088 & $\odot . \odot \odot 2$ & $\odot .071$ \\
\hline 13 & 14 & 2 & 2 & 148 & 146 & 145 & 5.96 & ๑. . 01466 & $\odot .057$ & $\odot .273$ \\
\hline 13 & 15 & 2 & 2 & 148 & 146 & 145 & 19.51 & $\odot .0 \odot \odot \odot 1$ & $\odot .334$ & $\odot .853$ \\
\hline 14 & 15 & 2 & 2 & 148 & 146 & 145 & 2.16 & $\odot .14155$ & $\odot .086$ & $\odot .494$ \\
\hline
\end{tabular}




\section{REFERÊNCIAS BIBLIOGRÁFICAS}




\section{REFERÊNCIAS BIBLIOGRÁFICAS*}

1. ABECASIS GR, COOKSON WOC. GOLD - Graphical Overview of Linkage Disequilibrium. Bioinformatics, v. 16, n. 2, p. 182-3, 2000.

2. ADAMS MS, NISWANDER JD. Developmental 'noise' and a congenital malformation. Genet Res, v. 10, n. 3, p. 313-317, 1967.

3. AIZENBUD D, CAMASUVI S, PELED M, BRIN I. Congenitally missing teeth in the Israeli cleft population. Cleft Palate Craniofac J, v. 42, n. 3, p. 314-7, 2005.

4. ALVES-SILVA J, DA SILVA SANTOS M, GUIMARAES PE, FERREIRA AC, BANDELT HJ, PENA SD, PRADO VF. The ancestry of Brazilian mtDNA lineages. Am J Hum Genet, v. 67, n. 2, p. 444-61, 2000.

5. ARDINGER HH, BUETOW KH, BELL GI, BARDACH J, VAN DEMARK DR, MURRAY JC. Association of genetic variation of the transforming growth factor-alpha gene with cleft lip and palate. Am J Hum Genet, v. 45, n. 3, p.34853, 1989.

6. ASTOLFI CM, SHINOHARA AL, DA SILVA RA, SANTOS MC, LINE SR, DE SOUZA AP. Genetic polymorphisms in the MMP-1 and MMP-3 genes may contribute to chronic periodontitis in a Brazilian population. J Clin Periodontol, v. 33, n. 10, p. 699-703, 2006.

7. AVILA JR, JEZEWSKI PA, VIEIRA AR, ORIOLI IM, CASTILLA EE, CHRISTENSEN K, DAACK-HIRSCH S, ROMITTI PA, MURRAY JC. PVRL1 variants contribute to non-syndromic cleft lip and palate in multiple populations. Am J Med Genet, v. 140A, n. 23, p. 2562-70, 2006.

8. BAILIT HL, THOMSON LA, NISWANDER JD. Dental eruption and hypodontia. J Dent Res, v. 47, n. 4, p. 669, 1968.

\footnotetext{
*Normas recomendadas para o uso no âmbito da Universidade de São Paulo com base no documento "Referências Bibliográficas: exemplos", emanado do Conselho Supervisor do Sistema Integrado de Bibliotecas da USP em reunião de 20 de setembro de 1990.
} 
9. BEATY TH, HETMANSKI JB, FALLIN MD, PARK JW, SULL JW, McINTOSH I, LIANG KY, VANDERKOLK CA, REDETT RJ, BOYADJIEV SA, JABS EW, CHONG SS, CHEAH FSH, WU-CHOW YH, CHEN PK, CHIU YF, YEOW V, NG ISL, CHENG J, HUANG S, YE X, WANG H, INGERSOLL $\mathrm{R}$, SCOTT AF. Analysis of candidate genes on chromosome 2 in oral cleft caseparent trios from three populations. Hum Genet, v. 120, n. 4, p. 501-18, 2006.

10. BEATY TH, HETMANSKI JB, ZEIGER JS ET AL. Testing candidate genes for non-syndromic oral clefts using a case-parent trio design. Genet Epidemiol, v. 22, n. 1, p. 1-11, 2002.

11. BEATY TH, MAESTRI NE, HETMANSKI JB ET AL. Testing for interaction between maternal smoking and TGFA genotype among oral cleft cases born in Maryland 1992-1996. Cleft Palate-Craniofac J, v. 34, n. 5, p. 47-54, 1997.

12. BEATY TH, WANG H, HETMANKSI JB ET AL. A case-control study of nonsyndromic oral clefts in Maryland. Ann Epidemiol, v. 11, n. 6, p. 434-42, 2001.

13. BEN-KHAIAL GS, SHAM RM. Effects of 5-fluorouracil on collagen synthesis in the developing palate of hamster. Anti-Cancer Drugs, v. 5, n. 1 p. 99-104, 1994.

14. BLANTON SH, CORTEZ A, STAL S, MULLIKEN JB, FINNELL RH, HECHT JT. Variation in IRF6 contributes to nonsyndromic cleft lip and palate. Am J Med Genet, v. 137A, n. 3, p. 259-62, 2005.

15. BLANTON SH, CROWDER E, MALCOLM S, WINTER R, GASSER DL, STAL S, MULLIKEN J, HECHT JT. Exclusion of linkage between cleft lip with or without cleft palate and markers on chromosomes 4 and 6 . Am J Hum Genet, v. 58, n. 1, p. 239-41, 1996.

16. BLANTON SH, BERTIN T, SERNA ME, STAL S, MULLIKEN JB, HECHT JT. Association of chromosomal regions 3p21.2, 10p13, and 16p13.3 with nonsyndromic cleft lip and palate. Am J Med Genet, v. 125A, n. 1, p. 23-7, 2004. 
17. BLAVIER L, LAZARYEV A, GROFFEN J, HEISTERKAMP N, DECLERCK YA, KAARTINEN V. TGF-beta3-induced palatogenesis requires matrix metalloproteinases. Mol Biol Cell, v. 12, n. 5, p. 1457-66, 2001.

18. BRISSENDEN JE, DERYNCK R, FRANCKE U. Mapping of transforming growth factor alpha gene on human chromosome 2 close to the breakpoint of the Burkitt's lymphoma t(2;8) variant translocation. Cancer Res, v. 45 (11 Pt 2), p. 5593-7, 1985.

19. BROWN NL, YARRAM SJ, MANSELL JP, SANDY JR. Matrix metalloproteinases have a role in palatogenesis. J Dent Res, v. 81, n. 12, p. 826$30,2002$.

20. BULLIET RF, ZIMMERMANN EF. The influence of the epithelium on palate shelf reorientation. J Embryol Exp Morph, v. 88, p. 265-79, 1985.

21. CALLAHAN N, MEIRA R, MODESTO A, VIEIRA AR. Further Evidence on the Association between TGFA and Human Tooth Agenesis. IADR General Session \& Exhibition. \#2411, 2007.

22. CALZOLARI EL PIERINI A, ASTOLFI G, BIANCHI F, NEVILLE AJ, RIVIERI F, and EUROCAT Working Group. Associated anomalies in multimalformed infants with cleft lip and palate: An epidemiologic study of nearly 6 million births in 23 EUROCAT registries. Am J Med Genet, v. 143A, n. 6, p. 528-37, 2007.

23. CARETTE MJ, FERGUSON MW. The fate of medial edge epithelial cells during palatal fusion in vitro: an analysis by DiI labelling and confocal microscopy. Development, v. 114, n. 2, p. 379-88, 1992.

24. CARLSON CS, EBERLE MA, RIEDER MJ, YI Q, KRUGLYAK L, NICKERSON DA. Selecting a maximally informative set of single-nucleotide polymorphisms for association analyses using linkage disequilibrium. Am J Hum Genet, v. 74, n. 1, p. 106-120, 2004.

25. CARSTENS MH. Development of the facial midline. J Craniofac Surg, v. 13, n. 1, p. 129-87, 2002. 
26. CHAKRAVARTI A. Finding needles in haystacks--IRF6 gene variants in isolated cleft lip or cleft palate. N Engl J Med, v. 351, n. 8, p. 822-4, 2004.

27. CHENEVIX-TRECH G, JONES G, GREEN AC, DUFFY DL, MARTIN NG. Cleft lip with or without palate: associations with transforming growth factor alpha and retinoic acid receptor loci. Am J Hum Genet, v. 51, n. 6, p. 1377-85, 1992.

28. CHENEVIX-TRECH G, JONES G, GREEN AC, MARTIN NG. Further evidence for an association between genetic variation in transforming growth factor alpha and cleft lip and palate. Am J Hum Genet, v. 48, n. 5, p. 1012-3, 1991.

29. CHRISTENSEN K, OLSEN J, NØRGAARD-PEDERSEN B ET AL. Oral clefts, transforming growth factor-alpha gene variants, and maternal smoking: a population-based case-control study in Denmark, 1991-1994. Am J Epidemiol, v. 149, n. 3 , p. 248-55, 1999.

30. COBOURNE MT. The complex genetics of cleft lip and palate. Eur J Orthod, v. 26, n. 1, p. 7-16, 2004.

31. DE SOUZA AP, TREVILATTO PC, SCAREL-CAMINAGA RM, BRITO RB, LINE SR. MMP-1 promoter polymorphism: association with chronic periodontitis severity in a Brazilian population. J Clin Periodontol, v. 30, n. 2, p. 154-8, 2003.

32. DEWINTER G, QUIRYNEN M, HEIDBÜCHEL K, VERDONCK A, WILLEMS G, CARELS C. Dental abnormalities, bone graft quality, and periodontal conditions in patients with unilateral cleft lip and palate at different phases of orthodontic treatment. Cleft Palate Craniofac J, v. 40, n. 4, p. 343$350,2003$.

33. DIEWERT VM, LOSANOFF S. Animal models of facial clefting: experimental, congenital, and transgenic. In: Mooney MP, Siegel MI. Understanding craniofacial anomalies: the etiopathogenesis of craniosynostosis and facial clefting. John Wiley and Sons, New York, p. 251-72, 2002. 
34. DIEWERT VM, LOZANOFF S. Growth and morphogenesis of the human embryonic midface during primary palate formation analyzed in frontal sections. J Craniofac Genet Dev Biol, v. 13, n. 3, p. 162-83, 1993.

35. DIXON DA. Defects of structure and formation of the teeth in persons with cleft palate and the effect of reparative surgery on the dental tissues. Oral Surg Oral Med Oral Pathol, v. 25, n. 3, p. 435-46, 1968.

36. DIXON MJ, GARNER J, FERGUSON MWJ. Immunolocalization of epidermal growth factor (EGF), EGF receptor and transforming growth factor alpha (TGF $\alpha$ ) during murine palatogenesis in vivo and in vitro. Anat Embryol (Berl), v. 184, n. 1, p. 83-91, 1991.

37. DIXON MJ, FERGUSON MWJ. The effects of epidermal growth factor, transforming growth factor $\alpha$ e $\beta$ and platelet-derived growth factor on murine palatal shelves in organ culture. Arch Oral Biol, v. 37, n. 5, p.395-410, 1992.

38. DONNAI D, HEATHER LJ, SINCLAIR P, THAKKER Y, SCAMBLER PJ, DIXON MJ. Association of autosomal dominant cleft lip and palate and translocation 6p23;9q22.3. Clin Dysmorphol, v. 1, n. 2, p. 89-97, 1992.

39. DUNLEAVEY L, BEYZADE S, YE S. Rapid genotype analysis of the matrix metalloproteinase- 1 gene $1 \mathrm{G} / 2 \mathrm{G}$ polymorphism that is associated with risk of cancer. Matrix Biol, v. 19, n. 2, p.175-7, 2000.

40. EERENS K, VLIETINCK R, HEIDBÜCHEL K, VAN OLMEN A, DEROM C, WILLEMS G, CARELS C. Hypodontia and tooth formation in groups of children with cleft, siblings without cleft, and nonrelated controls. Cleft Palate Craniofac J, v. 38, n. 4, p. 374-378, 2001.

41. EIBERG H, BIXLER D, NIELSEN LS, CONNEALLY PM, MOHR J. Suggestion of linkage of a major locus for non-syndromic orofacial cleft with F13A and tentative assignment to chromosome 6. Clin Genet, v. 32, n. 2, p. 129-32, 1987.

42. EROSHKIN A, MUSHEGIAN A. Conserved transactivation domain shared by interferon regulatory factors and Smad morphogens. J Mol Med, v. 77, n. 5, p. 
403-5, 1999.

43. FARRAL M, HOLDER S. Familial recurrence-pattern analysis of cleft lip with or without cleft palate. Am J Hum Genet, v. 50, n. 2, p. 270-7, 1992.

44. FENG H, SASSANI R, BARTLETT SP, LEE A, HECHT JT, MALCOLM S, WINTER RM, VINTINER GM, BUETOW KH, GASSER DL. Evidence from family studies for linkage disequilibrium between TGFA and a gene for nonsyndromic cleft lip with or without cleft palate. Am J Hum Genet, v. 55, n. 5, p. 932-6, 1994.

45. FERGUSON MWJ. Palate development. Development, v. 103 (Suppl), p. 4160,1988 .

46. FIELD LL, RAY K, MARAZITA ML. Transforming growth factor alpha: a modifying locus for nonsyndromic cleft lip with or without cleft palate? Eur J Hum Genet, v. 2, n. 3, p. 159-65, 1994.

47. FITCHETT JE, HAY ED. Medial edge epithelium transforms to mesenchyme after embryonic palatal shelves fuse. Dev Biol, v. 131, n. 2, p. 455-74, 1989.

48. FOGH-ANDERSEN. Inheritance of harelip and cleft palate. Copenhagen: Nyt Nordisk Forlag, Arnold Busck; 1942.

49. FOSTER TD, LAVELLE CL. The size of the dentition in complete cleft lip and palate. Cleft Palate J, v. 8, p. 177-84, 1971.

50. FREBOURG T, OLIVEIRA C, HOCHAIN P, KARAM R, MANOUVRIER S, GRAZIADIO C, VEKEMANS M, HARTMANN A, BAERT-DESURMONT S, ALEXANDRE C, LEJEUNE DUMOULIN S, MARRONI C, MARTIN C, CASTEDO S, LOVETT M, WINSTON J, MACHADO JC, ATTIE T, JABS EW, CAI J, PELLERIN P, TRIBOULET JP, SCOTTE M, LE PESSOT F, HEDOUIN A, CARNEIRO F, BLAYAU M, SERUCA R. Cleft lip/palate and $\mathrm{CDH} 1 / \mathrm{E}$-cadherin mutations in families with hereditary diffuse gastric cancer. $\mathbf{J}$ Med Genet, v. 43, n. 2, p. 138-42, 2006.

51. GARCIA-CASTRO M, BRONNER-FRASER M. Induction and differentiation of the neural crest. Curr Opin Cell Biol, v. 11, n. 6, p. 695-8, 1999. 
52. GHASSISBÉ M, BAYET B, REVENCU N, VERELLEN-DUMOULIN C, GILLEROT Y, VANWIJCK R, VIKKULA M. Interferon regulatory factor-6: a gene predisposing to isolated cleft lip with or without palate in the Belgian population. Eur J Hum Genet, v. 13, n. 11, p. 1239-42, 2005.

53. GOLDSBERRY G, O'LEARY D, HICHWA R, NOPOULOS P. Functional abnormalities in the neural circuitry of reading in men with non syndromic clefts of the lip or palate. Cleft Palate Craniofac J, v. 43, n. 6, p. 683-90, 2006.

54. GOVIL M, MARAZITA ML, MURRAY JC, FIELD LL, VIELAND VJ. Multipoint PPL analysis of cleft lip with/without cleft palate (CL/P) provides compelling evidence in favor of linkage. Annals of the 2006 Annual Meeting of the American Society of Human Genetics, Abstract \#1491, 2006.

55. GRAHNEN H. Hypodontia in the permanent dentition: a clinical and genetic investigation. Odont Revy, v. 7, p. 1-100, 1956.

56. HAINES JL, PERICAK-VANCE MA. Overview of mapping common and genetically complex human disease genes. In: Haines JL, Pericak-Vance MA, eds. Approaches to Gene Mapping in Complex Human Diseases. New York:Wiley- Liss; p. 1-16, 1998.

57. HANNAS AR, PEREIRA JC, GRANJEIRO JM, TJADERHANE L. The role of matrix metalloproteinases in the oral environment. Acta Odontol Scand, v. 65, n. 1, p.1-13, 2007.

58. HANSEN K, MEHDINIA M. Isolated soft tissue cleft lip: the influence on the nasal cavity and supernumerary laterals. Cleft Palate Craniofac J, v. 39, n. 3, p. 322-6, 2002.

59. HARRIS EF, HULLINGS JG. Delayed dental development in children with isolated cleft lip and palate. Arch Oral Biol, v. 35, n. 6, p. 469-73, 1990.

60. HASSEL JR, ORKIN RW. Synthesis and distribution of collagen in the rat palate during shelf elevation. Dev Biol, v. 49, n. 1, p. 80-8, 1976.

61. HECHT JT, WANG YP, BLANTON SH, MICHELS VV, DAIGER SP. Cleft lip and palate: no evidence of linkage to transforming growth factor alpha. 
Am J Hum Genet, v. 49, n. 3, p. 682-6, 1991.

62. HECHT JT, WANG Y, CONNOR B, BLANTON SH, DAIGER SP. Nonsyndromic cleft lip and palate: no evidence of linkage to HLA or factor 13A. Am J Hum Genet, v. 52, n. 6, p. 1230-3, 1993.

63. HINODA Y, OKAYAMA N, TAKANO N, FUJIMURA K, SUEHIRO Y, HAMANAKA Y, HAZAMA S, KITAMURA Y, KAMATANI N, OKA M. Association of functional polymorphisms of matrix metalloproteinase (MMP) -1 and -3 genes with colorectal cancer. Int J Cancer, v. 102, n. 5, p.526-9, 2002.

64. HOLDER SE, VINTINER GM, FARREN B, MALCOLM S, WINTER RM. Confirmation of an association between RFLPs at the transforming growth factor-alpha locus and non-syndromic cleft lip and palate. J Med Genet, v. 29, n. 6, p. 390-2, 1992.

65. HUNSTADBRATEN K. Hypodontia in the permanent dentition. ASDC J Dent Child, v. 40, n. 2, p. 115-7, 1973.

66. HWANG SJ, BEATY TH, PANNY SR, STREET NA, JOSEPH JM, GORDON S, MCINTOSH I, FRANCOMANO CA. Association study of transforming growth factor alpha (TGF $\alpha)$ TaqI polymorphism and oral clefts: indication of gene-environment interactions in a population-based sample of infants with birth defects. Am J Epidemiol, v. 141, n. 7, p. 629-36, 1995.

67. IAMAROON A, TAIT B, DIEWERT VM. Cell proliferation and expression of EGF, TGF- $\alpha$ and EGF receptor in the developing primary palate. $\mathbf{J}$ Dent Res, v. 75, n. 8, p.1534-9, 1996.

68. IAMAROON A, WALLON UM, OVERALL CM, DIEWERT VM. Expression of $72-\mathrm{kDa}$ gelatinase (matrix metalloproteinase-2) in the developing mouse craniofacial complex. Arch Oral Biol, v. 41, n. 12, p. 1109-19, 1996.

69. INGRAHAM CR, KINOSHITA A, KONDO S, YANG B, SAJAN S, TROUT KJ, MALIK MI, DUNNWALD M, GOUDY SL, LOVETT M, MURRAY JC, SCHUTTE BC. Abnormal skin, limb and craniofacial morphogenesis in mice deficient for interferon regulatory factor 6 (Irf6). Nat Genet, v. 38, n. 11, p. 
1335-40, 2006.

70. IOANNIDIS JP. Genetic associations: false or true? Trends Mol Med, v. 9, n. 4, p. 135-8, 2003.

71. IOANNIDIS JP, NTZANI EE, TRIKALINOS TA, CONTOPOULOSIOANNIDIS DG. Replication validity of genetic association studies. Nat Genet, v. 29, n. 3, p. 306-9, 2001.

72. ISHIKAWA K, NAGASE T, SUYAMA M, MIYAJIMA N, TANAKA A, KOTANI H, NOMURA N, OHARA O. Prediction of the coding sequences of unidentified human genes. X. The complete sequences of 100 new cDNA clones from brain which can code for large proteins in vitro. DNA Res, v. 5, p. 169176, 1998.

73. JAKSIC N, SCEPAN I, GLISIC B, STAMENIC E, STAMENKOVIC Z. Mesiodistal size of deciduous teeth in subjects with unilateral cleft lip and palate. Orthod Craniofac Res, v. 5, n. 1, p. 17-21, 2002.

74. JARA L, BLANCO R, CHIFFELLE I, PALOMINO H, CARRENO H. Evidence for an association between RFLPs at the transforming growth factor-alpha (locus) and nonsyndromic cleft lip/palate in a South American population. Am J Hum Genet, v. 56, n. 1, p. 339-41, 1995.

75. JARA L, BLANCO R, CHIFFELLE I, PALOMINO $\mathrm{H}$, CARRENO $\mathrm{H}$. Association between alleles of the transforming growth factor alpha locus and cleft lip and palate in the Chilean population. Am J Med Genet, v. 57, n. 4, p. 548-51, 1995.

76. JEZEWSKI PA, VIEIRA AR, NISHIMURA C, LUDWIG B, JOHNSON M, O'BRIEN SE, DAACK-HIRSCH S, SCHULTZ RE, WEBER A, NEPOMUCENA B, ROMITTI PA, CHRISTENSEN K, ORIOLI IM, CASTILLA EE, MACHIDA J, NATSUME N, MURRAY JC. Complete sequencing shows a role for MSX1 in non-syndromic cleft lip and palate. J Med Genet, v. 40, n. 6, p. 399-407, 2003.

77. JIROUTOVA O. Hypodontia in patients with isolated cleft palate, its 
relationship to etiopathogenesis. Acta Chir Plast, v. 33, n. 1, p. 57-63, 1991.

78. JOHNSTON MC, BRONSKY PT. Craniofacial embryogenesis: abnormal developmental mechanisms. In: Mooney MP, Siegel MI. Understanding craniofacial anomalies: the etiopathogenesis of craniosynostosis and facial clefting. John Wiley and Sons, New York, p. 61-124, 2002.

79. JUGESSUR A, LIE RT, WILCOX AJ, MURRAY JC, TAYLOR JA, SAUGSTAD OD, VINDENES HA, ABYHOLM FE. Cleft palate, transforming growth factor-alpha gene variants, and maternal exposures: assessing geneenvironment interactions in case-parent triads. Genet Epidemiol, v. 25, n. 4, p. 367-74, 2003.

80. JUGESSUR A, MURRAY JC. Orofacial clefting: recent insights into a complex trait. Curr Opin Genet Dev, v. 15, n. 3, p. 270-8, 2005.

81. KAARTINEN V, CUI XM, HEISTERKAMP N, GROFFEN J, SHULER CF. Transforming growth factor-beta3 regulates transdifferentiation of medial edge epithelium during palatal fusion and associated degradation of the basement membrane. Dev Dyn, v. 209, n. 3, p. 255-60, 1997.

82. KANG P, SVOBODA KK. Epithelial-mesenchymal transformation during craniofacial development. J Dent Res, v. 84, n. 8, p. 678-90, 2005.

83. KERRIGAN JJ, MANSELL JP, SENGUPTA A, BROWN N, SANDY JR. Palatogenesis and potential mechanisms for clefting. J R Coll Surg Edinb, v. 45 , n. 6 , p. 351-8, 2000.

84. KONDO S, SCHUTTE BC, RICHARDSON RJ, BJORK BC, KNIGHT AS, WATANABE Y, HOWARD E, DE LIMA RL, DAACK-HIRSCH S, SANDER A, MCDONALD-MCGINN DM, ZACKAI EH, LAMMER EJ, AYLSWORTH AS, ARDINGER HH, LIDRAL AC, POBER BR, MORENO L, ARCOSBURGOS M, VALENCIA C, HOUDAYER C, BAHUAU M, MORETTIFERREIRA D, RICHIERI-COSTA A, DIXON MJ, MURRAY JC. Mutations in IRF6 cause Van der Woude and popliteal pterygium syndromes. Nat Genet, v. 32 , n. 2, p. 285-9, 2002. 
85. KORMANN-BORTOLOTTO MH, FARAH LM, SOARES D, CORBANI M, MULLER R, ADELl AC. Terminal deletion 6p23: a case report. Am J Med Genet, v. 37, n. 4, p. 475-7, 1990.

86. KORNMAN KS, CRANE A, WANG HY, DI GIOVINE FS, NEWMAN MG, PIRK FW, WILSON TG JR, HIGGINBOTTOM FL, DUFF GW. The interleukin-1 genotype as a severity factor in adult periodontal disease. J Clin Periodontol, v. 24, n. 1, p. 72-7, 1997.

87. LAATIKAINEN T, RANTA R. Hypodontia in twins discordant or concordant for cleft lip and/or palate. Scand J Dent Res, v. 102, n. 2, p. 88-91, 1994.

88. LACOMBE D, PEDESPAN JM, FONTAN D, CHATEIL JF, VERLOES A. Phenotypic variability in van der Woude syndrome. Genet Couns, v. 6, n. 3, p. 221-6, 1995.

89. LANDER ES, SCHORK NJ. Genetic dissection of complex traits. Science, v. 265, n. 5181, p. 2037-48, 1994.

90. LARSON M, HELLQUIST R, JAKOBSSON OP. Dental abnormalities and ectopic eruption in patients with isolated cleft palate. Scand J Plast Reconstr Surg, v. 32, n. 2, p. 203-212, 1998.

91. LAVELLE CL, ASHTON EH, FLINN RM. Cusp pattern, tooth size and third molar agenesis in the human mandibular dentition. Arch Oral Biol, v. 15, n. 3, p. $227-37,1970$.

92. LI M, BOEHNKE M, ABECASIS GR. Efficient study designs for test of genetic association using sibship data and unrelated cases and controls. Am J Hum Genet, v. 78, n. 5, p. 778-92, 2006.

93. LIDRAL AC, MORENO LM. Progress toward discerning the genetics of cleft lip. Curr Opin Pediatr, v. 17, n. 6, p. 731-9, 2005.

94. LIDRAL AC, MURRAY JC, BUETOW KH ET AL. Studies of the candidate genes TGFB2, MSX1, TGFA and TGFB3 in the etiology of cleft lip and palate in the Phillipines. Cleft Palate Craniofac J, v. 34, n. 1, p. 1-6, 1997. 
95. LIDRAL AC, ROMITTI PA, BASART AM, DOETSCHMAN T, LEYSENS NJ, DAACK-HIRSCH S, SEMINA EV, JOHNSON LR, MACHIDA J, BURDS A, PARNELL TJ, RUBENSTEIN JL, MURRAY JC. Association of MSX1 and TGFB3 with nonsyndromic clefting in humans. Am J Hum Genet, v. 63, n. 2, p. 557-68, 1998.

96. LIDRAL AC, MURRAY JC. Genetic approaches to identify disease genes for birth defects with cleft lip/palate as a model. Birth Defects Res A Clin Mol Teratol, v. 70, n. 12, p. 893-901, 2004.

97. LIEVRE A, MILET J, CARAYOL J, LE CORRE D, MILAN C, PARIENTE A, NALET B, LAFON J, FAIVRE J, BONITHON-KOPP C, OLSCHWANG S, BONAITI-PELLIE C, LAURENT-PUIG P. Genetic polymorphisms of MMP1, MMP3 and MMP7 gene promoter and risk of colorectal adenoma. BMC Cancer, v. 24, n. 11, p. 270.

100. LOPES LD, MATTOS BSC, ANDRÉ M. Anomalies in number of teeth in patients with lip and/or palate clefts. Braz Dent J, v. 2, n. 1, p. 9-17, 1991.

101. LU W, VOLCIK K, ZHU H, WEN S, SHAW GM, LAMMER EJ, FINNELL RH. Genetic variation in the proto-oncogene SKI and risk for orofacial clefting. Mol Genet Metab, v. 86, n. 3, p. 412-6, 2005.

102. LUETTEKE NC, QIU TH, PFEIFFER RL, OLIVER P, SMITHIES O, LEE DC. TGF $\alpha$ deficiency results in hair follicle and eye abnormalities in targeted and waived-1 mice. Cell, v. 73, n. 2, p. 263-78, 1993.

103. MACHIDA J, YOSHIURA K, FUNKHAUSER CD ET AL. transforming growth factor- $\alpha$ (TGFA): genomic structure, boundary sequences, and mutation analysis in nonsyndromic cleft lip/palate and cleft palate only. Genomics, v. 61, n. 3, p. 237-42, 1999.

104. MAESTRI NE, BEATY TH, HETMANSKI JB ET AL. Application of transmission disequilibrium tests to nonsyndromic oral clefts: including candidate genes and environmental exposures in the models. Am J Med Genet, v. 73, n. 3, p. 337-44, 1997. 
105. MALANCZUK T, OPITZ C, RETZLAFF R. Structural changes of dental enamel in both dentitions of cleft lip and palate patients. J Orofac Orthop, v. 60, n. 4, p. 259-68, 1999.

106. MALIK SA. Missing and rudimentary upper lateral incisors: a statistical survey. J Dent, v. 1, n. 1, p. 25-7, 1972.

107. MANSELL JP, KERRIGAN J, MCGILL J, BAILEY J, TEKOPPELE J, SANDY JR. Temporal changes in collagen composition and metabolism during rodent palatogenesis. Mech Ageing Dev, v. 119, n. 1-2, p. 49-62, 2000.

108. MANN GB, FOWLER KJ, GABRIEL A, NICE AC, WILLIAMS RL, DUNN AR. Mice with a null mutation of the $T G F \alpha$ gene have abnormal skin architecture, wavy hair, and curly whiskers and often develop corneal inflammation. Cell, v. 73, n. 2, p. 249-61, 1993.

109. MANIATIS T. In: Molecular Cloning: A Laboratory Manual. $2^{\text {nd }}$ Edition, Ed. Cold Spring Harbor Laboratory Press, 1989.

110. MARAZITA ML, FIELD LL, COOPER ME, TOBIAS R, MAHER BS, PEANCHITLERTKAJORN S, LIU YE. Genome scan for loci involved in cleft lip with or without cleft palate, in Chinese multiplex families. Am J Hum Genet, v. 71, n. 2, p. 349-64, 2002.

111. MARAZITA ML, MAHER BS, MURRAY JC, LIDRAL A, FIELD LL, McHENRY TG, COOPER ME, DAACK-HIRSCH S, JUGESSUR A, RILEY B, MORENO L, CHINES P. Candidate gene analyses for nonsyndromic cleft lip (CL) with or without cleft palate (CP) in families from six countries. The American Society of Human Genetics. $56^{\text {th }}$ Annual Meeting. Platform Session 38: Molecular Basis of Disorders with Complex Inheritance. Session 166. 2006.

112. MARAZITA ML, MOONEY MP. Current concepts in the embryology and genetics of cleft lip and palate. Clin Plastic Surg, v. 31, n. 2, p. 125-40, 2004.

113. MARAZITA ML, MURRAY JC, LIDRAL AC, ARCOS-BURGOS M, COOPER ME, GOLDSTEIN T, MAHER NS, DAACK-HIRSCH S, SCHULTZ R, MANSILLA MA, FIELD LL, LIU YE, PRESCOTT N, MALCOLM S, 
WINTER R, RAY A, MORENO L, VALENCIA C, NEISWANGER K, WYSZYNSKI DF, BAILEY-WILSON JB, TUNCBILEK G, EDWARDS M, HARKIN L, SCOTT R, RODDICK LG. Meta-analysis of 13 genome scans reveals multiple cleft lip/palate genes with novel loci on 9q21 and 2q32-35. Am J Hum Genet, v. 75, n. 2, p. 161-73, 2004.

114. MARAZITA ML, SPENCE MA, MELNICK M. Genetic analysis of cleft lip with or without cleft palate in Danish kindreds. Am J Med Genet, v. 19, n. 1, p. 9-18, 1984.

115. MARTINEZ-ALVARES C, TUDELA C, PEREZ-MIGUELSANZ J, O'KANE S, PUERTA J, FERGUSON MWJ. Medial edge epithelial cell fate during palatal fusion. Dev Biol, v. 220, n. 2, p. 343-57, 2000.

116. MIETTINEN PJ, CHIN JR, SHUM L, SLAVKIN HC, SHULER CF, DERYNCK R, WERB Z. Epidermal growth factor receptor function is necessary for normal craniofacial development and palate closure. Nat Genet, v. 22, n. 1, p. 69-73, 1999.

117. MITCHELL LE. Transforming growth factor alpha locus and nonsyndromic cleft lip with or without cleft palate: a reappraisal. Genet Epidemiol, v. 14, n. 3, p. 231-40, 1997.

118. MORKŪNIENĖ A, STEPONAVICIUT D, UTKUS A, KUCINSKAS V. Few associations of candidate genes with nonsyndromic orofacial clefts in the population of Lithuania. J Appl Genet, v. 48, n. 1, p. 89-91, 2007.

119. MORRIS-WIMAN J, BURCH H, BASCO E. Temporospatial distribution of matrix metalloproteinase and tissue inhibitors of matrix metalloproteinases during murine secondary palate morphogenesis. Anat Embryol (Berl), v. 202, n. 2, p. 129-41, 2000.

120. MORRIS-WIMAN J, DU Y, BRINKLEY L. Occurrence and temporal variation in matrix metalloproteinases and their inhibitors during murine secondary palatal morphogenesis. J Craniofac Genet Dev Biol, v. 19, n. 4, p. 201-12, 1999.

121. MOSSEY PA, LITTLE J. Epidemiology of oral clefts: an international 
perspective. In: Wyszynski DF (ed.). Cleft lip and Palate. From origin to treatment. New York: Oxford, p.127-158, 2002.

122. MOXHAM BJ. The development of the palate - a brief review. Eur J Anat, v. 7, n. 1, p.53-74, 2003.

123. MULLER TP, HILL IN, PETERSON AC, BLAYNEY JR. A survey of congenitally missing permanent teeth. J Am Dent Assoc, v. 81, n. 1, p. 101-7, 1970.

124. MURRAY JC. Gene/environment causes of cleft lip and/or palate. Clin Genet, v. 61, n. 4 , p. $248-56,2002$.

125. NAGAI I, FUJIKI Y, FUCHIHATA H, YOSHIMOTO T. SUPERNUMERARY TOOTH ASSOCIATED WITH CLEFT LIP AND PALATE. J Am Dent Assoc, v. 70, p. 642-7, 1970.

126. NAGASE H, VISSE R, MURPHY G. Structure and function of matrix metalloproteinases and TIMPs. Cardiovasc Res, v. 69, n. 3, p. 562-73, 2006.

127. NATSUME N, SUZUKI T, KAWAI T. The prevalence of cleft lip and palate in the Japanese: their birth prevalence in 40,304 infants born during 1982. Oral Surg Oral Med Oral Pathol, v. 63, n. 4, p. 421-3, 1987.

128. NEISWANGER K, DELEYIANNIS FW, AVILA JR, COOPER ME, BRANDON CA, VIEIRA AR, NOORCHASHM N, WEINBERG SM, BARDI KM, MURRAY JC, MARAZITA ML. Candidate genes for oral-facial clefts in Guatemalan families. Ann Plast Surg, v. 56, n. 5, p. 518-21, 2006.

129. NYSTROM M, RANTA R. Dental age and asymmetry in the formation of mandibular teeth in twins concordant or discordant for oral clefts. Scand J Dent Res, v. 96, n. 5, p. 393-8, 1988.

130. PARK JW, CAI J, MCINTOSH I, JABS EW, FALLIN MD, INGERSOLL R, HETMANSKI JB, VEKEMANS M, ATTIE-BITACH T, LOVETT M, SCOTT AF, BEATY TH. High throughput SNP and expression analyses of candidate genes for non-syndromic oral clefts. J Med Genet, v. 43, n. 7, p. 598-608, 2006. 
131. PASSOS-BUENO MR, GASPAR DA, KAMIYA T, TESCAROLLO G, RABANEA D, RICHIERI-COSTA A, ALONSO N, ARAUJO B. Transforming growth factor-alpha and nonsyndromic cleft lip with or without palate in Brazilian patients: results of a large case-control study. Cleft Palate Craniofac J, v. 41, n. 4, p. 387-91, 2004.

132. PERES RC, LINE SR. Analysis of MMP-9 and TIMP-2 gene promoter polymorphisms in individuals with hypodontia. Braz Dent J, v. 16, n. 3, p. 2316, 2005.

133. PETERKA M, MULLEROVA Z. Tooth size in children with cleft lip and palate. Cleft Palate J, v. 20, n. 4, p. 307-313, 1983.

134. PRATT RM, KING CTG. Inhibition of collagen crosslinking associated with $\beta$ aminopropionitrile-induced cleft palate in the rat. Dev Biol, v. 27, n. 3, p. 322-8, 1972.

135. PRESCOTT NJ, LEES MM, WINTER RM, MALCOLM S. Identification of susceptibility loci for nonsyndromic cleft lip with or without cleft palate in a two stage genome scan of affected sib-pairs. Hum Genet, v. 106, n. 3, p. 345-50, 2000 .

136. PRZYBYLOWSKA K, KLUCZNA A, ZADROZNY M, KRAWCZYK T, KULIG A, RYKALA J, KOLACINSKA A, MORAWIEC Z, DRZEWOSKI J, BLASIAK J. Polymorphisms of the promoter regions of matrix metalloproteinases genes MMP-1 and MMP-9 in breast cancer. Breast Cancer Res Treat, v. 95, n. 1, p. 65-72, 2006.

137. PURCELL S, CHERNY SS, SHAM PC. Genetic Power Calculator: design of linkage and association genetic mapping studies of complex traits. Bioinformatics, v. 19, n. 1, p. 149-150, 2003.

138. RANADE K, CHANG MS, TING CT, PEI D, HSIAO CF, OLIVIER M, PESICH R, HEBERT J, CHEN YD, DZAU VJ, CURB D, OLSHEN R, RISCH N, COX DR, BOTSTEIN D. High-throughput genotyping with single nucleotide polymorphisms. Genome Res, v.11, n. 7, p. 1262-68, 2001. 
139. RANDALL LE, HALL RC. Temporospatial expression of matrix metalloproteinases 1, 2, 3 and 9 during early tooth development. Connect Tissue Res, v. 43, n. 2-3, p.205-11, 2002.

140. RANTA R. A review of tooth formation in children with cleft lip/palate. Am J Orthod Dentofacial Orthop, v. 90, n. 1, p. 11-8, 1986.

141. RANTA R. Associations of some variables to tooth formation in children with isolated cleft palate. Scand J Dent Res, v. 92, n. 6, p. 496-502, 1984.

142. RANTA R. Comparison of tooth formation in noncleft and cleft-affected children with and without hypodontia. ASDC J Dent Child, v. 49, n. 3, p. 197$9,1982$.

143. RANTA R. Hypodontia and delayed development of the second premolars in cleft palate children. Eur J Orthod, v. 5, n. 2, p. 145-8, 1983.

144. RANTA R. Numeric anomalies of teeth in concomitant hypodontia and hyperdontia. J Craniofac Genet Dev Biol, v. 8, n. 3, p. 245-251, 1988.

145. RANTA R, TULENSALO T. Symmetry and combinations of hypodontia in non-cleft and cleft palate children. Scand J Dent Res, v. 96, n. 1, p. 1-8, 1988.

146. RICE JP, SACCONE NL, RASMUSSEN E. Definition of the Phenotype. In: Genetic dissection of complex traits. Rao DC, Province MA, editors. San Diego: Academic Press, pp. 69-76, 2001.

147. RAPOLEE DA, BRENNER CA, SCHULTZ R, MARK D, WERB Z. Developmental expression of PDGF, TGF- $\alpha$ and $T G F-\beta$ genes in preimplantation mouse embryos. Science, v. 241, n. 4874, p. 1823-5, 1988.

148. RILEY BM, MANSILLA A, MA J, DAACK-HIRSCH S, MAHER BS, RAFFENSBERGER M, RUSSO ET, VIEIRA AR, DODÉ C, MOHAMMADI M, MARAZITA ML, MURRAY JC. Impaired FGF signaling contributes to cleft lip and palate. PNAS, v. 104, n.11, 2007.

149. RISCH NJ. Searching for genetic determinants in the new millennium. Nature, v. 405 , n. 6788, p. $847-56,2000$. 
150. ROMITTI PA, LIDRAL AC, MUNGER RG, DAACK-HIRSCH S, BURNS T, MURRAY JC. Candidate genes for nonsyndromic cleft lip and palate and maternal cigarette smoking and alcohol consumption: evaluation of genotypeenvironment interactions from a population-based study of orofacial clefts. Teratology, v. 59, n. 1, p. 39-50, 1999.

151. RUTTER JL, MITCHELL TI, BUTTICE G, MEYERS J, GUSELLA JF, OZELIUS LJ, BRINCKERHOFF CE. A single nucleotide polymorphism in the matrix metalloproteinase-1 promoter creates an Ets binding site and augments transcription. Cancer Res, v. 58, n. 23, p. 5321-5, 1998.

152. SABETI PC, REICH DE, HIGGINS JM, LEVINE HZ, RICHTER DJ, SCHAFFNER SF, GABRIEL SB, PLATKO JV, PATTERSON NJ, MCDONALD GJ, ACKERMAN HC, CAMPBELL SJ, ALTSHULER D, COOPER R, KWIATKOWSKI D, WARD R, LANDER ES. Detecting recent positive selection in the human genome from haplotype structure. Nature, v. 419, n. 6909, p. 832-7, 2002.

153. SAIKI RK, SCHARF S, FALOONA F, MULLIS KB, HORN GT, ERLICH HA, ARNHEIM N. Enzymatic amplification of beta-globin genomic sequencies and restriction site analysis for diagnosis of sickle cell anemia. Science, v. 230, n. 4732 , p. $1350-4,1985$.

154. SANGUINETTI CJ, DIAS NETO E, SIMPSON AJ. Rapid silver staining and recovery of PCR products separated on polyacrylamide gels. Biotechniques, v. 17, n. 5, p. 914-21, 1994.

155. SASSANI R, BARTLETT SP, FENG H, GOLDNER-SAUVE A, HAQ AK, BUETOW KH, GASSER DL. Association between alleles of the transforming growth factor-alpha locus and the occurrence of cleft lip. Am J Med Genet, v. 45, n. 5, p. 565-9, 1993.

156. SCAPOLI L, PALMIERI A, MARTINELLI M, PEZZETTI F, CARINCI P, TOGNON M, CARINCI F. Strong evidence of linkage disequilibrium between polymorphisms at the IRF6 locus and nonsyndromic cleft lip with or without cleft palate, in an Italian population. Am J Hum Genet, v. 76, n. 1, p. 180-3, 
2005.

157. SCAPOLI L, PEZZETTI F, CARINCI F, MARTINELLI M, CARINCI P, TOGNON M. Lack of linkage disequilibrium between transforming growth factor alpha Taq I polymorphism and cleft lip with or without cleft palate in families from Northeastern Italy. Am J Med Genet, v. 75, n. 2, p. 203-6, 1998.

158. SCHLIEKELMAN P, SLATKIN M. Multiplex relative risk and estimation of the number of loci underlying an inherited disease. Am J Hum Genet, v. 71, n. 6, p. 1369-85, 2002.

159. SCHROEDER DC, GREEN LJ. Frequency of dental trait anomalies in cleft, sibling and non-cleft groups. J Dent Res, v. 54, p. 802-7, 1975.

160. SCHUTTE BC, MURRAY JC. The many faces and factors of orofacial clefts. Hum Mol Genet, v. 8, n. 10, p. 1853-9, 1999.

161. SHAPIRA Y, LUBIT E, KUFTINEC M. Congenitally missing second premolars in cleft lip and cleft palate children. Am J Orthod Dentofacial Orthop, v. 115, n. 4, p. 396-400, 1999.

162. SHAPIRA Y, LUBIT E, KUFTINEC M. Hypodontia in children with various types of clefts. Angle Orthod, v. 70, n. 1, p. 16-21, 2000.

163. SHAW D, RAY A, MARAZITA M, FIELD L. Further evidence of a relationship between the retinoic acid receptor alpha locus and nonsyndromic cleft lip with or without cleft palate (CL +/- P). Am J Hum Genet, v.53, n. 5, p. 1156-7, 1993.

164. SHAW GM, WASSERMAN CR, LAMMER EJ, O'MALLEY CD, MURRAY JC, BASART AM, TOLAROVA MM. Orofacial clefts, parental cigarette smoking, and transforming growth factor-alpha gene variants. Am J Hum Genet, v. 58, n. 3, p.551-61, 1996.

165. SHI M, CAPRAU D, DAGLE J, CHRISTIANSEN L, CHRISTENSEN K, MURRAY JC. Application of kinetic polymerase chain reaction and molecular beacon assays to pooled analyses and high-throughput genotyping for candidate genes. Birth Defects Res, v. 70, n. 2, p. 65-74, 2004. 
166. SHIANG R, LIDRAL AC, ARDINGER HH, BUETOW KH, ROMITTI PA, MUNGER RG, MURRAY JC. Association of transforming growth-factor alpha gene polymorphisms with nonsyndromic cleft palate only (CPO). Am J Hum Genet, v. 53, n. 4, p. 836-43, 1993.

167. SHPRINTZEN RJ. Terminology and classification of facial clefting. In: Mooney MP, Siegel MI. Understanding craniofacial anomalies: the etiopathogenesis of craniosynostosis and facial clefting. John Wiley and Sons, New York, p. 17-28, 2002.

168. SHULER CF, HALPERN DE, GUO Y, SANK AC. Medial edge epithelium fate traced by cell lineage analysis during epithelial-mesenchymal transformation in vivo. Dev Biol, v. 154, n. 2, p. 318-30, 1992.

169. SIOMI H, DREYFUSS G. RNA-binding proteins as regulators of gene expression. Curr Opin Genet Dev, v. 7, n. 3, p. 345-53, 1997.

170. SLAYTON RL, WILLIAMS L, MURRAY JC, WHEELER JJ, LIDRAL AC, NISHIMURA CJ. Genetic association studies of cleft lip and/or palate with hypodontia outside the cleft region. Cleft Palate Craniofac J, v. 40, n. 3, p. 274-9, 2003.

171. SOFAER JA. Human tooth-size asymmetry in cleft lip with or without cleft palate. Arch Oral Biol, v. 24, n. 2, p. 141-6, 1979.

172. SOZEN MA, SUZUKI K, TOLAROVA MM, BUSTOS T, FERNANDEZ IGLESIAS JE, SPRITZ RA. Mutation of PVRL1 is associated with sporadic, non-syndromic cleft lip/palate in northern Venezuela. Nat Genet, v. 29, n. 2, p. 141-2, 2001.

173. SPERBER GH. Craniofacial embryogenesis: normal developmental mechanisms. In: Mooney MP, Siegel MI. Understanding craniofacial anomalies: the etiopathogenesis of craniosynostosis and facial clefting. John Wiley and Sons, New York, p. 31-60, 2002.

174. SPERBER GH. Formation of the primary palate. In: Wyszynski DF, editor. Cleft lip and palate: from origin to treatment. Oxford: Oxford University 
Press, p. 5-13, 2002.

175. SPERBER GH. Palatogenesis: closure of the secondary palate. In: Wyszynski DF, editor. Cleft lip and palate: from origin to treatment. Oxford: Oxford University Press, p. 14-24, 2002.

176. SRICHOMTHONG C, SIRIWAN P, SHOTELERSUK V. Significant association between IRF6 820G/A and non-syndromic cleft lip with or without cleft palate in the Thai population. J Med Genet, v. 42, n. 7, p. e46, 2005.

177. STAHL F, GRABOWSKI R, WIGGER K. Epidemiology of Hoffmeister's "genetically determined predisposition to disturbed development of the dentition" in patients with cleft lip and palate. Cleft Palate Craniofac J, v. 43, n. 4, p. 457-65, 2006.

178. STEIN J, MULLIKEN JB, STAL S, GASSER DL, MALCOLM S, WINTER R, BLANTON SH, AMOS C, SEEMANOVA E, HECHT JT. Nonsyndromic cleft lip with or without cleft palate: Evidence of linkage to BCL3 in 17 multigenerational families. Am J Hum Genet, v. 57, n. 2, p. 257-72, 1995.

179. STERNLICHT MD, WERB Z. How matrix metalloproteinases regulate cell behavior. Annu Rev Cell Dev Biol, v. 17, p. 463-516, 2001.

180. STOLL C, QIAN JF, FEINGOLD J ET AL. Genetic variation in transforming growth factor alpha: possible association of BamHI polymorphism with bilateral sporadic cleft lip and palate. Hum Genet, v. 92, n. 1, p. 81-2, 1993.

181. SUAZO J, SANTOS JL, SILVA V, JARA L, PALOMINO H, BLANCO R. Possible association due to linkage disequilibrium of TGFA, RARA and BCL3 with nonsyndromic cleft lip with or without cleft palate in the Chilean population. Rev Med Chil, v. 133, n. 9, p. 1051-8, 2005.

182. SUZUKI Y, JEZEWSKI PA, MACHIDA J, WATANABE Y, SHI M, COOPER ME, VIET le T, NGUYEN TD, HAI H, NATSUME N, SHIMOZATO K, MARAZITA ML MURRAY JC. In a Vietnamese population, MSX1 variants contribute to cleft lip and palate. Genet Med, v. 6, n. 3, p. 117-25, 2004.

183. TANABE A, TAKETANI S, TOKUNAGA R, HIRAMOTOS M. Analysis of 
the candidate genes responsible for nonsyndromic cleft lip and palate in Japanese people. Clin Sci, v. 99, n. 2, p. 105-11, 2000.

184. TANIGUCHI T, OGASAWARA K, TAKAOKA A, TANAKA N. IRF family of transcription factors as regulators of host defense. Annu Rev Immunol, v. 19, p. $623-55,2001$.

185. TAYA Y, O'KANE S, FERGUSON MW. Pathogenesis of cleft palate in TGFbeta3 knockout mice. Development, v. 126, n. 17, p. 3869-79, 1999.

186. THE INTERNATIONAL HAPMAP CONSORTIUM. The International HapMap Project. Nature, v. 426, p.789-96, 2003.

187. TONGE CH. Identification of cell patterns in human tooth differentiation. $\mathbf{J}$ Dent Res., v. 46, n. 5, p. 876-8, 1967.

188. TREVILLATO PC, LINE SRP. Use of buccal epithelial cells for PCR amplification of large DNA fragments. J Forensic Odonto Stomatol, v. 18, n. 1, p. 6-9, 2000.

189. TRICOLI JV, NAKAI H, BYERS MG, RALL LB, BELL GI, SHOWS TB. The gene for human transforming growth factor alpha is on the short arm of chromosome 2. Cytogenet Cell Genet, v. 42, n. 1-2, p. 94-8, 1986.

190. TSAI TP, HUANG CS, HUANG CC, SEE LC. Distribution patterns of primary and permanent dentition in children with unilateral complete cleft lip and palate. Cleft Palate J, v. 35, n. 2, p. 154-60, 1998.

191. TUDELA C, FORMOSO MA, MARTINEZ T, PEREZ R, APARICIO M, MAESTRO C, DEL RIO A, MARTINEZ E, FERGUSON M, MARTINEZALVAREZ C. TGF-beta3 is required for the adhesion and intercalation of medial edge epithelial cells during palate fusion. Int J Dev Biol, v. 46, n. 3, p. 333-6, 2002.

192. VAN DEN BOOGAARD MJH, DORLAND M, BEEMER FA, VAN AMSTEL HKP. MSX1 mutation is associated with orofacial clefting and tooth agenesis in humans. Nat Genet, v. 24, n. 4, p. 342-343, 2000. 
193. VANDERAS AP. Incidence of cleft lip, cleft palate, and cleft lip and palate among races: a review. Cleft Palate Craniofac J, v. 24, n. 3, p.216-25, 1987.

194. VASTARDIS H. The genetics of human tooth agenesis: new discoveries for understanding dental anomalies. Am J Orthod Dentofacial Orthop, v. 117, n. 6, p. 650-6, 2000.

195. VICHI M, FRANCHI L. Abnormalities of the maxillary incisors in children with cleft lip and palate. J Dent Child, v. 62, n. 6, p. 412-417, 1995.

196. VIEIRA AR. Association between the Transforming Growth Factor Alpha Gene and Nonsyndromic Oral Clefts: A HuGE Review. Am J Epidemiol, v. 163, n. 9, p. 790-810, 2006.

197. VIEIRA AR. Oral clefts and syndromic forms of tooth agenesis as models for genetics of isolated tooth agenesis. J Dent Res, v. 82, n. 3, p. 162-5, 2003.

198. VIEIRA AR, AVILA JR, DAACK-HIRSCH S, DRAGAN E, FELiX TM, RAHIMOV F, HARRINGTON J, SCHULTZ RR, WATANABE Y, JOHNSON M, FANG J, O’BRIEN SE, ORIOLI IM, CASTILLA EE, FITZPATRICK DR, JIANG R, MARAZITA ML, MURRAY JC. Medical sequencing of candidate genes for nonsyndromic cleft lip and palate. PloS Genet, v. 1, n. 6, p. e64, 2005.

199. VIEIRA AR, KARRAS JC, ORIOLI IM, CASTILLA EE, MURRAY JC. Genetic origins in a South American clefting population. Clin Genet, v. 62, n. 6, p. $458-63,2002$.

200. VIEIRA AR, MEIRA R, MODESTO A, MURRAY JC. MSX1, PAX9, and TGFA contribute to tooth agenesis in humans. J Dent Res, v. 83, n. 9, p. 723-7, 2004.

201. VIEIRA AR, MODESTO A, MEIRA R, BARBOSA AR, LIDRAL AC, MURRAY JC. Interferon regulatory factor 6 (IRF6) and fibroblast growth factor receptor 1 (FGFR1) contribute to human tooth agenesis. Am J Med Genet, v. 143A, n. 6, p. 538-45, 2007.

202. VIEIRA AR, MURRAY JC, TREMBATH D, ORIOLI IM, CASTILLA EE, COOPER ME, MARAZITA ML, LENNON-GRAHAM F, SPEER M. Studies 
of reduced folate carrier 1 (RFC1) A80G and 5,10-methylenetetrahydrofolate reductase (MTHFR) C677T polymorphisms with neural tube and orofacial cleft defects. Am J Med Genet, v. 135, n. 2, p. 220-3, 2005.

203. VIEIRA AR, ORIOLI IM, CASTILLA EE, COOPER ME, MARAZITA ML, MURRAY JC. MSX1 and TGFB3 contribute to clefting in South America. J Dent Res, v. 82, n. 4, p. 289-92, 2003.

204. VIELAND VJ. Bayesian linkage analysis, or: How I learned to stop worrying and love the posterior probability of linkage. Am J Hum Genet, v. 63, n. 4, p.:947-954, 1998.

205. VINTINER GM, HOLDER SE, WINTER RM, MALCOLM S. No evidence of linkage between the transforming growth factor-alpha gene in families with apparently autosomal dominant inheritance of cleft lip and palate. J Med Genet, v. 29, n. 6, p. $393-7,1992$.

206. VU TH, SHIPLEY JM, BERGERS G, BERGER JE, HELMS JA, HANAHAN D, SHAPIRO SD, SENIOR RM, WERB Z. MMP-9/gelatinase B is a key regulator of growth plate angiogenesis and apoptosis of hypertrophic chondrocytes. Cell, v. 93, n. 3, p. 411-22, 1998.

207. WARRINGTON A, VIEIRA AR, CHRISTENSEN K, ORIOLI IM, CASTILLA EE, ROMITTI PA, MURRAY JC. Genetic evidence for the role of loci at 19q13 in cleft lip and palate. J Med Genet, v. 43, n. 6, p. e26, 2006.

208. WEINBERG SM, NEISWANGER K, MARTIN RA, MOONEY MP, KANE AA, WENGER SL, LOSEE J, DELEYIANNIS F, MA L, DE SALAMANCA JE, CZEIZEL AE, MARAZITA ML. The Pittsburgh Oral-Facial Cleft study: expanding the cleft phenotype. Background and justification. Cleft Palate Craniofac J, v. 43, n. 1, p. 7-20, 2006.

209. WERNER SP, HARRIS EF. Odontometrics of the permanent teeth in cleft lip and palate: systemic size reduction and amplified asymmetry. Cleft Palate $\mathbf{J}$, v. 26, n. 1, p. 36-41, 1989.

210. WILCOX JN, DERYNCK R. Developmental expression of transforming 
growth factors alpha and beta in mouse fetus. Mol Cell Biol, v. 8, n. 8, p. 341522, 1988 .

211. WYSZYNSKI DF, MAESTRI N, LEWANDA AF, MCINTOSH I, SMITH EA, GARCIA-DELGADO C, VINAGERAS-GUARNEROS E, WULFSBERG E, BEATY TH. No evidence of linkage for cleft lip with or without cleft palate to a marker near the transforming growth factor alpha locus in two populations. Hum Hered, v. 47, n. 2, p. 101-9, 1997.

212. WYSZYNSKI DF, MAESTRI N, MCINTOSH I, SMITH EA, LEWANDA AF, GARCIA-DELGADO C, VINAGERAS-GUARNEROS E, WULFSBERG E, BEATY TH. Evidence for an association between markers on chromosome 19q and non-syndromic cleft lip with or without cleft palate in two groups of multiplex families. Hum Genet, v. 99, n. 1, p. 22-6, 1997.

213. YAMADA Y. Identification of genetic factors and development of genetic risk diagnosis systems for cardiovascular diseases and stroke. Circ J, v. 70, n. 10, p. 1240-8, 2006.

214. YAO PJ, O'HERRON TM, COLEMAN PD. Immunohistochemical characterization of clathrin assembly protein AP180 and synaptophysin in human brain. Neurobiol Aging, v. 24, n. 1, p. 173-8, 2003.

215. YE S, ERIKSSON P, HAMSTEN A, KURKINEN M, HUMPHRIES SE, HENNEY AM. Progression of coronary atherosclerosis is associated with a common genetic variant of the human stromelysin-1 promoter which results in reduced gene expression. J Biol Chem, v. 271, n. 22, p. 13055-60, 1996.

216. YE S, WATTS GF, MANDALIA S, HUMPHRIES SE, HENNEY AM. Genetic variation in the human stromelysin promoter is associated with progression of coronary atherosclerosis. Br Heart J, v.73, n. 3, p. 209-15, 1995.

217. YE S. Polymorphism in matrix metalloproteinase gene promoters: implication in regulation of gene expression and susceptibility of various diseases. Matrix Biol, v. 19, n. 7, p. 623-9, 2000.

218. YOUNG DL, SCHNEIDER RA, HU D, HELMS JA. Genetic and teratogenic 
approaches to craniofacial development. Crit Rev Oral Biol Medical, v. 11, n. 3, p. 304-17, 2000.

219. YOSHIURA K, MACHIDA J, DAACK-HIRSCH S, PATIL SR, ASHWORTH LK, HECHT JT, MURRAY JC. Characterization of a novel gene disrupted by a balanced chromosomal translocation $\mathrm{t}(2 ; 19)(\mathrm{q} 11.2 ; \mathrm{q} 13.3)$ in a family with cleft lip and palate. Genomics, v. 54, n. 2, p. 231-40, 1998.

220. YUAN KF, LAI QG, LI DR, YANG ZJ, ZHOU XH. Relationship between transforming growth factor-alpha gene polymorphism and non-syndromic cleft lip with cleft palate. Hua Xi Kou Qiang Yi Xue Za Zhi, v. 24, n. 6, p. 533-5, 2006.

221. XIE J, ZHU H, LARADE K, LADOUX A, SEGURITAN A, CHU M, ITO S, BRONSON RT, LEITER EH, ZHANG CY, ROSEN ED, BUNN HF. Absence of a reductase, NCB5OR, causes insulin-deficient diabetes. Proc Nat Acad Sci, v. 101, n. 29, p. 10750-5, 2004.

222. ZHANG B, HENNEY A, ERIKSSON P, HAMSTEN A, WATKINS H, YE S. Genetic variation at the metalloproteinase-9 locus on chromosome 20q12.2-13.1. Hum Genet, v. 105, n. 5, p. 418-23, 1999.

223. ZHU H, QIU H, YOON HWP, HUANG S, BUNN HF. Identification of a cytochrome b-type NAD(P)H oxidoreductase ubiquitously expressed in human cells. Proc Nat Acad Sci, v. 96, n. 26, p. 14742-7, 1999.

224. ZUCCHERO TM, COOPER ME, MAHER BS, DAACK-HIRSCH S, NEPOMUCENO B, RIBEIRO L, CAPRAU D, CHRISTENSEN K, SUZUKI Y, MACHIDA J, NATSUME N, YOSHIURA KI, VIEIRA AR, ORIOLI IM, CASTILLA EE, MORENO L, ARCOS-BURGOS M, LIDRAL AC, FIELD LL, LIU Y, RAY A, GOLDTEIN T, SCHULTZ RE, SHI M, JOHNSON MK, KONDO S, SCHUTTE BC, MARAZITA ML, MURRAY JC. Interferon regulatory factor 6 (IRF6) gene variants and the risk of isolated cleft lip or palate. New Engl J Med, v. 351, n. 8, p. 769-780, 2004. 
ABSTRACT 


\section{ABSTRACT \\ DENTAL ANOMALIES AS PHENOTYPIC EXTENSION OF ORAL CLEFTS: MOLECULAR STUDIES OF CANDIDATE GENES AND CHROMOSOMAL REGIONS}

Cleft lip with or without cleft palate (CL/P) is a common craniofacial anomaly in humans, and may occur as part of a syndrome or isolated, when the affected individuals do not present any associated structural anomalies. The etiology of CL/P is complex, with both genetic and environmental factors involved. Several genes/loci have been suggested in the past years although discrepancies among results are often found. Some investigators consider CL/P as part of a broader phenotype, and suggest that additional clinical characteristics, such as the presence of dental anomalies, could be used for a better description of the individual phenotype in genetic studies. Five hundred individuals with $\mathrm{CL} / \mathrm{P}$ and five hundred non-related individuals without CL/P were examined regarding type of cleft and dental anomalies and saliva samples were collected from each individual for molecular analysis. The frequencies of the dental anomalies were significantly higher in CL/P individuals than controls, and the preferential associations observed for certain anomalies in specific cleft subphenotypes were considered new subphenotypes and included in the molecular analyses. A total of 30 polymorphisms distributed in MMP1, MMP3, MMP9, TGFA, and IRF6 genes and in chromosome region $6 \mathrm{q}$ were assayed regarding association with $\mathrm{CL} / \mathrm{P}$ and its subphenotypes through restriction-fragment length polymorphism, kinetic PCR and Taqman methods. Differences in allele and genotype frequencies observed in cases and controls for each polymorphism were assessed using Chi-square test and Bonferroni correction. The pattern of linkage disequilibrium among the markers was also evaluated. Associations between CL/P and markers in MMP3, TGFA, and IRF6 genes were observed. Additionally, three genes (PRSS35, SNAP91 and CYB5R4) and two polimorphisms in chromosome $6 q$ region also demonstrated association to CL/P and its phenotypes in the population studied.

Key words: cleft lip/palate, subphenotype, dental anomalies, genetic polymorphisms. 
APÊNDICE 


\title{
APÊNDICE 1 - ARTIGO ORIGINAL PUBLICADO
}

Letra A, Silva RA, Menezes R, de Souza AP, Almeida ALPF, Sogayar MC, Granjeiro JM. Studies with MMP-9 (C-1562 T) Gene Promoter Polymorphism in Nonsyndromic Cleft Lip/Palate. Am J Med Genet Part A, v. 89, n. 1, p. 89-91, 2007.

\section{Research Letter Studies With MMP9 Gene Promoter Polymorphism and Nonsyndromic Cleft Lip and Palate}

\author{
Ariadne Letra, ${ }^{1}$ Rodrigo A. da Silva, ${ }^{2}$ Renato Menezes, ${ }^{1}$ Ana P. de Souza, ${ }^{2}$ \\ Ana L.P.F. de Almeida, ${ }^{3}$ Mari C. Sogayar, ${ }^{4}$ and Jose M. Granjeiro ${ }^{5 *}$ \\ ${ }^{1}$ Department of Biological Sciences, Bauru Dental School, University of São Paulo, Baun, São Paub, Brazil \\ ${ }^{2}$ Oral Biology Program, University of Sagrado Coraçào, Baunu, São Paulo, Brazil \\ ${ }^{3}$ Department of Periodontology, Hospital of Rehabilitation and Craniofacial Anomalies, University of São Paulo, \\ Bauru, São Paub, Brazil \\ Institute of Chemistry, University of Säo Paulo, Sào Paulo, Brazil \\ SDepartment of Cellubr and Molecular Biology, Fluminense Federal University, Niterói, Rio de Janeiro, Brazil
}

Received 9 May 2006; Accepted 20 Augrast 2006

How to cite this article: Letra A, daSilva RA, Menezes R, de Souza AP, de Almeida ALPF, Sogayar MC, Granjeiro JM. 2007. Studies with MMP9 gene promoter polymorphism and nonsyndromic cleft lip and palate. Am J Med Genet Part A 143A:89-91.

\section{To the Editor:}

Nonsyndromic deft lip with or without palate (CL/ $\mathrm{P}$ ) is one of the most common congenital defects in humans. Birth prevalence varies based on ethnicity and geographic location [Vanderas, 1987]. Etiology still remains undear whilst the molecular mechanisms that control palate development are complex and not thoroughly understood.

Palatogenesis requires remodeling of the extracellular matrix (ECM) and subsequent fusion of the palatal shelves. In normal physiologic conditions, ECM remodeling is a strictly controlled process necessary for embryonic development and organogenesis [Woessner, 1994]. Disnuption of the coordinated migration and fusion of facial processes by genetic, environmental, or combined factors at any time point couldlead to CL/P[Wong and Hägg, 2004].

Matrix metalloproteinases (MMPs) comprise a group of likely candidate proteins involved in the etiology of $\mathrm{CL} / \mathrm{P}$ because of their role in modeling craniofacial tissues [Iamaroon et al., 1996]. Temporospatial expression of MMPs 2, 3, 7, 9, and 13 was observed during murine palatal fusion [MorrisWiman etal., 1999, 2000]. Moreover, previous studies have demonstrated an involvement of MMPs in the developing palate implying that such process requires proteolytic degradation of ECM, and MMPs as a necessary step for lip and palatal fusion [MorrisWiman et al., 2000; Blavier et al., 2001; Brown et al., 2002]. MMP9 gene maps to chromosome 20q12.2 and is known for its ability in degrading type IV collagen, a main component of the ECM, and facilitating cell migration [Zhang et al., 1999]. Blavier et al. [2001] detected a selective expression of MMP-9 in the ossification centers in the midline of the developing maxilla; however, nothing has ever been mentioned known about a role of MMP9 in the occurrence of CL/P. Nevertheless, the finding that degradation of the basal membrane adjacent to the medial epithelial edge (MEE) occurs simultaneously to epithelial-mesenchymal transformation (EMT), and the overexpression of certain MMPs in the MEE between the palatal shelves during fusion suggest that they might somehow be involved [Kaartinen et al., 1997; Blavier et al., 2001; Brown et al., 2002; Kang and Svoboda, 2005].

Polymorphisms in genes including TGF [Ardinger et al., 1989; Machida et al., 1999; Jugessur et al., 2003], MSX1 [Jezewski et al., 2003; Vieira et al., 2003], and $T G F-\beta 3$ [Jugessur et al., 2003; Vieira et al., 2003] have been associated to $\mathrm{CL} / \mathrm{P}$ in nonsyndromic patients. A polymorphism on chromosome $16 p 13$, comprising MMP25 gene, has also yielded evidence for linkage and association with $\mathrm{CL} / \mathrm{P}$ [Blanton et al., 2004].

\footnotetext{
Grant sponsor: CAPES and PROAP/ROB/USP; Grant sponsor: FAPESP Grant numbers: 03/10422-8, 01/10707-7; Grant sponsor: CNPq; Grant number: $50.5350 / 2004-1$ and $479043 / 2004-3$.

"Correspondence to: Jose M. Granjeiro, Departamento de Biologia Celular, Universidade Federal Fuminense, Campus do ValonguinhoOuteiro de Sảo Joào Ba ptista s/n, Centro, Niterói, Rio de Janeiro, Brazil. E-mail: jmgranjeiro@vm uf $\mathrm{br}$

DOI $10.1002 / 2 \mathrm{jmg}$ a. 31492
} 
A polymorphism on the MMP9 gene promoter $(-1562 \mathrm{C} / \mathrm{T})$ causes a functional effect on transcription, in which a $\mathrm{C}$ to $\mathrm{T}$ substitution results in the loss of binding of a nudear protein to this region of the MMP9 gene and an increase in transcriptional activity [Zhang et al., 1999]. Palate EMT requires several steps for the two epithelial sheets to fuse at the apical membranes and some cells may move to the oral or nasal epithelium. The cells increase, among other signal ing molecules, in MMPs, for matrix degradation [Kang and Svoboda, 2005]. A decrease in MMP levels could hypothetically lead to failure of fusion and a cleft of the lip and/or palate.

To address this hypothesis, genomic DNA samples from 125 nonsyndromic cleft lip/palate individuals ascertained through the Hospital of Rehabilitation and Craniofacial Anomalies of the University of São Paulo, Bauru, SP, Brazil and 173 healthy control individuals were analyzed by PCR-RFLP and gel electrophoresis. The study was approved by the IRB of the University of São Paulo and by the Brazilian Council for Ethics and Research on Human Subjects. All patients signed an informed consent sheet in agreement to the terms of the study.

Basic parameters of the population studied are shown on Table I. Genotypes were detected by polymerase chain reaction-restriction fragment length polymorphism. (PCR-RFLP). PCR was carried out in a total volume of $25 \mu \mathrm{l}$ containing $50 \mathrm{ng}$ genomic DNA, $10 \mathrm{mM}$ Tris- $\mathrm{HCl}$ (pH 8.3), $50 \mathrm{mM} \mathrm{KCl}$, $1.5 \mathrm{mM} \mathrm{MgCl}_{2}, 1 \mu \mathrm{M}$ of each primer, $200 \mathrm{mM}$ dNTPs, and 2.5 units Taq DNA polymerase (Invitrogen, Carlsbad, CA). Primer sequences were $5^{\prime}$-GCC TGGCACATAGTAGGCCC- $3{ }^{\prime}$ (forward) and $5^{\prime}$ CTTCCTAGCCAGCCGGCATC-3' (reverse). Reaction cycles were $95^{\circ} \mathrm{C}$ for $3 \mathrm{~min}, 35$ cycles at $95^{\circ} \mathrm{C}$ for $1 \mathrm{~min}, 65^{\circ} \mathrm{C}$ for $45 \mathrm{sec}, 72^{\circ} \mathrm{C}$ for $45 \mathrm{sec}$, and final extension at $72^{\circ} \mathrm{C}$ for $7 \mathrm{~min}$. Enzyme digestion was realized adding $2 \mu \mathrm{l}$ of PCR products to a $8 \mu \mathrm{l}$ solution containing $1 \mu \mathrm{l} 10 \mathrm{X}$ NE buffer, $0.3 \mu \mathrm{l} S p b$ I (20 units/ml) (New England Biolabs, Ipswich, MA), and $6.7 \mu \mathrm{l}$ sterile deionized water at $37^{\circ} \mathrm{C}$ overnight. The total amount of the digest was electrophoresed on a $10 \%$ vertical nondenaturing polyacrylamide gel

TABIE I. Baseline Clinical Characteristics of Individuals

\begin{tabular}{|c|c|c|c|}
\hline & Cleft $(n=125)$ & Control $(\mathrm{n}=173)$ & \\
\hline & $\mathrm{n}(96)$ & $\mathrm{n}(95)$ & $P$-value \\
\hline $\begin{array}{c}\text { Age (mean, } \\
\text { years) }\end{array}$ & 19,42 & 26,61 & 0.9345 \\
\hline \multicolumn{4}{|l|}{ Gender (96) } \\
\hline Female & $58(46)$ & $114(66)$ & 0.0007 \\
\hline Male & $67(54)$ & $59(30$ & \\
\hline \multicolumn{4}{|l|}{ Ethric group } \\
\hline Caucasian & $106(85)$ & $13 i(77)$ & 0.00001 \\
\hline Japanese & $1(0.8)$ & $27(16$ & \\
\hline Afro-American & $18(14.2)$ & $12(7)$ & \\
\hline
\end{tabular}

at $20 \mathrm{~mA}$. Staining procedures followed previously published protocols [Sanguinetti et al., 1994].

We tested the association between the MMP9 $-1562 \mathrm{C} / \mathrm{T}$ polymorphism and $\mathrm{CL} / \mathrm{P}$ using a casecontrol design. Differences in frequencies of the polymorphism in both groups were assessed by Chisquare test $\left(\gamma^{2}\right)$ and using the odds ratio and $95 \%$ confidence intervals. Statistically significant differences were set at $P<0.05$. The distribution of the MMP9 genotypes in cases and controls was consistent with Hardy-Weinberg equilibrium $(P>0.05$; Table II). We found no evidence for genotypic association in any of the groups $(\mathrm{OR}=1.307,95 \% \mathrm{CI}$ : $0.74-2.30$; Table II). The TT genotype which is believed to increase MMP-9 transcription and reported to be very low was not observed in any of the groups. No significant differences were observed regarding allele frequencies in any of the groups $(P>0.05)$

Logistic regression showed no differences in genotype distribution between cases and controls adjusted by race and gender $(\mathrm{OR}=1.3821,95 \% \mathrm{CI}$ : $0.73-2.60$, and $\mathrm{OR}=1.6193,95 \%$ CI: $0.93-2.82$, respectively). The Brazilian population consists of a large ethnic mixture of Latin-European whites, AfroBrazilian blacks, and Amerindians, which makes it very difficult to match perfectly the ethnicity of cases and controls and may have accounted for some confounding effects of undetectable population stratification. However, the discrete difference in the frequency of the $T$ allele between cases and controls seems not to be enough to account for such effect. In an attempt to overcome the problem of population stratification, since most individuals in this study were of Caucasian ethnicity, we compared genotype and allele frequencies in Caucasians only, and observed no significant differences $(\mathrm{OR}=1.11,95 \% \mathrm{CI}: 0.57-2.13$ and $\mathrm{OR}=1.09,95 \%$ CI: $0.59-2.03$, for genotype and allele frequencies, respectively).

Somewhat interesting results were found when cleft lip only, deft lip with deft palate and cleft palate only were evaluated separately (Table III). The CL group did not present significant differences regarding genotype distribution, but CLP and CP groups presented significantly more CC genotypes than CT $(P<0.05)$ (Table III). In addition, the CLP group

TABLE II. Genotype and Allele Frequencies Between Cleft and Control Subjects

\begin{tabular}{|c|c|c|c|}
\hline Frequency & Clef: $(\mathrm{n}=125)$ & Control $(n=173)$ & OR $(95 \% \mathrm{Cr})^{\circ}$ \\
\hline \multicolumn{4}{|l|}{ Genotype } \\
\hline$\infty$ & 101 & 132 & $1.307(0.74-2.30)$ \\
\hline $\mathrm{CT}$ & 24 & 41 & \\
\hline \multicolumn{4}{|l|}{ Allele } \\
\hline C & 226 & 305 & $1.26(0.74-2.15)$ \\
\hline T & 24 & 41 & \\
\hline
\end{tabular}


TABIF. III. Genotype Frequencies Between Cleft Subgroups

\begin{tabular}{|c|c|c|c|c|c|}
\hline \multirow[b]{3}{*}{ Cleft group } & \multicolumn{4}{|c|}{ Genotype } & \multirow[b]{3}{*}{ OR $(95 \% \mathrm{CT})^{\circ}$} \\
\hline & \multicolumn{2}{|c|}{$\infty C$} & \multicolumn{2}{|c|}{$\mathrm{CT}$} & \\
\hline & M & $\mathrm{F}$ & M & $\mathrm{F}$ & \\
\hline $\mathrm{CL}(\mathrm{n}=7)$ & 4 & 1 & 1 & 1 & \\
\hline$C \perp P(n=96)$ & 47 & 32 & 6 & 11 & $21.59(10.29-45.31)$ \\
\hline $\mathrm{CPO}(\mathrm{n}=22)$ & 8 & 10 & 1 & 3 & $20.25(4.37-93.72)$ \\
\hline
\end{tabular}

showed differences in genotype distribution and gender. Male cases frequently presented more CC genotypesthan females; the opposite was true for the CT genotype $(\mathrm{OR}=2.57,95 \% \mathrm{CI}: 1.00-6.61)$.

Our hypothesis that $\mathrm{CL} / \mathrm{P}$ individuals would tend to present significantly more CC genotypes than controls, indicating a possible downregulation of the MMP9 gene promoter thus decreasing tissue remodeling and further leading to a possible oral deft was not confirmed. Perhaps this lack of association could be a result of sample size. A convenient sample of 500 cases and 500 controls should achieve $80 \%$ statistical power [Purcell et al., 2003]. In addition, other factors such as occupational exposure and certain dietary components might interact with the MMP-9 genotype or act as potential confounders in the analysis. Unfortunately, information on these factors in our case-control study was not available. It would be interesting to investigate the interaction between MMP-9 genotypes and these risk factors in future studies.

Although the results for the MMP9 $-1562 \mathrm{C} / \mathrm{T}$ polymorphism in this particular study do not provide evidence of a major role for this gene in NSCLP, other MMPs might present positive levels of involvement and their association with $\mathrm{CL} / \mathrm{P}$ is yet to be elucidated.

\section{ACKNOWLEDGMENTS}

We thank all the individuals that contributed DNA samples to this study. AL and RM were supported by CAPES and PROAP/FOB/LSP. Dr. Pardo and Dr. Sogayar were supported by FAPESP (grants 03/ $10422-8$ and $01 / 10707-7$, respectively). Dr. Granjeiro was supported by CNPq (grants 50.5350/2004-1 and 479043/2004-3). We also thank TL Silva, O. Sobrinho, and W. Orcini for the technical support and Prof. AR Vieira for the critical reading and comments on the manuscript.

\section{REFERENCES}

Ardinger $\mathrm{HH}$, Buetow KH, Bell GI, Bardach J, Van Denmark DR, Murray JC. 1989. Association of genetic variation of the transforming growth factor-alpha gene with cleft lip and palate. Am J Hum Genet 45:348-353.

Blanton SH, Bertin T, Sema ME, Stal S, Mulliken JB, Hecht J. 2004 Association of chromosomal regions $3 p^{2} 1.2,10 p 13$, and $16 \mathrm{p} 13.3$ with nonsyndromic cleft lip and palate. Am J Med Genet Part A 125 A: 23-27.

Bhvier L, Lazaryev A, Groffen J, Heisterkamp N, Declerk Y, Kaartinen V. 2001. TGFB3-induced palatogenesis requires matrix metalbproteinases. Mol Biol 12:1457-1466.

Brown NL, Yamam SJ, Mansell JP, Sandy JR 2002. Matrix metalloproteinases have a role in palatogenesis. J Dent Res $81826-830$.

Iamaroon A, Wallon UM, Overall CM, Diewert VM. 1996 Expression of $72 \mathrm{kDa}$ gelatinase (matrix metalloproteinase-2) in the developing mouse craniofacial complex. Arch Oral Biol 41:1109-1119.

Jezewski PA, Vieira AR, Nishimura C, Ludwig B, Johnsan M, O'Brien SE, Daack-Hirsch S, Schultz RE, Weber A, Nepomucena B, Romitti PA, Christensen K, Orioli IM, Castilla EE, MachidaJ, Natsume N, Murray JC. 2003. Complete sequencing shows a role for MSX1 in nonsyndromic deft lip and palate. J Med Genet 40:399-407.

Jugessur A, Lie R, Wilcox A, Murray J, Taybor J, Saugstad O Vindenes H, Abyholm F. 2003. Variants of developmental genes (TGFA, TGFB3, and MSX 1 ) and their assodations with oral clefts: A case-parent triad amalysis. Genet Epidemiol $24: 230-239$.

Kaartinen V, Cui XM, Heiste rkamp N, Groffen J, Shuler CF. 1997. Transforming growth factor- $\beta 3$ regulates transdifferentiation of medial edge epithelium during palatal fusion and assodated degradation of the basement membrane. Dev Dyn 209:255-260.

Kang P, Svoboda KKH. 2005. Epithelial-mesenchymal transformation during craniofacial development. J Dent Res 84678690.

Machida J, Yoshiura K, Funkhauser C, Natsume N, Kawai T, Murray J. 1999. Transforming growth factor- $\alpha$ (TGFA) Genomic structure, boundary sequences, and mutation analysis in nonsyndromic cleft lip/palate and cleft palate only. Genomics $61: 237-242$.

Morris-Wiman J, Du Y, Brinkley L. 1999. Occurrence and temporal variation in matrix metalloproseinases and their inhibitors of matrix metalloproteinases during murine and secondary palatal morphogenesis. J Craniof ac Genet Dev Biol 19:201-212.

Morris-Wiman J, Burch H, Basco E. 2000. Temporospatial distribution of matrix metalloproseimases and tissue inhibitors of metalloproteinases during murine secondary palate morphogenesis. Anat Embryol (BerD 202:129-141.

Purcell S, Cherny SS, Sham PC. 2003. Genetic power calculator: Design of linkage and association genetic mapping studies of complex traits. Bioinformatics 19:149-150.

Sanguinetti CJ, Dias Neto E, Simpson AJ. 1994. Rapid silver staining and recovery of PCR products separated on polyacrylamide gels. Biotechniques 17:914-921.

Vanderas AP. 1987. Incidence of cleft lip, deft pabte, and clefi lip and palate among races: A review. Cleft Palate J 24:216225.

Vieira A, Oriolli I, Castilla E, Cooper M, Marazita M, Murrayj. 2003. $M S X 1$ and TGFB3comtribute to defting in South America. J Dent Res 82:289-292.

Woessner JF. 1994. The family of matrix metalloproteimases. In: inhibition of matrix metalloproteinases: Therapeutic potential. Ann NY Acad So 732:11-21,

Wong FK, Hāgg U. 2004. An update on the aetiology of orofacial clefts. Hong Kong Med J 10:331-336.

Zhang B, Henney A, Eriksson P, Hamsten A, Watkins $H$, Ye S. 1999. Genetic variation at the metalloproteinase-9 bcus on chromosome 20q12.2-13.1. Hum Genet 105:418-423. 


\section{APÊNDICE 2 - ARTIGO ORIGINAL SUBMETIDO PARA PUBLICAÇÃO}

Letra A, Silva RA, Menezes R, Astolfi CM, Shinohara A, de Souza AP, Granjeiro JM. MMP gene polymorphisms as contributors for cleft lip/palate: association with MMP3 but not MMP1. Arch Oral Biol (em fase de revisão)

Elsevier Editorial System(tm) for Archives of Oral Biology

Manuscript Draft

Manuscript Number: AOB-D-06-00382R1

Title: MMP gene polymorphisms as contributors for cleft lip/palate: association with MMP3 but not MMP1.

Article Type: Original Paper

Section/Category:

Keywords:

Corresponding Author: Dr. Jose Mauro Granjeiro, DDS, MSc, DSc

Corresponding Author's Institution: Fluminense Federal University

First Author: Ariadne Letra, DDS, MS

Order of Authors: Ariadne Letra, DDS, MS; Rodrigo A Silva; Renato Menezes, DDS, MS, PhD; Claudia M Astolfi, DDS, MS; Andre Shinohara, DDS, MS; Ana Paula De Souza, DDS, MS, PhD; Jose M Granjeiro

Manuscript Region of Origin: 


\section{Uff}

Universidade Federal Fluminense Instituto de Biologia

Departamento de Biologia Celular e Molecular

Outeiro de São João Baptista, s/n, Campus do Valonguinho Centro/Niteroi - RJ CEP:24.020-150

FONE: (021) 26292324 - FAX: (021) 37011617

Niterói, February 6, 2007.

To Mr. Paul Crabtree

Journal Manager

Archives of Oral Biology

Ref.: Ms. No. AOB-D-06-00382

Title: "Studies of polymorphisms in MMP1 and MMP3 gene promoters as contributors for cleft lip and palate"

Thank you for the opportunity to resubmit our study, hereafter renamed "MMP gene polymorphisms as contributors for cleft lip/palate: association with MMP3 but not MMP1".

We have read the comments of both reviewers, which were very thorough and constructive and have made substantial alterations accordingly.

We hope that the manuscript is now appropriate for further review. We have addressed each of the referee's questions (in bold) in the List of Revisions.

Thank you very much.

Sincerely,

Prof. Dr. José Mauro Granjeiro (Corresponding author) (jmgranjeiro@vm.uff.br).

Department of Cell and Molecular Biology, Institute of Biology - Fluminense Federal

University /UFF, Outeiro de São João Baptista, s/n

Campus do Valonguinho, Centro/Niterói - RJ, CEP: 24.020-150

Phone: 552126292324 Fax: 552137011617 


\title{
* List of revisions made
}

\author{
Ref.: Ms. No. AOB-D-06-00382
}

Reviewer comments:

Reviewer \#1: This manuscript reports an association of a polymorphic variant of the MMP3 locus with cleft lip and/or palate in comparisons with unrelated controls.

Comments:

1. Abstract. Clarify that CLP here means "cleft lip and/or palate" not "cleft lip and palate" as stated in lines 4-5. Some of the cases had cleft palate only (CP). Yes, CLP has been corrected to CL/P meaning cleft lip with or without cleft palate.

2. Introduction. (a) The vast majority of the cases in this study had cleft lip with or without cleft palate. The description of development of the face seems to have mixed together the development of the upper lip with the development of the secondary palate, and is confused, and in need of being re-written. The lip develops before the secondary palate, from the fusion of facial prominences, not the fusion of "shelves". These primordia are not "midfacial" as stated, considering that the maxillary prominences are involved and come in from the sides of the embryo. The mesenchyme that achieves confluence to form the upper lip is not the "palatal mesenchyme". The MEE appears to be part of the secondary palate, not the lip. What is the "MES"? MES means Medial Epithelial Seam, but it has been changed to MEE to standardize nomenclature. In summary, the development of the upper lip needs to be described separately from the development of the secondary palate. The formation of primary and secondary palates were discussed separately.

3. Introduction. All of the studies cited that describe expression of MMPs in the orofacial complex are concerned with the secondary palate, but the vast majority of cases in this study have cleft lip, and the expression in the secondary palate may be irrelevant. MMP expression in the facial prominences is the information needed here, and if the studies do not exist and if it is not known whether MMP3 and MMP1 or any other MMPs are expressed in the facial prominences, this needs to be stated. I am aware of one study by lamaroon, Wallon, Overall and Diewert (1997, Arch Oral Biol) that has studied MMP expression in the facial prominences. The study by lamaroon et al $\mathbf{1 9 9 6}$ was incorporated into the text as well as other studies regarding MMP3 and MMP1 during craniofacial development.

4. Introduction. MMP1 and MMP3 are on Chromosome 11q22 as stated. Linkage studies that specifically suggest the location of genes involved in cleft lip with or without cleft palate on Chromosome 11q should be cited and the fact that a known liability factor in Venezuela, PVRL1, is in the same region (11q22.3) should be noted. I wonder whether there is linkage disequilibrium between MMP3-5A and a CL(P) liability allele at PVRL1 in your population. Two additional references on the association of PVRL1 and CL/P have been added in the context of being close to the loci of both MMP1 and MMP3.

5. Materials and Methods. Subjects. It would be better to state here exactly how many had $\mathrm{CL}(\mathrm{P})$ and how many had $\mathrm{CP}$. The number of individuals per cleft type has been included in the M \& M section. Is access to dental care (the source of controls) more associated with socioeconomic status than access to cleft lip and palate clinics? Not in this study. The great majority of controls and cases were from the same region. Control individuals were seeking treatment at the University Clinics, a free service, as well as the treatment for cleft patients in HRAC hospital. The majority of the patients are of low socioeconomic 
status.

6. Materials and Methods. A reference or name of the analytical program used for logistic regression needs to be stated. Corrected.

7. Results. It is not clear what the results of the logistic regression indicate. These results seem to need to be expressed more clearly. What was the question being tested? We performed regression analyses to test if differences in ethnicity would affect genotype distribution, which was true for MMP3. This can be attributed to the mixed ethnicity seen in Brazilian individuals due to a mixture of Latin-European whites, Afro-Brazilian Blacks and Amerindians which makes matching cases and controls by ethnicity a hard task.

8. Results. The last paragraph is a bit misleading. The reason the $1 \mathrm{G} / 1 \mathrm{G}+5 \mathrm{~A} / 5 \mathrm{~A}$ haplotype is not significantly more common in cases is that both the cases and controls have small samples with this combination; the trend is for an excess of this genotype in the cases, as for all of the other haplotypes involving $5 \mathrm{~A} / 5 \mathrm{~A}$. We have decided to exclude this analysis from the manuscript, following suggestions of referee \#2.

9. Discussion. The first line is a bit ambiguous. Try "jointly involved". Corrected.

10. Discussion. Again, all the references $(13,15-17)$ are concerned with the secondary palate, which would lead to $C P$, not the facial prominences, which lead to $C L(P)$. See comment \#3. This problem, discussion of the secondary palate, when what needs to be discussed is the upper lip, occurs in several places in the discussion. Corrected.

11. Table 1 and Materials and Methods. How was "ethnicity" assigned? Many people are not from a single ethnic origin. Perhaps the "Caucasians"in the case group have more genetic admixture of aboriginal origins than the controls. Ethnic differences in clefting frequencies are well known. Explained in the Logistic regression part in the results section.

12. Table 5 and Discussion. My analyses of the data show that in addition to being not different from the CL/P group, the CP group is not significantly different from the control group either. The entire association of "CLP" with 5A may be derived from the CL/P (cleft lip) group. The current presentation in the paper seems to imply that the CP group contributes to the association, and it has no grounds for doing so. We have provided comparisons of each cleft type with controls.

13. Table 7. A reference for the specific statistical methods used to obtain $P$ values for each line on this table needs to be provided in the Materials and Methods, including the degrees of freedom. This is not the result of a simple Chi square test. As it stands it looks like it could be an invalid analysis. Table 7 has been excluded. 


\section{Reviewer \#2:}

This manuscript reports a highly significant association $(p=0.00001)$ between a polymorphism in the promoter of the gene for the matrix metalloproteinase 3 (MMP3) and nonsyndromic cleft lip + palate (CL/P) in a sample from Brazil. Negative results between CL/P and an MMP1 polymorphism are also reported. If this association between MMP3 and CL/P is confirmed, it will be an important addition to the literature on the genetics of CL/P. However, several aspects of the manuscript are of concern:

1. The rationale for studying MMPs as candidate genes for CL/P could be strengthened. As the authors note, there have been a few reports of MMP3 expression during murine palate formation (e.g., Brown et al., J Dent Res 81:826, 2002). More current literature should be cited on the MMPs (e.g. Verstappen and Von den Hoff, J Dent Res 85:1074, 2006) and the genetics of clefting (e.g., Zucchero, NEJM 351:19; 2004; Lidral and Moreno, Curr Opin Pediatr 17:731; 2005). This would provide a balanced view of the literature (much of which does not suggest a linkage between clefting and chromosome 11q23, where MMP3 and MMP1 are located), as well as a sense of the recent progress in identifying genes that increase risk for clefting. The introduction has been rewritten accordingly. The original papers cited in the review by Verstappen and von den Hoff (2006) had been cited previously.

As a related point, why look at only MMP1 and MMP3? There is a large family of MMPs involved in remodeling the extracellular matrix, some implicated in tooth development. Several MMP genes are located at chromosome 11q23, and could have been studied along with MMP1 and MMP3. The paper would be strengthened by discussing the MMP family as a whole, with a rationale for the specific choices of MMP1 and MMP3. We have emphasized the roles of other MMPs also and justified our reason for choosing MMP1 and MMP3.

2. Why weren't more of the original 535 individuals actually genotyped? In a genetic association study, sample sizes should always be as large as possible. If the total sample is unavailable, only those individuals who were actually genotyped should be mentioned, not the 535 individuals. Table 1 should be modified to reflect these smaller samples. Agreed. Table I now contains information of the subjects according to each gene tested.

3. As the authors appropriately note, population stratification might be a possible explanation for the positive MMP3 result. They report that their cases and controls differ significantly by ethnicity, which is a good reason to use population stratification to discount their result entirely. However, the association between MMP3 and clefting is very strong, and will likely remain after the cases and controls are adjusted to remove the ethnic differences. Analyzing and reporting only Caucasians, which make up the great majority of the sample, would fix this problem. If the authors follow this suggestion, they should still discuss the ethnicity of "Caucasians" in Brazil, since this is a complex designation in and of itself. There is no need to evaluate gender in this context, and the gender differences should be removed from this discussion (Page 7, last paragraph). Agreed. Analyses with Caucasians subjects only have been provided, in addition to the analyses with the total population.

4. The DNA Collection, Genotyping, and Gel electrophoresis sections in Materials and Methods can be considerably shortened. These are standard methods, and can be described as such, with appropriate citations to prior publications or lab manuals. The first two sentences of the results section fit better in Methods. Along these lines, Table 2 seems excessive; a citation to the appropriate primers for these polymorphisms would be sufficient here. Table 2 was removed and $M \& M$ section summarized. 
5. The MMP1 analysis was nonsignificant, and can be summarized quickly in a few sentences, eliminating the need for Tables 4 and 6 . Corrected accordingly.

6. Table 5 could be merged into Table 3 , thus shortening the paper, as well as providing all the MMP3 data in one place. The numbers in Table 5 do not add up to the totals provided at the top of the table; please correct these numbers. Corrected accordingly.

7. The haplotype analysis is inappropriate. Judging from the results of the two loci analyzed separately, the haplotype analysis appears to be driven by the MMP 3 finding, and does not add anything to the paper. It could be deleted, which would eliminate Table 6 and shorten the paper. It has been removed.

8. In general the manuscript is well written. However, it could still benefit from a careful editing, to catch typos (e.g., change MES to MEE, Introduction, second paragraph, twice) or awkward wording. Just a note: Manuscripts shouldn't be submitted with comments between authors left in the margins. Corrected.

Editor: We have two excellent reviews of your submission. Both recognize the originality and significance of your findings but have a number of concerns that warrant substantial revision. Both reviews are constructive and revision is feasible. If you choose to submit a revised version I will be happy to submit it to further review. If you choose to do this please include a description of how you have addressed each of the referee's concerns. 


\section{Abstract}

(1) Objective: Orofacial clefs result from failures of developing embryonic facial and palatal processes to either completely merge or fuse. Normal development of the facial primordia requires remodeling of the extracellular matrix, which is mediated in part by the matrix metalloproteinases (MMPs). MMPs can be considered a group of likely candidate proteins for the etiology of cleft lip with or without cleft palate $(\mathrm{CL} / \mathrm{P})$ due to their role in craniofacial modeling. The purpose of this study was to investigate if polymorphisms in $M M P 1$ and $M M P 3$ gene promoters were associated with $\mathrm{CL} / \mathrm{P}$.

(2) Design: DNA was extracted from buccal epithelial cells and genotypes obtained from cases and controls through kinetic PCR $(M M P 3, \mathrm{n}=333)$ and restriction-fragment length polymorphism techniques $(M M P 1, \mathrm{n}=395)$.

(3) Results: Significant differences were observed for $M M P 3(5 \mathrm{~A} / 6 \mathrm{~A})$ allele $(\mathrm{p}=0.00001)$, and genotype frequencies ( $\mathrm{p}=0.00001)$ between cases and controls; and between cleft types and controls ( $p=0.00001$ for $C L / P ; p=0.04$ for $C P$ ). No significant differences were found for $M M P 1$ allele and genotype frequencies between cases and controls or between cleft types and controls ( $\mathrm{p}>0.05$ ).

(4) Conclusions: An association between a polymorphism in $M M P 3$ gene and CL/P has been shown. Although the extent to which this polymorphism may actually contribute to the affected cleft status is yet to be clarified, polymorphisms of $M M P$ genes may be good candidates as genetic factors for their role in active ECM remodeling.

Key words: matrix metalloproteinase, polymorphism, cleft lip/palate. 


\section{Manuscript text}

MMP gene polymorphisms as contributors for cleft lip/palate: association with MMP3 but not MMPl.

Ariadne Letra ${ }^{1}$, Rodrigo A. Silva ${ }^{2}$, Renato Menezes ${ }^{1}$, Claudia M. Astolfi ${ }^{2}$, André Shinohara ${ }^{2}$, Ana Paula de Souza ${ }^{2}$, José Mauro Granjeiro ${ }^{3 *}$

${ }^{1}$ Department of Biological Sciences, Bauru Dental School, University of São Paulo

${ }^{2}$ Oral Biology Program, University of Sagrado Coração, Bauru, SP, Brazil

${ }^{3}$ Department of Cellular and Molecular Biology, Fluminense Federal University, Niterói,

RJ, Brazil

*Corresponding author:

Prof. Dr. José Mauro Granjeiro

Departamento de Biologia Celular

Universidade Federal Fluminense

Campus do Valonguinho

Outeiro de São João Baptista s/n, Centro, Niterói, RJ, Brazil.

Telephone: (55) 21 2629-2324.

Email: jmgranjeiro@vm.uff.br

Running title: MMP polymorphisms and cleft lip/palate. 


\section{Abstract}

(1) Objective: Orofacial clefs result from failures of developing embryonic facial and palatal processes to either completely merge or fuse. Normal development of the facial primordia requires remodeling of the extracellular matrix, which is mediated in part by the matrix metalloproteinases (MMPs). MMPs can be considered a group of likely candidate proteins for the etiology of cleft lip with or without cleft palate $(\mathrm{CL} / \mathrm{P})$ due to their role in craniofacial modeling. The purpose of this study was to investigate if polymorphisms in $M M P 1$ and $M M P 3$ gene promoters were associated with $\mathrm{CL} / \mathrm{P}$.

(2) Design: DNA was extracted from buccal epithelial cells and genotypes obtained from cases and controls through kinetic PCR $(M M P 3, \mathrm{n}=333)$ and restriction-fragment length polymorphism techniques (MMPl, $\mathrm{n}=395)$.

(3) Results: Significant differences were observed for $M M P 3$ ( $5 \mathrm{~A} / 6 \mathrm{~A})$ allele $(\mathrm{p}=0.00001)$, and genotype frequencies $(p=0.00001)$ between cases and controls; and between cleft types and controls $(\mathrm{p}=0.00001$ for $\mathrm{CL} / \mathrm{P} ; \mathrm{p}=0.04$ for $\mathrm{CP}$ ). No significant differences were found for $M M P 1$ allele and genotype frequencies between cases and controls or between cleft types and controls $(\mathrm{p}>0.05)$.

(4) Conclusions: An association between a polymorphism in $M M P 3$ gene and $\mathrm{CL} / \mathrm{P}$ has been shown. Although the extent to which this polymorphism may actually contribute to the affected cleft status is yet to be clarified, polymorphisms of $M M P$ genes may be good candidates as genetic factors for their role in active ECM remodeling.

Key words: matrix metalloproteinase, polymorphism, cleft lip/palate. 


\section{Introduction}

Orofacial clefting is a failure of developing embryonic facial and palatal processes to either completely merge or fuse which results in a predictable series of postnatal deformities. Clefts of the lip with or without palate (CL/P) account for about $65 \%$ of all congenital anomalies ${ }^{1}$ occurring in about $1 / 700$ live births with wide variability related to geographic origin ${ }^{2}$ and socioeconomic status ${ }^{3}$. Life-long treatment including surgical, dental, nutritional, speech, medical and behavioral interventions accompanies affected individuals throughout their entire lives ${ }^{4}$. Isolated or non-syndromic $\mathrm{CL} / \mathrm{P}$, which represents $70-90 \%$ of all $\mathrm{CL} / \mathrm{P}$ cases, is considered to be multifactorial in origin, with both genetic and environmental components involved ${ }^{1}$.

The distinct timing and complex coordination of developmental events leading to the formation of the primary palate clearly distinguish $\mathrm{CL} / \mathrm{P}$ and cleft palate only $(\mathrm{CP})$ as separate biological entities. The primary palate initially forms around the developing olfactory placodes with the rapid proliferation of the lateral epithelium and underlying mesenchyme $e^{5,6,7}$. Thereafter, spatial and biomechanical changes associated with craniofacial growth must occur in sequence within a critical period in development, during week 5 to week 7 in humans. The upper lip is completed after fusion of the maxillary and frontonasal prominences and requires critically timed coordination of growth between these processes, exact spatial localization and further differentiation (or degradation) of the epithelium to allow for the uninterrupted flow of mesenchymal cells within the upper lip by 7 weeks of development ${ }^{6,7,8}$. As with primary palatogenesis, closure and fusion of the secondary palate require strict coordination between the palatal shelves, including shelf growth and apoptosis (or further differentiation) of the epithelium along the medial edges of the palatal shelves. At week 8 of development, the palatal shelves rotate from a vertical 
position on each side of the tongue and elevate to a horizontal position forming the medial edge epithelia (MEE) between the two shelves. Upon contact in the midline, adhesive contact, seam fusion along the medial edges and apoptosis of the epithelium are essential for normal palatal closure ${ }^{6,7,8,9,10}$. Defects or failures at any time point during early embryonic development may result in the formation of clefts of the lip and/or palate $e^{11,12}$. During embryonic development, the process of morphogenesis is accompanied by changes within the composition of the extracellular matrix which further allows for cell migration and differentiation, cell-cell interactions and tissue resorption Matrix metalloproteinases (MMPs) are a family of proteolytic enzymes involved in normal and pathological tissue remodeling known for their ability of collectively degrading all components of the ECM and may be implicated in cleft lip/palate ${ }^{14}$. The MMP family is composed of 23 enzymes that share significant sequence homologies and is divided into five classes: collagenases, gelatinases, stromelysins, membrane-type MMPs, and others, including a few of the most recently identified $\mathrm{MMPs}^{13}$.

Strong evidence for implying MMPs as candidates for CL/P comes from a variety of biological studies. Regarding the primary palate, Iamaroon et al $(1996)^{15}$ demonstrated the temporo-spatial distribution of MMP-2 in early development of the mouse craniofacial complex, in which the expression of MMP-2 was intensely localized to the outgrowing regions of the primary palate, with concomitant localization of fibronectin, and further suggested that aberrant expression or function of the enzyme may have causative role in craniofacial anomalies. Other MMPs have been shown in the developing secondary palate $16,17,18$ associated with degradation of the extracellular matrix required for palatal fusion ${ }^{18}$. The increased expression of MMPs 2, 3,9 and 13 has been demonstrated within the medial mesenchyme surrounding the degenerating medial edge epithelia during murine palatal 
fusion, whereas MMP-3 showed the most extensive distribution of all MMPs during palatal shelf morphogenesis ${ }^{16,17}$.

MMP-3, also known as stromelysin-1, has been detected in vivo subjacent to the medial edge epithelium following contact of the palatal shelves ${ }^{14}$ and has been demonstrated to play a role in epithelial-mesenchymal transformation (EMT), once induction of its expression results in cleavage of cadherin, loss of the epithelial phenotype and subsequent stable conversion of epithelia into mesenchyme ${ }^{19}$. Constantly high levels of active MMP-3 were observed during the latter stages of palatogenesis and may represent an important stimulus for $\mathrm{EMT}^{14}$. MMP-3 presents a broad substrate specificity, including type III, IV and V collagens, and non-collagenous ECM components such as proteoglycans, fibronectin and laminin. MMP-3 is capable of activating other MMPs, including MMP-1. MMP-1, or collagenase-1, is the most widely expressed MMP that possesses proteolytic activities against fibrillar collagens (collagens types I, II and III), the most abundant class of ECM proteins in interstitial connective tissue ${ }^{21}$. Although until now there are no specific reports regarding MMP-1 expression during lip or palate development, MMP-1 is expressed during facial development and has been implicated as playing a key role during early tooth development ${ }^{22}$.

Both MMP1 and MMP3 genes are located near each other on chromosome 11q23 and the level of expression of these genes can be influenced by single nucleotide polymorphisms (SNPs) in the promoter region of their respective genes ${ }^{23,25}$. The promoter region of $M M P l$ contains a guanine insertion/deletion polymorphism $(1 \mathrm{G} / 2 \mathrm{G}$ polymorphism) at position -1607 . This $2 \mathrm{G}$ allele results in increased transcriptional activity because the guanine insertion creates a binding site for a member of the Ets transcription factor family ${ }^{24}$. The promoter region of the $M M P 3$ gene is characterized by a $5 \mathrm{~A} / 6 \mathrm{~A}$ 
promoter polymorphism at position -1171 in which one allele has six adenosines (6A) and the second has five adenosines $(5 \mathrm{~A})$. The $6 \mathrm{~A}$ allele has a lower promoter activity than the $5 \mathrm{~A}$ allele in vitro ${ }^{23}$.

Linkage studies have suggested loci on chromosomes $1,2,4,6,11,14,16,17$ and 19 as candidates for the risk of orofacial clefting ${ }^{26}$. Inactivation of MMP genes has been correlated with cleft palate ${ }^{27}$ and a region on chromosome $16 \mathrm{p} 13$, containing MMP25 gene, has yielded evidence for linkage and association with $\mathrm{CL} / \mathrm{P}$, suggesting some level of involvement of the MMP family in clefting ${ }^{28}$. Many MMP genes are clustered in chromosome 11q23 (MMP1, MMP3, MMP7, MMP8, MMP10, MMP12, MMP13, MMP20) but have not yet been shown in association to $\mathrm{CL} / \mathrm{P}$. Nevertheless, although the $11 \mathrm{q} 23$ locus has not been regarded as a very suggestive one, recent studies have shown that the PVRL1 gene, located in that same region (11q23.2) has been demonstrated as a liability factor for $\mathrm{CL} / \mathrm{P}$ in Venezuela ${ }^{29,30}$. Another recent study reported the lack of association between a polymorphism in $M M P 9$ and $\mathrm{CL} / \mathrm{P}$ patients ${ }^{31}$ although $M M P 9$ was considered a liable candidate gene as it has been demonstrated to be selectively expressed in the ossification centers of the maxilla during palatal fusion ${ }^{18}$.

Despite the relative unsuccessful results of the studies with MMP genes as possible contributors to $\mathrm{CL} / \mathrm{P}$, the fundamental role of the entire MMP family during $\mathrm{ECM}$ remodeling in the craniofacial complex warrants further investigations. Hence, the purpose of the present study was to investigate the association of polymorphisms in $M M P 1$ and $M M P 3$ gene promoters in individuals with isolated CL/P. 


\section{Material and methods}

Subjects

Table I presents the basic parameters of the studied population. Individuals with nonsyndromic cleft lip/palate were ascertained through the Hospital of Rehabilitation and Craniofacial Anomalies (HRAC) of the University of São Paulo, Bauru, SP, Brazil. Individuals without clefts and no positive family history of clefting were used as controls and were ascertained through the Dental Clinics of Bauru Dental School, University of São Paulo, Bauru, SP, Brazil. For $M M P 1,170$ individuals with CL/P (139 with CL/P and 24 with $\mathrm{CP}$ ) and 225 controls were genotyped; for $M M P 3,78$ individuals with $\mathrm{CL} / \mathrm{P}$ (62 with $\mathrm{CL} / \mathrm{P}$ and 11 with $\mathrm{CP}$ ) and 255 controls were genotyped. The study was approved by the local IRB and all patients signed a consent form in agreement to the terms of the study.

\section{Collection of DNA samples}

Genomic DNA was obtained from sampling of epithelial buccal cells as previously described. DNA samples were frozen at $-20^{\circ} \mathrm{C}$ until used for DNA extraction procedures using sequential ammonium acetate purification and salt/ethanol precipitation ${ }^{31}$.

MMP1 promoter SNP genotyping

The MMP1 genotyping was determined by PCR-restriction fragment length polymorphism (PCR-RFLP) assay. The primers sequences were: forward 5'

TCGTGAGAATGTCTTCCCATT 3' and reverse 5'

TCTTGGATTGATTTGAGATAAGTGAAATC 3'. PCR was performed in a $25 \mu \mathrm{L}$ volume containing $500 \mathrm{ng}$ genomic $\mathrm{DNA}, 10 \mathrm{mM}$ Tris- $\mathrm{HCl}(\mathrm{pH} 8.3), 50 \mathrm{mM} \mathrm{KCl}, 1.5 \mathrm{mM}$ 
$\mathrm{MgCl}_{2}, 1 \mu \mathrm{M}$ of each primer, $200 \mathrm{mM}$ each dNTP, and 2.5 units Taq DNA polymerase (Invitrogen, Carlsbad, CA, USA). The PCR cycling conditions were $1 \mathrm{~min}$ at $95^{\circ} \mathrm{C}$ followed by 35 cycles of $30 \mathrm{~s}$ at $95^{\circ} \mathrm{C}, 30 \mathrm{~s}$ at $54^{\circ} \mathrm{C}$ and $30 \mathrm{~s}$ at $72^{\circ} \mathrm{C}$, and with a final step at $72^{\circ} \mathrm{C}$ for $7 \mathrm{~min}$ to allow for the complete extension of all PCR fragments. A $5 \mu \mathrm{L}$ aliquot of PCR product was digested overnight at $37^{\circ} \mathrm{C}$ in a $5 \mu \mathrm{L}$ solution containing $2 \mu \mathrm{L} 10 \mathrm{X} \mathrm{NE}$ buffer (50mM NaCl, $10 \mathrm{mM}$ Tris- $\mathrm{HCl}$ pH 7.8, $10 \mathrm{mM} \mathrm{MgCl}_{2}, 1 \mathrm{mM}$ dithiothreitol $\mathrm{pH} 7.9$, $0.2 \mu \mathrm{L}$ of 20 units $/ \mathrm{mL} \mathrm{XmnI} \mathrm{(New} \mathrm{England} \mathrm{Biolabs} \mathrm{Inc.,} \mathrm{Beverly,} \mathrm{MA,} \mathrm{USA),} 0.3 \mu \mathrm{L}$ albumin (New England Biolabs Inc., Beverly, MA, USA) and $2.5 \mu \mathrm{L}$ sterile deionized water. After overnight digestion, the products were resolved and separated on a $10 \%$ vertical non-denaturing polyacrylamide gel stained according to previously published protocols $^{32}$. At position -1607 of the MMP-1 promoter, the enzyme $X m n I$ recognizes and cleaves the sequence 5' GAANN...NNTTC 3', and 3' CTTNN...NNAAG 5' originating two fragments of $29 \mathrm{bp}$ and $89 \mathrm{bp}$. The $1 \mathrm{G}$ allele has this recognition site, whereas the $2 \mathrm{G}$ allele destroys the recognition site by inserting a guanine. After electrophoresis, homozygous $2 \mathrm{G}$ alleles were represented by a DNA band with size at $118 \mathrm{bp}$, homozygous $1 \mathrm{G}$ alleles were represented by DNA bands with sizes at 29 and 89 bp, whereas heterozygotes displayed a combination of both alleles (118, 29 and 89 bp).

MMP3 promoter SNP genotyping

The MMP3 genotype was determined by the kinetic PCR assay using specific primers forward for $5 \mathrm{~A} / 6 \mathrm{~A}$ alleles and a common reverse primer. The primers sequences were: forward 5' GACAAGACATGGTTTTTC 3' (5A allele), forward 5' AAGACATGGTTTTTT 3' (6A allele) and reverse 5' AGACATGGGTCACGG 3'. PCR 
was performed in a total volume of $25 \mu \mathrm{L}$ containing $500 \mathrm{ng}$ genomic DNA, $10 \mathrm{mM}$ Tris- $\mathrm{HCl}$ (pH 8.3), $50 \mathrm{mM} \mathrm{KCl}, 1.5 \mathrm{mM} \mathrm{MgCl}_{2}, 1 \mu \mathrm{M}$ of each primer, $200 \mathrm{mM}$ each dNTP, and 2.5 units Taq DNA polymerase (Invitrogen, Carlsbad, CA, USA). The PCR cycling conditions were $3 \mathrm{~min}$ at $95^{\circ} \mathrm{C}$ followed by 35 cycles of $1 \mathrm{~min}$ at $95^{\circ} \mathrm{C}, 1 \mathrm{~min}$ at $41^{\circ} \mathrm{C}(6 \mathrm{~A}$ allele) $/ 1$ $\min$ at $44^{\circ} \mathrm{C}\left(5 \mathrm{~A}\right.$ allele) and $1 \mathrm{~min}$ at $72^{\circ} \mathrm{C}$, with a final step at $72^{\circ} \mathrm{C}$ for $7 \mathrm{~min}$. After amplification, the products were separated on a $10 \%$ vertical non-denaturing polyacrylamide gel stained according to previously published protocols ${ }^{32}$. After electrophoresis, the $5 \mathrm{~A}$ alleles were represented by DNA bands with sizes at $95 \mathrm{bp}$, the $6 \mathrm{~A}$ alleles were represented by a DNA band with size at $92 \mathrm{bp}$, whereas the heterozygotes displayed a combination of both alleles (95 and $92 \mathrm{bp}$ ).

\section{Statistical analysis}

Statistical analysis was performed using EpiInfo 3.3.2 software (http://www.cdc.gov/epiinfo). Chi-square and Fisher Exact tests were used to test for deviation in genotype distribution from the Hardy-Weinberg equilibrium and to compare $M M P 1$ and $M M P 3$ genotype and allele distribution in the study groups. Differences were considered significant when $\mathrm{p} \leq 0.05$. The odds ratio (OR) and $95 \%$ confidence interval (CI) were also calculated.

\section{Results}

The genotype distributions for both MMP1 and MMP3 polymorphisms were within Hardy-Weinberg equilibrium ( $\mathrm{p}=0.9979$ and $\mathrm{p}=0.9146$, respectively). 
$M M P 1$

No significant differences were found for genotype ( $\mathrm{p}=0.47$; $\mathrm{OR}=1.20,95 \% \mathrm{CI}: 0.90-1.60$ ) or allele $(\mathrm{p}=0.21 ; \mathrm{OR}=0.92,95 \% \mathrm{CI}: 0.61-1.37)$ frequencies between cleft and control groups. When comparing different cleft types ( $\mathrm{CL} / \mathrm{P}$ or $\mathrm{CP}$ ) with controls, no significant differences were observed for allele or genotype frequencies. (For $\mathrm{CL} / \mathrm{P} \times$ controls, $\mathrm{p}=0.18$; $\mathrm{OR}=0.81,95 \% \mathrm{CI}: 0.6-1.1$ for allele and $\mathrm{p}=0.33 ; \mathrm{OR}=1.2,95 \% \mathrm{CI}: 0.8-1.9$ for genotype; For $\mathrm{CP} x$ controls, $\mathrm{p}=0.98, \mathrm{OR}=1.00,95 \% \mathrm{CI}: 0.5-1.8$ for allele and $\mathrm{p}=0.78, \mathrm{OR}=1.2$, $95 \%$ CI: $0.5-3.0$ for genotype).

$M M P 3$

Significant statistical differences were found for allele and genotype frequencies between cases and controls. The $5 \mathrm{~A}$ allele and the $5 \mathrm{~A} / 5 \mathrm{~A}$ genotype (Table 2 ) were significantly more frequent in the cleft group (for allele, $\mathrm{p}=0.00001 ; \mathrm{OR}=2.47,95 \% \mathrm{CI}: 1.68-3.63$; for genotype, $p=0.00001 ; O R=2.37,95 \% C I: 1.40-4.03)$. In addition, significant differences were also observed for allele and genotype frequencies (Table 3) between each cleft type and controls (for $\mathrm{CL} / \mathrm{P} \mathrm{x}$ controls, $\mathrm{p}=0.00001$ for both allele and genotype frequencies; for $\mathrm{CP} \times$ controls, $\mathrm{p}=0.002$ and $\mathrm{p}=0.04$ for allele and genotype frequencies respectively).

\section{Logistic regression}

In order to verify if population stratification could influence distribution of $M M P 3$ genotypes, we performed logistic regression adjusted for ethnicity and found significant differences between the groups $(\mathrm{p}=0.01)$. Since the great majority of the sample consisted of Brazilian Caucasians (here considered any Brazilian individual without known contributions of Afro-American or Japanese genetic makeup), we compared genotype and 
allele frequencies between those individuals and controls and still observed significant differences among the groups $(p=0.0002$ and $p=0.00001$, for genotype and allele frequencies, respectively) (Table 2). Nevertheless, differences observed for genotype frequencies between each cleft type and controls remained significant when analyzing Caucasians only $(\mathrm{p}=0.00001$ for $\mathrm{CL} / \mathrm{P}$ and $\mathrm{p}=0.01$ for $\mathrm{CP}$ ) (Table 3 ).

\section{Discussion}

Several genes are likely to be jointly involved in the etiology of congenital anomalies. This may be due to disruption of important signaling pathways at various levels that are required for the formation of specific anatomical structures. The link between the complex multifactorial etiology of $\mathrm{CL} / \mathrm{P}$ and polymorphisms in MMP genes relies on alterations of ECM homeostasis and functions. Previous studies have suggested MMPs as potential candidate genes for $\mathrm{CL} / \mathrm{P}$ based on expression patterns and the roles they play in modeling craniofacial tissues during early embryogenesis ${ }^{15}$.

Naturally occurring sequence variation has been detected in the promoter of a number of MMP genes. Although the majority of DNA polymorphisms are probably functionally neutral, a proportion of them can exert allele-specific effects on the regulation of gene expression or function of the coded protein and thus contribute to inter-individual differences in susceptibility to common and complex diseases ${ }^{13}$.

Here, we report the frequencies of polymorphisms occurring in the promoter of $M M P 1$ and $M M P 3$ genes in cleft individuals, with positive association of the $M M P 3$ polymorphism and CL/P. A common adenine insertion/deletion polymorphism $(5 \mathrm{~A} / 6 \mathrm{~A})$ at position - 1171 of the $M M P 3$ gene promoter has been described with the $5 \mathrm{~A}$ allele correlating to higher enzyme activity ${ }^{23}$. MMP-3 can degrade a wide range of ECM proteins 
including proteoglycans, fibronectin, laminin and collagens IV, V, IX and X and is capable of activating other MMPs, making it likely a key player in ECM degradation and remodeling ${ }^{33}$. MMP-3 has been immunolocalized in vivo subjacent to the medial edge epithelia following contact of the palatal shelves. High expression of MMP-3 leads to MEE breakdown and cessation of this event by the addition of a synthetic MMP inhibitor allowed palatal shelf fusion ${ }^{14}$. This implies that MMP- 3 induces breakdown of the MEE if present in appropriate amounts. In the case of persistence of increased expression, degradation might be excessive and prevent fusion of the palatal shelves. Hypothetically, this might confirm the results of this study since we indeed found significant differences in allele and genotype distributions of this $M M P 3$ polymorphism between cleft and control groups.

We also investigated the frequency of the $-1607(1 \mathrm{G} / 2 \mathrm{G})$ polymorphism in the $M M P 1$ gene promoter but did not find any differences between cleft and control groups. Although there are no specific reports on MMP-1 expression during palatogenesis, we decided to include the $M M P I$ gene in the study because it is adjacently located to the $M M P 3$ gene in chromosome $11 \mathrm{q} 22.3$ and the two loci are in linkage disequilibrium and considered to act in cooperation ${ }^{34}$. MMP-1 is considered particularly important as it presents proteolytic activities against collagen types I, II and III ${ }^{20}$. The major structural component of the palatal matrix is type I collagen ${ }^{36}$ and previous reports have suggested the need for stable, cross-linked collagen, during palate development. Induction of unstable, poorly cross-linked collagen has been associated to $\mathrm{CL} / \mathrm{P}$ for failure in incorrect shelf elevation prior to fusion ${ }^{36,37}$. Hence, alterations in the rate of collagen degradation, perhaps by an increased transcription of the $M M P I$ gene could affect the stability of the cross-links necessary during palate development. 
Only two other studies have attempted to investigate MMP polymorphisms in oral clefts and thus a thorough comparison and interpretation of the results is rather difficult. Blanton et al. (2004) $)^{28}$ examined different blocks of MMP genes including MMPI and $M M P 3$, in multiplex families of non-syndromic cleft individuals, and found slight evidence of linkage and association for only one locus containing $M M P 25$. However, the markers tested in this study represented suggestive chromosomal regions obtained from genomic scans and not necessarily indicated the region of the MMP genes where the variation occurred. Our results derive from the investigation of polymorphisms in the promoter of these genes, which could eventually change the rate of transcription and further lead to alterations in the expression of these enzymes during lip and palate formation. Since it has been reported that the presence of MMPs is spatially and temporarily regulated during craniofacial development ${ }^{16,17}$, such alterations could implicate in disruptions in this process and further lead to the occurrence of a cleft of the lip and/or palate. We have also used the same "promoter polymorphism" approach for a previous study with $M M P 9$ gene and $\mathrm{CL} / \mathrm{P}^{30}$. Although this polymorphism was not associated with $\mathrm{CL} / \mathrm{P}$ in our particular population, other populations might demonstrate different distributions.

Contradictory results on gene polymorphisms-disease association studies are often found, and this may occur primarily because distinct populations may have different risk alleles for a same disease ${ }^{38}$. The Brazilian population represents a mixture of LatinEuropean whites, Afro-Brazilian blacks, and Amerindians, which makes it very difficult to properly classify and match perfectly the ethnicity of cases and controls. Even though our sample population did not show any discrepancies regarding ethnic distribution, logistic regression adjusted for ethnicity revealed statistical difference in genotype distribution for $M M P 3$. To overcome this situation, we analyzed the Caucasian group only, which 
accounted for the great majority of the sample, and still observed the association of $M M P 3$ with the cleft phenotype, indicating that this gene might be somewhat associated with $\mathrm{CL} / \mathrm{P}$ in our particular population.

Nevertheless, the extent to which polymorphisms in $M M P$ genes may actually contribute to the affected cleft status is yet to be clarified. The complexity of the MMP family, in a context that if one enzyme is knocked out, another may become highly expressed to compensate for the loss highlights the difficulties in distinguishing each individual enzyme's role in different scenarios. Nevertheless, polymorphisms of $M M P$ genes may be good candidates as genetic factors for diseases whose pathogenesis involve active ECM degradation and remodeling such as cleft lip/palate.

\section{Acknowledgments}

The authors are indebted to the participants of this study. Thanks to HRAC (Hospital of Rehabilitation and Craniofacial Anomalies of the University of São Paulo), Bauru Dental Schoo/USP and University Sagrado Coração, Bauru,SP, Brazil. This work was supported by CAPES/BEX 3413/05-5, FAPESP (The State of São Paulo Research Foundation - 99/10655-5, 01/10707-7, and 04/08095-1), and CNPq (National Council for Scientific and Technological Development - 350084/03-3, 475721/2003-9, 505350/04-1).

\section{References}

1. Murray JC. Gene/environment causes of cleft lip and/or palate. Clin Genet 2002; 61: 2481.

2. Vanderas AP. Incidence of cleft lip, cleft palate, and cleft lip and palate among races: a review. Cleft Palate J 1987; 24:216-225. 
3. Murray JC, Daack-Hirsch S, Buetow KH, Munger R, Espina L, Paglinawan N et al. Clinical and epidemiologic studies of cleft lip and palate in the Philippines. Cleft Palate Craniofac J 1997; 34:7-10.

4. Strauss RP. The organization and delivery of craniofacial health services: the state of the art. Cleft Palate Craniofac J 1999; 36:189-95.

5. Cartens MH. Development of the facial midline. J Craniofac Surg 2002; 13:129-87.

6. Johnston MC, Bronsky PT. Craniofacial embryogenesis: abnormal developmental mechanisms. In: Mooney MP, Siegel MI, editors. Understanding craniofacial anomalies: the etiopathogenesis of craniosynostosis and facial clefting. New York: John W. Wiley and Sons 2002, p. 61-124.

7. Diewert VM, Losanoff S. Animal models of facila clefting: experimental, congenital, and transgenic. In: Mooney MP, Siege1 MI, editors. Understanding craniofacial anomalies: the etiopathogenesis of craniosynostosis and facial clefting. New York: John W. Wiley and Sons 2002 , p. $251-72$.

8. Sperber GH. Craniofacial embryogenesis: normal developmental mechanisms. In: Mooney MP, Siegel MI, editors. Understanding craniofacial anomalies: the etiopathogenesis of craniosynostosis and facial clefting. New York: John W. Wiley and Sons 2002, p. 31-60.

9. Shprintzen RJ. Terminology and classification of facial clefting. In: Mooney MP, Siege1 MI, editors. Understanding craniofacial anomalies: the etiopathogenesis of craniosynostosis and facial clefting. New York: John W. Wiley and Sons 2002, p. 17-28. 10. Sperber GH. Palatogenesis: closure of the secondary palate. In: Wyszynski DF, editor. Cleft lip and palate: from origin to treatment. Oxford: Oxford University Press; 2002. p.1424. 
11. Pelton RW, Hogan BL, Miller DA, Moses HL. Differential expression of genes encoding TGFs beta 1 , beta 2 , and beta 3 during murine palate formation. Dev Biol 1990; 141:456-60.

12. Behnan SM, Guo C, Gong TW, Shum L, Gong SG. Gene and protein expression of transforming growth factor $\beta 2$ gene during murine primary palatogenesis. Differentiation $2005 ; 73: 233-9$.

13. Hannas AR, Pereira JC, Granjeiro JM, Tjäderhane L. The role of matrix metalloproteinases in the oral environment. Acta Odontol Scand 2007; 65: 1-13.

14. Brown NL, Yarram SJ, Mansell JP, Sandy JR. Matrix metalloproteinases have a role in palatogenesis. J Dent Res 2002; 81:826-830.

15. Iamaroon A, Wallon UM, Overall CM, Diewert VM. Expression of 72-kDa gelatinase (matrix metalloproteinase-2) in the developing mouse craniofacial complex. Arch Oral Biol $1996 ; 41: 1109-19$.

16. Morris-Wiman J, Du Y, Brinkley L. Occurrence and temporal variation in matrix metalloproteinases and their inhibitors of matrix metalloproteinases during murine and secondary palatal morphogenesis. J Craniofac Genet Dev Biol 1999; 19:201-12.

17. Morris-Wiman J, Burch H, Basco E. Temporospatial distribution of matrix metalloproteinases and tissue inhibitors of metalloproteinases during murine secondary palate morphogenesis. Anat Embryol (Berl) 2000; 202:129-41.

18. Blavier L, Lazaryev A, Groffen J, Heisterkamp N, Declerk Y, Kaartinen V. TGFB3induced palatogenesis requires matrix metalloproteinases. Molec Biology 2001; 12:145766.

19. Lochter A, Galosy S, Muschler J, Freedman N, Werb Z, Bissell MJ. Matrix metalloproteinase Stromelysin-1 triggers a cascade of molecular alterations that leads to 
stable epithelial-to-mesenchymal conversion and a premalignant phenotype in mammary epithelial cells. J Cell Biol 1997; 139:1861-72.

20. Mansell JP, Kerrigan J, McGill J, Bailey J, TeKoppele J, Sandy JR. Temporal changes in collagen composition and metabolism during rodent palatogenesis. Mech Aging and Development 2000; 110:49-62.

21. Dunleavey L, Beyzade S, Ye S. Rapid genotype analysis of the matrix metalloproteinase-1 gene $1 \mathrm{G} / 2 \mathrm{G}$ polymorphism that is associated with risk of cancer. Matrix Biol 2000; 19:175-7.

22. Randall LE, Hall RC. Temporospatial expression of matrix metalloproteinases 1, 2, 3 and 9 during early tooth development. Connect Tissue Res 2002; 43:205-11.

23. Ye S, Eriksson P, Hamsten A, Kurkinen M, Humphries SE, Henney AM. Progression of coronary atherosclerosis is associated with a common genetic variant of the human stromelysin-1 promoter which results in reduced gene expression. J Biol Chem 1996; 271:13055-60.

24. Rutter JL, Mitchell TI, Buttice G, Meyers J, Gusella JF, Ozelius LJ, Brinckerhoff CE. A single nucleotide polymorphism in the matrix metalloproteinase-1 promoter creates an Ets binding site and augments transcription. Cancer Res 1998; 58:5321-5.

25. Tower GB, Coon CC, Benbow U, Vincenti MP, Brinckerhoff CE. Erk $1 / 2$ differentially regulates the expression from the $1 \mathrm{G} / 2 \mathrm{G}$ single nucleotide polymorphism in the MMP-1 promoter in melanoma cells. Biochim Biophys Acta 2002; 1586:265-74.

26. Eppley BL, van Aalst JA, Robey A, Havlik RJ, Sadove AM. The spectrum of orofacial clefting. Plast Reconstr Surg 2005; 115:101-14. 
27. Miettinen PJ, Chin JR, Shum L, Slavkin HC, Shuler CF, Derynck R, Werb Z. Epidermal growth factor receptor function is necessary for normal craniofacial development and palate closure. Nature Genet 1999; 22:69-73.

28. Blanton SH, Bertin T, Serna ME, Stal S, Mulliken JB, Hecht J. Association of chromosomal regions $3 \mathrm{p} 21.2,10 \mathrm{p} 13$, and $16 \mathrm{p} 13.3$ with non syndromic cleft lip and palate. Am J Med Genet 2004; 125A:23-27.

29. Sozen MA, Suzuki K, Tolarova MM, Bustos T, Fernandez Iglesias JE, Spritz RA. Mutation of PVRL1 is associated with sporadic, non-syndromic cleft lip/palate in northern Venezuela. Nat Genet 2001; 29:141-2.

30. Avila JR, Jezewski PA, Vieira AR, Orioli IM, Castilla EE, Christensen K, DaackHirsch S, Romitti PA, Murray JC. PVRL1 variants contribute to non-syndromic cleft lip and palate in multiple populations. Am J Med Genet $A$ 2006; 140:2562-70.

31. Letra A, Silva RA, Menezes R, de Souza AP, Almeida ALPF, Sogayar MC, Granjeiro JM. Studies with MMP9 gene promoter polymorphism and nonsyndromic cleft lip and palate. Am J Med Genet $A$ 2007; 143:89-91.

32. Trevilatto PC, Line SRP. Use of buccal epithelial cells for PCR amplification of large DNA fragments. J Forensic Odonto Stomatol 2000; 18:6-9.

33. Sanguinetti CJ, Dias Neto E, Simpson AJ. Rapid silver staining and recovery of PCR products separated on polyacrylamide gels. Biotechniques $1994 ; 17: 914-21$.

34. Nagase H, Woessner JF Jr. Matrix metalloproteinases. J Biol Chem 1999; 274:21492-4. 35. Hinoda Y, Okayama N, Takano N, Fujimura K, Suehiro Y, Hamanaka Y, Hazama S, Kitamura Y, Kamatani N, Oka M. Association of functional polymorphisms of matrix metalloproteinase (MMP)-1 and MMP-3 genes with colorectal cancer. Int J Cancer 2002; 102:526-9. 
36. D'Angelo M, Chen JM, Ugen K, Greene RM. TGF beta-1 regulation of collagen metabolism by embryonic palate mesenchymal cells. J Experim Zool 1994; 270:189-201. 37. Pratt RM, King CT. Inhibition of collagen cross-linking associated with betaaminoproprionitrile-induced cleft palate in the rat. Dev Biol 1972; 27:322-8.

38. Hassel JR, Orkin RW. Synthesis and distribution of collagen in rat palate during shelf elevation. Dev Biol 1976; 49:80-8.

39. Itagaki M, Kubota T, Tai H, Shimada Y, Morozumi T, Yamazaki K. Matrix metalloproteinase- 1 and -3 gene promoter polymorphisms in Japanese patients with periodontitis. J Clin Periodontol 2004; 31:764-9. 
Table(s)

Table 1. Characteristics of the population studied: a) for MMP1 $-16071 \mathrm{G} / 2 \mathrm{G}$; b) for MMP-3 -1171 5A/6A

\begin{tabular}{|c|c|c|c|c|c|c|}
\hline \multirow[t]{2}{*}{ Characteristics } & \multicolumn{3}{|c|}{ MMP1 } & \multicolumn{3}{|c|}{ MMP3 } \\
\hline & $\begin{array}{c}\text { Cleft } \\
(n=170)\end{array}$ & $\begin{array}{l}\text { Control } \\
(\mathbf{n}=\mathbf{2 2 5})\end{array}$ & P value & $\begin{array}{c}\text { Cleft } \\
(n=78)\end{array}$ & $\begin{array}{l}\text { Control } \\
(\mathrm{n}=\mathbf{2 5 5})\end{array}$ & $P$ value \\
\hline Age (years) $\pm \mathrm{SD}$ & $\begin{array}{c}17.1 \pm \\
9.1\end{array}$ & $\begin{array}{l}38.1 \pm \\
12.8\end{array}$ & & $\begin{array}{l}17.7 \pm \\
10.2\end{array}$ & $\begin{array}{c}36.2 \pm \\
13\end{array}$ & \\
\hline \multicolumn{7}{|l|}{ Gender } \\
\hline Male & 89 & 86 & & 40 & 96 & \\
\hline Female & 81 & 139 & & 38 & 159 & \\
\hline \multicolumn{7}{|l|}{ Ethnic group } \\
\hline Caucasian & 131 & 193 & 0.1919 & 64 & 219 & 0.6694 \\
\hline Japanese & 32 & 30 & & 11 & 29 & \\
\hline Afro-American & 3 & 2 & & 2 & 4 & \\
\hline Unknown & 4 & 0 & & 1 & 3 & \\
\hline
\end{tabular}

* Chi-square test; statistically significant if $\mathrm{p} \leq 0.05$. 
Table(s)

Table 2. Allele and genotype distribution of MMP3 (-1171 5A/6A) polymorphism in cases and controls.

\begin{tabular}{|c|c|c|c|c|c|c|c|c|}
\hline & \multicolumn{3}{|c|}{ All individuals } & \multirow[b]{2}{*}{$\begin{array}{c}\text { OR } \\
(95 \% \mathrm{CI}) \\
\end{array}$} & \multicolumn{4}{|c|}{ Caucasians only } \\
\hline & $\begin{array}{c}\text { Cleft } \\
(\mathrm{n}=78)\end{array}$ & $\begin{array}{l}\text { Control } \\
(\mathrm{n}=\mathbf{2 5 5})\end{array}$ & $\begin{array}{c}P \\
\text { value }\end{array}$ & & $\begin{array}{c}\text { Cleft } \\
(\mathrm{n}=64)\end{array}$ & $\begin{array}{c}\text { Control } \\
(\mathbf{n}=219)\end{array}$ & $\mathbf{P} *$ & $\begin{array}{c}\text { OR } \\
(95 \% \mathrm{CI})\end{array}$ \\
\hline \multicolumn{9}{|c|}{$\begin{array}{l}\text { MMP-3 } \\
(-11715 \mathrm{~A} / 6 \mathrm{~A})\end{array}$} \\
\hline \multicolumn{9}{|l|}{ Allele } \\
\hline $5 \mathrm{~A}$ & 110 & 251 & .00001 & $\begin{array}{c}2.47 \\
(1.7-3.6)\end{array}$ & 92 & 225 & 0.00001 & $\begin{array}{c}2.4 \\
(1.6-3.7)\end{array}$ \\
\hline $6 \mathrm{~A}$ & 46 & 259 & & & 36 & 213 & & \\
\hline \multicolumn{9}{|l|}{ Genotype } \\
\hline $5 \mathrm{~A} / 5 \mathrm{~A}$ & 35 & 65 & .00001 & $\begin{array}{c}2.37 \\
(1.4-4.0)\end{array}$ & 31 & 60 & 0.0002 & $\begin{array}{c}2.5 \\
(1.4-4.4)\end{array}$ \\
\hline $5 \mathrm{~A} / 6 \mathrm{~A}$ & 40 & 121 & & & 30 & 105 & & \\
\hline $6 \mathrm{~A} / 6 \mathrm{~A}$ & 3 & 69 & & & 3 & 54 & & \\
\hline
\end{tabular}

* Chi-square test; statistically significant if $\mathrm{p} \leq 0.05$.

** $\mathrm{OR}$, odds ratio; $\mathrm{CI}$, confidence interval. 
Table(s)

Table 3. Allele and genotype distribution of MMP3 (-1171 5A/6A) polymorphism in individuals with $\mathrm{CL} / \mathrm{P}$ and $\mathrm{CP}$.

\begin{tabular}{|c|c|c|c|c|}
\hline & \multicolumn{2}{|c|}{$\begin{array}{l}\text { All individuals } \\
(\mathrm{n}=78)^{*}\end{array}$} & \multicolumn{2}{|c|}{$\begin{array}{c}\text { Caucasians only } \\
(\mathrm{n}=64)^{* *}\end{array}$} \\
\hline & $\begin{array}{c}\mathrm{CL} / \mathrm{P} \\
(\mathrm{n}=62)\end{array}$ & $\begin{array}{c}\mathrm{CP} \\
(\mathrm{n}=11)\end{array}$ & $\begin{array}{c}\mathrm{CL} / \mathrm{P} \\
(\mathrm{n}=\mathbf{5 0} 0)\end{array}$ & $\begin{array}{l}\mathrm{CP} \\
(\mathrm{n}=10)\end{array}$ \\
\hline \multicolumn{5}{|l|}{$\begin{array}{l}\text { MMP-3 } \\
(-11715 \mathrm{~A} / 6 \mathrm{~A})\end{array}$} \\
\hline \multicolumn{5}{|l|}{ Allele } \\
\hline $5 \mathrm{~A}$ & 87 & 17 & 72 & 16 \\
\hline $6 \mathrm{~A}$ & 37 & 5 & 28 & 4 \\
\hline P value & 0.00001 & 0.002 & 0.0001 & 0.012 \\
\hline \multicolumn{5}{|l|}{ Genotype } \\
\hline $5 \mathrm{~A} / 5 \mathrm{~A}$ & 27 & 6 & 24 & 6 \\
\hline $5 \mathrm{~A} / 6 \mathrm{~A}$ & 33 & 5 & 24 & 4 \\
\hline $6 \mathrm{~A} / 6 \mathrm{~A}$ & 2 & 0 & 2 & 0 \\
\hline P value & 0.00001 & 0.04 & 0.00001 & 0.011 \\
\hline
\end{tabular}

* Unknown cleft type $=5$.

** Unknown cleft type $=4$.

*** Chi-square test, when compared to controls. Significant if $p \leq 0.05$. 


\section{APÊNDICE 3 - ARTIGO ORIGINAL SUBMETIDO PARA PUBLICAÇÃO}

Letra A, Menezes R, Granjeiro JM, Vieira AR. Defining Subphenotypes for Oral Clefts Based on Dental Development. J Dent Res (em fase de revisão)

Defining Cleft Subphenotypes Based on Dental Development.

A. Letra ${ }^{1,2}$, R. Menezes ${ }^{1}$, J.M. Granjeiro ${ }^{3}$, A.R. Vieira ${ }^{1 *}$.

${ }^{1}$ Department of Oral Biology and Center for Craniofacial and Dental Genetics, School of Dental

Medicine, University of Pittsburgh, Pittsburgh, PA, USA.

${ }^{2}$ Department of Biological Sciences, School of Dentistry, University of São Paulo, Bauru, SP, Brazil. Bolsista CAPES/BEX, Brasilia, Brazil.

${ }^{3}$ Department of Cellular and Molecular Biology, Biology Institute, Fluminense Federal University, Niterói, RJ, Brazil.

* Corresponding author:

Prof. Alexandre R. Vieira

614 Salk Hall, Department of Oral Biology

Center for Craniofacial and Dental Genetics

School of Dental Medicine, University of Pittsburgh

3501 Terrace Street, Pittsburgh, PA 15261

Tel.: (412) 383-8972; Fax: (412) 624-3080

Running head: Subphenotypes for Clefts

Key words: Cleft Lip; Cleft Palate; Tooth Agenesis; Dental Anomalies; Hypodontia

Number of words in abstract: 129

Number of words in abstract and text: 2270

Number of tables and figures: 4

Number of cited references: 26

Conflicts of interest: None. 


\begin{abstract}
Individuals with clefts present considerably more dental anomalies than individuals without clefts. We used dental development to subphenotype clefts with the goal of identifying cleft subgroups that could have specific genetic contributions. We examined 1000 individuals, 500 with clefts and 500 non-related controls. Several clinical features, such as cleft completeness or incompleteness, laterality, and the presence of dental anomalies, were used to assess each individual's cleft status. Standard chi-square and Fisher exact tests were performed to compare differences in the frequencies of observed anomalies between cases and controls, and between individuals with different cleft subphenotypes. Agenesis of the lateral incisor on the opposite side of the cleft was the most remarkable observation, which could indicate that such cases could be considered incomplete forms of bilateral clefts of the lip.
\end{abstract}




\section{INTRODUCTION}

Fogh-Andersen, in 1942, provided evidence that cleft of the lip and cleft of the palate, which frequently occur together, are developmentally distinct entities. However, differences in etiology or epidemiology of these complex traits may remain undetected because of the high variability in disease phenotype. Whilst many studies assign cleft phenotype as of simply affected or unaffected status, evidences indicate that these phenotypes are sometimes overlooked and should be fully considered with regards to other clinical markers that may help unravel the genetic basis for the condition (Rice et al., 2001).

The formation of tooth germs and the occurrence of cleft lip/palate have a close embryological relationship in terms of timing and anatomical position and numerous studies have reported the presence of dental anomalies in association with various forms of cleft lip, cleft palate, or both (Jordan et al., 1966; Ranta, 1982; 1983; 1986; Tsai et al., 1998; Werner and Harris, 1989; Shapira et al., 2000; Slayton et al., 2003). It has been proposed that individuals with clefts present considerably more dental anomalies than individuals without clefts, and moreover, that severity of anomalies appears to be directly related to severity of the cleft (Adams and Niswander, 1967; Schroeder and Green, 1975; van den Boogard et al., 2000; Eerens et al., 2001; Slayton et al., 2003; Vieira, 2003; Aizenbud et al., 2005; Stahl et al., 2006). In that context, recent studies have implied that the presence of dental anomalies may represent an additional clinical marker for oral clefts suggesting a common genetic background between the two anomalous conditions. Furthermore, the hypothesis of broadening the cleft phenotype would allow identification of healthy individuals presenting an increased risk to be carrying cleft genes, and hence gene-mapping efforts will have increased power and the ability to provide effective genetic counseling (reviewed by Weinberg et al., 2006). 
The purpose of this study was to determine if cleft phenotypes and associated dental anomalies could be used in combination to provide new definitions of cleft subphenotypes.

\section{MATERIAL AND METHODS}

\section{Subjects}

The cleft group consisted of 500 individuals aged 4-59 years old (average age 17.3) enrolled for treatment at the Hospital of Rehabilitation and Craniofacial Anomalies (HRAC) of the University of São Paulo, Bauru, Brazil, with no history of syndromic clefting. Controls consisted of 500 healthy, non-related individuals, aged 4-94 years old (average age 36.8). The study was conducted with the consent of the parents and approved by the Research and Ethics Committee of the Hospital of Rehabilitation and Craniofacial Anomalies, University of São Paulo. In the case of children under 15 years of age, authorization was also requested from their parents or from the individual legally in charge of the child.

\section{Determination of Cleft Phenotypes}

Cleft individuals were examined clinically and through their medical files to determine the type and side of the cleft as well as to determine individual's cleft status. Cleft status was based on cleft completeness or incompleteness (comprising primary and secondary palates entirely) and laterality (left, right, bilateral, and central in the cases of median clefts and cleft palate only). An "unknown" cleft status means that either type and/or side of the cleft could not be determined after reviewing medical records. 


\section{Determination of Dental Anomalies}

Dental anomalies such as tooth agenesis (including hypodontia and oligodontia), microdontia, supernumerary teeth, tooth malposition (rotation or inclination), impaction, shape anomalies and transposition were assessed clinically and though radiographs and recorded for each individual from both groups. For every anomaly, the inclusion criterion was that at least one permanent tooth was affected (children 8 years-old or younger were excluded for this purpose). Instances of anomalies adjacent to the cleft area were not included, because the absence of such teeth is likely the consequence of local development anomalies at the cleft site. Multiple anomalies were characterized by the simultaneous presence of two or more types of dental anomalies in the same individual.

\section{Statistical Analysis}

Standard Chi-square and Fisher's exact probabilities were evaluated on all sets of comparisons. Differences observed in the frequencies of dental anomalies between cleft and control groups were assessed by the chi-square test with statistical significance set at $p \leq 0.05$. Odds ratio calculations were performed as well. Regarding differences observed in the frequencies of dental anomalies between different cleft subphenotypes and controls, significance figures were accounted for using Bonferroni correction taking into account the number of tests carried out. With the Bonferroni correction, alpha will be 0.0002 (0.05/176 comparisons). Median and unknown-type clefts were not included in the analysis due to the small number of cases found (Table 1). 


\section{RESULTS}

\section{Cleft Phenotypes}

Out of the 500 cleft individuals, 400 had a cleft lip with cleft palate (168 with left cleft lip, 154 with bilateral cleft lip, 76 with right cleft lip, and 2 median clefts), 6 had cleft lip only ( 2 on the right side and 4 on the left side), 66 had cleft palate only and 28 had unknown cleft types. Thereafter, we subdivided these cleft types based on cleft completeness or incompleteness and laterality, which generated 18 subtypes of cleft, thoroughly describing each individual's cleft status (Table 1). Since there were only 6 individuals presenting cleft lip only (unilateral left, $n=4$; unilateral right, $\mathrm{n}=2$ ), we decided to include them in the cleft lip and palate group for statistical analysis.

\section{Dental Anomalies}

The frequency of dental anomalies observed in each individual divided by cleft status is presented on Table 1. Significant differences between cases and controls are expressed as bold characters.

Cleft individuals presented significantly more dental anomalies than controls $(\mathrm{p}=0.00001)$. The presence of tooth agenesis $(\mathrm{p}=0.00001)$, microdontia $(\mathrm{p}=0.0063)$, supernumerary teeth $(\mathrm{p}=0.00001)$, malposition $(\mathrm{p}=0.00001)$, transposition $(\mathrm{p}=0.0011)$ and multiple anomalies (two or more associated anomalies) ( $\mathrm{p}=0.00001$ ) were consistently more frequent in the cleft group. Tooth impaction also presented a trend to be more common in the cleft group $(\mathrm{p}=0.0578)$ (Table 2).

Regarding tooth agenesis, excluding third molars which were the most frequently absent teeth in both cases $(179 / 352 ; \mathrm{p}=0.00001)$ and controls $(34 / 62 ; \mathrm{p}=0.00001)$, premolars were most 
commonly absent in the cleft group $(108 / 352 ; \mathrm{p}=0.0002)$ with no significant differences regarding each individuals' cleft status, while control individuals presented more agenesis of the lateral incisors $(13 / 62 ; \mathrm{p}=0.0491)$.

Differences in observed frequencies of dental anomalies between individuals of each cleft status and controls are available as supplemental material.

\section{Searching for cleft subphenotypes}

The frequencies of tooth agenesis, microdontia, supernumerary teeth and malposition when divided by side of the anomaly and cleft side are presented on Table 3.

We noticed that tooth agenesis occurred most frequently in cases with complete cleft lip and palate, unilaterally or bilaterally, and also in cases with incomplete bilateral cleft lip and palate plus cleft palate, when compared to controls (Table 1). We also observed that tooth agenesis affected most often the noncleft side in cases with unilateral clefts: agenesis on the right side was more frequent with left clefts $(\mathrm{p}=0.0106)$ and agenesis on the left side was more frequent with right clefts ( $\mathrm{p}=0.0115$ ) (Table 3 ). Furthermore, the absence of maxillary left lateral incisors was significantly associated with unilateral right clefts $(12 / 78 ; \mathrm{p}=0.0073)$ and, contrarily, the maxillary right lateral incisors were most commonly absent with unilateral left clefts $(15 / 172$; $\mathrm{p}=0.00001)$.

Following a similar pattern, microdontia and supernumerary teeth were also most frequent on the noncleft side, and particularly more common on the right side in cases with unilateral left clefts $(\mathrm{p}=0.0682$ and $\mathrm{p}=0.0232$, respectively) (Table 3 ). However, microdontia did not seem to be associated to any cleft phenotype whereas the presence of supernumerary teeth was most frequently associated to complete unilateral cleft lip and palate (Table 1). 
Malposition was a common feature in cleft individuals also, and showed preferential association with several cleft lip and palate phenotypes (Table 1). Mandibular canines were the most commonly affected teeth $(39 / 47 ; \mathrm{p}=0.00001)$ often associated to complete bilateral cleft lip and palate.

Tooth impaction showed preferential association with complete cleft palate $(\mathrm{p}=0.00001)$ (Table 1).

Transposition was observed in cases with complete bilateral or incomplete unilateral left cleft lip and palate and affected mostly the maxillary premolars $(6 / 7 ; \mathrm{p}=0.0075)$ while no control individuals were affected.

The presence of multiple anomalies occurred most commonly in cases with complete and incomplete unilateral left cleft lip and palate (Table 1). Of the 23 cases of multiple anomalies, 20 included tooth agenesis. The most frequent combinations were agenesis plus malposition (11/20) and agenesis plus supernumerary teeth $(8 / 20)$. Tooth agenesis plus microdontia was seen in one case only, with complete unilateral right cleft lip and palate.

\section{DISCUSSION}

Despite the several reports on the incidence of dental anomalies in cleft individuals, to our knowledge, no attempts were ever made to use dental anomalies to subphenotype the three major categories of oral clefts (cleft lip only, cleft lip with cleft palate and cleft palate only).

We used dental development to classify cleft types with the goal of identifying subgroups that could have specific genetic contribution. Therefore, in addition to the major categories aforementioned, we have included detailed descriptions of the subphenotypes observed, which further enabled us to notice preferential associations of specific dental anomalies with each cleft 
subphenotype. We believe these more sophisticated clinical definitions provide a powerful tool in gene identification for clefts.

As in agreement to previous reports, the cleft individuals evaluated presented considerably more dental anomalies than controls (Table 2) suggesting a common genetic background for these developmental processes (Shprintzen et al., 1985; Ranta, 1986; Shapira et al., 1999; Eerens et al., 2001; Vieira, 2003). Previous reports have related higher frequencies of dental anomalies as the severity of the cleft increased (Adams and Niswander, 1967; van den Boogard et al., 2000; Eerens et al., 2001; Slayton et al., 2003; Aizenbud et al., 2005). We found this to be true as most cases of multiple anomalies affected individuals in the cleft lip and palate group. However, if this observation were to be always true, we would expect to see more anomalies in cases of bilateral cleft lip and palate but instead, we observed most cases of multiple anomalies to occur in individuals with unilateral left cleft lip and palate (Table 1). We are unaware of other similar studies to compare to our results.

The frequency of tooth agenesis was significantly different between the groups of this study, observed in approximately $26 \%$ of the cleft and $7 \%$ of the control individuals (Table 2). In humans, tooth agenesis is the most frequent congenital anomaly. Excluding the third molars, which are absent in approximately $20 \%$ of the general population, the prevalence of tooth agenesis varies from $2.6 \%$ to $11.3 \%$ (Nieminen et al., 1995; Larmour et al., 2005) and our results for the control group fall in that range. In cleft individuals, however, previous studies have reported a much higher incidence of tooth agenesis, as high as $67 \%$ up to $77 \%$ (Shapira et al., 2000; Aizenbud et al., 2005). Discrepancies among ours and these results might be attributed to the inappropriate inclusion of missing teeth in the area of the cleft in those studies. The absence of such teeth is likely the consequence of local development anomalies at the cleft site and 
therefore was not considered in our study. Nevertheless, similar to our findings, hypodontia outside the cleft region was reported to occur in $27 \%$ of the affected children and $11 \%$ of their siblings when compared to $3.6 \%$ control children only (Eerens et al., 2001).

Our results demonstrate that the prevalence of dental anomalies as signs of disturbances in dental development was several times higher in cleft individuals than in control individuals and further indicate that dental anomalies can be considered an extended phenotype for clefts. We noticed that the presence of multiple anomalies was significantly more common with complete clefts. Within the cleft lip and palate group, multiple anomalies were more common in unilateral left clefts. We were also able to observe interesting patterns regarding presence of some dental anomalies with specific cleft subphenotypes. For instance, although tooth agenesis was frequently observed in both complete and incomplete cleft lip and palate cases, we noticed that it was significantly more frequent in unilateral complete cases, and both bilateral complete and incomplete plus cleft palate (Table 1). Interestingly, supernumerary teeth were associated to unilateral complete and bilateral incomplete clefts.

The consistent presence of dental anomalies on the opposite side of unilateral clefts with preferential tooth agenesis of the lateral incisor leads us to believe that these unilateral clefts with dental anomalies on the noncleft side could be "unsuccessful" bilateral clefts, which should be considered carefully regarding the genetic etiology of the different cleft types. Moreover, we may even hypothesize that the genes that contribute to laterality of the cleft may be different resulting in alternate phenotypes for dental anomalies also. In such context, we are proposing new subphenotypes based on dental development (Figure 1). 


\section{ACKNOWLEDGMENTS}

The authors are indebted to the participants of the study and their families. AL was supported by CAPES/BEX Grant 3413055 (Brasilia, Brazil). This work was also supported by NIH R21DE016718.

\section{REFERENCES}

Adams MS, Niswander JD (1967). Developmental 'noise' and a congenital malformation. Genet Res 10:313-317.

Aizenbud D, Camasuvi S, Peled M, Brin I (2005). Congenitally missing teeth in the Israeli cleft population. Cleft Palate Craniofac J 42:314-317.

Avila JR, Jezewski PA, Vieira AR, Orioli IM, Castilla EE, Christensen K, Daack-Hirsch S, Romitti PA, Murray JC (2006). PVRL1 variants contribute to non-syndromic cleft lip and palate in multiple populations. Am J Med Genet 140:2562-2570.

Eerens K, Vlietinck R, Heidbuchel K, Van Olmen A, Derom C, Willems G, Carels C (2001). Hypodontia and tooth formation in groups of children with cleft, siblings without cleft, and nonrelated controls. Cleft Palate Craniofac J 38:374-378.

Fogh-Andersen P (1942). Inheritance of Harelip and Cleft Palate. Copenhagen: Arnold Busck. Jordan RE, Kraus BS Neptune CM (1966). Dental abnormalities associated with cleft lip and/or palate. Cleft Palate J 3: 22-25

Larmour CJ, Mossey PA, Thind BS, Forgie AH, Stirrups DR (2005). Hypodontia - a retrospective review of prevalence and etiology. Part I. Quintessence Int 36:263-270.

Nieminen P. Arte S, Pirinen S, Peltonen L, Thesleff I (1995). Gene defect in hypodontia: exclusion of MSX1 and MSX2 as candidate genes. Human Genet 96:305-308. 
Ranta R (1982). Comparison of tooth formation in non-cleft and cleft-affected children with and without hypodontia. J Dent Child 49:197-199.

Ranta R (1983). Association of hypodontia and delayed development of the second premolars in cleft palate children. Eur J Orthod 5:145-148.

Ranta R (1986). A review of tooth formation in children with cleft lip/palate. Am J Orthod Dentofac Orthop 90:11-18.

Rice JP, Saccone NL, Rasmussen E (2001). Definition of the Phenotype. In: Genetic dissection of complex traits. Rao DC, Province MA, editors. San Diego: Academic Press, pp. 69-76.

Schroeder DC, Green LJ (1975). Frequency of dental trait anomalies in cleft, sibling and noncleft groups. J Dent Res 54:802-807.

Shapira Y, Lubit E, Kuftinec M (1999). Congenitally missing second premolars in cleft lip and cleft palate children. Am J Orthod Dentofacial Orthop 115:396-400.

Shapira Y, Lubit E, Kuftinec M (2000). Hypodontia in children with various types of clefts. Angle Orthod 70:16-21.

Shprintzen RJ, Siegel-sadewitz VL, Amato J, Goldberg RB (1985). Anomalies associated with cleft lip, cleft palate, or both. Am J Med Genet 20:585-595.

Slayton RL, Williams L, Murray JC, Wheeler JJ, Lidral AC, Nishimura CJ (2003). Genetic association studies of cleft lip and/or palate with hypodontia outside the cleft region. Cleft Palate Craniofac J 40:274-279.

Stahl F, Grabowski R, Wigger K (2006). Epidemiology of Hoffmeister's "genetically determined predisposition to disturbed development of the dentition" in patients with cleft lip and palate. Cleft Palate Craniofac J 43:457-465. 
Tsai TP, Huang CS, Huang CC, See LC (1998). Distribution patterns of primary and permanent dentition in children with unilateral complete cleft lip and palate. Cleft Palate J 35:154-160.

van den Boogard MJ, Dorland M, Beemer FA, van Amstel HK (2000). MSX1 mutation is associated with orofacial clefting and tooth agenesis in humans. Nat Genet 24:342-343.

Vieira AR (2003). Oral clefts and syndromic forms of tooth agenesis as models for genetics of isolated tooth agenesis. $J$ Dent Res 82:162-165.

Vieira AR, Avila JR, Daack-Hirsch S, Dragan E, Felix TM, Rahimov F, Harrington J, Schultz RR, Watanabe Y, Johnson M, Fang J, O'Brien SE, Orioli IM, Castilla EE, Fitzpatrick DR, Jiang R, Marazita ML, Murray JC (2005). Medical sequencing of candidate genes for nonsyndromic cleft lip and palate. PLoS Genet 1:e64.

Vieira AR, Orioli IM, Castilla EE, Cooper ME, Marazita ML, Murray JC (2003). MSX1 and TGFB3 contribute to clefting in South America. J Dent Res 82:289-292.

Warrington A, Vieira AR, Christensen K, Orioli IM, Castilla EE, Romitti PA, Murray JC (2006). Genetic evidence for the role of loci at $19 \mathrm{q} 13$ in cleft lip and palate. JMed Genet $43: \mathrm{e} 26$.

Weinberg SM, Neiswanger $\mathrm{K}$, martin $\mathrm{R}$, Mooney MP, Kane AA, Wenger SL, Losee J, Deleyiannis F, Phil M, Ma, L, De Salamanca JE, Czeizel AE, Marazita ML. The Pittsburgh OralFacial Cleft Study: Expanding the Cleft Phenotype. Background and Justification (2006). Cleft Palate Craniofac J 43:7-20.

Werner SP, Harris EF (1989). Odontometrics of the permanent teeth in cleft lip and palate: systemic size reduction and amplified asymmetry. Cleft Palate J 26:36-41. 
Table 1. Distribution of individuals according to cleft status and frequencies of observed dental anomalies ${ }^{a, b}$.

\begin{tabular}{|c|c|c|c|c|c|c|c|c|c|c|}
\hline Cleft type/subphenotype & $\begin{array}{c}\text { No. } \\
\text { of } \\
\text { indi } \\
\text { vid } \\
\text { uals }\end{array}$ & $\begin{array}{c}\text { Agenes } \\
\text { is }\end{array}$ & $\begin{array}{c}\text { Microd } \\
\text { ontia }\end{array}$ & $\begin{array}{c}\text { Supernu } \\
\text { merary } \\
\text { teeth }\end{array}$ & $\underset{\text { ion }}{\text { Malposit }}$ & $\begin{array}{l}\text { Impacti } \\
\text { on }\end{array}$ & $\begin{array}{c}\text { Shape } \\
\text { anom } \\
\text { aly }\end{array}$ & $\begin{array}{c}\text { Transpo } \\
\text { sition }\end{array}$ & $\begin{array}{c}\text { Multiple } \\
\text { anomali } \\
\text { es }\end{array}$ & $\begin{array}{c}\text { Total } \\
\text { anomali } \\
\text { es }\end{array}$ \\
\hline \multicolumn{11}{|l|}{ Cleft Palate } \\
\hline complete & 21 & 4 & 0 & 0 & 0 & 2 & 0 & 0 & 2 & 8 \\
\hline incomplete + submucous & 45 & 10 & 0 & 1 & 4 & 0 & 1 & 0 & 0 & 16 \\
\hline Total & 66 & 14 & 0 & 1 & 4 & 2 & 1 & 0 & 2 & 24 \\
\hline \multicolumn{11}{|l|}{ Cleft lip and palate } \\
\hline Complete & 300 & 90 & 7 & 16 & 30 & 3 & 0 & 5 & 17 & 168 \\
\hline incomplete & 104 & 23 & 1 & 4 & 12 & 1 & 0 & 2 & 3 & 46 \\
\hline Unilateral & 250 & 71 & 6 & 16 & 27 & 3 & 0 & 3 & 16 & 142 \\
\hline complete & 175 & 57 & 5 & 14 & 19 & 2 & 0 & 1 & 13 & 111 \\
\hline incomplete & 75 & 14 & 1 & 2 & 8 & 1 & 0 & 2 & 3 & 31 \\
\hline right & 78 & 28 & 2 & 3 & 9 & 1 & 0 & 0 & 2 & 45 \\
\hline complete & 54 & 23 & 2 & 3 & 6 & 0 & 0 & 0 & 2 & 36 \\
\hline incomplete & 16 & 3 & 0 & 0 & 3 & 0 & 0 & 0 & 0 & 6 \\
\hline incomplete + cleft palate & 8 & 1 & 0 & 0 & 1 & 0 & 0 & 0 & 0 & 2 \\
\hline left & 172 & 43 & 4 & 13 & 18 & 2 & 0 & 3 & 14 & 97 \\
\hline complete & 121 & 34 & 3 & 11 & 13 & 2 & 0 & 1 & 11 & 75 \\
\hline incomplete & 46 & 9 & 1 & 2 & 5 & 0 & 0 & 2 & 3 & 22 \\
\hline incomplete + cleft palate & 5 & 0 & 0 & 0 & 0 & 0 & 0 & 0 & 0 & 0 \\
\hline bilateral & 154 & 42 & 2 & 4 & 15 & 1 & 0 & 4 & 4 & 72 \\
\hline complete & 125 & 33 & 2 & 2 & 11 & 1 & 0 & 4 & 4 & 57 \\
\hline incomplete & 8 & 1 & 0 & 1 & 1 & 0 & 0 & 0 & 0 & 3 \\
\hline incomplete + cleft palate & 17 & 7 & 0 & 1 & 3 & 0 & 0 & 0 & 0 & 11 \\
\hline incomplete mixed & 4 & 1 & 0 & 0 & 0 & 0 & 0 & 0 & 0 & 1 \\
\hline $\begin{array}{l}\text { right cleft lip + left } \\
\text { cleft lip and palate }\end{array}$ & 3 & 1 & 0 & 0 & 0 & 0 & 0 & 0 & 0 & 1 \\
\hline $\begin{array}{l}\text { left cleft lip }+ \text { bilateral } \\
\text { cleft palate }\end{array}$ & 1 & 0 & 0 & 0 & 0 & 0 & 0 & 0 & 0 & 0 \\
\hline median cleft & 2 & 0 & 0 & 0 & 0 & 0 & 0 & 0 & 0 & 0 \\
\hline Total & 406 & 113 & 8 & 20 & 42 & 4 & 0 & 7 & 20 & 214 \\
\hline Unknown type/side of cleft & 28 & 4 & 1 & 1 & 1 & 0 & 1 & 0 & 1 & 9 \\
\hline Total clefts & 500 & 131 & 9 & 22 & 47 & 6 & 2 & 7 & 23 & 247 \\
\hline No cleft (controls) & 500 & 36 & 1 & 1 & 2 & 1 & 0 & 0 & 1 & 42 \\
\hline
\end{tabular}


Table 2. Differences in observed frequencies of dental anomalies between cleft and control groups.

\begin{tabular}{lcccc}
\hline $\begin{array}{l}\text { Dental } \\
\text { anomaly }\end{array}$ & $\begin{array}{c}\text { Cleft } \\
(\mathrm{n}=500)\end{array}$ & $\begin{array}{c}\text { Control } \\
(\mathrm{n}=500)\end{array}$ & p value $^{*}$ & Odds ratio $(\mathbf{9 5} \% \mathbf{C I})^{* *}$ \\
\hline Agenesis & 131 & 36 & 0.00001 & $4.57(3.08-6.78)$ \\
Microdontia & 9 & 1 & 0.0063 & $9.14(1.15-72.47)$ \\
Supernumerary & 22 & 1 & 0.00001 & $22.96(3.08-171.05)$ \\
Malposition & 47 & 2 & 0.00001 & $25.83(6.23-106.96)$ \\
Impaction & 6 & 1 & 0.0578 & $6.06(0.72-50.52)$ \\
Malformation & 2 & 0 & 0.0830 & -- \\
Transposition & 7 & 0 & 0.0011 &.- \\
Multiple & 23 & 1 & 0.00001 & $24.06(3.23-178.87)$ \\
Total & 247 & 42 & 0.00001 & $10.64(7.41-15.28)$ \\
\hline
\end{tabular}

* Chi-square, 1 degree of freedom; $\mathrm{p} \leq 0.05$ indicates statistical difference.

** CI, confidence interval. 
Table 3. Number of dental anomalies observed in cleft individuals, divided by side of anomaly.

\begin{tabular}{|c|c|c|c|c|c|c|}
\hline \multirow[t]{2}{*}{ Anomaly } & \multirow[t]{2}{*}{ Side } & \multicolumn{4}{|c|}{ Cleft side } & \multirow{2}{*}{$\begin{array}{c}\mathbf{p} \\
\text { value }^{*}\end{array}$} \\
\hline & & $\begin{array}{l}\text { Right } \\
(n=78)\end{array}$ & $\begin{array}{c}\text { Left } \\
(\mathrm{n}=172)\end{array}$ & $\begin{array}{l}\text { Bilateral } \\
(n=154)\end{array}$ & $\begin{array}{l}\text { Central } \\
(n=66)\end{array}$ & \\
\hline \multirow[t]{4}{*}{ Agenesis } & Right & 5 & 16 & 2 & 2 & 0.0106 \\
\hline & Left & 8 & 6 & 5 & 0 & 0.0115 \\
\hline & Bilateral & 13 & 18 & 34 & 12 & 0.0401 \\
\hline & Unknown & 2 & 3 & 1 & 0 & 0.3177 \\
\hline \multirow[t]{4}{*}{ Microdontia } & Right & 0 & 3 & 0 & 0 & 0.0682 \\
\hline & Left & 2 & 1 & 1 & 0 & 0.2923 \\
\hline & Bilateral & 0 & 0 & 1 & 0 & 0.4329 \\
\hline & Unknown & 0 & 0 & 0 & 0 & -- \\
\hline \multirow[t]{4}{*}{ Supernumerary } & Right & 0 & 4 & 0 & 0 & 0.0232 \\
\hline & Left & 2 & 3 & 0 & 1 & 0.1511 \\
\hline & Bilateral & 0 & 0 & 0 & 0 & --- \\
\hline & Unknown & 1 & 6 & 4 & 0 & 0.2062 \\
\hline \multirow[t]{4}{*}{ Malposition } & Right & 3 & 11 & 6 & 1 & 0.3857 \\
\hline & Left & 4 & 3 & 2 & 2 & 0.2840 \\
\hline & Bilateral & 2 & 2 & 6 & 0 & 0.1085 \\
\hline & Unknown & 0 & 2 & 1 & 1 & 0.5875 \\
\hline
\end{tabular}

${ }^{*}$ Chi-square, 3 degrees of freedom; $\mathrm{p} \leq 0.05$ indicates statistical difference (in bold). 
Figure 1. List of cleft subphenotypes used in epidemiological/genetic studies and the proposed additional subphenotypes based on dental development.

\begin{tabular}{|c|c|}
\hline $\begin{array}{l}\text { Cleft subphenotypes used in the most recent } \\
\text { genetic studies a }\end{array}$ & $\begin{array}{l}\text { Proposed cleft subphenotypes based on dental } \\
\text { development }{ }^{\text {b }}\end{array}$ \\
\hline $\begin{array}{l}\text { - All cleft types } \\
\text { - Cleft lip with or without cleft palate (CL/P) } \\
\text { (all lips) } \\
\text { - Cleft lip only (CLO) } \\
\text { - Cleft lip and palate (CLP) } \\
\text { - Cleft lip and palate + cleft palate (all palates) } \\
\text { - Cleft palate only (CPO) }\end{array}$ & $\begin{array}{l}\text { - Cleft lip with or without cleft palate (CL/P) } \\
\text { - unilateral right } \\
\text { - with/without tooth agenesis outside the } \\
\text { cleft area } \\
\text { - unilateral left } \\
\text { - with/without tooth agenesis outside the } \\
\text { cleft area } \\
\text { - with/without microdontia or supernumerary } \\
\text { teeth on the noncleft side } \\
\text { - with/without multiple dental anomalies } \\
\text { - bilateral } \\
\text { - with/without tooth agenesis outside the } \\
\text { cleft area } \\
\text { - with/without supernumerary teeth } \\
\text { - with/without malposition of lower canines } \\
\text { - with/without multiple dental anomalies } \\
\text { - unsuccessful bilateral (unilateral CL/P with } \\
\text { agenesis of the lateral incisor on the noncleft } \\
\text { side) } \\
\text { - with/without multiple dental anomalies } \\
\text { - Cleft palate only (CPO) } \\
\text { - complete } \\
\text { - with/without tooth impaction } \\
\text { - with/without multiple dental anomalies } \\
\text { - incomplete } \\
\text { - with/without tooth malposition }\end{array}$ \\
\hline
\end{tabular}

\footnotetext{
${ }^{a}$ Vieira et al., 2003; Vieira et al., 2005; Avila et al., 2006; Warrington et al., 2006.

${ }^{\mathrm{b}}$ Small number of cleft lip only (CLO) did not allow analysis of this specific cleft subtype.
} 


\section{SUPPLEMENTAL MATERIAL I}

Differences in observed frequencies of dental anomalies between each different cleft phenotype and controls. Significance figures (in bold) were accounted for using Bonferroni correction $(0.05 / 176$ tests; $\alpha=0.0002)$.

\section{Complete Cleft Palate x Control}

\begin{tabular}{lccc}
\hline Dental Anomaly & $\begin{array}{c}\text { Complete Cleft } \\
\text { Palate } \\
(\mathrm{n}=21)\end{array}$ & $\begin{array}{c}\text { Control } \\
(\mathrm{n}=500)\end{array}$ & p value \\
Agenesis & 4 & 36 & \\
Microdontia & 0 & 1 & 0.0457 \\
Supernumerary & 0 & 1 & 0.8374 \\
Malposition & 0 & 2 & 0.8374 \\
Impaction & 2 & 1 & 0.7715 \\
Malformation & 0 & 0 & $\mathbf{0 . 0 0 0 0 1}$ \\
Transposition & 0 & 0 & --- \\
Multiple & 2 & 1 & -- \\
Total & 8 & 42 & $\mathbf{0 . 0 0 0 0 1}$ \\
& & & $\mathbf{0 . 0 0 0 0 1}$ \\
\hline
\end{tabular}

\section{Incomplete Cleft Palate $x$ Control}

\begin{tabular}{lccc}
\hline Dental Anomaly & $\begin{array}{c}\text { Incomplete Cleft } \\
\text { Palate } \\
(\mathrm{n}=45)\end{array}$ & $\begin{array}{c}\text { Control } \\
(\mathrm{n}=500)\end{array}$ & p value \\
Agenesis & 10 & 36 & \\
Microdontia & 0 & 1 & 0.0005 \\
Supernumerary & 1 & 1 & 0.7639 \\
Malposition & 4 & 2 & 0.0316 \\
Impaction & 0 & 1 & $\mathbf{0 . 0 0 0 0 1}$ \\
Malformation & 1 & 0 & 0.7639 \\
Transposition & 0 & 0 & 0.0008 \\
Multiple & 0 & 1 &.--- \\
Total & 16 & 42 & 0.7639 \\
& & & $\mathbf{0 . 0 0 0 0 1}$ \\
\hline
\end{tabular}




\section{Total Cleft Palate $x$ Control}

\begin{tabular}{lccc}
\hline Dental Anomaly & $\begin{array}{c}\text { Cleft Palate } \\
(\mathrm{n}=66)\end{array}$ & $\begin{array}{c}\text { Control } \\
(\mathrm{n}=500)\end{array}$ & p value \\
Agenesis & 14 & 36 & $\mathbf{0 . 0 0 0 1}$ \\
Microdontia & 0 & 1 & 0.7161 \\
Supernumerary & 1 & 1 & 0.0905 \\
Malposition & 4 & 2 & $\mathbf{0 . 0 0 0 0 1}$ \\
Impaction & 2 & 1 & 0.0029 \\
Malformation & 1 & 0 & 0.0058 \\
Transposition & 0 & 0 & --- \\
Multiple & 2 & 1 & 0.0029 \\
Total & 24 & 42 & $\mathbf{0 . 0 0 0 0 1}$ \\
\hline
\end{tabular}

\section{Complete Cleft Lip and Palate (unilateral + bilateral) $x$ Control}

\begin{tabular}{lccc}
\hline Dental Anomaly & $\begin{array}{c}\text { Complete Cleft } \\
\text { Lip and Palate } \\
(\mathrm{n}=300)\end{array}$ & $\begin{array}{c}\text { Control } \\
(\mathrm{n}=500)\end{array}$ & p value \\
Agenesis & 90 & 36 & 0.00001 \\
Microdontia & 7 & 1 & 0.0033 \\
Supernumerary & 16 & 1 & 0.00001 \\
Malposition & 30 & 2 & 0.00001 \\
Impaction & 3 & 1 & 0.1204 \\
Malformation & 0 & 0 & --- \\
Transposition & 5 & 0 & 0.0037 \\
Multiple & 17 & 1 & 0.00001 \\
Total & 168 & 42 & 0.00001 \\
\hline
\end{tabular}

5. Incomplete Cleft Lip and Palate (unilateral + bilateral) x Control

\begin{tabular}{lccc}
\hline Dental Anomaly & $\begin{array}{c}\text { Incomplete Cleft } \\
\text { Lip and Palate } \\
(\mathrm{n}=104)\end{array}$ & $\begin{array}{c}\text { Control } \\
(\mathrm{n}=500)\end{array}$ & p value \\
Agenesis & 23 & 36 & $\mathbf{0 . 0 0 0 0 1}$ \\
Microdontia & 1 & 1 & 0.2187 \\
Supernumerary & 4 & 1 & $\mathbf{0 . 0 0 0 1}$ \\
Malposition & 12 & 2 & $\mathbf{0 . 0 0 0 0 1}$ \\
Impaction & 1 & 1 & 0.2187 \\
Malformation & 0 & 0 &.--- \\
Transposition & 2 & 0 & 0.0018 \\
\hline
\end{tabular}




\begin{tabular}{lccc}
\hline Multiple & 3 & 1 & 0.0021 \\
Total & 44 & 42 & $\mathbf{0 . 0 0 0 0 0 0 1}$ \\
\hline
\end{tabular}

6. Unilateral Cleft Lip and Palate $x$ Control

\begin{tabular}{lccc}
\hline Dental Anomaly & $\begin{array}{c}\text { Unilateral Cleft } \\
\text { Lip and Palate } \\
(\mathrm{n}=250)\end{array}$ & $\begin{array}{c}\text { Control } \\
(\mathrm{n}=500)\end{array}$ & p value \\
Agenesis & 71 & & \\
Microdontia & 6 & 36 & $\mathbf{0 . 0 0 0 0 1}$ \\
Supernumerary & 16 & 1 & 0.0031 \\
Malposition & 27 & 1 & $\mathbf{0 . 0 0 0 0 1}$ \\
Impaction & 3 & 2 & $\mathbf{0 . 0 0 0 0 1}$ \\
Malformation & 0 & 1 & 0.0763 \\
Transposition & 3 & 0 &.-- \\
Multiple & 16 & 1 & 0.0141 \\
Total & 139 & 42 & $\mathbf{0 . 0 0 0 0 1}$ \\
\hline
\end{tabular}

7. Complete Unilateral Cleft Lip and Palate $x$ Control

\begin{tabular}{lccc}
\hline Dental Anomaly & $\begin{array}{c}\text { Complete } \\
\text { unilateral Cleft } \\
\text { Lip and Palate } \\
(\mathrm{n}=175)\end{array}$ & $\begin{array}{c}\text { Control } \\
(\mathrm{n}=500)\end{array}$ & p value \\
Agenesis & 57 & & \\
Microdontia & 5 & 36 & $\mathbf{0 . 0 0 0 0 1}$ \\
Supernumerary & 14 & 1 & 0.0012 \\
Malposition & 19 & 1 & $\mathbf{0 . 0 0 0 0 1}$ \\
Impaction & 2 & 2 & $\mathbf{0 . 0 0 0 0 1}$ \\
Malformation & 0 & 1 & 0.1065 \\
Transposition & 1 & 0 &.--- \\
Multiple & 13 & 1 & 0.0907 \\
Total & 111 & 42 & $\mathbf{0 . 0 0 0 0 1}$ \\
\hline
\end{tabular}


8. Incomplete Unilateral Cleft Lip and Palate x Control

\begin{tabular}{lccc}
\hline Dental Anomaly & $\begin{array}{c}\text { Incomplete } \\
\text { Unilateral Cleft } \\
\text { Lip and Palate } \\
(\mathrm{n}=75)\end{array}$ & $\begin{array}{c}\text { Control } \\
(\mathrm{n}=500)\end{array}$ & p value \\
Agenesis & 14 & 36 & \\
Microdontia & 1 & 1 & 0.0010 \\
Supernumerary & 2 & 1 & 0.1267 \\
Malposition & 8 & 2 & 0.0064 \\
Impaction & 1 & 1 & $\mathbf{0 . 0 0 0 0 1}$ \\
Malformation & 0 & 0 & 0.1267 \\
Transposition & 2 & 0 & - \\
Multiple & 3 & 1 & 0.0003 \\
Total & 31 & 42 & $\mathbf{0 . 0 0 0 2}$ \\
\hline
\end{tabular}

\section{Unilateral Right Cleft Lip and Palate $x$ Control}

\begin{tabular}{lccc}
\hline Dental Anomaly & $\begin{array}{c}\text { Total right Cleft } \\
\text { Lip and Palate } \\
(\mathrm{n}=78)\end{array}$ & $\begin{array}{c}\text { Control } \\
(\mathrm{n}=500)\end{array}$ & p value \\
Agenesis & 28 & 36 & $\mathbf{0 . 0 0 0 0 1}$ \\
Microdontia & 2 & 1 & 0.0068 \\
Supernumerary & 3 & 1 & 0.0003 \\
Malposition & 9 & 2 & $\mathbf{0 . 0 0 0 0 1}$ \\
Impaction & 1 & 1 & 0.1301 \\
Malformation & 0 & 0 & -- \\
Transposition & 0 & 0 & - \\
Multiple & 2 & 1 & 0.0068 \\
Total & 45 & 42 & $\mathbf{0 . 0 0 0 0 1}$ \\
\hline
\end{tabular}

10. Complete Unilateral Right Cleft Lip and Palate $x$ Control

\begin{tabular}{lccc}
\hline Dental Anomaly & $\begin{array}{c}\text { Complete } \\
\text { Unilateral Right } \\
\text { Cleft Lip and } \\
\text { Palate }(\mathrm{n}=54)\end{array}$ & $\begin{array}{c}\text { Control } \\
(\mathrm{n}=500)\end{array}$ & p value \\
Agenesis & 23 & 36 & \\
Microdontia & 2 & 1 & $\mathbf{0 . 0 0 0 0 1}$ \\
Supernumerary & 3 & 1 & 0.0008 \\
\hline
\end{tabular}




\begin{tabular}{lccc}
\hline Malposition & 6 & 2 & $\mathbf{0 . 0 0 0 0 1}$ \\
Impaction & 0 & 1 & 0.7422 \\
Malformation & 0 & 0 & --- \\
Transposition & 0 & 0 & -- \\
Multiple & 2 & 1 & 0.0008 \\
Total & 36 & 42 & $\mathbf{0 . 0 0 0 0 1}$ \\
\hline
\end{tabular}

11. Incomplete Unilateral Right Cleft Lip and Palate $\mathrm{x}$ Control

\begin{tabular}{lccc}
\hline Dental Anomaly & $\begin{array}{c}\text { Incomplete } \\
\text { Unilateral Right } \\
\text { Cleft Lip and } \\
\text { Palate } \\
(\mathrm{n}=16)\end{array}$ & $\begin{array}{c}\text { Control } \\
(\mathrm{n}=500)\end{array}$ & p value \\
Agenesis & 3 & 36 & \\
Microdontia & 0 & 1 & 0.0853 \\
Supernumerary & 0 & 1 & 0.8578 \\
Malposition & 3 & 2 & 0.8578 \\
Impaction & 0 & 1 & $\mathbf{0 . 0 0 0 0 1}$ \\
Malformation & 0 & 0 & 0.8578 \\
Transposition & 0 & 0 & --- \\
Multiple & 0 & 1 & --- \\
Total & 6 & 42 & 0.8578 \\
\hline
\end{tabular}

\section{Incomplete Unilateral Right Cleft Lip and Palate + Cleft Palate $x$ Control}

\begin{tabular}{lccc}
\hline Dental Anomaly & $\begin{array}{c}\text { Incomplete } \\
\text { Unilateral Right } \\
\text { Cleft Lip and } \\
\text { Palate + Cleft } \\
\text { Palate } \\
(\mathrm{n}=8)\end{array}$ & $\begin{array}{c}\text { Control } \\
(\mathrm{n}=500)\end{array}$ & p value \\
Agenesis & 2 & & \\
Microdontia & 0 & 36 & \\
Supernumerary & 0 & 1 & 0.0576 \\
Malposition & 0 & 1 & 0.8992 \\
Impaction & 1 & 2 & 0.8992 \\
Malformation & 0 & 1 & 0.8577 \\
Transposition & 0 & 0 & 0.8578 \\
Multiple & 0 & 0 & --- \\
Total & 3 & 1 & - \\
\hline
\end{tabular}


13. Unilateral Left Cleft Lip and Palate $\mathrm{x}$ Control

\begin{tabular}{lccc}
\hline Dental Anomaly & $\begin{array}{c}\text { Unilateral Left } \\
\text { Cleft Lip and } \\
\text { Palate } \\
(\mathrm{n}=172)\end{array}$ & $\begin{array}{c}\text { Control } \\
(\mathrm{n}=500)\end{array}$ & p value \\
Agenesis & 43 & 36 & $\mathbf{0 . 0 0 0 0 1}$ \\
Microdontia & 4 & 1 & 0.0051 \\
Supernumerary & 13 & 1 & $\mathbf{0 . 0 0 0 0 1}$ \\
Malposition & 18 & 2 & $\mathbf{0 . 0 0 0 0 1}$ \\
Impaction & 2 & 1 & 0.1023 \\
Malformation & 0 & 0 & - \\
Transposition & 3 & 0 & 0.0030 \\
Multiple & 14 & 1 & $\mathbf{0 . 0 0 0 0 1}$ \\
Total & 97 & 42 & $\mathbf{0 . 0 0 0 0 1}$ \\
\hline
\end{tabular}

14. Complete Unilateral Left Cleft Lip and Palate $x$ Control

\begin{tabular}{lccc}
\hline Dental Anomaly & $\begin{array}{c}\text { Complete } \\
\text { Unilateral Left } \\
\text { Cleft Lip and } \\
\text { Palate } \\
(\mathrm{n}=121)\end{array}$ & $\begin{array}{c}\text { Control } \\
(\mathrm{n}=500)\end{array}$ & p value \\
Agenesis & 34 & & \\
Microdontia & 3 & 36 & $\mathbf{0 . 0 0 0 0 1}$ \\
Supernumerary & 11 & 1 & 0.0051 \\
Malposition & 13 & 1 & $\mathbf{0 . 0 0 0 0 1}$ \\
Impaction & 2 & 2 & $\mathbf{0 . 0 0 0 0 1}$ \\
Malformation & 0 & 1 & 0.0386 \\
Transposition & 1 & 0 & ---- \\
Multiple & 11 & 0 & 0.0419 \\
Total & 75 & 1 & $\mathbf{0 . 0 0 0 0 1}$ \\
\hline
\end{tabular}

\section{Incomplete Unilateral Left Cleft Lip and Palate $\mathrm{x}$ Control}

\begin{tabular}{lccc}
\hline Dental Anomaly & $\begin{array}{c}\text { Incomplete } \\
\text { Unilateral Left } \\
\text { Cleft Lip and } \\
\text { Palate } \\
(\mathrm{n}=46)\end{array}$ & $\begin{array}{c}\text { Control } \\
(\mathrm{n}=500)\end{array}$ & p value \\
Agenesis & 9 & 36 & \\
Microdontia & 1 & 1 & 0.0035 \\
Supernumerary & 2 & 1 & 0.0339 \\
\hline
\end{tabular}




\begin{tabular}{lccc}
\hline Malposition & 5 & 2 & $\mathbf{0 . 0 0 0 0 1}$ \\
Impaction & 0 & 1 & 0.7614 \\
Malformation & 0 & 0 & --- \\
Transposition & 2 & 0 & $\mathbf{0 . 0 0 0 0 1}$ \\
Multiple & 3 & 1 & $\mathbf{0 . 0 0 0 0 1}$ \\
Total & 22 & 42 & $\mathbf{0 . 0 0 0 0 1}$ \\
\hline
\end{tabular}

16. Incomplete Unilateral Left Cleft Lip and Palate + Cleft Palate $x$ Control

\begin{tabular}{lccc}
\hline Dental Anomaly & $\begin{array}{c}\text { Incomplete } \\
\text { Unilateral Left } \\
\text { Cleft Lip and } \\
\text { Palate + Cleft } \\
\text { Palate } \\
\text { (n=5) }\end{array}$ & $\begin{array}{c}\text { Control } \\
(\mathrm{n}=500)\end{array}$ & p value \\
Agenesis & & & \\
Microdontia & 0 & 36 & \\
Supernumerary & 0 & 1 & 0.5335 \\
Malposition & 0 & 1 & 0.9202 \\
Impaction & 0 & 2 & 0.9202 \\
Malformation & 0 & 1 & 0.8873 \\
Transposition & 0 & 0 & 0.9202 \\
Multiple & 0 & 0 & ---- \\
Total & 0 & 1 & --.9202 \\
\hline
\end{tabular}

17. Bilateral Cleft Lip and Palate $x$ Control

\begin{tabular}{lccc}
\hline Dental Anomaly & $\begin{array}{c}\text { Bilateral Cleft Lip } \\
\text { and Palate } \\
(\mathrm{n}=154)\end{array}$ & $\begin{array}{c}\text { Control } \\
(\mathrm{n}=500)\end{array}$ & p value \\
Agenesis & 42 & 36 & $\mathbf{0 . 0 0 0 0 1}$ \\
Microdontia & 2 & 1 & 0.0724 \\
Supernumerary & 4 & 1 & 0.0028 \\
Malposition & 15 & 2 & $\mathbf{0 . 0 0 0 0 1}$ \\
Impaction & 1 & 1 & 0.3772 \\
Malformation & 0 & 0 &.-- \\
Transposition & 4 & 0 & 0.0003 \\
Multiple & 4 & 1 & 0.0028 \\
Total & 72 & 42 & $\mathbf{0 . 0 0 0 0 1}$ \\
\hline
\end{tabular}


18. Complete Bilateral Cleft Lip and Palate $x$ Control

\begin{tabular}{lccc}
\hline Dental Anomaly & $\begin{array}{c}\text { Complete } \\
\text { Bilateral Cleft Lip } \\
\text { and Palate } \\
(\mathrm{n}=125)\end{array}$ & $\begin{array}{c}\text { Control } \\
(\mathrm{n}=500)\end{array}$ & p value \\
Agenesis & 33 & 36 & \\
Microdontia & 2 & 1 & $\mathbf{0 . 0 0 0 0 1}$ \\
Supernumerary & 2 & 1 & 0.0460 \\
Malposition & 11 & 2 & 0.0460 \\
Impaction & 1 & 1 & $\mathbf{0 . 0 0 0 0 1}$ \\
Malformation & 0 & 0 & 0.2976 \\
Transposition & 4 & 0 & - \\
Multiple & 4 & 1 & $\mathbf{0 . 0 0 0 0 1}$ \\
Total & 57 & 42 & 0.0008 \\
\hline
\end{tabular}

19. Incomplete Bilateral Cleft Lip and Palate $x$ Control

\begin{tabular}{lccc}
\hline Dental Anomaly & $\begin{array}{c}\text { Incomplete } \\
\text { Bilateral Cleft Lip } \\
(\mathrm{n}=8)\end{array}$ & $\begin{array}{c}\text { Control } \\
(\mathrm{n}=500)\end{array}$ & p value \\
Agenesis & 1 & 36 & 0.5671 \\
Microdontia & 0 & 1 & 0.8992 \\
Supernumerary & 1 & 1 & $\mathbf{0 . 0 0 0 0 1}$ \\
Malposition & 1 & 2 & $\mathbf{0 . 0 0 0 0 1}$ \\
Impaction & 0 & 1 & 0.8992 \\
Malformation & 0 & 0 & --- \\
Transposition & 0 & 0 & -- \\
Multiple & 0 & 1 & 0.8992 \\
Total & 3 & 42 & 0.0040 \\
\hline
\end{tabular}

20. Incomplete Bilateral Cleft Lip and Palate + Cleft Palate $\mathbf{x}$ Control

\begin{tabular}{lccc}
\hline Dental Anomaly & $\begin{array}{c}\text { Incomplete } \\
\text { Bilateral Cleft Lip } \\
\text { and Palate + Cleft } \\
\text { Palate } \\
(\mathrm{n}=17)\end{array}$ & $\begin{array}{c}\text { Control } \\
(\mathrm{n}=500)\end{array}$ & p value \\
Agenesis & 7 & 36 & $\mathbf{0 . 0 0 0 0 1}$ \\
Microdontia & 0 & 1 & 0.8535 \\
Supernumerary & 1 & 1 & $\mathbf{0 . 0 0 0 2}$ \\
Malposition & 3 & 2 & $\mathbf{0 . 0 0 0 0 1}$ \\
\hline
\end{tabular}




\begin{tabular}{lccc}
\hline Impaction & 0 & 1 & 0.8535 \\
Malformation & 0 & 0 & --- \\
Transposition & 0 & 0 & -- \\
Multiple & 0 & 1 & 0.8535 \\
Total & 11 & 42 & $\mathbf{0 . 0 0 0 0 1}$ \\
\hline
\end{tabular}

21. Incomplete Mixed Bilateral Cleft Lip and Palate x Control

\begin{tabular}{lccc}
\hline Dental Anomaly & $\begin{array}{c}\text { Incomplete Mixed } \\
\text { Bilateral Cleft Lip } \\
\text { and Palate } \\
(\mathrm{n}=4)\end{array}$ & $\begin{array}{c}\text { Control } \\
(\mathrm{n}=500)\end{array}$ & p value \\
Agenesis & 1 & 36 & 0.1739 \\
Microdontia & 0 & 1 & 0.9286 \\
Supernumerary & 0 & 1 & 0.9286 \\
Malposition & 0 & 2 & 0.8991 \\
Impaction & 0 & 1 & 0.9286 \\
Malformation & 0 & 0 & --- \\
Transposition & 0 & 0 & -- \\
Multiple & 0 & 1 & 0.8991 \\
Total & 1 & 42 & 0.2365 \\
\hline
\end{tabular}

22. Total Cleft Lip and Palate $x$ Control

\begin{tabular}{lccc}
\hline Dental anomaly & $\begin{array}{c}\text { Total Cleft Lip } \\
\text { and Palate } \\
(\mathrm{n}=406)\end{array}$ & $\begin{array}{c}\text { Control } \\
(\mathrm{n}=500)\end{array}$ & p value \\
Agenesis & 113 & 36 & $\mathbf{0 . 0 0 0 0 1}$ \\
Microdontia & 8 & 1 & 0.0075 \\
Supernumerary & 20 & 1 & $\mathbf{0 . 0 0 0 0 1}$ \\
Malposition & 42 & 2 & $\mathbf{0 . 0 0 0 0 1}$ \\
Impaction & 4 & 1 & 0.1126 \\
Malformation & 0 & 0 & - \\
Transposition & 7 & 0 & 0.0032 \\
Multiple & 20 & 1 & $\mathbf{0 . 0 0 0 0 1}$ \\
Total & 217 & 42 & $\mathbf{0 . 0 0 0 0 1}$ \\
\hline
\end{tabular}

